UNIVERSIDADE DE SÃO PAULO FACULDADE DE ARQUITETURA E URBANISMO DEPARTAMENTO DE PROJETO

Valério Marcos Nogueira Pietraróia Arquitetura do Espetáculo em Cena 

UNIVERSIDADE DE SÃO PAULO

FACULDADE DE ARQUITETURA E URBANISMO

DEPARTAMENTO DE PROJETO

Valério Marcos Nogueira Pietraróia

\section{Arquitetura do Espetáculo em Cena}

Dissertação apresentada à Faculdade de Arquitetura e Urbanismo da Universidade de São Paulo para obtenção do título de Mestre em Arquitetura e Urbanismo.

Área de concentração: Projeto de Arquitetura

Orientador: Prof. Dr. Paulo Júlio Valentino Bruna

Exemplar revisado e alterado em relação à versão original, sob responsabilidade do autor e anuência do orientador.

O original se encontra disponível na sede do programa.

São Paulo, 20 de maio de 2014. 
Autorizo a reprodução e divulgação total ou parcial deste trabalho, por qualquer meio convencional ou eletrônico, para fins de estudo e pesquisa, desde que citada a fonte.

vpietra@usp.br ; vpietra@npc-arq.com.br

Pietraróia, Valério Marcos Nogueira

P625a Arquitetura do espetáculo em cena / Valério Marcos Nogueira

Pietraróia. - São Paulo, 2014.

328 p. : il.

Dissertação (Mestrado - Área de Concentração: Projeto de Arquitetura) - FAUUSP.

Orientador: Paulo Júlio Valentino Bruna

1.Teatro 2.Cenário 3.Áreas centrais - São Paulo (SP)

4.Arquitetura - São Paulo (SP) I.Título

CDU 725.822 
para Enrico e Gabriel, que me demonstram

diariamente que a vida vale a pena, e para Cristina, que me fez. 



\section{Agradecimentos}

Ao Prof. Dr. Paulo Júlio Valentino Bruna, pela preciosa e decisiva orientação.

Aos professores Valentin Fabre e Jean Perrottet, por me apresentarem o tema, com toda a sabedoria de anos de dedicação a ele.

A Profa. Dra. Maria Lúcia Pupo, que apoiou desde o início minha proposta.

A todos os funcionários da biblioteca da FAU-USP, cuja disponibilidade muito contribuiu nas investigações realizadas; em especial, à Rejane Alves e à Valéria Valente.

Ao Instituto Lina Bo e Pietro Maria Bardi, em particular à Vivian Lazzareschi, por permitir momentos importantes de pesquisa.

Aos colegas e aos professores da Pós-Graduação, Ricardo Marques de Azevedo, Hugo Segawa, Mônica Junqueira, Adilson Macedo, Alexandre Delijaicov, Francisco Spadoni e Helio Piñon, pelos fundamentais ensinamentos.

Ao Prof. Dr. Abílio Guerra, por acreditar neste trabalho.

A Profa. Dra. Maria Eugênia Poulet, pela inestimável ajuda no encontro da bibliografia.
A gentileza da Profa. Marie-Josée Fourtanier, em nos apresentar obras tão fundamentais.

A Nelson Kon, pela qualidade do trabalho que vem desenvolvendo e disponibilizando para o enriquecimento de nossos projetos.

Ao UNA Arquitetos, pela ajuda incondicional.

A Patrícia Casadei, pelas versões sempre precisas.

A Gabriel Pietraróia, pela dedicação e qualidade do material gráfico apresentado.

A Claudia Nucci, que entendeu e apoiou esse projeto desde o início.

A Dra. Cleyde Casadei que ainda nos fornece bibliografias.

A Pat Metheny, West Montegomery e Boogaloo Joe Jones, pela companhia.

A minha mãe, Antonieta, por ter me ensinado a ler $e$ escrever, e à meu pai, Rangel, por ter me ensinado a desenhar.

A Cristina Pietraróia, eternamente presente, que lê, entende, revisa e constrói diariamente este percurso. 


\section{Resumo}

O objetivo desta dissertação é o entendimento da arquitetura do espetáculo e sua relação com os questionamentos artísticos que vêm se manifestando desde a década de 1920. 0 cenário recente aponta para a reconquista da cidade como território das manifestações artísticas, como lugar do espetáculo.

Após discutir questões nocionais e metodológicas para o estudo do tema, analisamos 0 Lugar do Espetáculo, apresentado como uma reflexão sobre os meios utilizados para que tais manifestações cumpram seu papel transformador.

A Metrópole em Cena apresenta os desdobramentos, desde a década de 1950, por inúmeras manifestações artísticas de caráter urbano em que a cidade não é apenas cenário, mas é também argumento, roteiro e personagem.

Para tanto, o trabalho investiga as noções e as manifestações da arquitetura do espetáculo nesse período e estabelece, em particular, um paralelo com obras produzidas por mestres como Walter Gropius, Eric Mendelsohn, Mies van der Rohe, Rino Levi, Lina Bo Bardi e Paulo Mendes da Rocha.

Tendo os centros urbanos como território, em especial a região central da cidade de São Paulo, foram também estudadas estratégias e metodologias de projeto aplicadas à arquitetura do espetáculo e as recentes intervenções em seu patrimônio construído.

O fio condutor de nossa pesquisa é a identificação dos valores essenciais da arquitetura do espetáculo que têm inspirado tanto arquitetos quanto encenadores e pensadores teatrais.

Palavras-chave: arquitetura do espetáculo; centro São Paulo; arquitetura - São Paulo; teatros (arquitetura moderna) 



\begin{abstract}
The objective of this dissertation is to understand the architecture of the spectacle and its relation to artistic questions which have been posed since the 1920s. The recent scenario points to reconquering the city as territory for artistic manifestations, as the place of the spectacle.

After discussing notional and methodological questions to study the theme, we analyze The Place of the Spectacle which is presented as a reflection about the means used so that such manifestations can perform their transforming role.

The Metropolis in Scene describes the developments, since the 1950s, through several artistic manifestations of urban nature in which the city is not only scenario, but also argument, script and character.

Therefore, this dissertation investigates the notions and manifestations of the architecture of the spectacle in this period and draws, particularly, a parallel to works produced by masters such as Walter Gropius, Eric Mendelsohn,
\end{abstract}

Mies van der Rohe, Rino Levi, Lina Bo Bardi and Paulo Mendes da Rocha.

Having urban centers as territory, specially São Paulo's city downtown area, project strategies and methodologies applied to the architecture of the spectacle as well as recent interventions in its built heritage are studied.

The line of reasoning of our research is to identify essential values of the architecture of the spectacle which has been inspiring both architects, directors and theatrical thinkers.

Key-words: theater (architecture); architecture of spectacle; architecture down town - Sao Paulo; architecture São Paulo; modern architecture. 

O risco de escrever um estudo sobre a arquitetura brasileira do século 20 é reproduzir inadvertidamente aquilo que se critica: uma visão totalizadora que apaga as diferenças, exalta as formas dominadoras e dissimula a diversidade. A história e a historiografia recentes ainda se refazem do impacto epistemológico provocado, por exemplo, pelas ideias de um Michel Foucault - escritos tecidos com a microtrama de uma complexa urdidura. Nesse caminho, a viabilidade de dar formas a problemas, de articular perguntas é muito mais intensa que nossa capacidade individual de formular respostas. 
Cap1. A arquitetura do espetáculo: noção e metodologia

1.1 O Concreto e o Imaginário 27

1.2 A Imagem do Espetáculo 29

1.3 O Sentido do Espetáculo 35

1.4 A Ideia de Espetáculo $\quad 41$

1.5 Abstração e Espetáculo 45

1.6 À Procura do Projeto 51

Cap 2. O Lugar da Arquitetura do 56 Espetáculo

2.1 Mobilidade em Cena 59

Sumário

2.2 O Lugar do Espetáculo 
Cap 3. A Arquitetura do Espetáculo

e a Modernidade

3.1 Auditorim Building

3.2 Bauhaus - Teatro Total

3.3 Complexo WOGA Berlin - 1928 - 1981

3.4 Teatro Nacional de Mannhein

Cap 4. A Metrópole Em Cena

4.1 Olhar e Ver

4.2 Percorrer

4.3 Fun Palace

4.3 Mummers Theater - Stage Center

4.4 Plateau Beau-bourg

4.5 IRCAM: A Arquitetura na Composição

Cap 5. A Arquitetura do Espetáculo e a

Arquitetura Moderna de São Paulo

5.1 O Espetáculo segundo Rino Levi

5.2 Edifício Diários Associados - Edifício Taba

Guaianases - São Paulo em São Paulo

6.1 Morte e Vida da Alegoria

6.2 O Espetáculo em uma Década

6.4 Praça das Artes - 28.500 m2 de área construída

6.5 Estação Julio Prestes - Sala São Paulo de

6.6 Complexo Cultural Luz

Considerações Finais

Bibliografia 
Introdução 
A riqueza das decorações, o charme da paisagem, da arquitetura e todos os efeitos dos cenários teatrais, repousam unicamente nas leis da perspectiva.

(BÖHLE, Theater-Kalechismu, 2009, p. 112-113)

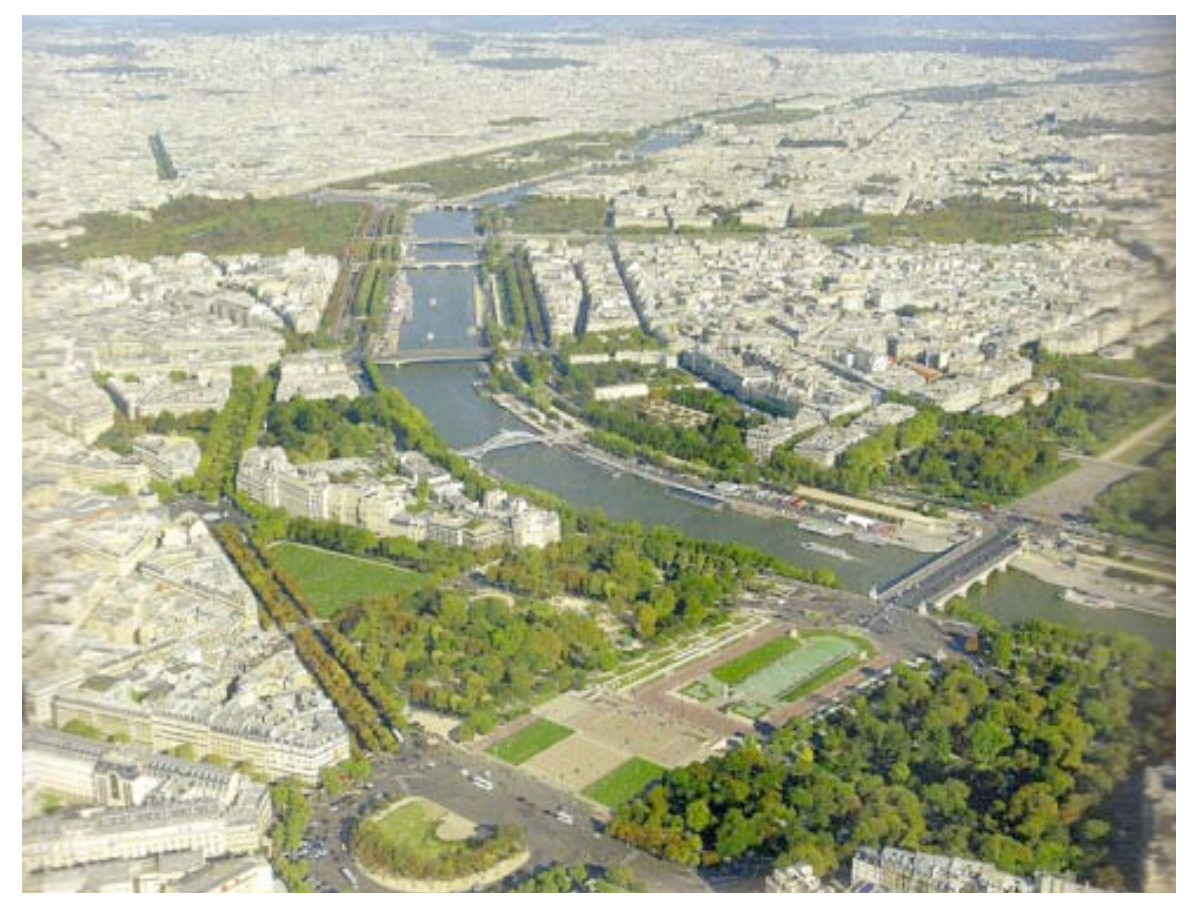

Fonte: Arch. Baukunst, Vue de Paris, in Architectures, Wallonie-Bruxelles. Inventaires 2005-2010
0 texto e a imagem ao lado elucidam a difícil tarefa que o tema de nossa pesquisa - arquitetura e espetáculo - apresenta, pela simples combinação das palavras e pelo surpreendente resultado da Paris vista do céu, sem seus grandes monumentos. 0 assunto pode parecer uma provocação e na realidade provoca sim à reflexão, como no trabalho apresentado pelo escritório Baukunst na revista Critcat ${ }^{1}$.

Baseado nas leis da perspectiva, as mesmas que orientaram os espetáculos teatrais e, consequentemente, não só sua cenografia mas sobretudo a própria arquitetura dos seus edifícios durante boa parte dos últimos séculos depois do Renascimento, Baukunst constrói uma nova realidade da metrópole francesa ao suprimir seus edifícios monumentais. Para a imagem em questão, poderíamos citar a retirada da Tour Eiffel e do Trocadéro, em primeiro pla-

1 Revista Criticat \#3,03/2009, p. 112-113. Baukunst Architects apresenta a vista aérea de Paris sem monumentos, a cidade com seus parques, eixos, boulevards, mas sem sua monumentalidade edificada. 
no, dos Les Invalides, Grand e o Petit Palais, mais ao centro, e mais ao fundo o Louvre, o arco do Carrousel, entre outros. o exercício permite verificar que tal monumentalidade está presente na essência da cidade, na forma de organização de seu território, independente de seus grandes edifícios. Estaríamos, dessa forma, observando o poder do projeto e da perspectiva como instrumento de projeto, como transmissor de conteúdos estéticos definidos.

Tomando como base a estratégia de Baukunst, poderíamos pensar que o estudo da produção arquitetônica atual nos encaminharia para discussões que abordam a arquitetura valendo-se de visões oriundas de diversas áreas do conhecimento ${ }^{2}$. No entanto, sob o ponto de vista do interesse de nossa pesquisa, algumas delas revelaram-se incapazes de contribuir para o debate proposto. Essa constatação não pretende negar a validade de tais visões mas sim afirmar a escolha por autores cujo trabalho está mais próximo dos assuntos primordiais do tema, ou seja, da arquitetura e do espetáculo.

Sendo assim, parece-nos importante abordar a es- petacularização da arquitetura, fenômeno que vem ocupando de maneira significativa boa parte das publicações recentes. Isto se faz necessário para a definição do caminho aqui escolhido, ou seja, aquele que pesquisa a arquitetura do espetáculo por meio de seus valores ligados ao conjunto de manifestações artísticas voltadas para o espetáculo.

Nas duas últimas décadas, a facilidade de movimentação de uma crescente população com recursos econômicos, a dinâmica cultural criada pelo incremento da disponibilidade do tempo de lazer, o bombardeio de imagens na sociedade do espetáculo, forjada no zapping televisivo, geradora das cenografias urbanas midiáticas, colocaram o museu de arte no centro do novo sistema icônico que toda cidade "globalizada" deseja possuir. Assim teve início uma concorrência entre os arquitetos renomados, que além de resolver os problemas técnicos e funcionais dos museus projetados, identificaram-nos com a sua linguagem pessoal. (SEGRE, in Kiefer, 2008, p.109)

2 A referência é feita, por exemplo, a importantes publicações como a de Kate Nesbitt - Uma nova Agenda para a Arquitetura. São Paulo, Cosac Naify, 2006 ou ainda O Campo Ampliado da Arquitetura: Antologia Teórica (1993-2009) DE A. KRISTA SYKES, SÃO PAULO, COSAC NAIFY, 2012. 
O raciocínio de Roberto Segre, construído para a situação de espetacularização da arquitetura dos museus, pode ser estendido para grande parte da produção de arquitetura recente.

O espetáculo da arquitetura ocupou, nos últimos anos, um espaço significativo na mídia especializada em particular e em toda a mídia em geral. É notável como as relações de mercado e a propaganda política lançam mão da espetacularização da arquitetura em benefício próprio. A situação pode estar ainda mais próxima da própria natureza da arquitetura , como observa Guy Duplat:

Os mais importantes arquitetos sonham com sua mise en scène, sua cenografia pessoal, seu look (...) - atuam como personagens de teatro. O que importa em arquitetura, a partir de então, é «fazer o acontecimento», e a informática permite conceber arquiteturas que «fazem acontecer». [destaques do autor $]^{3}$

$\mathrm{Na}$ realidade, pode-se admitir que se trata de uma situação mais abrangente, pois o que estamos assistindo é a espetacularização da vida, da própria vida cotidiana. Guy Debord (1992) já detectara de maneira precisa esse processo desde a década de 1960. Mario Vargas Llosa ampliou a abrangência do tema em sua recente obra $A$ Civilização do Espetáculo (2013), o que confirma as observações percebidas no campo da arquitetura, como vamos discutir mais adiante.

O processo pode ser encarado como fruto da falta de formação ou da desinformação ou ainda da má formação do espectador urbano. Para Otília Arantes (1998, p. 145-146), não se trata mais de encará-lo como "o homem da multidão", repetindo com maior intensidade a alegoria de Baudelaire. Estamos lidando com outro personagem, cuja falta de substância fica clara pela forma como se deixa fascinar pelo caos urbano, pelo mundo de frivolidade, conclui. A afirmação da autora se apoia num discurso filosófico para situar-nos perante o público que assiste ao espetáculo das intervenções urbanas desmedidas baseadas numa avalanche discursiva e projetual, dentro do contexto arquitetônico da década de 1990. No que se refere à arquitetura como protagonis-

3 COMMUNAUTÉ FRANÇAISE WALLONIE-BRUXELLES - Architectures, Wallonie-Bruxelles. Inventaires 2005-2010, p. 124. Nossa tradução do texto original: Les architectes les plus importants soignent leur mise en scène, leur scénographies personnelles, parfois leur look (....), et jouent des personnages de théâtre. En architecture aussi, ce qui compte désormais pour certains, est de "faire l'événement" et les programmes informatiques permettent aux architectes de concevoir des architectures qui "font l'événement". 
ta dessas intervenções, tal processo se intensifica como um dos sintomas da própria transformação cultural que se acelera nas duas décadas posteriores a esse texto, como ainda veremos nesta introdução.

Tal fenômeno, no que se refere à produção arquitetônica, tem sido detectado há um certo tempo por outros autores. Peter Collins já admitira a existência de rivalidades entre arquitetos, o que, segundo ele, contribuiu para esse processo, mas o explica com outros argumentos:

Infelizmente, a introdução da fotografia tem atuado contra a estandardização funcional, pois antes da aparição das revistas não parecia irracional que localidades distantes tivessem edifícios públicos similares, mas a facilidade de comparar duas fotografias criou inevitavelmente o falso sentido de rivalidade entre os arquitetos, para que cada comunidade se sinta obrigada a ter edifícios públicos que sejam originais, embora a solução racional do problema seja resultante de formas padronizadas. (COLLINS, 1998, p. 236) ${ }^{4}$
Collins pretende explicar com esse raciocínio o porquê da busca obsessiva da originalidade na arquitetura em prejuízo das qualidades essenciais da obra representada, naquele momento, pelos preceitos da Modernidade.

0 que estaríamos assistindo agora é a predominância de projetos que privilegiam valores de singularidade em detrimento da identidade da obra. Encontrar maneiras de se destacar, criar uma valor singular, em relação a determinado território em que a obra se insere, indiferentemente às condições do lugar, apontando uma clara sobreposição a suas características locais, seria uma busca evidente de espetacularização da obra. Nesse caso fica clara a falta de identidade da obra, daquilo que demonstra sua essência, que seria compensada ou substituída pelo valor de singularidade, pelo poder da diferença, do extraordinário, do espetacular.

Há quem, como Helio Piñon, acredite que o projeto de arquitetura como conhecimento é uma atividade desprovida de praticidade, do imediatismo das soluções da vida contemporânea, o que explicaria, segundo ele, a baixa

4 Nossa tradução do texto original: Desgraciadamente, la introducción de la fotografía ha actuado contra esta estandardización funcional; pues antes de que existiesen las revistas ilustradas de arquitectura, no parecía irracional que dos localidades lejanas, tuvieran edificios públicos similares; pero la facilidad de comparar dos fotografías ha creado inevitablemente un falso sentido de rivalidad entre los arquitectos, por el que cada comunidad se siente obligada a tener edificios públicos que sean "originales", aunque la solución racional del problema de la acomodación esté resulta por formas estandard. 
qualidade da arquitetura atual, restrita a sua espetacularização:

Não há dúvidas de que esse modo de proceder conta com o relativismo mais generoso como referência estética idônea para sua sobrevivência: responde à situação atual na qual a ideia de arte mais difundida é a que a confunde com o espetáculo, e o espetáculo se identifica com a exibição do despudor, tanto nas televisões como nas cidades. (PIÑON, 2006, p. 82)[nosso destaque]

O trecho da citação de Hélio Piñon em destaque leva-nos a perceber a dificuldade de se estudar a arquitetura e o espetáculo, tema que se situa também na difícil fronteira que tem unido ou separado profissionais do espetáculo e os arquitetos ao longo da história.

Cabe, dessa forma, precisar que o que tratamos como tema é a Arquitetura do Espetáculo, que significa o espaço de manifestações artísticas - dramáticas, musicais, folclóricas etc. - concebido, apropriado ou transformado, e pertencente ao território da cidade que, em nossa disser- tação, é o território da cidade de São Paulo e sua região central.

Dentre as diversas razões que podem justificar a escolha desse território estão aspectos importantes que têm feito parte do debate face à urbanização descontrolada: os ganhos sociais e econômicos gerados por equipamentos culturais inseridos em centros urbanos problemáticos já são conhecidos em diversas experiências realizadas nos últimos anos. Casos emblemáticos no contexto latino americano, como o de Medellín na Colômbia ${ }^{5}$, podem ser citados como bem sucedidas intervenções em que a Arquitetura é a protagonista. Porém sabe-se também que, como afirmou Ana Carla Fonseca ${ }^{6}$ em recente seminário realizado sobre o assunto, "Um equipamento cultural, sozinho, não impacta no entorno - vide a Sala São Paulo, que é magnífica como equipamento cultural, mas não se insere no espaço em que se situa."

O objetivo do presente trabalho, portanto, é compreender o papel da arquitetura do espetáculo nesse processo de reconquista do espaço urbano deteriorado e aferir qual

5 Rede de parques-bibliotecas instalados em regiões violentas da cidade; acessível em: http://www.isatvideo.com.br/Canais/culturaetransformacaourbana/Channel.aspx

6 Ver Folha de São Paulo, de 16/02/13. Ana Carla Fonseca é economista e doutora em urbanismo, foi curadora do Seminário Internacional de Cultura e Transformação Urbana, realizado em 22 e 23/11/2011 em São Paulo. Acessível em http://www.redbcm.com.br/arquivos/cidadescriativas/ana-carla-fonseca-cidadescriativas.pdf 
é sua contribuição para a prática da própria arquitetura e para a construção de uma metodologia. Dessa forma, as seguintes perguntas podem ser formuladas: há qualidades adquiridas pela arquitetura em função das condições e exigências do tema? No sentido inverso, em que medida o mundo do espetáculo se beneficia da qualidade arquitetônica das obras?

Durante nosso processo de pesquisa relativa à Arquitetura do Espetáculo percebemos a necessidade de estudar a noção desse tema e sua manifestação na Modernidade. Isso se justifica pela autonomia da forma assumida pela Arquitetura desde o século XVIII e consolidada pelo Arquitetura Moderna, ou seja, a autonomia e a abstração organizadas segundo critérios visuais capazes de revelar a essência do objeto arquitetônico. Esse aspecto nos é útil para entendermos os valores assumidos pela arquitetura do espetáculo na metrópole e qual foi sua capacidade em indicar caminhos e em se tornar referência urbana.

Para esse estudo, propomos relacionar obras significativas, selecionadas em função de sua relevância dentro do cenário da historiografia da Arquitetura Moderna, e obras realizadas recentemente na cidade de São Paulo para, dentro dessa forma de análise, destacar aspectos importantes relacionados ao tema e à reconquista dos espaços urbanos deteriorados, em particular, o Centro de São Paulo.

Há portanto um "roteiro", um trajeto que parte de estudos dessas obras da Arquitetura Moderna até chegar à região central de São Paulo. Essa escolha foi também motivada pela vigência na cidade da Lei dos Teatros ${ }^{7}$, que visa incentivar a construção de equipamentos com essa finalidade - o espetáculo -, não considerando sua área construída para efeito dos cálculos de área máxima permitida, até o limite de $25 \%$ do total. Por essa diretriz é possível constatar que a arquitetura do espetáculo será associada a conjuntos multifuncionais, a fim de poder desfrutar dos benefícios da lei, cujos efeitos práticos não serão discutidos por nós. 
Capítulo 1 a Arquitetura do Espetáculo: Noção e Metodologia 
Toda a vida das sociedades em que reinam as condições modernas de produção apresenta-se como uma imensa acumulação de espetáculos. Tudo aquilo que era diretamente vivido se distanciou em uma representação. ${ }^{8}$

(DEBORD, 1992, p. 15)

Uma das estratégias que utilizamos em nossa pesquisa foi, como dito na introdução, a pesquisa bibliográfica de autores, nem sempre especializados, que apresentaram pontos de vistas que avaliamos serem úteis para a melhor compreensão do tema. Não nos pareceu, como poderemos observar neste capítulo, haver um arcabouço ou um lastro teórico definido que possa ser considerado detentor das bases de uma análise segura e definitiva sobre a Arquitetura do Espetáculo. Ficará demonstrado que a forma apresentada, como um mosaico de reflexões, muitas vezes opostas ou contraditórias, ilustram a própria dificuldade de definição do tema.

Por que então dedicar tanto espaço à noção e à metodologia e não as tomar prontas de uma corrente teórica? Acreditamos ser necessário construí-las, discutir o que dizem os autores, ainda que esse caminho não tenha sido suficiente para definir uma linha de análise definitiva para as etapas seguintes do trabalho. Ele apontou, no entanto, fundamentos significativos tanto do ponto de vista da relação da arquitetura com o espetáculo como deste com a cidade, o que, dessa maneira, mostrou sua importância para orientar cada uma das etapas. Em outras palavras, as noções recolhidas junto aos autores estudados, ainda que sem uma aparente linha de raciocínio clara, uma teoria, trouxeram para a pesquisa elementos que nos auxiliam no conhecimento do tema e mesmo na tentativa de definí-lo: o que é a Arquitetura do Espetáculo? ou haveria uma Arquitetura do Espetáculo?

8 Nossa tradução do texto original: Toute la vie des sociétés dans lesquelles règnent les conditions modernes de production s'annonce comme une immense accumulation de spectacles. Tout ce qui était directement vécu s'est éloigné dans une représentation. 
Para alguns autores, deveríamos fazer, a princípio, uma distinção clara entre espetáculo e teatro. É o caso de Pierre Francastel ${ }^{9}$, para quem essa distinção deve ser observada em função da sua evolução em determinadas civilizações e em períodos históricos precisos. Haveria diferenças significativas, em especial a partir do momento em que o teatro deixou de ser a visualização do texto sacro, durante o Renascimento. Mas o teatro é antes de mais nada um espetáculo, acrescenta o autor. Francastel observa com bastante pertinência que a grande discussão que se coloca é em relação à definição do lugar do espetáculo, "o Lugar do Teatro", em suas palavras. Seria para uns o espaço físico, material, a arquitetura onde se passa o espetáculo teatral. É nesse ponto que se pode estabelecer a relação entre o projeto e a cidade. Há quem defenda, afirma por outro lado Francastel, que é o quadro mental, o texto, a ação, um «lugar essencialmente imaginário". Aqui podemos relacioná-lo com a cidade e a cena. Seria esse um dos grandes desafios da arquitetura do espetáculo: como conciliar um lugar ma-

O Concreto e o Imaginário terial e um lugar imaginário.

9 FRANCASTEL, P. Le Théâtre est-il un Art Visuel? in Bablet, [1963] 2002, p. 77. 
0 autor faz ainda em sua conferência ${ }^{10}$ um paralelo entre a música e o teatro, ao afirmar que da invenção do instrumento até a criação da obra escrita há sempre um longo período de aprimoramento, que passa obrigatoriamente pela construção de diversos outros instrumentos que são abandonados ao longo do tempo, mas que são fundamentais para a dinâmica geral da criação artística. Isso fica claro em uma de suas afirmações:

As grandes obras são aquelas que ultrapassaram os meios técnicos disponíveis. (...) Há sempre uma relação dialética entre o instrumento e a obra, um afrontamento. (FRANCASTEL, [1963] 2002, p. 80) ${ }^{11}$

Comparar o teatro com o espaço urbano, com o surgimento da cidade, com a era das capitais e com a metrópole é um procedimento que será encontrado com frequência em nosso trabalho, como aconteceu na leitura de Lewis Munford. $\mathrm{O}$ autor faz diversas referências ao tema em seu livro A Cidade na História (1982). Em suas reflexões ele observa como, desde as colonizações primitivas temporárias, havia aspectos que se relacionavam com uma vivência mais

10 O livro, Le Lieu Théâtral dans la Société Moderne (BABLET, Denis, Paris, CNRS Ed., 2002), é o registro das conferências apresentadas durante o colóquio do mesmo nome realizado em Raimond, França, em 1961.

11 Nossa tradução do texto original: Les grandes oeuvres sont celles qui ont dépassé les moyens techniques existants. (...) II y a toujours rapport dialectique entre l'instrument et l'oeuvre, affrontement. valiosa e significativa, além da simples sobrevivência física, onde podemos perceber os primórdios de instituições cívicas tais como o teatro, além da universidade e do templo.

A relação desperta ainda maior interesse quando Munford afirma:

Não é apenas no teatro que o espectador sente serem os atores maiores do que na vida real. É esta uma ilusão característica produzida pela cidade, porque o centro urbano é, na realidade, um teatro. (1982, p. 83)

A citação ilustra como a arquitetura urbana vai se tornando o lugar dos jogos sociais, das relações humanas próprias de cada momento civilizatório, alimentando um verdadeiro drama diário, ou, como diz o autor que aqui nos serve de referência: "Dentro do teatro da cidade, representavam-se novos dramas da vida." (MUNFORD, 1982, p. 613)

Observamos nesse caso como essa criação humana, a cidade, passa de mero cenário a instrumento, ou seja, deixa de ser o suporte para inspirar novos textos, novas ações, para ser o engenho capaz de gerar novos conteúdos, torna-se cena. 
Preocupado com aspectos de outra ordem, muito mais próximos da construção visual da cidade, Kevin Linch, na obra A Imagem da Cidade (2011), observa que o modo atual da experiência urbana nos faz ser atraídos por formas de organização em sequência, seguindo um modelo temporal, familiar ao teatro e à música. Assim, a cidade tradicional, clássica, possui início, clímax e final, enquanto a metrópole se assemelha muito mais a peças aparentemente indetermináveis, variadas, muito próximas do jazz.

Seu texto é fartamente ilustrado por fotografias e desenhos que demonstram de maneira precisa suas ideias, constituindo-se em um verdadeiro roteiro pleno de cenários urbanos.

Algumas de suas afirmações se aproximam, por exemplo, das preocupações estéticas dos realizadores teatrais das vanguardas artísticas do início do século XX, como Adolphe Appia e Gordon Craig ${ }^{12}$. Na medida em que os valores estéticos são baseados na abstração da forma, essa relação fica mais clara. Isso pode ser observado quando ele fala

\section{A Imagem do Espetáculo} sobre Qualidades da Forma:

12 Sobre Appia e Graig ver o cap. O Lugar do Espetáculo. 
Precisamos de novas ideias sobre a teoria das formas que são percebidas como uma continuidade no tempo, bem como de arquétipos de design que exibam uma sequência melódica dos elementos da imagem, ou uma sucessão formal de espaço, textura, movimento, luz ou silhueta. (LYNCH, 2011, p. 120)

Poderíamos dizer, baseando-nos em suas análises, que o juízo de valores dessas "novas ideias" seria necessário para uma percepção do território da cidade como construção visual de ordem superior, como proposto pelas vanguardas artísticas da década de 1920, de que fizeram parte Appia e Craig no teatro.

Apesar de dedicar sua obra às artes plásticas, Fernad Leger, em Funções da Pintura (1989), entende que encarar o mundo em todas as suas manifestações visuais é uma das necessidades fundamentais de nossa existência, é verdadeiramente falar de espetáculo. Nesse sentido se aproxima das ideias de Lynch ao chamar a atenção para a importância do forte significado expressivo da qualidade visual da cidade, ao mesmo tempo em que reserva um espaço significativo para a ruptura com as formas estabelecidas:

Romper entre o visual da sala e o da cena, fazer o indivíduo desaparecer, para usar o material humano. Criar uma cena de invenção. O material humano aparece, mas igual, como valor-espetáculo, ao objeto e ao cenário. (LEGER, 1989, p.131)

Leger, durante conferência na década de 1920, apresenta por meio desse raciocínio a importância da construção visual da ação como estratégia para a renovação da arte através do espetáculo. Por esse caminho, o artista-estrela não poderia se tornar um obstáculo para a unidade visual da cena, como completa o autor.

Podemos exemplificar tal proposta com o espetáculo Einstein on the Beach, de Robert Wilson e Philip Glass, de 1989, uma obra musical lírica baseada na construção de um universo gráfico e espacial em que os elementos cênicos, luz, objetos e atores, são tratados de maneira semelhante.

Há quem, com uma outra visão, não compartilhe das

13 No livro Funções da Pintura, o trecho é parte da conferência O Espetáculo Luz, cor, imagem móvel, objeto-espetáculo, de 1924, publicada no Bulletin de I'Effort Moderne, Paris. 

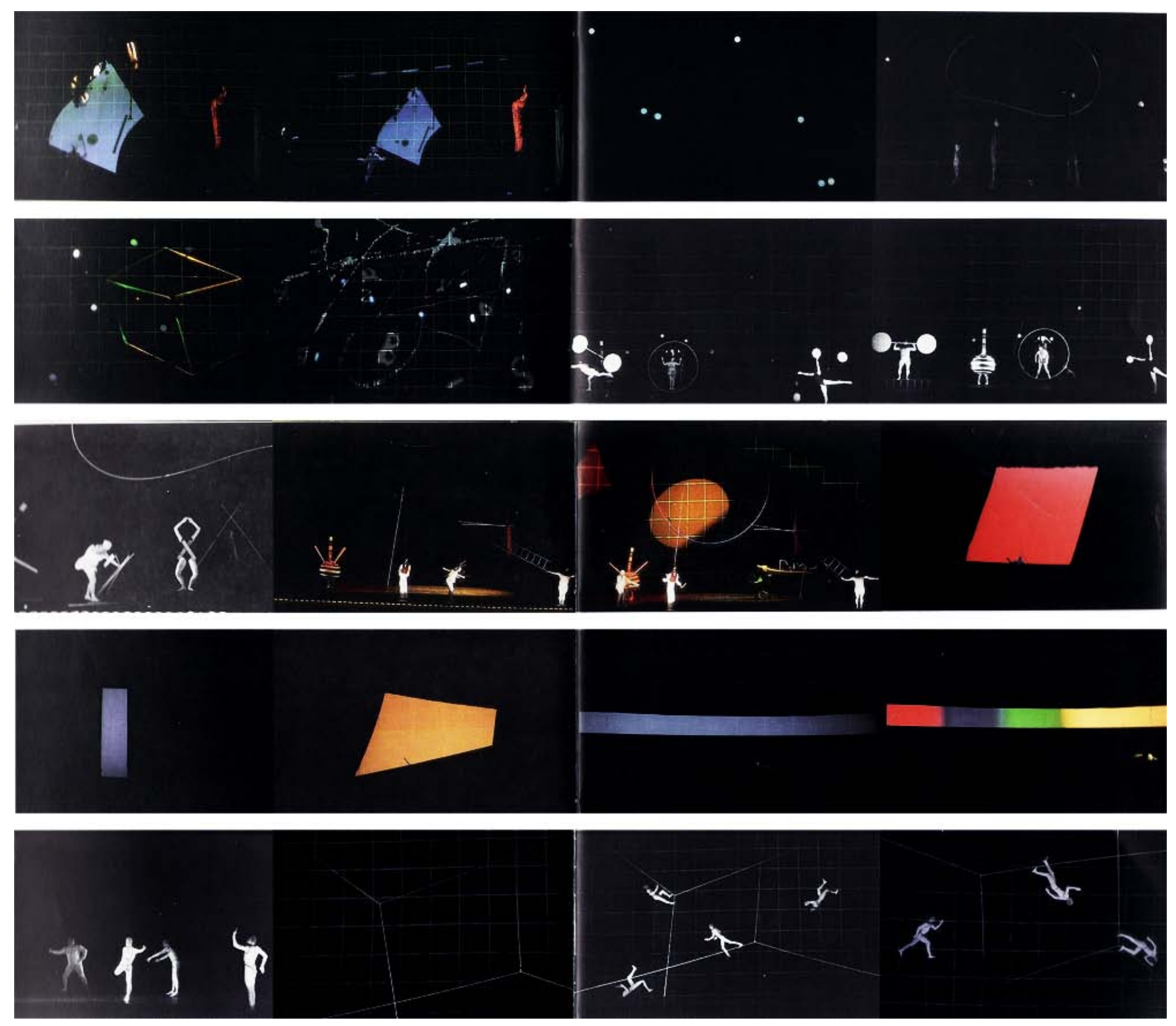

Einstein on the Beach, Robert Wilson e Philip Glass. Fonte: Staatsthheater Stutgart, 1989. 
considerações de Lynch e da visão pictórica de Leger, como Jane Jacobs que afirma sobre a Ordem Visual da Cidade:“... uma cidade não é uma obra de arte." (2009, p. 415)

Para a autora, a forma adequada é dada à cidade por sua vitalidade, sua dinâmica e complexidade. Isso explicaria, de uma certa maneira, o porquê da decadência ou do caos urbanos: a ausência de clareza em sua ordem funcional levaria determinadas regiões ao descontrole e ao abandono. Mas ela admite, mais adiante, que a afirmação anterior não pode ser tão radical como possa parecer em uma primeira análise. Isso fica mais claro quando acrescenta:

Não é necessário que os projetistas tenham um controle literal sobre todo campo de visão para dar ordem visual às cidades. É raro a arte ser tão cabalmente literal, e se for, é uma arte pobre. (JACOBS, 2009, p. 421)

Nesse caso, Jacobs estaria admitindo, de maneira menos direta, a importância que a ordem visual representa para a vitalidade da cidade, ainda que baseada, segundo ela, na complexidade e na força dos usos de determinadas regiões.

Mas não estaríamos, com esse debate, distanciando-nos do interesse do presente trabalho? Acreditamos que não, na medida em que entender as ideias ligadas diretamente ao tema - a arquitetura do espetáculo - e relacioná-las àquelas que permeiam o campo de sua aplicação - a cidade -, é um caminho que pode nos ajudar a responder às questões colocadas na introdução.

Se Jacobs dedica maior importância à diversidade de atividades como caminho para a recuperação das "regiões apagadas da cidade", conforme suas palavras, não descarta, entretanto, o projeto como meio de atingi-la. Faz, ao contrário, uma reflexão sobre os "limites e potencialidades da ordem visual", à qual dedica todo um capítulo.

Não nos parece também que autora faça apenas uma oposição ao funcionalismo ingênuo ao propor a dinâmica funcional da cidade baseada na diversidade. Condena, é verdade, a criação de conjuntos especializados, como os centros administrativos ou os centros culturais que desfi- 
guraram determinadas cidades durante as décadas de 1960

e 1970, como é o caso do Carnegie Hall e do Lincoln Center em Nova York:

(...) o Carnegie Hall é uma peça de xadrez vital que atua conjuntamente com outras peças. O plano mais desastroso que se poderia arquitetar nessa vizinhança seria a demolição do Carnegie Hall e sua substituição por outro edifício de escritórios. Foi exatamente isso o que quase aconteceu em resultado da decisão do município de Nova York de pegar todas as peças culturais mais expressivas, ou potencialmente expressivas, e segregá-las num núcleo planejado chamado Lincoln Center for Performing Arts. O Carnegie Hall foi salvo por um fio, graças à obstinada pressão política de cidadãos, embora não vá mais ser a sede da Filarmônica de Nova York, que se "descontaminará" da cidade comum. (JACOBS, 2009, p. 185) [Em itálico e entre aspas no texto original]

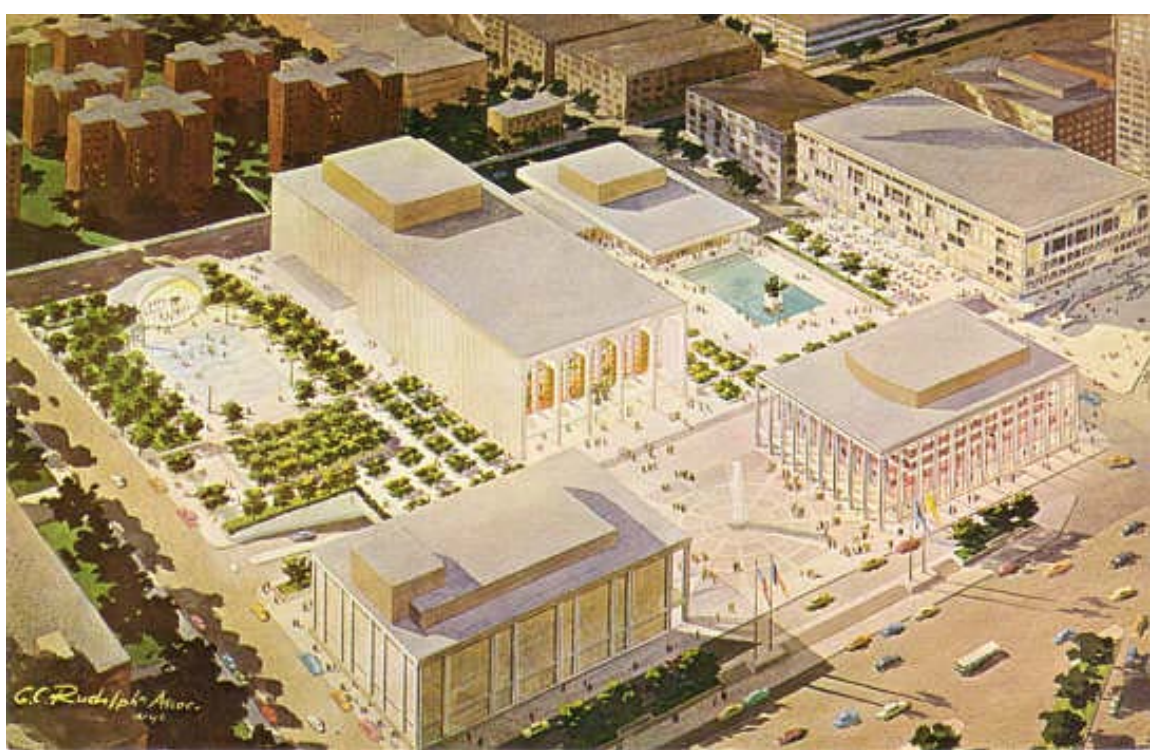

Lincoln Center - Nova York - Vista aérea ilustrada. Fonte: Lincoln Center 
As ideais de Peter Collins (1998), já citado por nós, colocam a arquitetura do espetáculo como sendo de especial interesse para compreender a evolução da arquitetura na Modernidade. Segundo ele, os teatros, além dos hospitais e prisões, tornaram-se ilustração histórica permanente no idealismo funcionalista desde o século XVII. Segundo ele, foram esses temas tratados com destaque por arquitetos, tratadistas e pensadores que discutiram a renovação da arquitetura dentro de uma perspectiva funcional, baseada em modelos e protótipos.

0 autor salienta que a relação entre as exigências funcionais, isto é, a visibilidade, a acústica, as condições de segurança, e a expressão arquitetônica é um dos problemas cruciais da era moderna, e conclui:

O problema de criar inequivocamente uma expressão arquitetônica pode parecer insolúvel por três atitudes mutuamente excludentes. Por exemplo, pode-se declarar que cada programa é susceptível de várias soluções; pode-se declarar que um edifício moderno necessita ser o mais adap- 
tável possível, e portanto que o exterior deve expressar esta flexibilidade; ou se pode ter a visão de que o funcionalismo implica formas compositivas padronizadas. (COLLINS, 1998, p. 238) $)^{14}$

Essa reflexão nos pareceu útil para estabelecer parâmetros de compreensão e de comparação entre os projetos analisados nos próximos capítulos. Collins percebe claramente a dificuldade que a Arquitetura enfrentara mais intensamente a partir do século XIX na conciliação entre seus preceitos, sua funcionalidade e seu papel perante a cidade, situação que se torna ainda mais evidente na produção arquitetônica recente, o que poderemos aferir pelo percurso estabelecido nessa pesquisa. Isso torna-se importante se pretendemos estabelecer uma metodologia de análise que não se restrinja a um determinado ponto de vista ou ainda a um recorte excludente, o que poderia reduzir nossas possibilidades de compreensão. É o que ocorre, por exemplo, na obra a seguir.

José Teixeira Coelho Netto, em seu livro A Construção do Sentido em Arquitetura, utiliza a arquitetura teatral para verificar sua formulação em busca de uma Teoria da Produção do Espaço (1979, p. 111-116).

$\mathrm{O}$ autor parte dos conceitos da Economia Política, que ele sugere gerar uma outra disciplina, a Economia Política do Espaço, e conclui não haver a produção do espaço teatral, pois não se pode falar em produção arquitetônica teatral, na medida em que todas as etapas de tal teoria, produção, distribuição e consumo, não se concretizam. Nesse caso, a recepção do conteúdo teatral não se daria devido a problemas de ordem técnica e de organização, baseados na configuração da sala, que impediriam que o processo se completasse. Segundo ele, ao observar teatros históricos de cena frontal à italiana, fica claro que o distanciamento do espectador, posicionado em pontos cegos da plateia, impede que haja as etapas necessárias para a plenitude do espetáculo. Com esses argumentos, para Coelho Neto, estaria comprometida a troca entre autores, atores e o público, função primordial do teatro.

Tal argumento se torna frágil, mesmo considerando o momento em que o texto foi escrito (final da década

14 Nossa tradução do texto original: El problema de crear inequívocamente una expresión arquitectónica puede parecer insoluble por tres actitudes mutuamente excluyentes. Por ejemplo, se puede declarar que cada programa es susceptible de varias soluciones ( y por lo tanto no cabe ya pensar en una sola expresión funcional auténtica); se puede declarar que un edificio moderno necesita ser lo más adaptable posible (y por lo tanto que el exterior debe expresar esta "flexibilidad"), o se puede tener la visión (ya expuesta con respecto a los teatros, hospitales y 
de 1970), pois apesar dos limites que tal solução tradicional representa, não se pode desconhecer as pesquisas que tanto arquitetos como encenadores e pensadores teatrais vêm empreendendo desde o século XIX, como bem lembrou Collins. Tais pesquisas, intensificadas durante a década de 1920, têm sido alvo de grande interesse desde as últimas décadas do século XX e início do século XXI, como trataremos no capítulo A Metrópole em Cena.

Pode-se tentar ainda entender seu posicionamento quando afirma que: “...a recepção das formas de arte dispensa a intelecção racional e é mesmo grande a tentação de declarar que o juízo é mesmo prejudicial à percepção estética."(COELHO NETO, 1979, p. 130)

A visão de Coelho Netto em nada contribui para o compreensão dos fatos urbanos, em particular aqueles ligados à presente pesquisa. Se o conhecimento do tema e a procura do seu entendimento são condições para sua avaliação, é razoável que seja feito um esforço para a compreensão da obra arquitetônica por seus valores essenciais. Nisso, auxilia-nos Hélio Piñon:
Cada produto da concepção moderna encontra sua legalidade formal ao concluir o processo de concepção: a ordem é específica de cada objeto e aparece só ao final do projeto. Tal estrutura, própria de cada artefato, lhe confere uma identidade concreta: lhe faz "ser algo", sem necessidade, portanto, de "parecer-se algo".

A identificação do problema, prévia à proposta arquitetônica - de caráter artístico - seria necessariamente racional, mas a arquitetura não baseia seus critérios de concepção em preconceitos racionais, senão em processos de intelecção visual nos quais a proposta de forma resolve situações de projeto, ao mesmo tempo que revela o caráter atípico de sua natureza. (PIÑON, 2008, p. 50)

0 raciocínio de Piñon não se opõe às dificuldades apontadas por Collins para a concepção do projeto. Ao contrário, explica a arquitetura como disciplina, capaz de construir seu sentido através dos processos que lhe são próprios e não daqueles originários de outras disciplinas.

Nesse caso estaríamos nos aproximando do proje- 
to do lugar do espetáculo baseado no estabelecimento de tipos ou de protótipos, como proposto pelo Movimento Moderno?

Se a resposta for afirmativa, deveríamos seguir o traçado de Nikolaus Pevsner (1979) ao descrever a história da arquitetura baseada no elenco das obras mais significativas, classificadas por tipologia de usos, como os Teatros. Esse mecanismo é útil para compreendermos a evolução técnica dos edifícios teatrais, mas se torna limitado para entendermos os processos de projeto e sua relação com os valores próprios da arquitetura, com a história e com a cidade. Isto é, a comparação entre as diversas obras nos parece um procedimento fundamental, porém a perspectiva deve prosseguir dentro das condições estabelecidas pela própria arquitetura, sem que sejam abandonados os mecanismos usados inicialmente, que, de acordo com cada momento histórico, podem ter sido de ordem tecnológica, estética ou mesmo política.

Se, ao contrário, relativizarmos esse caminho conhecido pela historiografia, poderemos melhor avaliar as obras escolhidas ao identificarmos seus mecanismos de projeto, próprios da arquitetura, ou mesmo, próprios da arquitetura do espetáculo, sem contudo perder a perspectiva em relação ao quadro urbano e social com o qual ela se relaciona, o que nos parece mais apropriado. Em outras palavras, se admitimos que desde as vanguardas artísticas da década de 1920 ocorre um profundo questionamento da própria atividade do teatro, do lugar essencialmente imaginário a que se refere Francastel, seria razoável dizer que o método de classificação por tipologias seria de difícil sustentação. Como conclui Alan Colquhoun, sobre a Tipologia e Metodologia de Projeto:

Minha intenção ao sublinhar esse fato [sobre a preexistência de complexos tipológicos para a resolução de problemas] não é defender o retorno de uma arquitetura que aceita a tradição de modo irrefletido. Isso seria o mesmo que afirmar a existência de uma relação fixa e imutável entre formas e significados. A mudança é a característica de nosso tempo, e justamente por isso é preciso investigar o papel que as modificações de soluções-tipo desempenham com relação aos problemas e soluções que não têm precedentes em qualquer tradição. (in NESBITT, 2006, p. 282) 


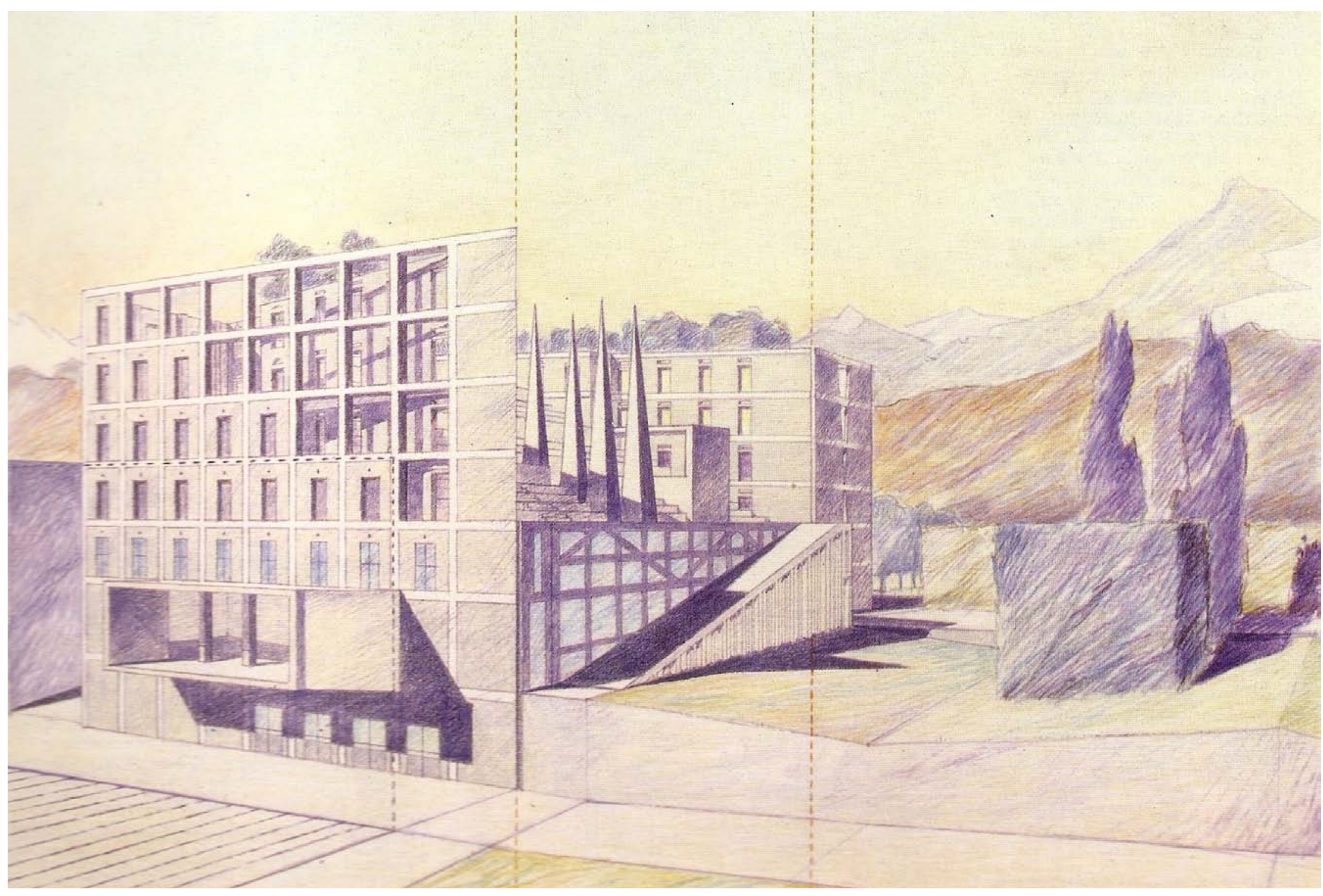


Na visão de teóricos do teatro, como Denis Bablet (2002), o questionamento do lugar do espetáculo não deve passar pelas modificações dos detalhes decorativos interiores ou exteriores do edifício. Na realidade, o pesquisador alerta para o fato desse questionamento se dar muito mais em relação à estrutura do espaço, que vai dos modelos mais tradicionais da cena frontal à ocupação de edificações históricas ou abandonadas, ou ainda os espetáculos ao ar livre ou sob tendas móveis. Baseando-se nos raciocínios de grandes cenógrafos, diretores teatrais e pensadores do teatro como Gordon Craig, Adolphe Appia e Reinhart, Bablet lembra que os inúmeros teatros transformáveis, construídos tanto na Europa como na América do Norte, já mostraram todo o seu potencial de flexibilidade, mas as dificuldades de agilidade e os custos envolvidos para tal atributo não devem ser ignorados. E conclui:

Antes de ser um problema de estrutura arquitetô- 
Ora, vivemos em uma sociedade profundamente instável, em plena transformação. A variedade de propostas em matéria de lugar teatral é a imagem dessa instabilidade. Em período de transição não se pode desejar soluções definitivas, ou mesmo duráveis, nem elaborar uma doutrina rígida. Em primeiro lugar uma sociedade e uma dramaturgia, em seguida uma arquitetura teatral que delas se emane. (BABLET, 2002, p. 25) ${ }^{15}$

Tal transformação, a que se refere Bablet em 1962, pode ser comprovada pela própria evolução da noção de cultura, que, como nos mostra Mario Vargas Llosa (2013), modificou-se de maneira assustadora em pouco mais de meio século, uma "metamorfose", usando sua definição. Para prová-lo, o autor faz uma revisão de ensaios significativos sobre o assunto, desde a noção da "alta cultura" de T. S. Eliot, até a "cultura-mundo" de Gilles Lipovetsky e Jean Serroy, passando por importantes publicações de George

15 Nossa tradução do texto original: Avant d'être un problème de structure architectonique, de moyens d'expression et d'esthétique, le problème du théâtre est d'abord un problème de société. Or nous vivons dans une société profondément instable, en pleine transformation. La variété des propositions en matière de lieu théâtral est à l'image de cette instabilité. En période de transition on ne peut souhaiter de solution sinon définitive, du moins durable, ni élaborer une doctrine rigide. D'abord une société et une dramaturgie, ensuite une architecture théâtrale qui en soit l'émanation.

\section{Steiner e Guy Debord. ${ }^{16}$}

Por esse panorama percebe-se como a cultura vai se subordinando à imagem em detrimento da palavra, do discurso falado e escrito. Steiner, citado por Vargas Llosa, discorre sobre como a contracultura eliminou a hierarquia ou a linha divisória entre as culturas superior e inferior, entre o civilizado e o primitivo. Considera sua evolução vítima do abandono da tradição, em que "a vida ativa passará a ter a vida artificial do arquivo". (STEINER, G. apud LLOSA, 2013, P. 18-19)

Ao mesmo tempo, as proposições de Guy Debord, que Vargas Llosa considera muito mais que culturais, pois utilizam raciocínios econômicos, filosóficos e históricos, confirmam como a vida se transformou em espectadora de si mesma, como a representação substituiu a vivência, um sintoma de empobrecimento humano, segundo ele.

A metamorfose chega a nossos dias através dos con-

160 autor destaca (p. 11-27) os seguintes ensaios sobre a metamorfose da nocão de cultura:

ELIOT, T. S. - Notas para uma Definição de Cultura, Madrid, Faber and Faber, 1962; primeira edição 1948.

STEINER, George - En el Castillo de Barba Azul. Aproximación a un nuevo concepto de cultura. Barcelona, Gedisa, 2006; primeira edição 1971.

DEBORD, Guy. La Société du Spectacle. Paris, Galimard, 1992.

LIPOVETSKY, Gilles e SERROY, Jean. La Cultura-mundo. Resposta a una sociedad desorientada. Barcelona, Anagrama, 2010. 
ceitos desenvolvidos por Lipovetsky e Serroy, em especial a cultura-mundo, que é a verdadeira cultura de massas, graças à ação da revolução científica e tecnológica que vem eliminando as fronteiras geográficas, promovendo a aproximação entre tradições, crenças e línguas. A indústria cultural se apropriou dessa condição favorável para transformar a cultura em artigo de consumo de massas. Isso é possível pelo predomínio da imagem e do som sobre a palavra, o que os autores chamam de mundo-tela, que dessincronizou e desregulou o espaço-tempo da cultura:

De T.S. Eliot a Frédéric Martel a ideia de cultura experimentou muito mais que uma evolução paulatina: uma mudança traumática, da qual surgiu uma realidade nova em que restam apenas rastros da que foi substituída. (LLOSA, 2013, p. 27)

Poderíamos, então, admitir que a identificação desses "rastros" a que se refere Vargas LLosa nos auxiliaria na compreensão do quadro atual que rege a arquitetura do espetáculo e o próprio espetáculo. Quais seriam os valores da arte do espetáculo na busca de novos universos dramáticos em sua aventura perante a cidade? 
Percebe-se que essa estreita relação entre teatro e cidade, ora a inspirar, ora a ser inspirada, revela ser parte do permanente confronto entre os questionamentos da arte e a sociedade. Novamente a comparação se manifesta nas declarações de Marcel Freydefont ([1997] 2008, p. 44):

A metáfora recíproca do teatro e da cidade se mantem portanto viva nesse início do século XXI. Considerá-la atualmente implica contudo se conscientizar de uma transformação da ideia que se possa fazer tanto do teatro como da própria cidade ${ }^{17}$.

Freydemont lembra-nos que o estreito elo entre teatro e cidade está presente desde Alberti ([1452] 2004), quando o arquiteto do Renascimento considerou a cidade como uma grande casa e a casa como uma pequena cidade, ou seja, por analogia, a cidade como um grande teatro e o teatro como uma pequena cidade.

Certamente Alberti referira-se à arquitetura, à cidade edificada. 0 que nos caberia entender agora é em que Abstração e Espetáculo medida as transformações atuais levaram à abstração da

17 Nossa tradução do texto original: La métaphore réciproque du théâtre et de la ville reste donc vive en ce début de XXIe siècle. La considérer aujourd'hui implique cependant de prendre acte d'une transformation de l'idée que l'on peut se faire aussi bien du théâtre que de la ville elle-même. 
cena, baseada na abstração da própria forma edificada, na abstração da cidade, da metrópole, ou seria, ao contrário, a busca da cidade como cenário, como ilustração dramática da cena? Isso significa dizer que a abstração na arte abrira o caminho para a procura dos valores universais presentes na cidade e que a amplificação das relações entre o espetáculo e a arquitetura, entre o espetáculo e a cidade, indica não necessariamente uma volta às suas origens mas sim o encontro dos valores contidos no espaço edificado.

A dúvida persiste sob o ponto de vista de um encenador teatral como Peter Brook:

Sobre qual fundo deve [o corpo] se destacar para estar em conformidade com os imperativos da criação do microcosmos? Como todo lugar fechado tem um fundo, o importante é saber se este serve e a que serve, se ele é vivo ou abstrato. Quanto menos o fundo aparece, mais a ação se destaca, mais a imagem se liberta.(...)

Devemos saber o que se ganha e o que se perde. Perdendo a acústica, perde-se um elemento primordial; o mesmo acontece com a concentração; aqueles que se lançam ao teatro de rua correm grande perigo de trair seu objetivo, não levam a sério o desafio técnico que isso significa. (in L'Architecture d'Aujourdshui 152, 1970, p. CXXXIV) ${ }^{18}$

Nessa passagem Peter Brook já identificava em 1970 a complexidade da relação entre a arquitetura e o espetáculo. Caberia uma profunda avaliação, segundo ele, a respeito dos conteúdos que os grupos teatrais pretendiam transmitir e quais seriam as possibilidades de tal ação. Seria esse um caminho para que as perdas citadas por ele não se transformassem em obstáculo, em dificuldade? Naquele momento, depois de uma década de intensa contestação da contra cultura, como observado por Steiner, Brook nos indaga se não estaríamos, em nome da liberação, colocando em jogo a comunicação do espetáculo, que exige foco e concentração.

Observamos que esse tipo de descontentamento segue uma linha no tempo que, apesar de responder a preo-

18 Nossa tradução do texto original: Sur quel fond doit-il se dégager pour être en conformité avec les impératifs de la création du microcosme? Comme tout lieu clos présente obligatoirement un fond, ce qui compte est de savoir si ce fond sert, et à quoi. Il y a deux possibilités, le fond vivant et le fond abstrait. (...) Moins on aperçoit le fond, plus l'image d'une action apparait libérée. Il faut savoir ce qu'on gagne et ce qu'on perd. En perdant l'acoustique on se prive d'un élément primordial. En perdant concentration aussi. Ceux qui tentent le théâtre de rue sont en grand danger de trahir leur but, ils ne prennent pas assez au sérieux le défi technique. 


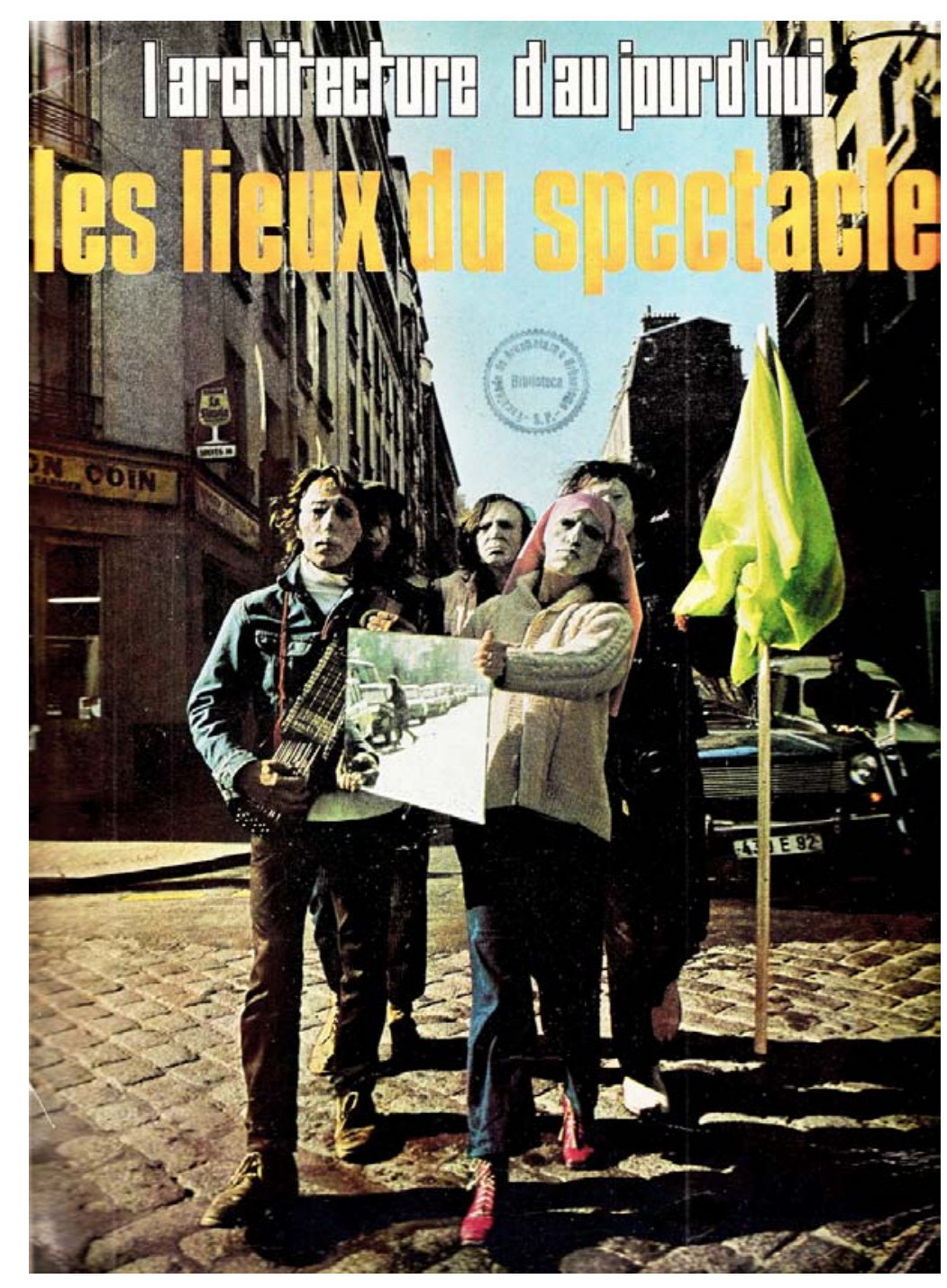

Os Lugares do Espetáculo, capa de L'Architecture d'Aujourd'hui, 152-1970 cupações distintas, ocupam de maneira clara os pensadores teatrais. Na medida em que a evolução da técnica estabelece um caminho fértil para tal liberação, os parâmetros de controle sobre a concentração e a comunicação vão se flexibilizando. Na realidade, poderíamos dizer que novas formas de comunicação e a diversificação dos mecanismos dos jogos dramáticos vêm, ao preencher essa função, compensar essa aparente perda:

\begin{abstract}
Na verdade o problema do lugar teatral só deve ser colocado em relação aos sentidos, ao conteúdo e ao uso do espetáculo. (...)

Para sair do teatro deve-se ter profundas razões. Talvez se tivermos coisas a dizer que não possam ser ditas em um teatro.

(CHEREAU, in L'Architecture d'Aujourd'hui 152, 1970, p. 3-4) ${ }^{19}$
\end{abstract}

Adolphe Appia (in Aujourd'hui, Art et Architecture 15,1958 p.7) declarou serem fundamentais o fim da passividade do espectador e a mudança de sintonia entre espetáculo e público. Para ele, a arte é antes de tudo uma atitude

19 Nossa tradução do texto original: En fait ce problème du lieu théâtral, on ne doit se le poser qu'en relation avec le sens, les contenus et l'utilisation du spectacle. (...) Pour sortir du théâtre il faut avoir des profondes raisons. Peut-être si l'on a à dire des choses qui ne peuvent être dites dans un théâtre. 
e, para que isso seja possível, a aproximação seria indispensável. Poderíamos interpretar essa postura pela materialização da sala em arena, com a plateia envolvendo a cena ou ainda como o espetáculo saindo ao encontro do público, ou seja, da cidade.

Tal proximidade preconizada por Appia pressupõe uma adesão, uma participação do público. Anne-Marie Gourdon (in L'Architecture d'Aujourd'hui 152, 1970, p. 8) explica como a participação se tornou um mito capaz de tudo resolver. Mas qual participação?, pergunta a autora.

Na realidade o teatro permitiu, desde o início do século XX, que fossem reunidas multidões em torno do espetáculo, como no Grosse Schaupielhaus de Hans Poelzig de 1919, uma forma de valorização quantitativa promovida pelo teatro popular, como na Antiguidade. Orientado pelo encenador Max Reinhart, Poelzig constrói em Berlin sua grande arena, um palco envolvido pela manifestação coletiva promovida por seus 3.500 espectadores.

Em seguida, a participação se transformou na adesão ao teatro político, que segundo Gourdon, seria uma

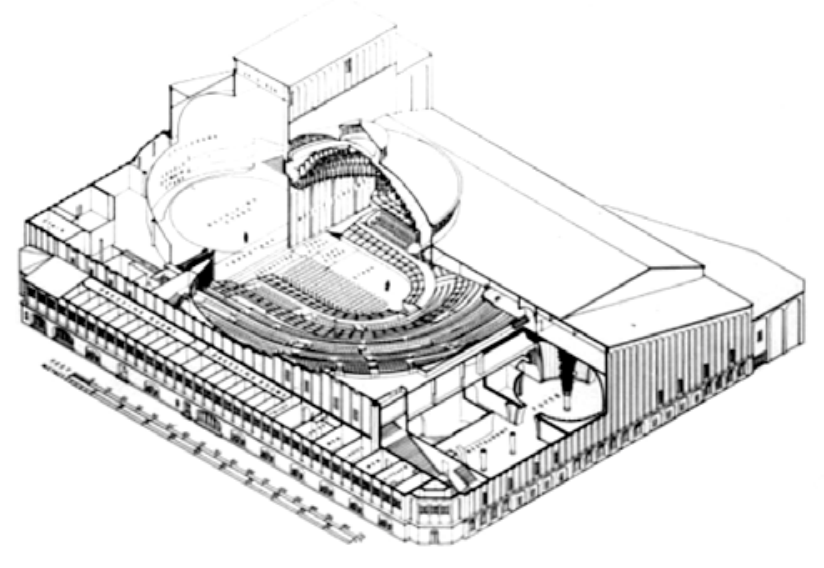

Grosse Schaupielhaus Berlim. Fonte: www.library.calvin.eu

participação imperativa, mais do que comunicativa. Nesse aspecto poderia ser considerada oposta àquela que estabelecia o distanciamento como forma de compreensão do espetáculo, pois o envolvimento do espectador com as personagens prejudicaria seu entendimento.

A evolução até aquele momento levou à cena que se desenvolve com os atores no meio do público, como é o caso do Living Theater $^{20}$, mas que não obriga uma participação, sendo na verdade uma forma participativa profunda através do recolhimento. Em outros casos, em especial em espetáculos do novo teatro norte americano, o público

20 Living Theater trabalha com teatro experimental desde 1947 em Nova York, defendendo a supressão dos limites entre teatro e vida, público e cena; é o teatro como luta política pela desobediência civil. Em 1970, colaborou com o Teatro Oficina em São Paulo. Importante notar que em inglês britânico a grafia correta é theatre enquanto em inglês americano é theater. 
é convidado a reagir, a criar parte da cena, realizando um verdadeiro encontro coletivo e participativo.

Para Dario Fo (in L'Architecture d'Aujourd'hui 199, 1978, p. 9), o teatro deveria se moldar à situação. 0 dramaturgo explica como a sociedade italiana se manifesta publicamente por meio de manifestações coletivas, públicas, de espetáculos, e as condições devem ser estabelecidas em função das necessidades de cada situação. Não haveria relevância no lugar do espetáculo desde que estivessem garantidas as condições para sua plena realização, em todos os espaços possíveis:

Com suas ruas, praças e edifícios públicos, a cidade é o mais vasto lugar de espetáculos. Em escalas diferentes, as manifestações valorizavam esses espaços, embelezavam-nos, até os idealizavam. (...)

Juntos, esses espaços, praças, igrejas, mercados, escolas, etc, formam um só lugar do espetáculo. Como uma cena que muda de cenário, a cidade é um teatro 21 .

(DUPAVILLON, in L'Architecture d'Aujourd'hui 199, 1978, p. 9)

21 Nossa tradução do texto original: Avec ses rues, ses places et ses édifices publics, la ville est le plus vaste lieu de spectacle. A des échelles différentes, ces manifestations valorisaient ces espaces, les embellissaient, les idéalisaient même (...) Ensemble ces lieux ne forment bien qu'un seul espace du spectacle. Comme une scène qui change de décor, la ville est un théâtre.

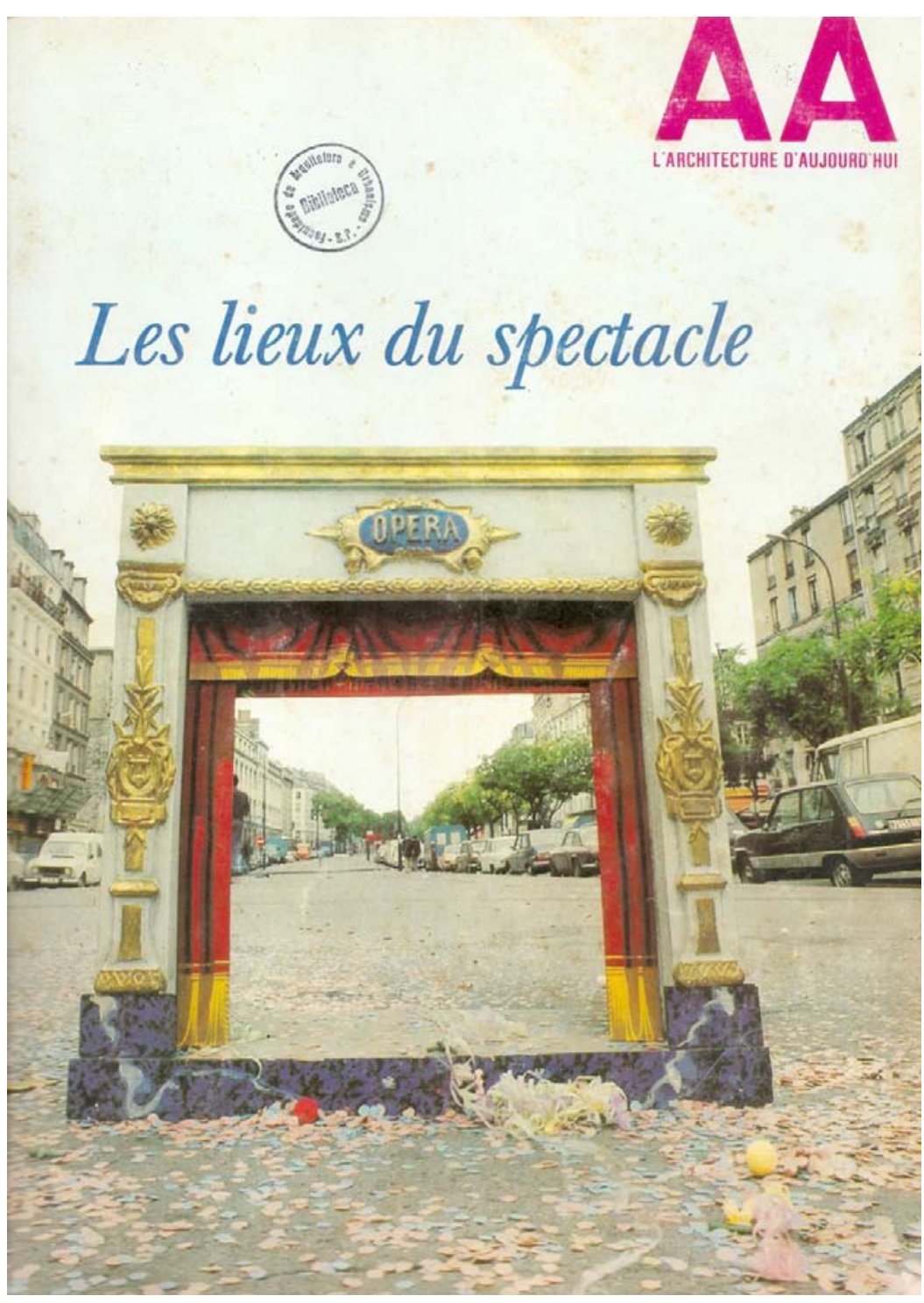

Os Lugares do Espetáculo, capa de L'Architecture d’Aujourd'hui, 199 - 1978 
Dentro do panorama descrito acima, complexo e em muitos casos contraditório, parece-nos oportuno investigar o tema não pela compreensão de seus aspectos de natureza social e nem mesmo sob a perspectiva da renovação de seus conteúdos teatrais - pois estaríamos nos distanciando dos nossos objetivos principais ligados ao projeto arquitetônico e sua metodologia - mas sim, analisar como o tema foi abordado pela Arquitetura Moderna e de que forma vem se manifestando. Acreditamos ser essa uma contribuição para o entendimento de algo que há muito nos surpreende: um aparente distanciamento entre os encenadores ${ }^{22}$ teatrais e

\section{À Procura do Projeto} a arquitetura do espetáculo.

22 Segundo a professora Maria Lúcia Puppo, em depoimento recolhido, encenador é o diretor teatral que dá um passo adiante e lança um conceito de teatro, uma ideia sobre a cena, é um verdadeiro criador, alguém que pensa a cena e quase sempre escreve sobre o assunto. 


\section{Como bem observa Marina Waissman:}

(...) a arquitetura é uma atividade concreta e prática, e qualquer tipo de reflexão a que ela se refere conservará uma relação mais ou menos direta com a praxis. É dessa forma que a teoria, definida como sistema de pensamento, pode assumir a forma normativa, isto é, um sistema de leis ou normas que determinam como deve ser a arquitetura

$$
\text { (...) (WAISSMAN, 1993, p. 29) }{ }^{23}
$$

Pretendemos assim utilizar o Projeto não somente como objeto de análise crítica mas também entendê-lo como instrumento de pesquisa e reflexão.

Acreditamos que essa estratégia de pesquisa pode, através da compreensão do objeto projetado ou construído, reconhecer suas qualidades e seus defeitos. Isso significa perceber qual foi o conhecimento e o caminho adotados por cada arquiteto na solução do problema apresentado pela arquitetura do espetáculo. Nesse sentido parece-nos inoportuno restringir o trabalho ao reconhecimento de teorias aplicadas às obras estudadas ou mesmo inseri-las histori-

23 Nossa tradução do texto original: (...) la arquitectura es una actividad concreta y práctica, y cualquier tipo de reflexión que a ella se refiera conservará una relación más o menos directa con la praxis. De ahí que la teoría, definida como sistema de pensamiento, puede asumir la forma de una normativa, esto es, un sistema de leyes o normas que determinan cómo ha de ser la arquitectura (...) camente em seu contexto para entendê-las.

Essa é uma forma de classificação encontrada em grande parte da historiografia crítica que aborda o tema, o que nos parece insuficiente para a compreensão da arquitetura que aqui destacamos e, sobretudo, sua íntima relação com a cidade.

Segundo Helio Piñon, é fundamental que a atividade de projetar seja apoiada em juízos de reconhecimento das estruturas internas da obra, e, para isso, é preciso educar o olhar. Citando Kant, ele acrescenta: “O juízo estético não pode ser ensinado, aprende-se com a prática" 24

A comparação é também o recurso de verificação que todo artista, consciente ou inconsciente, utiliza e pelo qual ele aprende a manifestar o verdadeiro (para ele) o mais definidamente possível. Ele compara cada obra nova com a anterior, de sua própria produção tanto quanto a de outros. Ele compara o próprio trabalho com a natureza, assim como com outra arte. Essa comparação é o exercício de sua visão das relações e leva o artista a ver e comparar os opostos: o individual e o universal. (MONDRIAN, 2008, p. 114) [em itálico no texto original]

24 PfElfFER, Helen - Helio Piñón. Idéias e Formas, 1999, p. 53. 

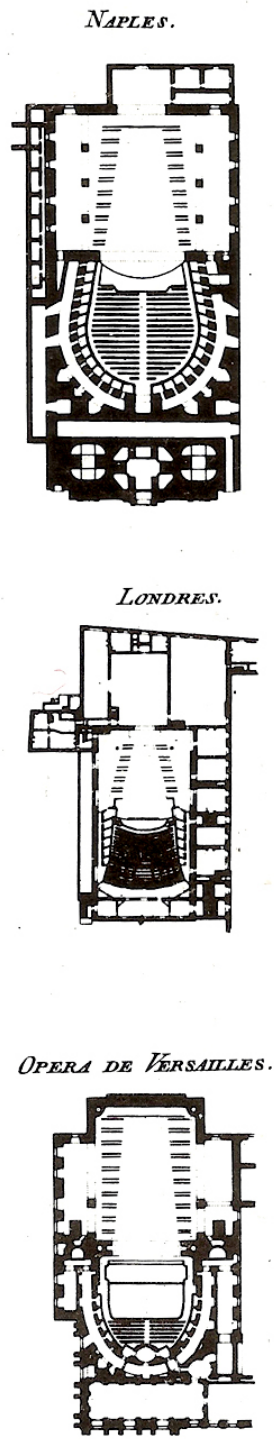
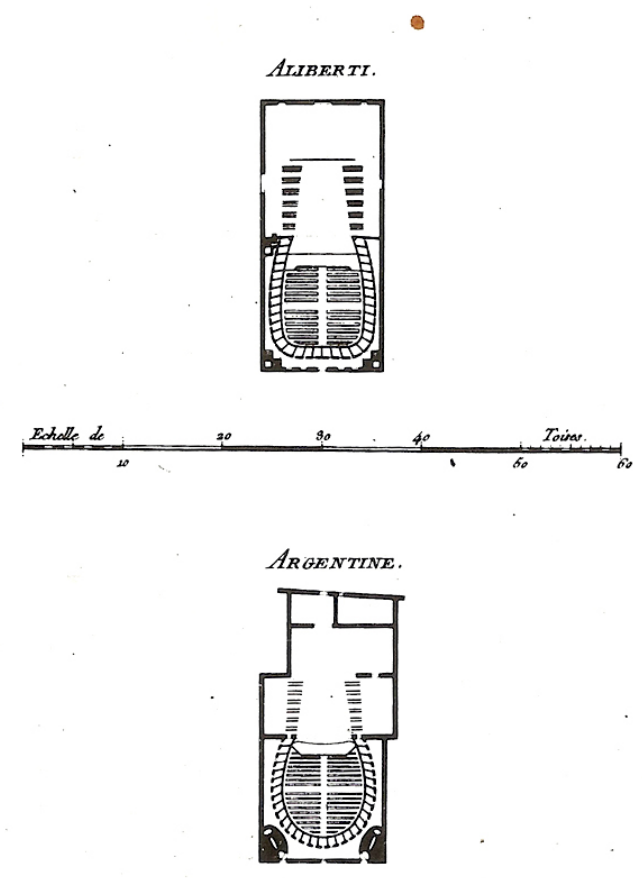

BORDEAUX.

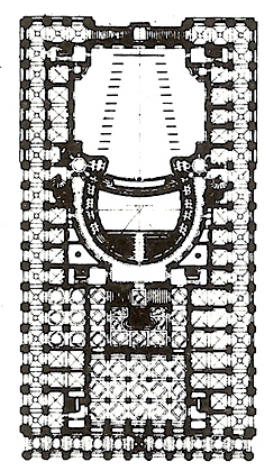

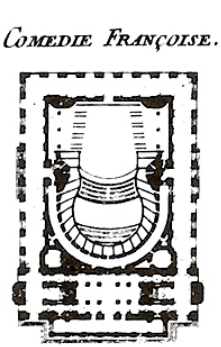

LroN
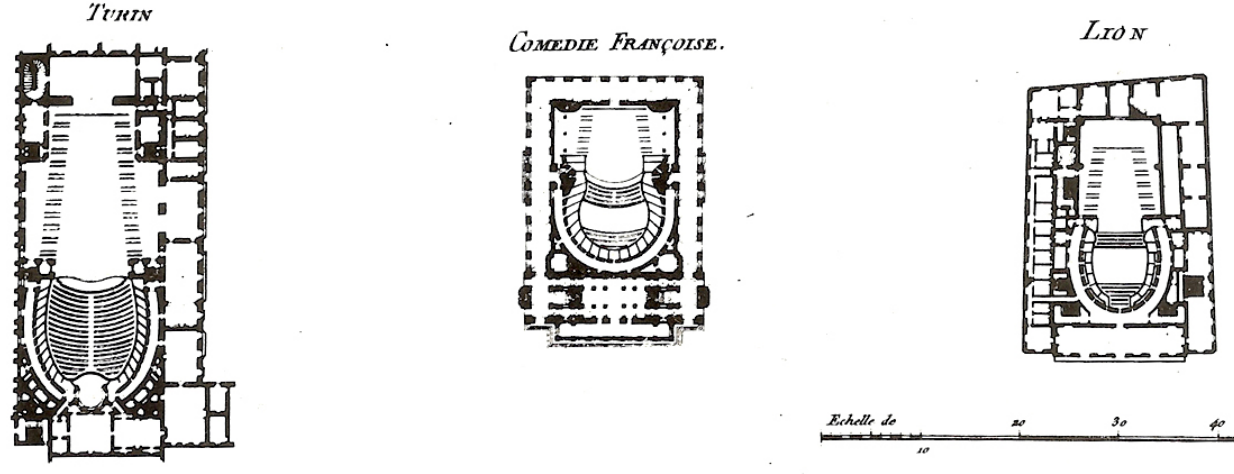

Brthelle de
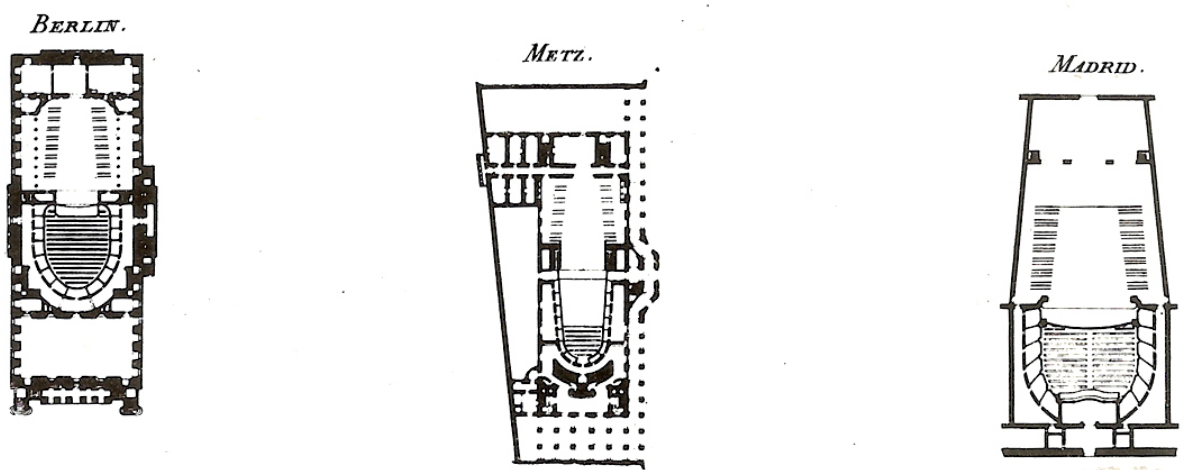

ANCENN OPERA DE PARS.

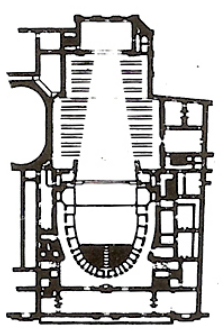

COMÉDIE ITALDENAN
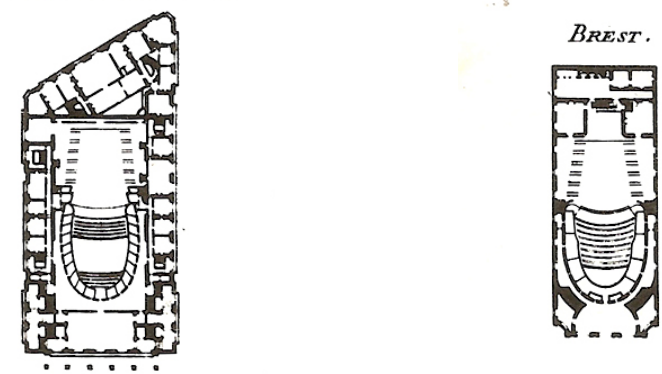

Comparação das plantas dos maiores teatros europeus do século XVIII. Fonte: Pevsner, 1979. 
Colocar lado a lado experiências nem sempre contemporâneas entre si revelou a existência de questões recorrentes que, de uma certa forma, já fazem parte da essência do tema, como poderá ser observado. Poderíamos, então, considerá-las como subtemas a fim de organizar as obras segundo a estreita relação encontrada por seus autores.

Os projetos serão apresentados, de uma certa forma, baseados nesses subtemas:

O Lugar da Arquitetura do Espetáculo, que investiga o espetáculo e sua relação com o lugar, com a transformação do lugar, sua transitoriedade e sua permanência.

A Modernidade como detentora de reflexões que levaram à renovação dos conteúdos cenográficos e arquitetônicos baseados na plena percepção do espaço.

A Metrópole em Cena, que apresenta a Cidade como Teatro, emprestando seus espaços públicos como lugar de cortejos, manifestações; a mobilidade, a cidade como palco, em que a paisagem construída é tema, é cenário, e a Cidade como Monumento que, mesmo desprovida do seus monu- mentos ícones - arcos, torres, catedrais, obeliscos - ainda mantem sua monumentalidade.

Para responder à complexidade das questões levantadas, foi-nos necessário introduzir em nossa proposta metodológica outros subtemas, nem sempre evidentes, encontrados com frequência e utilizados exaustivamente por arquitetos, autores, encenadores e todos os pensadores do mundo do espetáculo, como o valor primordial da obra, a tecnologia, ou ainda a revitalização ou reconversão da arquitetura e do próprio espaço da cidade. Nesses casos, as obras apresentadas, desde o capítulo que aborda a Modernidade chegando até a produção recente em São Paulo, são reveladoras dos aspectos mencionados, como poderemos verificar a seguir. 


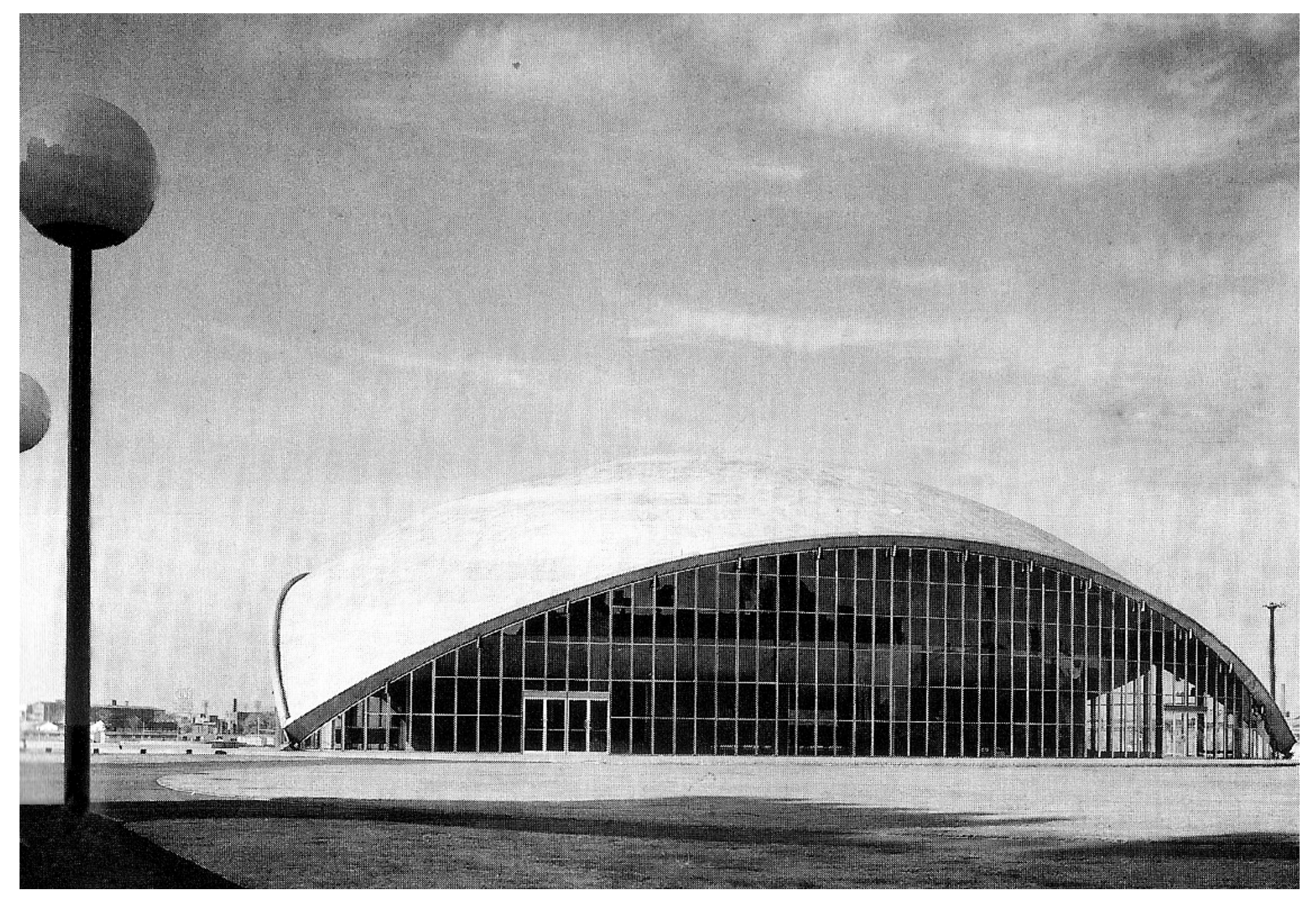

Auditório do Mit - Harvard - Eero Saarinen, 1960, Fonte Forsyth, 1985 
Capítulo 2

- Lugar da Arquitetura do Espetáculo 
(...) o lugar teatral, a partir do momento que deixa de ser improvisado num sítio natural, numa praça pública, ou num local não especializado, desde que é convocado para garantir uma continuidade de representações, torna-se edifício teatral.

$$
\text { (JACQUOT, in BABLET, 2002, p. 225) }{ }^{25}
$$

Como observamos, o lugar do espetáculo está direta e fisicamente relacionado com a cidade ou com o território da cidade, cidade como monumento e como território de apropriações, como meio de expressão. São conhecidas inúmeras manifestações artísticas de caráter urbano em que a cidade não é apenas cenário mas também é argumento, roteiro, personagem.

Houve recentemente um momento significativo da historiografia da arquitetura em que modernidade foi questionada em sua incapacidade de se relacionar com o entorno e em construir cidades.

25 Nossa tradução do texto original: (...) le lieu théâtral, dès qu'il cesse d'être im provisé dans un site naturel, une place publique, ou un local non spécialisé, dès qu'il est appelé à assurer une continuité des représentations, devient édifice théâtral.
Nesse capítulo interessa-nos investigar de que maneira a arquitetura do espetáculo se relacionou com o lugar, ou com a criação da noção de lugar e como contribuiu para sua permanência e sua evolução.

Esse exercício nos parece positivo na medida em que busca entender como o tema foi abordado nas obras destacadas e qual foi a repercussão em relação à produção da arquitetura.

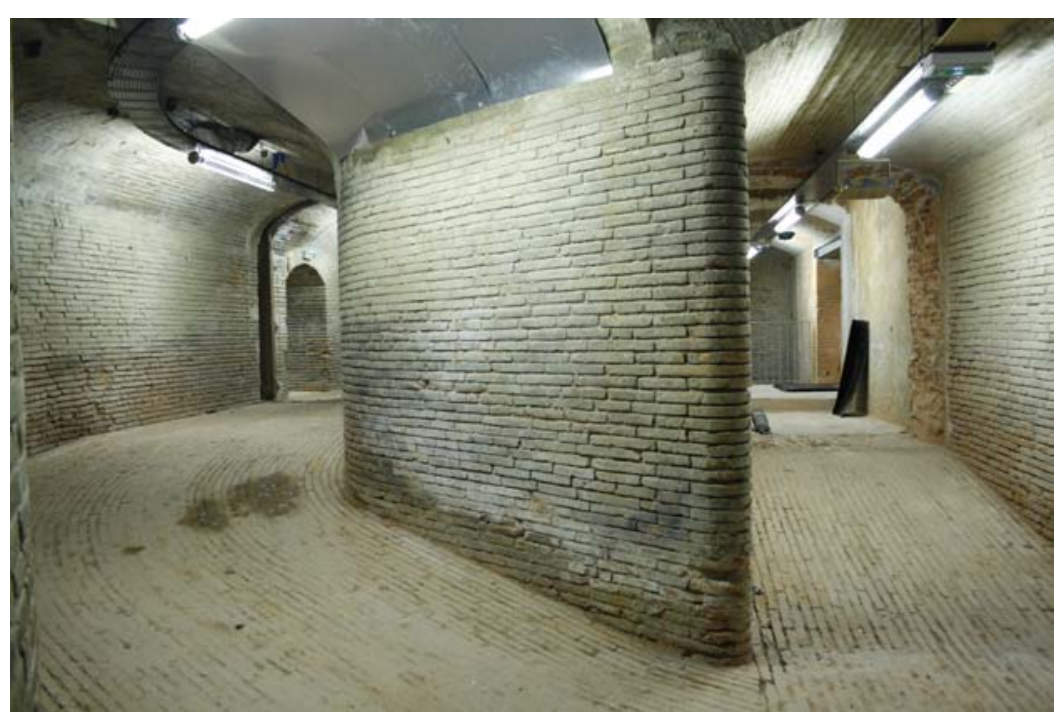

Théâtre Garonne - Toulouse-Galerias da adutora do rio Garonne. Foto: Valério Pietraróia 


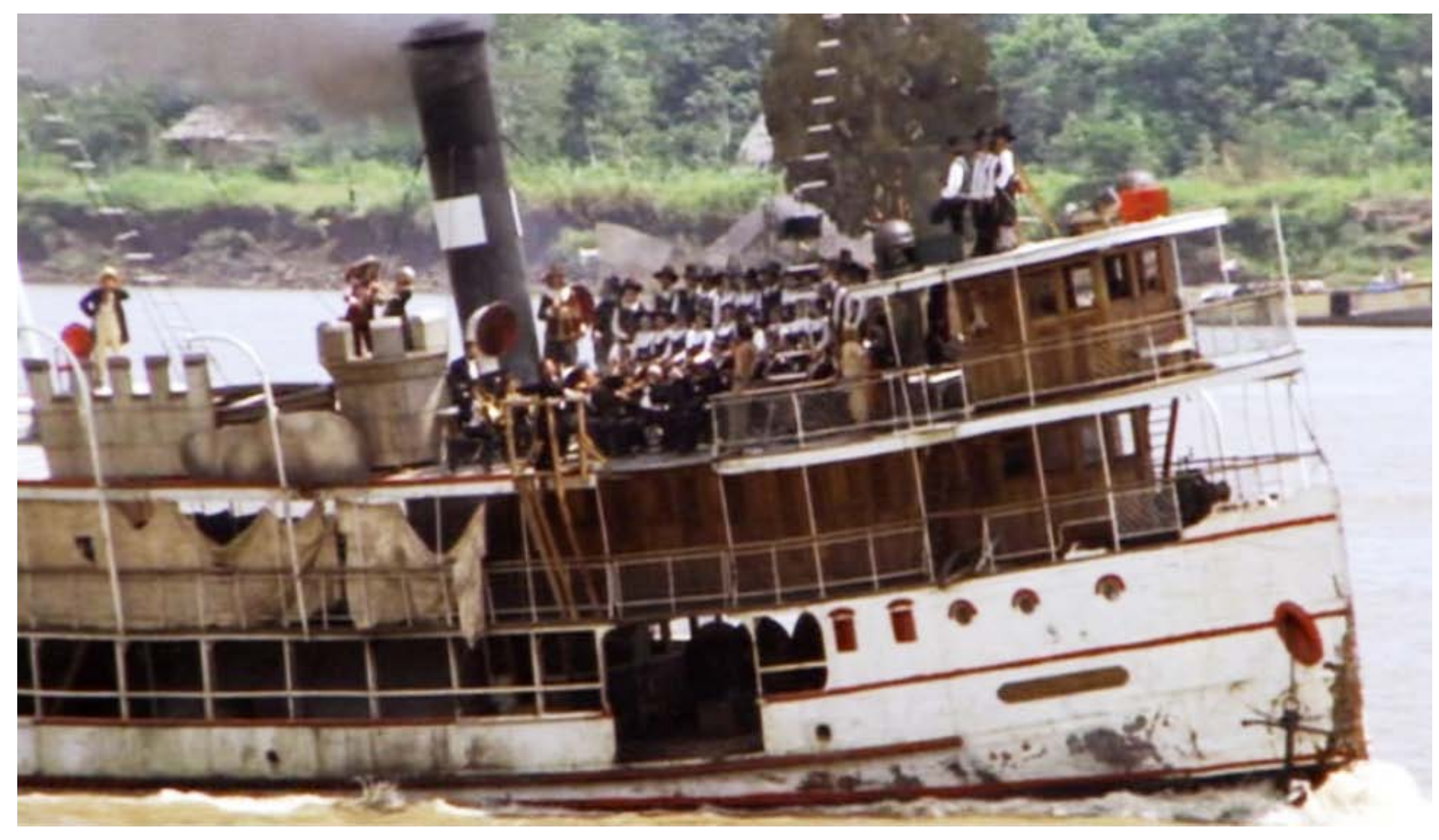

Fitzcarraldo, filme de Werner Herzog, 1982 
Na sequência final do filme Fitzcarraldo ${ }^{26}$, o personagem principal, depois de percorrer sua Odisseia Amazônica, na obsessão de edificar uma ópera em meio à floresta, retorna derrotado ao porto inicial, onde embarcara em seu gaiola ${ }^{27}$, voltando ao início de sua aventura. A construção flutuante, sobrevivente de ataques indígenas e de escaladas morro acima, retorna da longa viagem paradoxalmente de forma triunfante, executando uma ópera em que maestro, músicos e cantores se instalam em decks generosos, e espalham melodias durante seu trajeto fluvial, aplaudidos pela plateia que os assiste em terra firme.

A imagem citada, em que o barco é palco e o rio é teatro, com suas margem repletas de espectadores, ilustra de forma lírica, bem ao gosto do diretor alemão, como as manifestações artísticas expressas por meio de espetáculos representam fonte de inspiração para construtores e realizadores. Podem ser feitas leituras distintas dessa situação excepcional: a ópera fluvial está relacionada com a tradição dos cortejos folclóricos ou religiosos, em que as embarca-

Mobilidade em Cena ções, principal meio de comunicação das populações ribei-

26 Filme de 1982, do cineasta alemão Werner Herzog, com Klaus Kinsk e Claudia Cardinale.

27 Gaiolas: embarcações a motor, que fazem o transporte fluvial de passageiros, no norte e nordeste do Brasil; os passageiros dormem em redes no convés, o que segundo a tradição oral deu origem ao nome gaiolas; as redes balançam de um lado para o outro, tal como os poleiros dos pássaros nas gaiolas. 
rinhas, é o veículo desse espetáculo itinerante. Mas para Herzog a situação criada é o meio para que a expressividade do seu cinema esteja presente no aspecto monumental da obra flutuante. 0 gaiola é o engenho criado pelo homem, capaz de transpor as dificuldades representadas pela floresta e de promover, portanto, o espetáculo.

É interessante lembrar que o aspecto épico e, de certa forma, quase barroco da obra de Herzog, tem um paralelo na monumentalidade da música de George Friedrich Handel. Uma de suas obras mais conhecidas, $W a-$ ter Music, encomendada pelo Rei Jorge I, foi apresentada em 17 de julho de 1717 durante um cortejo naval pelo rio Tâmisa em Londres. A corte foi levada em barcaças abertas do Palácio Real, em Whitehall, até Chelsea, ouvindo, em outra barcaça, a orquestra de 50 músicos tocar a composição de Haendel. Ao longo do trajeto, nas duas margens do rio, a população acompanhou o esplendoroso espetáculo, que se repetiu no retorno do cortejo, após a comemoração dos convidados, até a madrugada ${ }^{28}$. Esse acontecimento ilustra como o lugar escolhido e sua forma de apresentação torna-

28 Ver BURROWS, J.- Guia de Música Clássica, 2008, p. 115.

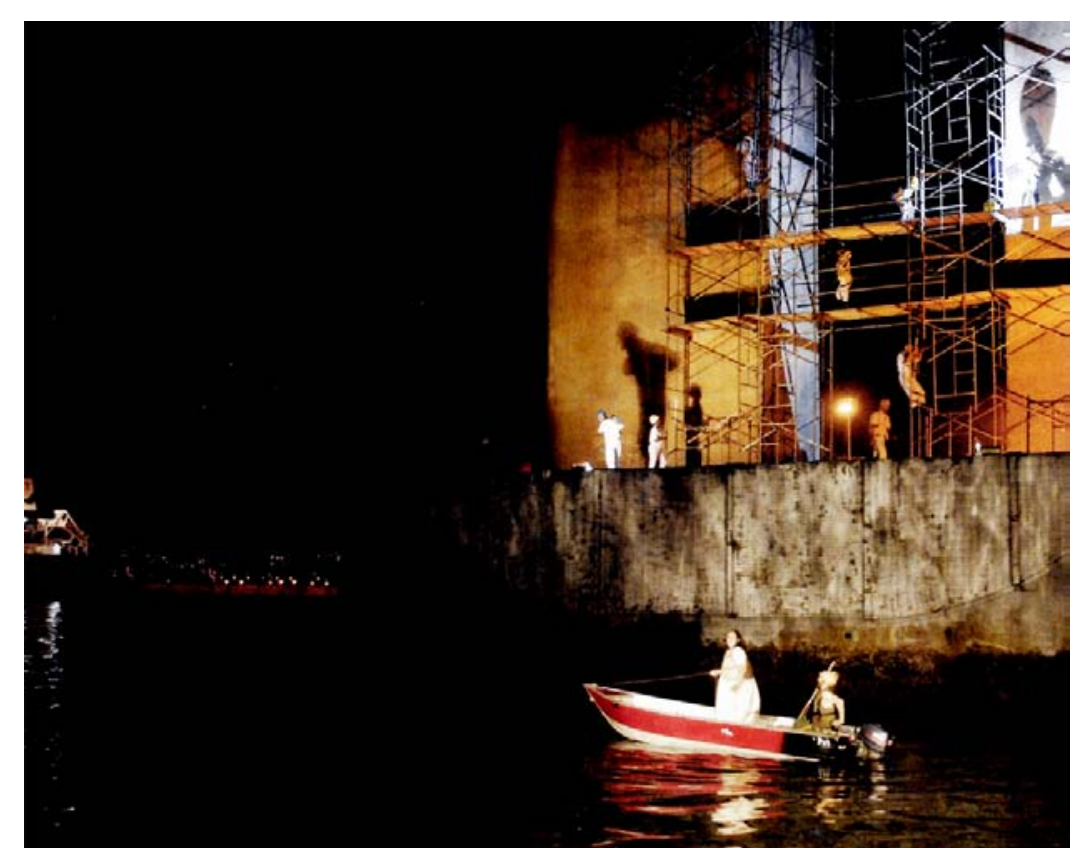

BR3 - Teatro da Vertigem, 2006. A construção de Brasília - metáfora nos viadutos do Cebolão sobre o rio Tietê. Fonte: FERNANDES, 2010.

ram o espetáculo tema, o que está totalmente relacionado com a música de Haendel que, segundo Otto Maria Carpeaux, é grandiosa, assombrosa e sabe, como nenhuma outra, envolver os sentidos. (CARPEAUX, 1958, p. 87)

BR3 $^{29}$ é um espetáculo que foi produzido em São Paulo em 2006 pelo Teatro da Vertigem, em que o barco é

29 Ver FERNANDES, S. 2010, p.95; ver também BARRETO, G. M. 2008. 
a plateia, onde o espectador navega pelo poluído rio Tietê na capital paulista. A ação se desenvolve nas diversas situações criadas e baseadas na pesquisa do grupo voltada para as identidades ou não identidades brasileiras, como explica Sílvia Fernandes. Os lugares escolhidos como cenário fazem parte de uma geografia artificial, um ambiente modificado pela engenharia e pela arquitetura da metrópole, e dão suporte à dramaturgia construída durante as longas viagens de investigação feitas pelo grupo no norte e no centro-oeste do país.

Como afirma Sílvia Fernandes, trata-se de um convite ao público para o "desgarramento", cuja intenção é a de "potencializar o experimento da catástrofe social por meio da vivência real no rio morto (...)" (FERNANDES, S. 2013, p. 415).

Essa imersão radical a que o espetáculo submete o público é fruto do desejo do Grupo de transitar por situações limites como a do "Bom Retiro 958 metros", que encena a vida na metrópole (cf. capítulo 4, A Metropóle Em Cena).
Em Veneza todas as pessoas andam como se estivessem a atravessar um palco: nos seus afazeres, com que nada fazem, ou nos seus devaneios vazios, surgem constantemente a dobrar uma esquina para desaparecerem de imediato numa outra e têm nisso sempre alguma coisa de atores, que à direita e à esquerda da cena não são nada, a representação só acontece ali e não tem qualquer motivação na realidade do antes, nem qualquer consequência na realidade do depois. (SIMMEL, 2011, p. 44)

Quando Georg Simmel fala de Veneza em sua obra $A$ Estética e a Cidade, relaciona, em determinado momento do texto, sua dinâmica urbana ao fato de que o significado do seu cotidiano está baseado na presença, uma presença de palco. Todo o cenário representado pela cidade lacustre estabelece o contraponto ao movimento do público, o ator urbano. Essa permanência da arquitetura como cenário seria renovada de forma definitiva pela vida de seus habitantes.

0 valor de permanência da arquitetura tem interesse particular na obra de Aldo Rossi. O Teatro del Mondo, 

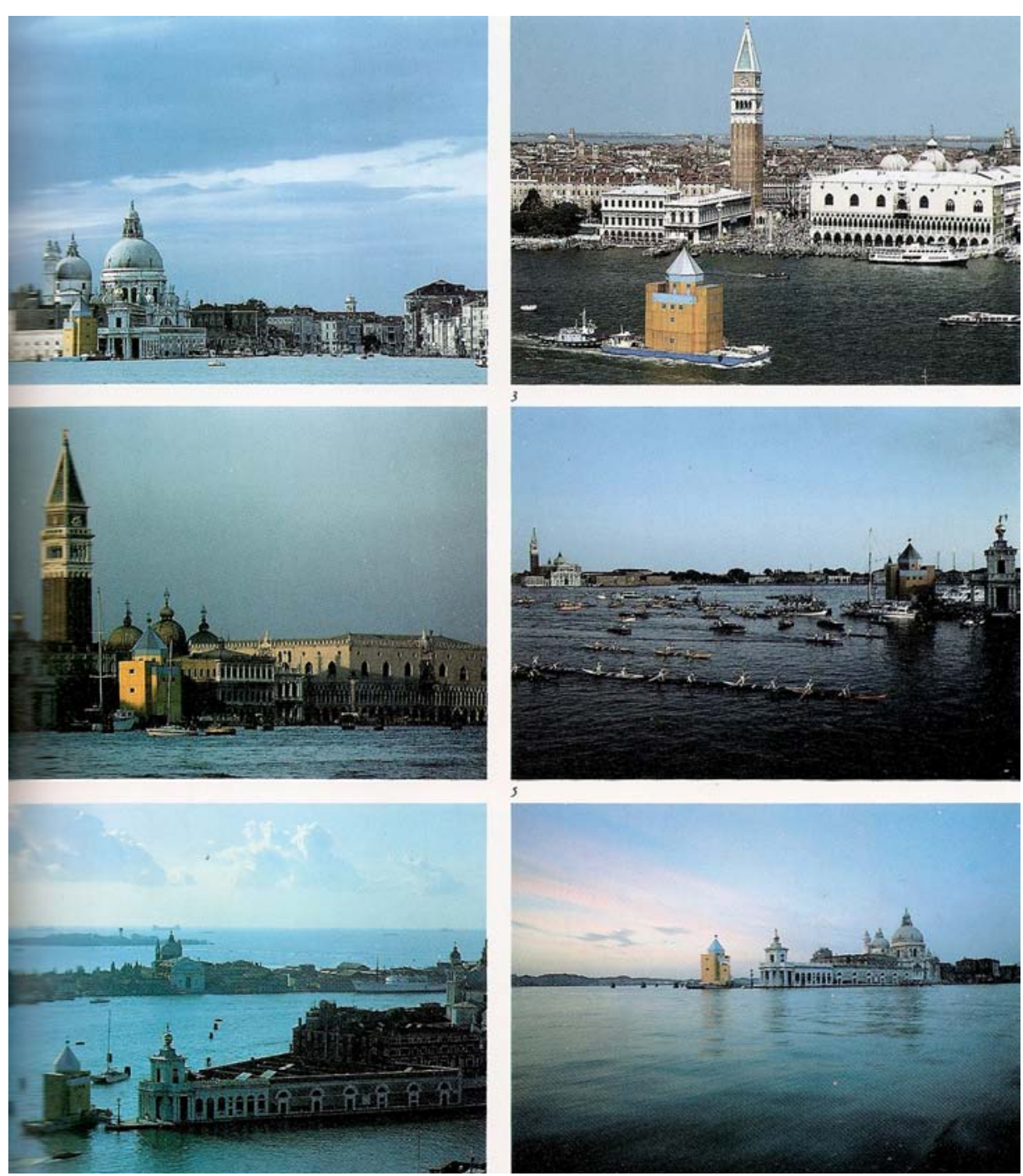

Teatro del Mondo Veneza. Fonte: ROSSI, 1985.

30 DEL NERO, C. - Máquina para os Deuses: anotações de um cenógrafo e o discurso da cenografia. 2009, p.73.

31 ROSSI, A. - A Arquitetura da Cidade, São Paulo, Martins Fontes, 2001. construído para a Bienal de Arquitetura de Veneza de 1980, ao contrário da embarcação usada por Fitzcarraldo como palco, ou o barco do $B R 3$ que é plateia, é o próprio teatro navegante, possível graças à associação do conhecimento naval ao conhecimento teatral. É conhecida na historiografia a contribuição dos conhecimentos da tecnologia náutica para a arquitetura. No caso específico do teatro italiano, toda a tecnologia cênica, que caracteriza sua tipologia de palco, está baseada nos conhecimentos náuticos adquiridos até aquele momento ${ }^{30}$. Aldo Rossi projeta seu teatro veneziano baseado nos conceitos de tipologia ${ }^{31}$ por ele desenvolvidos, bem como na permanência das estruturas arquitetônicas na memória e na cultura da cidade ao longo do tempo. Dessa maneira, essa obra representa para a paisagem da cidade de Veneza o resgate das tradições dos espetáculos marítimos na laguna. 
(...) o Teatro del Mondo navegou até Veneza e aí aportou com a naturalidade de quem é parte do lugar.

(...) atrelado ao locus para o qual foi projetado, exemplifica um paradoxo entre mobilidade e enraizamento. (BOGÉA, 2009, p. 212)

A afirmação de Marta Bogéa pode ser verificada pelo registro fotográfico do percurso do Teatro em Veneza. A leveza de sua materialidade contrasta com a ordem arquitetônica consolidada, mas se aproxima com extrema afinidade do equilíbrio e simetria estabelecidos pelo cenário existente. Entretanto, é na mobilidade inerente desse projeto que está sua capacidade de interferência em lugares distintos, modificando situações, recriando o monumento. Estaria nessa qualidade, segundo Josep Maria Montaner (1993, p. 191), sua verdadeira monumentalidade.

A instigante inversão, a do teatro que é barco, permite dotar o primeiro dessa mobilidade tão reclamada pelos grupos teatrais contemporâneos ${ }^{32}$, levando-o a interferir em diversos contextos da cidade italiana. Com essa estraté-

32 A mobilidade na dramaturgia de grupos como a Cia. São Jorge de Variedades, o Teatro da Vertigem e Teatro do Centro da Terra foi analisada em Teatralidades Contemporâneas, FERNANDES, S. 2010, e Performatividade e Gênese da Cena FERNANDES, S., 2013 gia Rossi demonstra como a arquitetura constrói e modifica cidades, mesmo na paisagem consolidada de Veneza, em uma ação plena de contemporaneidade.

O Teatro del Mondo é composto por uma sala quadrada em que a cena central é definida por duas plateias paralelas, em arquibancada. 0 componente vertical, dois níveis de galerias na periferia do quadrado, assemelha-se à situação do Teatro Elisabetano do século $\mathrm{XVI}^{33}$, e confere ao pequeno edifício o aspecto monumental procurado por Aldo Rossi.

Após o término do evento, para enfatizar o caráter transitório da obra, o Teatro del Mondo viajou para a costa da Iugoslávia, até a cidade de Dubrovnik, intervindo também na paisagem dessa antiga colônia vêneta, antes de ser desmontado.

Estamos diante de uma arquitetura do espetáculo provisória, temporária, dotada de mobilidade. Entretanto não é a solução formal criada por Rossi que interfere, que modifica a natureza do lugar. É a instituição que se manifesta. Para Montaner, o projeto de Rossi tem uma missão

33 Teatros construídos durante o reinado de Elisabeth I fora das muralhas de Londres, após sua proibição pela Cartes des Comédiens em 1574, sendo os primeiros em que os proprietários eram os próprios atores, reunidos em sociedades acionárias. Dentre os mais conhecidos, o Globe Theatre, foi criado por Willian Shakespeare em 1599, projeto dos irmãos Burbage, na margem direita do rio Tâmisa. Foi destruído pelo grande incêndio da cidade em 1666. Ver BRETON, G. - Théâtres, 1989, e L'Archa n. 01, 1986. 
simbólica, ele constrói a narrativa para o acontecimento, demonstrando como a arquitetura, por seu valor intrínseco, ultrapassa as questões funcionais. (MONTANER, 2001, p. 75)

(...) por trás dessa realidade que muda de uma época para outra, há uma realidade permanente que, de algum modo, consegue furtar-se à ação do tempo. (ROSSI, 2001, p. 7)
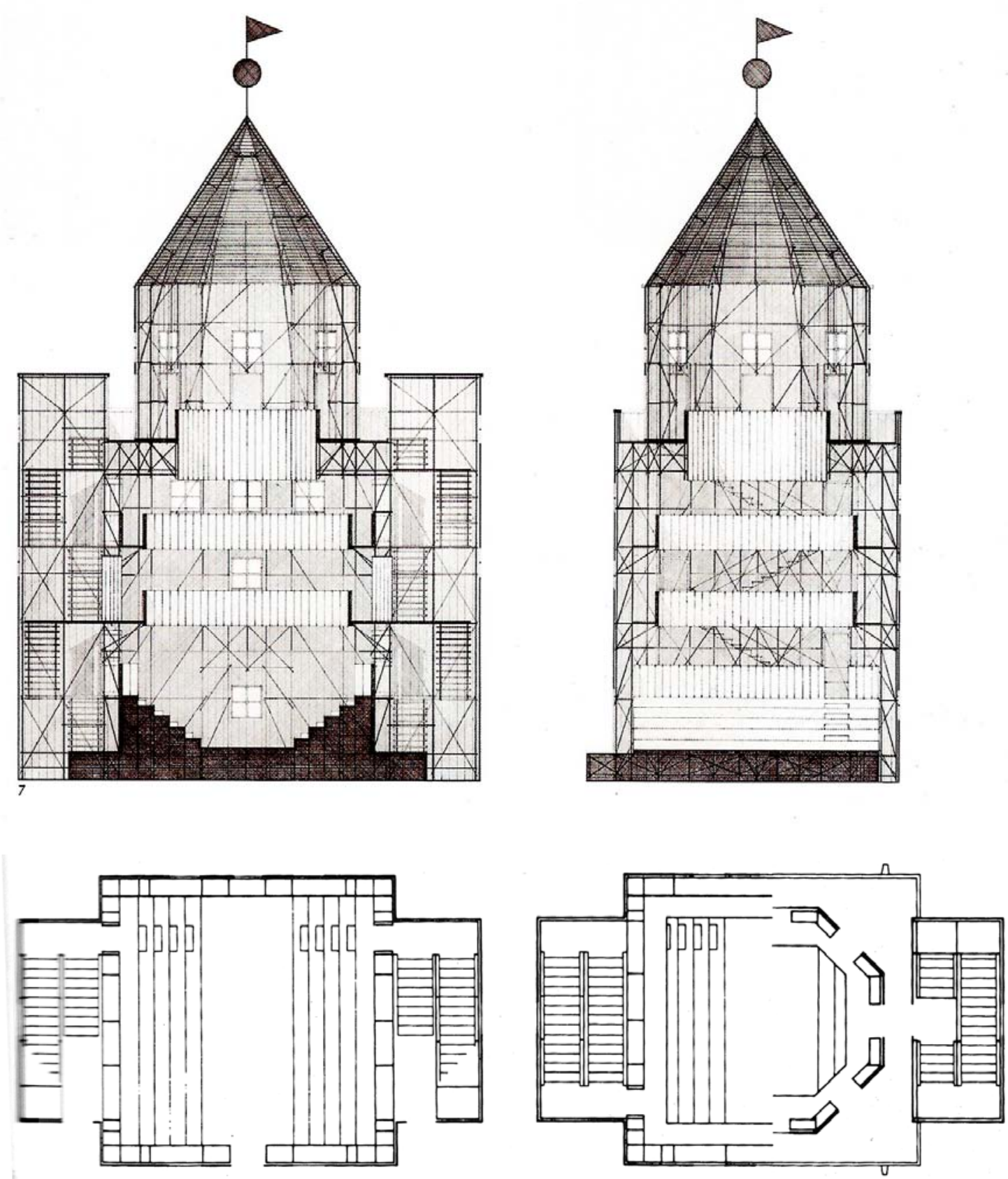

Plantas e cortes, escala 1:400 Teatro del Mondo Veneza. Fonte: ROSSI, 1985. 


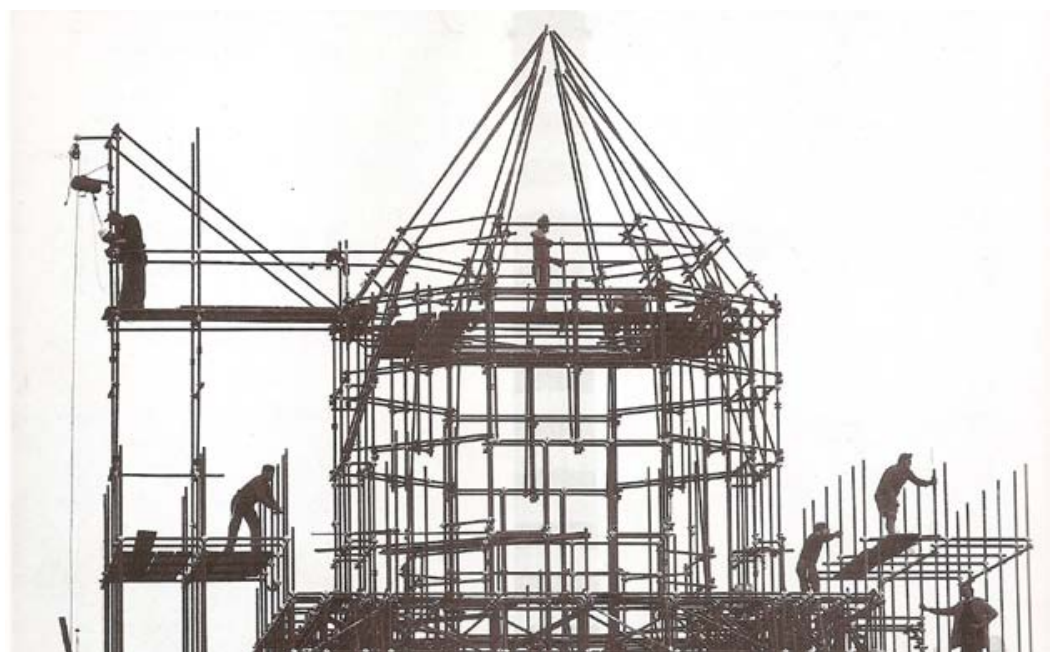

Montagem

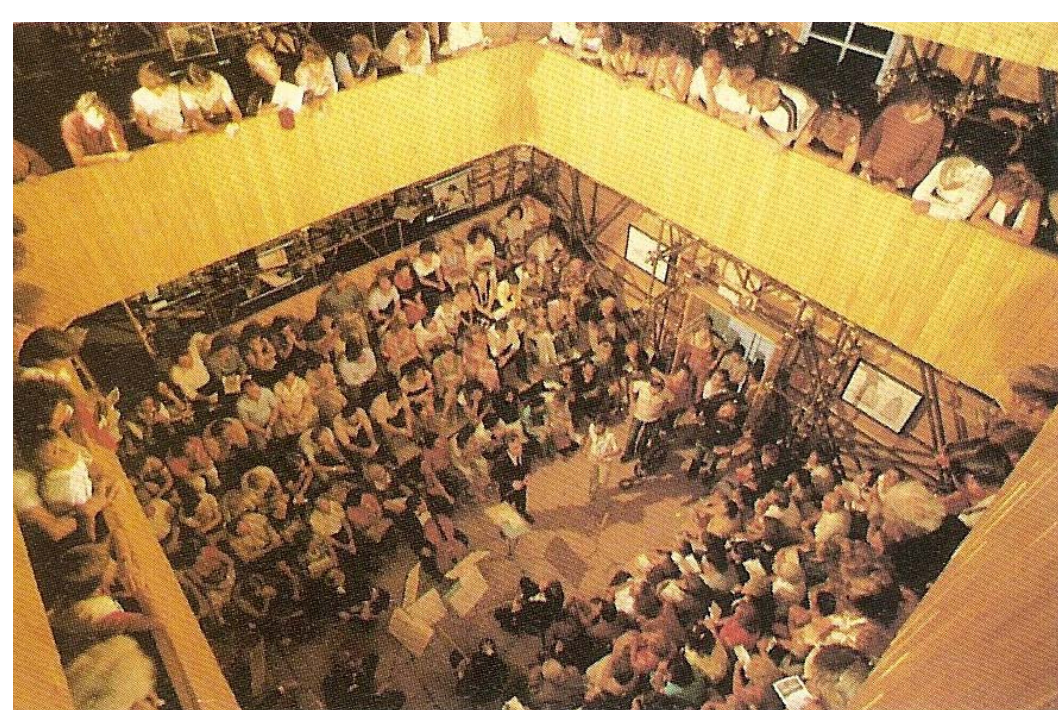

Interior

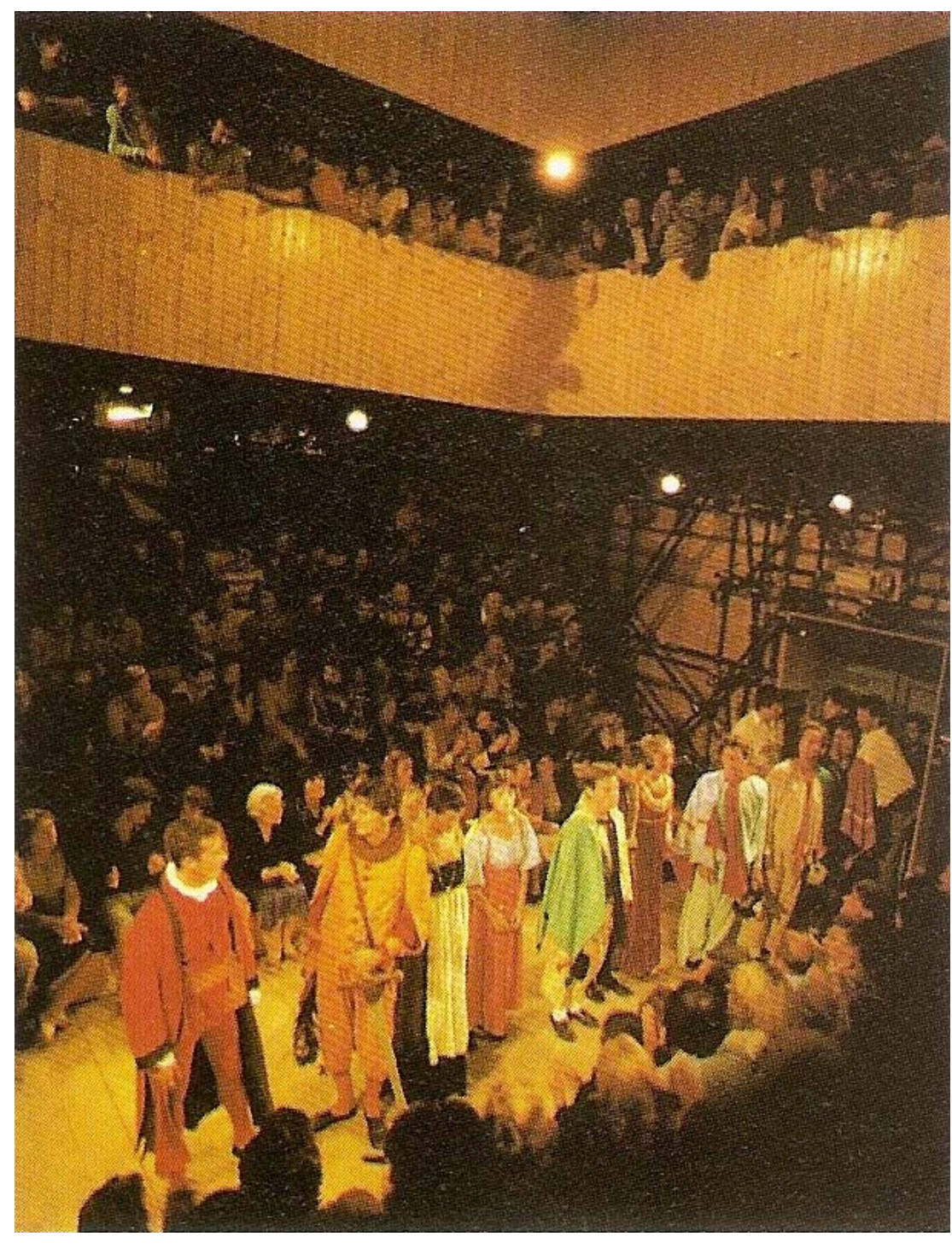

Interior. Teatro del Mondo Veneza. Fonte: ROSSI, 1985. 


\section{Karaza, Teatro Ritual e Situação}

Ao final da década de 1960, quando os ventos de protesto contra os sistemas e culturas instituídos sopravam com mais força em todo o mundo, também no pacífico Japão explodiu uma energia criativa sem paralelos em sua história. $O$ ponto alto de sua resistência cultural foi o avanço do país na área da arte vanguardista. A Associação de Arte Gutai de Kansai, na arte moderna, e o teatro de situações, liderado por Karajuro, além do Tenjo Sajiki do grupo de Shuji Terayama, no teatro Angura, exibiam sua presença dominante.

(ANDO, 2010, p. 343)

A arquitetura de Tadao Ando, autor da citação acima e responsável pelo projeto do Teatro Karaza, é conhecida por sua relação entre luz e sombra, entre o vazio e o sólido do concreto, entre o etéreo e o definitivo e, sobretudo, por sua capacidade de ritualização, aspecto fundamental da cultura japonesa.

O ritual, no projeto do Teatro Karaza, está presente primeiramente na sua condição de itinerante, na montagem e desmontagem do edifício. Está também presente em sua organização espacial e a relação que estabelece com o público.

Concebido para abrigar o grupo teatral de vanguarda, dirigido por Karajuro, em Tokyo, a solução original de Ando projeta uma construção em estrutura de madeira e fechamento em bambu. A obra executada em 1987 às margens do rio Sumida teve sua estrutura inicial substituída por um sistema metálico de andaimes tubulares de rápida manipulação, o que permite que seja montado em trinta dias, nos lugares mais variados, pela disponibilidade do sistema. Essa solução, além de garantir a estabilidade da estrutura, permite ainda que nela seja distribuída a infraestrutura cênica do espetáculo.

(...) esses tubos de ferro expressam uma sensibilidade afim ao temperamento de Karajuro, fazendo deles o material mais apropriado para essa proposta. Isso porque o Teatro Shitamachi Karaza, nascido de um tipo de guerrilha urbana, requeria uma construção única, mas que tivesse em sua origem uma trivialidade cotidiana. (ANDO, 2010, p. 343) 

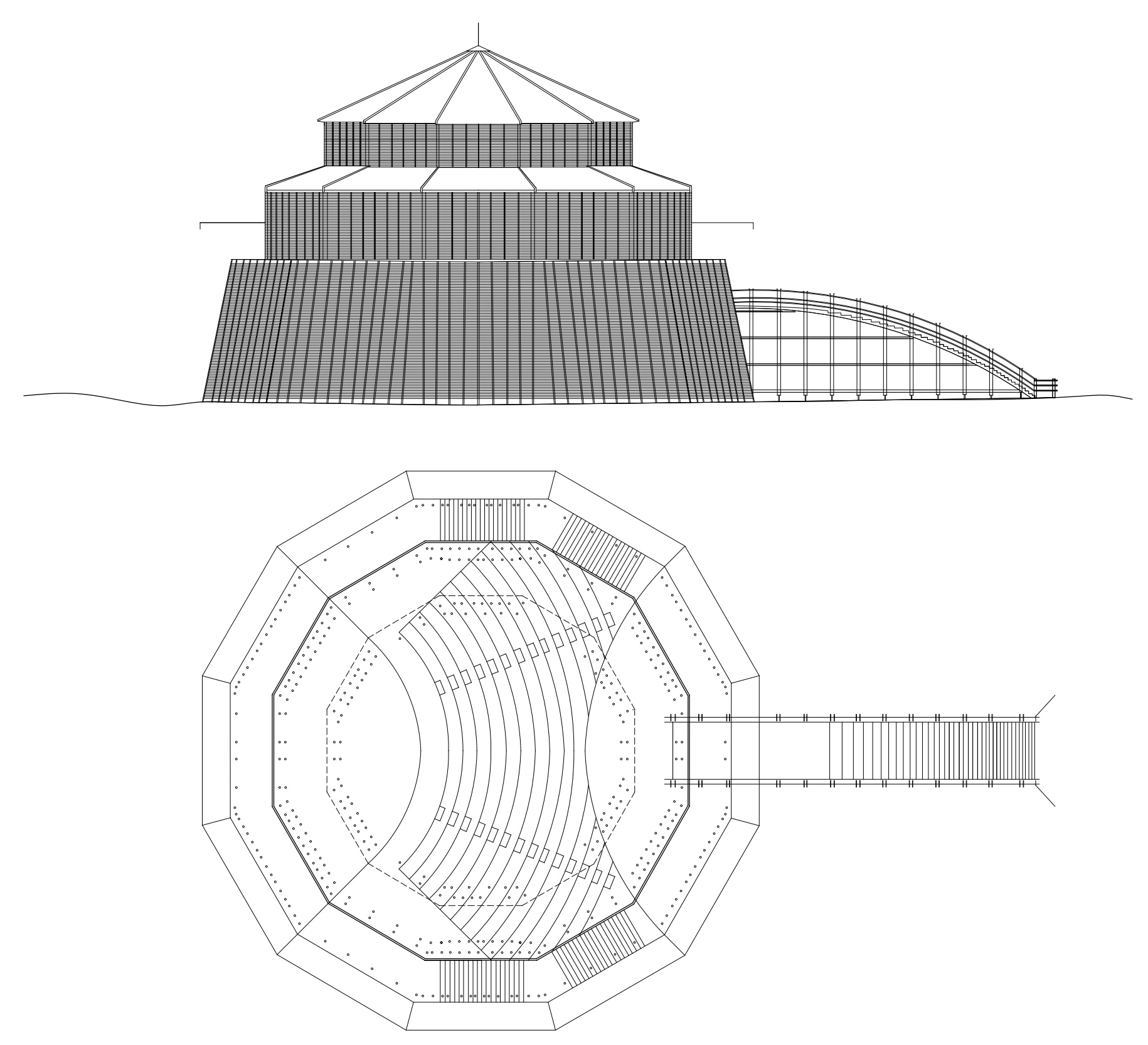

Elevação e planta, escala 1:500. Teatro Karaza - Tokyo. Fonte: BRETON, 1989 
Ando busca formas essenciais. 0 volume, um dodecágono, organiza a sala em anfiteatro, envolvida por duas galerias de circulação, a primeira um deambulatório interno e a seguinte, um terraço anelar protegido pela fachada da edificação. Essa associação de espaços periféricos se conecta com o terreno natural através de uma passarela em arco, completando o percurso. A arquitetura cria o ritual de preparação para o espectador pela sucessão de espaços, de travessias.

Dentro da tradição de simplicidade do espaço tradicional da arquitetura japonesa, o Teatro Kuraza é a síntese da ideia primordial que o arquiteto procura defender, evitando toda interferência secundária, capaz de criar qualquer ruído em relação à sua obra. (MONTANER, 2001, p. 151-153)

O projeto garantiu a universalidade defendida pelo Movimento Moderno, em virtude da solução construtiva adotada. Tadao Ando, crítico do internacionalismo como valor da arquitetura, apresenta nesse projeto o que chama de Modernidade Fechada ${ }^{34}$, representada pela precisão da técnica, que permite uma leitura muito mais profunda do que sua aparência geométrica. A distribuições e as junções da malha tubular definem com o conjunto de equipamentos cênicos o tratamento interno da sala. Admite o arquiteto que está na escolha do sistema construtivo a grande virtude do projeto, o que, no seu entendimento, permitiria sua construção em qualquer lugar do mundo.

A opacidade do volume é gradual em função da sucessão de fechamentos, representados por cada galeria anelar. A luz, fundamental em sua obra, assim como o ruído exterior são filtrados por camadas.

Observa-se que uma "permanência temporária", ou seja, a solução construtiva em malha tubular, a mesma usada por Aldo Rossi para o também itinerante Teatro del Mondo, viabilizou a obra, não somente em termos financeiros mas sobretudo por dissimular seu caráter transitório. A arquitetura de Tadao Ando, baseada nos valores tectônicos do concreto armado encontrou aqui sua força na organização e no sequenciamento dos movimentos antes, durante e após o espetáculo, uma imagem que ainda nos parece presente. 
Além de Tokyo, foram programadas montagens em Osaka, Kyoto e nas docas de Nova York. Porém Ando admitiu, anos depois, que os custos envolvidos para erguer seu teatro móvel foram responsáveis por inviabilizar sua reprodução em outras situações, como desejara:

Contudo, meu sonho de que o teatro móvel fosse reaparecer mais tarde, em alguma outra cidade, afinal não se concretizou. O Shitamachi Karaza fora construído, sem dúvida, com base no conceito de "teatro móvel imprevisível”, mas naturalmente a construção resultou em custos e consumiu prazos consideráveis (...) A arquitetura é uma arte de expressão, mas, pelo fato de demandar recursos elevados e uma enorme mobilização humana, construir é um ato produti-

vo extremamente social. (ANDO, 2010, p.353)
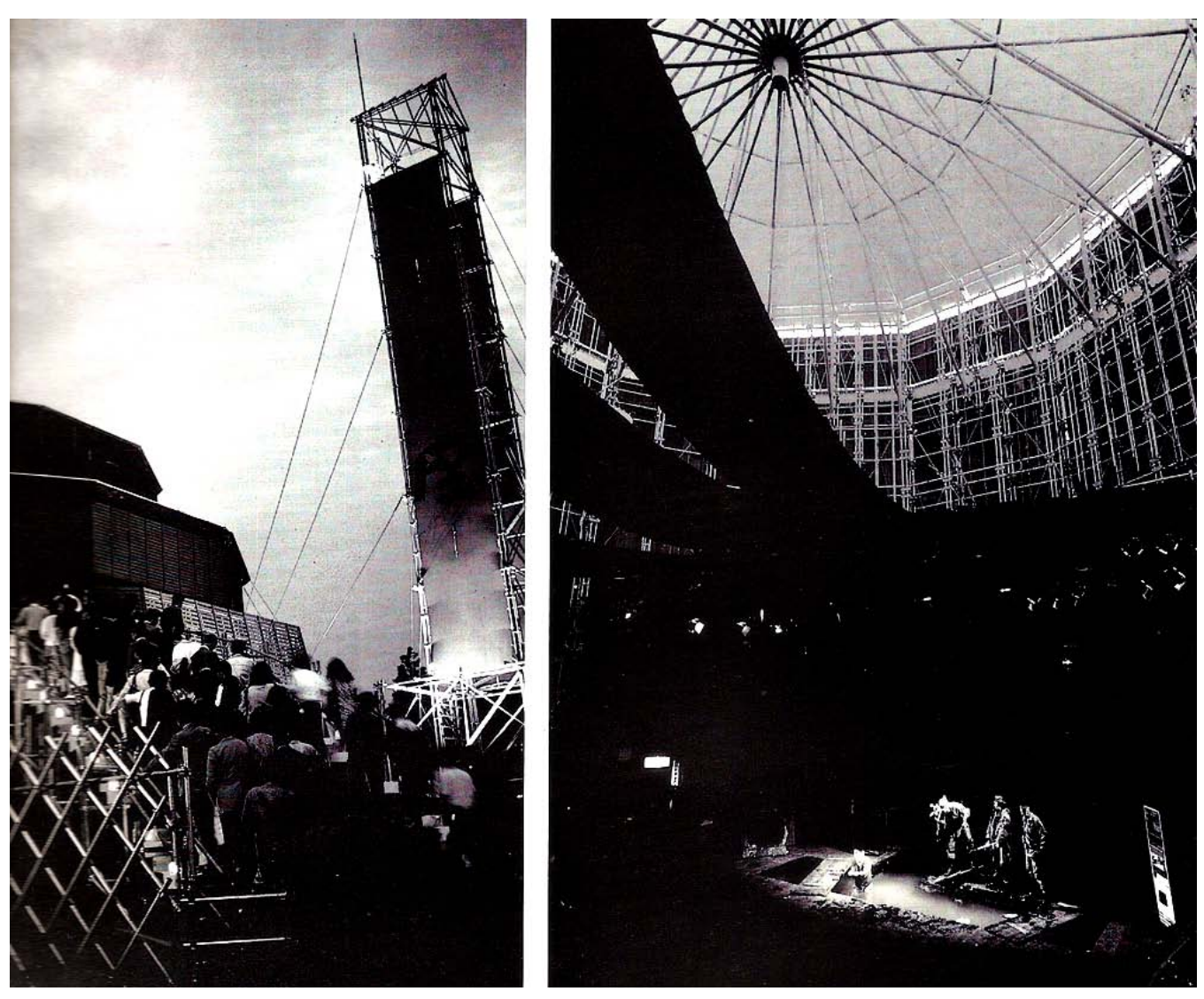

Teatro Karaza - Tokyo. Fonte: BRETON, 1989 


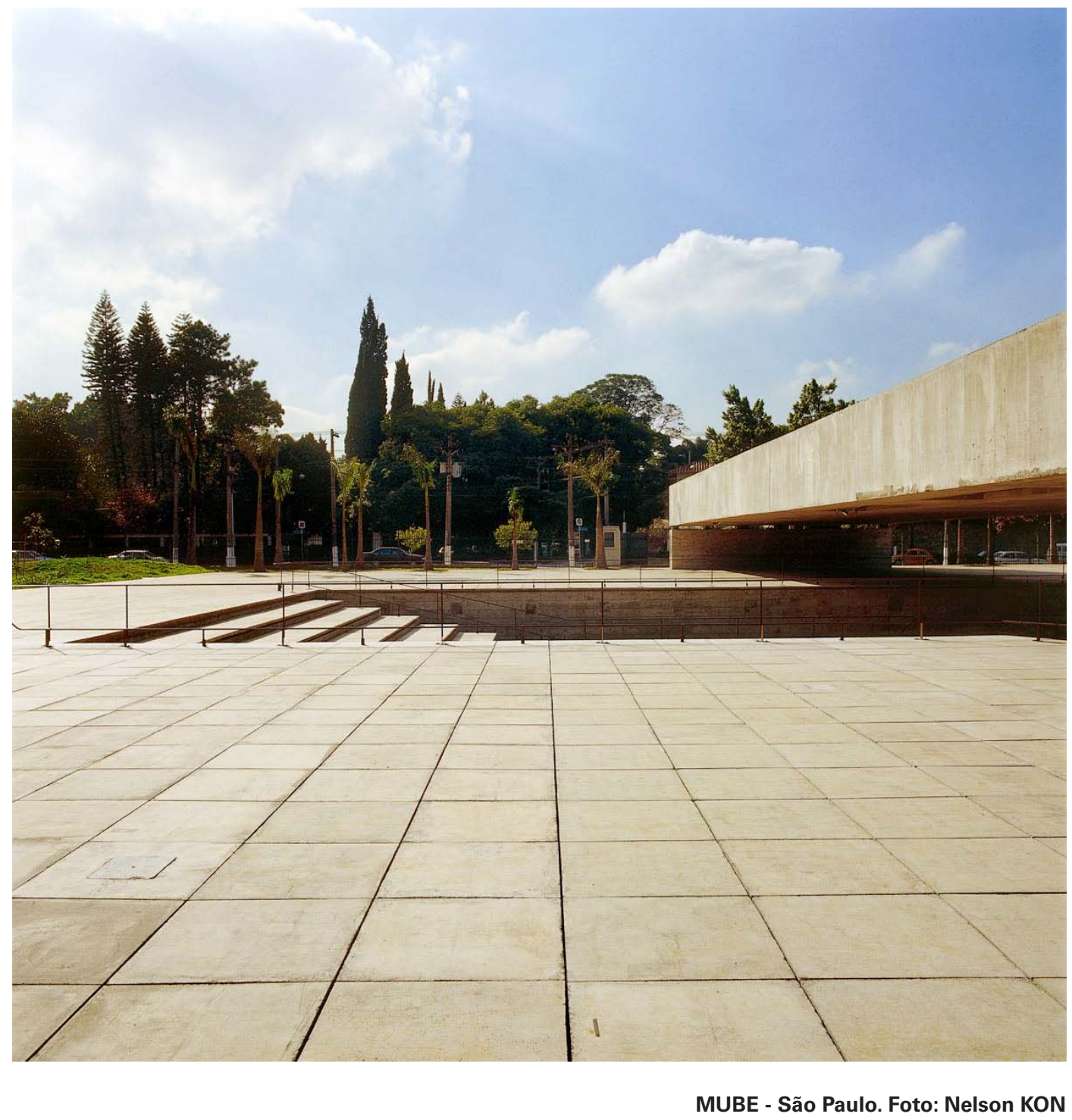


Os centros urbanos da metrópole contemporânea passaram por momentos de esquecimento e abandono. A busca do mercado por novas fronteiras urbanas deixou para trás um passivo sobre o qual a cidade agora se debruça na tentativa de recuperar o patrimônio comprometido.

A Arte nesses casos é um agente que se apresenta na linha de frente das lutas por essa reconquista. São ações de denúncia ao abandono, de ocupação de espaços desconhecidos, são intervenções que buscam a sensibilização e convocam à reflexão.

No exemplo concreto da cidade de São Paulo as manifestação teatrais vêm desempenhando papel relevante nesse processo ${ }^{35}$. Um dos grupos teatrais de maior destaque, a Cia dos Satyros, instala-se no início da década de 2000 em um imóvel localizado na Praça Roosevelt.

Esse espaço público, a Praça Roosevelt, é um exemplo do que Hugo Segawa chama de Episódios de um Brasil Grande e Moderno 1950-1980 (2002, p. 159), uma grande 
doviário leste oeste que corta a cidade ${ }^{36}$. 0 interesse nesse lugar, despertado nos Satyros e em outros grupos teatrais que vieram ali se instalar em seguida, deve-se a condições significativas : a total deterioração em que se encontrava e, por outro lado, sua localização estratégica, próxima ao bairro da Bela Vista, tradicional reduto do teatro paulistano, bem como de edifícios de grande valor cultural e arquitetônico para a cidade, como o Teatro Cultura Artística ${ }^{37}$ e o Cine Bijou, que introduziu na cidade programação cinematográfica alternativa ao cinema comercial e que funcionou no local de 1961 a 1995.

O processo, hoje emblemático, de retomada do uso desse espaço público deu-se depois de uma década de atividades teatrais que trouxeram de volta o público e as atividades culturais e comerciais decorrentes dessa nova animação. Esse movimento culminou com a reestruturação total do espaço físico por parte do poder público, devolvendo a Praça à cidade, agora com uma proposta considerada aberta e integradora.

Cabe-nos aqui observar, justamente, de que maneira

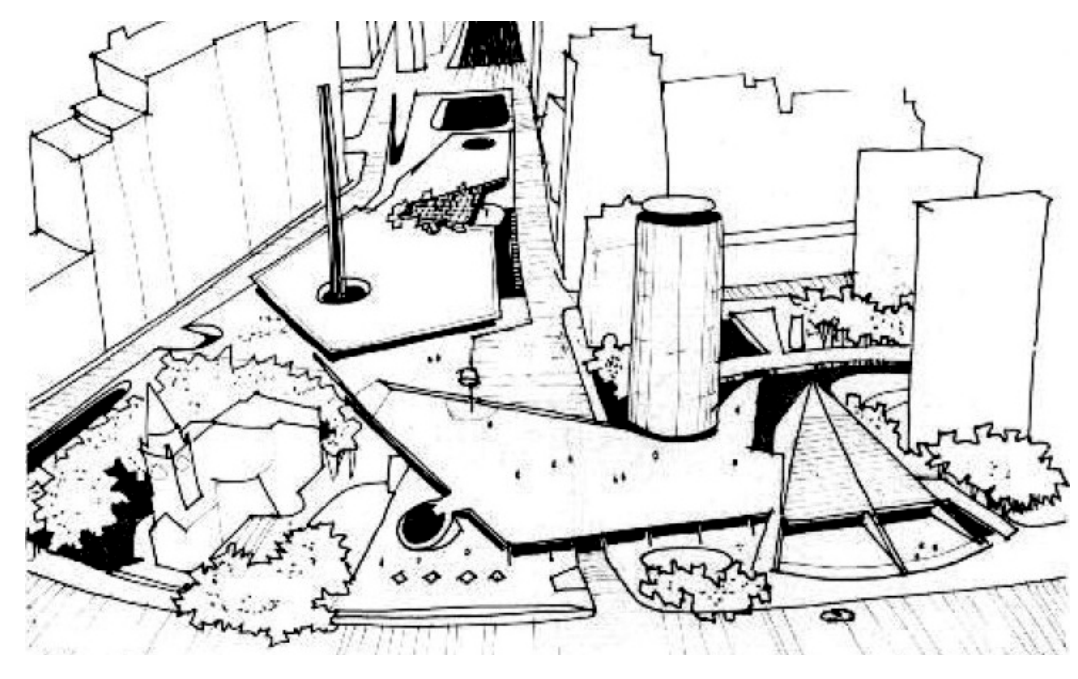

Praça Roosevelt, projeto original, Roberto Coelho Cardozo. Fonte: Revista Acrópole n. 780, 12/1970

o espaço do espetáculo participou dessa transformação do lugar. Em que medida podemos perceber que houve uma contribuição para a construção do caráter do lugar, no sentido do que o diferencia, do que lhe dá características próprias em relação a outro?

Tomemos como base de análise, ou como caminho de análise, o processo de apropriação, por parte da Arte do Espetáculo, do espaço físico necessário para desenvolver seu trabalho. A Cia. dos Satyros, e as outras que a sucede-

36 Elevado Costa e Silva - Radial Leste. Praça Roosevelt, obra de Roberto Coelho Cardozo, 1970. Outros exemplos: Praça da Sé e Metrô, obra da equipe Emurb; Praça da Bandeira e Garagem Emurb, 1973, obra nunca terminada.

37 Teatro Cultura Artística, obra de Rino Levi Arquitetos Associados, 1942. 
ram, se instalou no pavimento térreo e no mezanino de um dos diversos edifícios torres que desde a década de 1960 definem os limites físicos da Praça.

As intervenções realizadas nesses edifícios trouxeram interessantes formas de utilização do espaço cênico, que dissolve as barreiras entre plateia e palco, já conhecidas em outras experiências na cidade ${ }^{38}$.

Os diagramas apresentados a seguir registram uma das montagens realizadas em um desses espaços transformados:

\section{Espaço Satyros I}

Praça Roosevelt, 214. Espetáculo: Roberto Zucco ${ }^{39}$, de Bernard-Marie Koltès, março 2011.

O espaço do espetáculo nesse caso parte do tratamento genérico desse grande ambiente em que a ação se desenvolve. A arquitetura original do edifício não participa como ilustração, artifício, rudimento, elemento básico, primitivo. Ela simplesmente não é vista, não é evidente. Porém

38 Ver Teatro Oficina, de 1984, obra de Lina Bo Bardi e Edson Elito para o grupo de mesmo nome liderado por José Celso Martinez Corrêa.

39 Peça do dramaturgo francês Bernard-Marie Koltès, de 1988, inspirada em um cartaz de "procura-se", de um assassino em série chamado Roberto Succo, um doente mental de 26 anos que fora internado em 1981 por ter matado seus pais, e que em 1986 foge do hospital de forma espetacular, voltando a cometer novos crimes. está sim presente nas proporções generosas, na escala do lugar, que permitiram a concepção do espaço imaginário criada pela direção do espetáculo, caracterizada pelas incursões espaciais horizontais e verticais do drama.

Como mostram os diagramas acima, a ação se desenvolve em posições e situações distintas em que o artefato que pontua as mudanças é a plateia em forma de arquibancada metálica, provida de rodízios, movidas pela própria força dos atores, que no momento da movimentação não fazem parte diretamente da ação, transformando-se no principal equipamento de que o grupo lança mão durante todo o espetáculo, uma ação com o público.

A estratégia está muito próxima das teorias elaboradas por criadores cenógrafos e pensadores do teatro do início do século XX, como Adolphe Appia e Gordon Craig ${ }^{40}$. Para Appia, a dimensão cênica é dada pela busca da dinâmica entre espaço e tempo - movimento - que oscilam entre si e dificilmente encontram um equilíbrio, mas estão sempre em uma interdependência, uma subordinação. É em Appia que encontraremos a desmaterialização da cena, o

40 Ver: . BABLET, Denis - Le lieu théâtral dans la société moderne, 2002, cap. La Remise en Question du Lieu Théâtral, p.15.

- LIMA, Evelyn F. Wernwck - Arquitetura e Teatro. O Edifício Teatral de Andrea Palladio a Christian de Portzamparc, 2010, p. 121. DEL NERO, C. 2009, p. 217-263 


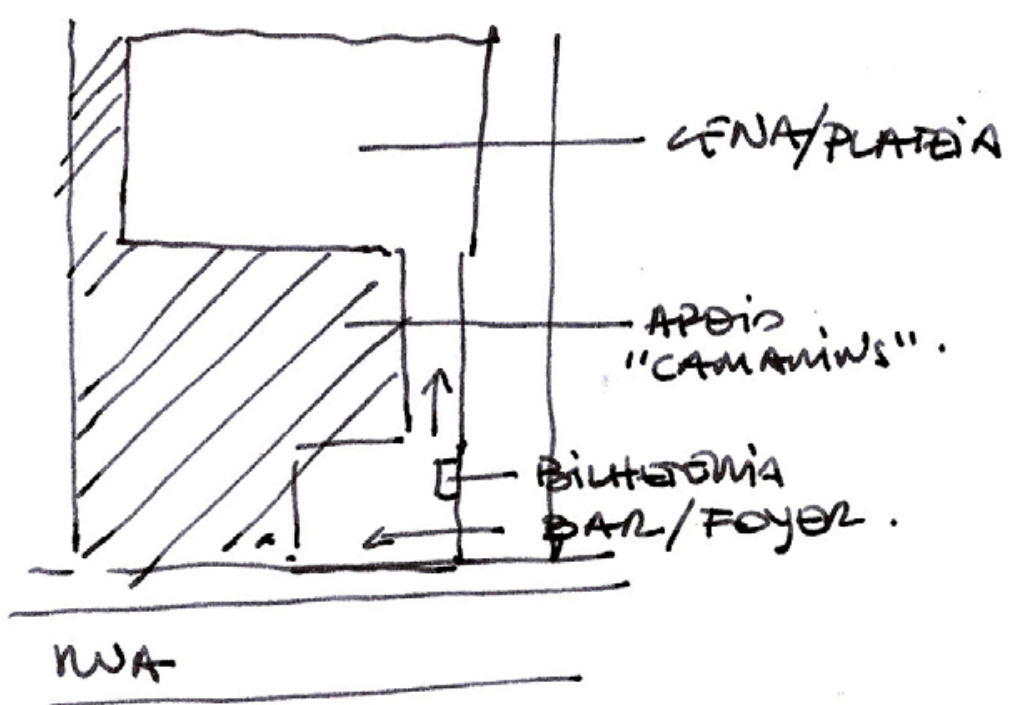

MOO SEVELD.

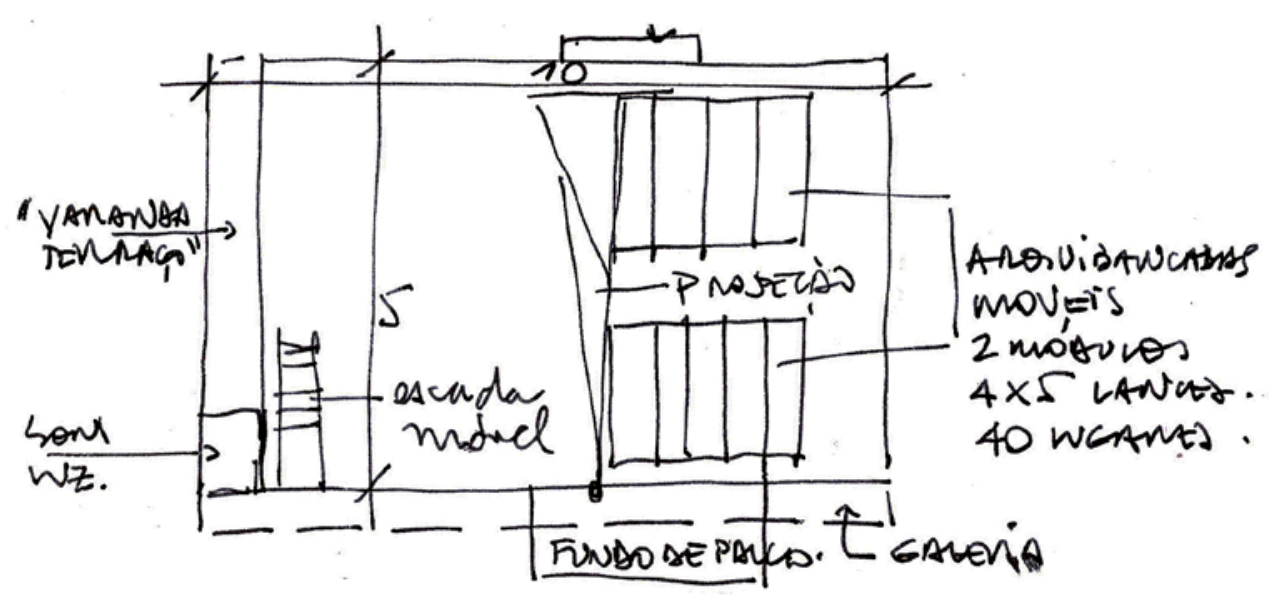

uso intensivo dos recursos de iluminação e da música para a construção das sensações, sendo, no entanto, preservada a única realidade fundamental, a do ator em cena.

Craig defendia o teatro como um espaço vazio, pleno de ideias a serem construídas. Deveríamos encontrar apenas um piso, paredes e telhado, onde a cada espetáculo seria concebida uma arquitetura específica, onde cada drama encontraria o seu lugar cênico.

Há no caso do espetáculo Roberto Zucco estratégias semelhantes às desses cenógrafos alinhados com as vanguardas artísticas da década de 1920. A princípio temos o espaço vazio delimitado por piso, paredes e teto, que envolve a todos, ator e espectador. A construção da ação se dá pelo desempenho dos atores e pelos recursos sonoros e de iluminação. Mas o projeto cênico foi além ao movimentar a plateia e criar novas configurações de sala.

Trata-se da cena com recursos ou princípios cinéticos, usada para o encadeamento do texto, mas aqui o movimento está na plateia que se desloca, se decompõe e se recompõe em formatos distintos, isto é, a ação também se dá 
(1)

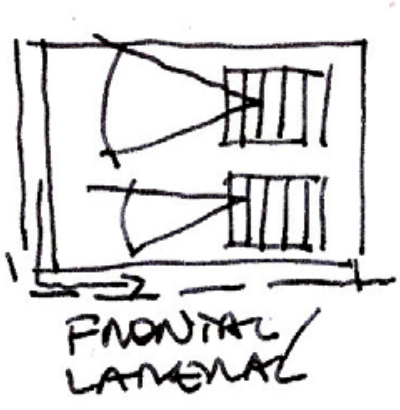

(2)
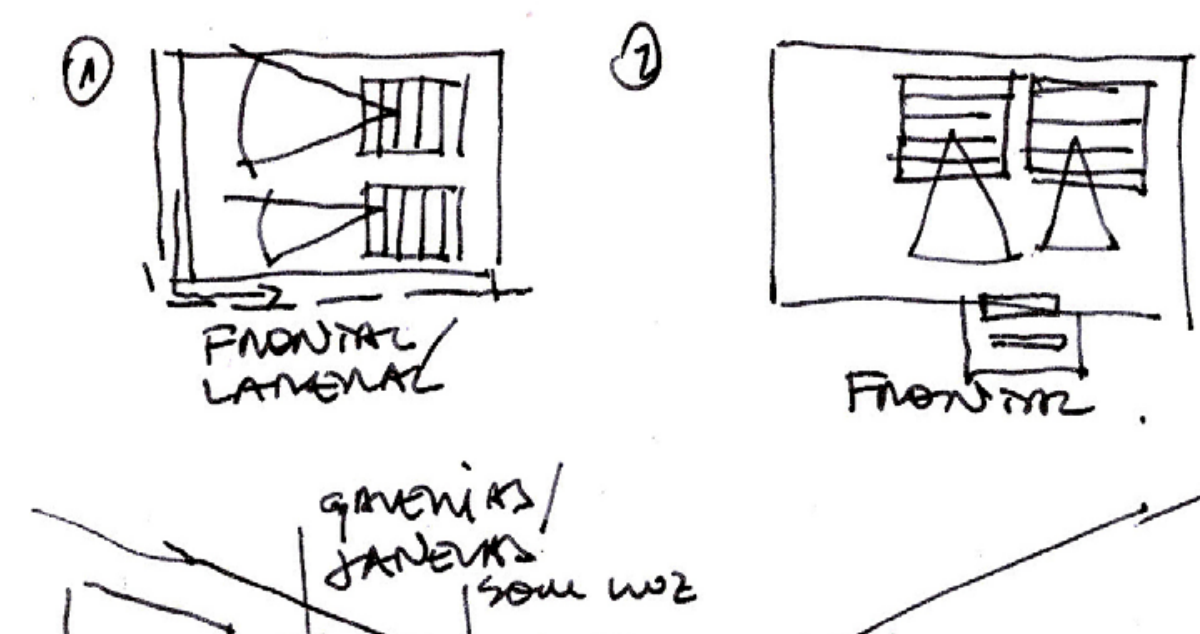

(3)

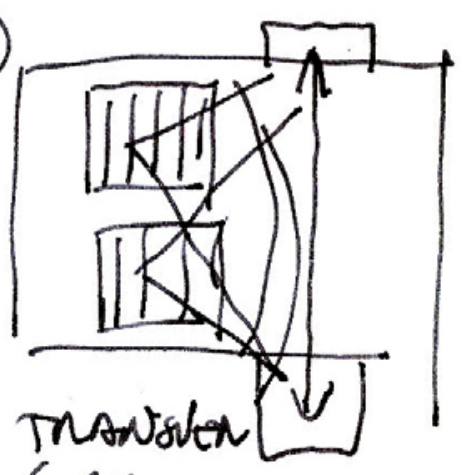

4 a 5 metrs.
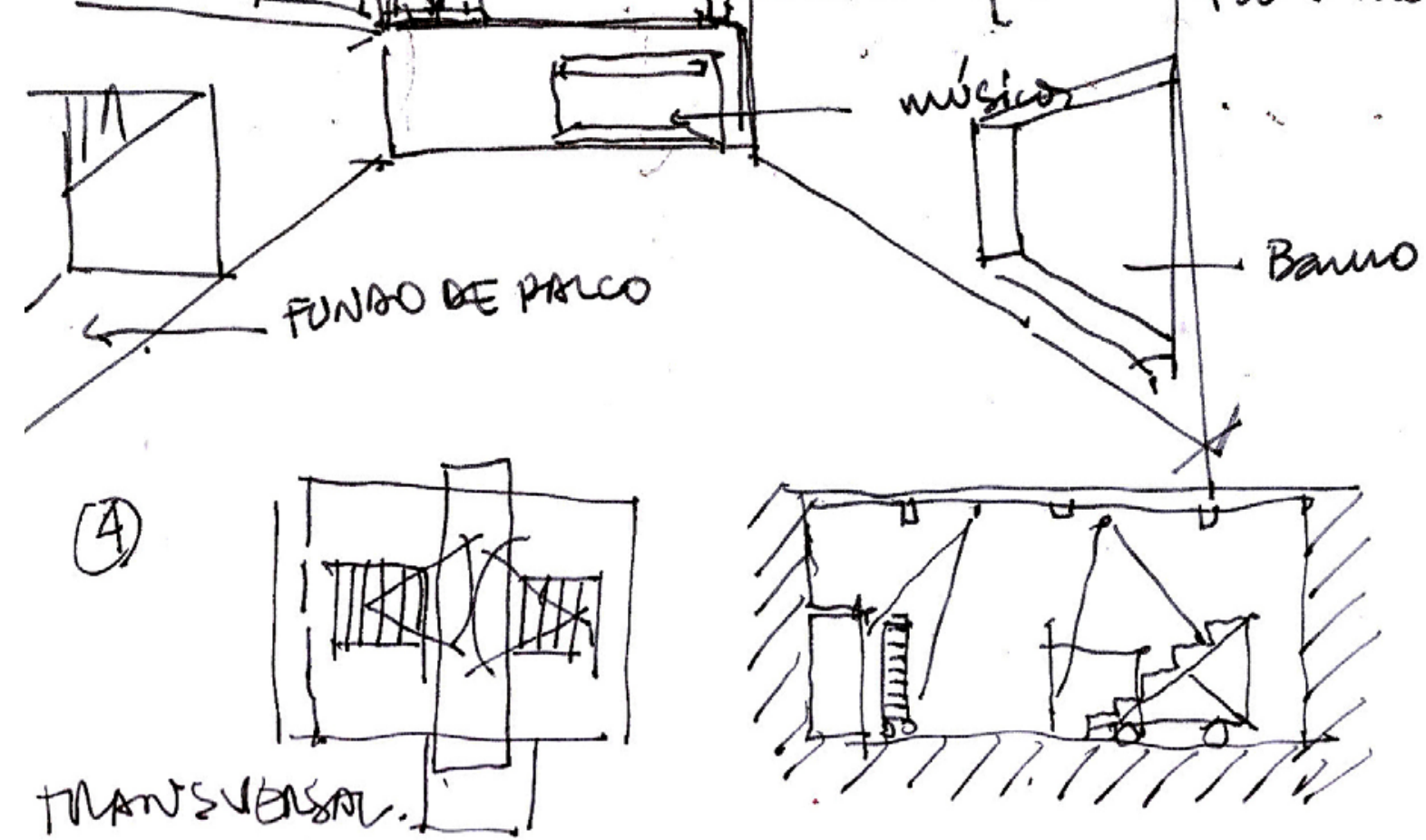

Espaço Satyro 1 - São Paulo. Diagramas Valério Pietraróia

75 
na desorganização e reorganização do público. A percepção se modifica em função dos diversos pontos de vista que são oferecidos, como pode ser melhor observado pela descrição a seguir.

Podemos perceber no esquema 1, que mostra como a sala está montada para a receber público, a cena frontal, que se prolonga pela lateral. Nesse caso a ação é bidimensional, não há profundidade, é quase uma tela contra a parede, em que o trabalho de iluminação é o recurso utilizado para a criação da ambientação necessária.

No esquema 2, o giro das arquibancadas da cena central encontra na lateral uma configuração próxima do tradicional palco à italiana. Aqui o nicho existente é tratado como um cenário de um apartamento, mas nessa situação o espectador não penetraria no interior mas estaria, como um voyeur, observando de fora, através da fachada envidraçada.

O deslocamento descrito no esquema 3 permite, ao inverter totalmente a organização inicial do espetáculo, desenvolver a ação pela marcação de uma linha, uma direção, um fluxo urbano que pode ser lido como uma situação de rua.

É no esquema 4 que a sala atinge seu ponto de maior tensão, em que o texto se apoia em situações de conflito, intensificadas pelo próprio confronto da plateia dividida e colocada frente a frente, sendo o cenário agora o próprio público, dividido em duas arquibancadas colocadas face a face, onde as reações podem ser percebidas, fazendo parte da atmosfera de tensão que pontua todo o espetáculo.

Esse método não é inédito, como pode ser exemplificado na cenografia de Joseph Furttenbach, de 1665, em $\mathrm{Ulm}^{41}$. Nela que o espectador gira no centro do espaço composto por quatro cenas fixas. Na situação usada pelos Satyros a singularidade está no fato de haver um reconstrução do espaço a cada ato, a cada movimento, levando, do início ao final do espetáculo, a uma tensão espacial constante, ingrediente fundamental para o tema tratado pelo espetáculo. 0 espectador é submetido a uma experiência espacial distinta a cada cena, baseada em uma nova ordem espacial, dentro de uma mesma estrutura.

41 BABLET, op. cit. ilustração XXXVII. 


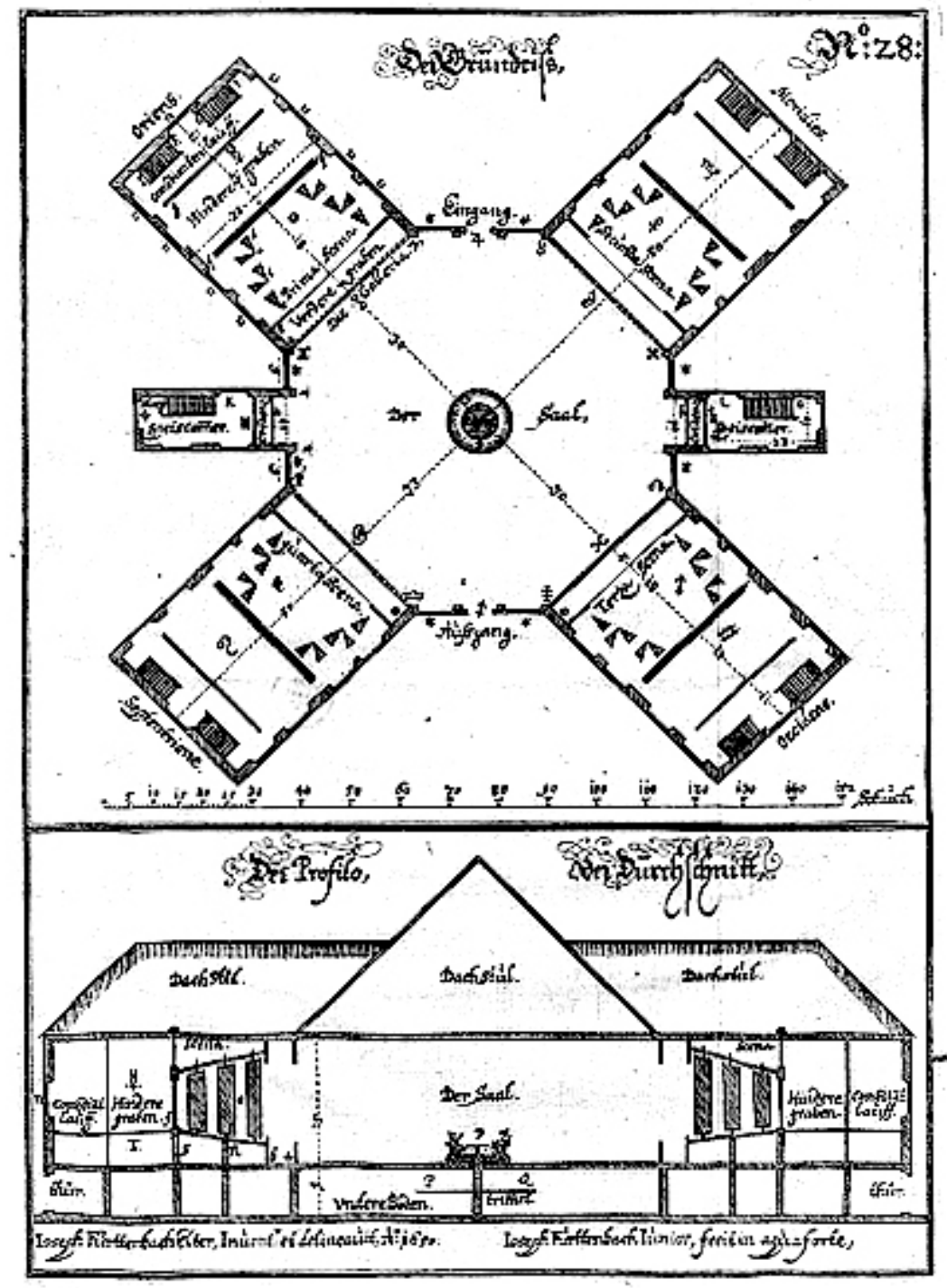

Planta. Teatro de Ulm. Fonte: BABLET, 2002.

\section{A Transformação do Lugar}

Se tomarmos as noções entre Espaço e Lugar, discutidas por Josep Maria Montaner (2001, p. 30; 37) segundo as quais o lugar se diferencia do espaço pela presença da experiência, podemos considerar que a Cia dos Satyros operou em dois níveis distintos:

Do ponto de vista do espaço interno criado, a montagem do espetáculo Roberto Zucco baseou-se nos postulados modernos da forma genérica, da abstração, da condição indefinida, foi uma construção mental. Por essa linha de observação a obra não contribuiu para a construção do caráter do edifício, do caráter do lugar. Em outras palavras, a arquitetura proposta não foi o agente indutor, não participou diretamente da transformação do lugar - no caso da praça - por ter se limitado à cenografia.

Em outro nível, podemos entretanto afirmar que foi a partir da observação do lugar e de sua apropriação que as atividades retornaram ao local. Foi a rearticulação das diversas peças urbanas - praça, rua, avenida, edifícios - que revelaram à cidade o seu caráter, sua vocação oculta por 
anos de abandono. Não foi o Projeto responsável por essa revitalização, mas sim o que ele trouxe.

No entanto mesmo não sendo o objeto arquitetônico protagonista dessa ação reveladora, podemos considerá-lo um personagem relevante, ainda que indiretamente.

Não há nesse espetáculo evidências do projeto como instrumento capaz de discutir as soluções para os objetivos propostos. Não há a priori objetivos transformadores a serem atingidos pois a construção se dá no âmbito do espaço interior, por meio dos recursos cênicos descritos acima.

O resultado atingido - a recuperação do espaço público - é fruto de diversas ações, entre as quais essa experiência dos Satyros deve ser incluída.

Se observarmos as reflexões de Martin Heidegger sobre a essência do lugar, "os espaços onde se desenvolve a vida são antes de tudo lugares" ${ }^{42}$, poderemos notar que esse processo em curso significa a retomada de valores qualitativos em detrimento do processo intensivo de banalização dos centros urbanos (DEBORD,1992, p. 163), exemplificado aqui pela deterioração da Praça. Montaner, ao relacionar Heidegger à arquitetura moderna da segunda geração, o faz

42 Heidegger, apud Montaner, op. cit. p. 40. Ver também: FRAMPTON, Kenneth - História Crítica da Arquitetura Moderna, São Paulo, 2003, p. 342. afirmando que não seria somente a recriação da ideia de lugar nos interiores, dos valores simbólicos, mas também a busca de um lugar que não existe, a transformação do não lugar americano em lugar (MONTANER, 2001, p. 41). A acumulação do espaço do mercado deve dissolver a autonomia e a qualidade do lugar.

Por outro lado, Kenneth Franpton, quando fala em Lugar, Produção e Cenografia (2003, p. 342), o faz desenvolvendo a visão de Manfredi Tafuri sobre as vanguardas, com o que podemos fazer um paralelo com esses grupos teatrais, cuja estratégia estaria mais alinhada à uma "tática de subversão, à injeção de ruído no sistema", como o fez o Grupo Archigram ${ }^{43}$ nos anos de 1960. Mas o autor alerta mais adiante que isso dependeria da complexidade das intenções do empreendimento como um todo. As manifestações da arquitetura no período citado estariam muito mais próximas das utopias urbanas do que as intervenções dos Satyros.

43 ver o capítulo A Metrópole Em Cena. 


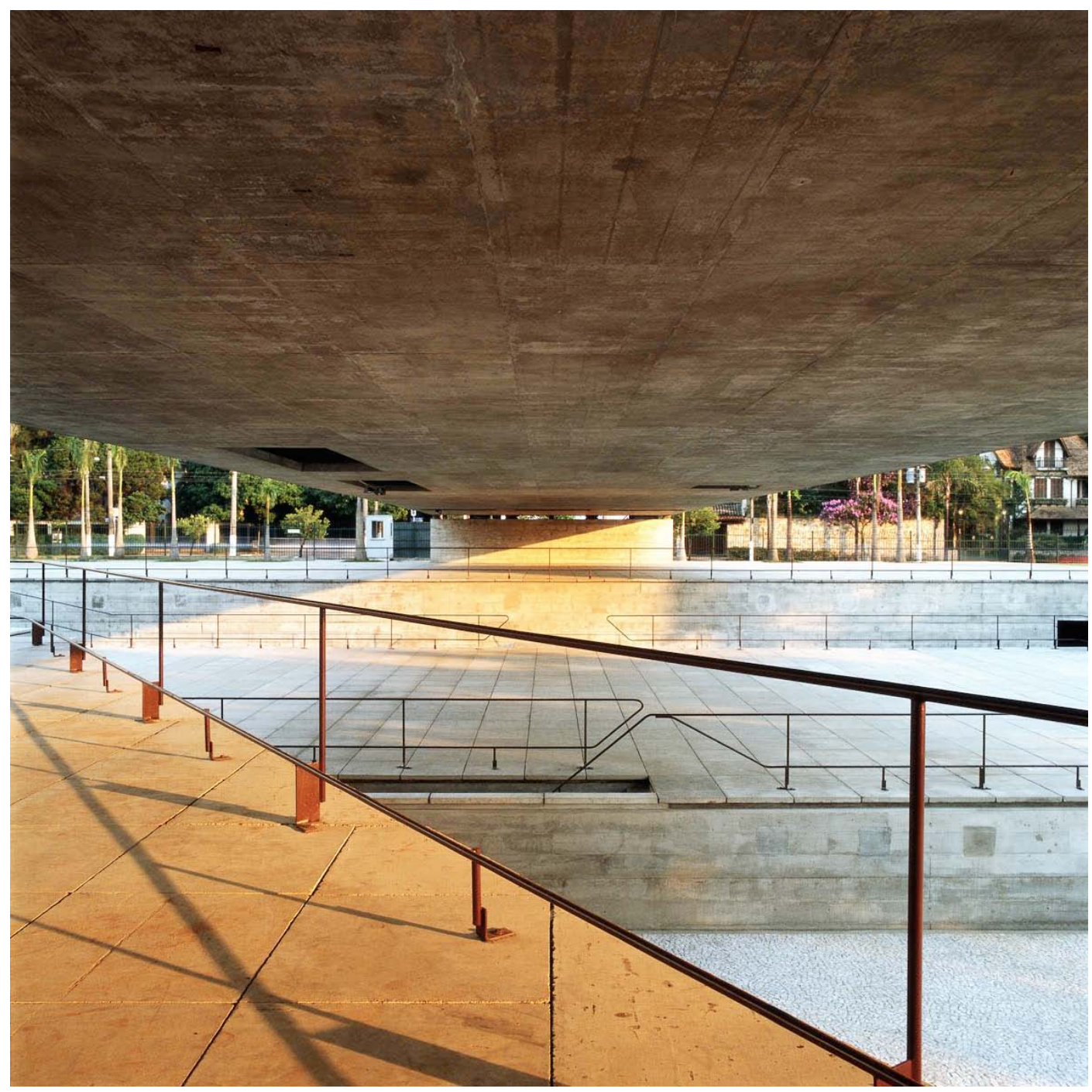

MUBE - São Paulo. Foto: Nelson KON 
En la arquitectura contextualista, la presión del lugar sirve para disolver la identidad del objeto en la atmosfera ambiental del sector urbano en el que se encuentra. En la arquitectura moderna, por el contrario, la con-sideración de los alrededores del edificio proporciona elementos que intervendrán en el sistema formal que afirmará la identidad de la obra: en efecto, el edificio aparece, en este caso, como elemento de un conjunto estructurado por vínculos de relación visual, de modo que la coherencia no se alcanza por armonía, sino por equilibrio de los distintos elementos que intervienen en el episodio arquitectónico.

(PIÑON, 2005. apud BARRERA, 2009)

No trecho acima, Helio Piñón, ao comparar a arquitetura contextualista e a arquitetura moderna em relação à presença do lugar, utiliza as ideias em que se apoia sua Teoria do Projeto (2006). A leitura e a compreensão do contexto traz ao projeto sua legitimidade, a "afirmação de sua identidade". Não seria a incorporação das condições do lu- 
o objeto arquitetônico atinja sua integridade. A essência de algo é a qualidade que se constrói, que legitima sua pertinência.

O Projeto enquanto ordenamento do entorno físico, capaz de gerar o prazer estético, independentemente do cumprimento de seus atributos funcionais: essa seria a relação primordial da modernidade em relação ao lugar e a sua permanência.

A avaliação a seguir coloca-se dentro dessa perspectiva, para dessa forma entendermos qual foi o lugar do Projeto na obra estudada.

\section{MUBE, Museu Brasileiro da Escultura}

A obra do arquiteto Paulo Mendes da Rocha, projetada em 1987, no bairro Jardim Europa em São Paulo, não é um Teatro. 0 programa do concurso fechado que escolheu a proposta construída era fundamentalmente museugráfico, em que estava previsto um ambiente com características de auditório, para que palestras, encontros e debates pudessem ser acolhidos, dentro da vocação principal do edifício, um Museu da escultura.

Segundo o texto manuscrito por Paulo Mendes para o concurso, "O Museu de esculturas, Pinacoteca de ecologia será visto como um grande jardim, com uma sombra e um teatro ao ar livre, rebaixado no recinto." (in PIÑóN, 2002, p.96)

O Projeto constrói uma nova geografia que se apropria do desnível existente entre as duas ruas que configuram o terreno, uma geografia artificial, mineral, sobre a qual ele vai repousar sua pedra, sua escultura. 0 programa está organizado sob esses tetos planos, plataformas que recebem esculturas e que configuram o seu Teatro, por onde o visitante passeia, como um espectador atento.

0 Teatro é composto pela plateia em anfiteatro, na continuidade do plano longitudinal. A cobertura do palco, a grande viga suspensa que domina o horizonte, é proteção e também apoio cênico. Ela avança até a avenida Europa, marcando sua forte presença. Os meios-níveis criados são balcões, camarotes ou apoios de cena. Pelas rampas e escadas laterais surgem as personagens, em aparições. Os ca- 


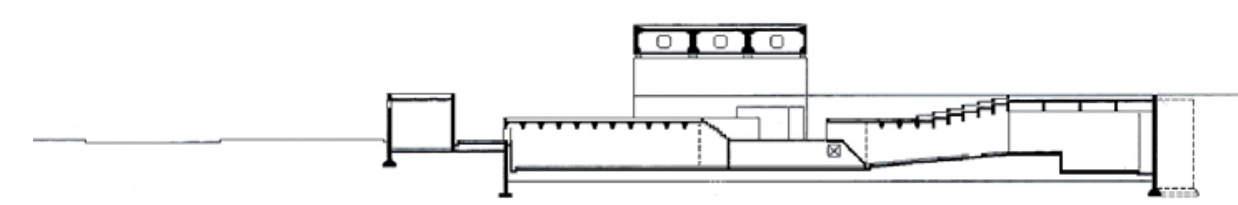

Corte Longitudinal, escala 1:750

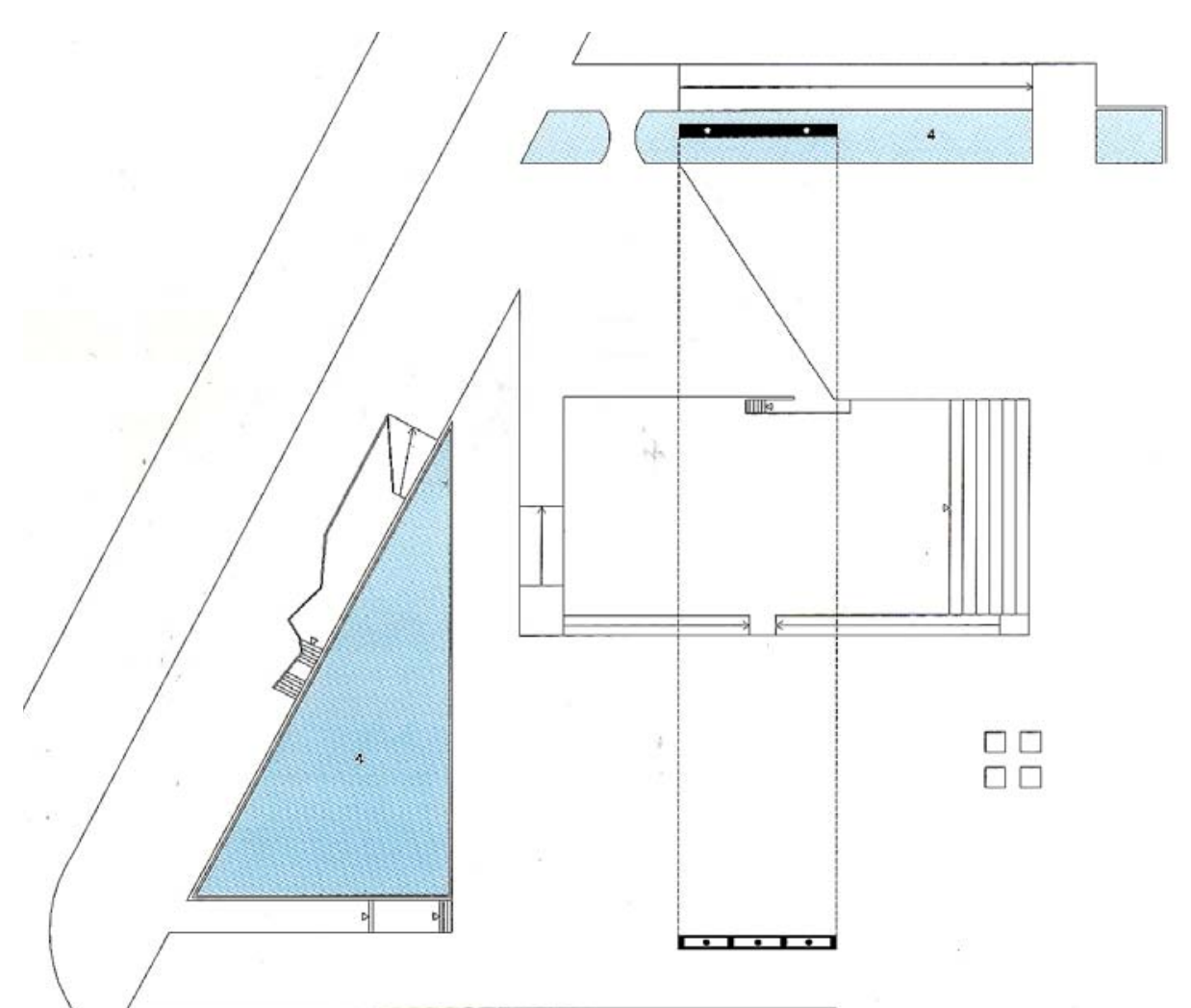

Planta superior, escala 1:750

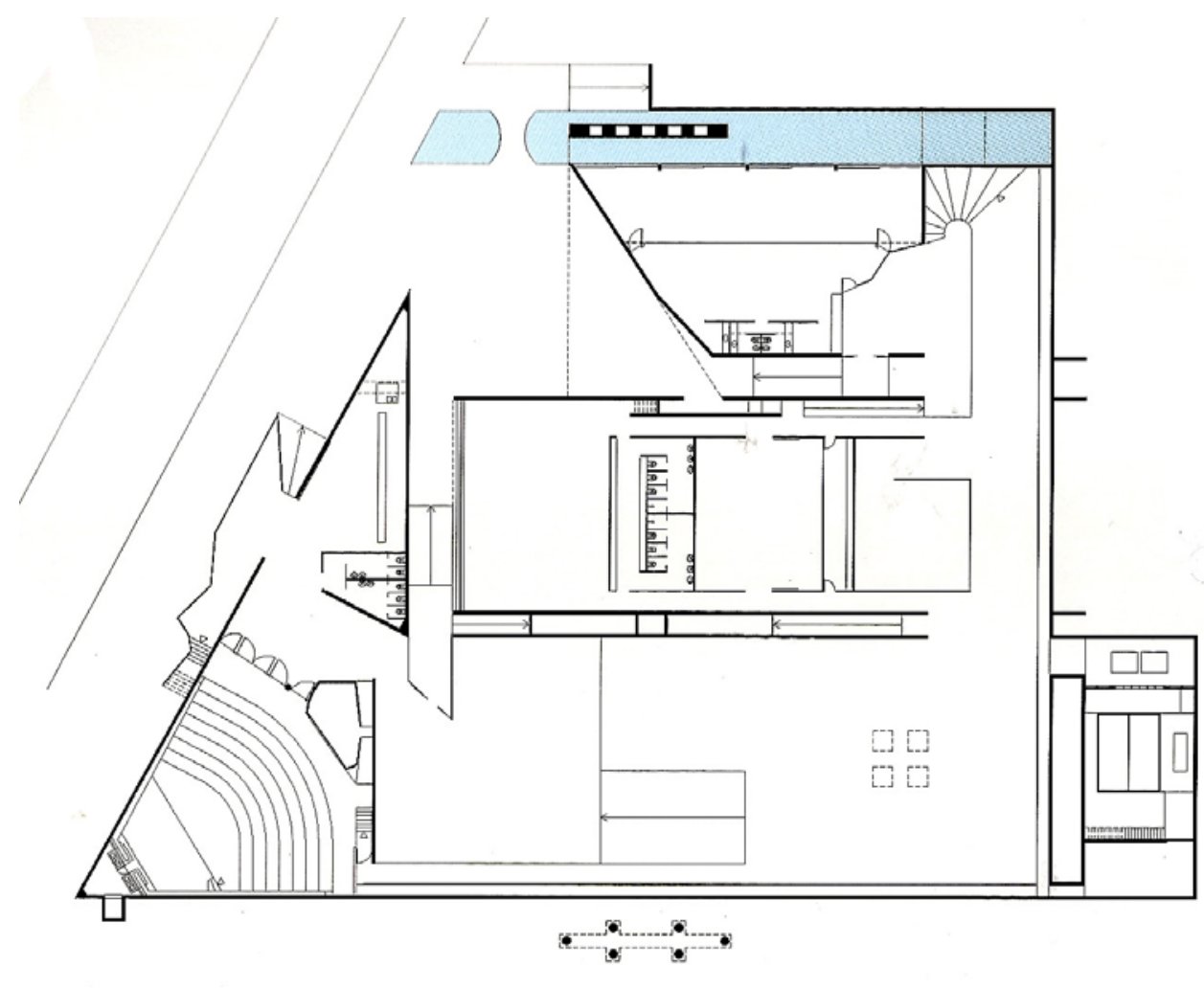

Planta Inferior, escala 1:750 MUBE - São Paulo. Fonte: Artigas, 2000. 
marins e as áreas de apoio estão sob a plataforma, diluídos no programa do Museu. 0 foyer é a grande esplanada, um foyer urbano, delimitado pelo jardim e pelo espelho d'água.

Esse percurso que acabamos de descrever pode ser seguido pela observação atenta das plantas, cortes e imagens apresentadas. As dimensões e proporções se apresentam de forma precisa. Paulo Mendes da Rocha exercita mais uma vez sua autenticidade. Há uma noção de invariante, usando as definições de Ozenfant e Jeanneret (2005, p.55) e a busca da arte pela invariabilidade, que nos permite entender que a natureza age à maneira de uma máquina da qual surge uma malha, uma geometria. As leis dispensam o acaso.

(...) por traz da diversidade, podem ser encontradas propriedades invariantes diferentemente combinadas. (LEVI-STRAUSS, apud MONTANER, 1993, p.179)

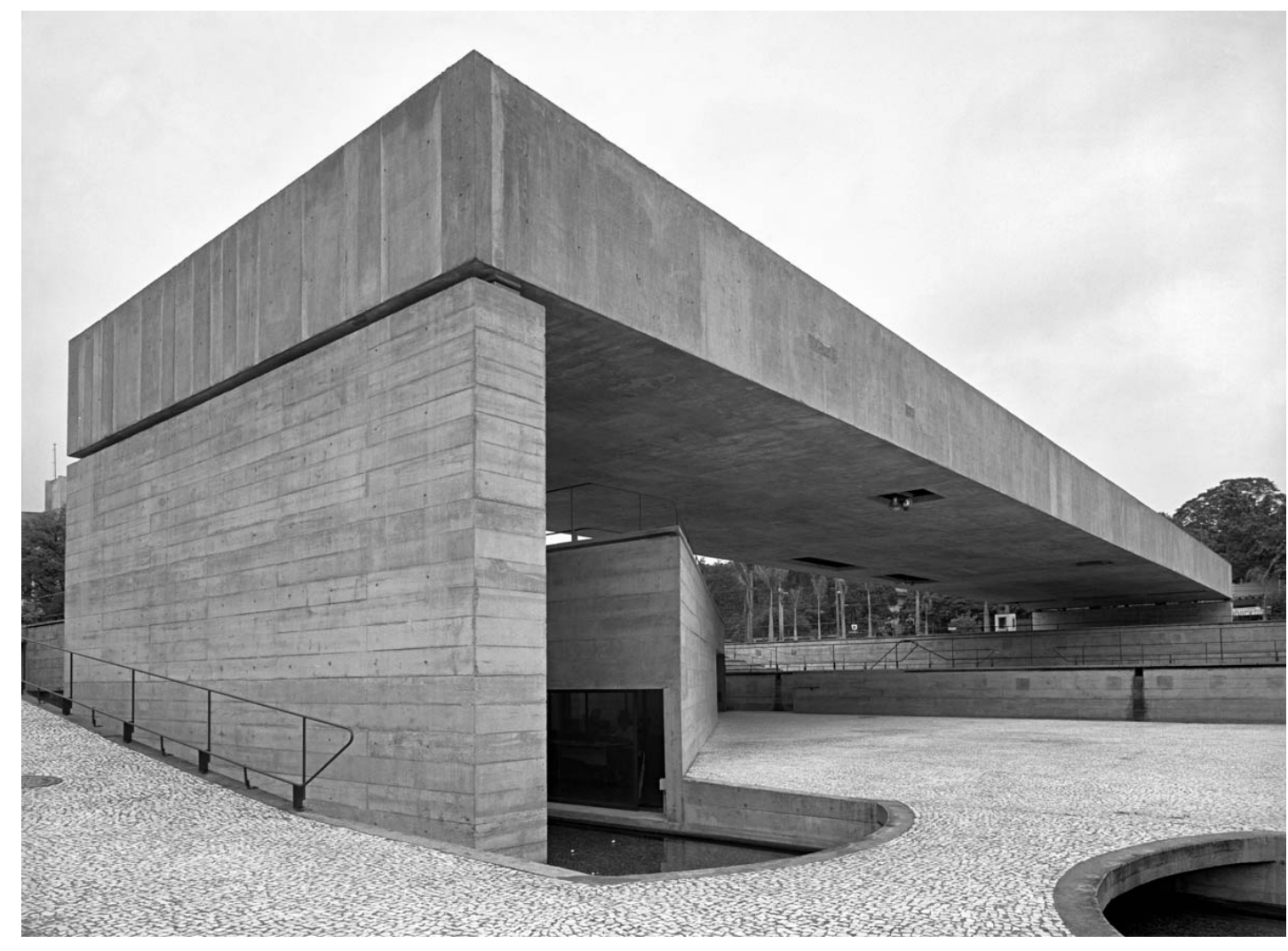

MUBE - São Paulo. Foto: Nelson KON 


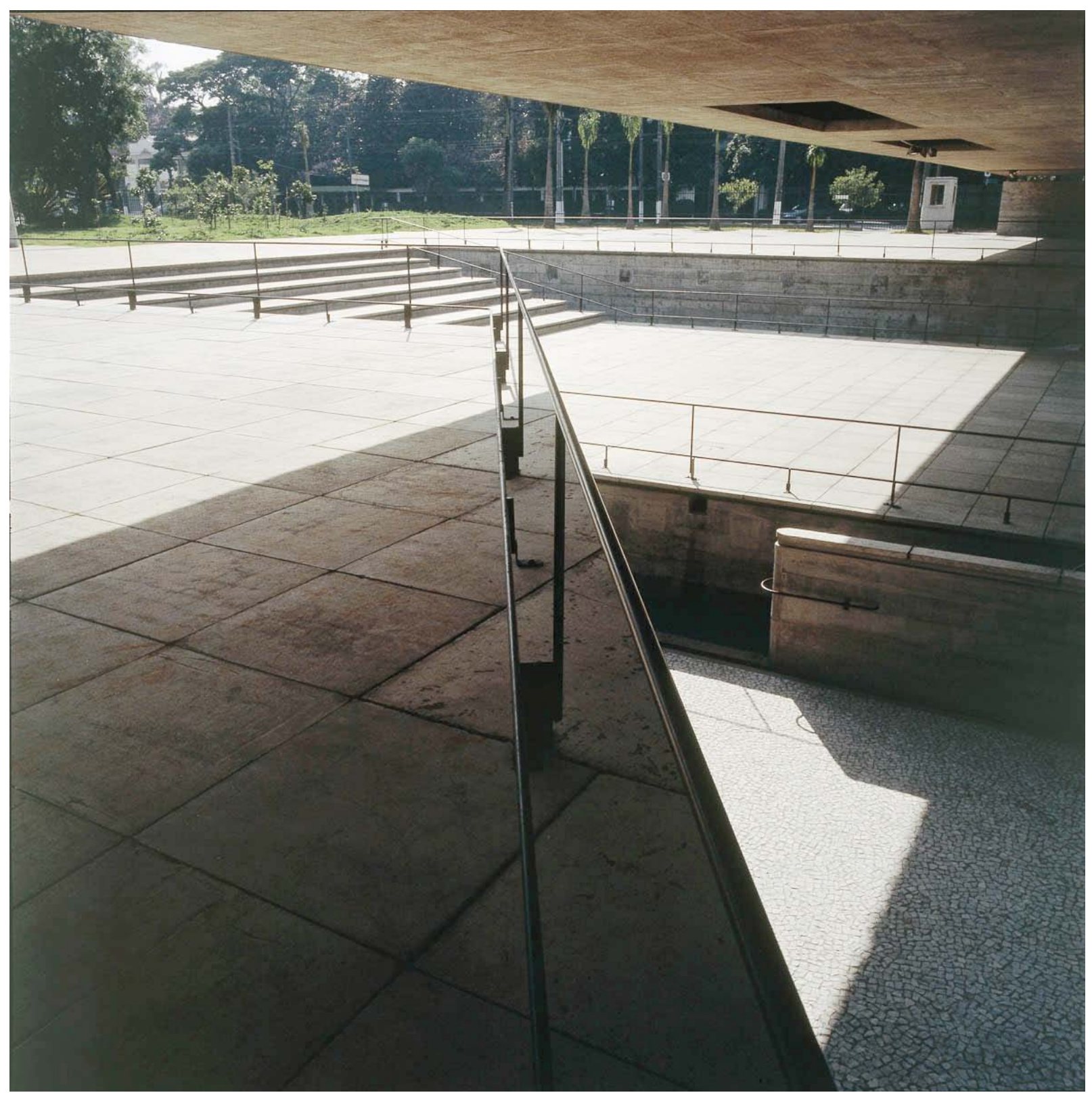

MUBE - São Paulo. Foto: Nelson KON 
O território em Paulo Mendes é ordenado segundo essas estratégias, essas leis. Nada aqui é fruto do acaso. Podemos exemplificá-lo nas palavras de Lamarck: "A palavra acaso exprime somente nossa ignorância da causa "45

Não seria então o caso de reduzirmos nossa análise ao que alguns autores chamam de "predomínio da forma estrutural”, às formas arquetípicas das quais o arquiteto procura se aproximar, como nos apresenta Montaner (2001, p. 204). Estaríamos muito mais diante de uma "experiência física do lugar condensada (...) pois afinal se trata de um museu da escultura", nas palavras de Ruth Verdi Zein (apud ARANTES, 1998, p. 204), ou mesmo de "máquinas que regeneram o caos metropolitano", como bem complementa Montaner.

É evidente que o aspecto da técnica é fundamental na obra de Paulo Mendes da Rocha, e tem sido evidenciado em diversos estudos ${ }^{46}$. No entanto, no nosso caso, parece-nos mais apropriado entender esses projetos como "os momentos quando ocorrem as inovações estruturais e técnicas, quando se solapam diversos tipos para produ- zir novos, como os momentos mais intensos e criativos do desenvolvimento arquitetônico", conforme a visão bastante precisa de Rafael Moneo em seu ensaio "Sobre a Tipologia". (MONTANER, 2001, p. 124)

Percorrer essa extensa esplanada pontuada por esculturas, ladeada pelos jardins projetados por Roberto Burle Marx, é uma experiência necessária na construção do sentido dessa obra, é saber que o edifício poderia emergir, mas seria uma solução óbvia. Seria mais um volume no centro de um terreno, como muitos de seus vizinhos. Nesse caso, a natureza do lugar não estaria revelada, não contribuiria para a definição do objeto arquitetônico.

0 estudo que acabamos de fazer procura estabelecer a relação entre o Projeto e o Lugar do Espetáculo, a Arquitetura do Espetáculo. Admitimos a presença da Arquitetura pelo fato da existência do Projeto. Nas palavras de Giulio Carlo Argan, «(...) o projeto é a relação direta entre uma atividade puramente intelectual e uma atividade manual.» (1993, p. 156)

No primeiro caso analisado, o Espaço dos Satyros I

45 apud OZENFANT, A. e JEANNERET, C. - Depois do Cubismo, 2005.

46 Ver ESPALLARGAS GIMENEZ, Luis - Autenticidade e rudimento. Paulo Mendes da Rocha e as intervenções em edifícios existentes, 1988 


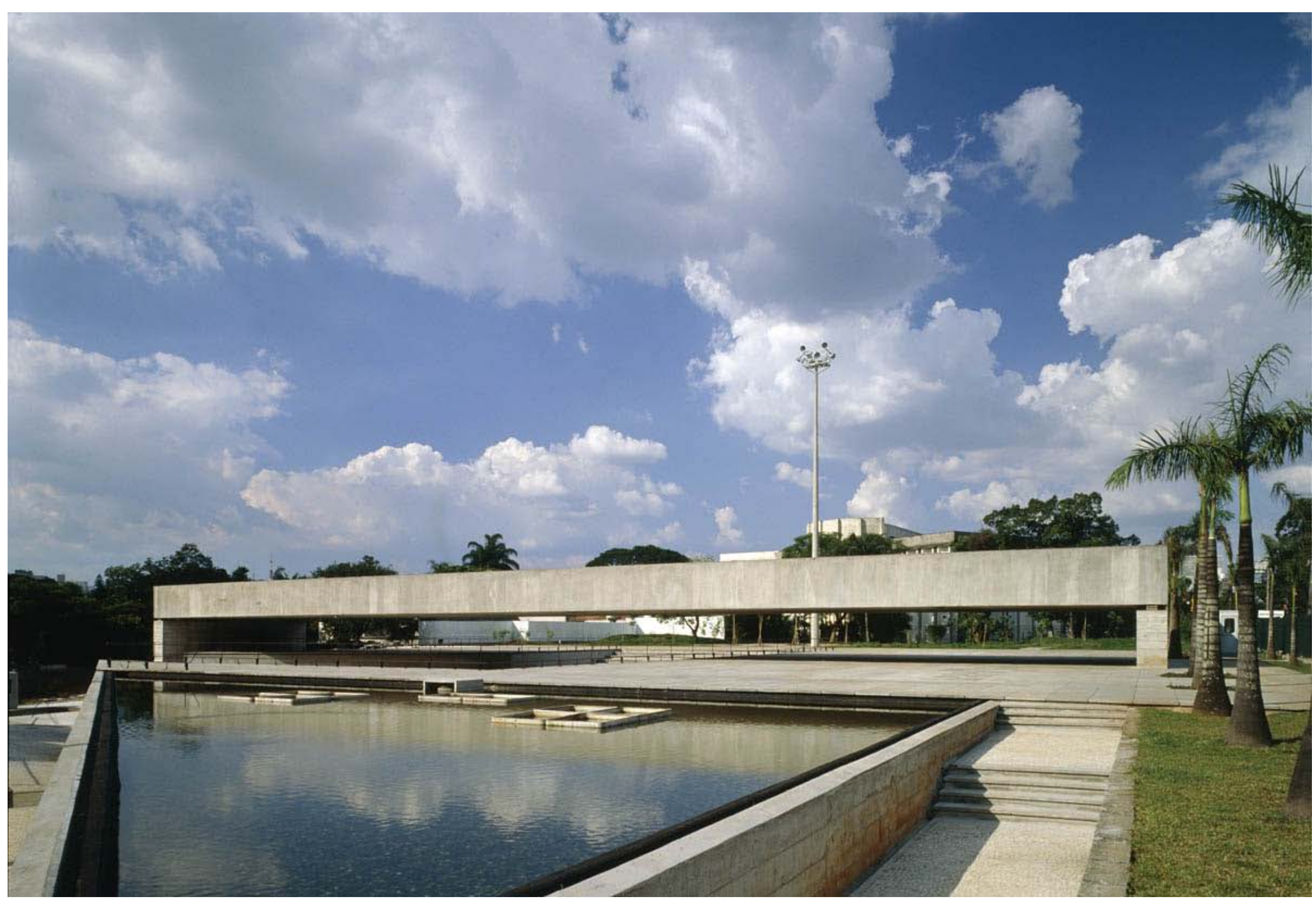

MUBE - São Paulo. Foto: Nelson KON 
na Praça Roosevelt, as intenções de ocupação do espaço e as estratégias de viabilização do trabalho do teatro de grupo antecedem as operações técnicas e intelectuais para a construção do lugar do espetáculo. 0 teatro como texto, como atuação, vem antes. Não é apenas um programa que, nesse caso, poderia, em nossa avaliação, ser desprovido de valor por sua transitoriedade, pela ausência de permanência. Parece-nos que é muito mais do que isso.

Alguns autores, como Evelyn F. Werneck Lima (2010, p. 50), afirmam por exemplo, que há um momento em que a interação entre artistas e espectadores, atraídos para um determinado espaço, é o verdadeiro espírito do lugar teatral, "o sentido expresso entre espaço e dinâmica social." A autora apresenta esse raciocínio para descrever como Paris no século XVIII foi a primeira cidade a ter um bairro voltado para o espetáculo, o Boulevard du Temple, que possuía diversas fachadas de teatros contínuas num mesmo espaço urbano. No caso da Praça Roosevelt, a dinâmica social foi transformada, foi renovada, o que obrigou a própria renovação do espaço público. Infelizmente a continuidade desse processo ou sua manutenção ainda estão para ser verificados, dentre os inúmeros desafios enfrentados pela metrópole.

Na obra de Paulo Mendes da Rocha o Projeto é o ato primordial. Paradoxalmente, sua esplanada constituída de plataformas em concreto foi concebida com a mesma atitude técnica utilizada na Praça Roosevelt, mas com resultados bastante distintos. 0 que assistimos, foi o Projeto, enquanto atividade intelectual, que mediou as operações de transformação do meio. Um Teatro feito de pedras, uma geografia esculpida, escavada na pedra artificial, tão próximo dos melhores exemplares da antiguidade, como o Teatro de Siracusa, cavado na rocha de mármore branco. 


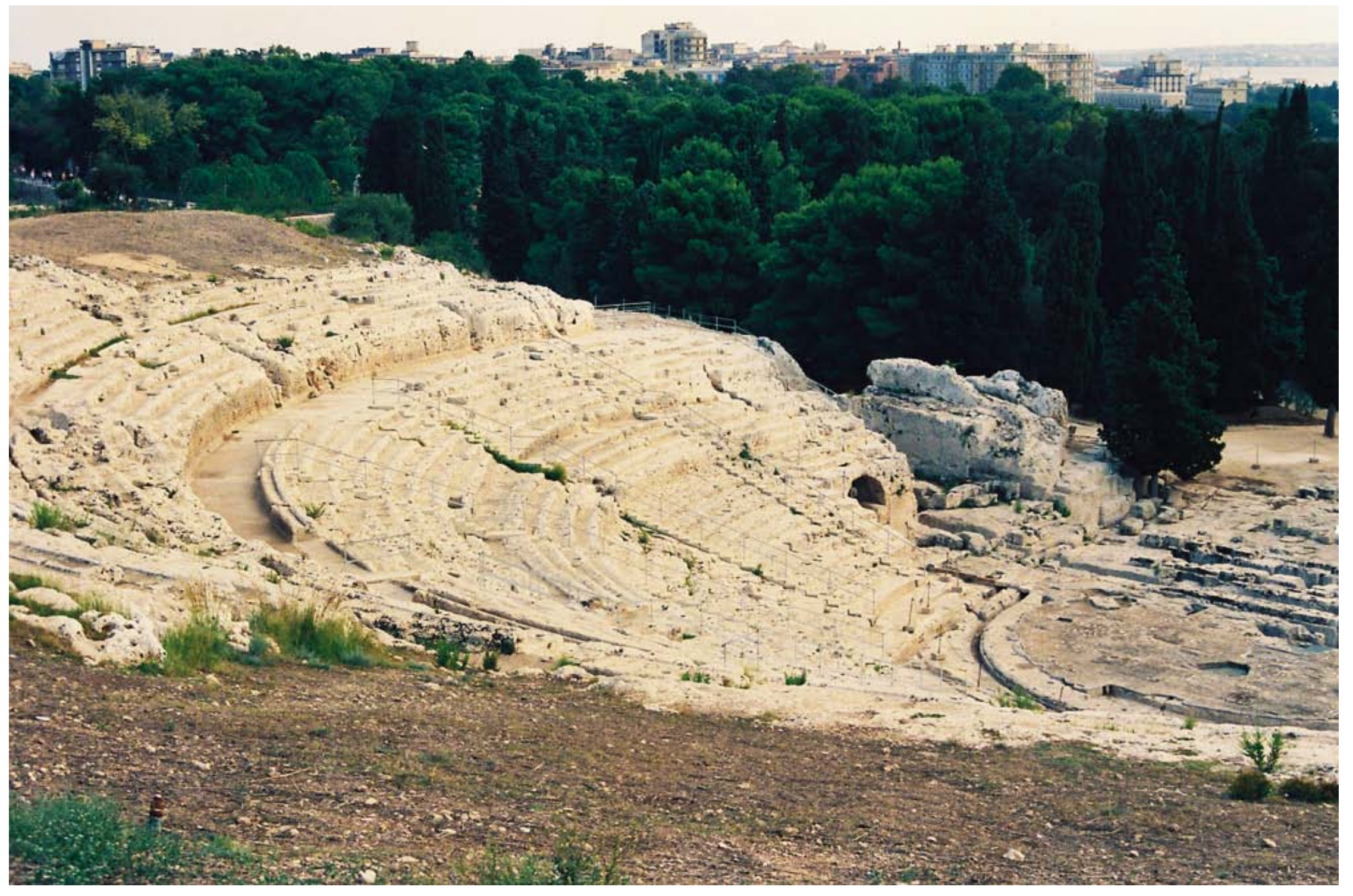

Teatro de Siracusa. Foto: Valério Pietraróia 
Capítulo 3

a Arquitetura do Espetáculo e a Modernidade 
Erwin Piscator ${ }^{47}$ foi o encenador teatral que, em 1926, convidou Walter Gropius para projetar o Teatro Total, síntese das convicções das vanguardas artísticas da época e exemplo até hoje de edifício repleto de inovações, de mobilidade, de espaço adaptável, flexível, livre para as criações teatrais. Posteriormente, em 1961, durante um colóquio sobre o assunto, Piscator viria a afirmar posteriormente:

Conhecemos todas as objeções feitas a esse tipo de projeto[o Teatro Total] devemos examiná-las com cuidado. Afirma-se que o equipamento se tornaria muito complexo, muito pesado, muito especial, e finalmente inútil para diferentes mises en scène; [diz-se também que] quanto mais simples um teatro, mais ele permite a liberdade de imaginação, ao passo que a tecnologia torna-se um obstáculo a ela paralisando a fantasia. (in BABLET, 2002, p. 181) ${ }^{48}$

Essa reflexão confirma um dos sentimentos compartilhados por diversos profissionais da área teatral, que ao longo do tempo viram sua criatividade reduzida pelo excesso de possibilidades e ao mesmo tempo de regras e

47 Erwin Friedrich Maximilian Piscator, encenador teatral, liderou o Volksbühneem, teatro sociopolítico na Alemanha nas décadas de 1920 e 1930.

48 Nossa tradução do texto original: Nous connaissons toutes les objections que l'on fait à ces projets: nous devons les examiner consciencieusement. On dit que l'appareil deviendrait trop complexe, trop lourd, trop spécial, et en fin de compte inutilisable pour les différentes mises en scène; plus un théâtre est simple, plus il permet le libre jeu de l'imagination, tandis que la technique lui fait obstacle en paralysant la fantaisie. procedimentos a serem respeitados para que o conjunto de equipamentos fosse utilizado em um aparente benefício do espetáculo.

O presente capítulo desta dissertação analisa justamente os projetos que trataram do tema, Arquitetura do Espetáculo, e sua relação com o Movimento Moderno, e qual sua contribuição para a discussão que percorre nosso trabalho, como no exemplo acima citado. Cada um deles encerra aspectos relevantes em relação ao tema, como descrito nos sub capítulos que tratam sobre eles.

A escolha de uns e a ausência de outros não significa que tenha sido feito um juízo de valor, mas sim, a identificação em quais deles pode-se observar os aspectos relacionados no capítilo 1: Arquietura do Espetáculo: Noção e Metodologia. Foram selecionados alguns projetos considerados significativos conforme a lista a seguir:

1. Auditorim Building em Chicago de Dankmar Adler e Louis Sullivan, 1886; 2. Teatro Total de Walter Gropius, 1928; 3. Complexo Woga em Berlim, de Eric Mendelsohn 1928; 4. Teatro Nacional de Mannhein, de Mies van der Rohe de 1953 


\section{LONGITUDINA. SECTION}

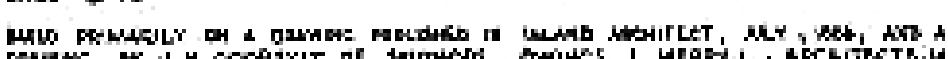

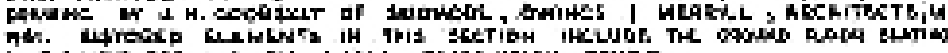

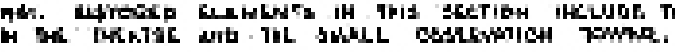

persy

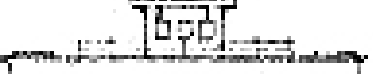

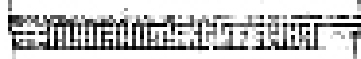

GIIIIIIII!

far mon

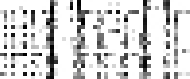

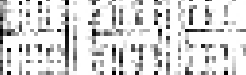

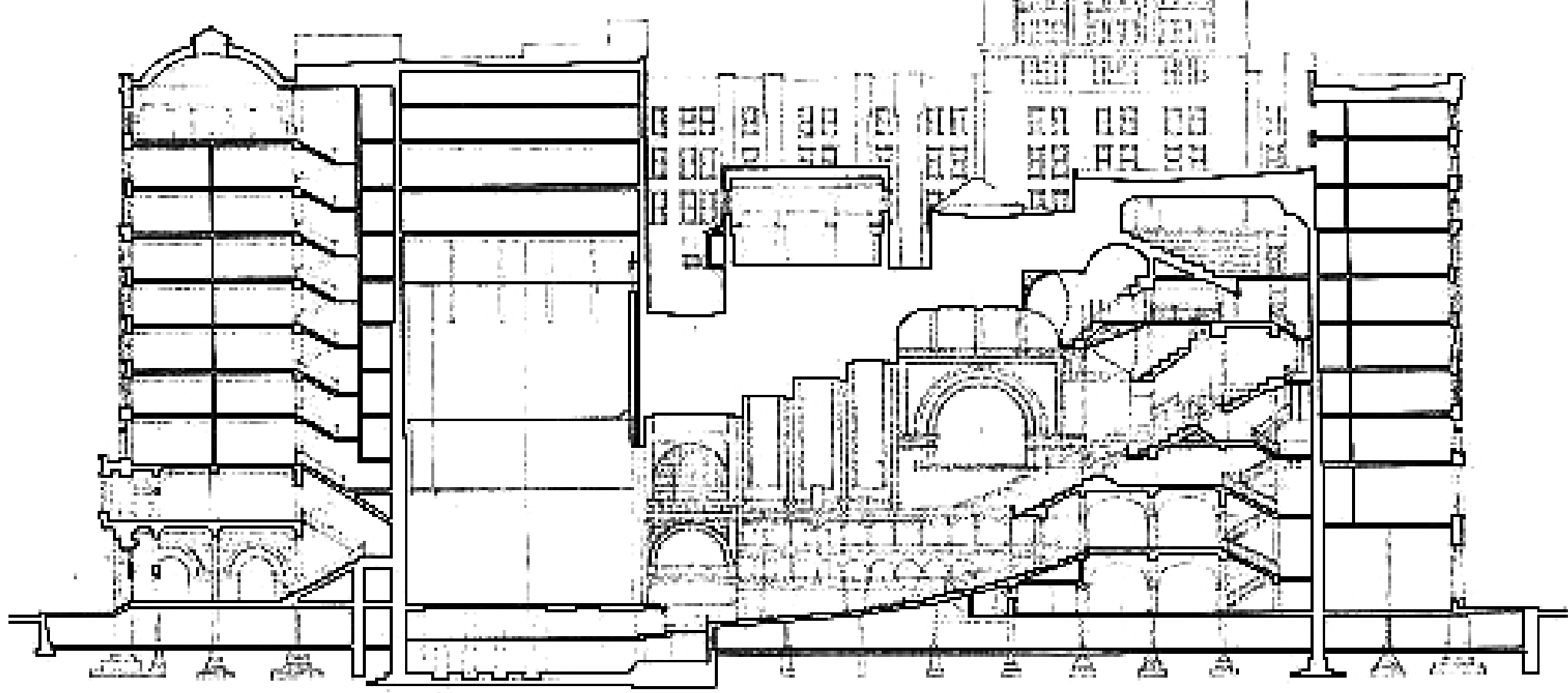

Corte Longitudinal, sem escala. Auditorium Building - Chicago. Fonte: Library of Congress - USA 
Antes de 1886, Adler e Sullivan ocupavam-se sobretudo com pequenas estruturas para escritórios, armazéns e lojas de departamentos, uma atividade comercial que de vez em quando era variada pela encomenda de projetos residenciais. Esses primeiros edifícios, limitados a cerca de seis andares, não lhes davam muita liberdade, exceto na expressão da estrutura, fosse ela de ferro, alvenaria ou a mistura de ambos, e pouco podiam fazer, salvo manipular a clássica divisão da fachada em base, meio e topo.

Tudo isso mudou em 1886, com a encomenda de projetar o Auditorium Building, uma estrutura cuja contribuição global para a cultura de Chicago deveria ser tanto tecnológica como conceitual. o arranjo básico desse complexo de usos múltiplos era exemplar. Pediu-se aos arquitetos que instalassem, em meio quarteirão de Chicago, uma casa de ópera grande e moderna, tendo dos dois lados onze andares, que seriam destinados em parte a escritórios, em parte a um hotel. 
As palavras acima, escritas por Kenneth Frampton para iniciar um dos capítulos de seu livro História Crítica da Arquitetura Moderna, demonstram a importância dada por esse autor a uma obra chave para a consolidação das mudanças que vinham acontecendo na Chicago do final do século XIX. $O$ grande incêndio que marcou a história da cidade já havia ocorrido há 15 anos. A forte pressão pela verticalização das obras impulsionara o aperfeiçoamento das técnicas construtivas em estrutura metálica que, associadas ao desenvolvimento dos elevadores, já permitiam atender à forte demanda que inflacionara o preço dos terrenos. Esse processo, admitido pelo próprio Louis Sullivan em sua autobiografia (1926), seria em sua avaliação, responsável pelas modificações profundas na forma de construir.

As razões enumeradas acima já seriam suficientes para a análise da obra. 0 fato de ser o primeiro complexo cultural e comercial (FORSYTH, 1985, p. 232), um precursor dos conjuntos multiuso, em que o auditório é o espaço de maior complexidade a ser edificado, torna ainda mais obrigatória sua presença nesse trabalho.

\section{A Implantação e as três fachadas}

A observação do corte longitudinal nos permite verificar que o edifício multifuncional de Adler e Sullivan atinge onze pavimentos em toda a extensão das três fachadas, cujos volumes criados abrigam as atividades de escritório e hotel. Esse último ainda se destaca por meio de uma torre que duplica a altura do conjunto. A sala de espetáculos, o Auditorium, no centro do conjunto, é envolvida pela massa periférica, que protege e isola a sala, oferecendo-lhe uma melhor condição para o seu isolamento acústico, como fica claro na planta do pavimento térreo.

As soluções construtivas foram decisivas, não só para atingir a capacidade de ocupação e o volume construído da sala, com a mesma altura do conjunto, mas sobretudo para resolver seu tratamento acústico e a flexibilidade desejada, que permite abrigar de 2.500 a 7.000 espectadores ${ }^{49}$.

Para atingir esse resultado, Adler e Sullivan utilizaram um sistema de painéis dobráveis e telas verticais , como pode ser visto no detalhe do corte perspectivado. A

49 Pela verificação dos documentos disponíveis, podemos dizer que os mecanismos previstos não são suficientes para quase triplicar a capacidade da sala, mesmo para o uso em convenções, como afirma Keneth Franptom. A consulta ao site oficial do Auditorium indica que Adler e Sullivan projetaram 4.200 lugares. O histórico disponível descreve que, durante a Convenção do Partido Republicano realizada no Auditorium em 1888, foi possível acomodar 6.000 participantes, ao ocupar o palco, o lobby e as galerias de circulação.

http://auditoriumtheatre.org/wb/pages/home/education/historic-theatre-tours. php?wb_session_id=522f042f1ffa $7441062 \mathrm{cbfde} 2 \mathrm{bb} 9 \mathrm{c} 27 \mathrm{~b}$ 


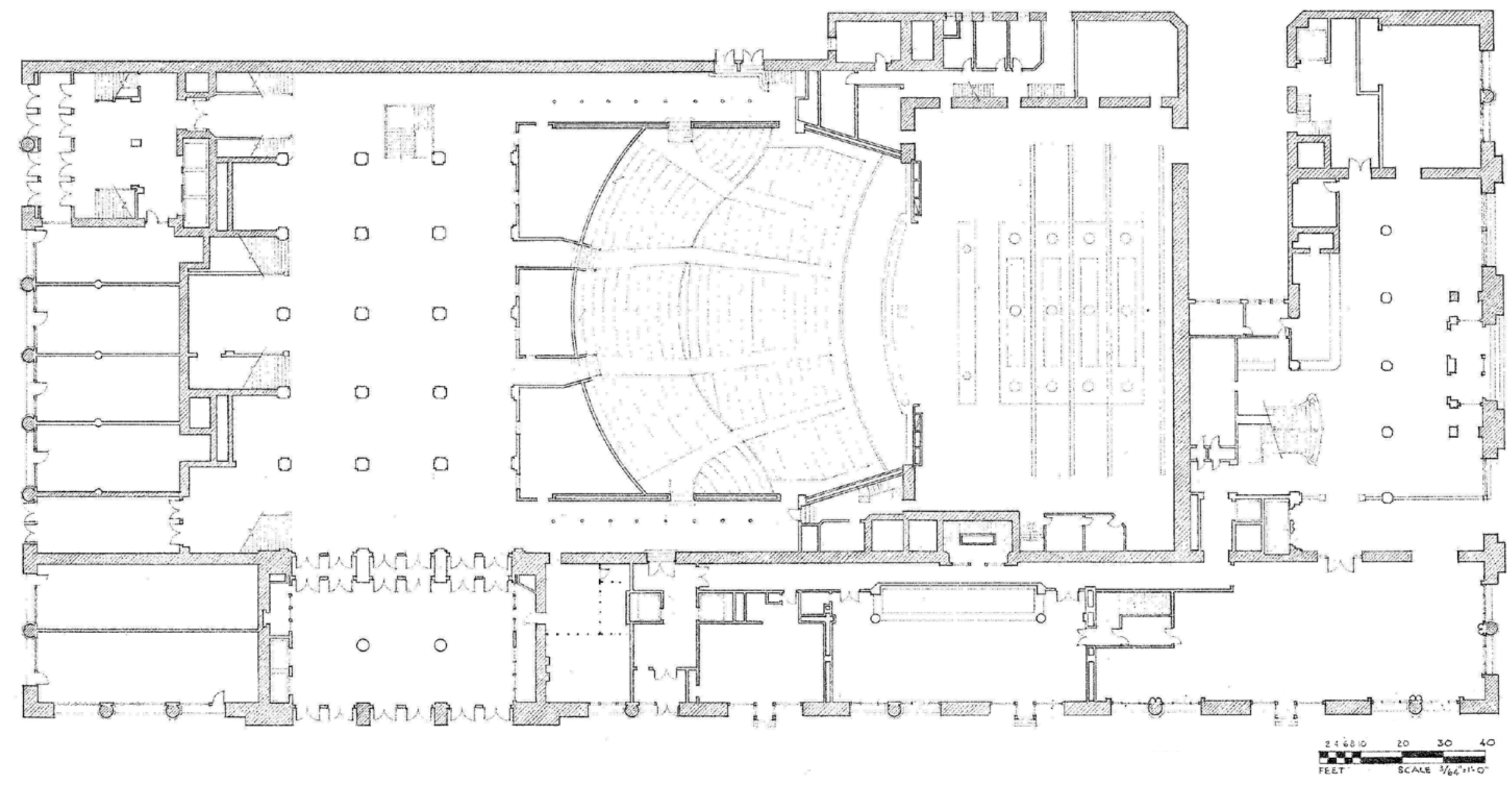

PlantaTérreo Platéia. Auditorium Building - Chicago. Fonte: Library of Congress - USA 


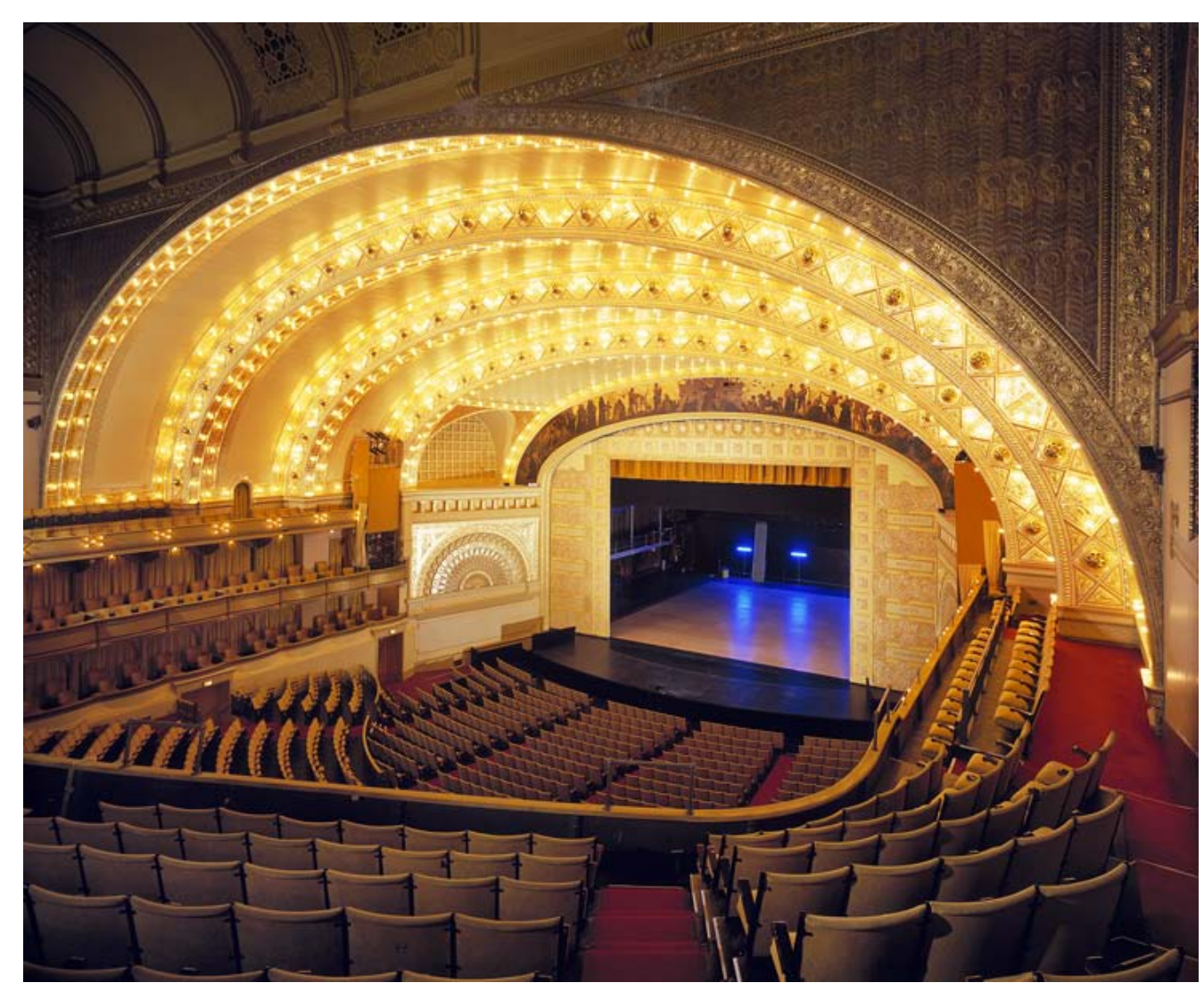

Interior. Auditorium Building - Chicago. Fonte: Library of Congress - USA estrutura metálica formada por treliças em arco cobrem o grande auditório e, embora a totalidade da estrutura do conjunto não seja aparente, não se expresse diretamente, é possível perceber a generosidade dos vãos (cerca de 36 m) e das alturas que ela proporciona. Adler viria a admitir que as formas não convencionais geradas a partir dessas soluções foram responsáveis pela qualidade acústica atingida pela sala. Entretanto, o desempenho acústico para o uso como sala de concertos não foi satisfatório em função da multiplicidade de usos e da grande capacidade para que fora previsto o Auditorium, apesar do grande sucesso dos festivais de óperas, espetáculos musicais e convenções.

Michel Forsyth destaca ainda o fato de ser o Auditorium a primeira sala a utilizar a curva isostática de John Scott Russel para atingir tal qualidade sonora ${ }^{50}$. Todas essas preocupações técnicas para dar à sala a melhor

50 Op. cit. p. 232. Em 1838 John Scott Russel publica um tratado baseado nos ângulos de visão, conhecido como curva isostática, que ainda hoje é usado. Ver a íntegra do documento Tretise on Sightlines em IZENOUR, Theater Design, pg. 597-599. 
condição de visibilidade e de acústica tornaram Adler, ao lado de Wallace Clement Sabine, referência para a concepção dos auditórios no século XX.

Ainda que seja possível avaliar a dimensão que a evolução técnica representou, não há uma preocupação para que sua expressão seja objeto do resultado estético desejado. Podemos admitir, no entanto, que a linguagem que Sullivan viria a empregar em obras conhecidas, como o Garanty Building ${ }^{51}$, já se apresenta no Auditorium Building, ainda que de forma latente.

Não há, também nesse caso, o desejo de colocar em evidência a grande massa representada pelo Auditorium. Ela está no interior do conjunto, mas não dentro de um outro edifício, como num palácio renascentista. A proteção representada pelos blocos que o circundam é a prova da busca pela expressão de uma arquitetura de forte caráter urbano em que a composição vertical, proporcionada pelas soluções estruturais, domina todas as demais. Como ponderou Colin Rowe, a importância da estrutura para o Arquitetura Moderna coloca Chicago em uma posição comparável

51 Garanty Building, Bufallo, 1895 à Florença durante o Renascimento e conclui: "Ainda que a estrutura metálica tenha aparecido antes em outros locais, é em Chicago que seus resultados formais foram mais rapidamente elucidados". (ROWE, 1999, p. 92)

Como contribuição para nosso estudo devemos destacar os seguintes aspectos:

. 0 Auditorium Building é um lugar do espetáculo de destacada importância dentro da historiografia da Arquitetura Moderna, como obra que impulsionou o trabalho de

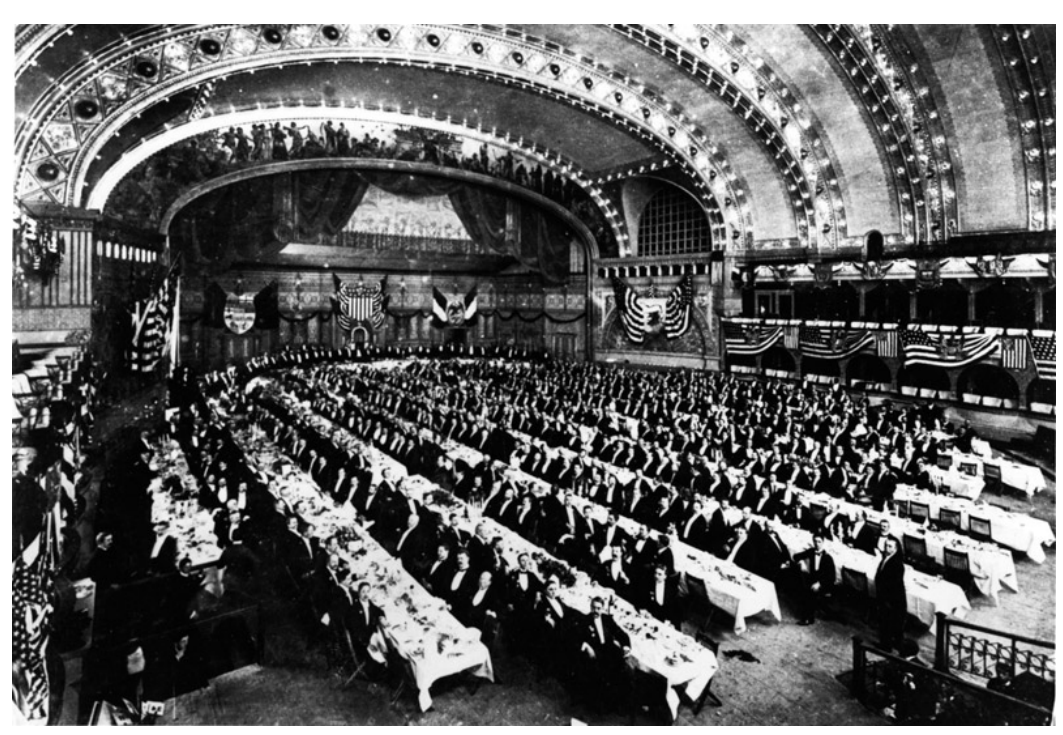

Convenção do Partido Republicano de 1888. Auditorium Building - Chicago. Fonte: Library of the Congress - USA 
Adler e Sullivan durante as transformações ocorridas na arquitetura de Chicago naquele período.

. É um exemplo significativo de conjunto multifuncional (o primeiro na história a assumir tal programa) em que o lugar do espetáculo é o gerador da implantação, isto é, as outras funções se organizam em torno dele. Dessa forma, ele representa uma solução de destacado interesse por sua maneira de articulação e subordinação entre os conjuntos funcionais. Paul Goldberger confirma essa importância ao afirmar que o Auditorium Building é "precursor dos edifícios multifuncionais (...) ele emerge como vasto edifício a enriquecer a cidade". (1985, p. 20-21)

. A expressão estrutural se manifesta, seguindo a tendência que iria se estabelecer de maneira definitiva nas décadas seguintes e se tornando a pura expressão da Modernidade: a técnica como expressão de uma determinada monumentalidade.

. Não se pode falar de Chicago sem se referir à a presença das inúmeras torres desse período, dentre as quais o Auditorium Building, que atribuíram a identidade da ci- dade. Kevin Lynch (2011, p. 11-12) afirma que seria difícil pensar em Chicago sem imaginar o Lago Michigam. Podemos complementar dizendo que, dentro da perspectiva de construção da imagem da cidade, as torres, como conjunto de obras, são tão fundamentais quanto o lago, ou até mais, na medida em que constituem o ambiente construído pela obra arquitetônica.

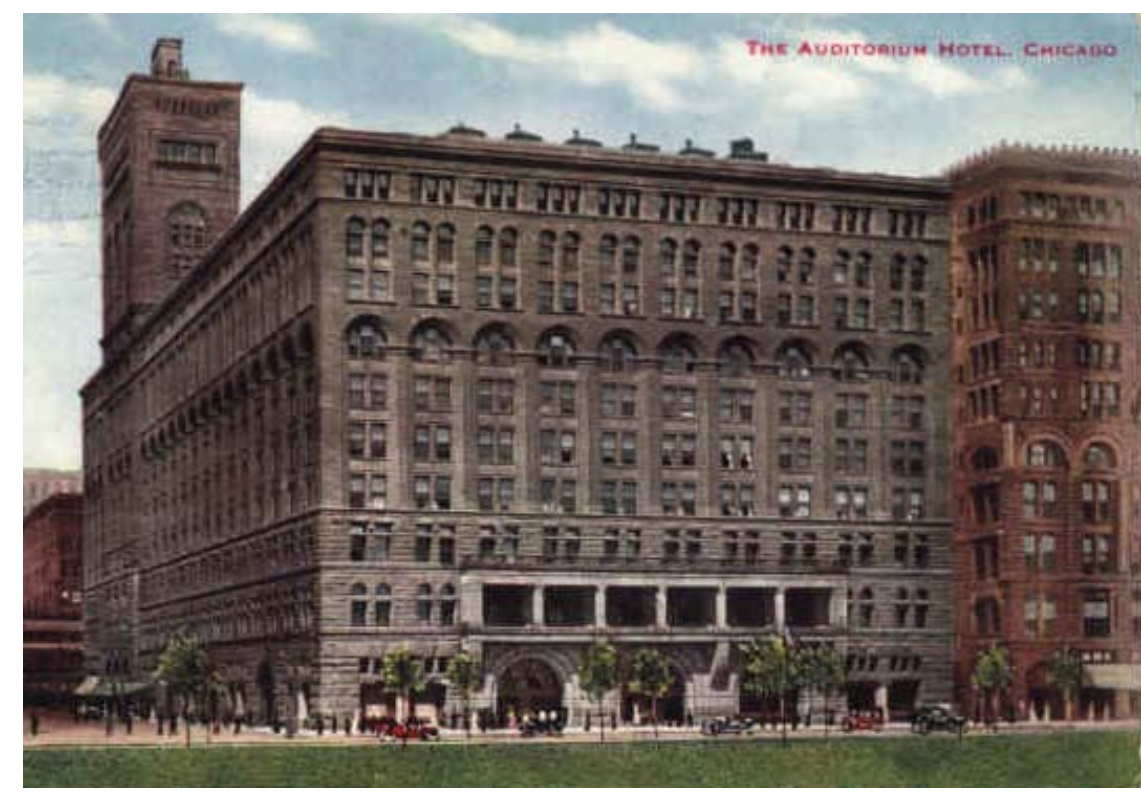

Vista do lago Michigan. Auditorium Building - Chicago. Fonte: Library of the Congress - USA 


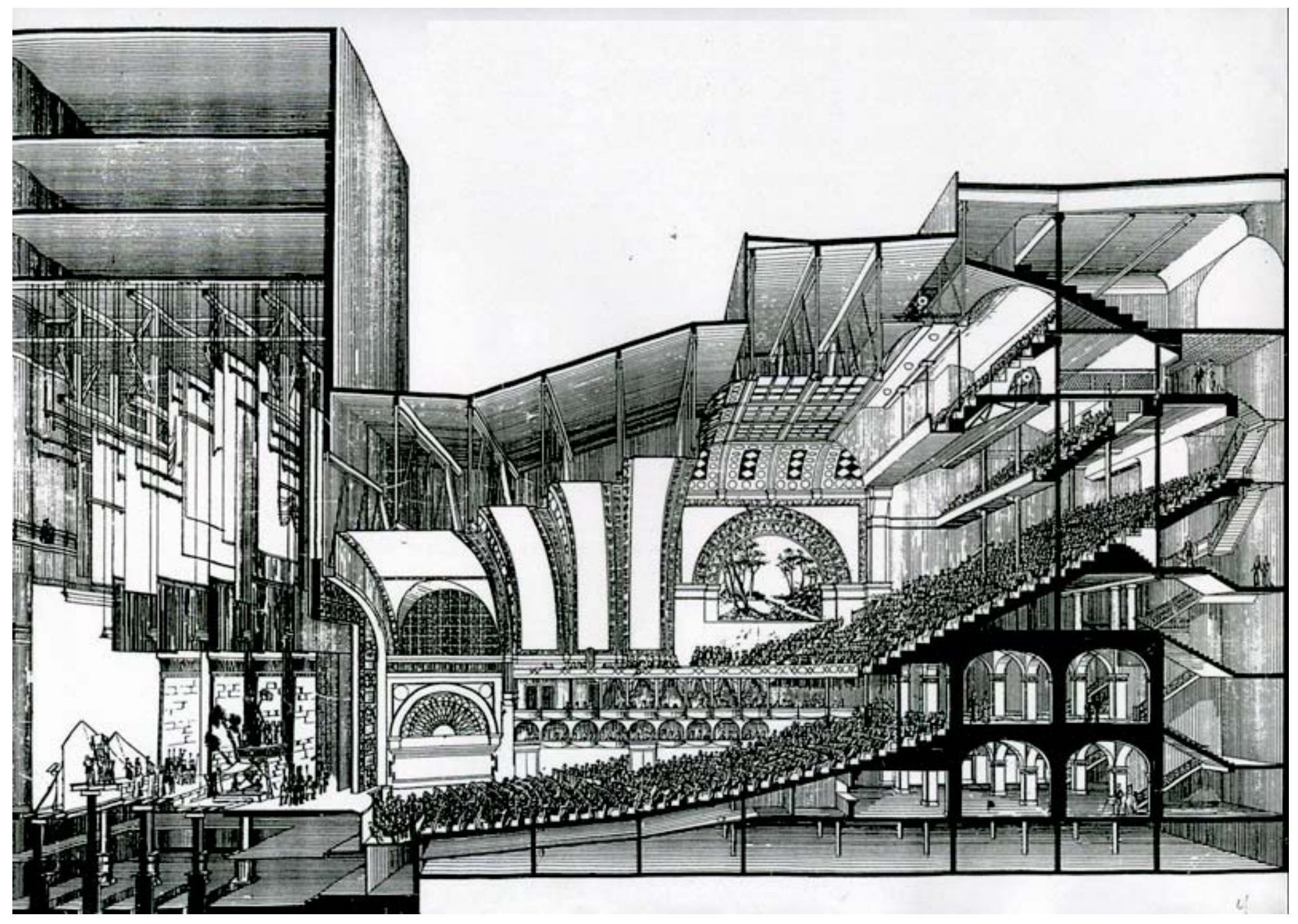

Corte Perspectivado. Auditorium Building - Chicago. Fonte: FORSYTH, 1985. 


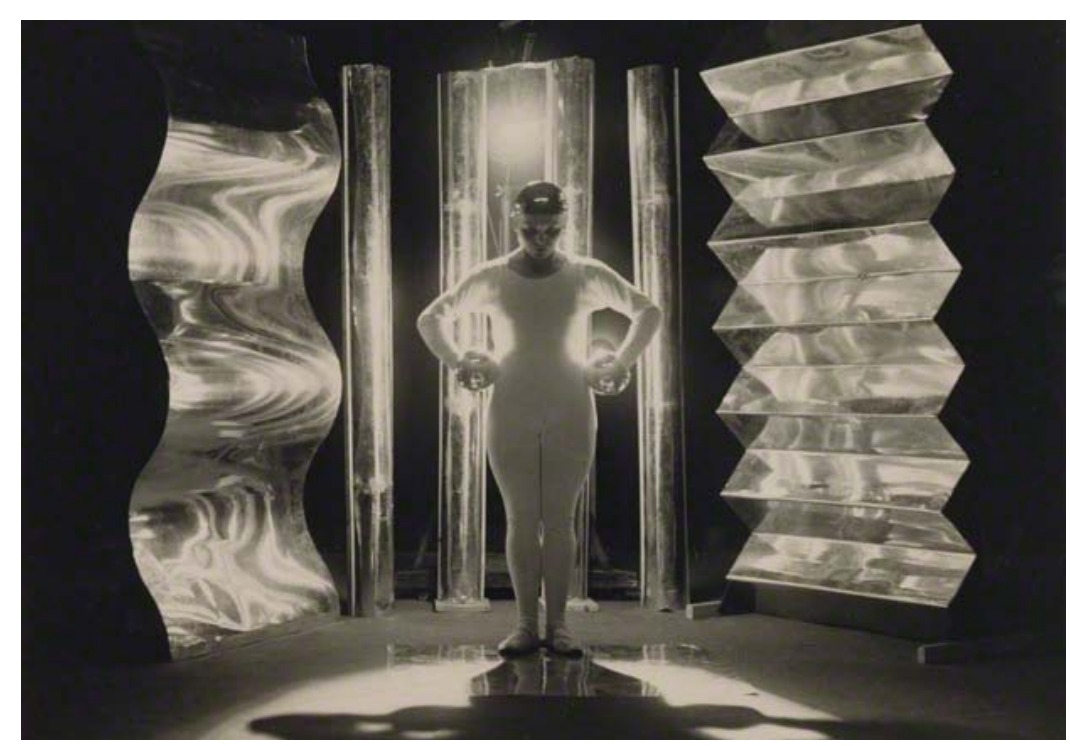

Metal Dance - 1929. Foto Lux Feininger fonte: http://strangeflowers.wordpress.com/2013/04/10/t-lux-feininger-photographs/ 
Oskar Schelemmer e Lászlo Maholy-Nagy foram alguns dos artistas responsáveis pela área teatral durante os anos em que a Bauhaus funcionou sob a direção de Walter Gropius, até 1928. Os espetáculos e trabalhos produzidos nesse período são o resultado da aplicação das questões estéticas e educacionais discutidas pela escola, o que consolida o caminho para o que podemos chamar de Teatro Abstrato, baseado nas propostas de Adolphe Appia e Gordon Craig, como abordado aqui no capítulo, O Lugar do Espetáculo.

Os ensinamentos de Schlemmer estão focados na busca de uma nova interpretação do espaço, baseada na relação do corpo, das formas puras e fundamentais, em uma construção formal apoiada em relações matemáticas: palco cênico como um espetáculo vivo de formas e cores, uma composição arquitetônica de ordens e planos" - nas palavras de Evelyn W. Lima (2010, p. 129). Seus ateliês de escultura podem ser considerados precursores da estética "elementarista". (FRAMPTON, 2003, P. 152) 
sa linha de raciocínio ao considerar a ação como um conjunto de situações entre forma e movimento, corpo e luz. pode-se compreender melhor suas propostas para o teatro pelas observações de Colin Rowe ${ }^{52}$, que mostram como as pinturas de Maholy-Nagy são dotadas do que ele chama de transparência fenomenal: "a luz em movimento, a visão em movimento, pinturas livres de qualquer elemento que lembre a natureza" (FRAMPTON, 2003, P. 150). É importante também mencionar que Maholy-Nagy reserva um espaço significativo para a eliminação da lógica nos conteúdos teatrais: o improvável e o surpreendente assumem papel relevante, aproximando-se de outras correntes das vanguardas artísticas da década de 1920, como a dadaísta.

Podemos considerar que a contribuição significativa da Bauhaus para o tema da presente pesquisa, Arquitetura do Espetáculo, está mais distante do aleatório e extremamente próxima da abstração formal de Maholy-Nagy e daquela produzida por Schlemmer - as criações do Neoplasticismo, do Construtivismo e do Suprematismo encontram aqui seu equivalente na dramaturgia. De um lado podemos

52 ROWE, Collin - Maneirismo e Arquitetura Moderna, 1991. Sobre o tema, ver o capítulo Transparência: Literal e Funcional, p. 156 e 160. observar que nos ateliês desse último não há uma proposição direta, objetiva, que oriente a concepção do local do espetáculo, que direcione o projeto do edifício teatral. É provável que nesse momento tal proposição não fosse fundamental para a introdução e desenvolvimento de novas situações dramáticas, como viria a se tornar posteriormente. Em outras palavras, a ação poderia se dar no interior do edifício especializado, ou em outro adaptado, ou ainda no espaço urbano. Mas nesse caso as combinações gráficas e sonoras preconizadas pela Escola se situariam em outra dimensão, a dimensão urbana.

Por outro lado é inegável considerar pioneira e duradoura uma determinada revolução estética da cena, um movimento de mudança partindo do interior da atividade teatral, que viria a marcar definitivamente o lugar do espetáculo. A cena mostra-se indutora de transformações dessa ordem ao criar novas situações, novas necessidades, ao se alimentar, ou mesmo se contrapor ao cenário urbano, à arquitetura da metrópole (encontramos aqui mais um exemplo da estreita relação entre a cidade e a cena).

A fotografia de Lux Feinninger registra parte do edifício da Bauhaus como palco de um dos espetáculos produzidos na Escola nesse período. 


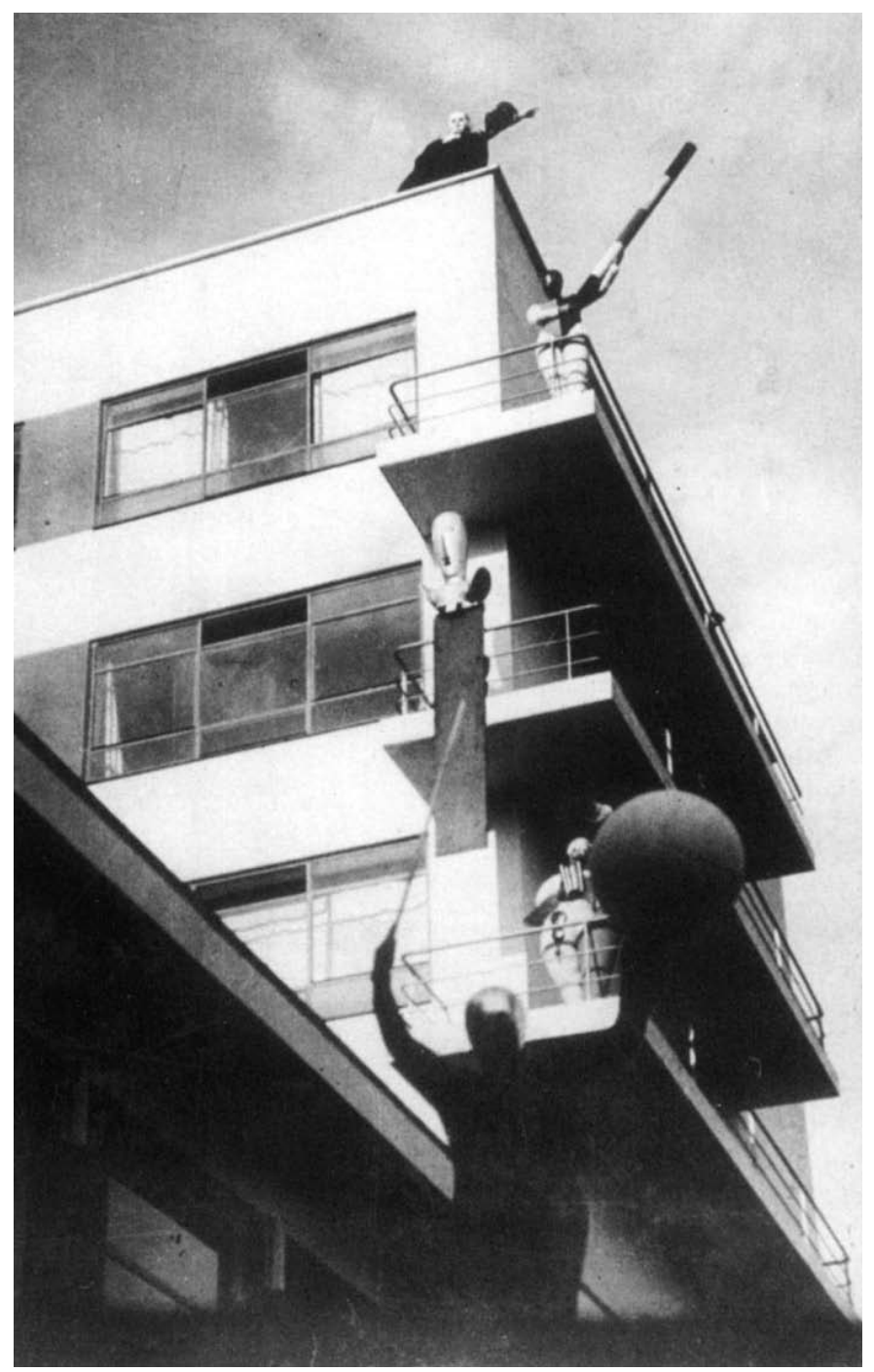

A Building as Stage. Foto: Lux Feinninger

fonte: http://rosswolfe.wordpress.com/2013/07/20/theater-buhne/ 


\section{O Lugar da Tecnologia}
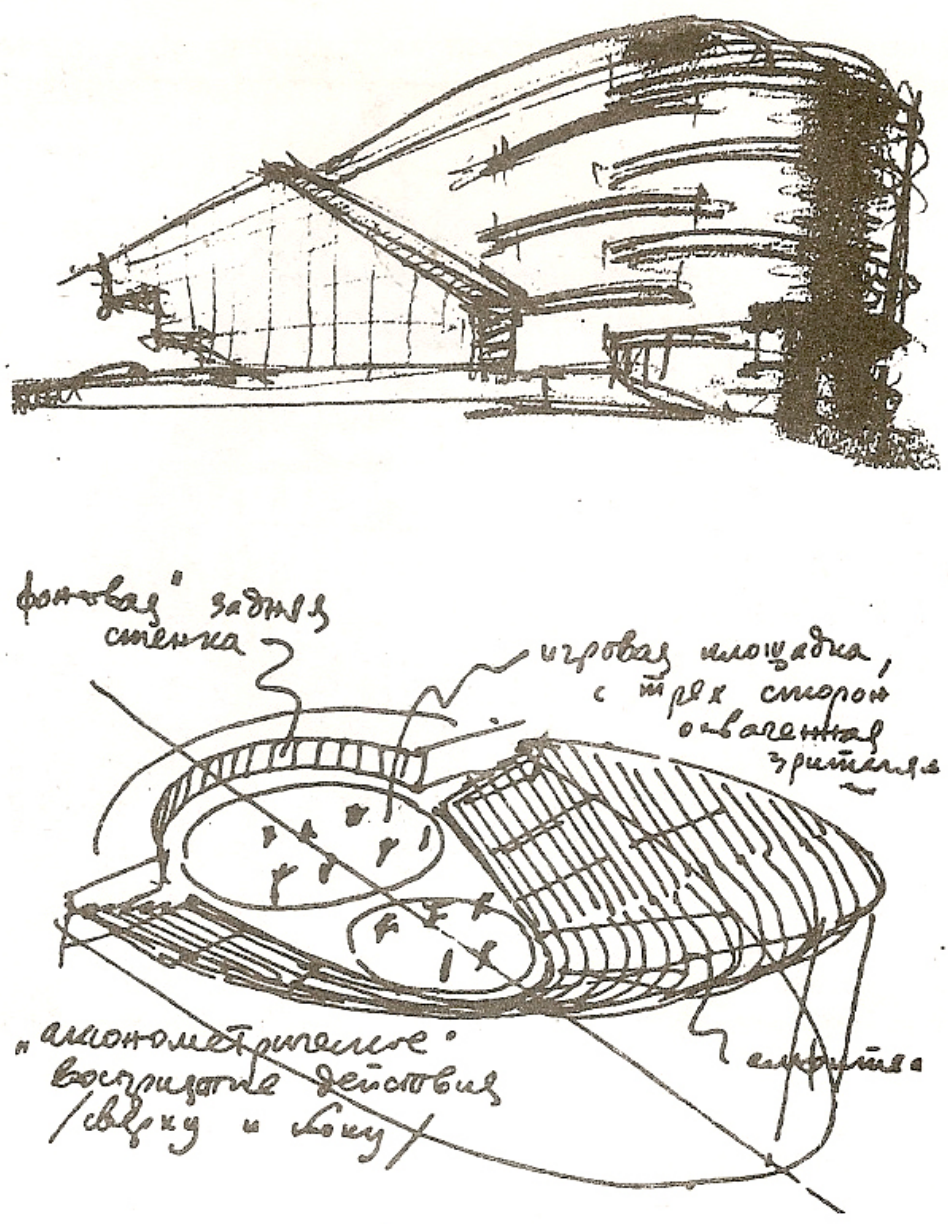

Croquis. Teatro Meyerhold de EI Lissyzky. Fonte: KOOP, 1988
$\mathrm{O}$ período entre guerras, no início do século $\mathrm{XX}$, é sem dúvida um momento em que a produção teatral está totalmente voltada para as novas experimentações visuais e dramáticas, de forte cunho político e social (ZILIO, 2010, p.164). Esse período coincide com os anos de existência da Bauhaus, marcado pela intensa busca da interação entre produção artística e industrial, entre a criação e a tecnologia.

(...) o Piscatorbühne de Gropius foi em grande parte projetado para satisfazer às exigências de um palco biomecânico, que proporcionasse o espaço para um "teatro de ação" conforme o haviam esboçado Meyerhold e seus colegas do Proletkult. (FRAMPTON, 2010, P. 167)

A afirmação de Frampton estabelece de maneira precisa a aproximação entre a arte, a educação e a tecnologia, defendidas por Walter Gropius na Bauhaus, e a dramaturgia como mecanismo de integração social.

Para Giulio Argan (1957, p. 109) a concepção de 
cidade defendida por Gropius nesse período baseia-se na centralidade urbana, em que o teatro é o centro educacional coletivo, não mais para abrigar a educação moral ou dos sentimentos, mas para o desenvolvimento da capacidade perceptiva para a organização e construção do espaço.

O Teatro Total elaborado por Gropius em 1928 para Piscator destaca-se em relação às diversas iniciativas que lhe são contemporâneas, o que nos leva a examinar as razões de tal especificidade.
Mais do que representativo no conjunto de sua obra arquitetônica, o projeto é considerado por diversos autores como precursor da aproximação entre atores e público, ao abolir as barreiras físicas entre palco e plateia. Seria esta uma clara proposta para promover a comunhão democrática entre os diversos atores sociais, antecipando, dessa maneira, o teatro como luta de classes promovido por autores como Bertold Brecht.

Com objetivos semelhantes, não podemos deixar de

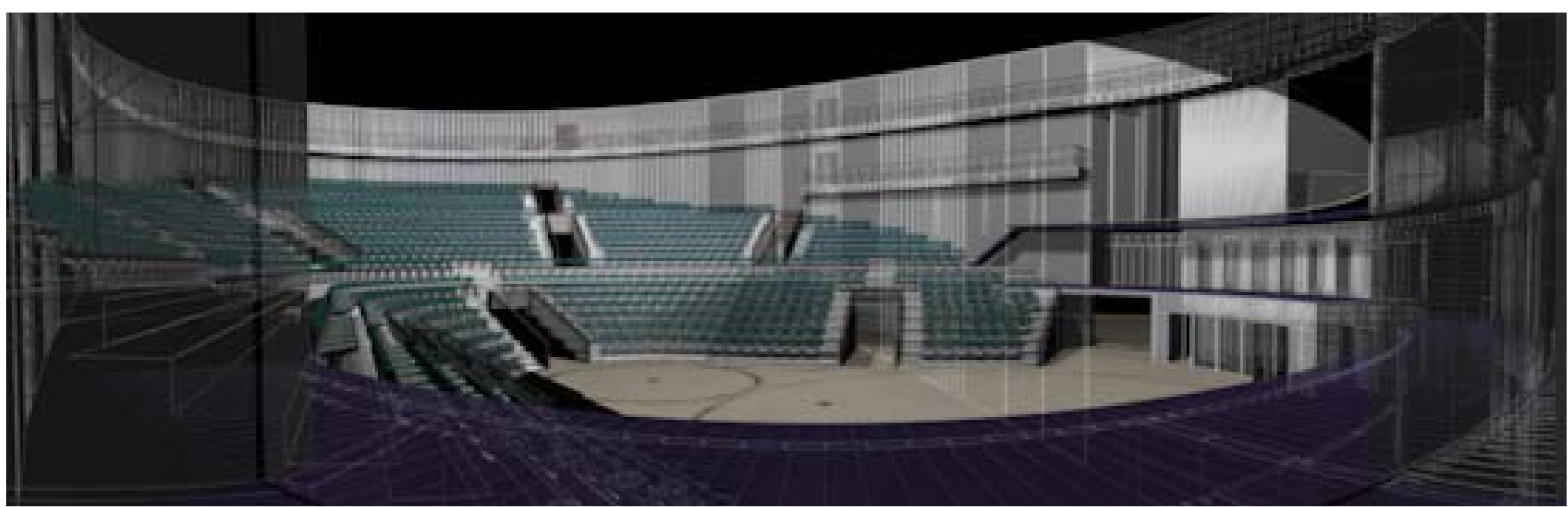

Imagem simulação do Teatro para Meyerhold. Fonte: www.3D Visa.com 


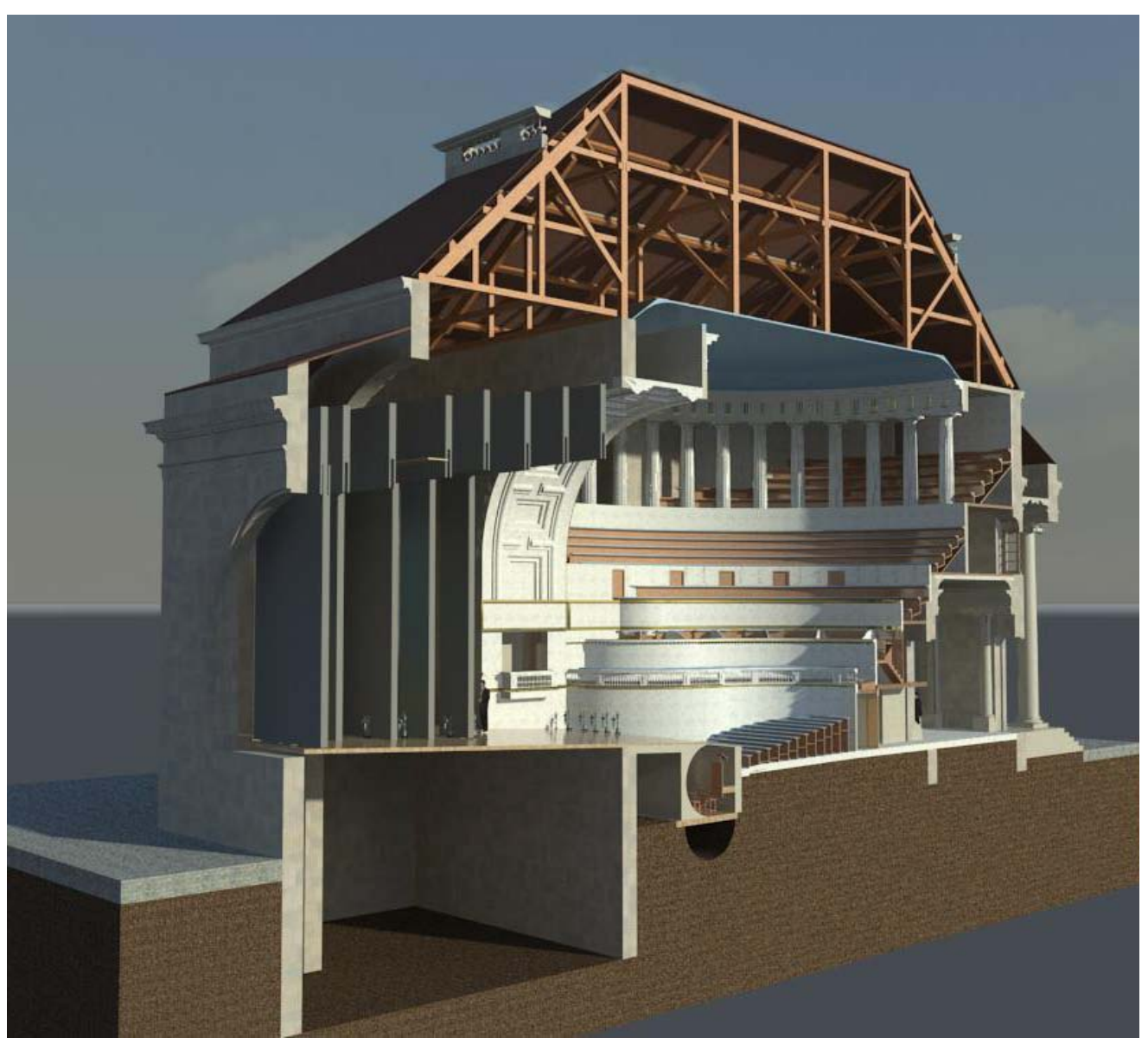

lembrar da significativa mudança introduzida anteriormente por dois projetos também emblemáticos: o Théâtre de Besançon, de Claude Nicolas Ledoux, em 1784, e a Bayreuth Festspielhaus, de 0 . Brükwald, sob a orientação de Richard Wagner, em 1876. Ambos, cada um dentro de seu contexto histórico, organizam a plateia em anfiteatro, revalorizando a arquibancada do teatro da antiguidade, que prioriza as qualidades visuais e auditivas, como apresenta Ledoux: "A forma progressiva que converte a humanidade em igual." (LEDOUX, apud PEVSNER, 1979, p.96)

Entretanto a relação frontal da tradição italiana entre palco e plateia ainda está presente, apesar da valorização do proscênio. No caso de Ledoux, ainda é mantida uma determinada hierarquia social, pelo uso dos diversos níveis.

Em Bayreuth, Wagner vai além ao propor a plateia em anfiteatro de um único lance,

Corte do modelo. Teatro de Besançon.

Fonte: http://theatreledouxbesancon.blogspot.com.br/ 22/05/2011 
sem hierarquia aparente. 0 espetáculo seria, para ele, o único objetivo para a reunião do público. Não podemos esquecer que foi nessa obra que as luzes se mantiveram apagadas pela primeira vez na história durante um espetáculo, o que reforça seu desejo de concentrar toda a atenção na cena.

Erwin Piscator ao convidar Gropius para desenvolver o projeto do seu Teatro Total, já conhecia seu trabalho à frente da Bauhaus. Nesse momento busca edificar o que seria, em suas palavras, o teatro como máquina ${ }^{53}$, capaz de atender ao mesmo tempo o repertório nas configurações clássicas - o palco italiano, o proscênio e a arena - e criar ainda condições para todas as novas possibilidades.

53 PISCATOR, E. La technique Nécessité Artistique, in BABLET, 2002, p. 181.

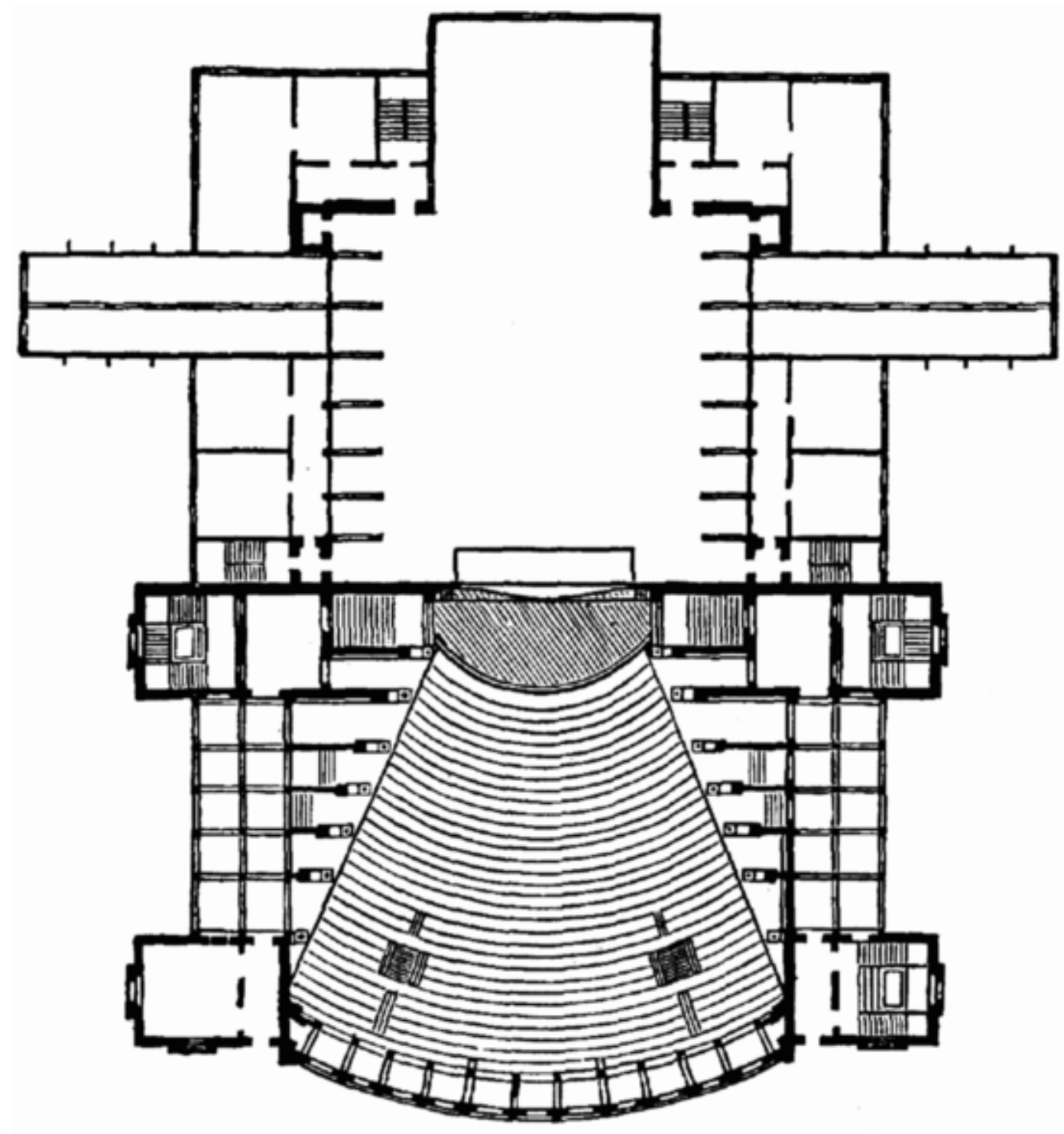

Planta. Bayreuth Festspielhaus. Fonte: FORSYTH, 1985. 

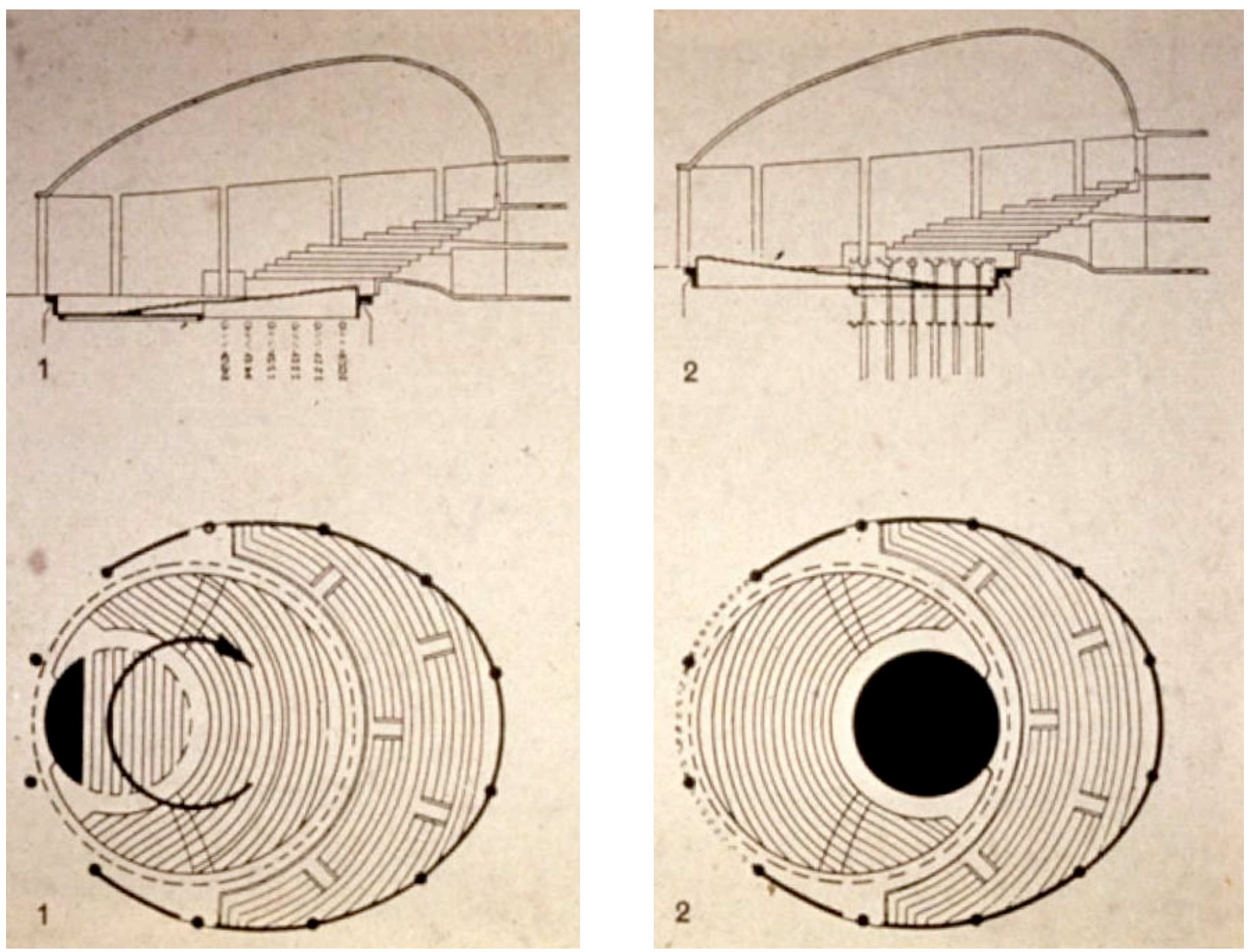
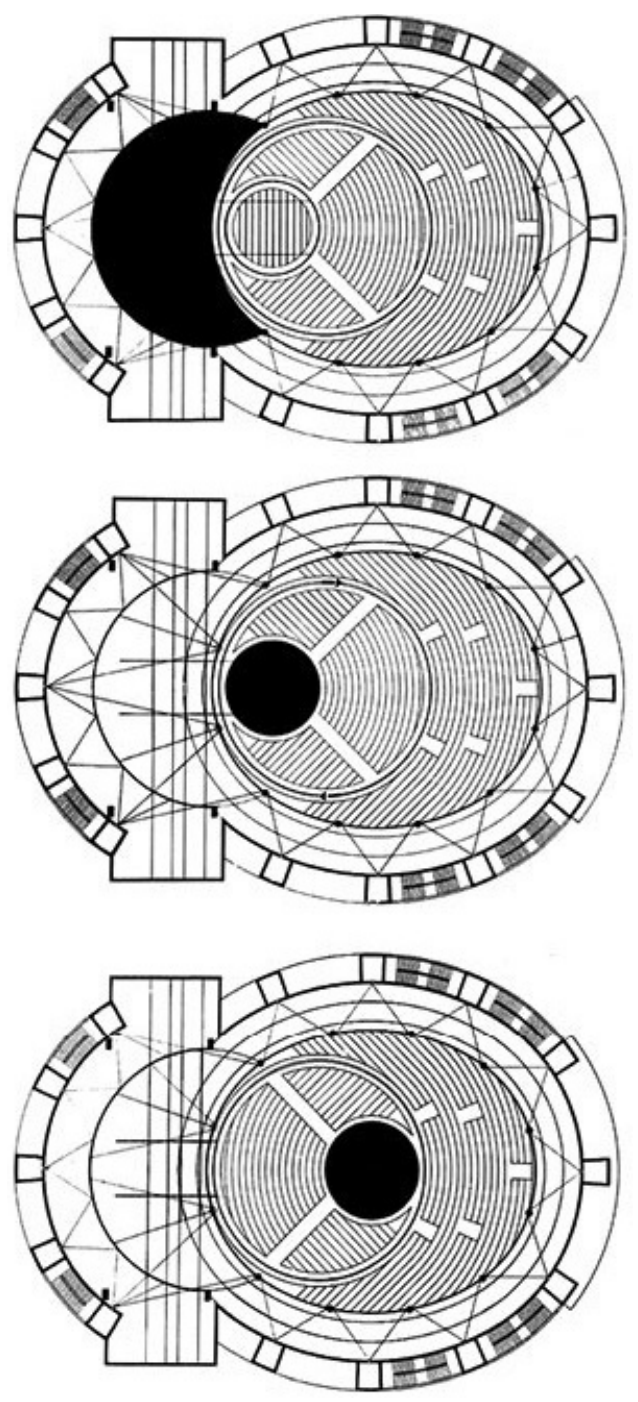

Variações da sala. Teatro Total. Fonte: www.theatre-architecture.eu 


\section{Gropius e a Tecnologia}

Na origem o Teatro nasce de uma nostalgia metafísica, logo ele serve à realização de uma ideia abstrata. A força de sua influência sobre a alma dos espectadores e da audiência depende do sucesso da transposição de uma ideia em um espaço perceptivo e compreensivo optica e acusticamente.

(GROPIUS, in Aujourd'hui, Art et Achitecture n. 15, 1958, pg.14) ${ }^{54}$

Como deixa claro na citação acima, Gropius considera que a essência de seu projeto para o Teatro Total está baseada na solução geométrica da sala. A engenhosa relação estabelecida entre os círculos inscritos no perímetro elíptico, que contém os pontos de apoio, permite que o menor círculo se movimente entre o foco e o centro da elipse. Isso é possível por ser o círculo maior uma plataforma giratória que pivota o menor. Esse movimento resolve duas situações fundamentais pretendidas: o palco em arena, com o círculo no centro da elipse, e o palco proscênio, com o círculo no foco da elipse.

Entorno da elipse, Gropius coloca os elementos in-

54 Nossa tradução do texto original: A son origine, le théatre est né d'une nostalgie métaphysique, il sert donc à la réalistaion d'une idée abstraite. La force de son influence sur les âmes du spectateur et de l'auditeur dépend de la réussite d'une transposition de l'idée dans un espace perceptible et comprénhensible optiquement et acoustiquement. dispensáveis de seu teatro:

. no eixo longitudinal, uma versão de caixa cênica tradicional adaptada à geometria oval da sala. Dessa maneira a situação de frontalidade, própria do palco italiano, pode ser utilizada de maneira independente ou associada às outras duas.

. uma galeria inclinada, onde estão distribuídas cabines de projeção cinematográficas posicionadas entre os vãos dos apoios , envolve a sala, dando continuidade à ação.

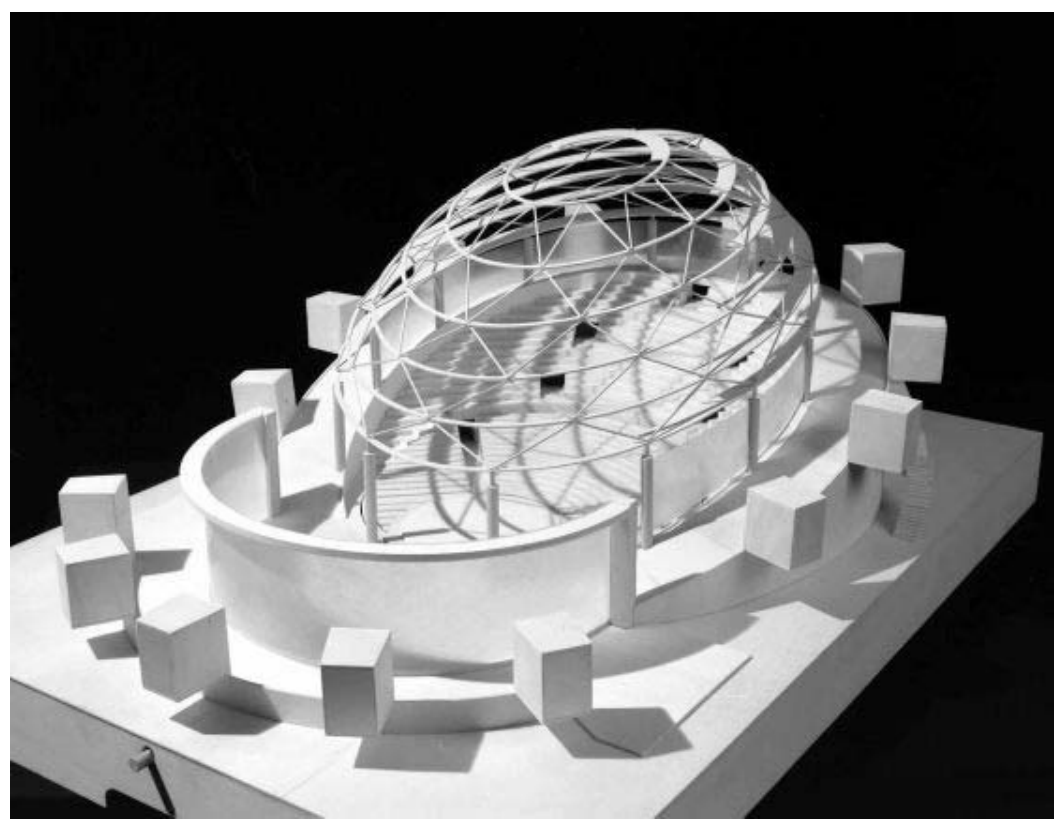

Maquete. Teatro Total. Fonte: www.theatre-architecture.eu 


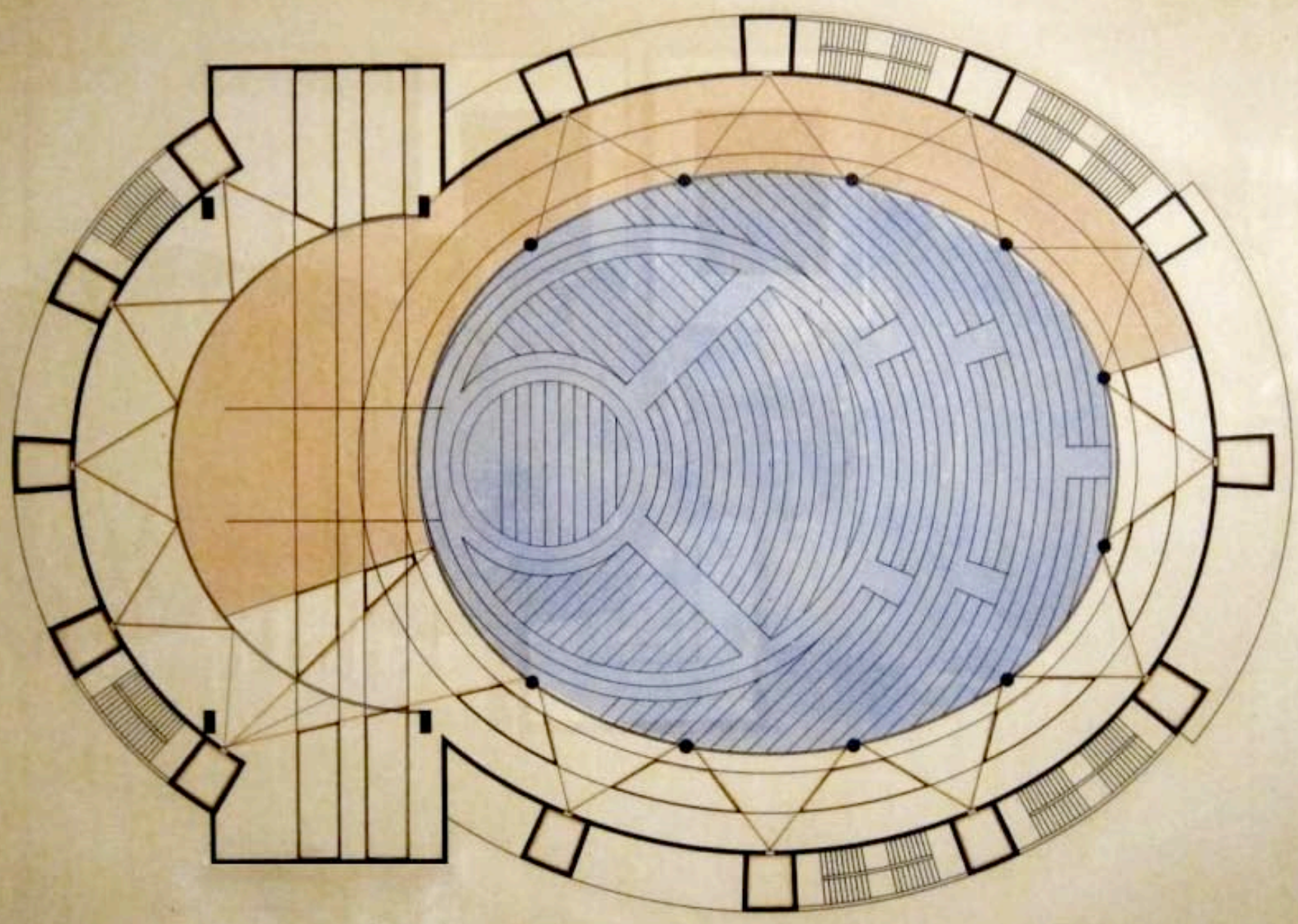

Planta. Teatro Total. Fonte: NERDINGER, 1988 
Esses apoios suportam a cobertura côncava da sala, cujo desenho acompanha a curva isoacústica. Nesse eixo vertical Gropius completa o teatro biomecânico de Piscator ao oferecer as possibilidades de uma ação em altura, um verdadeiro teatro tridimensional.

A solução da plateia em elipse que contém palcos circulares está presente também no projeto de El Lissitzky para o Teatro de Meyerhold em Moscou, como pode ser observado em seus croquis e na simulação apresentado. Entretanto a grande mobilidade da sala não é um recurso tão essencial nesse projeto. Há a inclusão do movimento na organização espacial da sala e da cena, em especial, pelo uso de poltronas giratórias, fileiras móveis, galerias, passarelas e rampas curvas. Nos dois casos o abandono do limite formal entre palco e plateia, entre cena e público, está presente. Essa plateia envolve a ação, mesmo na situação de frontalidade, podendo participar e interagir com ela, se for essa a intenção do espetáculo. 0 encenador teatral Vservolov Meyerhold foi responsável pela elaboração teórica do Teatro Biomecânico, um sistema de formação de atores baseada nas técnicas da cultura acrobática circense, na mecânica do corpo. A construção de seu teatro, entretanto, foi interrompida e a obra demolida pelo regime soviético em 1934; Meyerhold faleceu na prisão ${ }^{55}$.

Até a Revolução, apesar da participação de artistas dos movimentos artísticos de vanguarda, não havia mudança significativa na estética do teatro russo. Em 1922, em Moscou, Serge Eisenstein, diretor do teatro popular, declara ser obrigatório o conhecimento de técnicas de acrobacia para todos os atores. No mesmo ano Meyerhold, em seus artigos, $O$ Ator do Futuro e $O$ Emprego do Ator, apresenta sua teoria, depois célebre, da Biomecânica. Sua montagem para o Primeiro Vigneron, de Leon Tostoi, pode ser considerado o primeiro ensaio para a construção do palco baseado no dinamismo.

Apesar de Meyerhold não ter concretizado sua obra, os diversos níveis em rampas, em especial as que se entrelaçam no centro da ação, marcaram de maneira definitiva a historiografia da cenografia. Manfredo Tafuri (1985) ressalta esse fato no capítulo A Cena como "Cidade Virtual" de

55 O projeto final, cuja obra foi demolida, foi desenvolvido em 1934 por Barchin e Vachtangov; ver Casabella n. 431, 1977, pg. 22.

Ver também: Aujourd'hui, Art et Architecture n. 15, pg. 10, 1958 - Spectacles, 50 ans des Recherches, org. Jacques Polieri. 


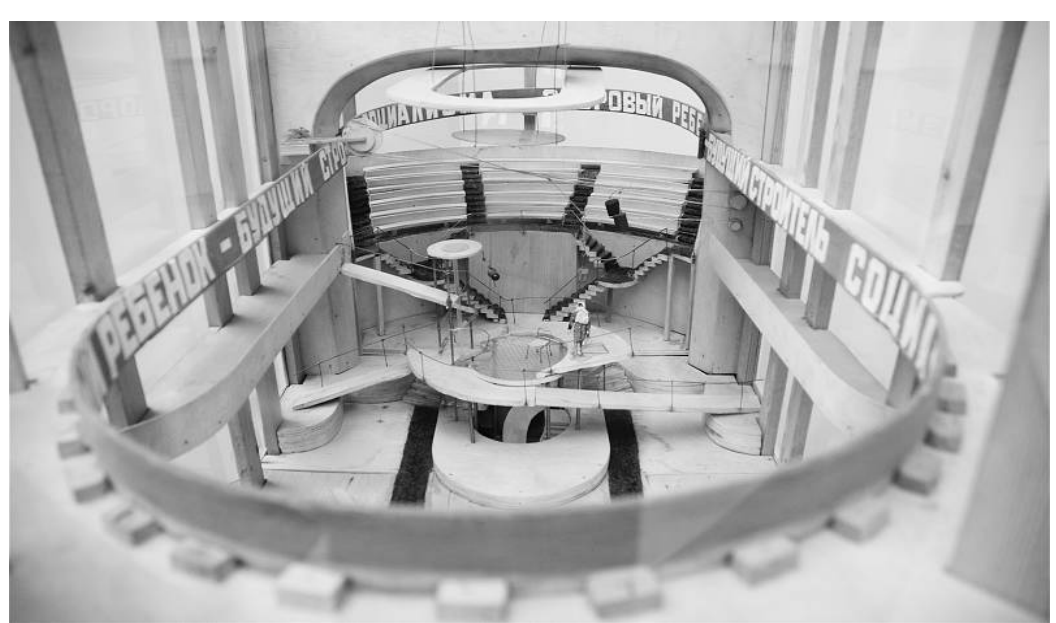

Maquete da sala. Teatro Meyerhold. Fonte: Van Abbemuseum, Eindhoven

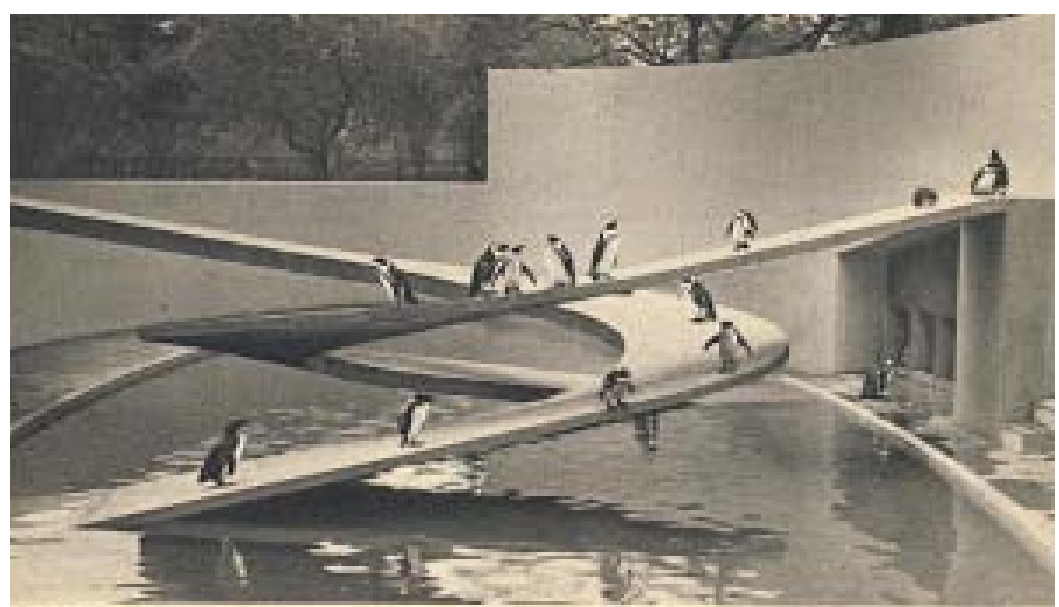

Piscina dos pinguins, Zoológico de Londres, 1930

Fonte: www.Thechmelhouse.org
A Esfera e $O$ Labirinto, ao lembrar da solução das rampas no centro da cena que viria a ser usada para a piscina dos pinguins, projetada por Berthold Lubetkin no zoológico de Londres em 1930, outro obra emblemática:

O construtivismo teatral terá uma posterior expressão tragicamente irônica. No foço dos pinguins do Zoológico de Londres (1932-1933), Berthold Lubetkin utilizara, quase como uma citação literal, as rampas helicoidais projetadas por El Lissizky para Meyerhold. O espaço envolvente é utilizado para um zoológico: aqui é o pinguim que é envolvido, enquanto o homem, fora da vala, reserva para si o papel de espectador passivo. (TAFURI, 1985. p. 144) ${ }^{56}$

\section{Gropius e a Nova Objetividade}

A mobilidade do espaço que o cinema introduziu e à qual habituou o espectador é a chave para entender a busca pela variabilidade, flexibilidade e dinâmica do edifício teatral. Nesse aspecto o Teatro Total assume a condição de modelo a ser seguido. Para Gropius essa seria uma forma

56 Nossa tradução do texto original: El constructivismo teatral tendrá todavía una ulterior expresión trágicamente irónica. En la fosa de los pingüinos del Zoo de Londres (1932-1933), Berthold Lubetkin utilizara, casi como una cita literal, las rampas helicoidales proyectadas por El Lissitzky para Meyerhold. El espacio envolvente es utilizado para un zoo: aquí es el pingüino el que es envuelto, en tanto que el hombre, mas allá de la valla, se reserva el papel de espectador pasivo." 
de criar uma nova consciência do espectador em relação ao espaço (FRAMPTON, 1997, PG. 168). No espaço neutro da cena escurecida, segundo ele, a construção se dará pelo uso da luz. (GROPIUS, W. in Aujourd'hui Art et Architecture n. 15, 1958)

Observamos que a concepção do Teatro Total nasce da resolução da sala, estando sua essência no seu interior. Entretanto há uma clara intenção de demonstrar todas as principais decisões de projeto na expressão do volume edificado. 0 foyer e os sistemas de circulação vertical de público são articulados em função dos elementos constitutivos da sala, mantendo-os à mostra, envolvidos por superfícies envidraçadas, revelando-se claramente à cidade.

Esse aspecto demonstra a diferença fundamental em relação às outras obras citadas no início do capítulo, o Théâtre de Besançon de Ledoux e o Bayereut Festspielhaus de Wagner.

No primeiro, a sala está envolta por uma edificação que segue uma ordem estabelecida pelos padrões de cidade ideal defendidas pelo arquiteto da luzes ${ }^{57}$. A leitura que se

57 Em particular, os projetos para a Cité Idéale de Chaux e as Salines de Arc-etSenans. Ver KAUFMANN, [1933], 2002, p.20-30. faz é a partir da imagem edificada previamente e da qual a sala não participa.

No segundo caso a volumetria exterior é resultado da justaposição de cada volume funcional. Porém o tratamento do conjunto edificado não estabelece nenhuma relação com sua função. Pode-se verificar que não há a preocupação de se relacionar os volumes funcionais segundo algum critério de visualidade organizada.

O projeto de Gropius, pelo contrário, alcança sua expressão graças à dinâmica interna do edifício, onde o movimento exerce papel fundamental na construção do volume. Argan (1957, p. 110) afirma que esse "movimento de concentração e expansão é o de uma máquina movida a espaço". A organização das massas construídas em torno das matrizes geométricas utilizadas alternam situações de abertura e fechamento, de dilatação de superfícies convexas à inflexão das superfícies côncavas.

Para Frampton (2003, p. 167) é no Teatro Total que Gropius mais se aproxima dos postulados da Nova Objetividade. Segundo o autor, a implantação em hélice do prédio da Bauhaus em Dessau já seria uma demonstração de que 


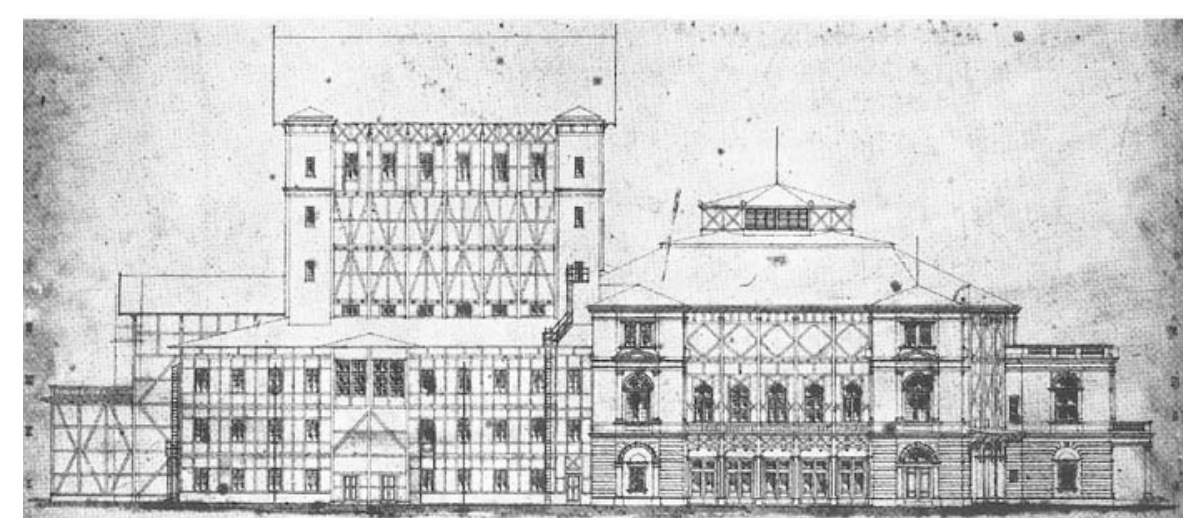

Elevação. Bayereut. Fonte: IZENOUR, 1996

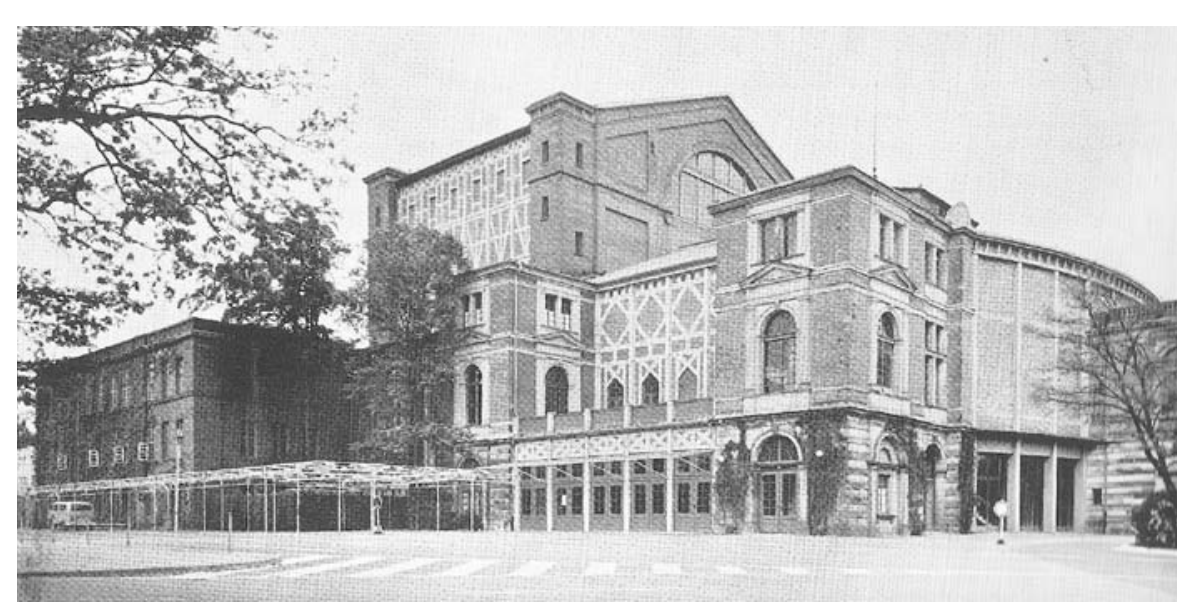

Vista frontal. Bayereut. Fonte: IZENOUR, 1996

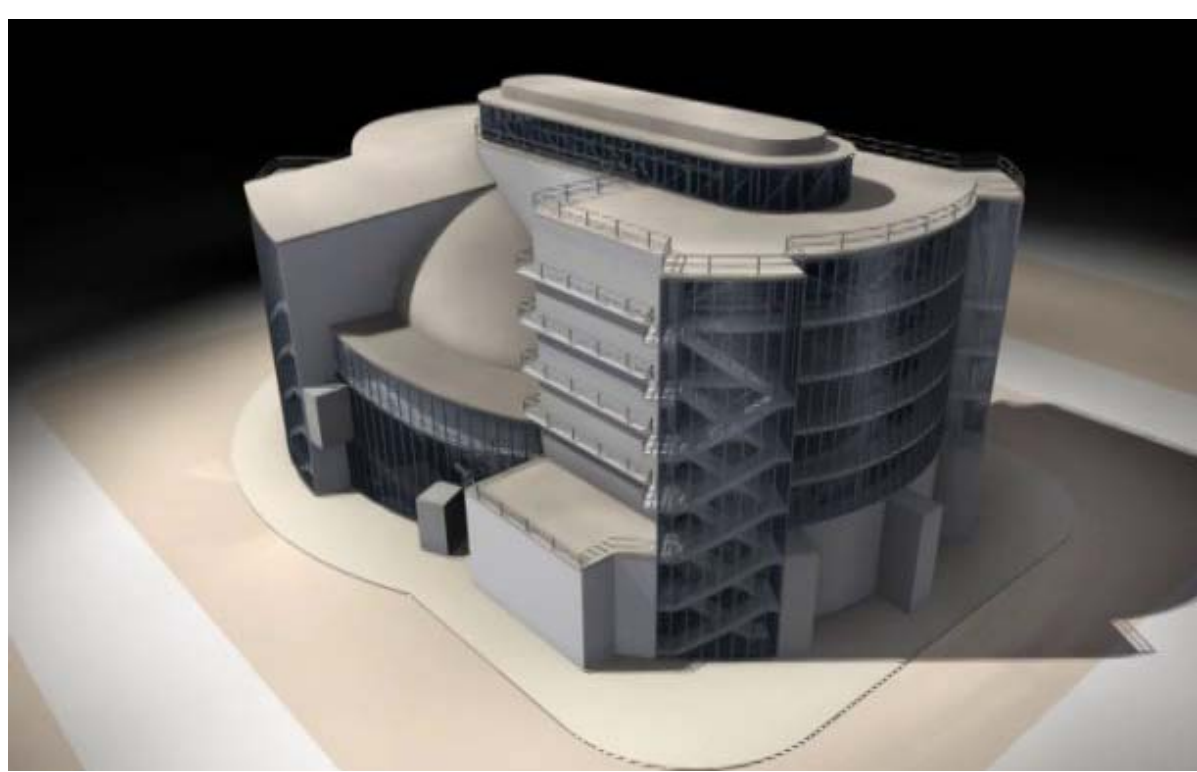

Modelo. Teatro Total. Fonte:Vimeo.com

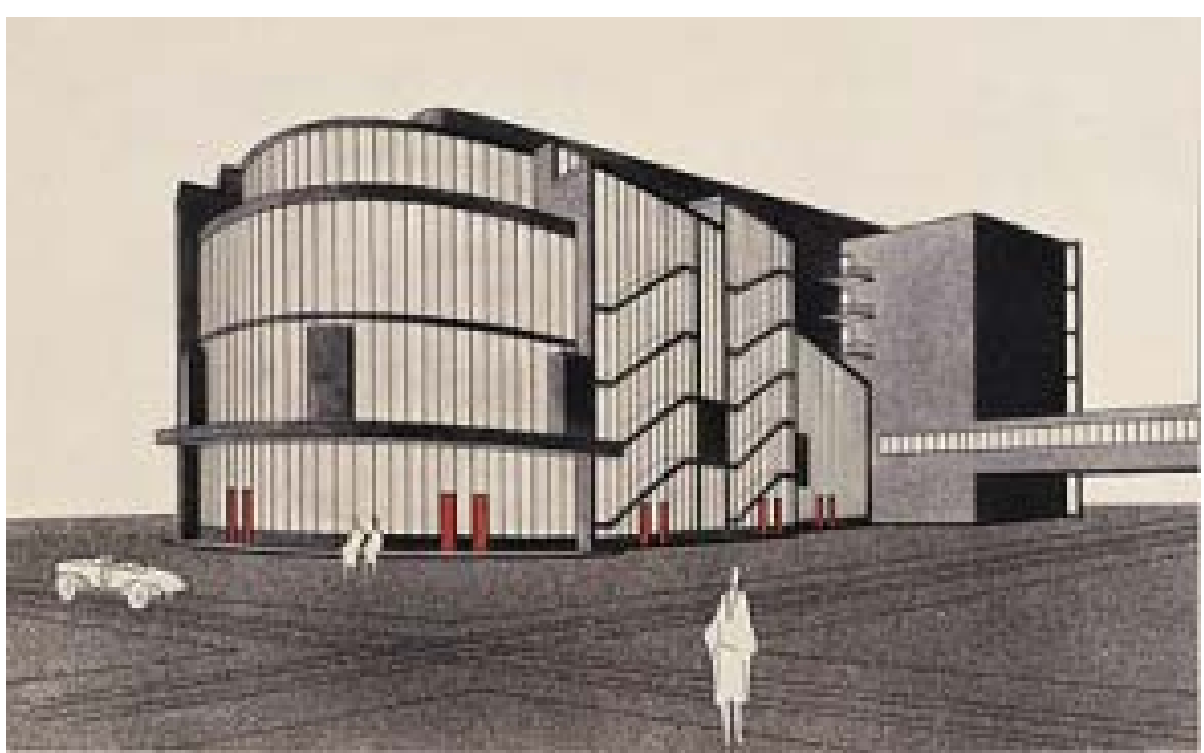

Teatro Total. Fonte: NERDINGER, 1988 
sua arquitetura estaria atenta a essa abstração formal anti-expressionista. Apesar de não fazer o mesmo raciocínio compositivo usado por Argan para analisar a obra, Frampton conclui que todas as estratégias de movimento reunidas para resolver o projeto, aparentes no volume edificado, foram fundamentais no resultado da estética construtiva da obra.

Em 1930, no concurso para o Teatro de Kharkov na Ucrânia, e em seguida em 1931, no concurso para Palácio do Soviet em Moscou, Gropius apresentou propostas em que alguns dos conceitos de mobilidade e flexibilidade do Teatro Total puderam ser aplicados. Há que se lembrar porém, no projeto de Kharkov, que a escala do programa, com capacidade para 4.000 espectadores, pode ter sido fator limitante no uso dessas soluções. Por outro lado, a relação franca e dinâmica do edifício em relação à cidade, observada no Teatro Total, é nesse caso bem mais clara, pela expressão das partes constitutivas do edifício e, sobretudo, pela transparência do foyer e de seu sistema de rampas esculturais. É interessante notar como essas soluções viriam influenciar outros projetos de inúmeros arquitetos.

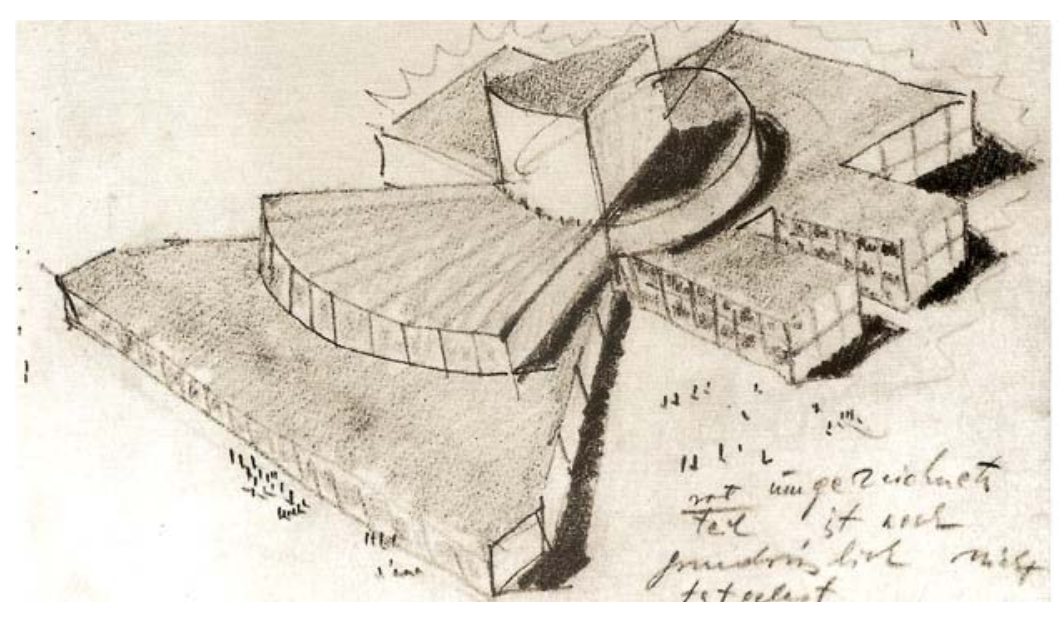

Teatro de Kharkov. Fonte: NERDINGER, 1988.

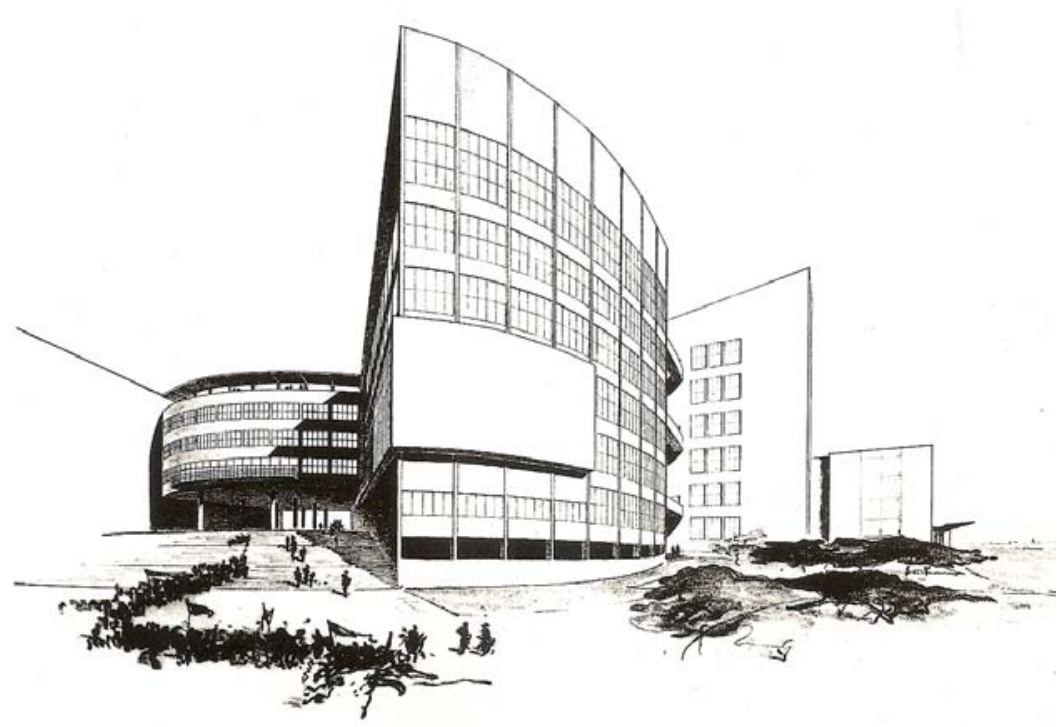

Desenho ilustrativo. Palácio do Soviet. Fonte: NERDINGER, 1988 

A obra de Eric Mendelsohn para o Complexo Woga em Berlin mereceu grande destaque dentro da historiografia da arquitetura moderna. Além de suas qualidades evidentes, que a identificam como exemplar na arquitetura de Mendelsohn, WOGA se destaca pela complexidade do programa e por sua implantação em quadra aberta, que incorpora aspectos dos princípios da Cidades Jardins, como pode ser observado na implantação da página 118:

O conjunto integra blocos habitacionais de cinco pavimentos nas laterais e no interior da quadra, articulados com edifícios baixos onde predominam usos comerciais, culturais e um hotel, voltados para a avenida Kurfürstendamm e para a Lehniner Platz. As habitações se abrem para o pátio arborizado, onde há duas quadras de tênis; os outros edifícios se integram ao espaço urbano por uma rua interna, para serviços e pedestres, uma espécie de praça linear, para onde os estabelecimentos podem abrir suas vitrines, dando continuidade exterior às suas atividades, mantendo

Complexo WOGA Berlin

1928 - 1981 uma forte integração com a animação urbana. Pela Cicerostrasse, a oeste, o pátio arborizado interno é aberto em 


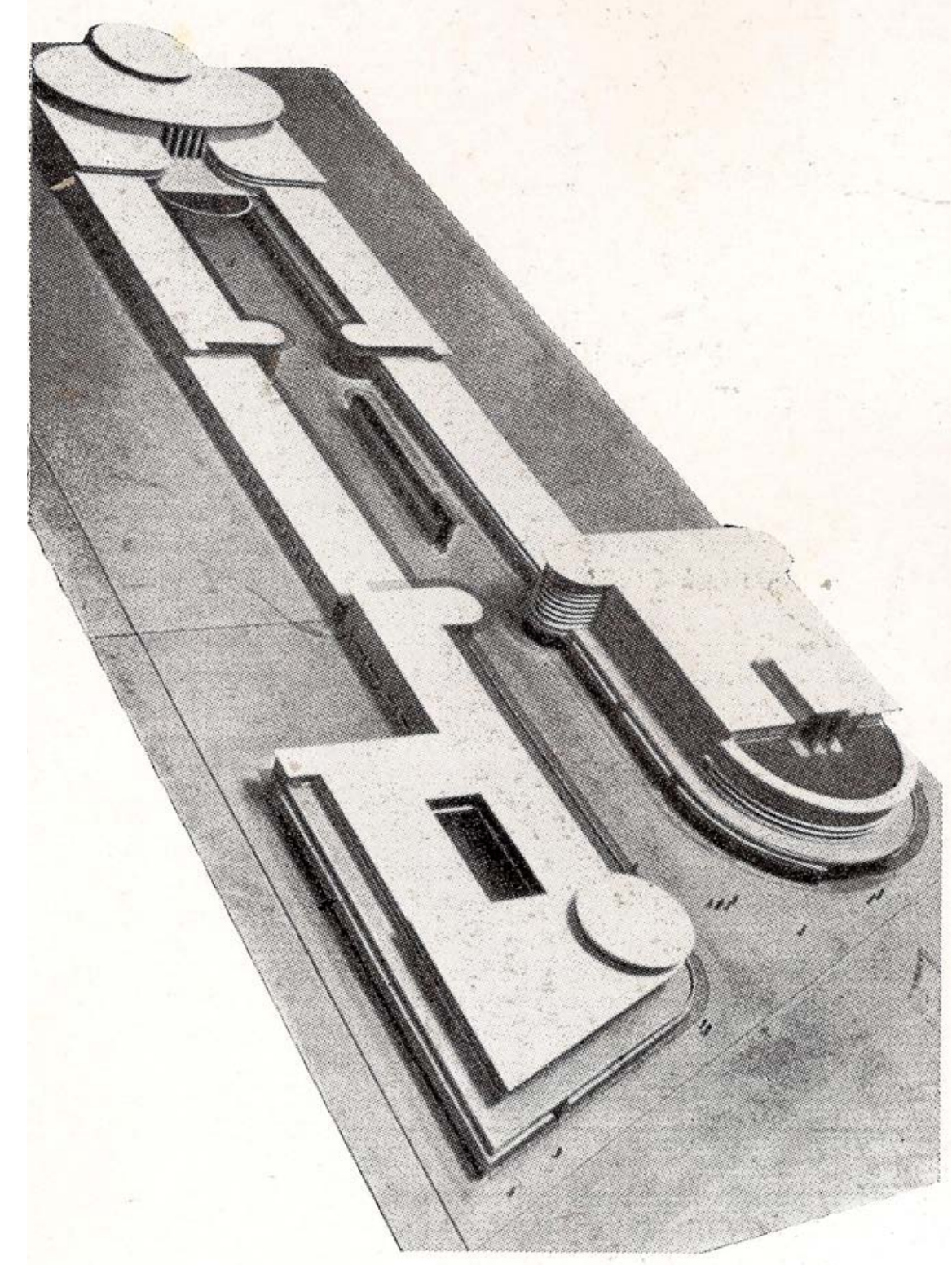

Maquete de estudo. Complexo WOGA. Fonte: ZEVI, 1970.
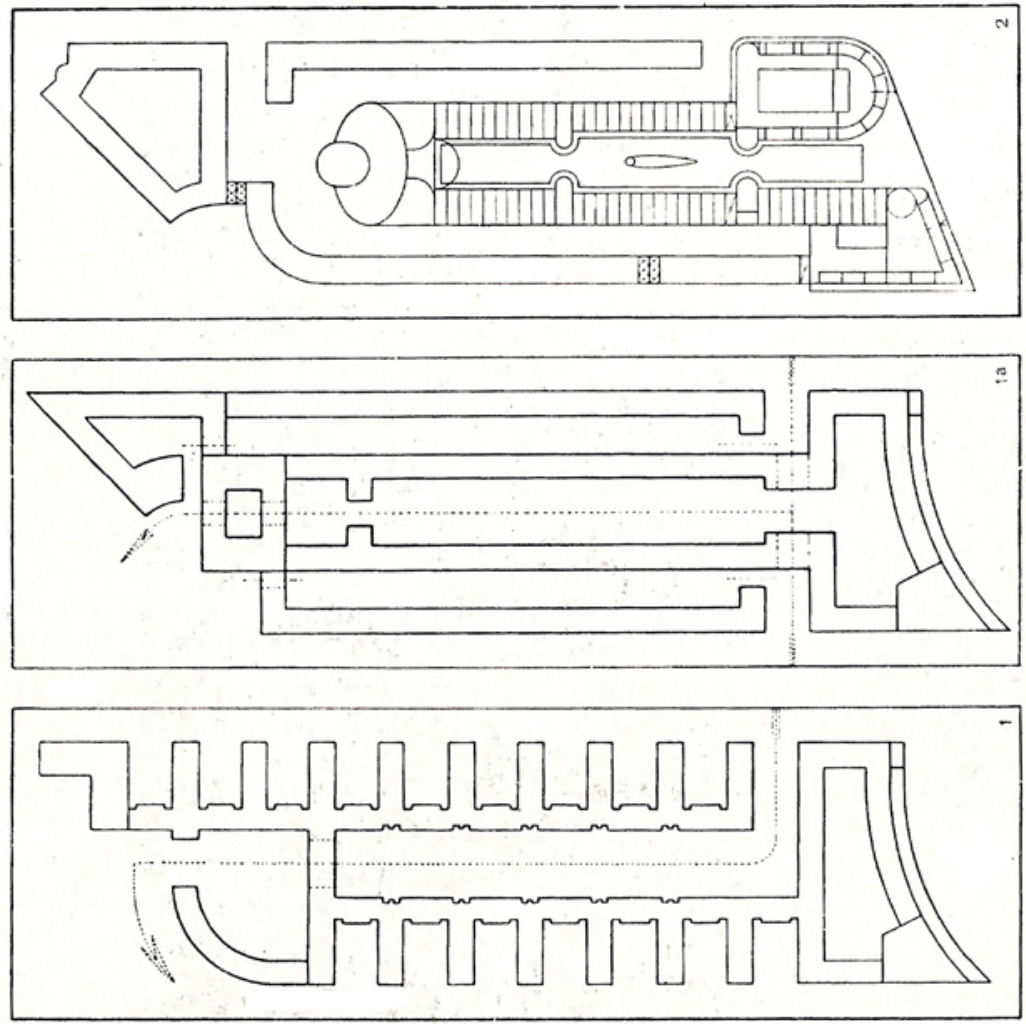

Estudo de implantação. Complexo Woga Fonte: ZEVI, 1970

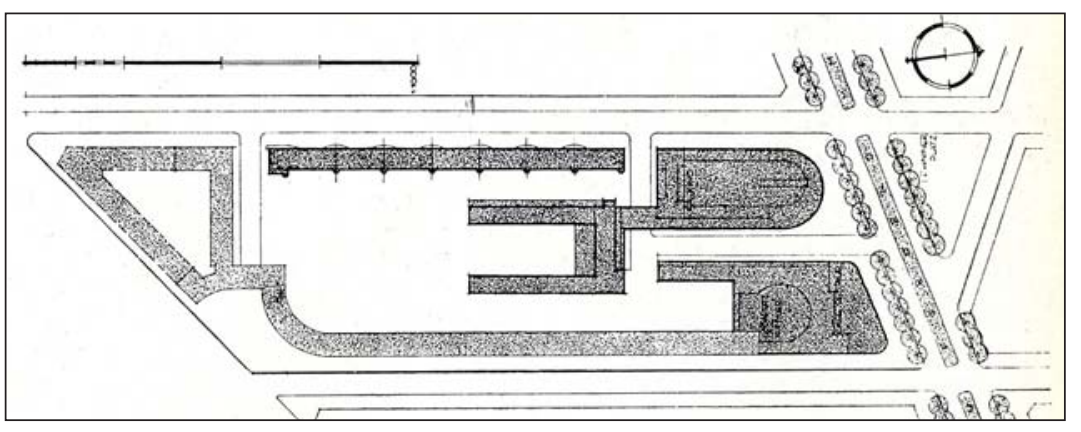

Implantação do projeto original. Complexo Woga. Fonte: ZEVI, 1970 
duas situações, próximas às suas extremidades, uma versão muito próxima das quadras abertas de conjuntos como o Britzsiedlung de Bruno Taut e Martin Wagner de 1927, ou o Siemensstadt de Hans Sharoun, Walter Gropius, Hugo Häring, Otto Bartning, Fred Forbat e Paul Rudolf Henning de $1929^{58}$.

Como mostra Bruno Zevi (1970), Mendelsohn trabalhou diversas alternativas de implantação, bem mais compactas, até chegar à solução próxima à versão construída, em que os locais de espetáculo, teatro e cinema assumiram o papel de protagonistas diante da avenida principal. Na versão que precedeu a proposta construída, o teatro chegou a ser posicionado na parcela posterior do conjunto, na busca de Mendelsohn por uma expressividade do espaço urbano.

Certamente, o elemento primário é a função, mas a função sem sensibilidade nada mais é além da mera construção. (MENDELSOHN, in FRAMPTON, 2003) ${ }^{59}$

A afirmação acima ilustra uma considerável mudança no trabalho de Mendelsohn, eminentemente de natureza plástica até as duas primeiras décadas do século XX, para uma expressividade mais voltada à estrutura e à natureza dos materiais. Segundo Frampton, essa evolução se deu após Mendelsohn visitar a Holanda e conhecer a arquitetura que estava sendo praticada por J. J. P. Oud e W. M. Dudok em Roterdã, e por Michel de Klerk e Dageraad de Piet Kramer em Amsterdã.

É possível que Frampton refira-se ao plano de massas, ao tratamento dos blocos de habitação e ao predomínio das linhas horizontas, pois, ao se avaliar os edifícios destacados na proa do conjunto, pode-se verificar o que Zevi considerou como "os croquis mais luminosos da fantasia mendelsohniana”. (ZEVI, 1970, p. 158)

O Complexo Woga é parte significativa da produção de Mendelsohn nesse período. A organização dos blocos na quadra aberta e sua relação hierárquica demonstram com clareza suas preocupações funcionais e sua relação com a cidade. A expressividade, tão cara a Mendelsohn, é conseguida pelo jogo geométrico dos volumes que formam o conjunto, potencializados pelo contraste entre a continuidade

58 Ver BRUNA, P. - Os Primeiros Modernos: Habitação Social no Brasil 1930-1950, 2010, p.96-106.

59 Trecho da carta enviada por Eric Mendelsohn à sua esposa, durante sua visita à Holanda em 1921. in Frampton, 2003 


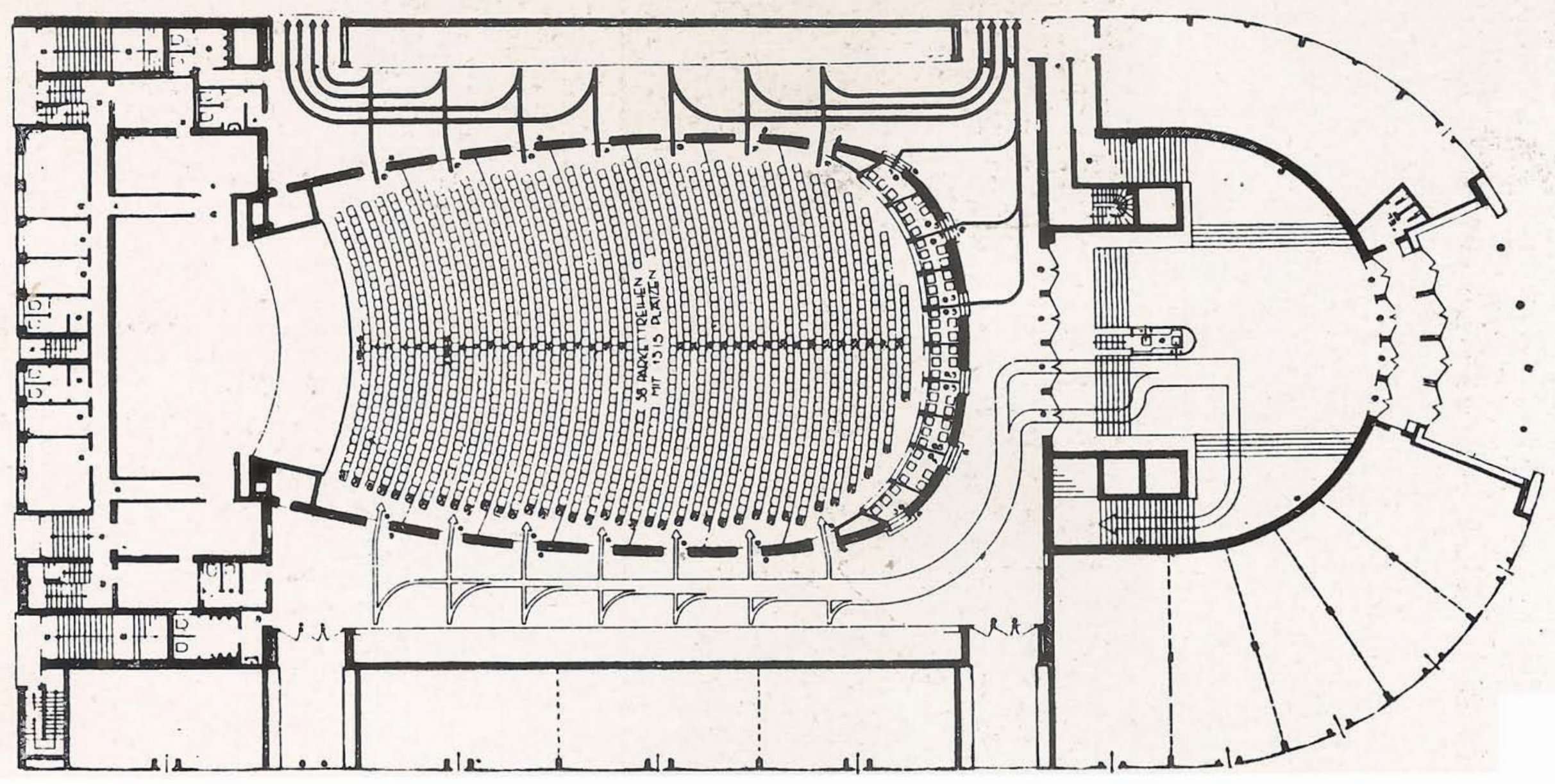

Planta do térreo, situação sem escala. Cine Unversum, 1928. Fonte: ZEVI 1970. 
das linhas horizontais e a constituição dos materiais utilizados.

Nesta obra pode-se destacar um dos aspectos de interesse em nosso trabalho: um complexo multifuncional em que Mendelsohn projetou um Café Teatro e um Cinema como os elementos de maior expressividade, de maior evidência, em especial esse último, ou seja, a arquitetura do espetáculo como destaque, como protagonista do conjunto.

O Teatro, com plateia circular, abrigou um formato de sala próprio do período entre guerras, o cabaré, em que o público distribuído em mesas apreciava espetáculos musicais. Nesse edifício, poderíamos nos deter no trabalho empreendido pelo arquiteto ao definir sua volumetria. Mendelsohn elabora de maneira clara e expressiva a articulação de seus espaços essenciais - teatro circular - com todas as funções que lhe foram associadas - restaurante, comércio e café - de maneira articulada com o espaço urbano e, em particular, com o edifício do cinema a seu lado. Mas é nesse último que está concentrado seu maior interesse em função de sua trajetória até nossos dias.

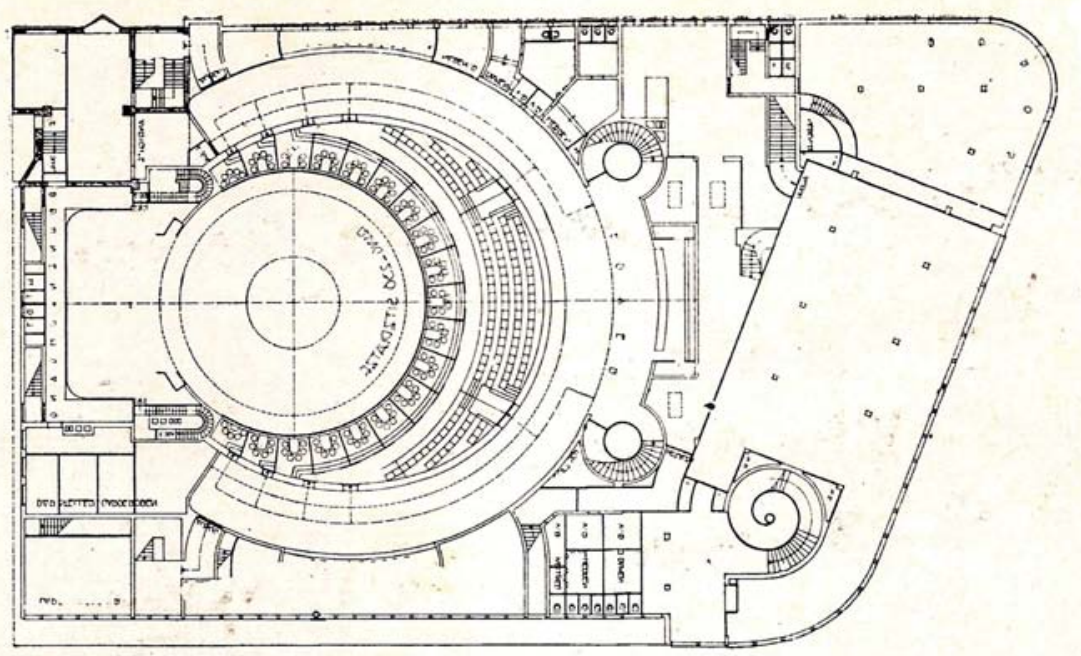

Planta pavimento superior.

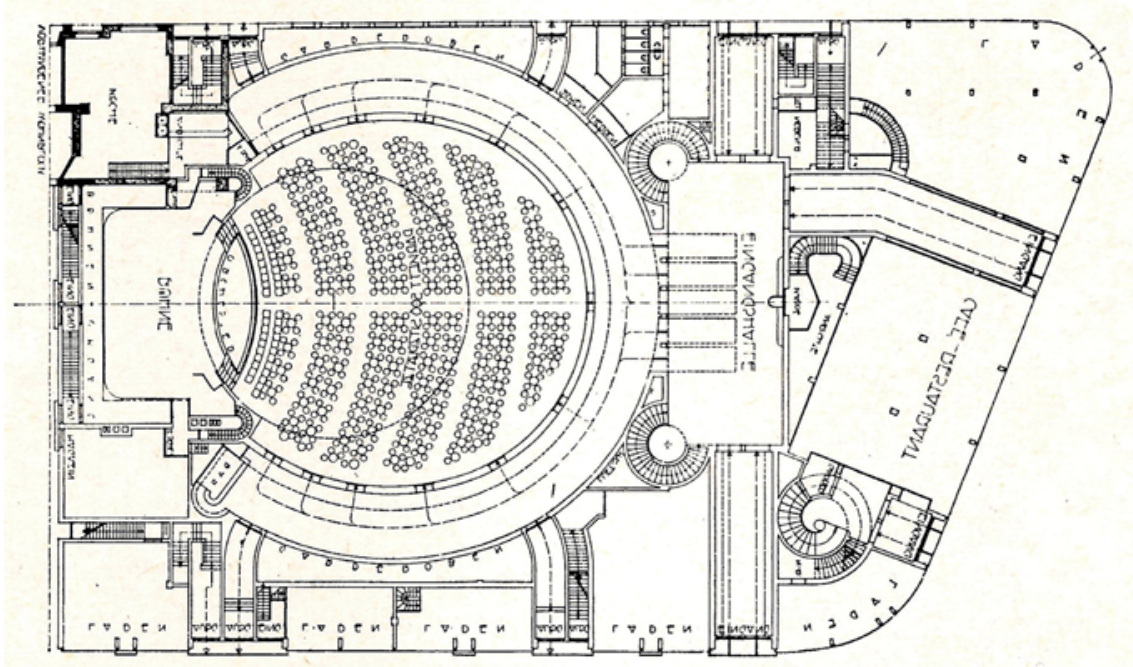

Planta térreo. Café Teatro - Cabaré. Fonte: ZEVI, 1970 
O Cinema Universum foi construído para a UFA - Universum Film $A G$-como o primeiro edifício concebido para essa finalidade. As soluções de projeto utilizadas por Mendelsohn para a sala de 1.800 lugares em ferradura, o palco e a tela de projeções se tornariam padrão em diversos outros cinemas construídos pela empresa ao redor do mundo.

A esse respeito, Renato Anelli (2001, p. 76) mostra como o Cinema Ufa Palácio, obra de Rino Levi em São Paulo, apresenta como único tratamento formal da sala as linhas de iluminação indireta horizontais, que encaminham o olhar para a tela, como na obra de Mendelsohn. Vale assinalar que Rino Levi nesse projeto já utiliza em corte as soluções de curva de visibilidade da plateia não consideradas por Mendelsohn em Berlim, conforme pode ser observado nos cortes dos dois projetos ${ }^{60}$.

Retornando ao Cinema Universum, após a destruição de seu interior durante os bombardeios da Segunda Grande Guerra, ele foi reconstruído e, na década de 1950, viria a contribuir para tornar a região conhecida por "Broa- dway of Berlin". Após diversas adaptações, como palco para musicais entre outras, o edifício fechou suas portas em 1973, com a projeção de Laranja Mecânica, filme de Stanley Kubrick.

Sua renovação, realizada pelo arquiteto Jürgen Sawade, entre 1978 e 1981, recuperou os principais elementos que caracterizam o exterior expressivo do projeto original de Mendelsohn, com o mesmo cuidado com que transformou seu interior para abrigar espetáculos simultâneos e de natureza variada, com recursos técnicos voltados para a flexibilidade e a pluralidade espacial. 


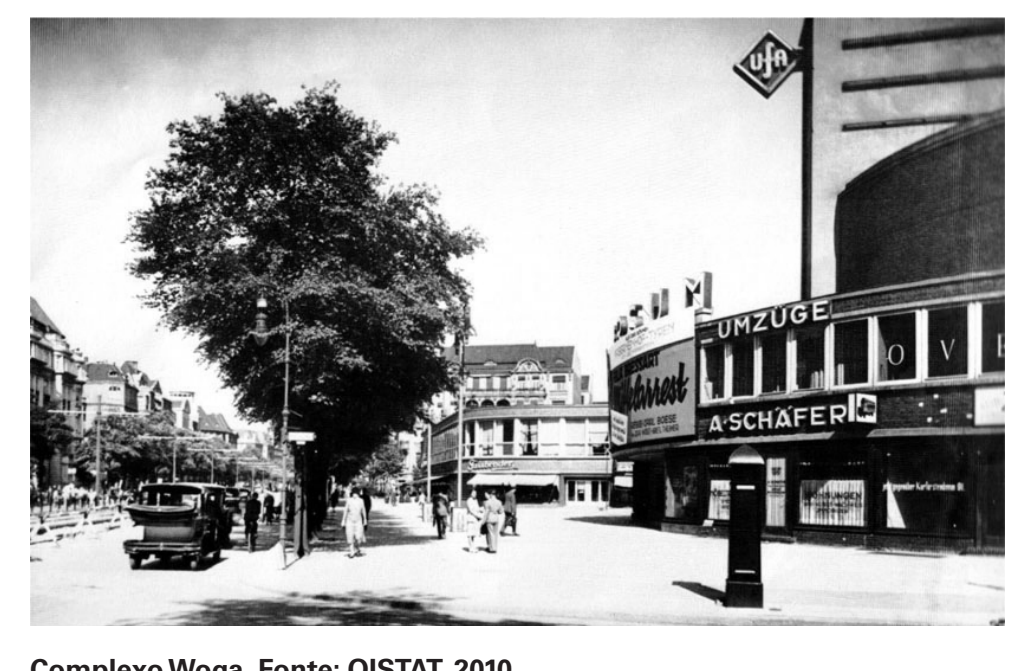

Complexo Woga. Fonte: OISTAT, 2010

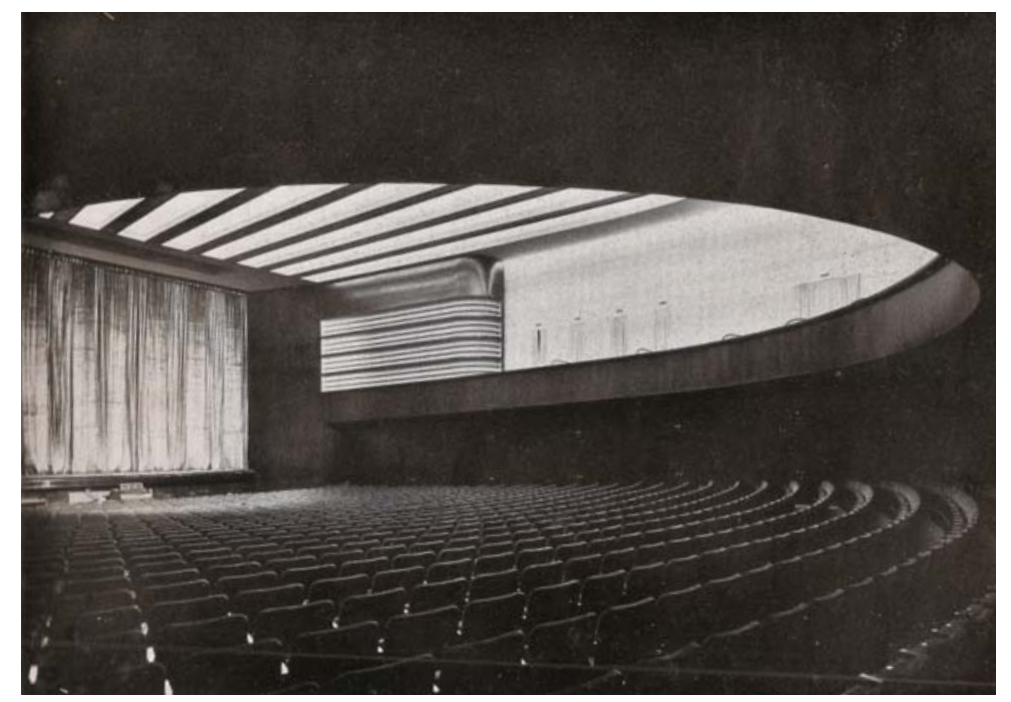

Interior. Cine Universo. Fonte: ZEVI, 1970 


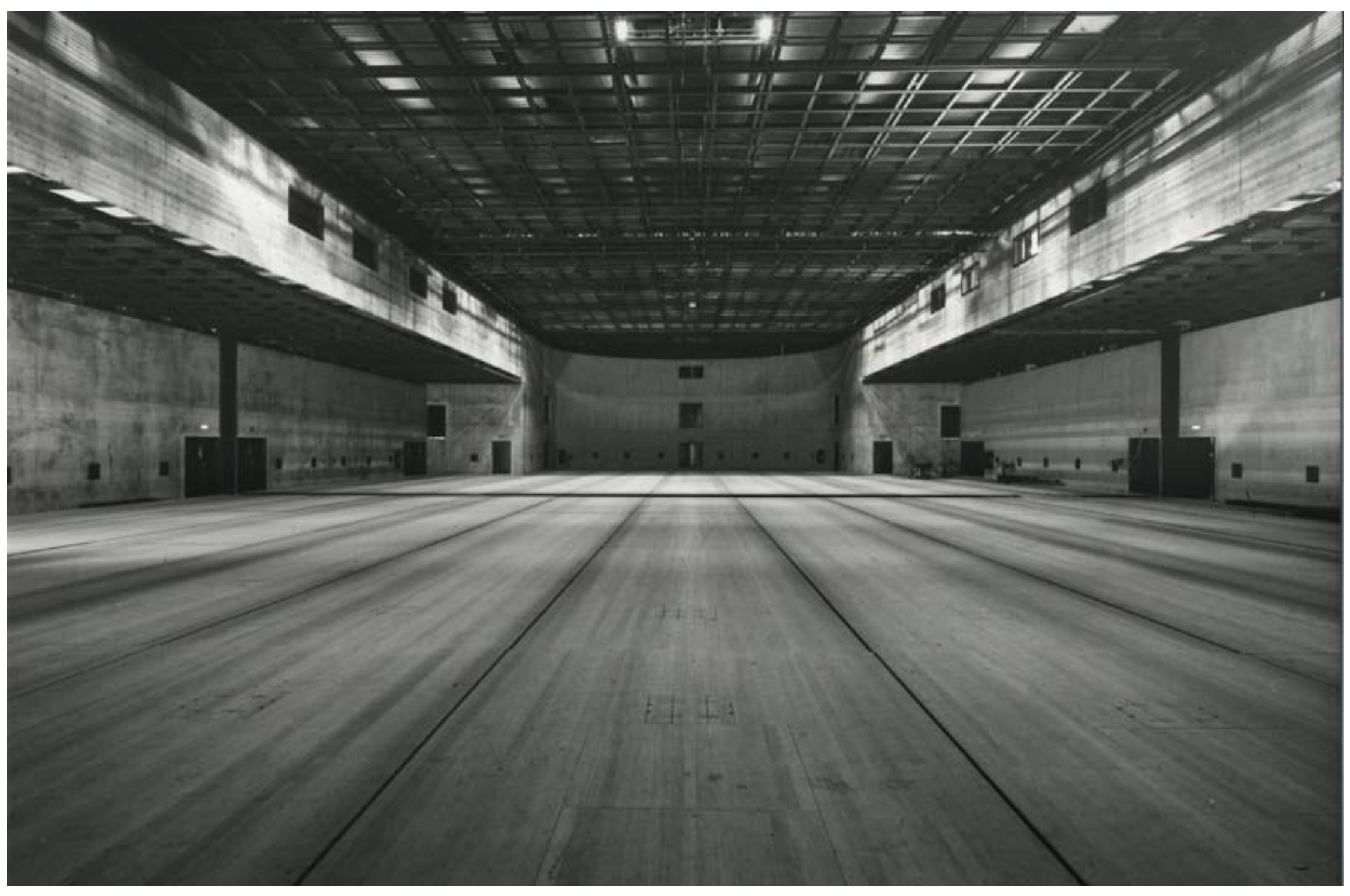

Vista interna eixo longitudinal. Schaubuhne - Complexo Woga. Fonte: BRETON, 1989 
O conjunto original, cinema e teatro, abriga desde 1981 a companhia de teatro Schaubühne, a primeira companhia teatral coletiva criada em Berlin, em 1962, que ocupa desde 1970 espaços teatrais não convencionais, tendo Peter Stein como um dos principais diretores. Gaelle Breton (1989, p. 64) lembra que o grupo utilizou regularmente estúdios de cinema e pavilhões de exposições, pelas possibilidades de adaptações e de proximidade com público, antes de se estabelecer na sede atual.

A escolha por sua renovação se deu após longo processo empreendido pelo grupo. Em um primeiro momento, um projeto em forma de diagrama procurou definir as condições de espaços funcionais capazes de atender às especificidades da atuação do grupo e às novas situações pretendidas, sempre mantendo como características a flexibilidade e a mobilidade do seu repertório. Assistidos pelo arquiteto Andreas Reidemeister, o grupo buscou diversas alternativas na cidade, chegando a desenvolver o anteprojeto para Anhalter ${ }^{61}$, a estação ferroviária de carga desativada, que apresentamos na página 126.

61 ver REIDEMEISTER, A., in L'Architecture d'Aujourd'hui p.199, 1978, 

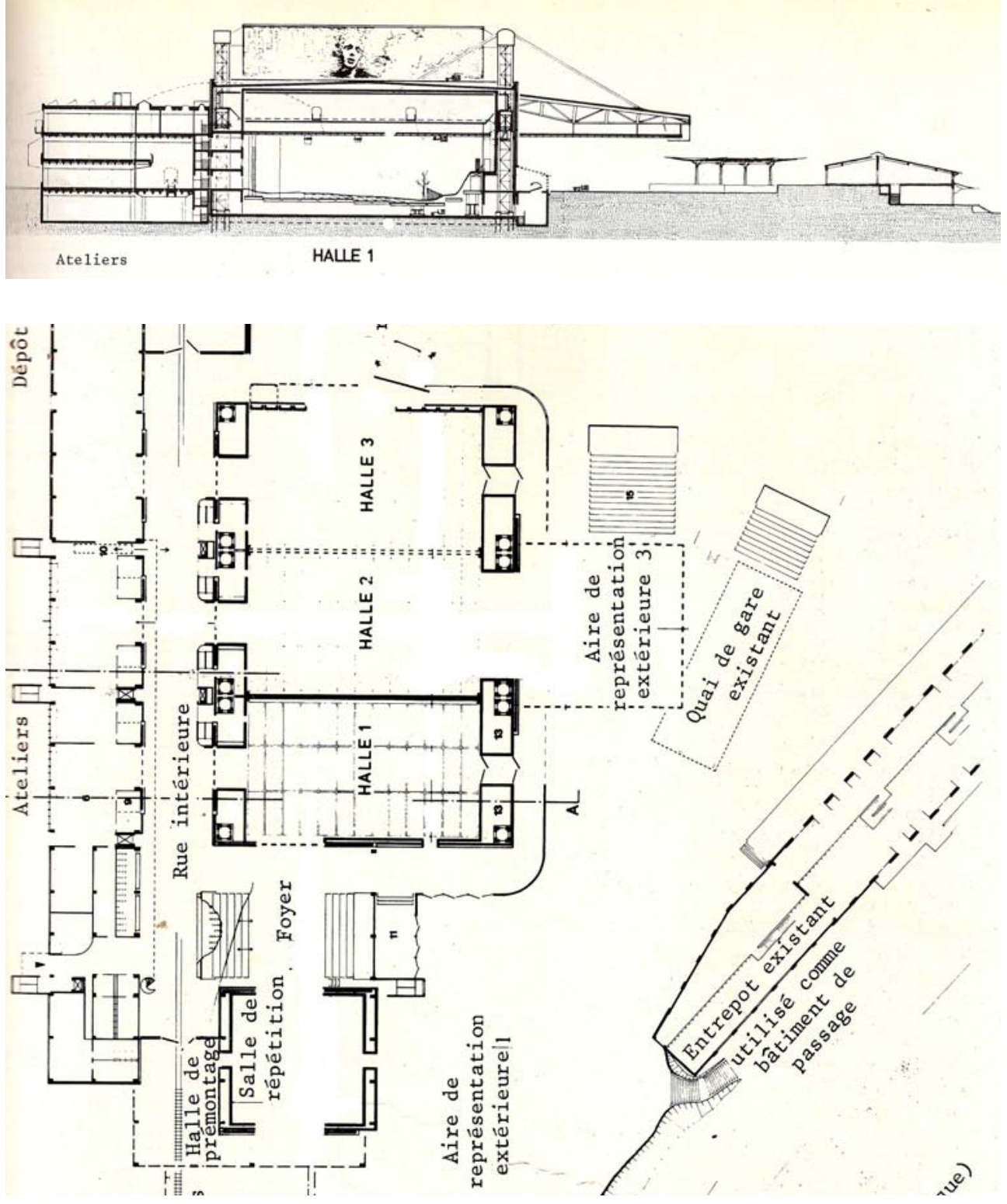

Schaubuhne. Ante projeto para Anhalter. L'Architecture d'Aujour'dui n.199, 1978.
0 anteprojeto caracteriza-se pelo uso intensivo de soluções próprias à arquitetura industrial, como a estrutura metálica, vencendo vãos de trinta metros, que cobre o galpão e suporta o forro técnico no seu interior, atendendo ao prolongamento na área externa de espetáculos. Todo o tratamento construtivo baseia-se na expressão da estrutura e dos equipamentos que possibilitam a repartição do grande galpão em três espaços projetados ou sua associação. A linha que atravessa longitudinalmente o conjunto, antigo leito da ferrovia, é o caminho do público. Pode-se observar referências claras ao projeto do Fun Palace ${ }^{62}$, de Cedric Price próprias da arquitetura do espetáculo, como a expressão da tecnologia e o uso da modularidade.

A escolha pela ocupação do conjunto de Mendelsohn se deu, segundo os membros da companhia, pela oportunidade de poder implantar o projeto elaborado ao mesmo tempo em que seria devolvida a vocação para a qual o edifício fora concebido.

Pode-se observar nesse caso um projeto de 62 ver cap. Metrópole Em Cena. 
conversão ou reconversão, desenvolvido sob medida para o repertório do grupo e sobretudo para abrir novas possibilidades de atuação. 0 Universum abriga hoje o lugar do espetáculo, apoiado por locais de ensaios e oficinas que ocupam parte do antigo café teatro e de outras construções do conjunto.

Essa situação é de grande interesse para a presente dissertação.

Em primeiro lugar pela importância que o complexo Woga representa para a obra de Eric Mendelsohn, como nos mostra a extensa bibliografia existente sobre o assunto.

Em seguida, pelo tema da reconversão, que não se tratou exatamente de uma mudança de uso, apesar das diferenças significativas entre cinema original e teatro atual. Como poderemos verificar mais adiante, essas grandes diferenças existentes no final da década de 1920 hoje se tornaram mais tênues, em outras palavras, vê-se atualmente que os recursos cinematográficos estão muito mais presentes nos espetáculos teatrais.

Não podemos deixar de enumerar também o fato de que o projeto do arquiteto Jürgen Sawade para a reconversão do Cinema Universum atende plenamente aos objetivos artísticos da companhia Schaubühne, partindo do espaço vazio e lançando mão da tecnologia para atingir as necessidades de flexibilidade exigidas para a modulação do espaço.

Nesse caso poderíamos mesmo analisá-lo como fazendo parte de duas estratégias que vimos com recorrência em nossa pesquisa: o vazio inspirador e a tecnologia. Klaus Wever, cenógrafo do grupo, afirma que o alto custo do investimento da obra justifica-se pelas qualidades que o edifício possui, como sua configuração em "basílica, com nave central, naves laterais, abside e nartex". (WEVER in L'Architecture d'Aujourd'hui 199, 1978. p.46)

Estamos diante de um exemplo em que a obra pode ser considerada um fato urbano capaz, segundo Aldo Rossi, de resistir à ação do tempo, imune às mudanças de uma época à outra. Para esse autor, fatos urbanos seriam portadores de uma arquitetura própria, provido de qualidade e de natureza singulares (ROSSI, 2001, p. 13). 

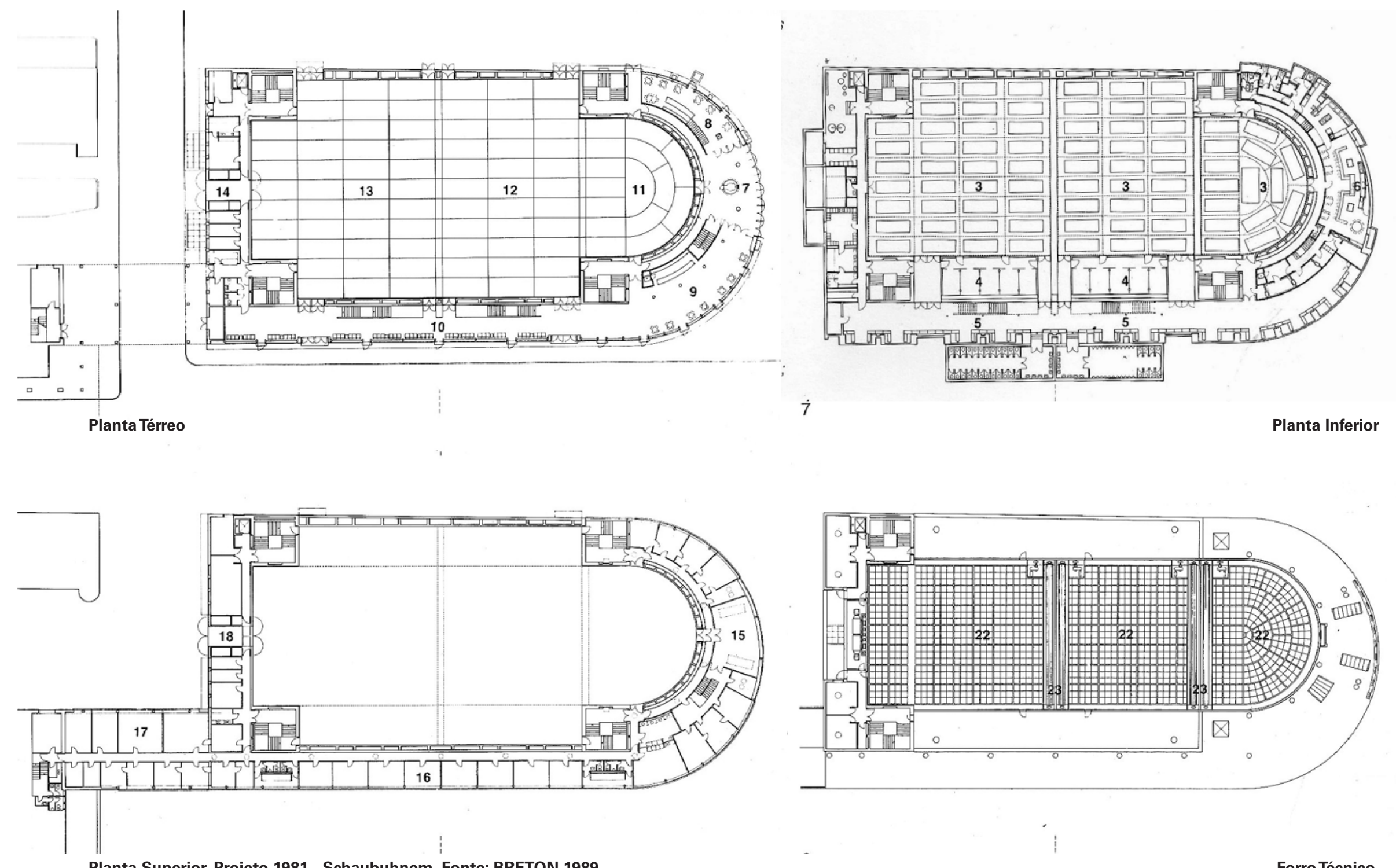

Planta Superior. Projeto 1981 - Schaubuhnem. Fonte: BRETON 1989

Forro Técnico 

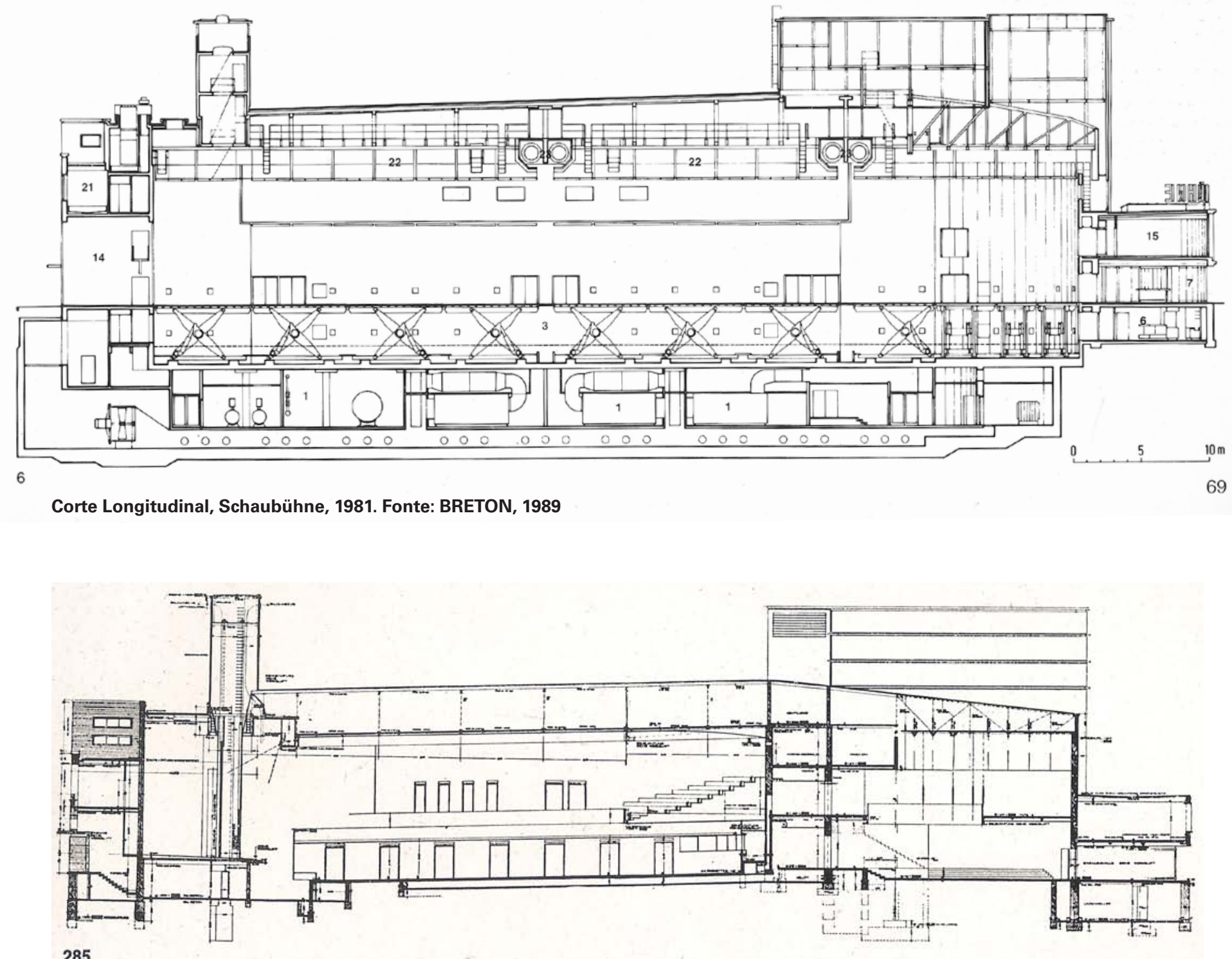

285

Corte Longitudinal, Cinema Universum, 1928. Fonte: ZEVI, 1970 


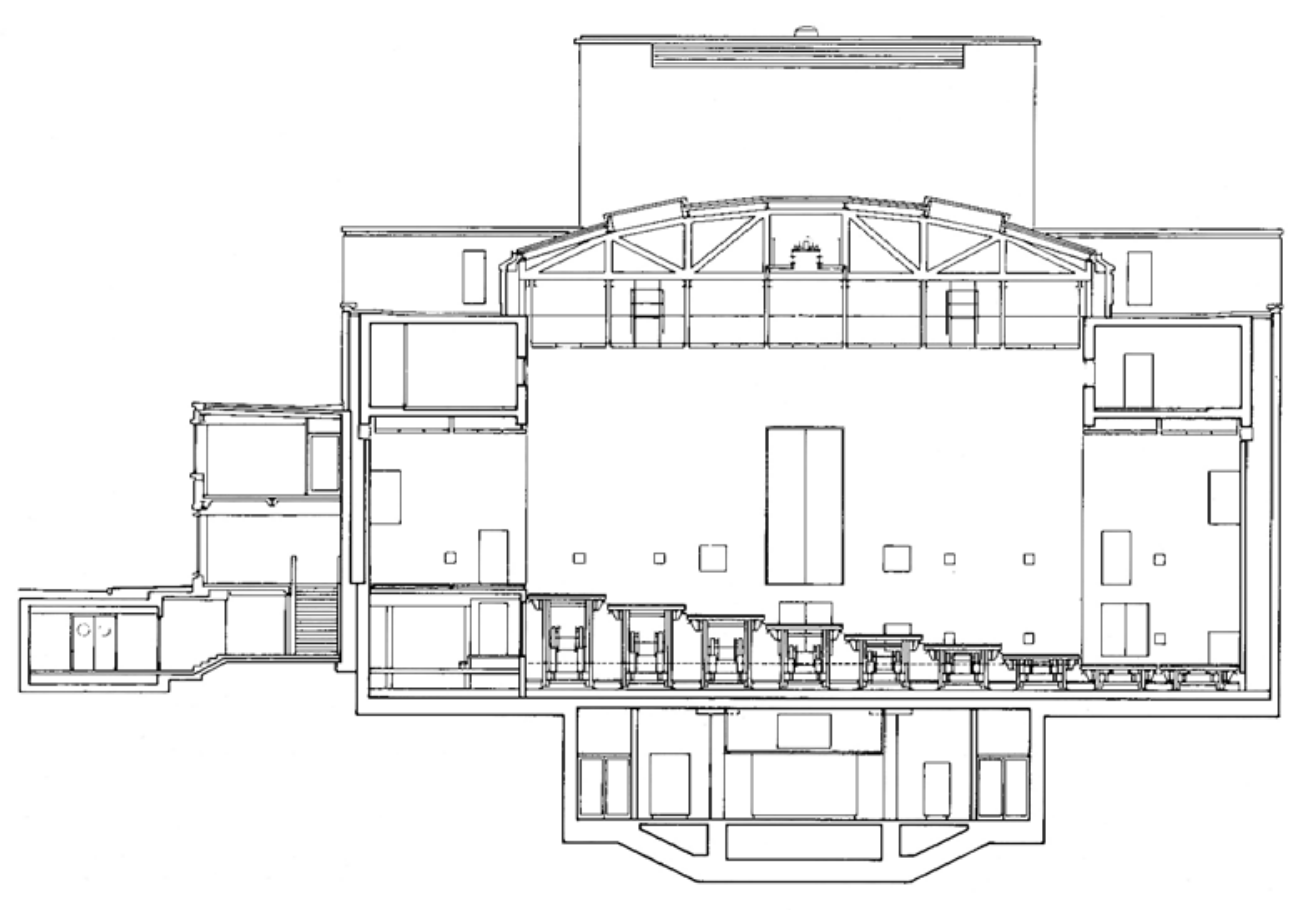

Corte Transversal. Fonte: BRETON 1989
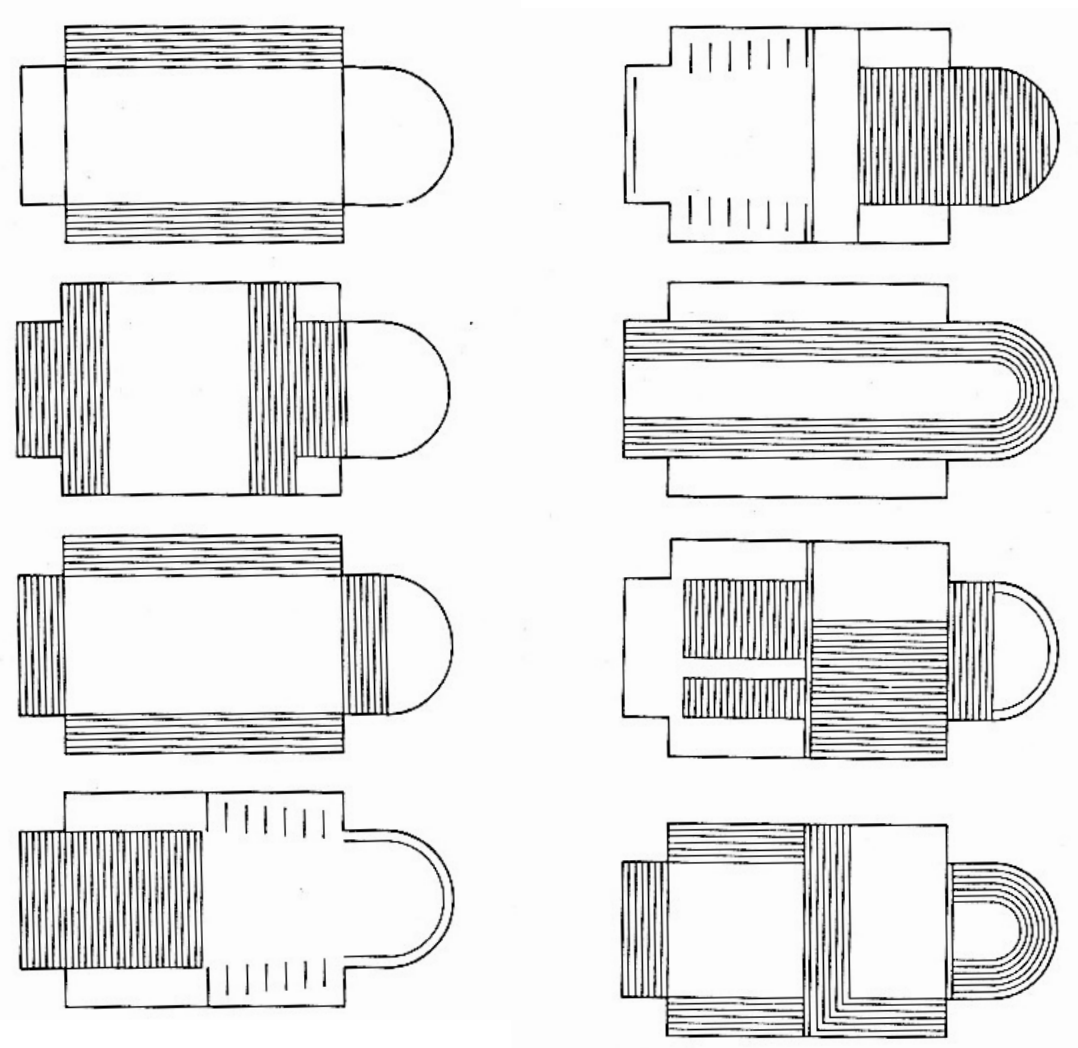

Diagramas de Ocupação. Fonte: BRETON, 1989 
Tal imunidade à que nos referimos está mais próxima da permanência de sua estrutura formal arquitetônica, dentro de um quadro de evolução de usos, do que da conservação integral dos seus aspectos estéticos, como monumento ou como obra de arte. Em outras palavras, as qualidades de natureza essencial, na concepção elementar de Marc-Antoine Laugier (apud AZEVEDO, 2009, P. 54), do projeto de Mendelsohn de 1928 foram determinantes para a sobrevivência e sobretudo para a evolução do conjunto. Isso fica claro ao compararmos as plantas e cortes originais com as do projeto da atual sede do Schaubüne.

A sala original foi transformada em sala integral, tanto pela incorporação da galeria de circulação que a circundava, como pela incorporação do balcão e do foyer semi-circular. As dimensões e proporções obtidas para essa grande nave permitem inúmeras formas de ocupação e transformação da sala, mesmo durante os espetáculos. 0 emprego de um sistema de elevadores hidráulicos pantográficos na totalidade do piso, cada um atendendo ao módulo de 3 × 7 m, chamado de "topografia transformável do lugar", assim como a adoção de uma grelha técnica na totalidade do forro, viabilizaram a mobilidade desejada. A altura interna livre foi compensada pela escavação de um nível inferior onde todo o sistema hidráulico dos elevadores pode ser acondicionado. Dessa forma a altura da cobertura do volume original manteve-se inalterada.

Não há limite entre palco e plateia, mas a tecnologia permite que esse limite possa existir se houver interesse, como pode ser observado nas simulações de ocupação apresentadas na página 130.

É inegável que a tecnologia desempenha um papel fundamental para atingir a mobilidade que vai da cena integral à simultaneidade do espaço tripartido. Vale lembrar que foi a tecnologia, a do cinema, que orientou a solução do projeto original de Mendelsohn. Entretanto, é evidente que o resultado alcançado seria inferior se a mesma tecnologia fosse empregada em um galpão genérico, desprovido dessas qualidades essenciais.

Há ainda a maneira como o Complexo Woga, que pode ser considerado a maior intervenção feita por Men- 
delsohn na escala urbana, foi fundamental na criação ou mesmo na transformação do lugar. Há uma ordem estabelecida pelo projeto original que não se submeteu às condições do entorno, não obedeceu à lógica da tradição berlinense, em que os blocos construídos seguem plenamente o alinhamento das vias, uma perspectiva contínua própria do século XIX. O conjunto multifuncional, ao contrário, é aberto, em que o lugar do espetáculo desempenha papel fundamental. As habitações são integradas às atividades culturais desenvolvidas no complexo, estendendo-se para o restante do espaço urbano. Na sua origem o projeto de Mendelsohn atendeu a um empreendimento imobiliário, ou seja, a uma função específica. Com o tempo adquiriu valor significativo que o identifica na morfologia da cidade, independente da evolução dos usos. Como afirma Aldo Rossi:

(...) o fato urbano apresenta uma qualidade específica, que é dada principalmente pela sua insistência num lugar, pelo desenvolvimento de uma ação precisa, pela sua individualidade. (ROSSI, 2001, p. 117)

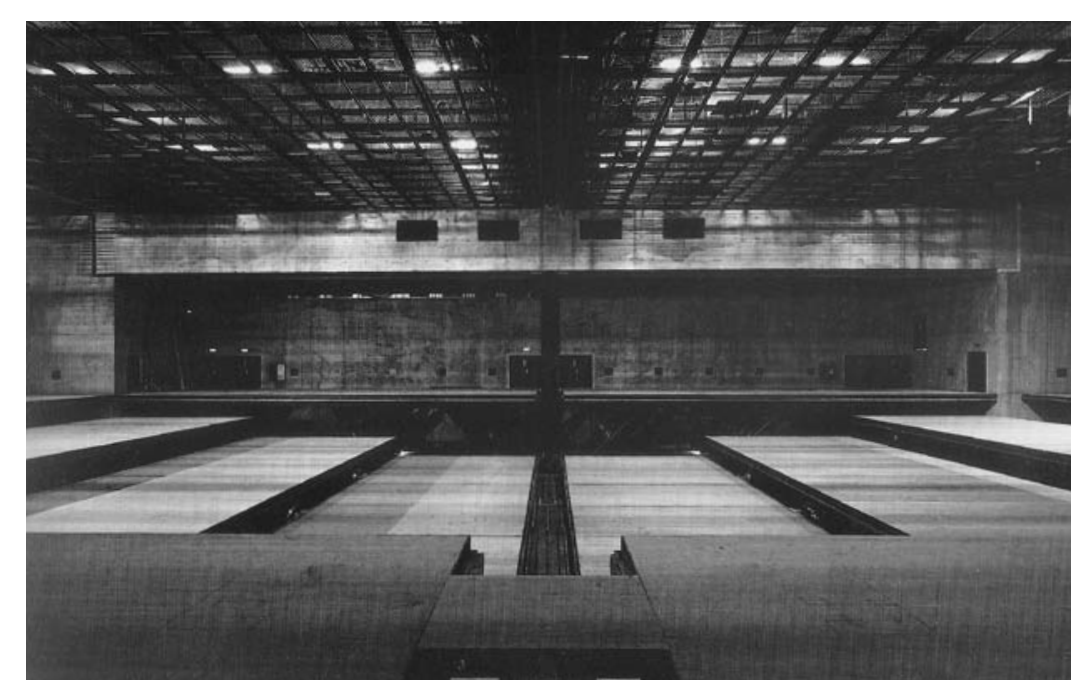

Vista Interior. Fonte: BRETON, 1989

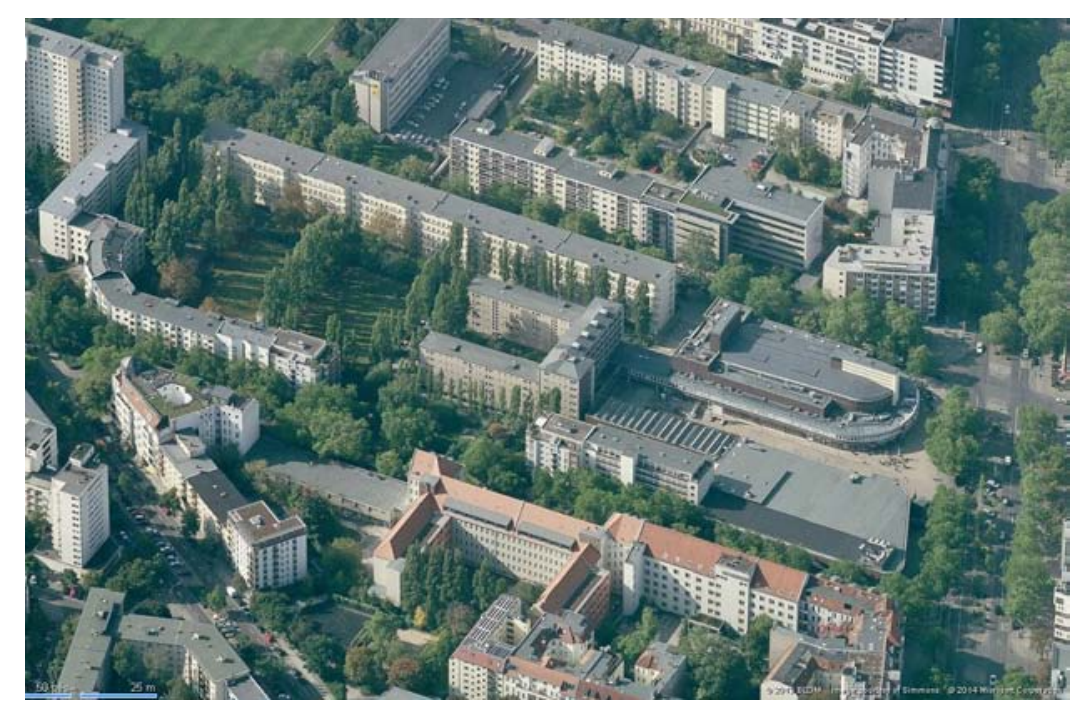

Complexo Woga, vista aérea leste. Fonte: www.bing.com 


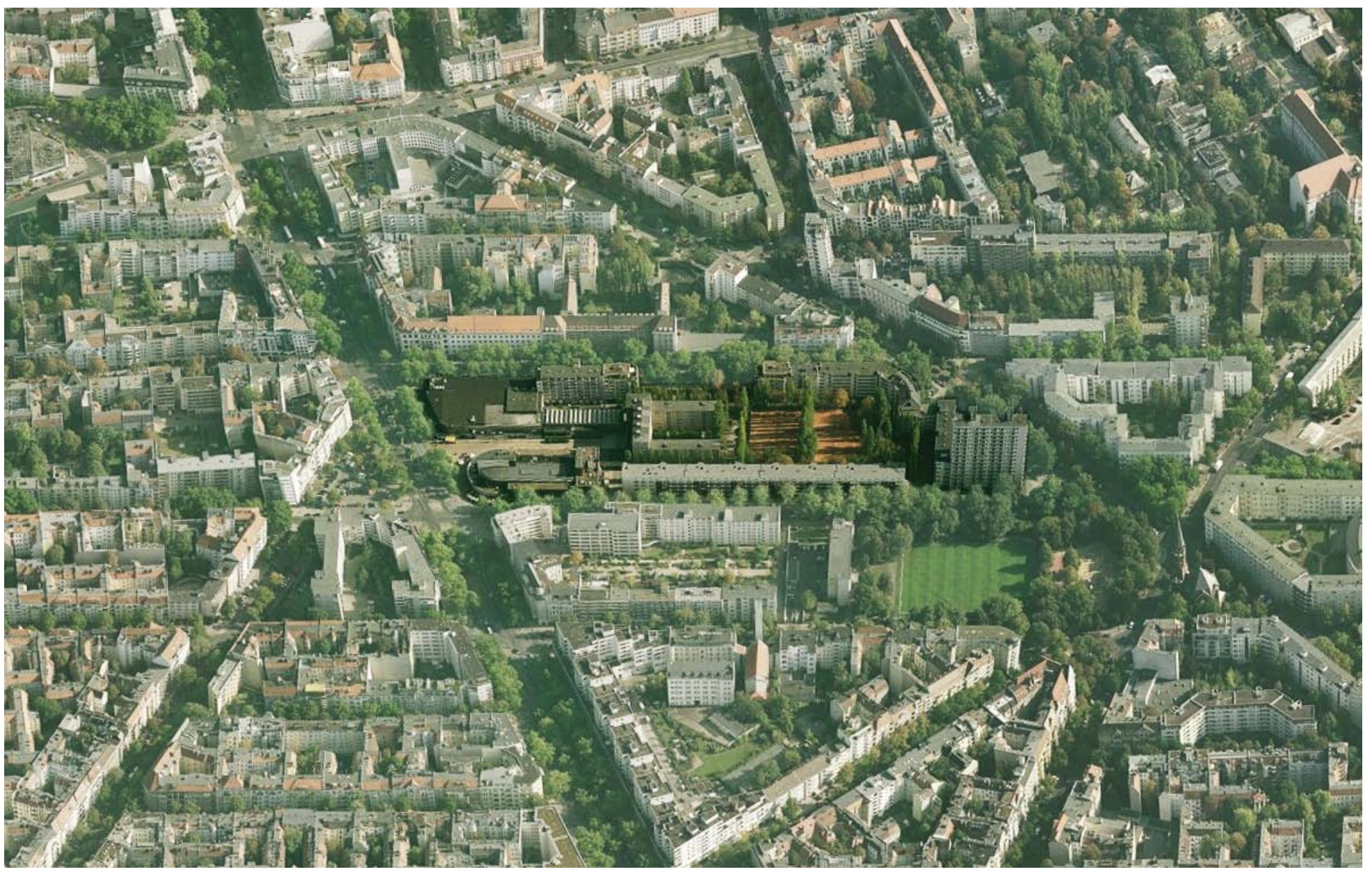

Complexo Woga, vista oeste. Fonte: www.bing.com 


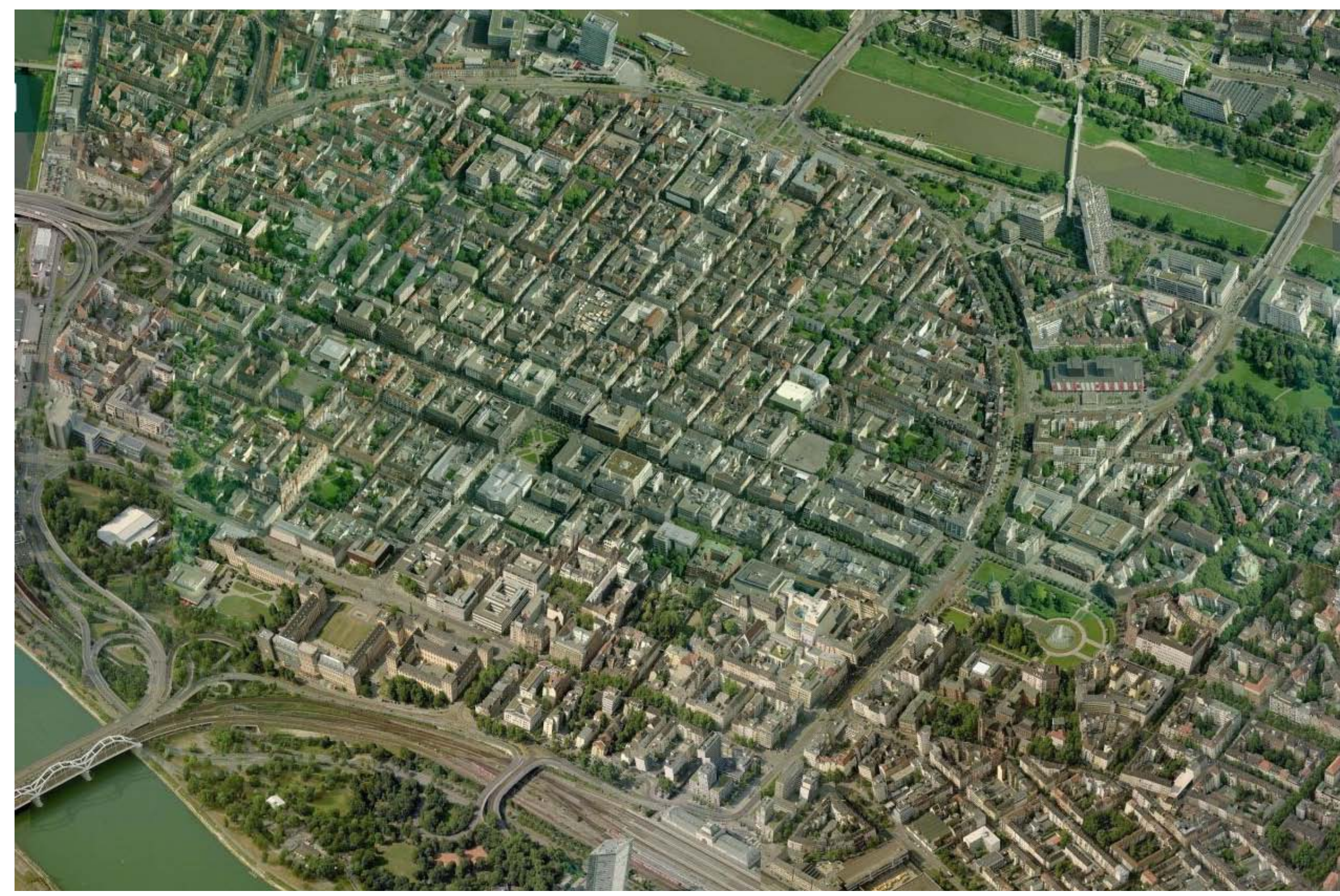

Mannhein Vista Aérea. Fonte: www.bing.com 
Estamos, convém lembrar, num momento de extrema tensão do movimento moderno na Alemanha; com Gropius, na linha de frente, situam-se Mendelsohn e Mies van der Rohe. Mas se para Mendelsohn as massas ainda procuram laminar-se, por uma tensão interna, em superfícies espelhantes, e se em Mies a estratificação dos planos busca organizar-se na estabilidade da massa (matéria que quer transformar-se em símbolo e símbolo quer encarnar-se na matéria), Gropius já transpôs o limite além do qual uma realidade e uma ilusão, uma matéria e um símbolo, não são separáveis, porque o próprio símbolo, pela racionalidade que produz, é tão verdadeiro quanto a realidade.

(ARGAN, 2005, p.130)

As observações de Giulio Carlo Argan referem-se ao período do século XX entre as duas Grandes Guerras. Foi necessário aguardar a década de 1950, já no pós Segunda Grande Guerra, que levara à imigração desses três mestres do Movimento Moderno à América, para que as posições de Mies van der Rohe em relação à arquitetura do espetáculo pudessem ser expressas, contrapondo-se aos seus contem- 

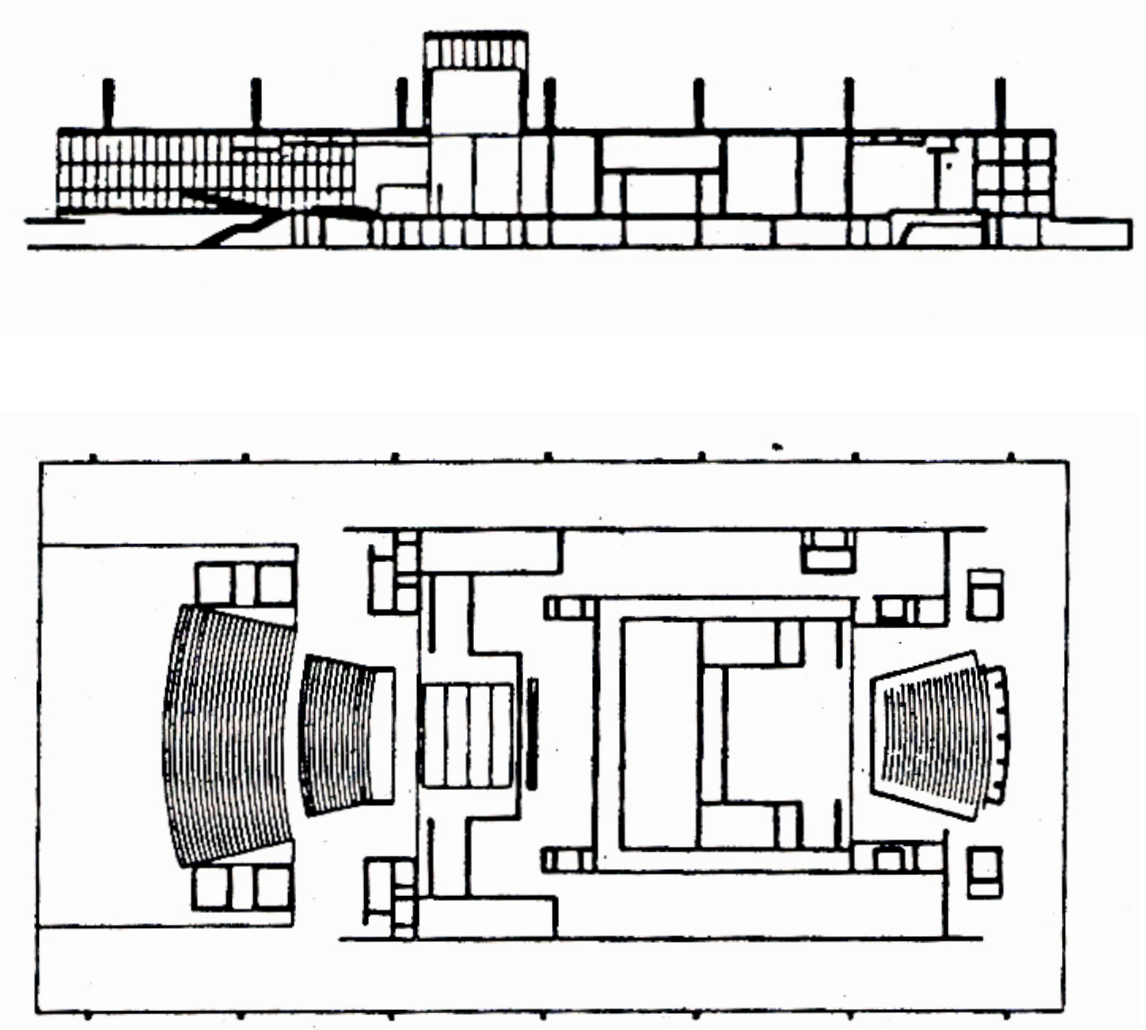

Projeto Mies Van der Rohe. Planta e corte.

Fonte: Architecture d'Aujourd'hui n152, 1970
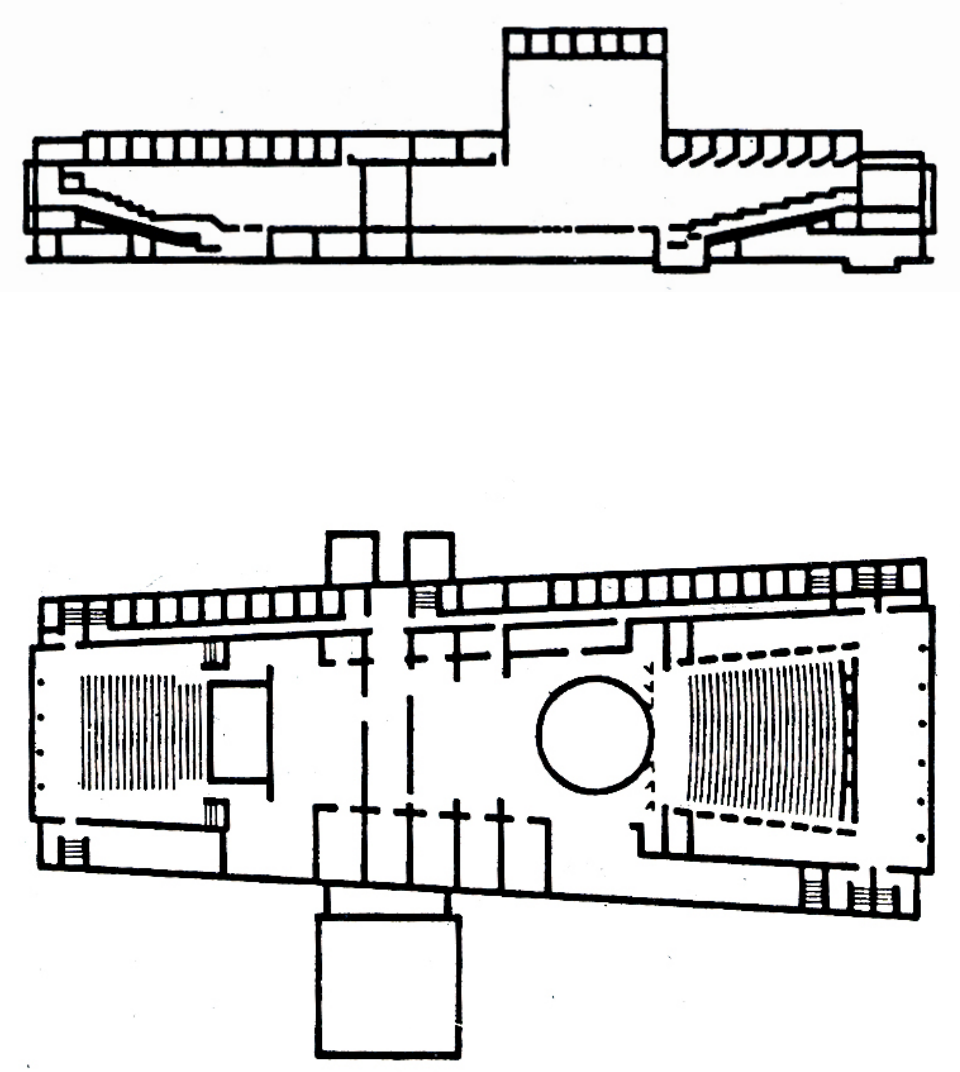

Projeto Gerhard Weber. Planta e corte. Fonte: Architecture d'Aujourd'hui n152, 1970 
porâneos acima citados.

Para o concurso do novo Teatro Nacional de Mannhein em 1953 foram convidados expoentes da arquitetura alemã naquele momento: além do próprio Mies, havia Hans Scharoun e Gerhard Weber, que viria a ser o vencedor.

O programa do concurso previa a reconstrução do antigo Teatro Nacional, destruído durante os bombardeios da Segunda Grande Guerra, baseando-se em um programa contemporâneo com duas salas, a grande com 1.300 lugares e a menor com 500 lugares. Como mostra a vista aérea da página 134 , foi destinada para sua implantação uma quadra adjacente ao anel viário, originário da muralha que protegera a cidade, inscrita entre as margens dos rios Reno e Neckar, característica marcante na formação desse território. Na outra extremidade o terreno está adjacente ao Luisenpark. A situação privilegiada é ainda valorizada por sua frente de cerca de 200 metros voltada para Goethestrasse, que indica claramente o predomínio desse eixo longitudinal na orientação para a implantação do conjunto, em continuidade com o eixo longitudinal do parque.

No momento do concurso, Mies já estava estabelecido há sete anos nos Estados Unidos e sua produção evoluíra, influenciando a indústria da construção civil norte- -americana, para cuja transformação viria a contribuir definitivamente.

A importância de Mies na América após 1950
deve-se ao fato de que ele trouxe uma maneira
decente de construir, que pode ser ensinada (...)
(SCULLY JUNIOR, 2002, p. 73)

Há autores, como Collin Rowe, que destacam esse momento americano como fundamental no trabalho de Mies, particularmente do ponto de vista do espaço, pois há uma clara mudança nas soluções estruturais em que o plano horizontal de cobertura se apoia em um sistema assimétrico de colunas e planos de apoio, característicos do período europeu, como no Pavilhão de Barcelona. 0 edifício agora é uma sucessão de espaços livres de interferências estruturais, decompostos em células estruturais individuais:

Com a considerável expansão do vão estrutural, e conseguindo que o edifício se expresse por uma única célula estrutural, se evitava o engessamento do espaço a que parecia conduzir a nova coluna [referindo-se à coluna predominante no período anterior] e, ao exteriorizar as vigas, podia preservar a horizontalidade "ideal" do teto. (ROWE, 1999, p. 144] ${ }^{63}$ [destaques do autor] 


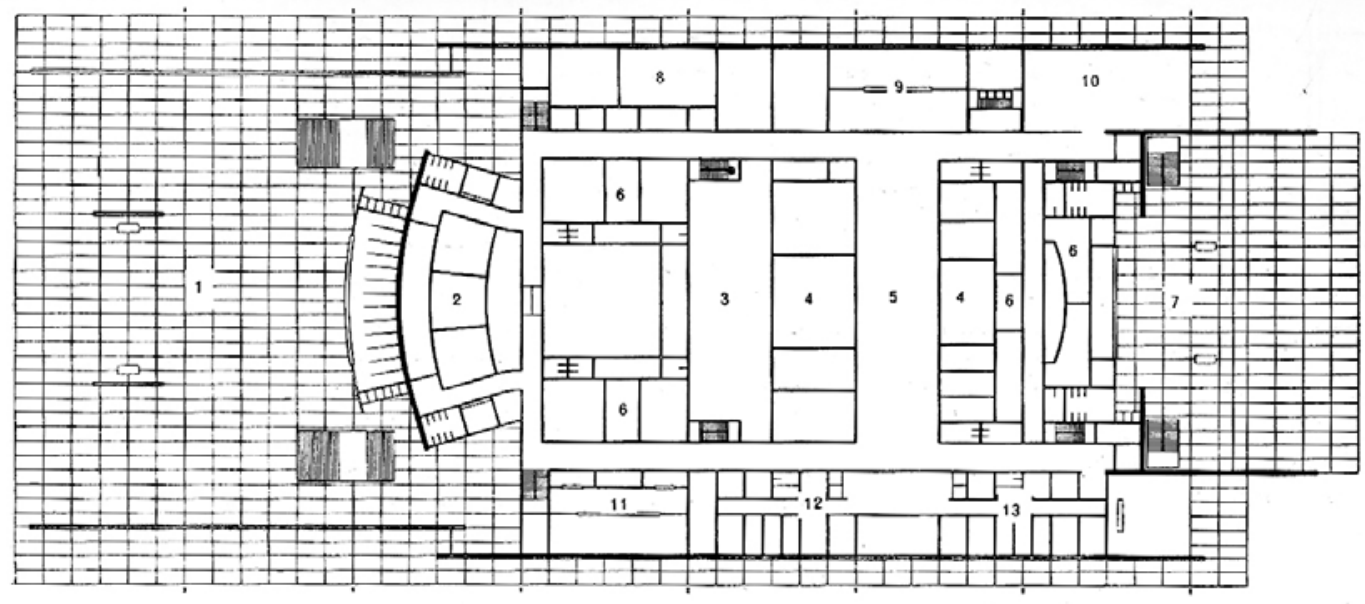

Planta do Inferior
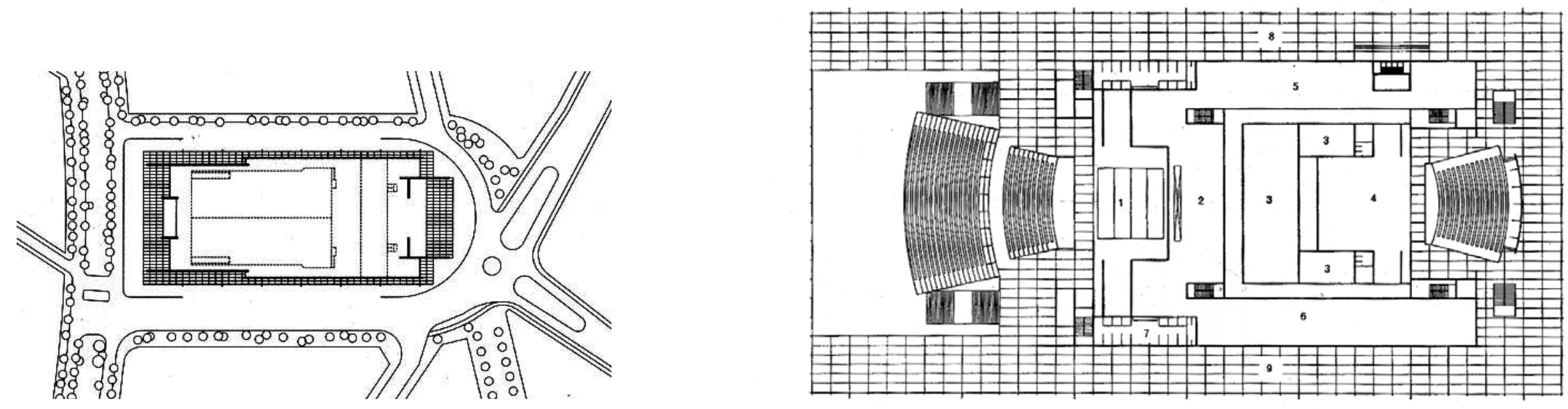


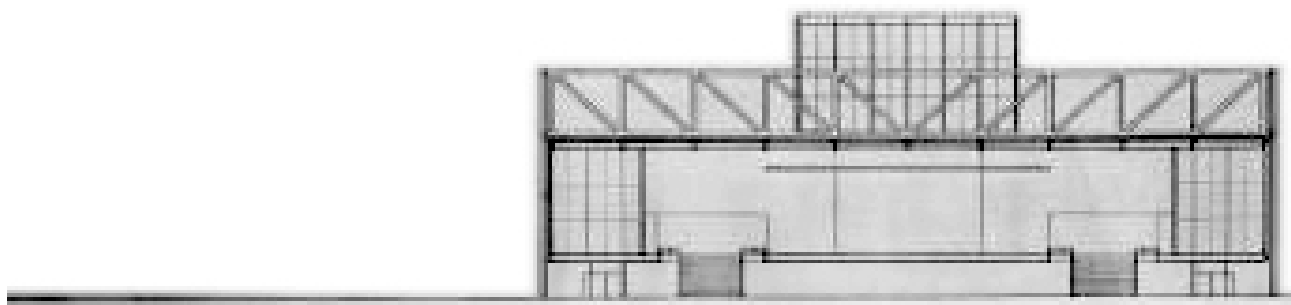

Corte Transversal. Fonte: www.viewpictures.co.uk

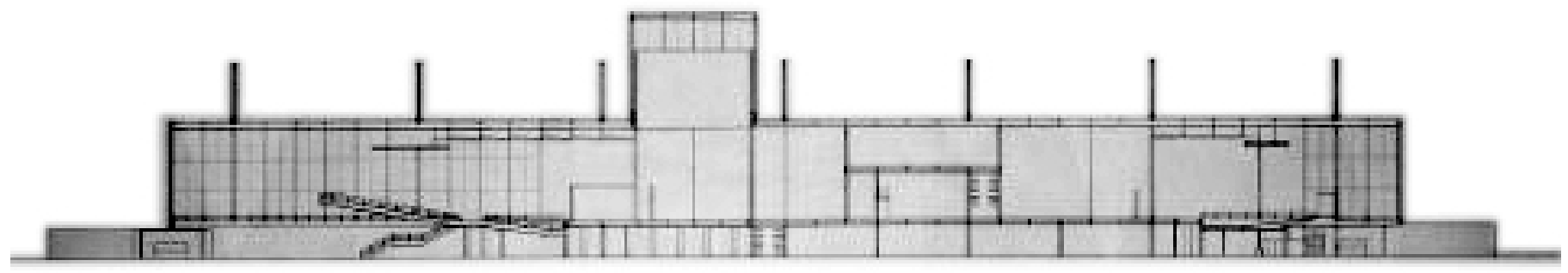

Corte longitudinal. Fonte: www.viewpictures.co.uk 


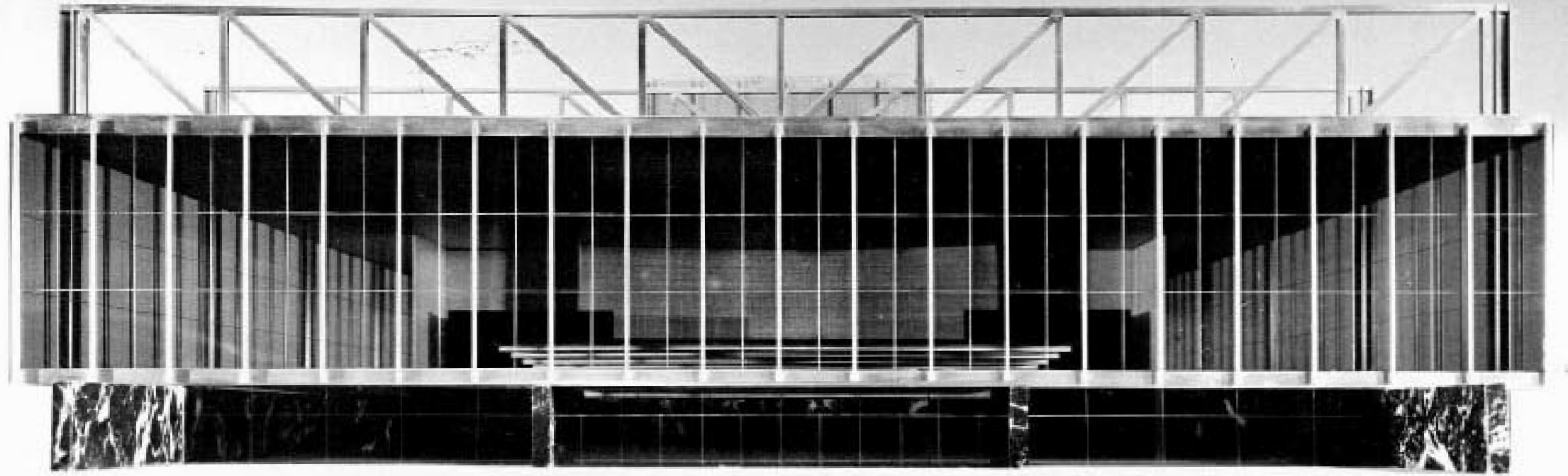

Modelo. Fonte: BABLET, 2002

Para Kenneth Frampton é o momento em que a desmaterialização da arquitetura, convertida na construção de planos mutáveis suspensos num espaço transparente, fluido - a imagem do Suprematismo, concilia-se com o espaço e a estrutura, com os elementos implacáveis de cobertura, vigas, colunas e paredes, conforme suas palavras. Para Frampton, o Teatro de Mannhein é um monumento tecnológico por excelência ${ }^{64}$. É o que o autor considera como a oscilação entre a assimetria e a simetria, entre as técnicas como fundo e a monumentalização da técnica como forma. É a partir dessas considerações iniciais que fica clara a compreensão do projeto apresentado por Mies para o concurso do Teatro Nacional de Mannhein. Sua proposta apresenta um volume retangular prismático, orientado no sentido do eixo maior do terreno, onde estão dispostos os dois auditórios, um em cada extremidade. A cobertura pla-

64 FRAMPTON, K. op. cit., p. 281-284. No capítulo Mies van der Rohe e a Monumentalização da Técnica, 1933-67, o autor analisa as transformações da produção de Mies desde o concurso para o Reichbank, até o projeto para o Seagran Building, destacando também o Teatro de Mannhein. 
na de 81 X 162 metros é suportada pela estrutura metálica exterior, composta por sete treliças e pilares distribuídos na periferia das fachadas longitudinais. 0 volume envidraçado em suas quatro faces repousa sobre uma base revestida em mármore, que é o pavimento de acesso e onde estão localizadas todas as funções de apoio necessárias.

Pela generosidade da solução adotada ficam claras as intenções do arquiteto em liberar de qualquer interferência o funcionamento dos dois auditórios e em valorizar a tecnica como a verdadeira natureza da arquitetura.

Segundo Philip Johnson, nesse momento de intensa produção, Mies expressa nesse projeto suas ideias sobre o teatro, que segundo o autor, ele defendia há muito tempo, como a caixa de palco totalmente inserida no volume para não dissimular o valor arquitetônico do conjunto e a plateia suspensa e incli-

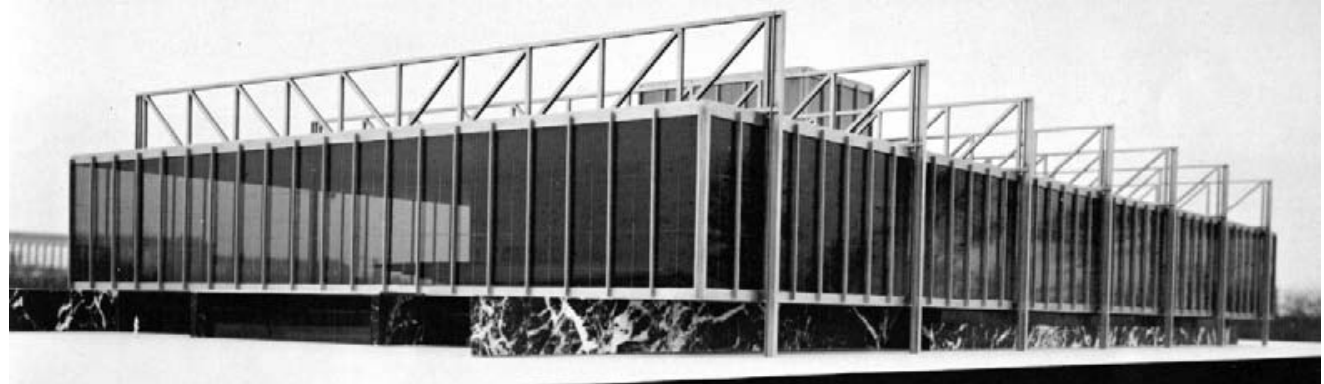

Modelo. Fonte: www.galileupix.com

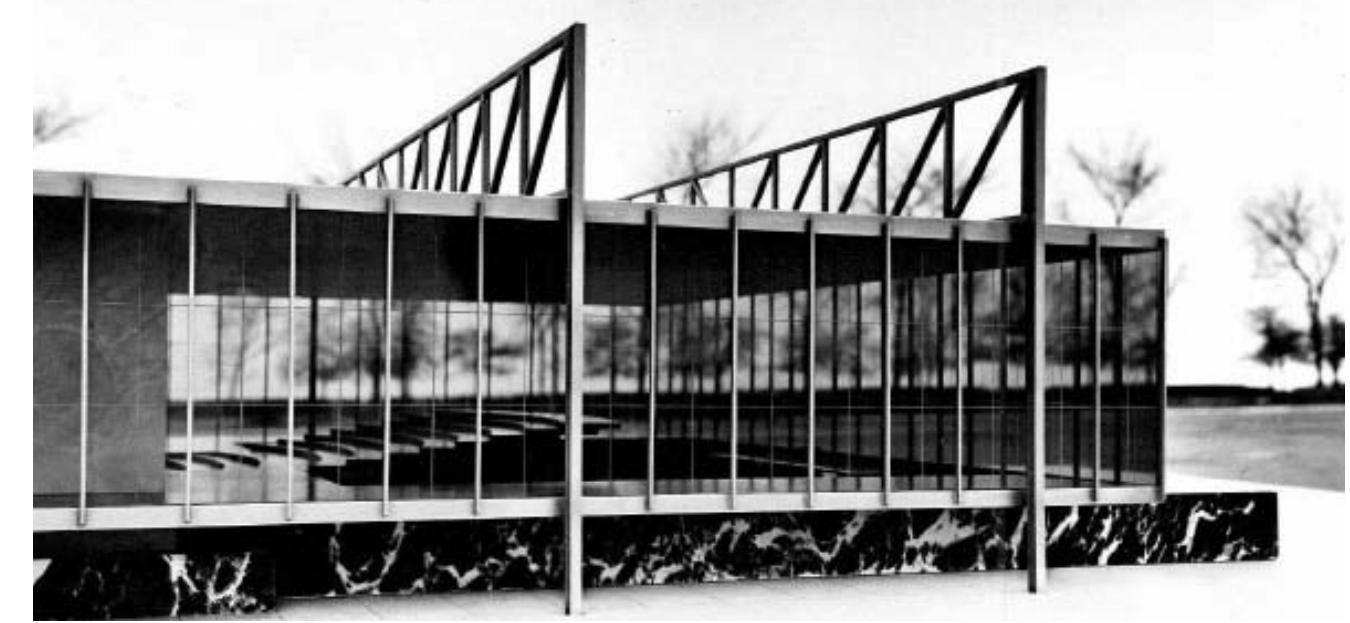

Modelo. Fonte: BABLET, 2002 


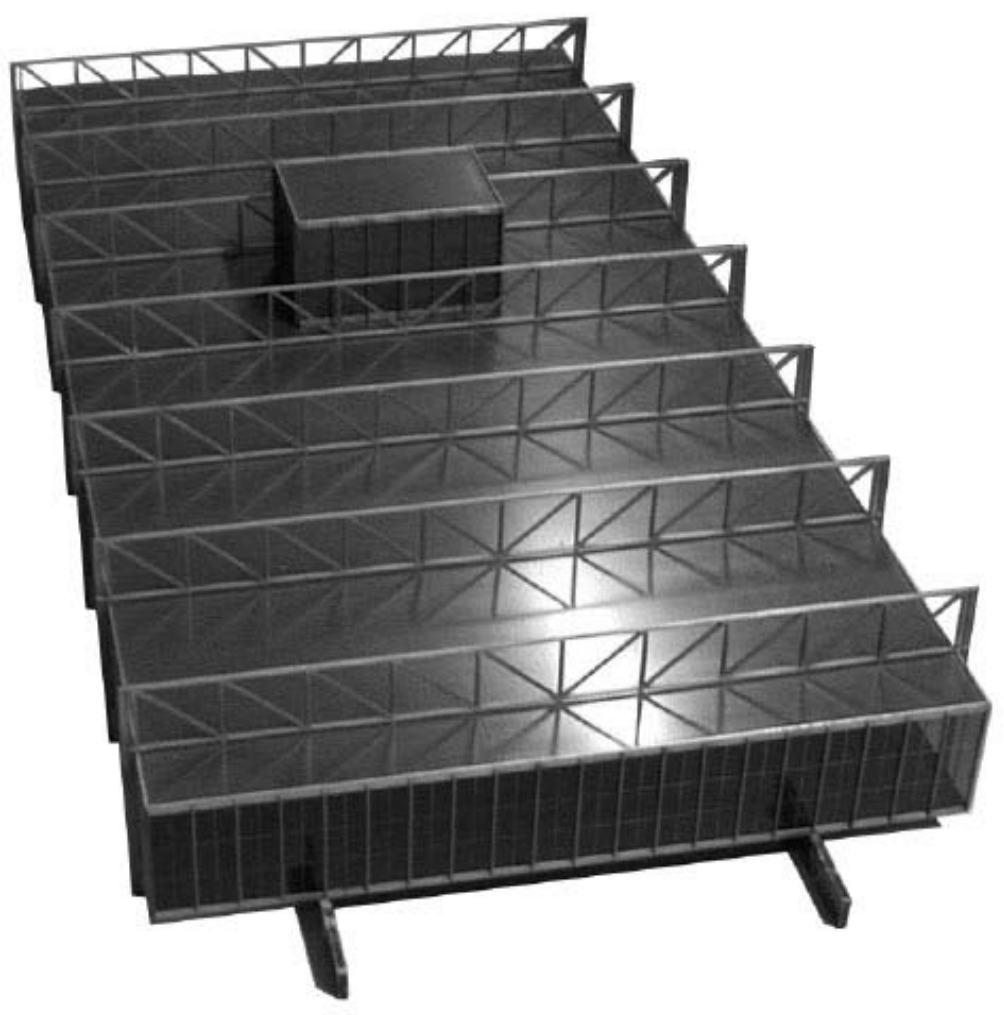

Modelo. Fonte: www.galileupix.com nada no espaço transparente, fazendo parte integrante de um grande espaço monumental ${ }^{65}$.

Por outro lado há um entendimento que nos parece fundamental e que se refere à relação de liberdade espacial e ao mesmo tempo às restrições simbolizadas pelo grande volume, precisamente definido. Assim como no Crown Hall, a rigidez não limita o domínio espacial, não impede que naquela extensa plataforma suspensa possa ser desenvolvida a liberdade criativa dos espetáculos. 0 que fica demonstrado quando esse aspecto é observado com mais profundidade, é que para Mies a monumentalidade da técnica estaria a serviço da expressividade criativa da cena. Em outras palavras, a arquitetura não se utilizou da tecnologia para distribuir equipamentos transformadores, capazes de criar um novo espaço a cada espetáculo, como propusera Gropius no Teatro Total. Entretanto o esforço técnico do projeto permitiu que fossem abertos novos caminhos a serem traçados por seus utilizadores. No entender de Franz Schulze, Mies não acreditava no frívolo experimentar por experimentar. As salas de espetáculos contidas na rígida geometria do

65 JOHNSON, 1960, p. 183. O autor destaca, no seu entendimento, o Teatro de Mannheim como sendo o ponto alto da etapa americana de Mies, assim como o Pavilhão de Barcelona fora o ponto alto da etapa europeia. 
projeto, precisamente definidas, expandem-se através de seus limites físicos, irradiando-se pelas fachadas envidraçadas, por sua vista e situação privilegiadas, de maneira que o espaço seja institucionalizado e monumentalizado:

De todas as estruturas diáfanas de Mies, essa era a demonstração mais convincente de que um espaço unitário podia aceitar a diversificação assim como proporcionar a flexibilidade.

(SCHULZE, 1986, p. 275)

Podemos ainda acrescentar, dentre as qualidades do projeto, sua capacidade de mudança ou de construção de uma nova realidade urbana. Não estava explícito no programa do concurso, mas deveria ser uma preocupação primordial dos arquitetos convidados a requalificação daquele setor historicamente significativo para Mannhein e que tinha no novo Teatro Nacional a oportunidade de reconquistar a dignidade perdida pelos anos de conflito armado.

O projeto apresentado por Hans Scharoum parece caminhar nessa direção, amparado pela expressividade formal, característica da arquitetura do autor, em que o conjunto se articula em função dos alinhamentos historicamente instituídos.

Hans Scharoum foi quem levou mais adiante a compreensão do território através do significado histórico do Teatro e da evolução de Mannhein. Sua equipe estudou detalhadamente diversas possibilidades de localização do projeto antes de desenvolver sua proposta, uma maneira de compreensão do território formado pela cidade de Mannheim entre os dois rios e sua evolução histórica.

Os dois auditórios, como na proposta de Mies, estão localizados nas extremidades longitudinais do lote, porém em posições diametralmente opostas e são interligados por um volume retangular, disposto na diagonal do lote, que abriga todas as áreas de apoio e espaços para workshops, uma contribuição de sua equipe ao programa original do concurso. Um prisma de linhas funcionalistas que contrasta com a liberdade formal dos auditórios, destacados mas articulados por ele. 0 desenho livre de cada sala é que determina a expressividade do conjunto. 0 volume retangular 


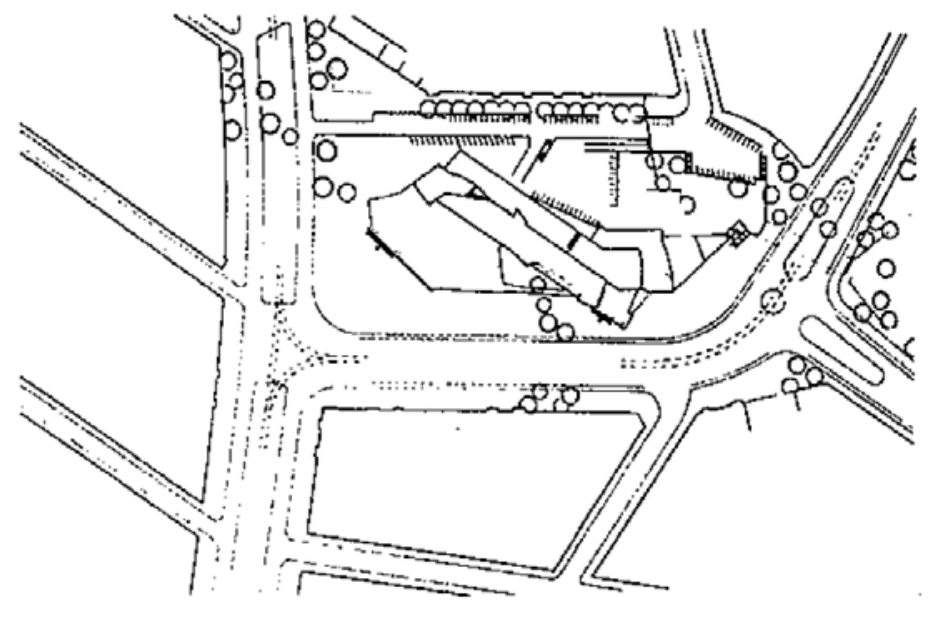

Implantação. Projeto Hans Scharoun. Fonte: Scharoum Archives

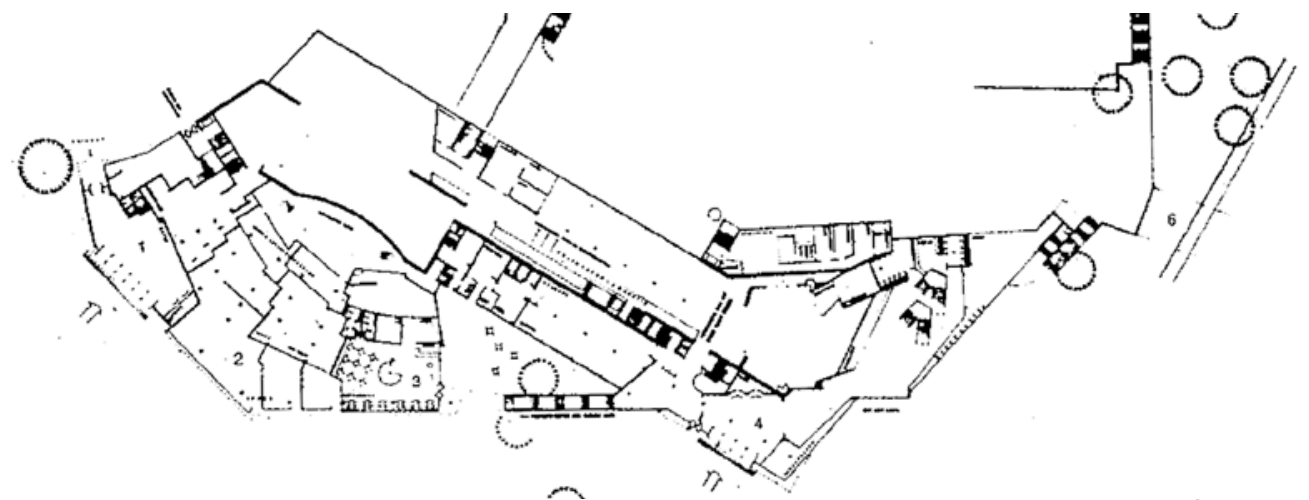

Planta térreo
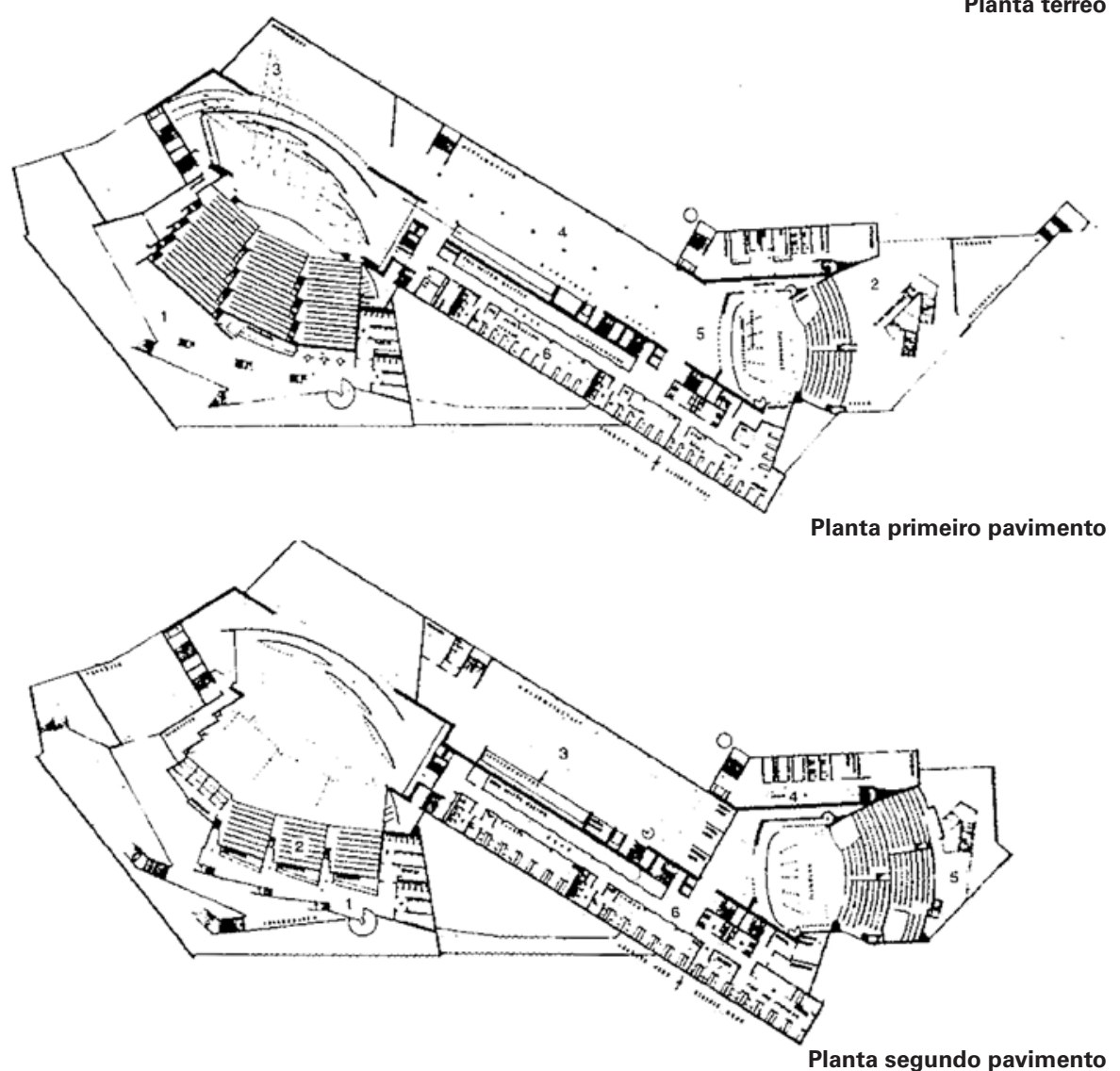
faz o contraponto, potencializando ainda mais a natureza escultórica do projeto.

Para Scharoum o desenho do interior da sala deveria estar claramente expresso em seu exterior. E esse desenho seria resultante do que o arquiteto considerava como o Palco não Perspectivado, em que a ação se valeria da profundidade e da superposição de planos para a construção de sua dramaturgia. Para que essa condição fizesse parte das possibilidades da sala principal, Scharoun trabalha com um palco extremamente largo, integrado ao proscênio, em que a sequência ou a sobreposição de planos possa ocorrer de maneira distinta, de acordo com as condições exigidas pelo espetáculo. Seria sua contribuição para uma cena não axial, uma leitura quase que cinematográfica da ação, o que permitiria a construção do espaço através de planos cênicos, cuja sincronia poderia se dar tanto no nível do palco como em qualquer outro oferecido por sua altura generosa. A situação seria ainda potencializada pela distribuição oblíqua da plateia, dividida em três conjuntos independentes, de onde a percepção do espetáculo poderia ser enriquecida.
Pode-se também avaliar a importância da proposta de Scharoum para Mannheim, apesar de não vencer o concurso, por ter sido o laboratório das ideias que viriam a ser concretizadas por ele três anos mais tarde quando projetou a sede da Orquestra Filarmônica de Berlim, uma de suas obras mais significativas. Em especial para Mannheim, fica evidente sua posição, mais do que em Berlin, de que o contraste da arquitetura escultórica assuma uma presença indiscutível perante o território e diante a evolução histórica da cidade.

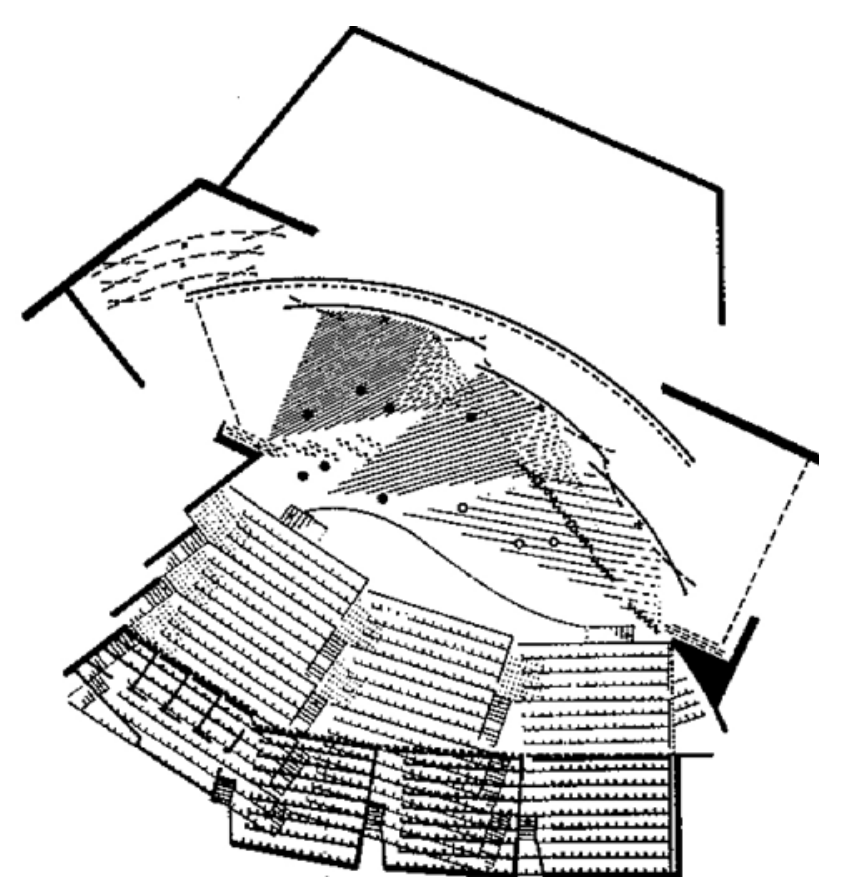

Planta do Auditório Principal. Fonte: Scharoum Archives 


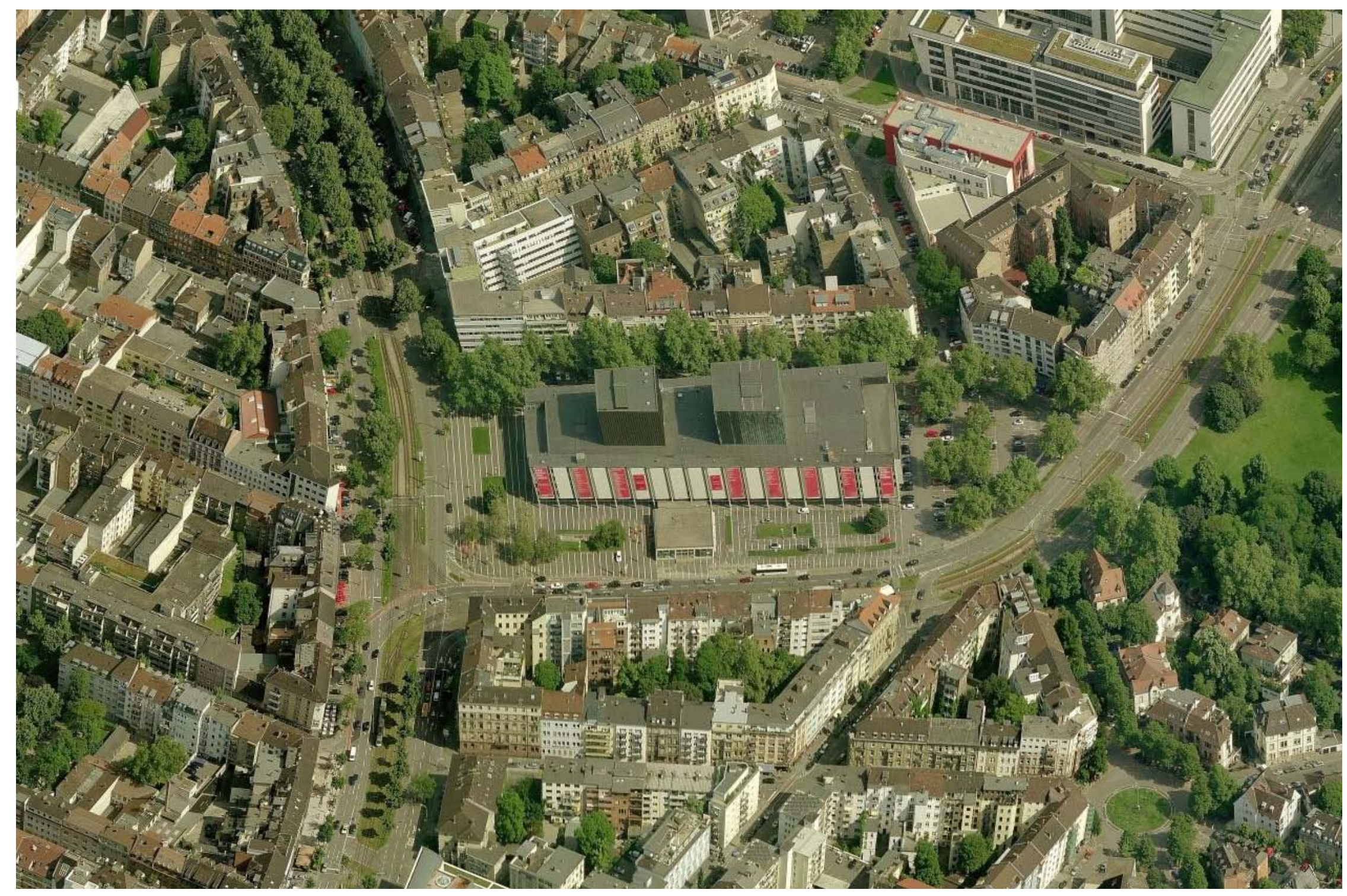

Projeto Gerhard Weber. Vista aérea Sul. Fonte: www.bing.com 
Apesar desses embates radicais, teóricos e arquitetos do movimento moderno não abriram mão da procura por uma expressão formal monumental distinta da acadêmica e identificada com novos valores formais e estéticos. Ou seja, a arquitetura dita moderna não deveria restringir seu enfoque aos problemas menores ou àqueles estritamente classificados como funcionais, como fábricas, casas populares, escolas, hospitais, etc. Ainda assim, princípios ditos universais como ordem, disciplina, tectônica e espirito do tempo continuaram sendo aplicados pelos mestres, entre eles Mies van der Rohe, que os considerava perfeitamente válidos. Louis Kahn, por exemplo, dedicou páginas significativas para esclarecer o sentido de monumentalidade na arquitetura moderna e demonstrar que surgia a necessidade de uma nova expressão para as instituições públicas.

(SEGRE, 2013, p. 286)

Finalmente, o projeto de Gerhard Weber, construído após vencer o concurso para o Teatro de Mannhein, caminhou em uma direção distinta. Sua organização parece em um primeiro momento se aproximar da proposta de Mies: um prisma longitudinalmente implantado, com os auditórios dispostos um em cada extremidade, compartilhando as áreas de apoio e os palcos no centro da edificação.

Um dos aspectos que deve ter sido determinante para a escolha do projeto de Weber foi a demonstração da flexibilidade da sala menor. Para Hans Gussmann (in BABLET, [1963] 2002, p. 115) o pequeno Teatro de Mannhein deve ser saudado com admiração por seu pioneirismo, por permitir que a atividade teatral possa passar da teoria à prática. Esse seria o caminho para que a prática artística descubra em que medida pode se distanciar das formas tradicionais e até onde evoluir sem impor novos limites ao teatro. 0 autor apontava a importância da tecnologia para que o teatro contemporâneo cumprisse seu papel, advertindo por outro lado que ela, da mesma maneira que a arquitetura teatral, não deveria se tornar um obstáculo. Gussmann ressalta ainda que mesmo as peças escritas para os antigos teatros podem ser montadas dentro de espaços de concepção inovadora, beneficiando-se do espaço reservado à interpretação segundo leis de uma dinâmica diferenciada. 


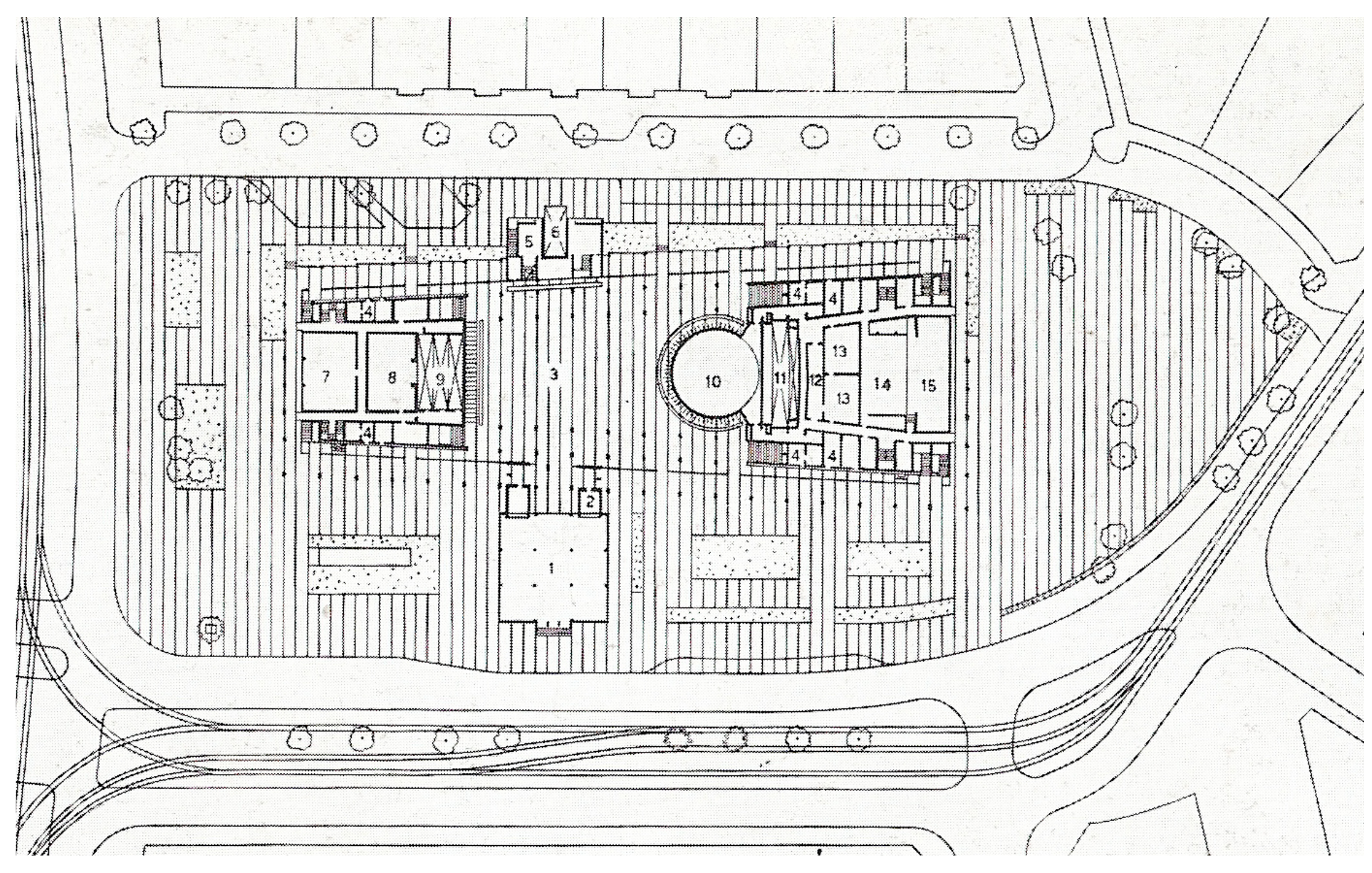

Projeto Gerhard Weber. Implantação Térreo. Fonte: ALOI, 1958 


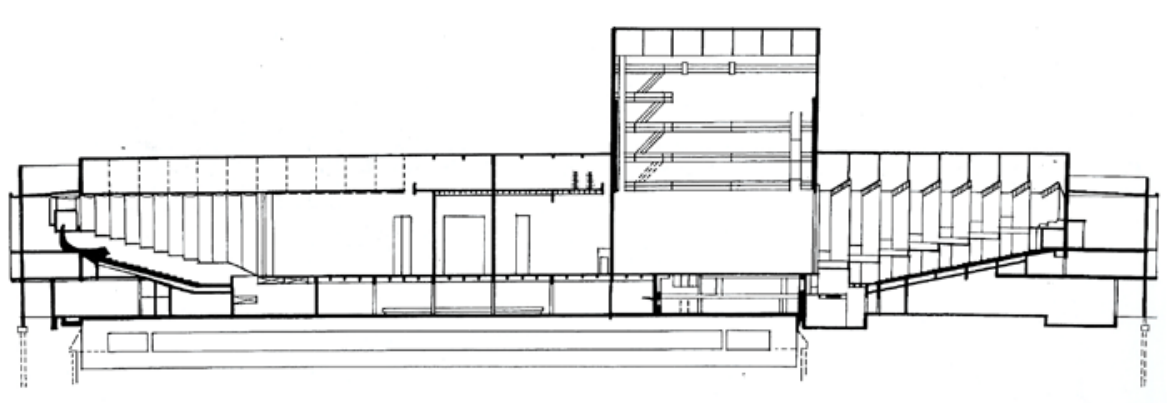

Projeto Gerhard Weber. Corte Longitudinal. Fonte: ALOI, 1958

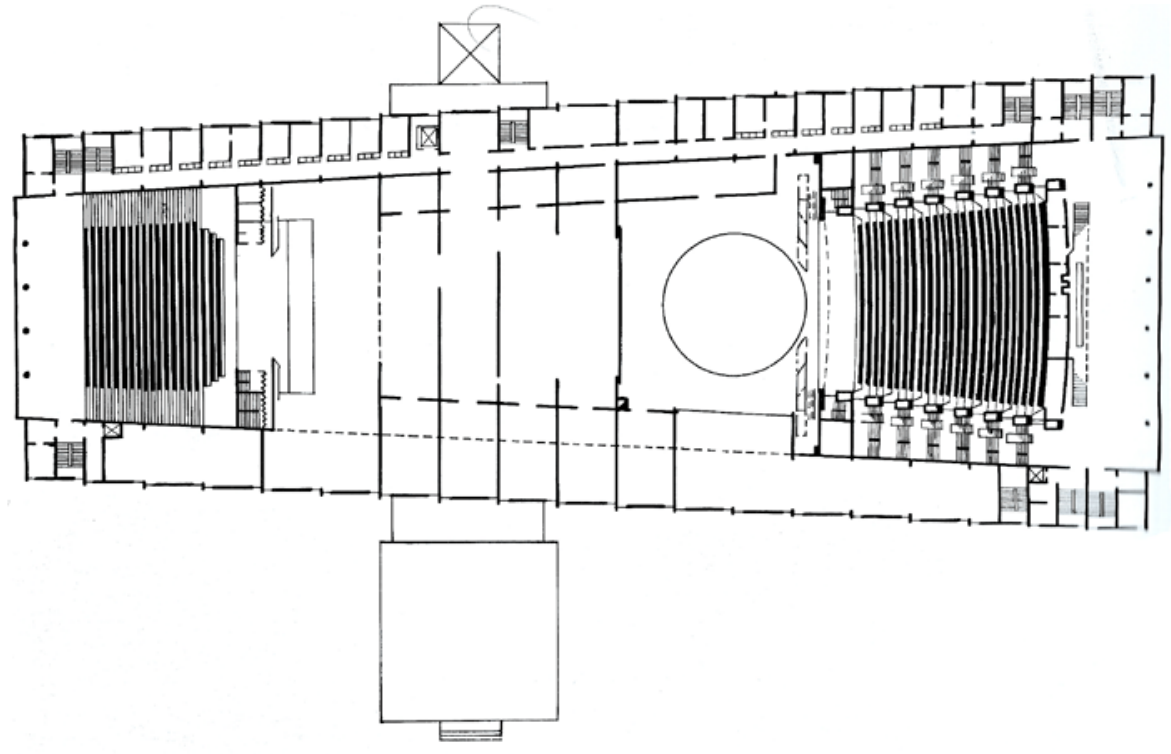

Projeto Gerhard Weber. Planta do Superior. Fonte: ALOI, 1958
Por outro lado, no mesmo colóquio ${ }^{66}$, o encenador Erwin Piscator, em sua conferência sobre a Tecnologia como Necessidade Artística, destaca a pequena sala do Teatro de Mannhein como portadora de incontestáveis vantagens e inconvenientes. Poucos anos após sua inauguração em 1957, Piscator, em sua montagem para a peça Os Bandoleiros (Die Räuber) de Friedrich von Schiller, pôde experimentar as possibilidades oferecidas por essa sala transformável. Para ele a livre organização do espaço e o contato da cena com o público são qualidades incontestáveis. Isso possibilitou que a peça se concretizasse de maneira muito próxima à concepção descrita no texto de Schiller. Entretanto, Piscator admite as dificuldades para que a flexibilidade prometida se manifestasse de maneira plena, ágil, dinâmica, sem os pesados investimentos exigidos pela tecnologia. Segundo a análise de Emile Coperfermann sobre essa montagem feita por Piscator, fica evidente que um hiato se instaurou desde a inauguração do Teatro - uma ferramenta que pesa estranhamente ${ }^{67}$

66 Colloque à l'Abbay de Royaumont, 1961. Transcrição conforme publicação: BABLET, Denis. Le Lieu Théatral dans la Société Moderne. Paris, CNRS. [1963] 2002.

67 Tréteaux Nus, in Techniques \& Architecture, 310-976, Rupture dans L'Architecture du Spectacle, p. 66. 
Se seu interior oferece possibilidades de ocupação que vão ao encontro às aspirações do meio teatral desde a década de 1920, apesar das limitações assinaladas por seus utilizadores, é em seu exterior, no arcabouço que abriga o conjunto de salas, que fica evidente a dificuldade da edificação em cumprir seu papel perante a cidade. Em oposição ao prisma transparente de Mies, que repousa entre o parque e o velho centro da cidade, ou a expressividade contundente da proposta de Scharoun, Weber concebe um volume fechado em concreto sobre pilotis, em que o ritmo dos módulos estruturais marcam de maneira precisa a fachada longitudinal. O resultado pouco contribui para a construção de uma imagem institucional que se insira de maneira objetiva no espaço urbano. Atualmente esses módulos de fachada são usados como suporte para a divulgação dos espetáculos do Teatro, uma espécie de fachada outdoor, o que confirma a dificuldade em se fazer um juízo preciso das atividades desenvolvidas em seu interior. Como afirma Piñon (2006, p. 150):

A cidade moderna é necessariamente diferente, não tanto pelos aspectos de seus edifícios quanto pela natureza distinta das relações que os vinculam para construir espaços urbanos de qualidade superior.

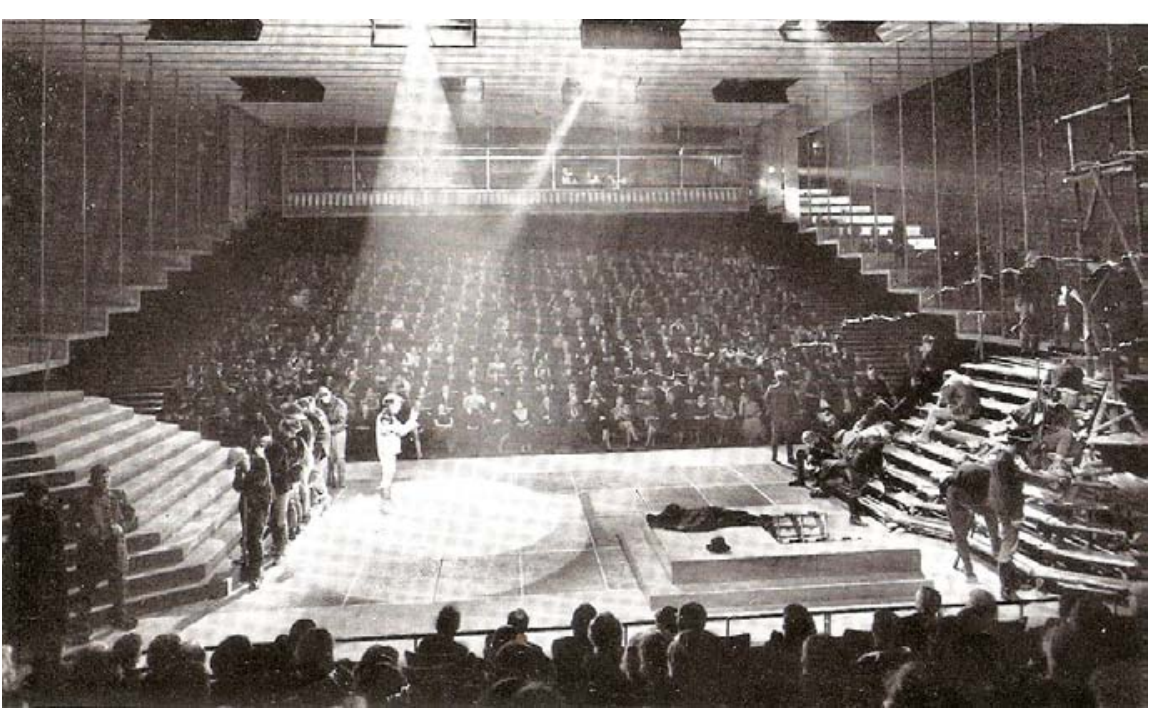

Pequeno Auditório. Fonte: ALOE, 1958
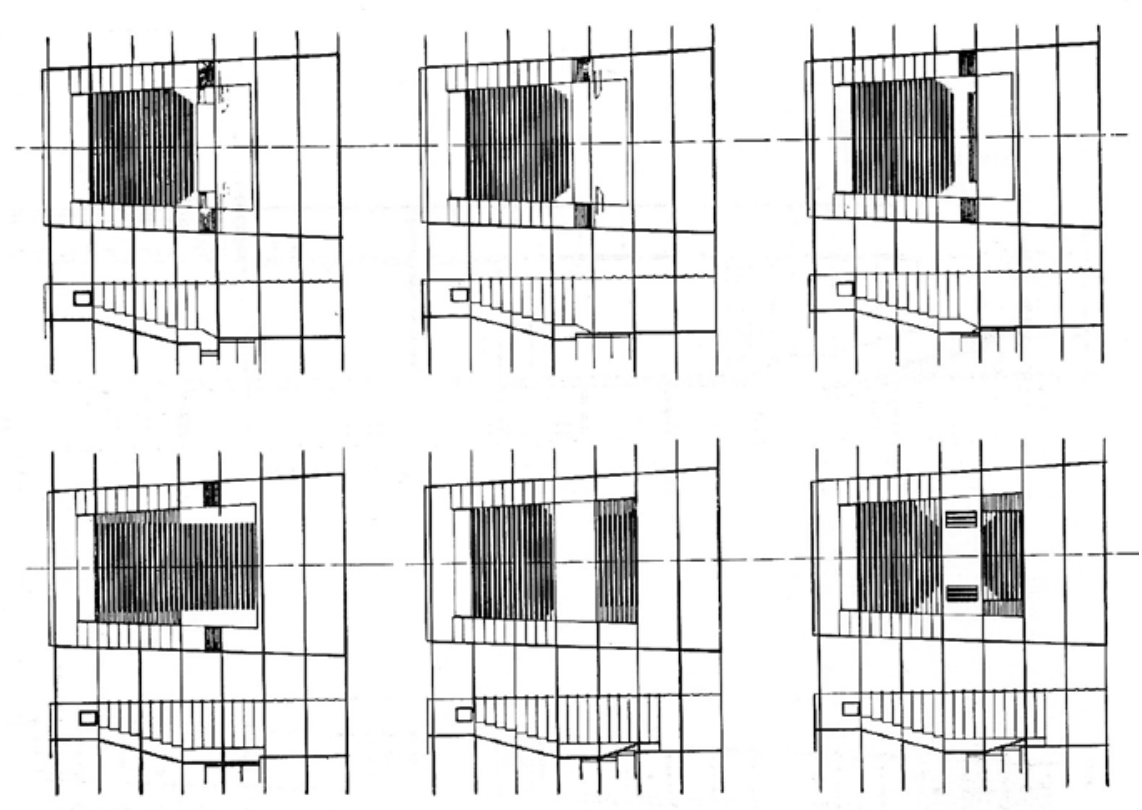

Pequeno Auditorio. Diagramas de ocupaçāo. Fonte: ALOE, 1958 


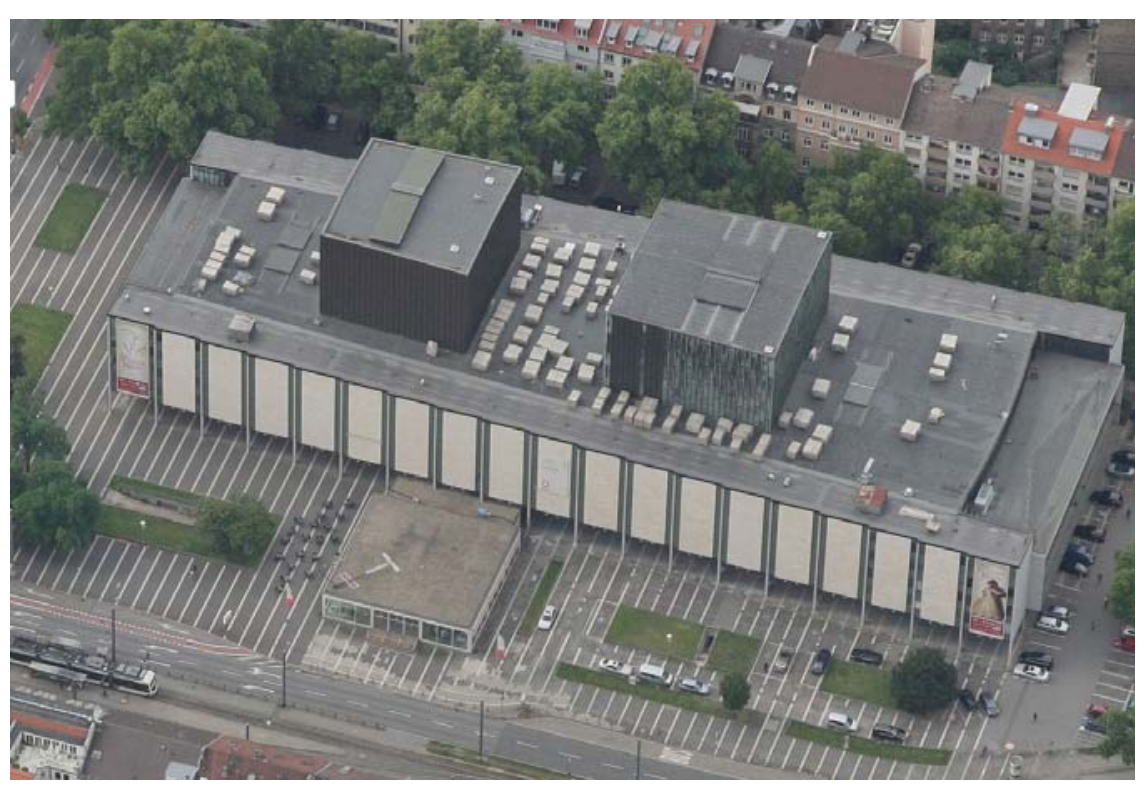

Projeto Gerhard Weber. Vista aérea Fachada Sul. Fonte: www.bing.com

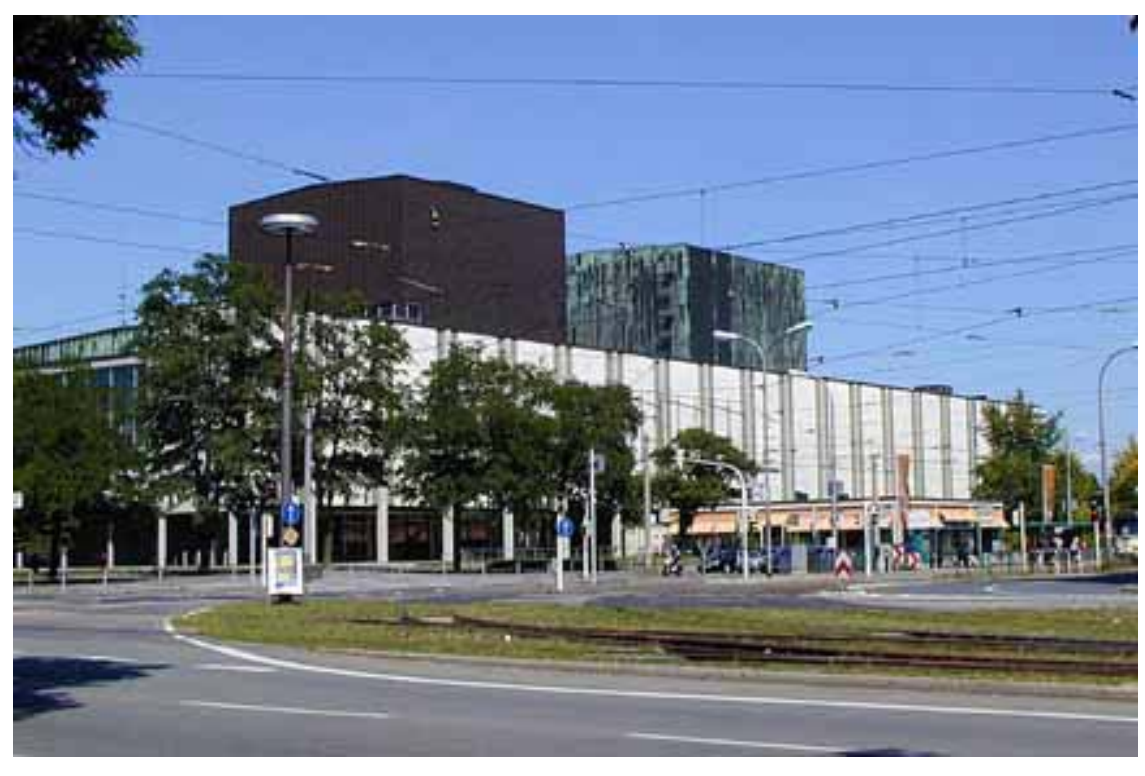

Projeto Gerhard Weber. Vista Fachada Sul. Fonte:Teatro Nacional de Manhein 
Capítulo 4

a Metrópole em Cena 
Tomemos a imagem de um tecido, constituído pela urdidura $^{68}$ e pela trama. Pode-se dizer que a urdidura estabelece o ordenamento básico do tecido e, ao fazê-lo, cria a oportunidade para que se consiga a maior variedade e colorido possíveis junto com a trama.

A urdidura deve em primeiro lugar e acima de tudo ser forte e possuir a tensão correta, mas, no que diz respeito à cor, tem apenas de servir de base. É a trama que dá a cor, padrão e textura ao tecido, dependendo da imaginação do tecelão. Urdidura e trama constituem um todo indivisível; uma não pode existir sem a outra e cada uma empresta à outra seu objetivo.

(HERTZBERGER, 1999, p.108)
Nossa hipótese de pesquisa trata a cidade como cena e o retorno do uso do espaço urbano como palco, como cenário para suas manifestações. Retorno, porque os espaços urbanos, originalmente, foram concebidos para manifestações coletivas que, como observa Christian Dupavillon ${ }^{69}$, valorizaram, embelezaram e idealizaram esses espaços. A própria arquitetura dos teatros inspirou-se nesses lugares.

Cabe precisar aqui o uso frequente dos termos cena e cenário. A cidade como cena expressa a ação propriamente dita, torna-se conteúdo a ser tratado pela dramaturgia do espetáculo, pode-se admitir que a cidade é "texto", é sujeito, personagem e é também tema, é ponto de partida ou finalidade para o desenvolvimento do espetáculo. 0 cenário, por sua vez, tem um caráter estático, surge como ilustração da ação. 0 cenário urbano inspira, acumula a dimensão temporal do espaço, e a cidade como cenário pode adquirir força por sua permanência, por suas qualidades primordiais.
68 As palavras urdidura para a tecelagem e urdimento para o teatro têm intensa relação. É interessante assinalar que é o urdimento que garante, sobre o palco, o suporte para os equipamentos cênicos da trama que se desenvolve no espetáculo. Como define Cyro del Nero: "Firme madeiramento, em forma de grade, que sustenta todas as manobras cenográficas, no qual se fixam roldanas, gornes, etc." (del NERO, 2009, p.354)
69 Dupavillon, in L'Architecture d'Aujoud'hui, 199, 1978, p.1. A publicação apresenta um panorama preciso do final da década de 1970, com depoimentos de importantes dramaturgos, como Dario Fo; grande parte dos projetos apresentados são de ocupação e conversão de edifícios existentes. 
Os lugares são mais fortes que as pessoas, o cenário mais forte que o acontecimento. Essa possibilidade de permanência é que faz a paisagem ou as coisas construídas superiores às pessoas

(ROSSI, APUD MONTANER, 2007, P. 139).

Quando a arquitetura no século XVI trouxe para o interior do edifício teatral o cenário da cidade renascentista, trouxe para o imaginário da dramaturgia a nova natureza urbana que se formara. Até então eram os espaços públicos os locais escolhidos para tais manifestações artísticas, pelo seu caráter transitório, diversificado e dinâmico. Em cortejos, paradas e festivais, a dramaturgia lançava mão das situações urbanas em formação para a construção do seu imaginário. A perspectiva de Leon Baptista Alberti se torna cenário permanente, seguindo a tendência observada nas pinturas de Pietro della Francesca, nos esboços de Peruzzi e nos tratados de Serlio. ${ }^{70}$

Para Lewis Munford, a nova perspectiva espacial da cidade barroca se manifestou antes nos cenários: "um telão de fundo para o poder absoluto". (PEVSNER, 1979, p. 75) 71

A proibição das representações no espaço público se deu a partir de 1574 com a Carte de Commédiens ${ }^{72}$, o que

70 Baldassare Peruzzi, Prospecttiva Scenica na Galleria degli Uffizi, e Sebastiano Serlio, seu colaborador. Ver SUMMERSON, 1982, p. 12-17; LIMA, 2010, p. 26-30. 71 Ver também MUMFORD, 1982, p. 410

72 Carte des Commédiens: documento que proibiu espetáculos de rua dentro do perímetro das muralhas de Londres.

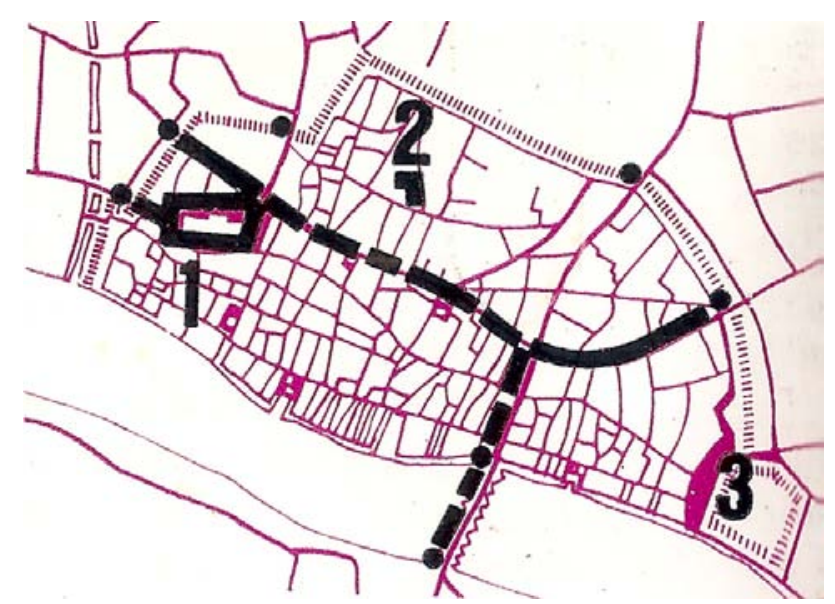

Lugares e ruas de espetáculos. Londres antes de 1574.

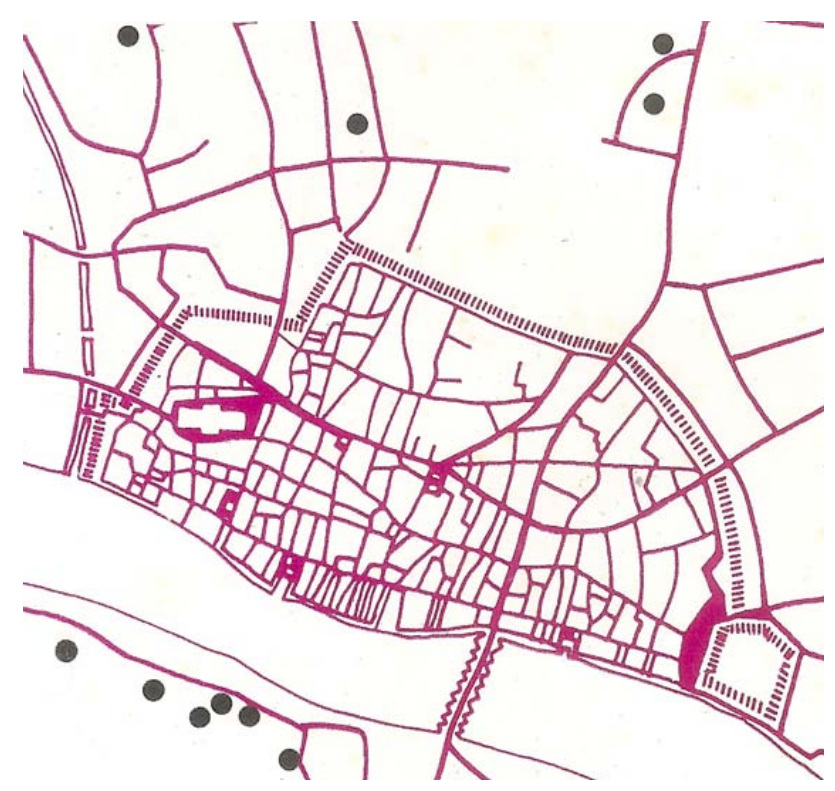

Teatros em Londres após 1554. Fonte: L’Architecture d'Aujourd'hui n.152, 1970 
levou os grupos teatrais a se aliarem a mecenas e entrar nos palácios.

Em seguida, os espetáculos ganharam os salões dos palácios, e se firmaram como espaços especializados - primeiramente - e em edifícios independentes a partir do século XVIII, assumindo autonomia e em muitos momentos monumentalidade:

Os teatros, em especial, constituíram-se em elemento indispensável, e durante o Setecentos refinou-se a forma da sala - semi círculo, sino, ferradura - para obter a melhor acústica. Novos teatros foram construídos tanto nas pequenas como nas grandes cidades e as salas no século precedente perderam logo seu lugar pois estes caracterizavam-se também pelo exterior, como monumento urbano (CURCIO, 2008, p. 89$)^{73}$.

A partir desse momento a arquitetura do espetáculo

73 Nossa tradução do texto original: I teatri, in particolare, costituisco un elemento ormai irrinunciabile e durante il Settecento si affinano le ricerche sulla forma della sala - a semicerchio, a campana, a ferro di cavallo - per ottenere I'acustica migliore. Nuovi teatri si costruiscono sia nelle grandi che nelle piccole città e le sale del secolo precedente lasciano presto il posto a edifici che si caratterizzano anche l'esterno quali monumenti urbani.

A autora destaca as seguintes obras desse período: San Carlo di Napoli (A. Medrano e A. Carasale, 1737-38), o Grande Teatro de Lyon (J.-G. Souflot, 1754-56) a Comédie Française em Paris (M.-J. Peyre e C. de Wally, de 1770), o Grande Teatro de Bordeaux (V. Louis, de 1772), o Scala de Milão (G. Piermarini, 1776-78), o Teatro do Hermitage de São Petersburgo (G. Quarenghi, 1786-87), o La Fenice de Veneza (G.A. Selva, 1787-90). Podemos acrescentar ainda como significativo

- Théâtre de Besançon, de Claude-Nicolas Ledoux, 1778-1784.

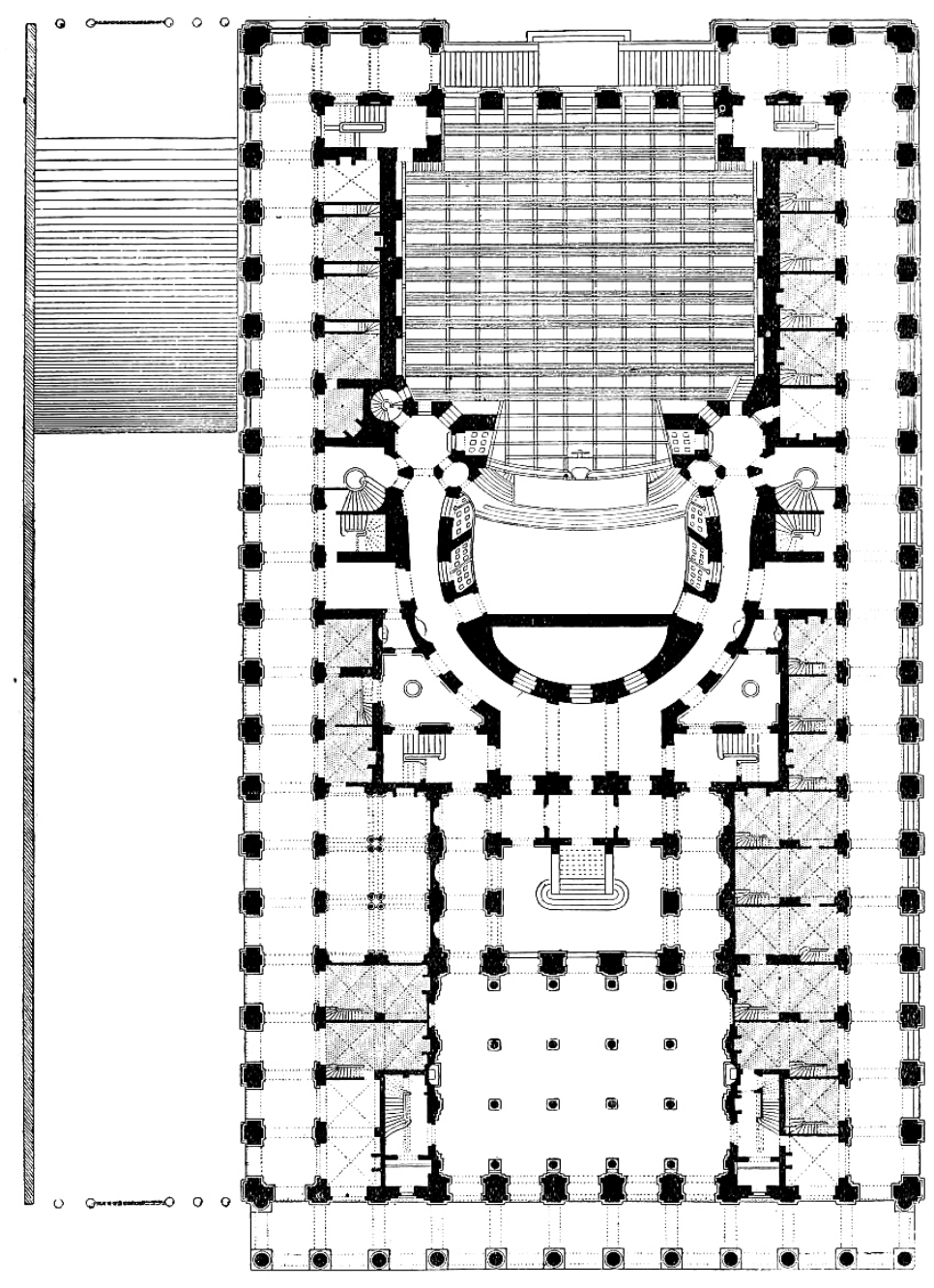

Grand Théâtre de Bordeaux. Fonte: www.archmaps.tublr.com 
assume na cidade valor de equipamento urbano que adquire distinção, significado, revelando-se como monumento, tornando-se obrigatório.

Na trama social, o teatro tem seu papel regulador, na trama urbana um papel de prestígio. A palavra evoca o edifício. Ele é edifício antes de ser instituição. Uma cidade sem teatro parece uma cidade sem glória.

(CHEREAU, in L'Architecture d'Aujourd'hui 152/1970, p. 2) ${ }^{74}$

Ocorre que, desse momento até o panorama atual, houve um intenso debate e questionamento sobre a validade da arquitetura do espetáculo até a própria função do espetáculo na sociedade. 0 que assistimos hoje é parte significativa dos temas que vêm sendo discutidos mesmo antes do Movimento Moderno. ${ }^{75}$

Esse debate vem gerando situações concretas relacionadas à arquitetura do espetáculo, situações essas fruto da realização de projetos significativos dentro da produção

74 Nossa tradução do texto original: Dans la trame sociale, le théâtre tient son rôle de régularisateur, dans la trame urbaine un rôle de prestige.

75 Há autores, como Ricardo Marques de Azevedo, que consideram em seu trabalho a Modernidade desde o séc. XVIII. Ver Antigos Modernos e também Metrópole: Abstração, 2006

Keneth Franpton é outro autor que dedica ao tema a primeira parte de sua História Crítica da Arquitetura Moderna: Evoluções Culturais e Técnicas Predisponentes, 1750-1939, 1997 arquitetônica contemporânea e de realizações espontâneas empreendidas por grupos teatrais que se apropriaram de edifícios e de espaços da cidade, transformando-os em cenários de suas realizações. Haveria, segundo esses últimos, uma incompreensão por parte dos arquitetos na concepção dos edifícios para o espetáculo. Segundo Pedro Pederneiras, diretor técnico do Grupo Corpo ${ }^{76}$, "O problema está no nascedouro, nossa principal deficiência é a forma de pensar os teatros. 0 erro acontece desde a hora de conceber o projeto." (apud Menezes, M. Eugênia - Jornal O Estado de São Paulo, 02/03/11).

Outras manifestações com conteúdos semelhantes são frequentes na tentativa dos produtores em justificar as dificuldades na realização de espetáculos que poderiam ir além da exploração da tradicional perspectiva frontal. Mas isso não nos parece suficiente para justificar a ocupação de edifícios concebidos para outros usos, ou mesmo territórios da cidade onde a infraestrutura urbana impera. Por que a procura do cenário urbano?

76 Grupo Corpo: companhia de dança sediada em Belo Horizonte desde 1975; define sua identidade artística como a combinação da técnica clássica com uma releitura contemporânea de movimentos extraídos dos bailados populares brasileiros; desde 1981 tendo como diretor artístico Rodrigo Pederneiras, o Grupo produz espetáculos em estreita colaboração com compositores da música popular brasileira, como João Bosco, Tom Zé, Arnaldo Antunes e Lenine. 
Como afirma a professora Sílvia Fernandes:

Refazendo o percurso do Teatro da Vertigem ${ }^{77}$ por São Paulo, é possível perceber claramente esse projeto de sociometria, que passa pela ocupação do lugar público. Na economia simbólica de uma cidade violenta como a nossa, descontínua, sem coerência estrutural nem marcos efetivos de localização, a trajetória do grupo é quase uma inversão da geografia urbana, na medida em que invade espaços coletivos para reativá-los por meio do trabalho do teatro. (FERNANDES, 2010, p. 67).

Não podemos afirmar que foi a arquitetura que se distanciou das iniciativas mais vigorosas do teatro de grupo, consideradas como as mais ativas na cena contemporânea, ou ainda que os grandes encenadores teatrais neguem o Teatro como lugar apropriado para suas incursões revolucionárias, como foi observado pela professora Evelin Werneck Lima:

Peter Brook ${ }^{78}$ enfatizou em várias ocasiões a falta de alma e a frieza dos teatros contemporâneos, alegando que os atores podem se sentir em melhor

77 Grupo teatral, liderado por Antônio Araújo, que desde os anos de 1990, desenvolve trabalho fora do espaço teatral especializado, se apropriando de edifícios e espaços públicos em que a arquitetura se materializa como cenário real. Ver também BARRETO, 2008.

78 Peter Brook, encenador teatral, trabalha desde 1964 com o que denomina $O$ Espaço Vazio, onde o espetáculo é centrado no ator, nos movimentos intuitivos do corpo. Em 1970 fundou o Centro Internacional de Pesquisa Teatral, na Manufacture Gobelins, em Paris; desde 1974 seu grupo tem como sede o Théâtre des Buffes du Nord na mesma cidade. harmonia no palco de um teatro histórico do que numa estrutura moderna. (...) Há quem veja que a especialização do espaço cênico retoma hoje seu lugar, ratificando seu valor como símbolo urbano e seu caráter sagrado característico dos teatros monumentos. (LIMA, 2010, p. 148).

As mesmas dificuldades já foram assinaladas em outros balanços realizados sobre o tema, em que as relações são muito mais fundamentais do que a simples disputa entre seus diversos atores, como é o caso dos argumentos apresentados por Christian Dupavillon:

Os diretores mais talentosos, como Patrice Chéreau, Luca Ronconni ou Peter Stein, demonstraram que a sala dita "à italiana" se mantém instrumento incomparável e que aqueles que a destróem ou minimizam sua importância, são os agentes de um poder que despreza a cultura. Por outro lado, a sala dita "polivalente" não tem mais defensores nem depreciadores. $O$ que falta são utilizadores competentes. Alhures, a cenografia do espetáculo substitui a arquitetura das salas. (...) Fora desses edifícios, há a cidade que desperta. ${ }^{79}$

79 DUPAVILLON, In L'Architecture d'Aujourd'hui, 199, 1978, P.1. Nossa tradução do texto original: Les plus talenteux metteurs en scène, Patrice Chéreau, Luca Ronconni ou Peter Stein, ont démontré que la salle dite "à Italienne," demeure l'outil incomparable et que ceux qui la détruisent ou dégradent son ordonnance sont les agents d'un pouvoir méprisant la culture. La salle dite "polyvalente" n'a, d'autre part, plus de défenseur ou de détracteur. Son problème est le manque d'utilisateurs compétents. Ailleurs, la scénographie des spectacles se substitue à l'architecture des salles; (...) Hors de ces bâtiments, il y a la ville qui s'éveille. 
Ou ainda, o depoimento de Ariane Mnouchkine, recolhido por Gaelle Breton, também revelador de um sentimento que fundamenta a evolução de seu pensamento sobre o assunto, dentro de sua trajetória intensa e duradoura:

Inicialmente, o lugar teatral deve ser um vazio inspirador - inspirador para os atores, para os diretores e também para o público. ${ }^{80}$ (BRETON, 1989, p. 16)

E mais adiante:

La Cartoucherie ${ }^{81}$ é o inverso da caixa preta, essa famosa caixa técnica polivalente, mas na realidade plena de proibições. Há alguns anos os diretores diziam: - "Nos deem um espaço neutro que agente se vira!" Eu não estou certa de que hoje eles ainda diriam isSo. ${ }^{82}$ (BRETON 1989, p.17)

Em recentes declarações o dramaturgo Anthony

80 Nossa Tradução. Texto original: Au départ, le lieu théâtral doit être un vide inspirant - inspirant pour les acteurs, pour les metteurs en scène, et aussi pour les spectateurs.

81 La Cartoucherie, uma antiga fábrica de munição do exército francês situada a leste de Paris, é desde 1970 a sede do grupo francês Théâtre du Soleil, fundado em 1964 e dirigido por Ariane Mnouchkine.

82 Nossa tradução do texto original: La Cartoucherie, c'est l'inverse des black box, ces fameuses boittes techniques polyvalentes, mais en fait pleines d'interdictions. Il y a quelques années, les metteurs en scène disaient: "Donneznous un espace neutre et on se débrouillera!." Je ne suis pas sûre qu'on dirait
Neilson ${ }^{83}$ considera que o experimentalismo possa ter afastado o público dos espetáculos teatrais. Defensor da renovação da linguagem teatral, Neilson admite que a crise entre público e espetáculo permanece, mesmo depois das tentativas em romper com o passado e com o repertório tradicional do teatro inglês.

Antunes Filho concorda com Neilson, mas acrescenta: 0 teatro estava atrasado, e hoje está mais ainda. Essa calamidade pós dramática insuportável, chata, aborrecida, provou-se que não dá mais." (cf. nota 83 )

Antunes argumenta que a busca incondicional pelo que chamou de "estilhaçamento do drama", daquilo que é primordial, e os excessos do teatro autorreferencial, destruiu o prazer de simplesmente contar uma história, levou-o para um "cenário vazio".

A Virada Cultural em São Paulo é um evento de dimensões metropolitanas que nos últimos anos tem revertido, durante vinte e quatro horas, a tendência de es-

83 Anthony Nielson, dramaturgo e diretor teatral escocês, integrante do grupo In-Yer-Face, e Antunes Filho, diretor de teatro em São Paulo há mais de 60 anos, participaram do Quinto Ciclo do Núcleo de Dramaturgia SESI-British Council; ver Fioratti, G. - Folha de São Paulo, 04/10/2013. 
vaziamento do centro. A Virada se apropria do território urbano, criando espaços públicos de espetáculos, ocupando ruas, praças e viadutos, mas sem nenhuma interação evidente com a arquitetura existente. As ações se caracterizam pela transitoriedade, pela não permanência e, nesse aspecto, não contribuem para que a arquitetura cumpra um papel relevante para o êxito do evento e para que seu valor seja integrado à construção desse cenário cultural. Concordamos com Abílio Guerra:

Passear a noite pelo belo centro de São Paulo, sem medos ou receios, é uma sensação inspiradora, que nos coloca diante de uma possibilidade concreta de reconquista das ruas e do centro. (GUERRA, 2011)

Experiências espontâneas na cidade de São Paulo atestam a retomada desse movimento, entre elas a ocupação da região da Praça Roosevelt por grupos teatrais, uma espécie de renascimento daquele espaço urbano; a apropriação dos mais diversos tipos de locais públicos pelo grupo Teatro da Vertigem; as montagens do Teatro do Centro da Terra em túneis do metrô em obras sob o rio Pinheiros; as intervenções dos Parlapatões.

Como afirma Maria Lúcia Puppo:

A busca por modalidades teatrais que possam dar conta das inquietações do homem contemporâneo tem acarretado as contínuas metamorfoses que vêm perpassando a cena ao longo do século XX. (...) A manifestação teatral sai do palco italiano e se instala em locais diversificados e insólitos da cidade - barracões, galpões, ruas, igrejas, hospitais, presídios - de maneira a estabelecer relações de outras naturezas com os espectadores. (PUPPO, 2010 p.01)

O que Puppo analisa do ponto de vista do conteúdo teatral pode ser entendido pela maneira como as cidades e, em particular, as metrópoles se transformaram em ambientes férteis de reflexão criadora ${ }^{84}$. Esse meio ambiente edificado, a cidade, não é mais apenas abrigo mas , nas palavras de Giulio Carlo Argan, "passa à transmissão de conteúdos urbanos”(Argan, 1998, p. 235). “A cidade favorece a arte, é a

84 Ver AZEVEDO, Ricardo Marques de - Metrópole: Abstração. São Paulo, Perspectiva, 2006. 
própria arte"(Munford, apud Argan, 1998, p.73).

As discussões recentes sobre a reconquista dos centros urbanos e, dentro desse universo, do centro da cidade de São Paulo, demonstram a urgência de estratégias de intervenção e de metodologias de projetos que venham se somar às iniciativas coletivas na ocupação de importantes áreas de nosso patrimônio urbano.

Dentro desse panorama, fica claro que, além de toda a infraestrutura instalada que o centro possui, da necessidade já tão estudada de moradia fixa nessas áreas, e dos grandes equipamentos culturais implantados nos últimos anos ou em vias de implantação, há que se pensar em intervenções passíveis de consolidar tais tendências.

\section{Ainda segundo Puppo:}

A relação com o público escapa assim do mero consumo; ampliam-se e diversificam-se os circuitos de produção e recepção teatral (...). o processo criativo não se resume mais à montagem (...) $O$ teatro transborda de suas margens até aqui consagradas: a reflexão sobre o processo de criação, a realização de oficinas, encontros, ensaios abertos, intervenções nos ambientes urbanos ampliam a envergadura daquilo que a cena dá a conhecer. (PUPPO, 2010, p. 2,3)

Os grupos teatrais que se instalaram nos últimos anos nos centros urbanos buscam agora a natureza urbana pós-industrial, assim definida por Carlos M. Teixeira:

A paisagem das grandes cidades é composta por muitos elementos residuais: terrenos baldios, vazios ociosos, lacunas ilhadas; áreas subutilizadas esperando ser ativadas, reservatórios de oportunidades abertos às pressões das demandas cívicas e sociais. (TEIXEIRA, 2001, apud BARRETO, 2008)

Os edifícios não mais abrigam as funções para as quais foram concebidos. Está nessa ausência um dos ingredientes fundamentais para tais apropriações, sendo o que Ariane Mnouchkine chama de lieux trouvés ${ }^{85}$. Ela desenvolve seu raciocínio afirmando que esse lugar não deve ser simplesmente receptivo, acolhedor, o que é essencial mas

85 Lugar encontrado, lugar revelado, no sentido de descoberta, de colocar em evidência valores não evidentes. 
não suficiente. E concluí: "Há lugares magníficos mas tão completos que não têm necessidade de abrigar um teatro" (MNOUCHKINE apud BRETON, 1989, p. 16).

Por que a Arquitetura desprovida de seu uso primordial desperta então esse fascínio? Estaríamos diante da busca de seus valores essenciais, da expressão de suas regras construtivas, do seu conteúdo compositivo? Se a princípio o espaço deve ser o vazio para motivar diretores e atores, como um edifício qualquer pode ser mais inspirador do que um teatro? São respostas a perguntas como essas que contribuirão para a compreensão de nosso tema de pesquisa. 
Da mesma forma, precisamos aprender a ver as formas ocultas na vasta extensão de nossas cidades. (LYNCH, 2011, p. 14)

Uma forma de responder às perguntas feitas na página 161 seria considerar que a experiência contemplativa é tão fundamental quanto a atitude ativa, pois o valor estético da arquitetura pode ser preservado mesmo quando seu valor funcional acaba (ver ARGAN, 1998, p. 229).

Não nos referimos apenas ao patrimônio construído que assumiu sentido histórico, muito mais próximo do simbólico, do monumental. A esse reservamos um espaço específico nesse trabalho, que inclui o patrimônio edificado da metrópole moderna, com todas as suas conhecidas dificuldades. Tais dificuldades, decorrentes em certa medida pelo crescimento descontrolado, vêm gerando extenso território marcado pela transformação, pelo abandono e pela descaracterização desse patrimônio, como ocorreu com maior intensidade nos centros urbanos. 
Na realidade, a arquitetura autêntica deveria ser sempre reversível, já que sua identidade formal é precisamente o que fica quando se prescinde do seu destino específico: dita identidade se baseia no uso mas, por sua vez, o transcende, na medida em que o edifício está ordenado de acordo com uma estrutura autônoma e consistente.

(PIÑON, 2006, p. 180)

Por meio do caminho que apontamos podemos encontrar uma grande diversidade de experiências na história em que o fenômeno se deu curiosamente no sentido inverso. Por qualidades semelhantes a que se refere Helio Piñon, o Teatro de Marcellus em Roma, construído no séc. I A.C., tornou-se um exemplo conhecido, assim como a Arena Romana de Lucca, lugares do espetáculo por concepção, ocupados como edifícios habitacionais após a queda do Império Romano. Para Aldo Rossi esse fato não se deve apenas por questões econômicas ou psicológicas. É necessário considerar que além de um bem essas edificações se tornaram uma referência. ${ }^{86}$

O processo que descrevemos no início desse capí-

86 ROSSI, A. 2001, p. 132. Ver também HERTZBERGER, Herman - Lições de Arquitetura, São Paulo, Martins Fontes, 1999. Hertzberger mostra como a forma arquitetônica e a forma urbana oferecem novas oportunidades de interpretação, assumindo funções variadas e numerosas aparências, permanecendo fundamentalmente a mesma.

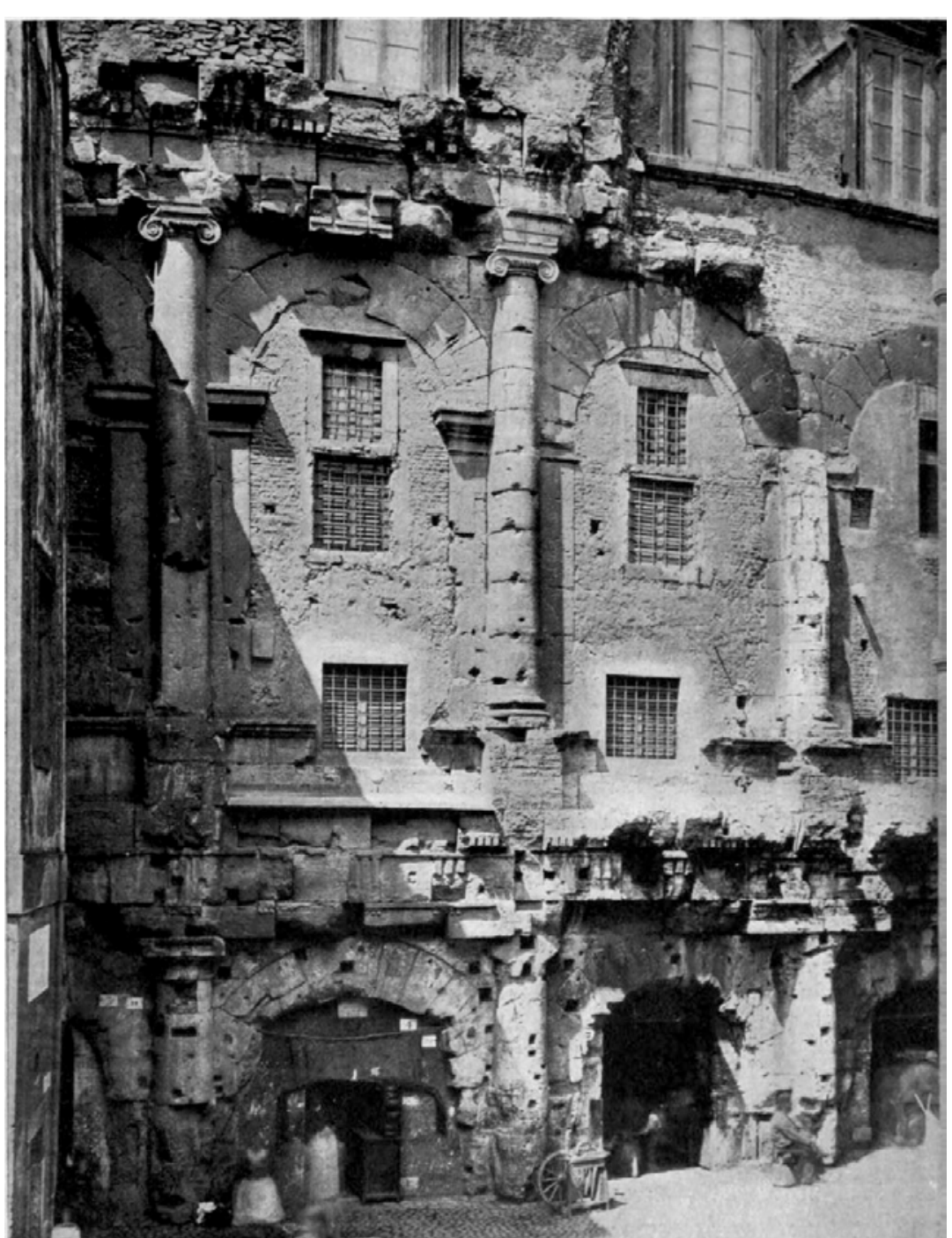

Teatro de Marcellus - Roma. Fonte: CHOAY, 2006 
tulo ocorre há um certo tempo, e foi intensificado desde a década de 1960. Em um primeiro momento é a ocupação de edifícios que perderam sua função primordial. E, posteriormente, é a própria cidade assumindo o papel de protagonista nesse movimento ${ }^{87}$.

Isso pode ser compreendido pela ampliação, para a escala da cidade, do processo de apropriação desse patrimônio. A necessidade da experiência, como componente essencial do espetáculo, vai de encontro à disponibilidade de espaços em mutação dinâmica.

A avaliação de Françoise Choay sobre o uso do Patrimônio Histórico na Era da Indústria Cultural é extremamente útil para compreender parte significativa desse processo.

É verdade que existem edifícios que, valendo-se do sublime, se impõem de forma imediata. Mas essa situação é rara. A arquitetura é a única das artes maiores, cujo uso faz parte de sua essência e mantém uma relação complexa com suas finalidades estética e simbólica, mais difícil de apreender no caso dos edifícios históricos que se tornaram órfãos da destinação prática que lhes deu origem. (CHOAY, 2006, p. 230-231)

87 Ver L'Architecture d'Aujourd'hui n. 152, 1970. A publicação traz diversas experiências de grupos teatrais que ganharam os espaços públicos; ver também BARRETO, G. A cidade como cena para os grupos teatrais: o caso do grupo Galpão, do grupo Armatrux e do teatro da Vertigem, São Paulo, Mestrado, FAUUSP, 2008.
Suas preocupações são dirigidas muito mais para as experiências institucionais ${ }^{88}$, o que podemos considerar como a Espetacularização do Patrimônio, usando as considerações de nossa introdução, o que a aproxima das contribuições que essa pesquisa busca. Entretanto, não se trata aqui da cidade histórica a que ela se refere, convertida em cenário, iluminada, maquiada para receber festivais de arte, comemorações ou falsos happenings, como afirma a autora e essa compreensão nos será útil no capítulo em que as obras de reconversão serão apresentadas .

É, no entanto, na sequência de seu raciocínio que a autora traz uma reflexão importante, parafraseando Eupa$\operatorname{linos}^{89}$ e afirmando ser o ato de percorrer fisicamente a arquitetura fundamental para a compreensão da obra. Nesse sentido introduz um componente próprio da modernidade: o movimento. Se admitimos que o teatro como espetáculo nasceu dos cortejos religiosos, o ato de percorrer e a mobilidade estão em sua gênese, são atitudes reveladoras de sua essência. Por essa visão, a arquitetura se aproxima ou se confunde com o próprio espetáculo.

88 A autora analisa com precisão como as várias estratégias institucionais de preservação, revitalização e de recuperação, entre outras, colocadas intensamente em prática nas últimas décadas, vêm prejudicando de maneira significativa a qualidade das obras e dos espaços urbanos. Ver CHOAY, Françoise - Alegoria do Patrimônio, 2006, p. 205

89 VALERY, Paul - Eupalinos ou o Arquiteto, 2006 
Colin Rowe faz uso do percurso para demonstrar uma das características da arquitetura moderna estudada por ele: a Transparência Fenomenal ${ }^{90}$. Ao avaliar o projeto do Palácio da Liga das Nações de Le Corbusier, de 1927, descreve o caminho que seria percorrido pelo observador, caso a obra tivesse sido construída. Através dessa descrição, o autor apresenta a diversidade de situações específicas que vão sendo percebidas, construídas, durante o percurso da obra, que transcende a relação axial do pavilhão do auditório, mais evidente, fazendo surgir uma projeção de volumes e planos dos blocos de escritórios:

Um fenda, um deslocamento lateral se produzem alinhados ao eixo menor; e, enquanto figura, se vê repetidamente rotacionada e decomposta em uma série de referências laterais - pelas árvores, a circulação, pelo ímpeto dos próprios edifícios de tal modo que, finalmente, devido a uma série de implicações positivas e negativas, toda a zona acaba sendo uma espécie de competição monumental, um debate entre um espaço real e profun-

90 Ver artigo Tranparência: Literal e Fenomenal, in: ROWE, Colin - Maneirismo y Arquitectura Moderna y otros Ensayos, Barcelona, Gustavo Gili, 1999, p. 155. do e entre um espaço ideal e superficial.

(ROWE, 1999, p. 167) ${ }^{91}$

Vimos então que, para a arquitetura e para o espetáculo, percorrer é uma forma essencial de conhecer, de ver, de assistir. A mobilidade é valiosa para a Modernidade. Não exclusivamente a mobilidade da obra mas também a do espectador.

91 Nossa tradução do texto original: Una hendidura, una dislocación y un corrimiento lateral se producen a lo largo de la línea del eje menor; y, en cuanto figura, se ve repetidamente rota y descompuesta en una serie de referencias laterales - por los árboles, la circulación, por el ímpetu de los edificios - de tal modo que, finalmente, debido a una serie de implicaciones positivas y negativas, toda la zona acaba siendo una especie de monumental contienda, un debate entre un espacio real y profundo y un espacio ideal y superficial. 


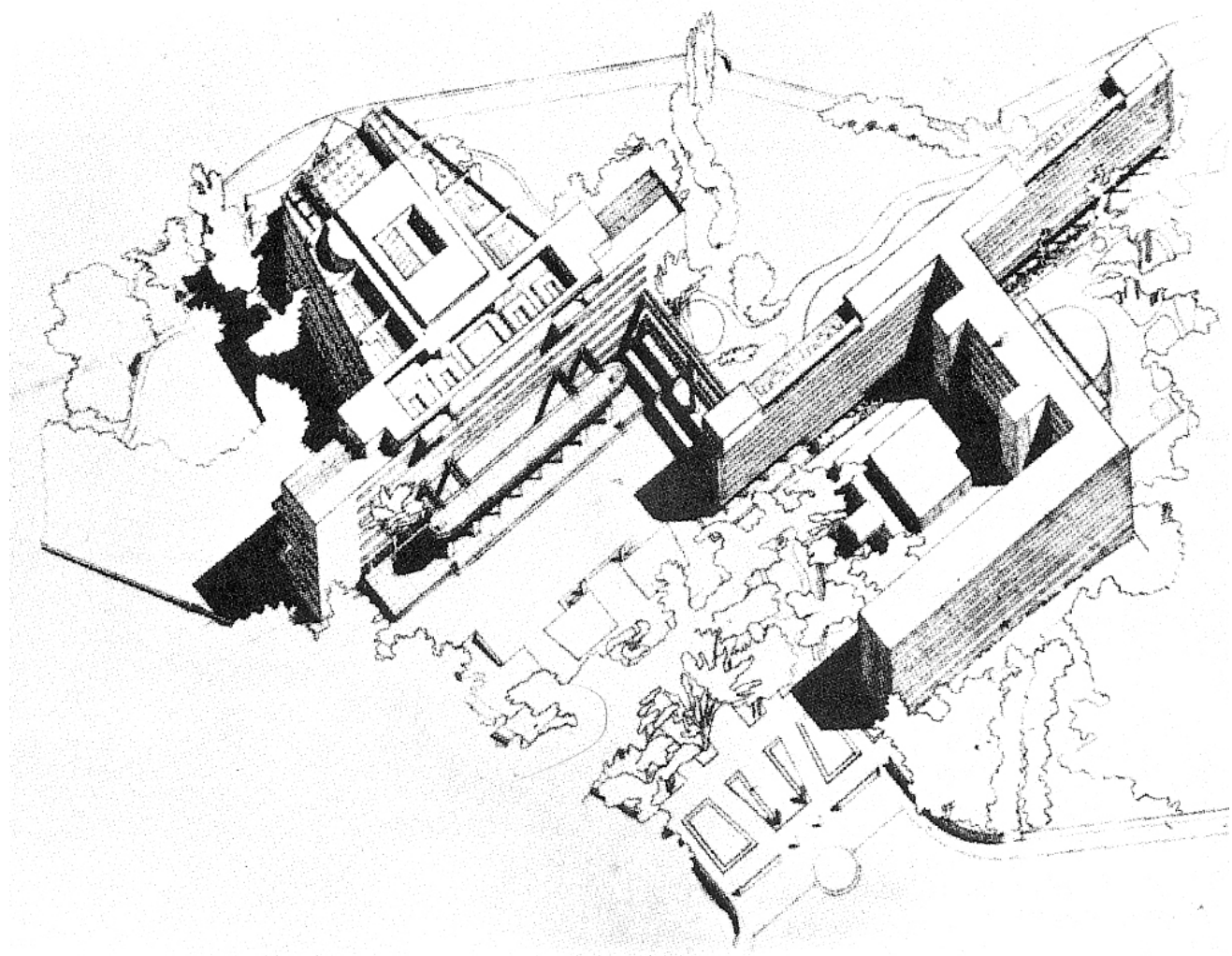

Perspectiva. Palácio da Liga das Nações, 1927 - Le Corbusier Fonte: ROWE, 1999

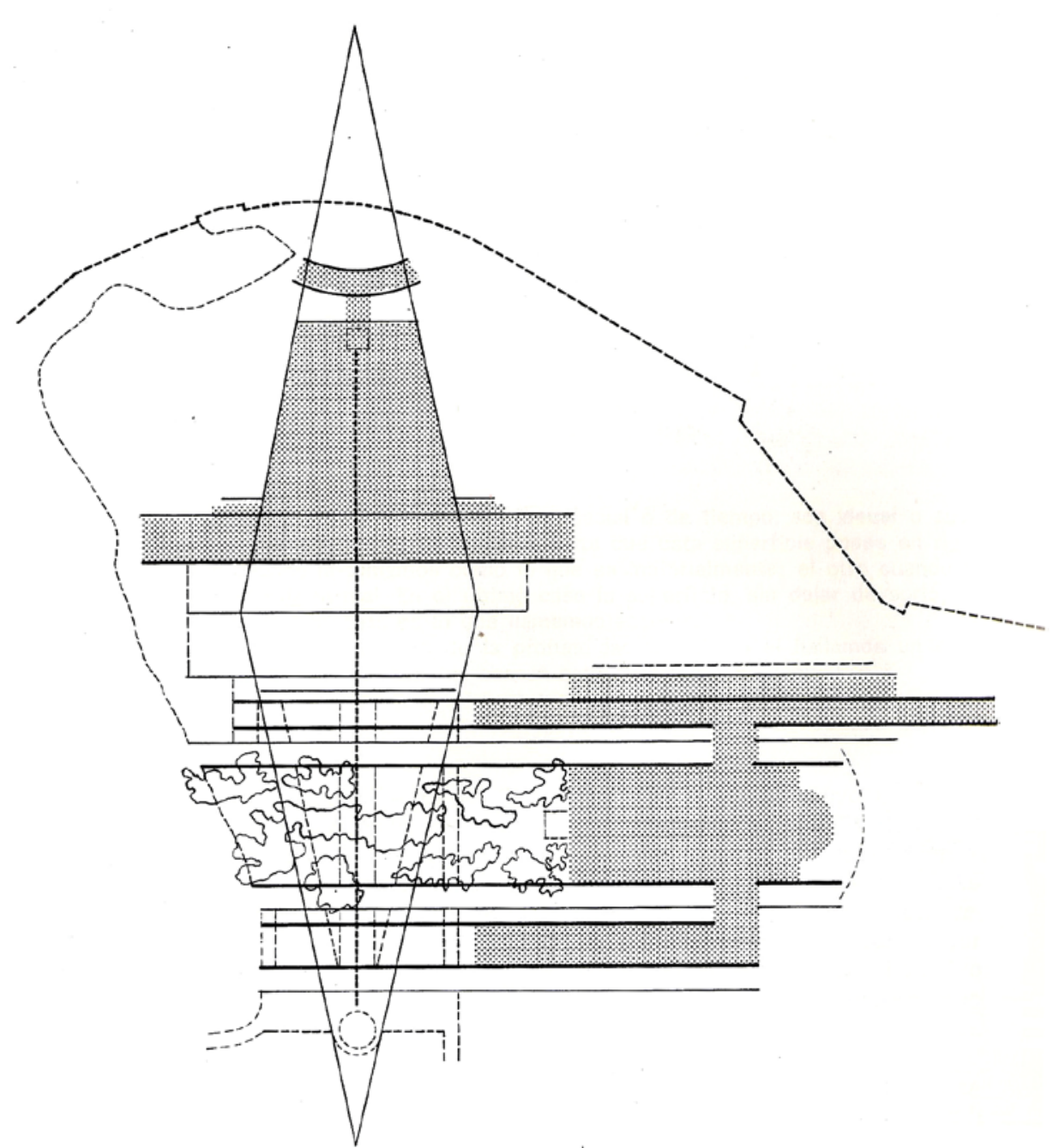

Diagrama sem escala 
(...) não sou por certo o único a reconhecer no atual renascimento do teatro de grupo o fato cultural público mais significativo hoje em São Paulo.

(PAULO ARANTES, 2007)

Em primeiro lugar podemos considerar a mobilidade do espectador perante a obra, perante a arquitetura, perante a cidade.

O espetáculo "Bom Retiro 958 metros", do Teatro da Vertigem, realizado em 2013, recorre a esse procedimento para desenvolver sua dramaturgia baseada na vida cotidiana de um bairro tradicional da cidade de São Paulo, marcado por sua formação essencialmente de imigrantes. A ação é desenvolvida ao longo de um itinerário de 958 metros em que atores e público se misturam à realidade, participando de situações criadas a partir do cotidiano dos moradores e trabalhadores do bairro.

É importante notar que a metrópole que recebe a ação e que a inspira não é a cidade monumento, patrimonial, a que se refere Françoise Choay. É da realidade da metrópole genérica que o grupo extrai seu conteúdo, após 
um longo trabalho de vivência e de compreensão do bairro. Como afirma Silvia Fernandes, é o Teatro Performativo do Real, que reconhece as tensões entre realidade e ficção e cujo objetivo maior são os processos, a dinâmica da transformação e a experiência ${ }^{92}$. Mas não se trata de importar a estética dos lugares comuns. Mais do que isso, os lugares existem por si e o trabalho da obra teatral parece construir uma nova realidade que ali está, ou seja, aproxima a cena-ação, do cenário-arquitetura, cidade. Como explica a autora:

Em parte, o convívio intenso que se conquista na cena-travessia das ruas e dos espaços públicos do Bom Retiro decorre da prática de derivas, de inspiração situacionista, usadas como dispositivo de intervenção urbana. (FERNANDES, 2013, p. 415) ${ }^{93}$

0 que é percebido é a intenção de inserir o percurso e a mobilidade, mas não como estratégia evolutiva da ação perante a cidade. A imersão em que é colocado o espectador está mais vinculada à compreensão da gênese do espetáculo, do processo criativo que desvenda a estrutura do espaço urbano, à essência do Bom Retiro, que é personagem.

92 FERNANDES, S. 2013. A autora sustenta que para a compreensão dos processos construtivos e da cena híbrida do final do século XX e início do XXI são necessárias as noções de performatividade, teatro performático e teatro do real.

93 Conforme nota da autora, "os membros do grupo defendem as derivas como práticas de psicogeografia, afirmando que as perambulações ao acaso pela cidade estimulariam reinterpretações do espaço com base na experiência vivida».
Aí está o olhar de um flâneur, cujo modo de vida dissimula, atrás de uma miragem benéfica, a angústia dos futuros habitantes de nossas metrópoles. (BENJAMIN, 2004, p. 31) ${ }^{94}$

Parte da crítica ao idealismo da arquitetura Moderna na década de 1950 esteve ancorada na compreensão dessa cidade espontânea e na riqueza de situações espaciais que ela apresenta, que deve ser descoberta, percorrida, como é o caso do Team $X^{95}$. A atitude presente nos projetos de Georges Candilis e Shadrach Wood, por exemplo, demonstra forte respeito à diversidade cultural dessa cidade genérica para a construção de suas estruturas urbanas:

O Homem pode identificar-se de imediato com seu próprio lar, mas não se identifica facilmente com a cidade em que está situado. "Pertencer" é uma necessidade emocional básica - suas associações são da ordem mais simples. Do "pertencer" - identidade - provém o sentido enriquecedor da urbanidade. (TEAM X, apud Frampton, 2003, p. 330) [destaques do autor]

Suas estruturas, quase sempre malhas sobre as

94 Nossa tradução do texto original: C'est là le regard d'un flâneur, dont le genre de vie dissimule derrière un mirage bienfaisant la détresse des habitants futurs de nos métropoles.

95 Ver JOEDICKE, Jürgen - Candilis-Josic-Woods. 1968. Ver também BARONE, Ana Cláudia Castilho. Team 10 Arquitetura como Crítica, 2004. 
quais vão se articulando os fluxos, as funções, reservando espaço para o livre crescimento dentro de parâmetros estabelecidos, foram exaustivamente estudadas e aplicadas por integrantes do grupo em diversas escalas urbanas.

Ao observarmos obras realizadas, como por exemplo a Universidade Livre de Berlin ou a Universidade de Toulouse Le Mirail ${ }^{96}$, podemos notar claramente a distribuição aparentemente aleatória mas articulada das funções, alternadas com os vazios, estruturadas por ruas internas, sem uma aparente hierarquia. Há sempre presente uma estrutura formal baseada fundamentalmente na infraestrutura e na circulação, um senso de construção sistêmica, que orienta mas não impõe o sentido, dirige mas não restringe o olhar.

É interessante notar a presença de lugares destinados a reuniões de grupos, como auditórios e anfiteatros, de maneira livre. Na proposta de Candilis para Toulouse não há a sinalização que identifique ou que destaque esses lugares de reunião. Como todo o projeto, o valor das edificações dentro desse sistema segue a noção de equivalência.

96 CANDILIS, Georges. Toulouse le Mirail: Gebrut Einer Neuen Stadt, 1975
Otília Arantes reconhece nessa aparente dissimulação uma das formas encontradas para os questionamentos urbanos surgidos após a Segunda Grande Guerra, como aqueles empreendidos pelo Team $\mathrm{X}$ :

Num primeiro instante, no imediato pós-guerra, seja como reação à modernização predatória que se consumava nos Estados Unidos, seja como esforço de recuperação das antigas cidades europeias, igualmente destruídas, só que pela guerra, somados à necessidade de refazer o tecido social através da reativação da memória e dos valores locais visíveis tanto nos monumentos comemorativos quanto na arquitetura vernacular, começaram a surgir novas concepções arquitetônicas $e$ urbanísticas que só aos poucos acabaram se firmando como alternativa (nem sempre definitiva) ao conceito de planificação global, ou de modelos abstratos de reorganização da cidade, tanto quanto ao International Style. (...) Fatos urbanos memoráveis que deveriam propiciar aos moradores de uma mesma cidade a oportunidade de reatar com formas de vida social desativadas, reanimar por esse modo uma vida pública não mais possível em meio ao caos urbano ou às novas cidades, justamente sem alma. [a respeito dos dissidentes do Movimento Moderno, entre os quais o Team X] - (ARANTES, 1998 p. 165) 


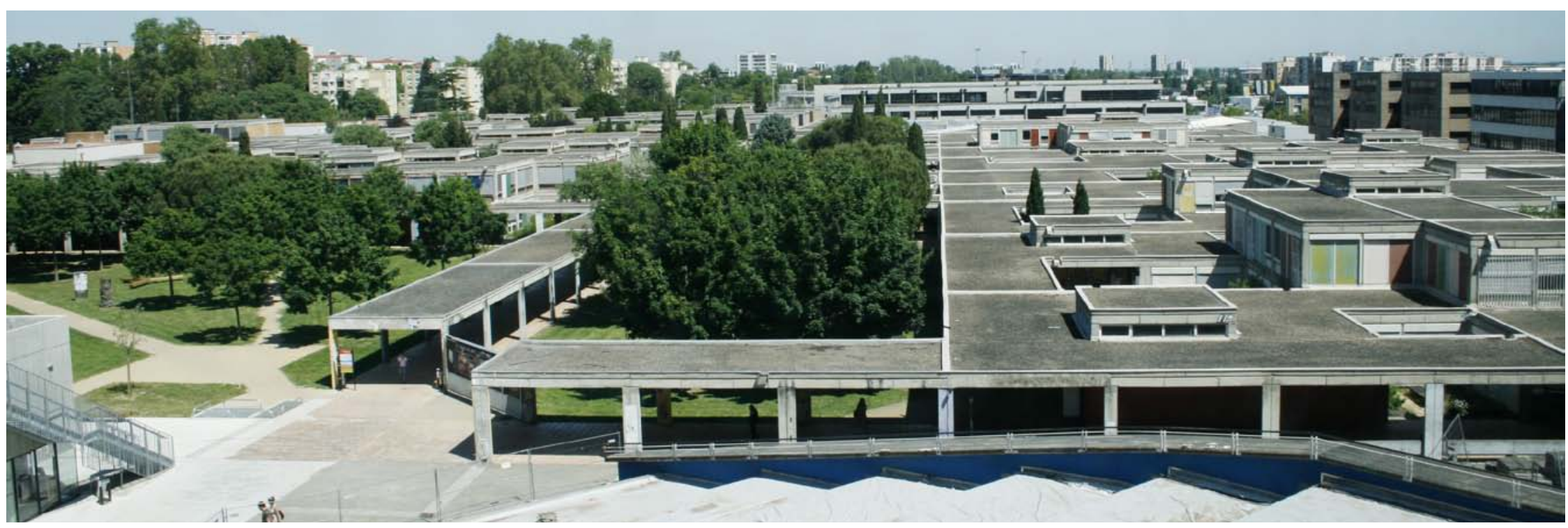

Université Toulouse Le Mirail. Vista aérea. Foto: Valério Pietraróia

O projeto para Toulouse é resolvido por uma rede que interrelaciona as funções promovendo o que seria, na visão dos arquitetos, o intercâmbio do conhecimento dentro de uma universidade moderna. Apesar de Woods não admitir a existência de uma megaestrutura e sim de uma estrutura mínima, a solução se mostrou, após quatro décadas, plena de limites, dificultando o crescimento e as mudanças preconizadas. Na opinião de Keneth Frampton (2003), mais do que a visão arquitetônica do Team $\mathrm{X}$, foi a força da arquitetura como crítica que permaneceu ${ }^{97}$.

97 Ver também FRAMPTON, F. 2003, p. 339. Ver também HERTZBERGER, Herman - Lições de Arquitetura, 1999, p.116.
Estamos diante de uma proposta que compreende a arquitetura e, portanto, a cidade pela valor da experiência, como no espetáculo Bom Retiro 958 metros. Seria como a atual condição de dispersão a que se refere Ignazi de Solà-Morales, citado por Montaner:

(...) opõe-se ao conceito estático de lugar, propondo a noção de lugar como fluxo, como dinamicidade, conjunto de acontecimentos, encontro de energias. (Montaner, 2007, p. 134) ${ }^{98}$

98 Montaner cita o ensaio "Lugar: permanência ou produção» de Solà-Morales 

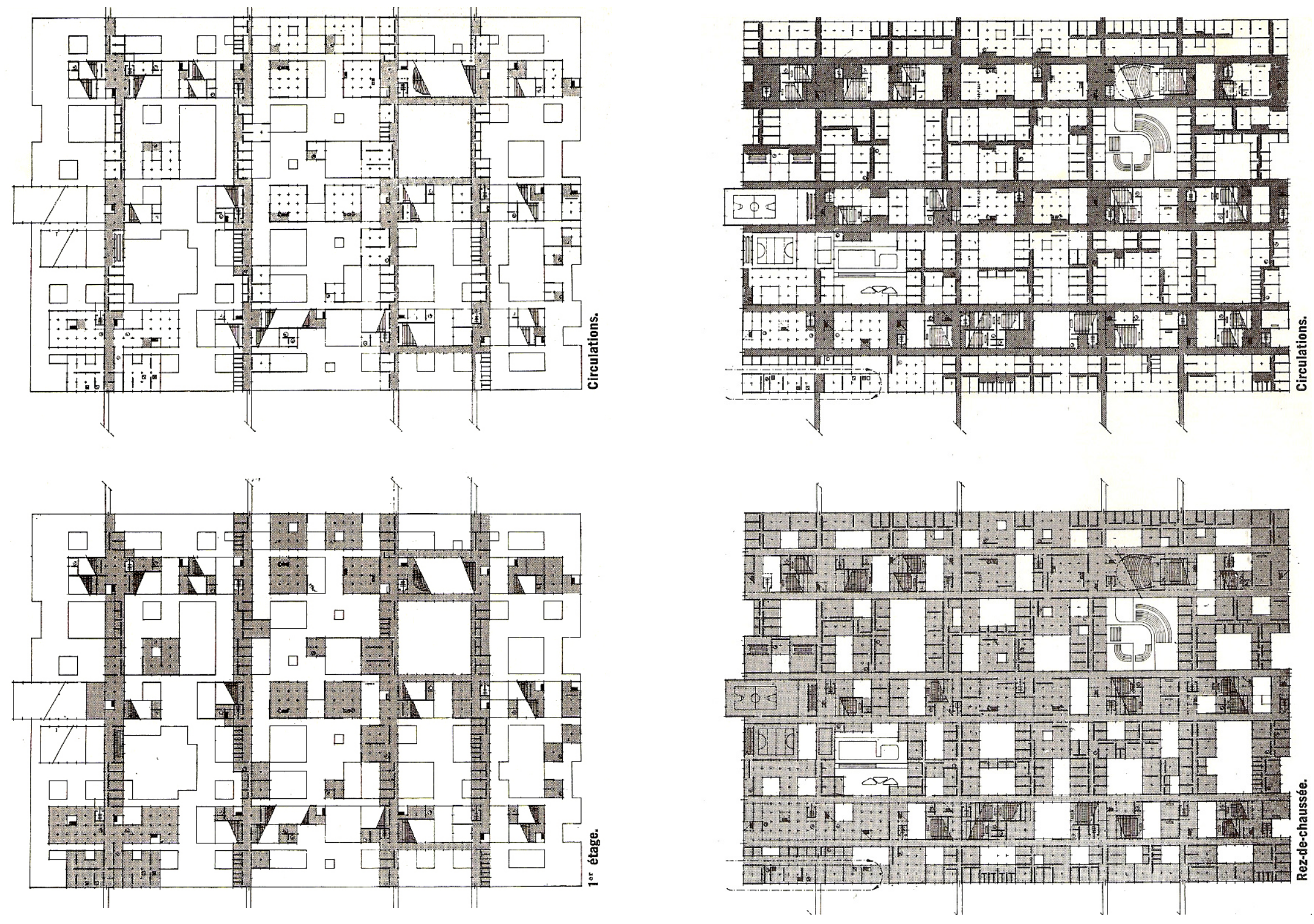

Université Toulouse Le Mirail. Plantas pavimento superior.

Université Toulouse Le Mirail. Plantas pavimento térreo. Fonte: CANDILLIS, 1975

Fonte: CANDILLIS, 1975 


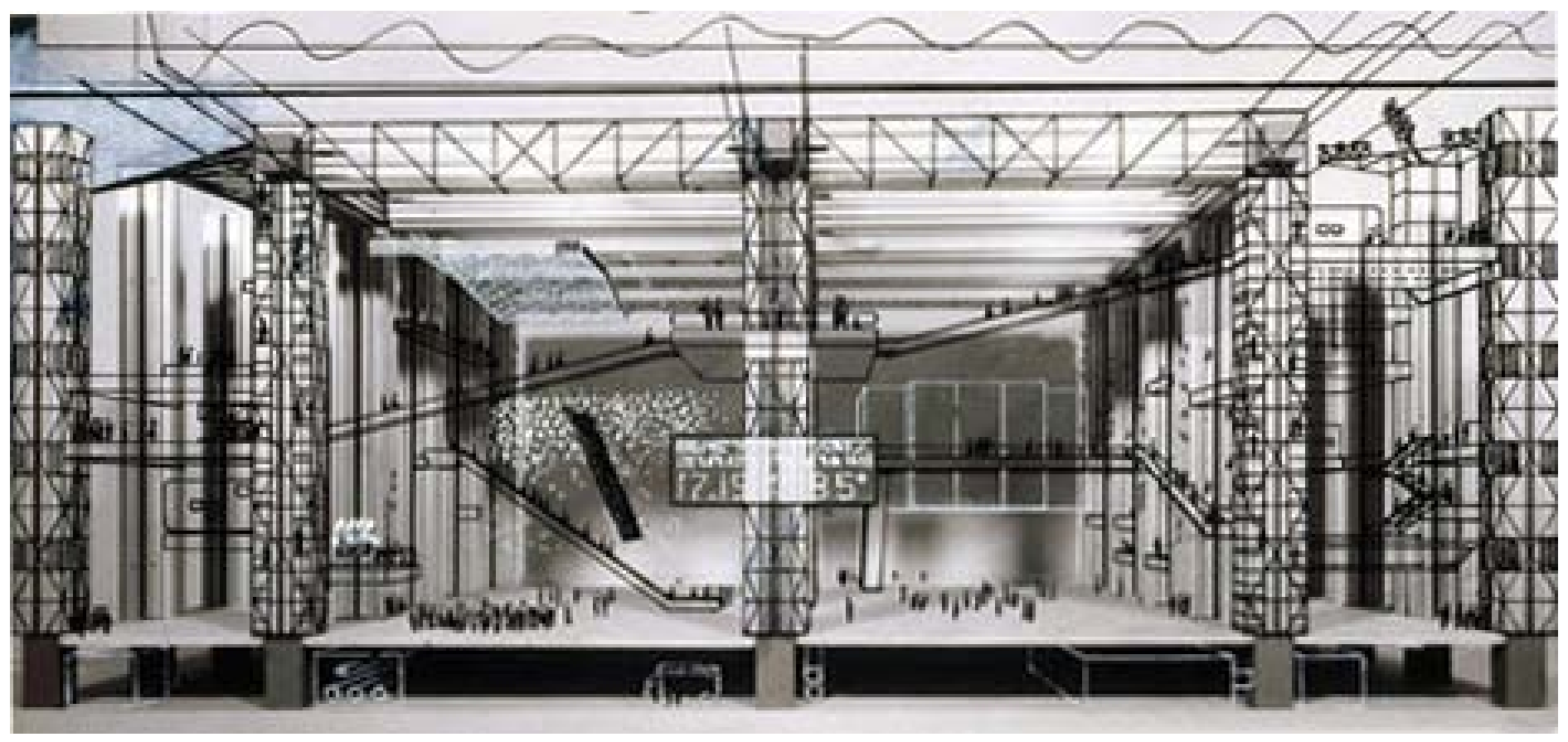

Fun Palace. Fonte: Centre Canadian d'Architecture 
A força crítica da década de 1950, a que nos referimos anteriormente, pode ser observada no projeto de Cedric Price elaborado para a diretora de teatro inglesa Joan Littlewood ${ }^{99}$, do Theatre Workshop, em 1961. Para Littlewood, haveria a necessidade de um laboratório do espetáculo, do "divertimento", preparado para a prática da música, dança, drama e artes circenses.

0 projeto é a força da tecnologia expressa em sua totalidade. Apesar de não construído, mesmo com as inúmeras tentativas fracassadas de Price em obter a autorização municipal ${ }^{100}$, o Fun Palace foi referência para inúmeras obras realizadas na década seguinte.

Se o urdimento é fundamental para estruturar todos os recursos cênicos da caixa de palco desde o Renascimento, para Cedric Price a tecnologia é a resposta para concretizar seu conglomerado efêmero destinado a espetáculos variados, "operando como uma plataforma, livre”, conforme

Fun Palace suas palavras.

99 Joan Maud Littlewood, diretora teatral, criou em 1945 o Theatre Workshop, instalado desde 1953 no Theatre Royal em Stratford, Londres; baseou-se na aproximação entre espectadores e atores como uma forma de vivência do espetáculo.

100 Versões simplificadas foram apresentadas ao poder público até 1970, sem sucesso. 
Os sistemas estruturais e mecânicos definem o projeto. A grelha de treliças metálicas é o sistema fixo que recebe todos os outros, que são móveis ou concebidos por unidades modulares pré-fabricadas, como o teatro suspenso, o cinema, as salas para workshops, o restaurante, o que facilitaria sua montagem e desmontagem, permitindo a modificação de sua configuração. Toda a infraestrutura necessária para o funcionamento desse megaequipamento está posicionada e distribuída através do sistema estrutural.

Como pode ser observado, a total dependência a esses sistemas é vista pelo arquiteto como um manifesto, uma resposta aos questionamentos à arquitetura estabelecida naquele momento. Para ele o uso correto da tecnologia poderia permitir ao público completo domínio sobre aquele ambiente, o que concorreria para o bom desempenho da edificação.

Podemos verificar que o projeto do Fun Palace encerra muitas das aspirações dos realizadores das vanguardas teatrais da década de 1920 em sua plenitude. Não é somente o palco e a plateia que são transformáveis. Todo o

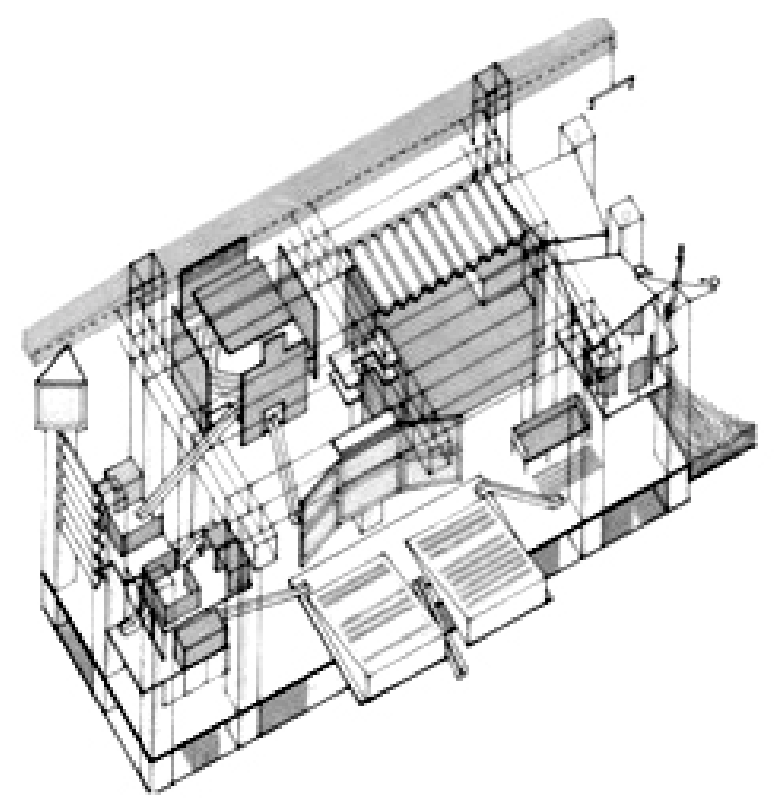

Perspectiva. Fonte: Centre Canadien d'Architecture

edifício se transforma, se reinventa. 0 urdimento de Price é mais do que o complemento necessário para as possibilidades de um Teatro Total ${ }^{101}$, como propusera Gropius para o teatro de Erwin Piscator. Ele não se limita a integrar a arquitetura da sala, pois ele é a própria arquitetura.

Price estudou exaustivamente o programa do seu centro do espetáculos. Fazendo-se valer de diagramas, grá- 


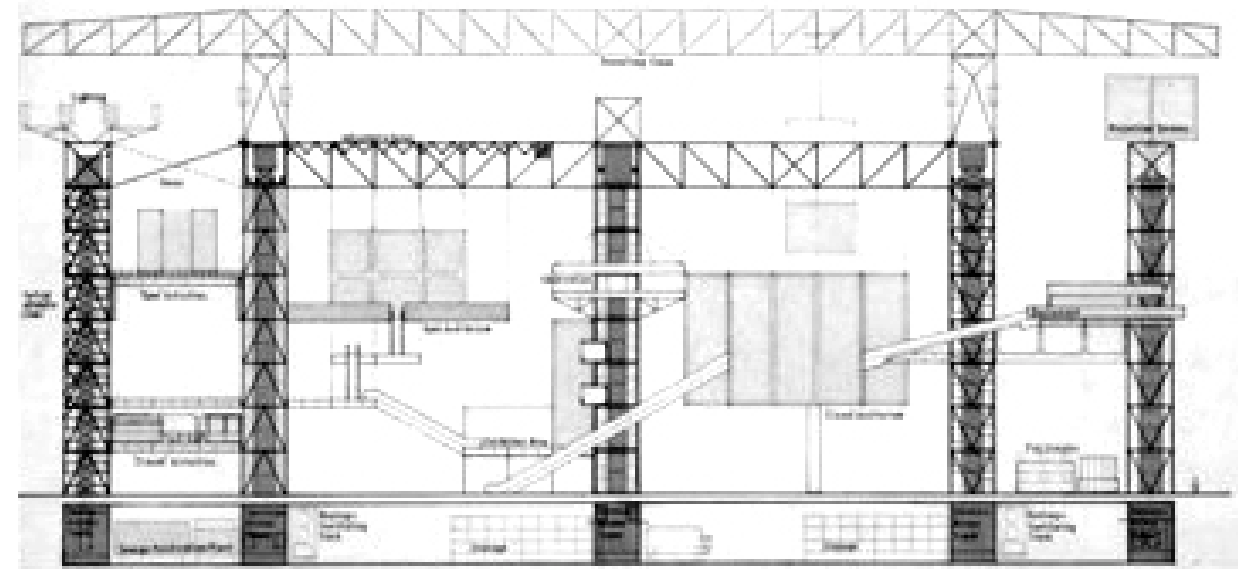

Corte longitudinal

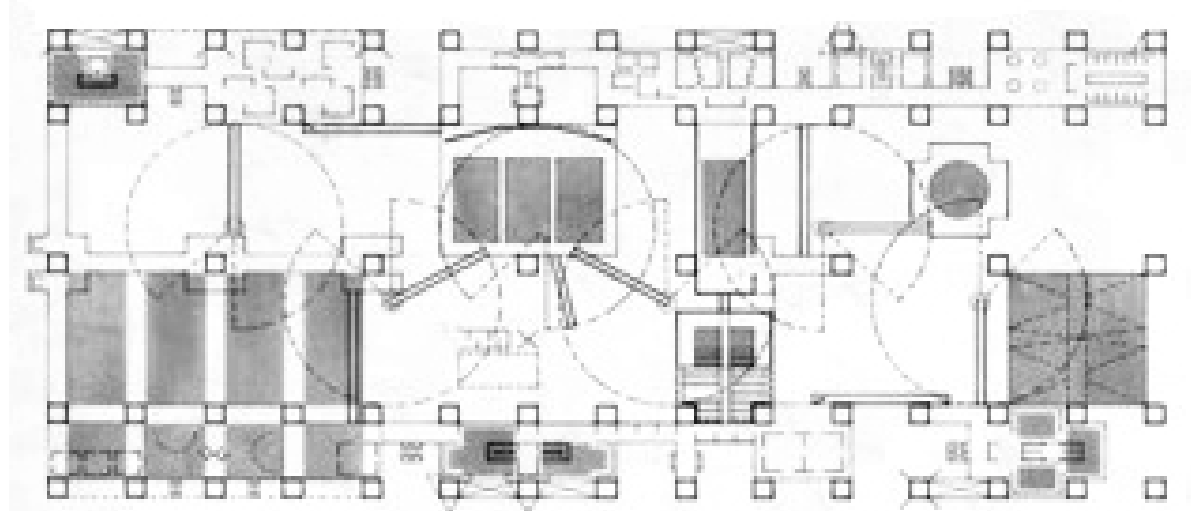

Planta pavimento superior. Fonte: Centre Canadien d'Architecture.
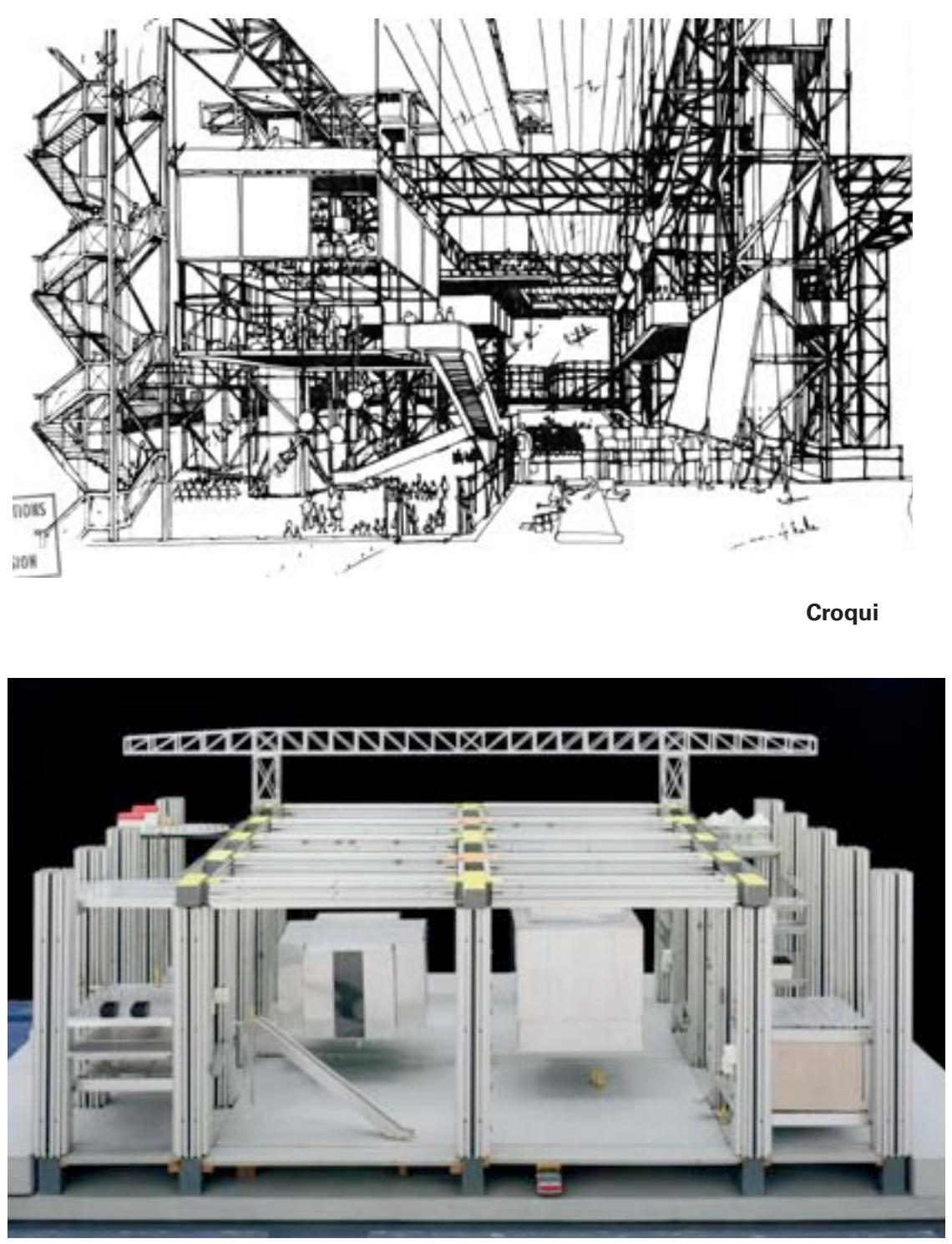

Maquete 


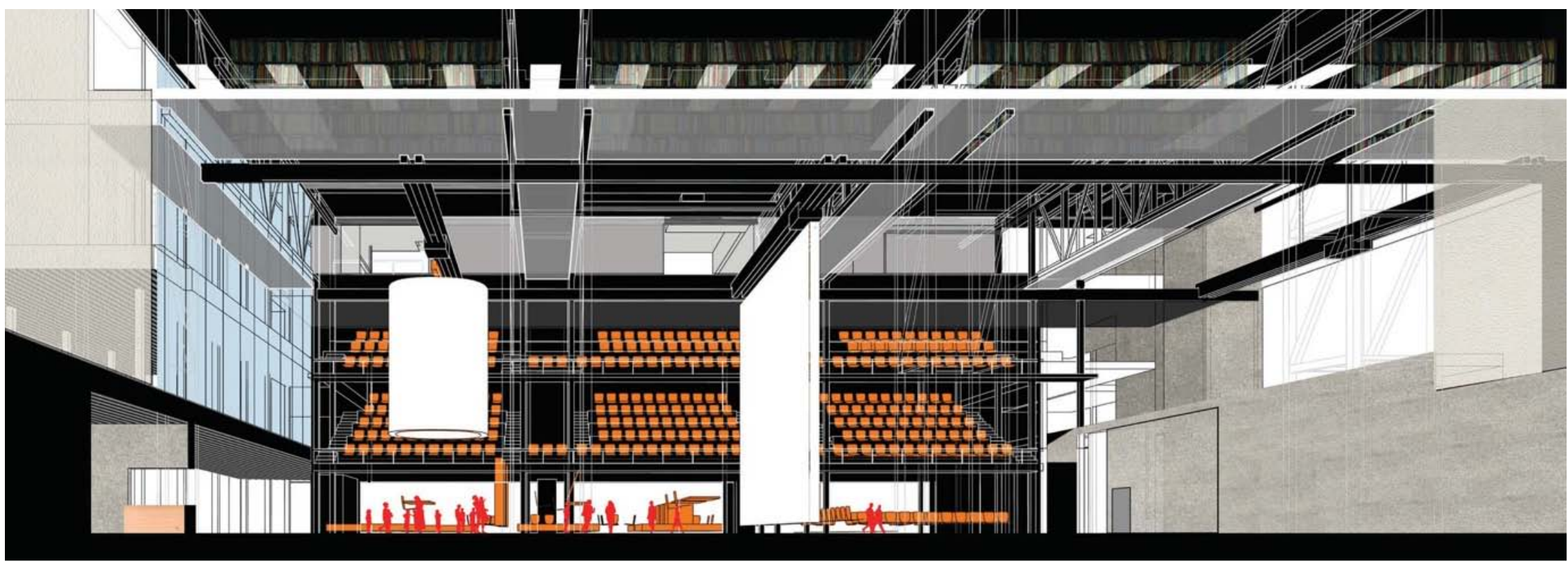

Vista interna. Fonte: Centre Canadien d'Architecture

ficos e planilhas ${ }^{102}$, o arquiteto deixa clara sua crença na interatividade entre as ações que se desenvolveriam no conjunto de componentes, distribuídos estrategicamente.

A crítica à cidade ideal aqui está formalizada pela presença da malha, a grelha estrutural que organiza e que amplia os horizontes de artistas e público. Se as megaestruturas do Team X demonstraram-se limitantes, o Fun Pa-

102 Grande parte do acervo deixado por Cedric Price (morto em 2003) a respeito do projeto é composto por documentos desse tipo. O Centre Canadian d'Architecture possui 275 desenhos e 1.130 documentos como tabelas, gráficos, textos e diagramas desse projeto. lace se apropria dessa ideia básica de uma matriz infraestrutural que procura garantir a liberdade de ocupação e de usos.

Antes dele o grupo Archigran lançou suas megaestruturas sobre a cidade real, uma crítica utópica neofuturista, sem a preocupação com sua viabilidade técnica ${ }^{103}$. Curiosamente o grupo viria a vencer um concurso para a

103 Não por acaso Keneth Framptom chama o capítulo em que cita o Archigram de Lugar, Produção e Cenografia, em sua obra História Crítica da Arquitetura Moderna, 2003, p. 342 
construção de um Circo em Monte Carlo, composto de uma plataforma superior configurando um auditório para receber 1.350 espectadores, sob a qual seriam distribuídas outras atividades destinadas à diversão do público, como shows, espetáculos audiovisuais, etc. É importante notar a escala da obra, apesar de ser uma das poucas que o grupo poderia ter viabilizado, um volume circular horizontal, em que o diâmetro previsto seria de aproximadamente 75 metros.

Esse é um momento em que fica clara a aproximação entre a crítica social da contracultura, da cultura Pop da década de 1960, baseada na participação e na transgressão, e a retomada, pelos grupos teatrais, de formas primordiais de atuação, baseados na origem dos espetáculos de rua. É nesse momento que Anne Marie Gourdon, no artigo Participação, Mito ou Realidade ${ }^{104}$, discute a importância da participação do espectador que se tornou obrigatória, levando a influenciar a arquitetura da sala, e para isso ele cita exemplos significativos, como o Living Theater ${ }^{105}$.

104 L'Architecture d'Aujourd'hui n. 155, 1970, p. 8-9. Ver cap. 1.

105 Ver nota 20 cap. 1.
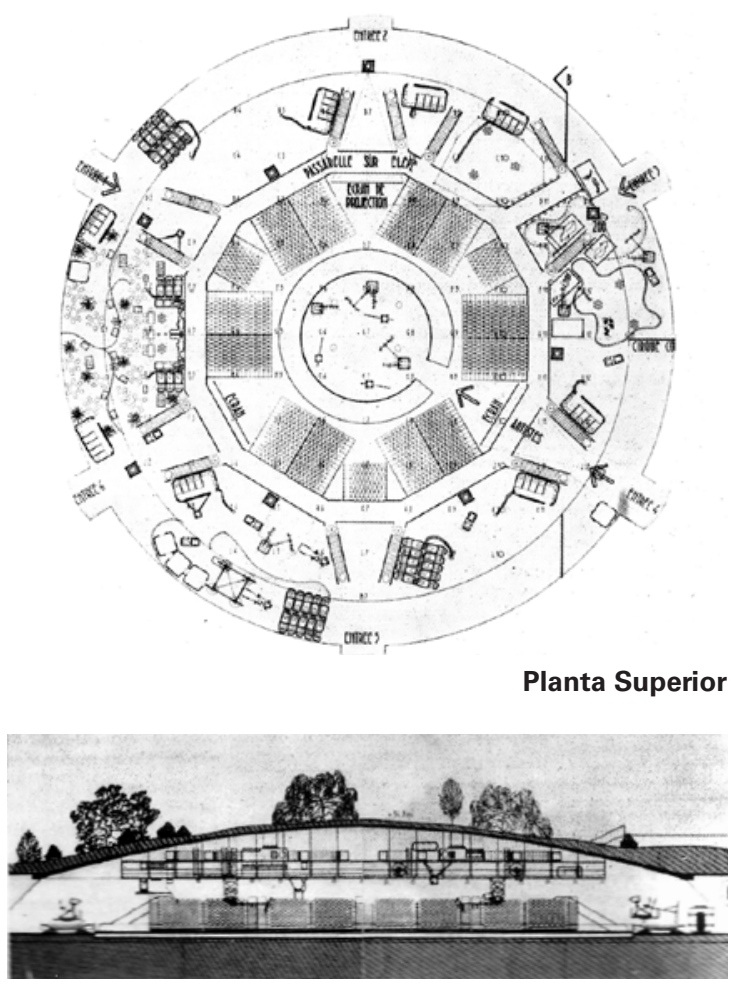

Corte

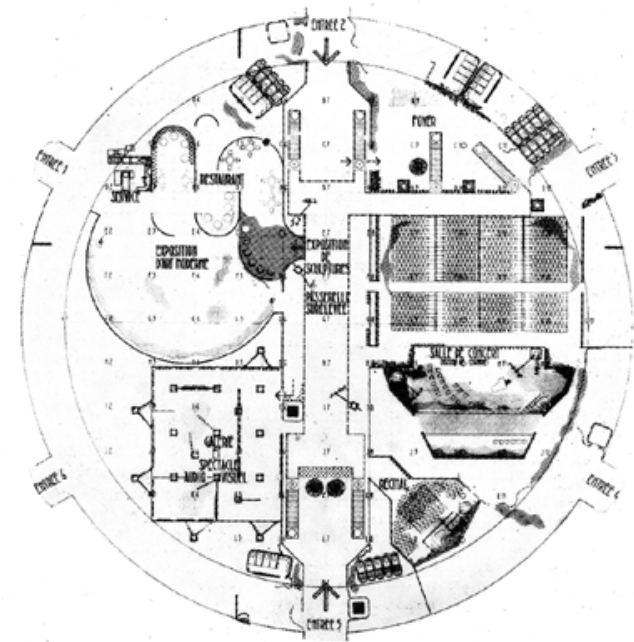

Planta Térreo

Circo Montecarlo. Grupo Archigran. Fonte: L'Architecture d'Aujourd'hui 152, 1970 


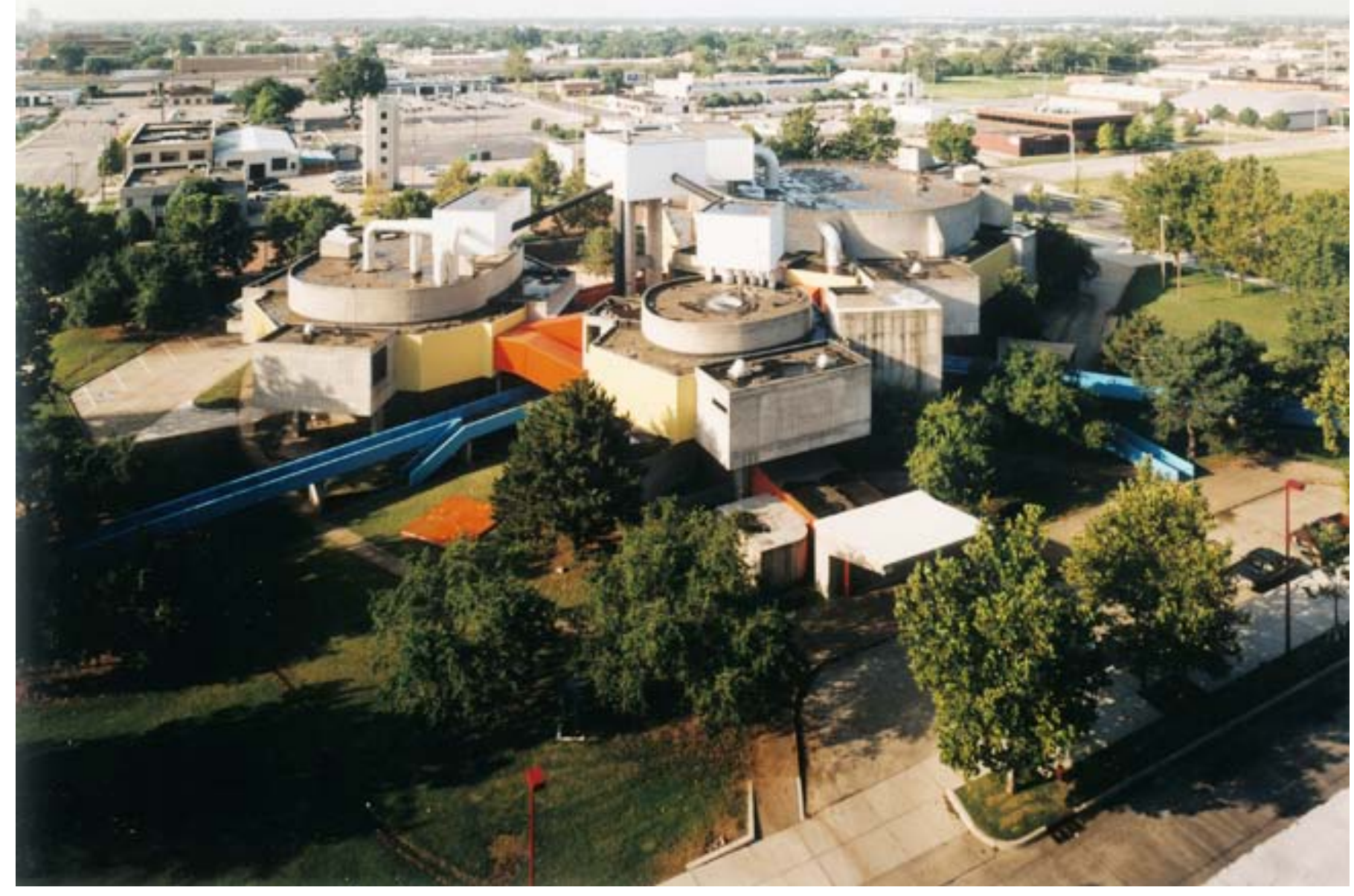

Mummers Theatre. Oklahoma City. Fonte: www.johnmjonansen.com 
Uma obra que materializou aspectos dos questionamentos ocorridos nesse período é o Mummers Theater de John M. Johansen, de 1970. Originalmente construído para abrigar a companhia local de teatro, o conjunto, implantado no interior de um parque, se destaca na paisagem plana de Oklahoma City por sua organização não usual. Originalmente concebido para uma companhia local de teatro, que além do seu repertório, abrigava também uma escola de teatro, a obra ganhou importância ao se inserir dentro de um amplo plano de reordenação urbana da cidade.

Na descrição do arquiteto, trata-se de um organismo formado pela superposição de camadas, como em um circuito eletrônico, em que são distribuídas e sobrepostas todas as funções, a infraestrutura e a circulação.

O conjunto elevado abriga três espaços especializados para espetáculos, predominantemente em arena: um teatro de 600 lugares, que compensa a escala reduzida de seu palco pela generosidade do seu proscênio em arena, um pequeno teatro transformável e um teatro escola. Dois sistemas de passarela, um elevado que interliga os teatros 


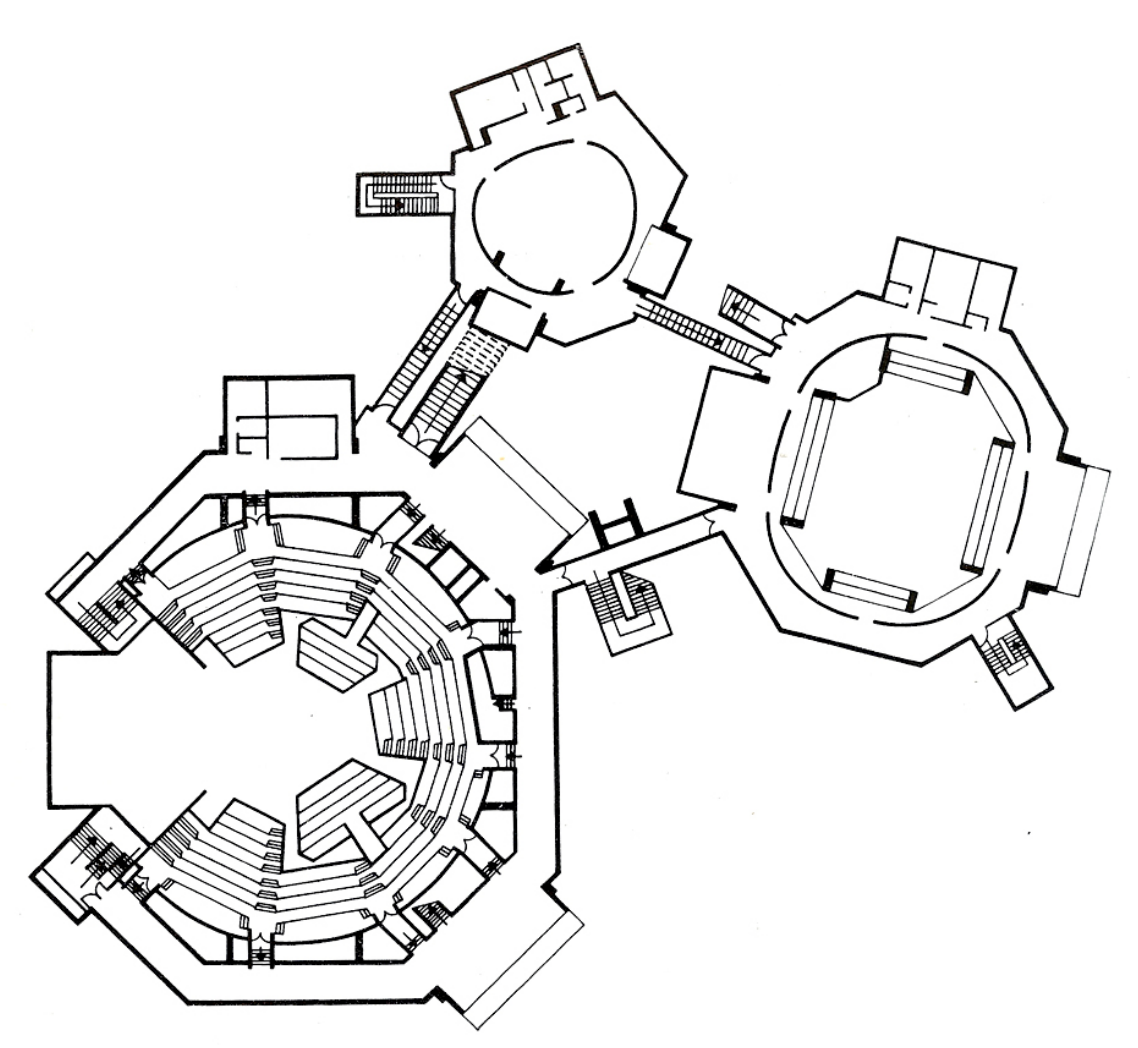

Planta superior

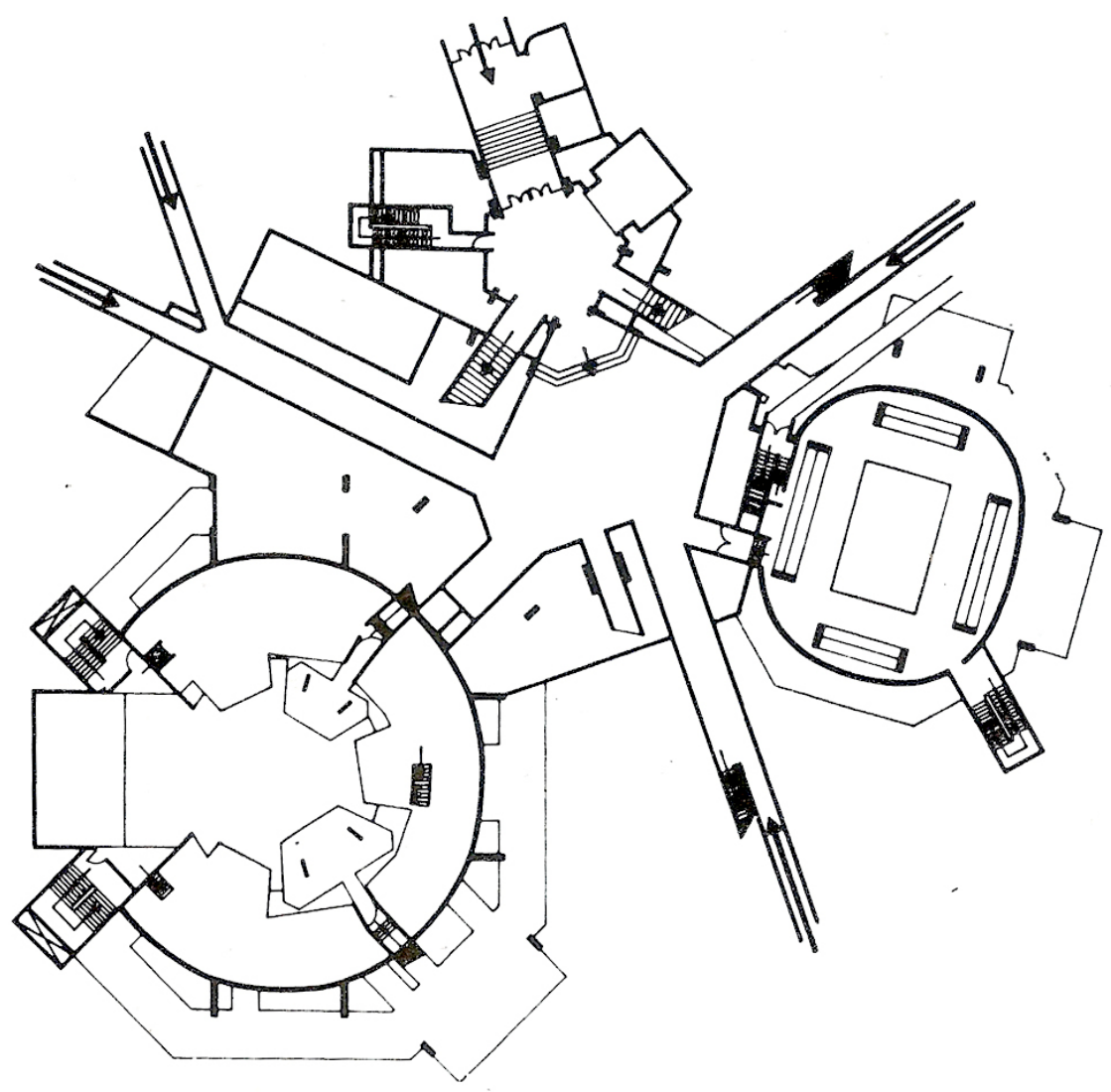

Planta térreo, escala 1:750.

Fonte: L'Architecture d'aujourd'hui 152, 1970. 
e outro no nível do solo, permitem que não só os espectadores mas também o público que visita o parque possam participar das atividades desenvolvidas no local. Essa seria, segundo seu autor, a grande qualidade da obra: poder agir como uma trama urbana em pequena escala, cujos fluxos permitem o intercâmbio cultural na cidade, e é o que se espera de uma escola. Acima de todo esse sistema uma camada superior de volumes e dutos garantem a distribuição de toda a infraestrutura necessária para seu funcionamento.

0 que é marcante na paisagem é que a articulação entre todo esse sistema faz explícita referência às construções dos silos agrícolas do meio oeste americano. Não estamos na metrópole, mas também aqui a megaestrutura de John Johansen domina, repousa. A obra exprime a essência das atividades por ela desempenhadas.

O Mummers Theater se mostrou de difícil operação por conta do alto custo de operação e manutenção. Os relatórios da Oklahoma City Community Fondation ${ }^{106}$, indicam, desde o início de sua operação, que as diversas instituições sucessoras da companhia Mummers apontaram esse obstáculo que impediu o pleno desempenho de suas atividades. Chamado de Stage Center desde 1984, o complexo foi definitivamente fechado em 2010, por conta dos prejuízos causados por fortes tempestades. Quarenta anos após sua inauguração foi cogitado pela municipalidade local destruí-lo para a construção de outro edifício com outras atribuições. Um movimento organizado pelas instituições locais conseguiu evitar sua demolição. Segundo a mesma Fundação, em 2013 o conjunto foi incluído no National Register of Historic Places. 0 artigo de Daid Hill na revista Archtectural Record (02/2012) informa que estudos de viabilidade estão sendo desenvolvidos para transformá-lo em um museu infantil e um museu da arquitetura e do design.

Esse fato apresenta a obra num caminho inverso ao encontrado na presente pesquisa. Se observarmos a ocupação de edifícios não especializados, em que a arquitetura preexistente contribui para a construção do espetáculo, o Mummers parece se dirigir em sentido oposto. É o lugar do espetáculo mostrando-se capaz de assumir novas atribuições. Seria um exemplo de como suas qualidades constitutivas, inspiradas nas utopias de grupos como o Archigram, permitem que a arquitetura continue a cumprir o seu papel, apesar de todas as dificuldades enumeradas aqui.

106 Stage Center Timeline, disponível em: https://occf.org/documents/stagecentertimeline.pdf, visualizado em 15/02/2014; esse documento relata os custos de manutenção, suas dificuldades e as diversas instituições que sucederam o Mummers Theater na administração do conjunto. 


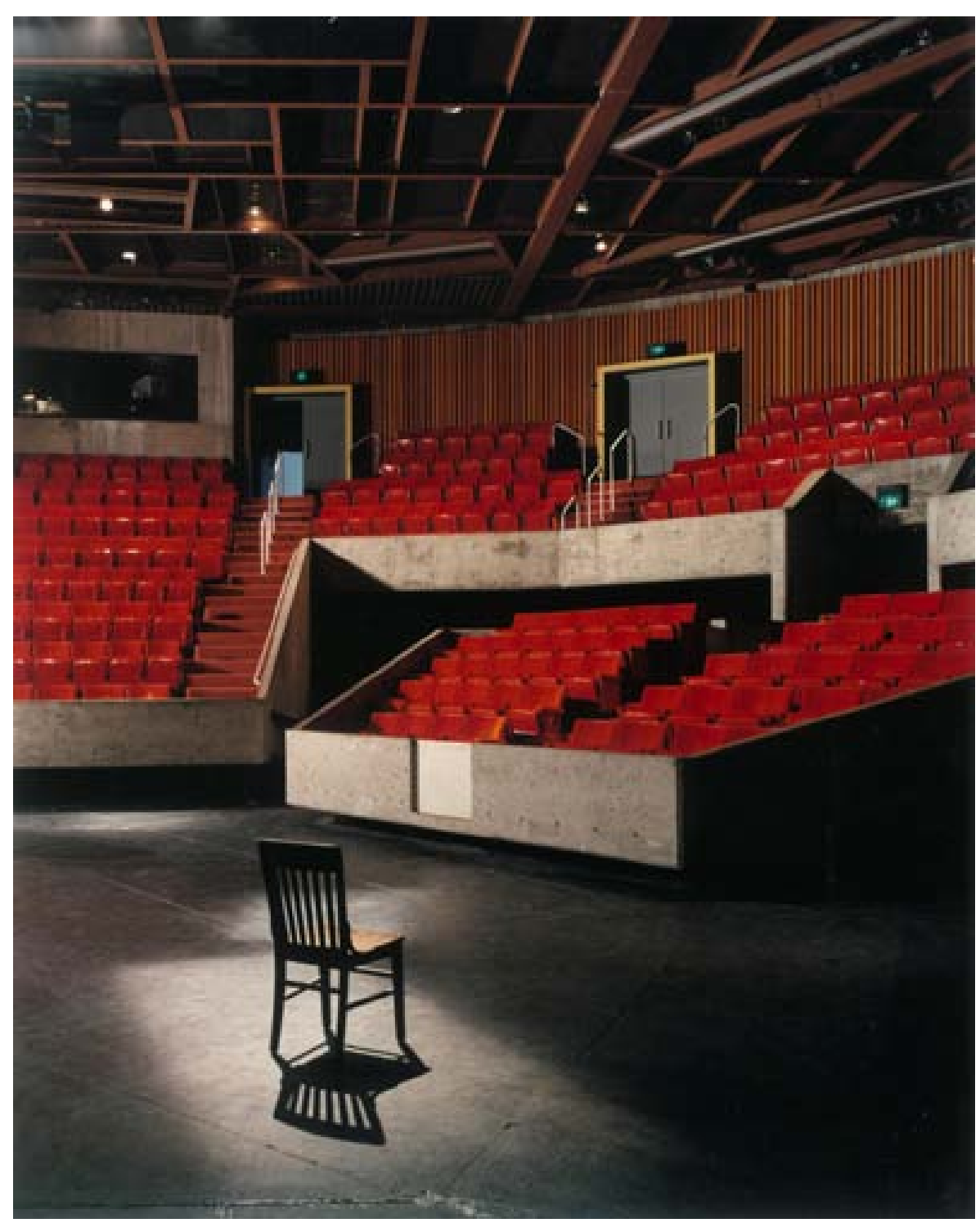

Auditório Principal. Mummers Theatre. Oklahoma City.

Fonte: www.johnmjonansen.com

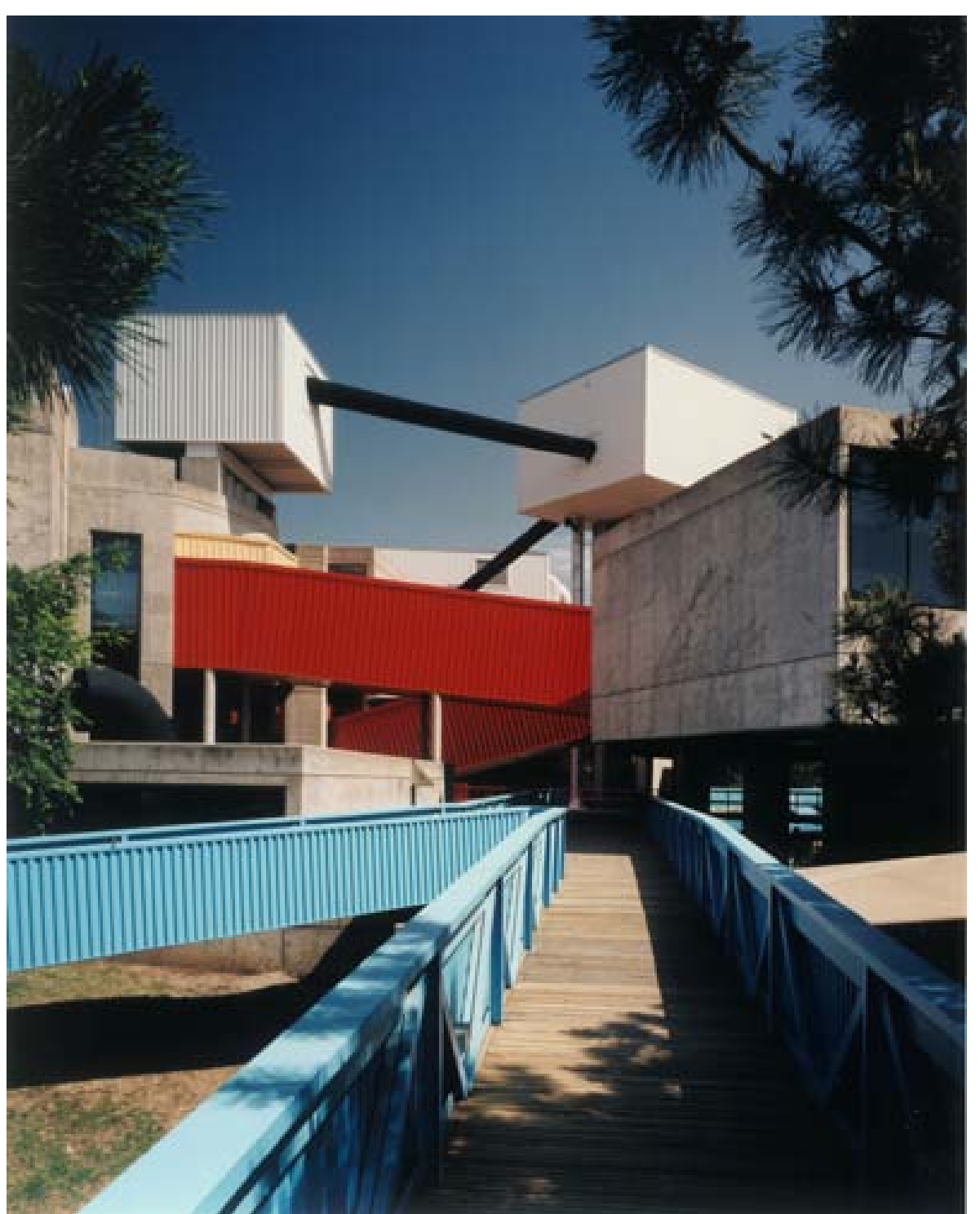

Acesso Norte. Mummers Theatre. Oklahoma City. Fonte: www.johnmjonansen.com 


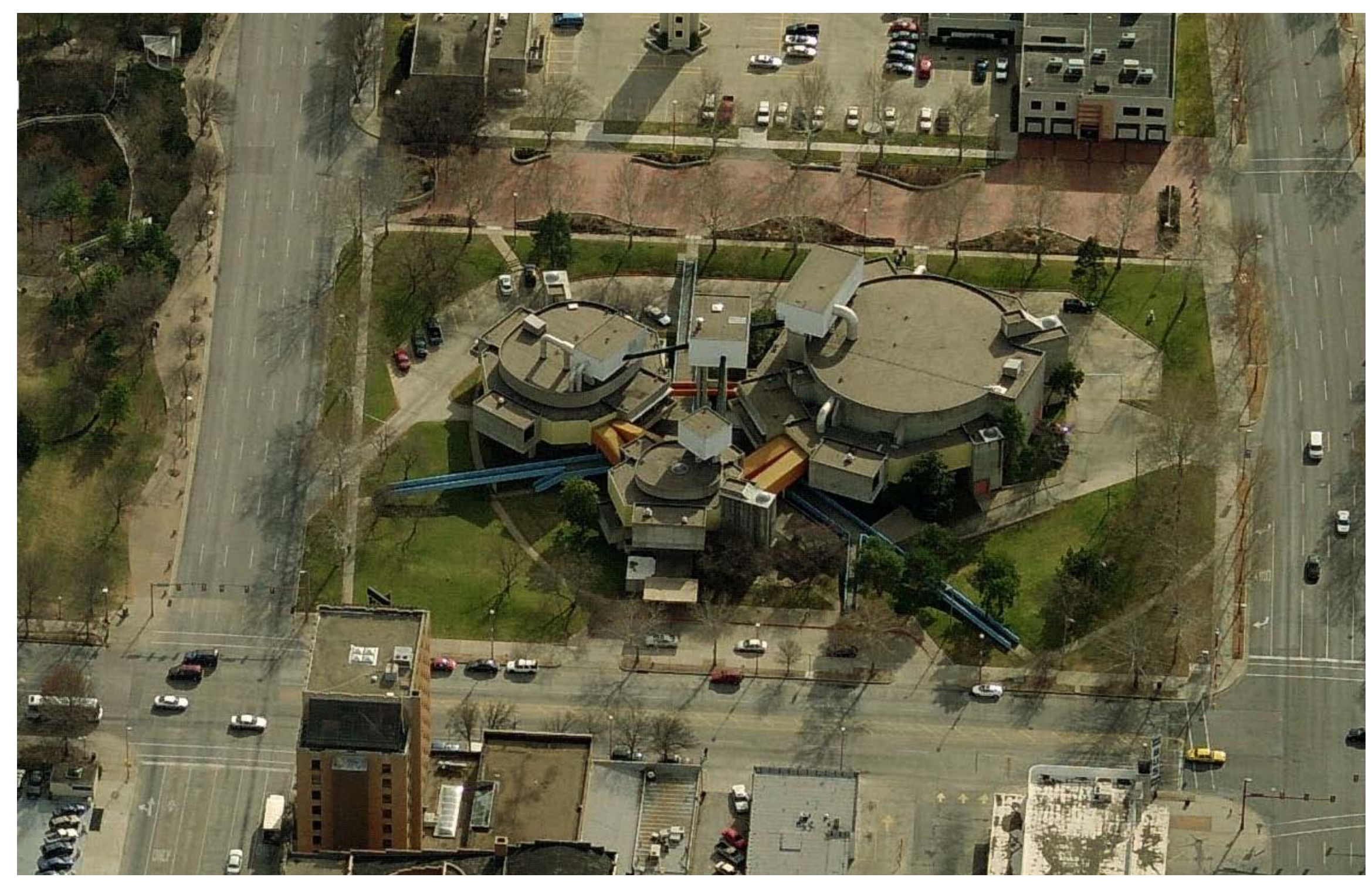

Vista aérea norte. Fonte: www.bing.com 


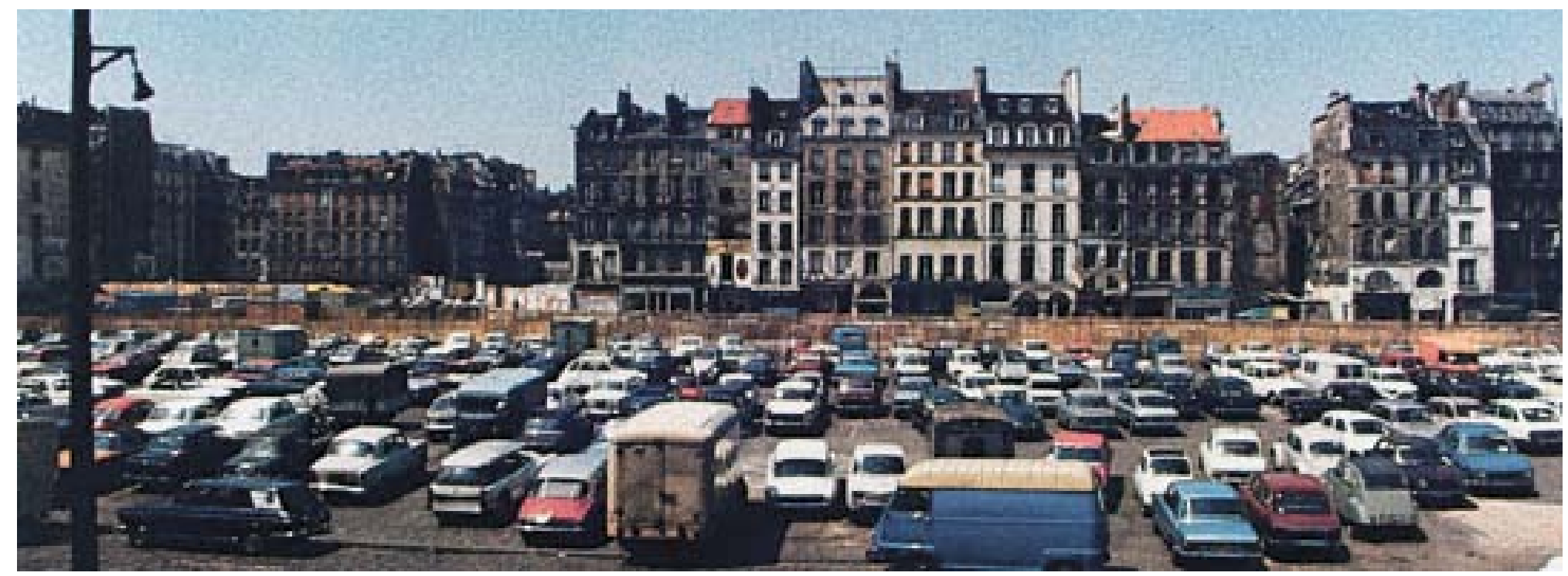

Plateau Beaubourg antes do concurso. Fonte: Fundazione Renzo Piano 
Um edifício, mas também parte de um edifício, explica a si mesmo ao mostrar como funciona $e$ para que serve. Tentamos tornar cada elemento claramente legível isoladamente e em relação com os outros, tornando-se dessa maneira não apenas parte de uma estrutura maior, como também de um todo autônomo. Ao mostrar como as coisas funcionam, e ao deixar cada elemento falar por si próprio no que se refere a um todo maior, a arquitetura de um edifício pode intensificar nossa consciência dos fenômenos que compõem nosso ambiente.

(HERTZBERGER, 2010, p. 242)

O objetivo deveria ser costurar novamente esse projeto, esse retalho de cidade, na trama urbana - e, ao mesmo tempo, fortalecer toda a trama ao redor.

(sobre Projetos de Revitalização, JACOBS, 2009, p. 437)

As citações acima indicam, por pontos de vista diferentes, a complexidade representada pela abordagem do tema dentro das condições oferecidas pelo Beaubourg, o Centre Pompidou, em Paris.

107 Numa tradução livre, palco da bela vila. O dicionário Robert define plateau como extensão plana que domina um território; palco de um teatro, cena; e bourg como grande vila em que há um mercado. 


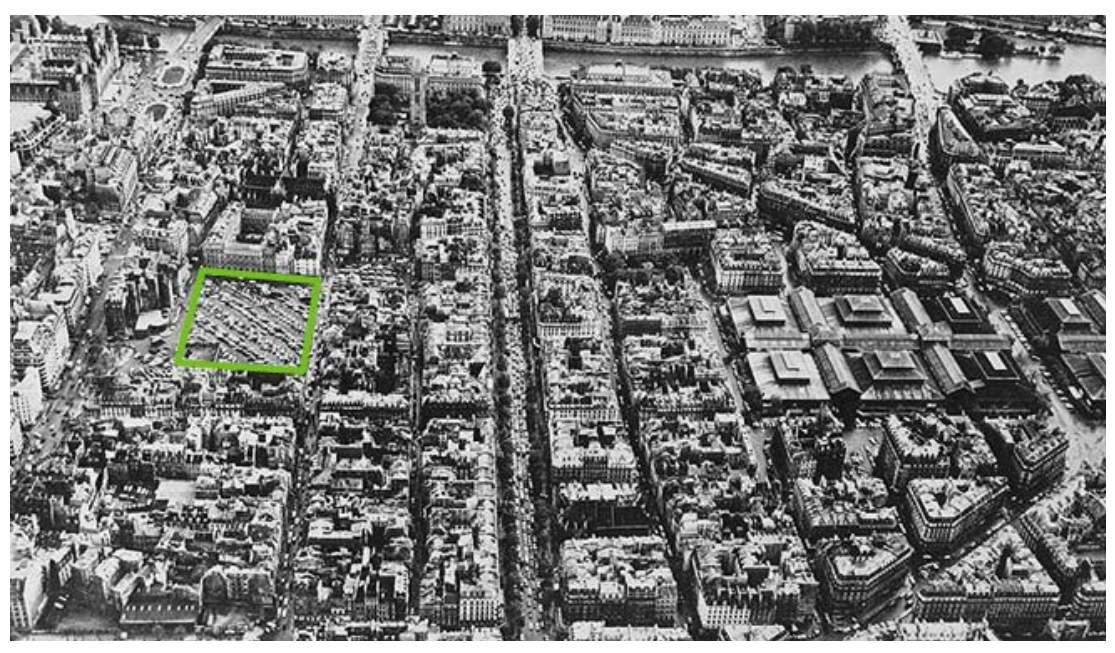

Plateau Beaubourg antes do concurso. Fonte: Fundazione Renzo Piano

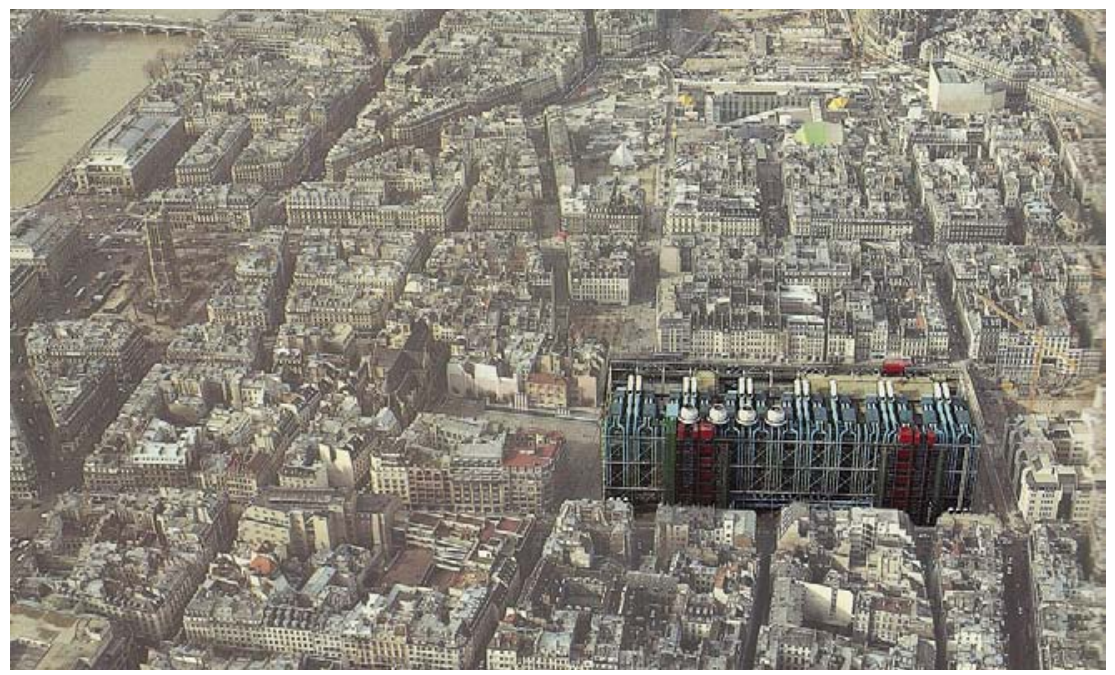

Beaubourg vista aérea Leste. Fonte: $A+U, n 12,1988$
O Beaubourg não é um teatro, ou um centro de entretenimento, pelo menos não no sentido literal do termo.

A equipe vencedora do concurso internacional realizado em 1971, liderada por Richard Rogers e Renzo Piano, foi sensibilizada por essa situação geográfica sobre a qual o antigo estacionamento do mercado central de Paris resistiu à ocupação desde as grandes obras urbanas do Barão Haussmann $^{108 .}$

É notável como sua implantação privilegia a constituição de uma esplanada inclinada, que libera cerca de metade da área, a reverenciar o templo da cultura, uma plateia urbana atenta. 0 croqui de Richard Rogers confirma a interessante proximidade da relação entre plateia e caixa de palco, e todo seu aparato tecnológico que encerra o espetáculo. É o plano inclinado urbano, que se configura com o alargamento de dimensões generosas do eixo de circulação de pedestres de leste a oeste.

Outros aspecto a assinalar, que coloca o projeto de Rogers e Piano no encadeamento das obras desse período manifestamente ligadas à cultura de massas da década de

108 Sua última ocupação se deu após a construção em 1848 do Mercado Central de Victor Baltard no centro de Paris, o terreno vago foi utilizado como estacionamento até a construção do Beaubourg, em 1970. 
1960, é o fato dele concretizar as utopias transgressivas do grupo Archigram e de Cedric Price. Já nas peças gráficas utilizadas para vencer o concurso fica claro o uso de uma atmosfera da animação cultural urbana que o Centro deveria assumir.

Poderíamos dizer que se trata de uma maneira de demonstrar que todo o expressivo aparato tecnológico que define a obra, estranho àquele ambiente, seria suavizado pela atmosfera convivial por ele gerada. A arquitetura chamaria o grande público para a cultura, em um primeiro momento pela força da atração gerada por esse contraste.

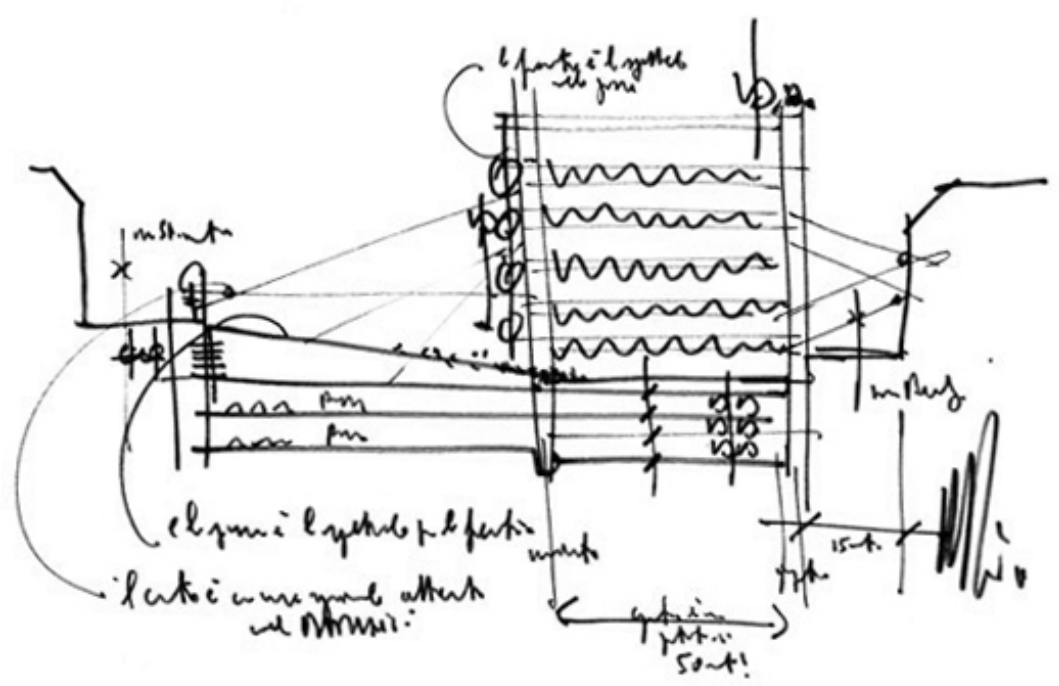

Croqui do concurso. Fonte: Fundazione Renzo Piano

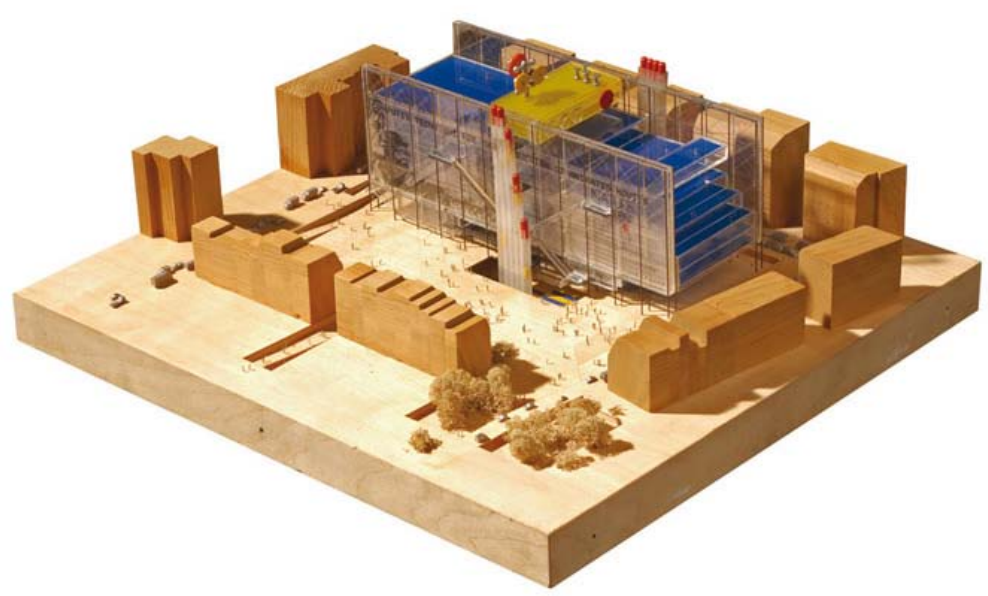

Maquete do concurso do concurso. Fonte: Fundazione Renzo Piano

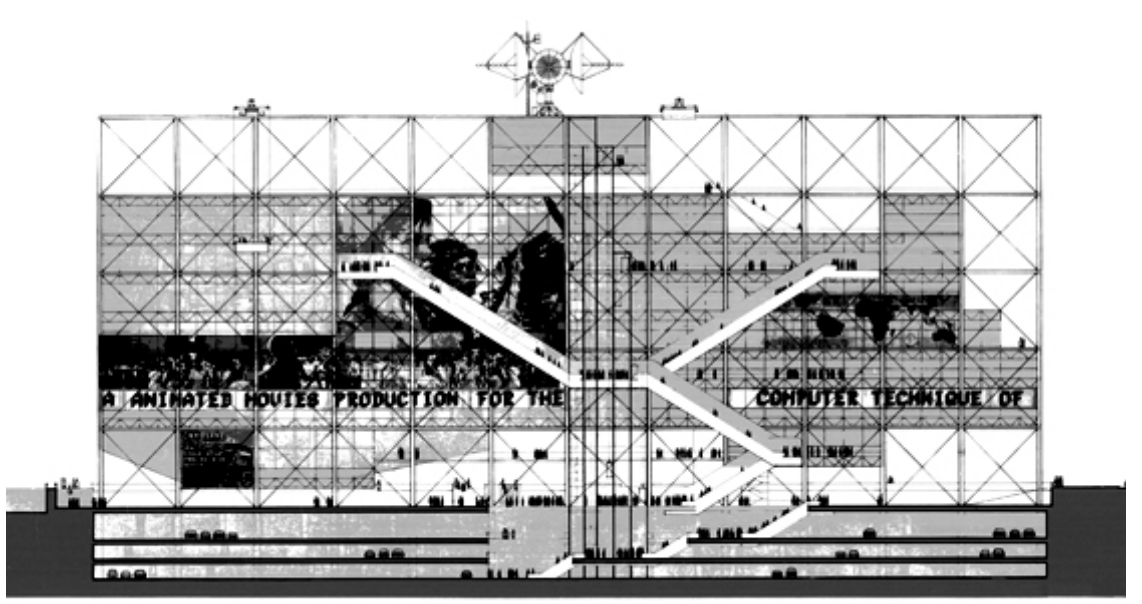

Elevação do concurso. Fonte: Fundazione Renzo Piano 


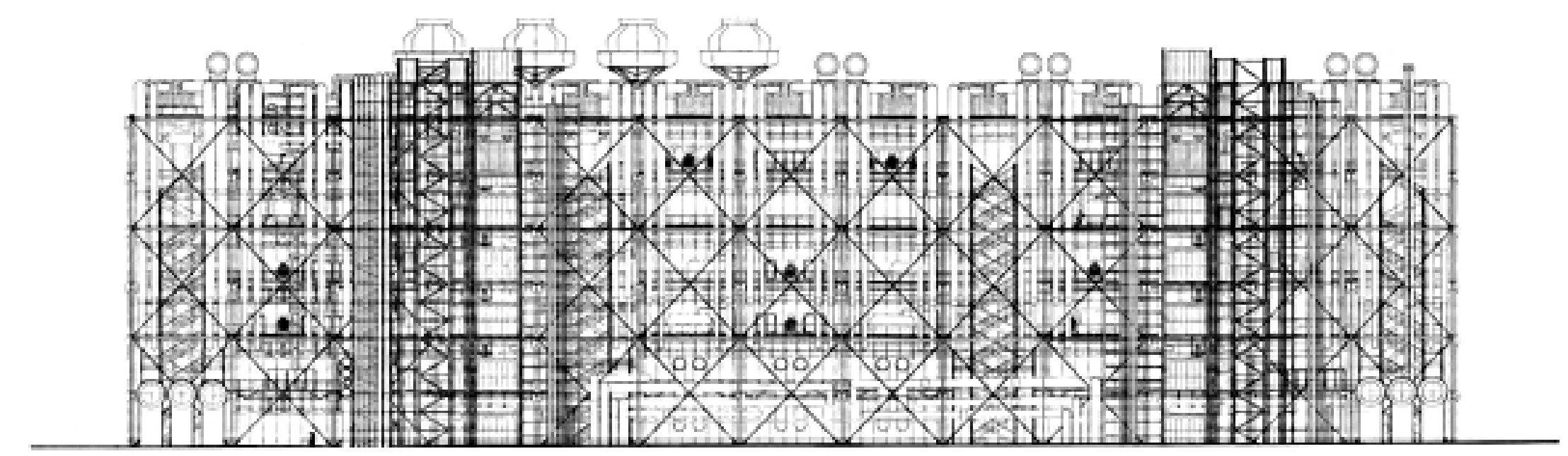

Elevação Leste. Fonte: Fundazione Renzo Piano

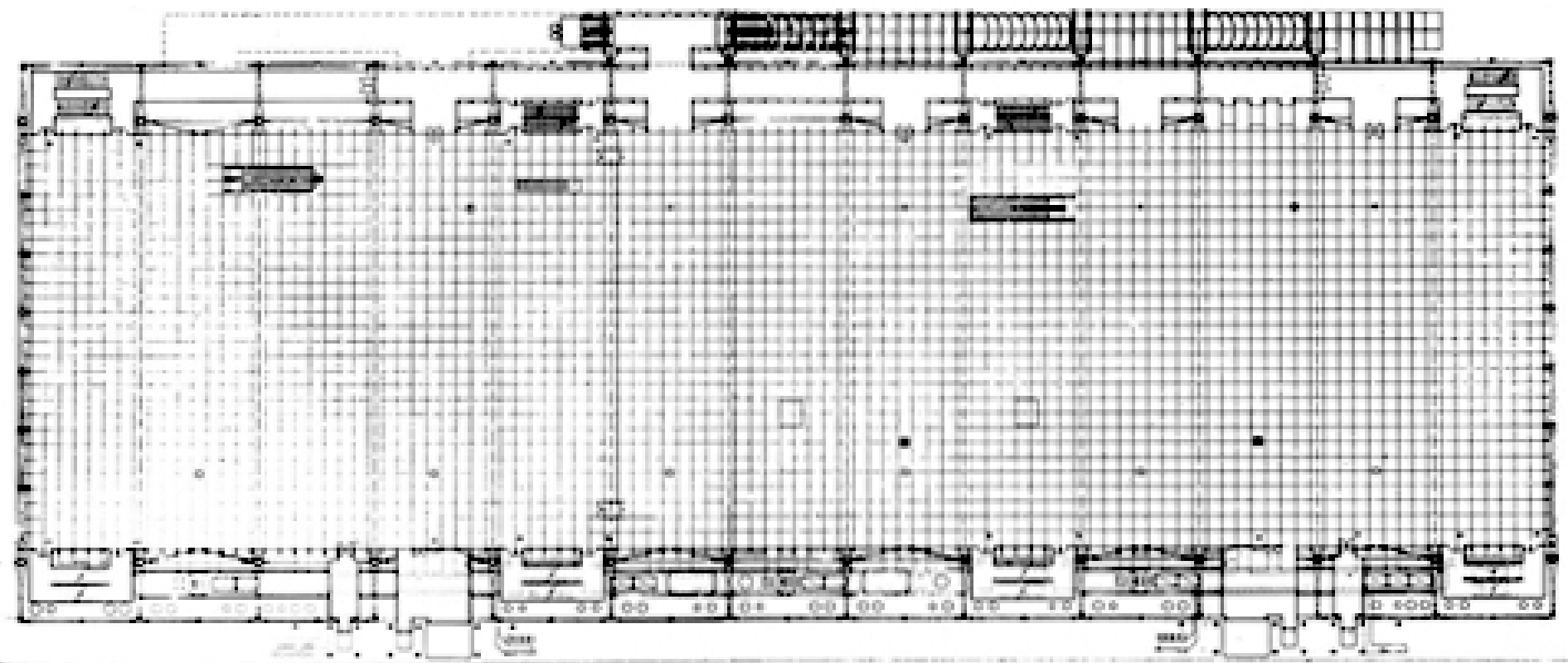

Planta terceiro pavimento. Fonte: Fundazione Renzo Piano 


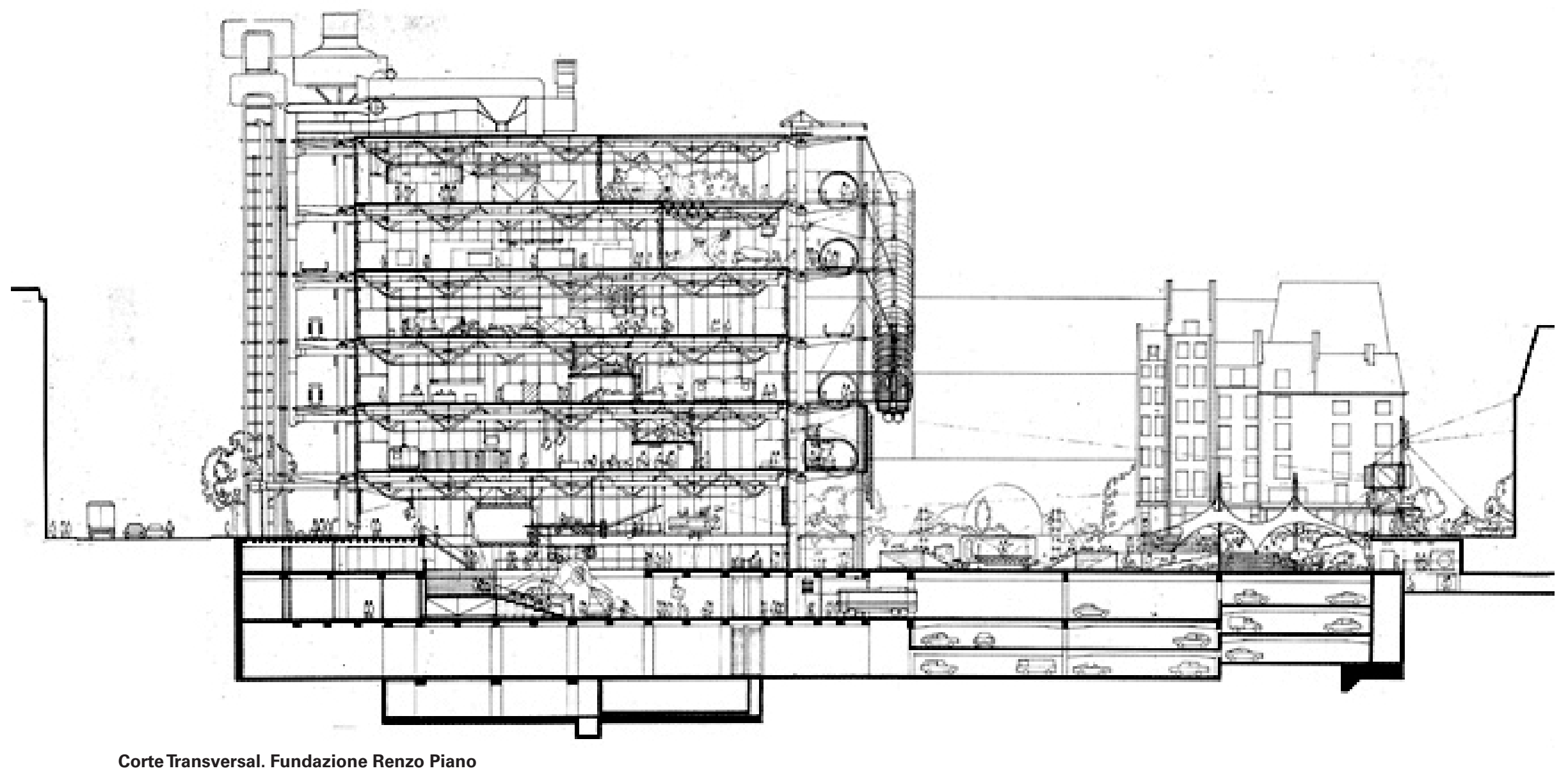


Retornando novamente ao corte, podemos verificar que a esplanada inclinada, que favorece o ingresso, como em um templo, como em uma catedral que facilita o deslocamento rumo ao altar, rumo ao céu, permite ao mesmo tempo assistir à animação dos seus cinco níveis ${ }^{109}$ e se torna palco das mais diversas manifestações culturais urbanas. A sequência de escadas mecanizadas, que define a fachada oeste, é uma rua que acede, anima e assiste e de onde, no seu ápice, pode ser vista toda a cidade.

Para o interesse dessa pesquisa, o projeto se torna de vital importância, não pela sua contribuição como instituição, nem por conta das funções culturais para as quais foi construído, mas por materializar a mudança de visão de cidade que se pretendia ter naquele momento. Aqui retornamos novamente às questões ligadas à participação do público, durante o espetáculo, nesse caso, durante a vida cotidiana da cidade. Mais do que a evidente implantação em anfiteatro, uma das razões do grande sucesso de público dessa iniciativa é o fato de o projeto relançar o debate sobre a ideia de cidade como lugar público, palco de manifestações culturais:
O fenômeno Beaubourg encerra um ciclo da arquitetura internacional. Mais de uma década de polêmica e afluência integrou-o de tal modo no repertório parisiense, que acabou inaugurando outro ciclo. Sobre a nova cidade cujo desenho ele ajudou a compor, impregnando-lhe o imaginário, paira uma nova mentalidade projetual inteiramente voltada para as relações entre a arquitetura e a cidade. $O$ projeto não poderia imaginar que relançasse, ampliando em novas bases, o debate em torno da cidade enquanto lugar público. (ARANTES, 1993, p. 189) [destaque da autora]

Retornando ao início do texto, as citações elencadas apontam diversas abordagens que o projeto do Beaubourg suscita.

Quando aplicado a essa obra, a descrição de Hertzberger revela como a tecnologia nele explícita contribui para a compreensão e domínio do ambiente, como Cedric Price desejara: a arquitetura materializada pela alta tecnologia tornada pública de maneira didática, nos seus detalhes fundamentais. É notável o uso do acabamento colorido diferenciando seus componentes, como atendendo às nor- 


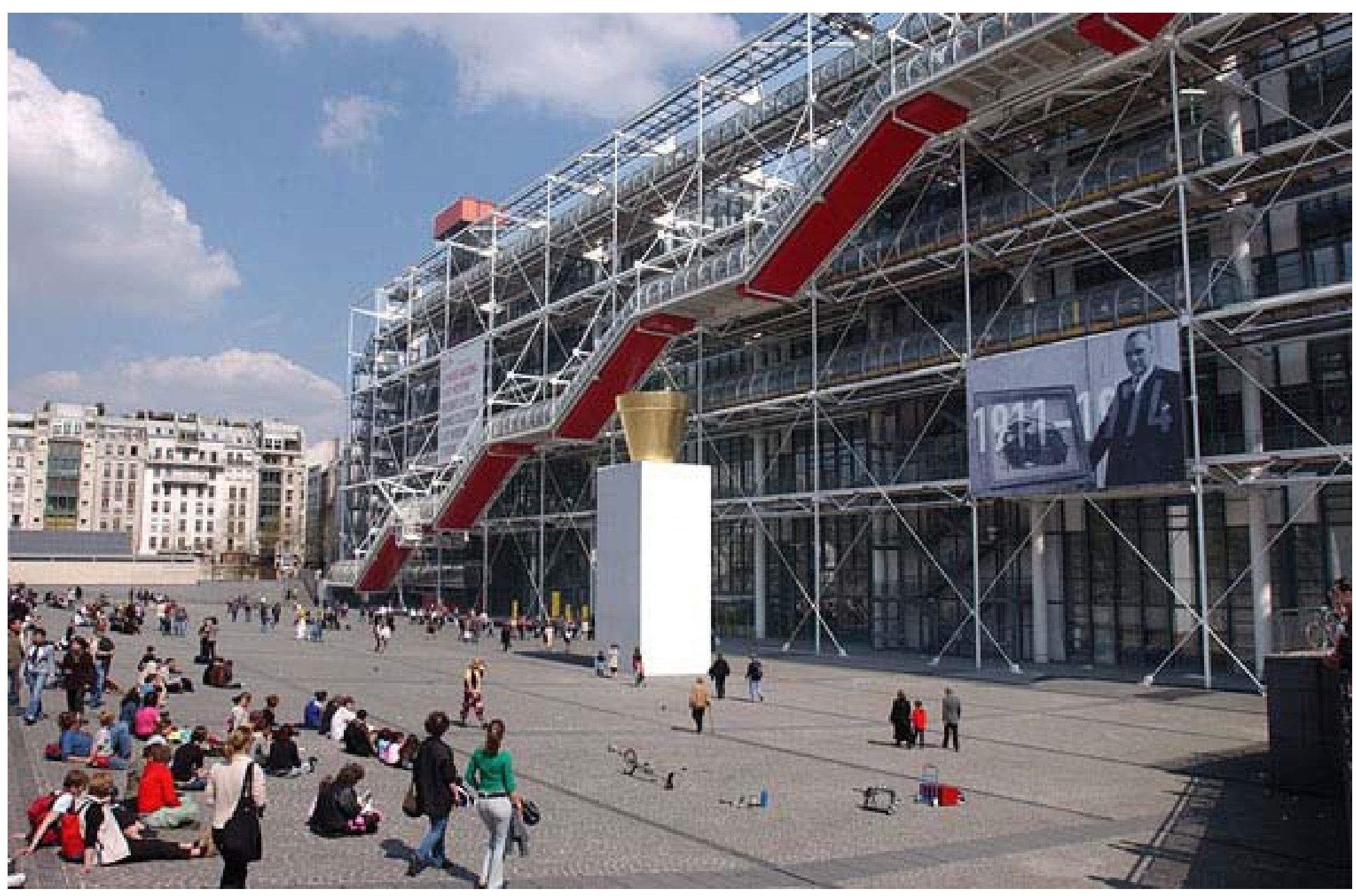

Esplanada. Fonte: Fundazione Renzo Piano 
mas da construções industriais em que se inspira.

Revitalizar, dar vida novamente, trazer nova vida, o processo a que se refere Janes Jacobs, se aplica de modo objetivo ao Beaublourg. O Plateau tornara-se, depois de décadas de esquecimento, elemento de referência, capaz de induzir atividades, como áreas de vitalidade capazes de reduzir as áreas apagadas ou trevas ${ }^{110}$, conforme argumenta a autora.

A leitura que faz Otília Arantes do Paradoxo Beaubourg $^{111}$ é, em um primeiro momento, extremamente crítica no que se refere às reais intenções e resultados colhidos com a política cultural inaugurada por ele na década de 1970 e intensificada na década seguinte com as grandes obras, chamadas pela governo socialista de Architectures Capitales ${ }^{112}$. Entretanto ela reconhece ser de extrema importância o fato de a obra ter trazido de forma concreta para o debate do projeto as relações entre arquitetura e ci-

110 É importante assinalar que Jacobs insiste na necessidade não só da intensidade das áreas de vitalidade mas também da diversidade dessas áreas: Os distritos que apresentam vários recortes visuais não costumam intimidar nem oprimir as pessoas na prática; costumam ser caracterizados antes como amistosos e ser identificados como distritos. Afinal, é a intensidade da vida humana que está sendo reconhecida e enfatizada e, além do mais, enfatizada no que ela tem de mais inteligível e familiar. (JACOBS, 2000, p. 425)

111 Tanto na publicação de 1993, O Lugar da Arquitetura Depois dos Modernos, quanto na de 1998, Urbanismo em Fim de Linha.

$112 \mathrm{O}$ título se refere às diversas publicações e exposições realizadas nesse momento sobre o tema, como por exemplo a de Sabine FACHARD - Architectures dade, resgatando o lugar público como valor de projeto. É verdade que, se em um primeiro momento sua arquitetura trouxe estranheza às tradições daquele lugar, ela foi aos poucos nele se impregnando de tal forma que inspirou a reconstrução do entorno imediato e terminou por contagiar a cidade:

Pois ele, com sua rede de tubulações e seu ar de edifício de exposição ou de feira universal, com sua fragilidade (calculada) dissuasiva de toda a mentalidade ou monumentalidade tradicional, proclama abertamente que nosso tempo não será jamais o da duração, que nossa única temporalidade é a do ciclo acelerado e da reciclagem, a do circuito e do trânsito de fluidos. ${ }^{113}$ (BAUDRILLARD, 1977, p. 17)

113 Nossa tradução do texto original: Car celle-ci, avec ses réseaux de tuyaux et son air de bâtiment d'expo ou de foire universelle, avec sa fragilité (calculée) dissuasive de toute mentalité ou monumentalité traditionnelle, proclame ouvertement que notre temps ne sera plus jamais celui de la durée, que notre seule temporalité est celle du cycle accéléré et du recyclage, celle du circuit et du transit des fluides. 


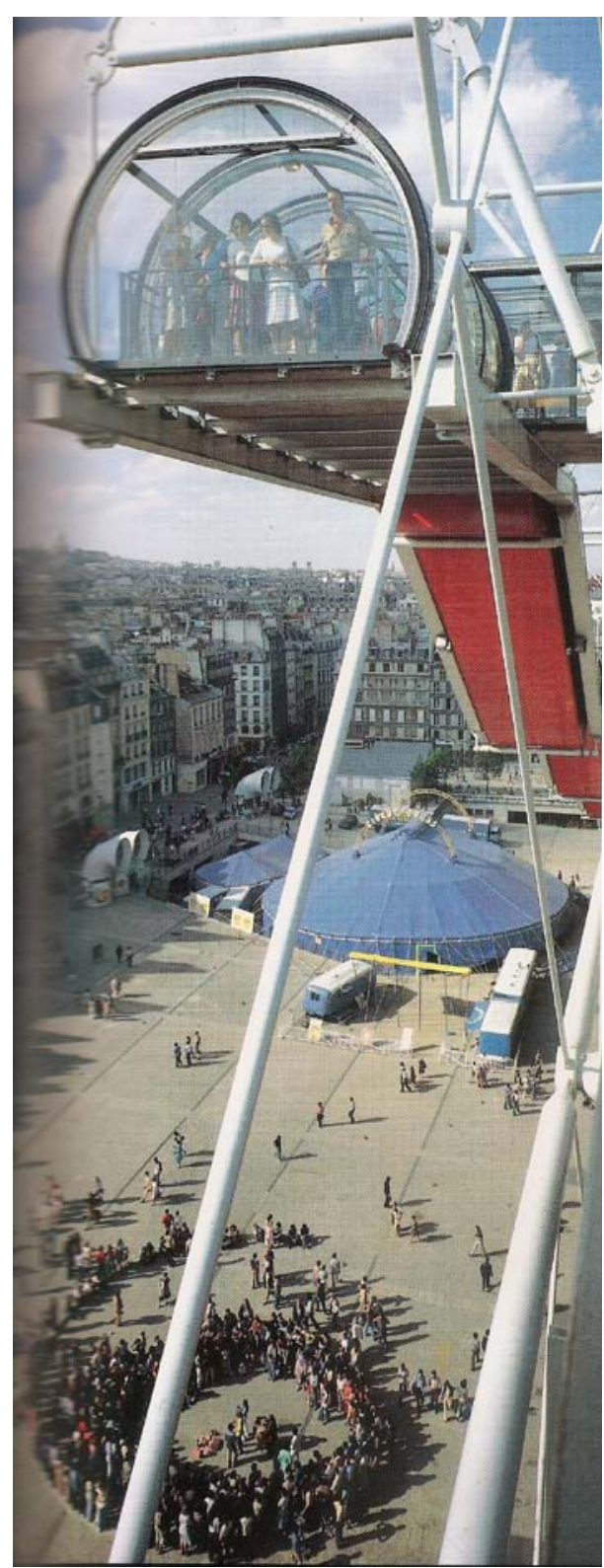

Vista do quinto pavimento. Fonte A+U 12/1988

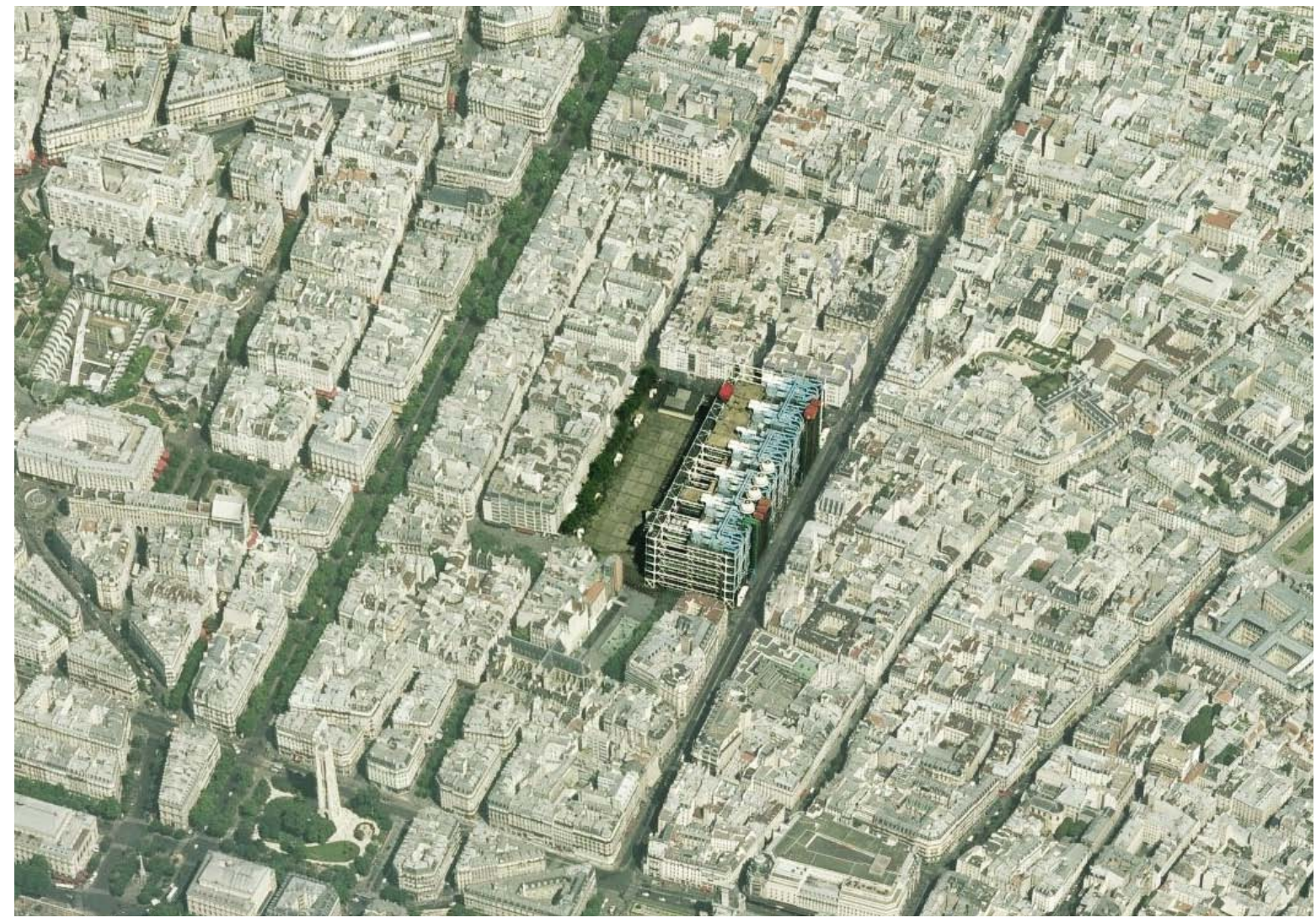

Vista aérea Sul. Fonte: www.bing.com 


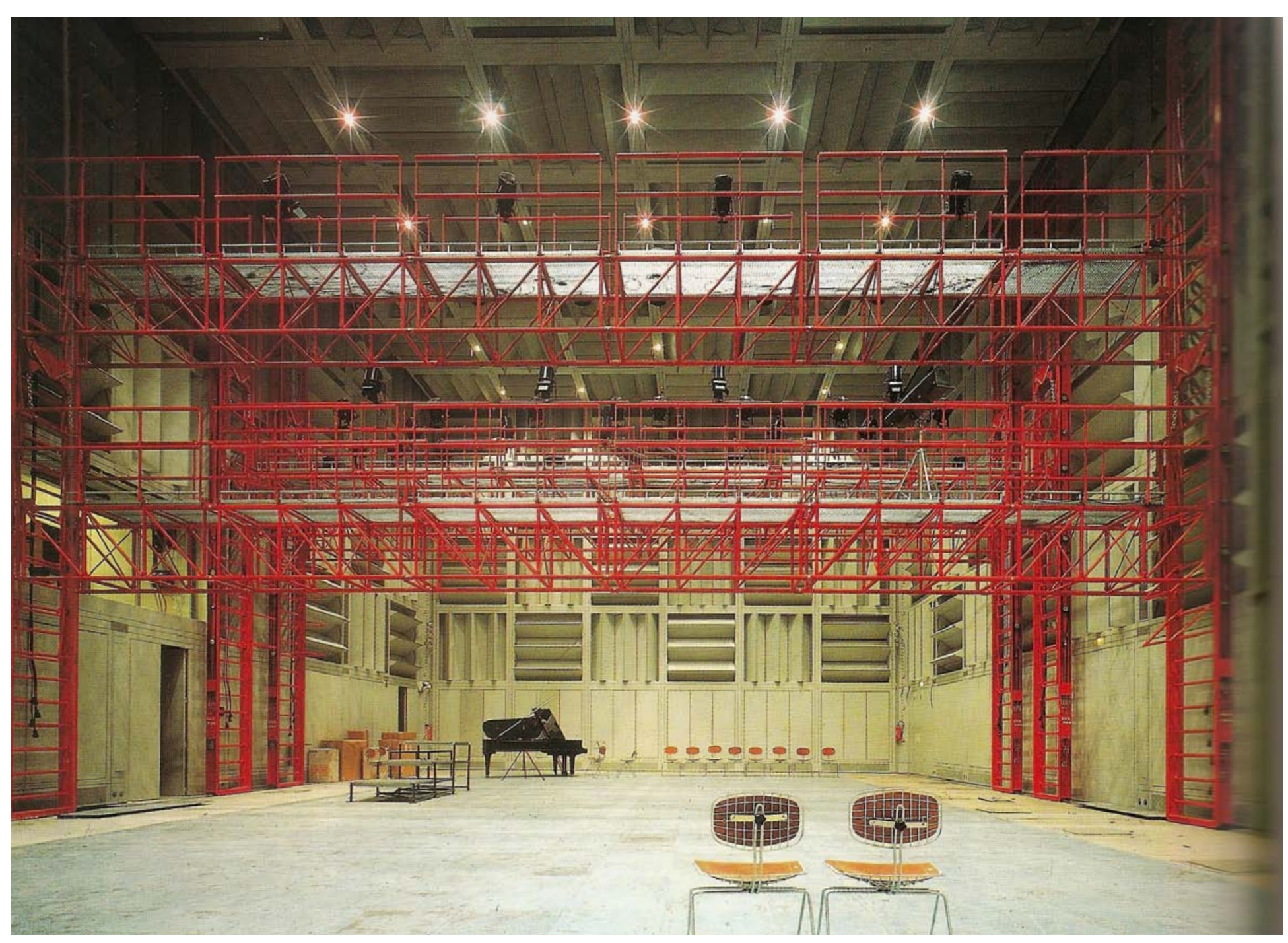

IRCAM - Auditório. Fonte: A+U 12/1998 
Como consequência natural do desenvolvimento do projeto do Beaubourg, Richard Rogers e Renzo Piano foram designados para elaborar o centro de criação e de pesquisa musical idealizado pelo maestro e compositor Pierre Boulez, o IRCAM.

A solução encontrada pela equipe para implantar o edifício na pequena praça na lateral sul do Beaubourg foi a de uma edificação subterrânea cujo acesso é possível pela intervenção realizada nos imóveis históricos residenciais que foram incorporados à obra. A opção se justifica pela situação de total isolamento que o seu programa funcional exigia. Se de um lado o Beaubourg trouxe o grande público para a animação cultural a que ele se propunha, de outro, o IRCAM pressupunha total capacidade de pesquisar e compor música contemporânea sem nenhuma interferência exterior.

0 que o distingue de outras experiências realizadas $^{115}$, em que a colaboração entre arquiteto e maestro foi 
biente deveria criar a composição musical em função da relação sonora dos equipamentos responsáveis pela emissão dos sons e o comportamento acústico da sala. Ou seja, a sala foi construída com diversos recursos de ajuste e regulagem de toda sua superfície interior (painéis de forro, painéis de paredes e plataformas de piso), de maneira que sua calibragem aparece descrita nas partituras. É a arquitetura transformada em instrumento, é a arquitetura na composição musical. Como afirma Michel Forsyth: ...é um instrumento de música, em si, pois seus ajustes estão impressos nas partituras. (FORSYTH, 1985, p. 304)

As características sobre o IRCAM descritas aqui levam-nos a refletir sobre a os valores essenciais da arte que busca a música de Pierre Boulez e sua perfeita relação com a arquitetura do espetáculo. Com considerações semelhantes, mas percorrendo um outro caminho, Alan Conquhoun apresenta-nos outro feliz colaboração entre músico e arquitetura:
...Yannis Xenakis, que, ao desenhar o projeto do Pavilhão Philips, enquanto trabalhava no escritório de Le Corbusier, empregou processos matemáticos para determinar a forma da estrutura da cobertura da construção. No livro que a Philips publicou para descrever esse pavilhão, Xenakis diz que os cálculos proporcionaram a forma característica da estrutura, mas que, feito isso, a lógica não funcionou mais e a composição final teve de ser decidida com base na intuição. (COLQUHOUN, in NESBITT, 2008 p. 278) ${ }^{116}$

116 Michael Forsyth também relata como Xénakis, músico e matemático, relacionou a música e arquitetura através de modelos matemáticos, na composição Metastaseis de 1953 e no Pavilhão da Philips para a Exposição Universal de Bruxelas em 1958, como colaborador do escritório de Le Corbusier, com quem trabalhou por 12 anos. 


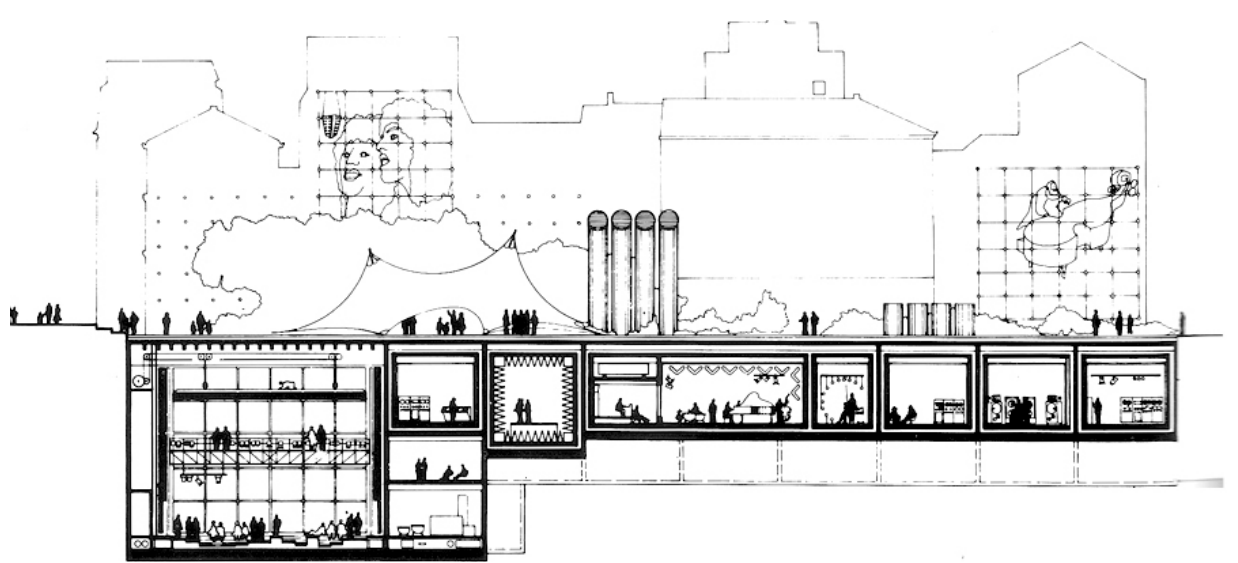

Corte Longitudinal Auditórios Fonte: A+U 12/1998

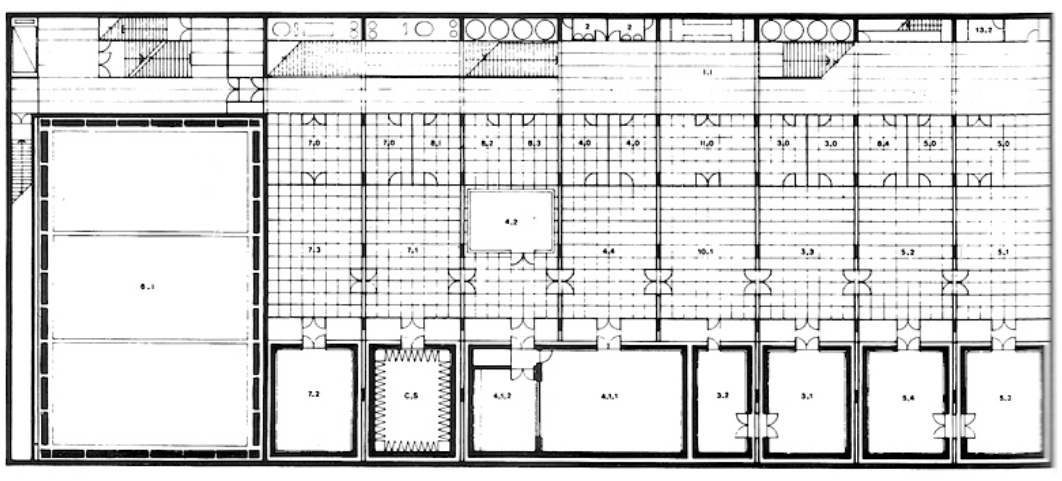

Planta

Fonte: A+U 12/1998

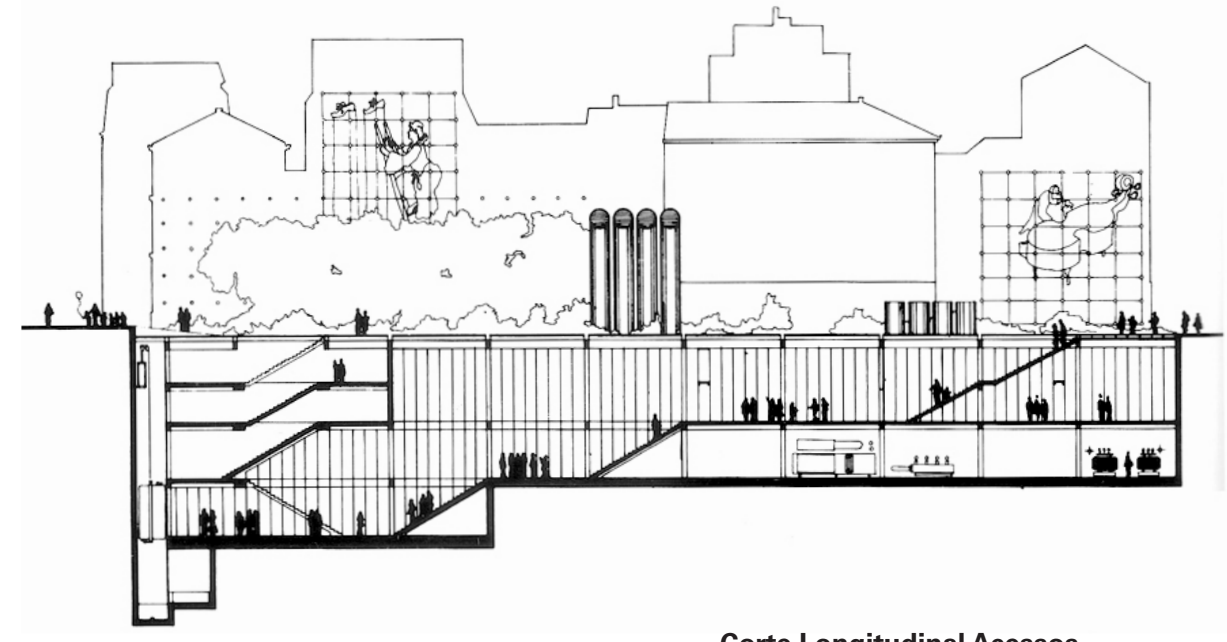

Corte Longitudinal Acessos Fonte: A+U 12/1998

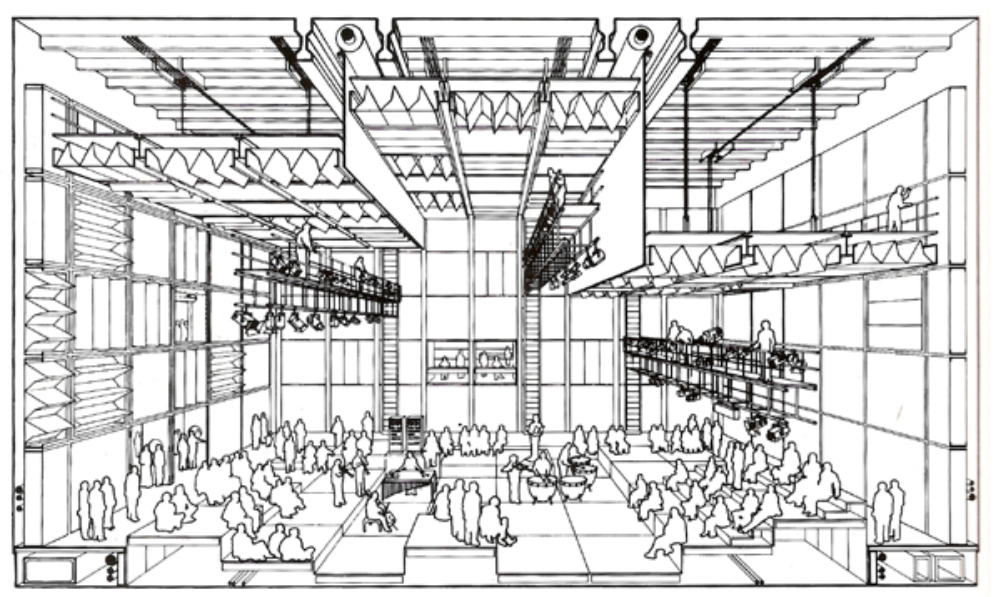

Auditório Perspectiva Fonte: A+U 12/1998 
Capítulo 5

a Arquitetura do Espetáculo e a Arquitetura Moderna de São Paulo 
Para lançar luz sobre o território de estudo escolhido nesse trabalho, o presente capítulo traça um panorama analítico de obras significativas da Arquitetura Moderna em São Paulo que possuem relação com a arquitetura do espetáculo. São conhecidas, dentro da obra de mestres como Rino Levi, Lina Bo Bardi e Paulo Mendes da Rocha ${ }^{117}$, intervenções na cidade e em especial no centro de São Paulo que foram determinantes no panorama artístico em que se inseriram, e ainda continuam sendo edifícios dignos de citação e estudo.

117 A obra de Paulo Mendes da Rocha selecionada, o MUBE - Museu Brasileiro da Escultura, foi tratado no capítulo 2, O Lugar da Arquitetura do Espetáculo, por sua estreita relação com a construção de uma nova geografia do lugar. 


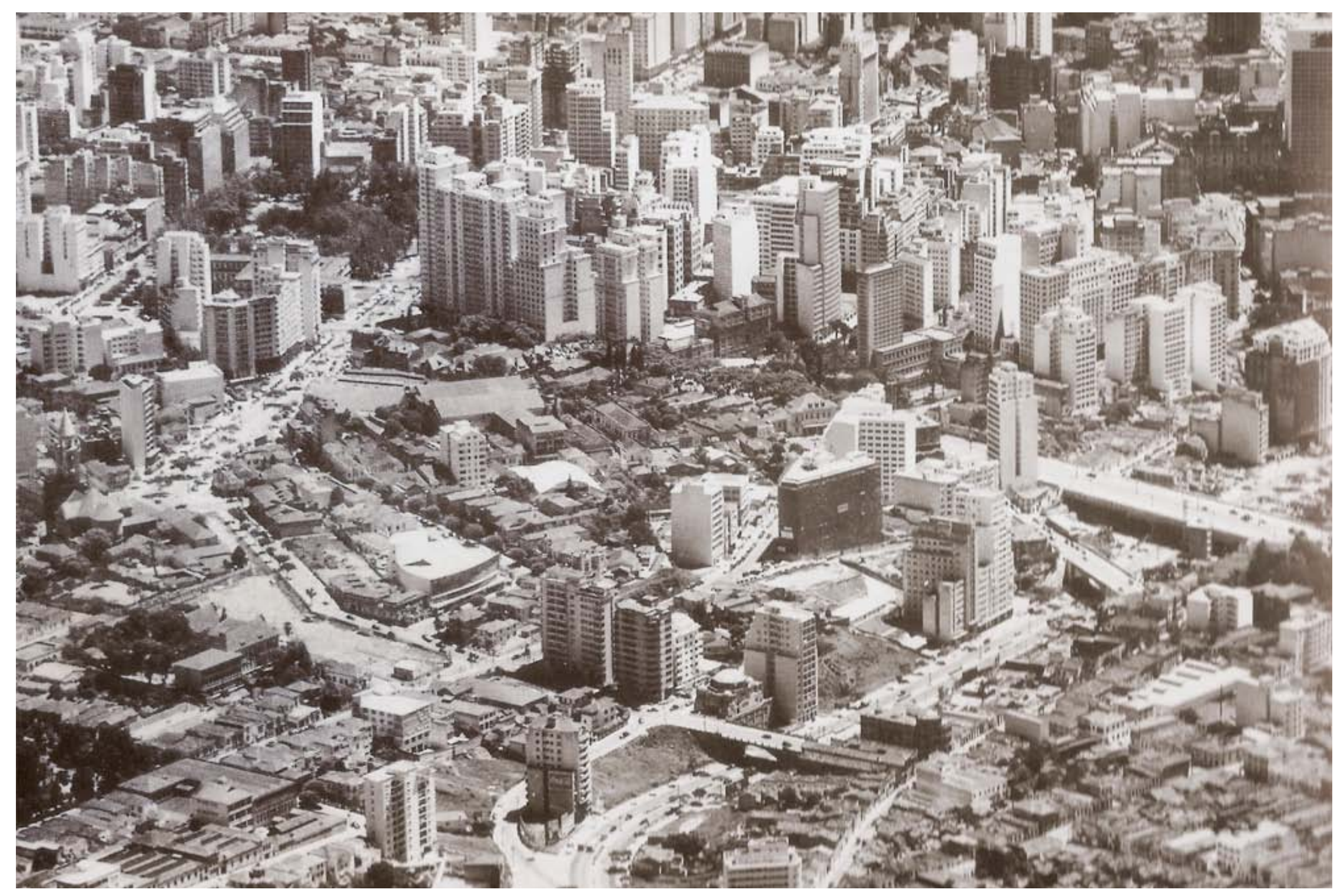

São Paulo, vista aérea, final da década de 1940. À esquerda o Teatro Cultura Artística e à direita o

terreno dos diários associados, junto ao vale da avenida Nove de Julho. Fonte: SEGAWA, 2012 
(...) por volta de 1930, para o cinema falado que, graças à sua própria pista sonora, é independente da acústica da sala (tinha-se o habito de desenhar salas de cinema o mais "mortas" possível, até o momento em que se tomou consciência de que o som direto de um alto falante, privado de qualquer reflexão sobre as superfícies murais, parece muito artificial; atualmente, concebem-se salas de cinema com uma acústica ligeiramente "viva", de tal forma que o espectador se sinta envolvido pelo som gravado).

(CREMER e MULLER, apud FORSYTH, 1985, p.253-254) $)^{118}$

Dentre os inúmeros programas a que o escritório Rino Levi se dedicou, os cinemas e teatros foram, sem dúvida, um dos que mais marcaram sua longa trajetória, em especial aqueles edificados nas décadas de 1930 e 1940, quando o escritório se firmara no cenário da arquitetura em São Paulo. As obras realizadas nesse período comprovam o perfil interdisciplinar que Rino Levi empreendeu às equipes coordenadas por ele e posteriormente por seus associados, sendo

\section{O Espetáculo segundo Rino Levi} responsável pela qualidade técnica da arquitetura praticada.

118 Nossa tradução do texto original: (...) vers 1930, pour le cinéma parlant qui, grâce à sa propre piste sonore, est indépendant de l'acoustique de la salle lon avait l'habitude de dessiner les salles de cinéma aussi "mortes" que possible, jusqu'au moment où l'on a pris conscience que le son direct d'un haut-parleur, privé de toute réflexion sur des surfaces murales, semble très artificiel; à l'heure actuelle, on conçoit les salles de cinéma avec une acoustique légèrement "vivante", si bien que l'auditeur se sent enveloppé par le son enregistré). 

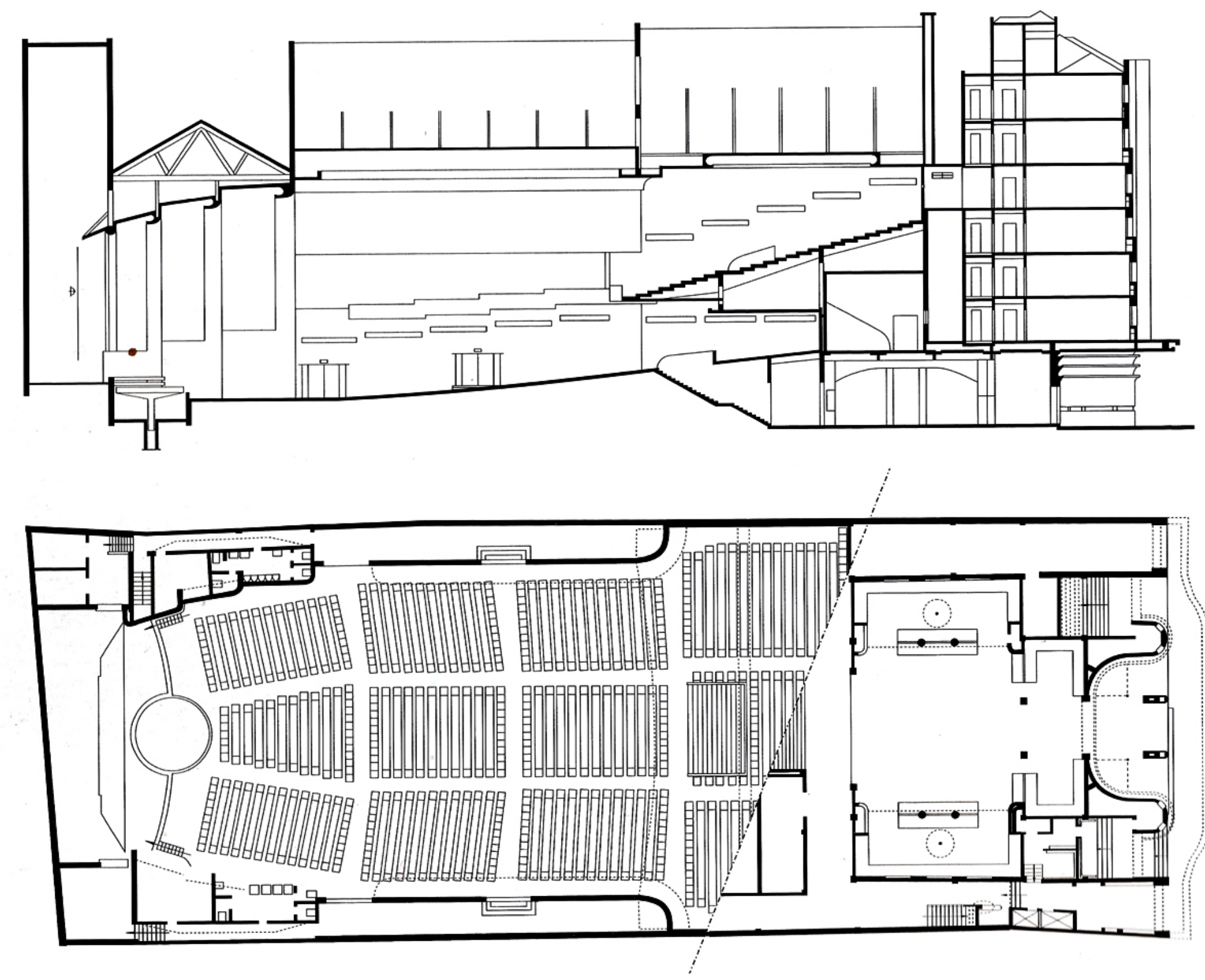

Planta e corte Longitudinal, escala 1:500. Cine Ufa Palácio. Fonte: ANELLI, 2001 


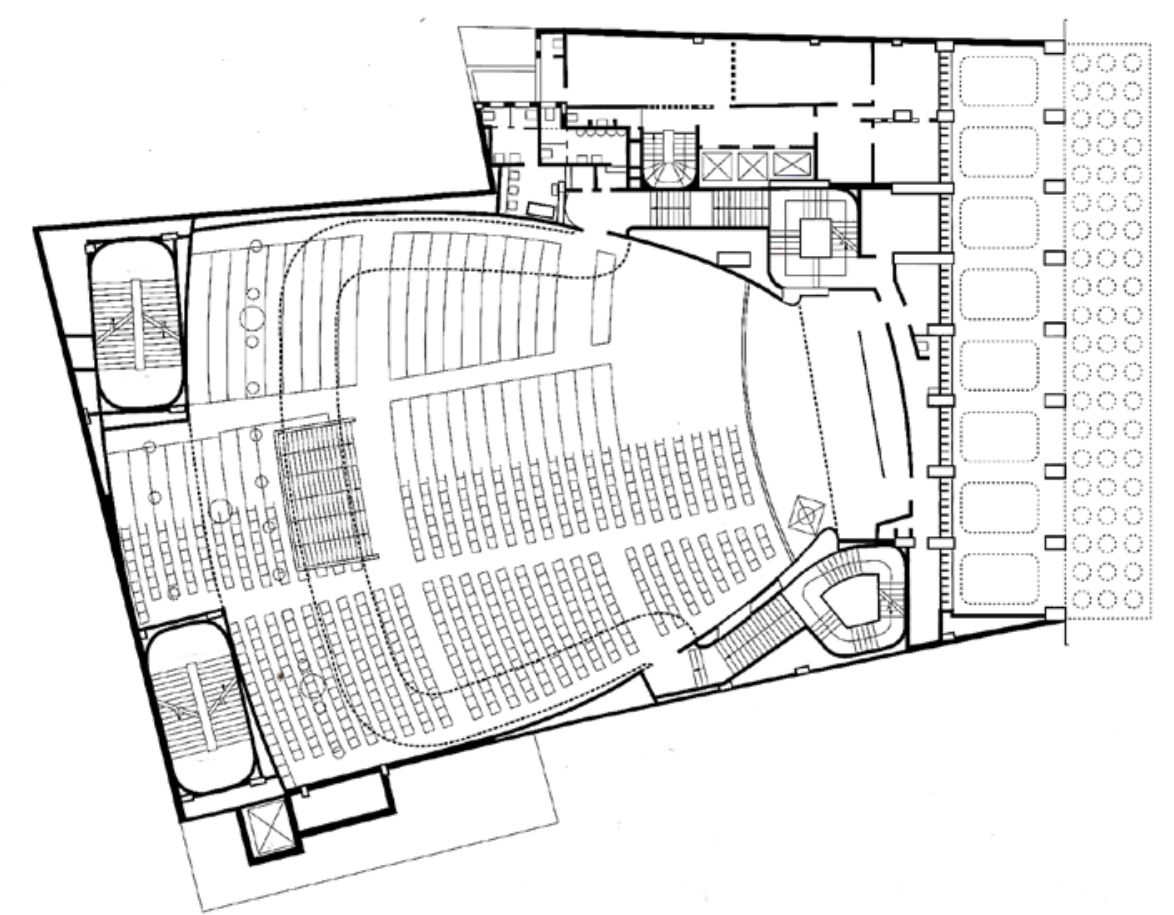

Planta platéia

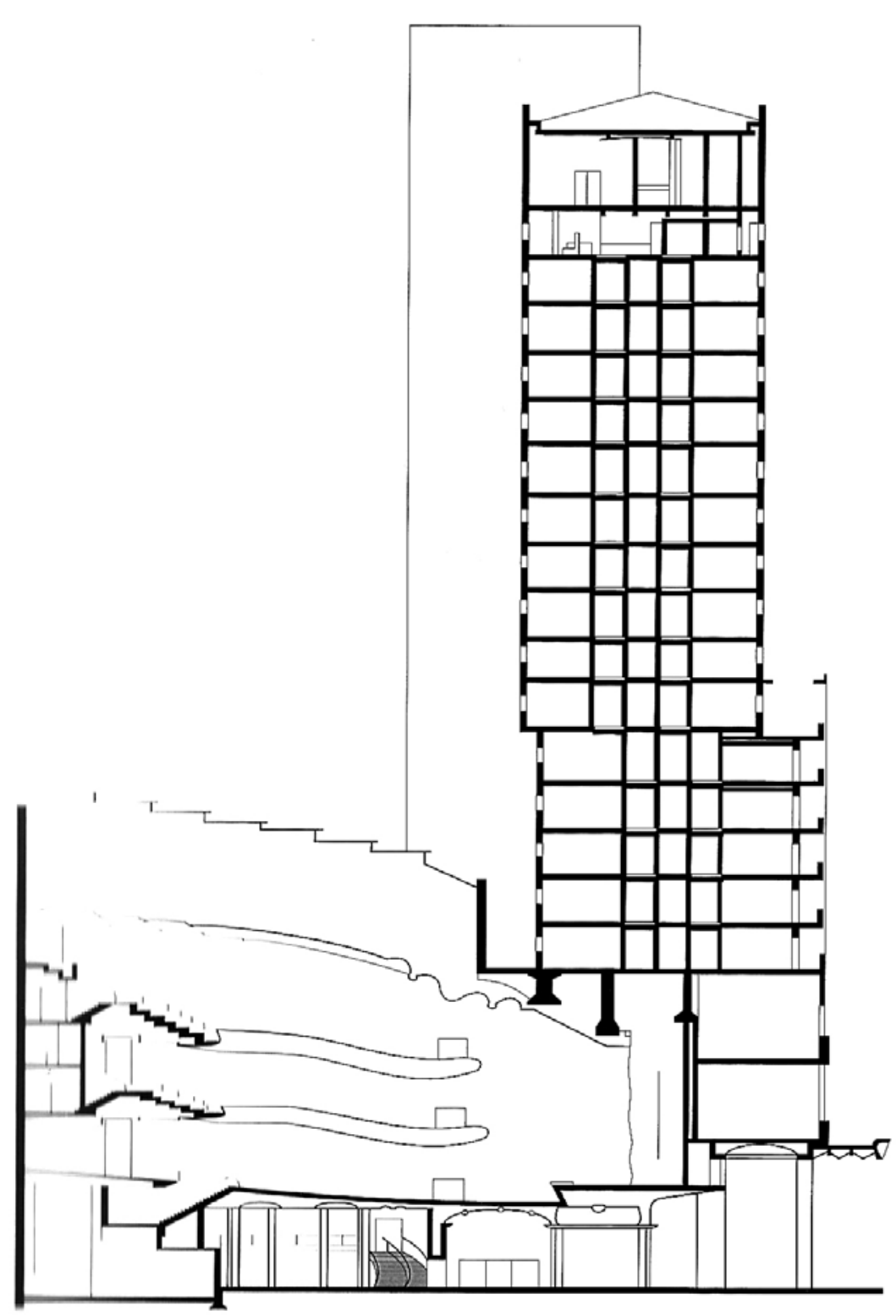

Corte Longitudinal, escala 1:500. Hotel e Cine Ipiranga. Fonte: ANELLI, 2001 
Conforme assinala Renato Anelli (2001 p. 179$183)^{119}$, na obra de Rino Levi, os projetos dos cinemas constituem o primeiro programa a exigir a incorporação de conhecimentos científicos capazes de influenciar a concepção da forma. Rino Levi trouxera de sua formação na Itália as preocupações do desenho da sala baseado na curva de visibilidade e nos princípios acústicos de reflexão. Dessa maneira, o resultado não seria mais decorrente da simples correção do projeto para atingir a qualidade técnica desejada. Ao contrário, o desenho da sala, ou seja, a maior liberdade na definição da forma, muito mais próxima dos preceitos da Modernidade, seria decorrente do bom uso desses conhecimentos.

Como mostram os estudos desenvolvidos por Anelli, a sólida formação científica e a capacidade de trabalhar em equipe permitiram a Rino Levi aperfeiçoar tais projetos durante esse período, culminando com a obra mais significativa, o Teatro Cultura Artística ${ }^{120}$ em 1942, em que todo esse conhecimento pôde ser ainda mais aprimorado.

Além dos aspectos científicos para a concepção das salas, é importante assinalar dois outros de interesse para nosso tema.

Em primeiro lugar, assim como fez desde o primeiro cinema projetado, o Ufa- Palácio de 1936 em São Paulo, houve a previsão de palco com caixa cênica, proscênio com plataforma levadiça, fosso de orquestra e camarins, o que demonstra a preocupação de equipá-los para o uso em espetáculos teatrais e musicais, além de sua função primordial: a projeção cinematográfica.

Em segundo lugar, as salas foram associadas a conjuntos multifuncionais, que previam de habitação a hotéis, o que introduziu uma dificuldade a mais na definição da localização e no desenho de tais salas:

Não se trata mais de uma simples sobreposição ou justaposição dos dois volumes funcionais, mas de um projeto em que eles interagem de forma complexa, resultando num conjunto com grande tensão interna para a obtenção de alguma organicidade do todo.

(ANELLI, 2001, p. 183)

119 Ver também ANELLI, Arquitetura de Cinemas em São Paulo, in Textos Fundamentais sobre História da Arquitetura Moderna Brasileira: v.1, org. Abílio Guerra - São Paulo, Romano Guerra, 2010

120 A Sociedade de Cultura Artística, fundada em 1912, foi responsável pela construção do teatro e por sua manutenção em atividade até o incêndio de 2008. A Sociedade reconstrói atualmente o Teatro no mesmo local, com projeto do escritório Paulo Bruna Arquitetos Associados. 


\section{o Cultura Artística}

e a Praça Roosevelt

Como vimos no capítulo O Lugar da Arquitetura, o Cultura Artística, como ficou conhecido o Teatro, foi uma das obras responsáveis pela vocação dessa região do centro da cidade de São Paulo, voltada para o espetáculo. Localizado a meio caminho entre o centro novo e o bairro da Bela Vista, onde os teatros se instalaram nas décadas seguintes ${ }^{121}$, tornou-se referência como sala de concertos, mantendo atividade intensa nessa área durante mais de seis décadas, o que contribuiu para a retomada desse espaço urbano da cidade, representado pela Praça Roosevelt. Em outras palavras, se não foram os concertos realizados há décadas no local responsáveis diretamente por essa reconquista, eles são, sem dúvida, fundamentais para sua permanência e para a continuidade ativa dessa importante região da cidade ${ }^{122}$.

Podemos admitir que as qualidades constituintes da obra permitiram sua identificação, que ela se tornasse referência, percebida não só por seus frequentadores mas tam-

121 Sobre o tema, ver BECKER, 2000. A degradação da área se deu posteriormente nas décadas de 1980 e 1990, após a construção da Praça Roosevelt, como parte da ligação rodoviária leste-oeste da cidade, na década anterior. Ver capítulo O Lugar da Arquitetura do Espetáculo.

122 Devemos lembrar ainda do Cine Bijou, localizado na mesma quadra do Cultura Artística, o primeiro especializado no cinema de arte alternativo ao circuito comercial, que manteve seu funcionamento de 1960 até 1995. bém pela população em geral que circula diariamente pelo bairro. A foto aérea mostra com clareza a presença marcante do Teatro frente à praça em formação, materializando o marco referencial da arquitetura da cidade.

As peças de xadrez devem ser colocadas para fortalecer e ampliar a vitalidade existente e também ajudar a equilibrar, nos locais estratégicos, os desequilibrios de horários existentes. (JACOBS, 2009, pg. 185.)

\section{Teatro Cultura Artística,} $1942-2014$

A arquitetura de Rino Levi é um discurso sobre o discurso de Mendelsohn, Gropius e Le Corbusier. (ZEVI, B. apud ARANHA, 2010, pg. 51)

Apesar de sua capacidade relativamente generosa para a época, 1.560 lugares, a sala principal do Teatro Cultura Artística, projetado por Rino Levi em 1942, esteve sempre à frente entre as melhores salas de concerto de São Paulo.

Sua plateia característica em leque, com pouca profundidade e grande largura, foi a resposta encontrada por 


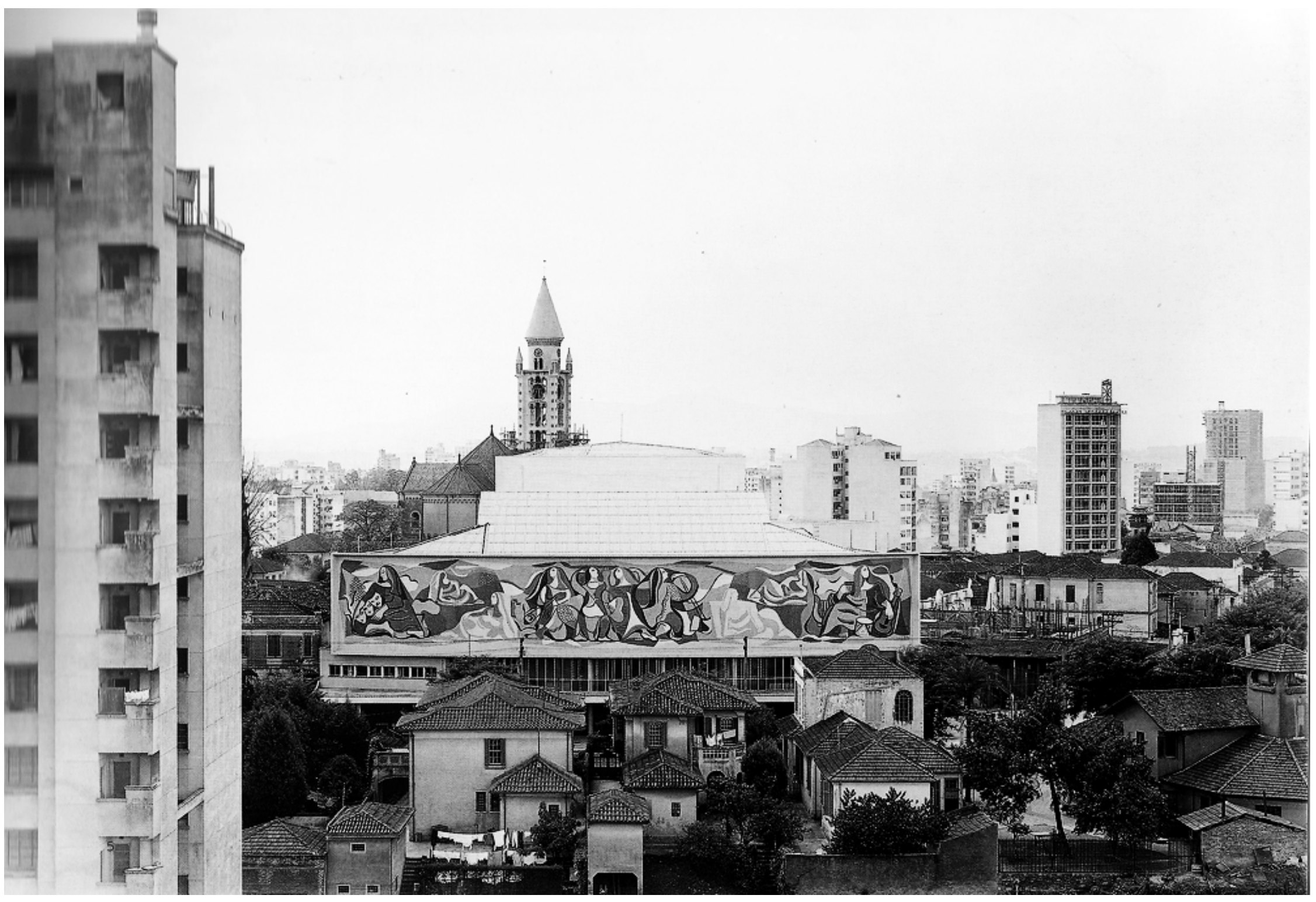

Teatro Cultura Artística. Vista da fachada painel Di Cavalcanti. Fonte: ANELLI, 2001. 
Rino Levi e Roberto Cerqueira Cesar ${ }^{123}$ para responder ao primeiro desafio encontrado: as limitações físicas do terreno. A forma que segue os preceitos de difusão do som contraria a solução retangular, historicamente consagrada, adotada nas principais salas europeias e norte-americanas desde o século XIX. Segundo Michael Forsyth (1985, p. 256), nas décadas de 1920 e 1930 os arquitetos europeus iniciam o uso de um diagrama geométrico para determinar a totalidade da forma da sala, em corte e em planta, seguindo o trajeto do som tal qual ele é emitido em um auditório. São exemplo conhecidos desse princípio a Câmara de Debates da Sala das Nações de Le Corbusier, de 1927, e a primeira grande sala construída, a Sala Pleyel em Paris, também de 1927, dos arquitetos Aubertin, Granel e Mathon.

Como pode ser observado na página 210 e 211, a sala principal do Cultura Artística ocupa a totalidade do lote, cujo perímetro irregular tem na ampla testada voltada para a rua Nestor Pestana sua principal qualidade. A solução proposta elevou a grande sala em relação à rua, o que permitiu a criação dos acessos principais, protegidos por

123 Nesse momento, Rino Levi já tinha Roberto Cerqueira Cesar como associado. uma marquise, que avança sobre o passeio, o que os arquitetos chamaram de "pórtico de entrada". Permitiu assim atingir a capacidade de público desejada e ainda criar outra sala de menor capacidade, sob a plateia elevada, além de distribuir todas as áreas de apoio, como camarins, depósitos e áreas técnicas.

O foyer no nível do térreo, em continuidade com a

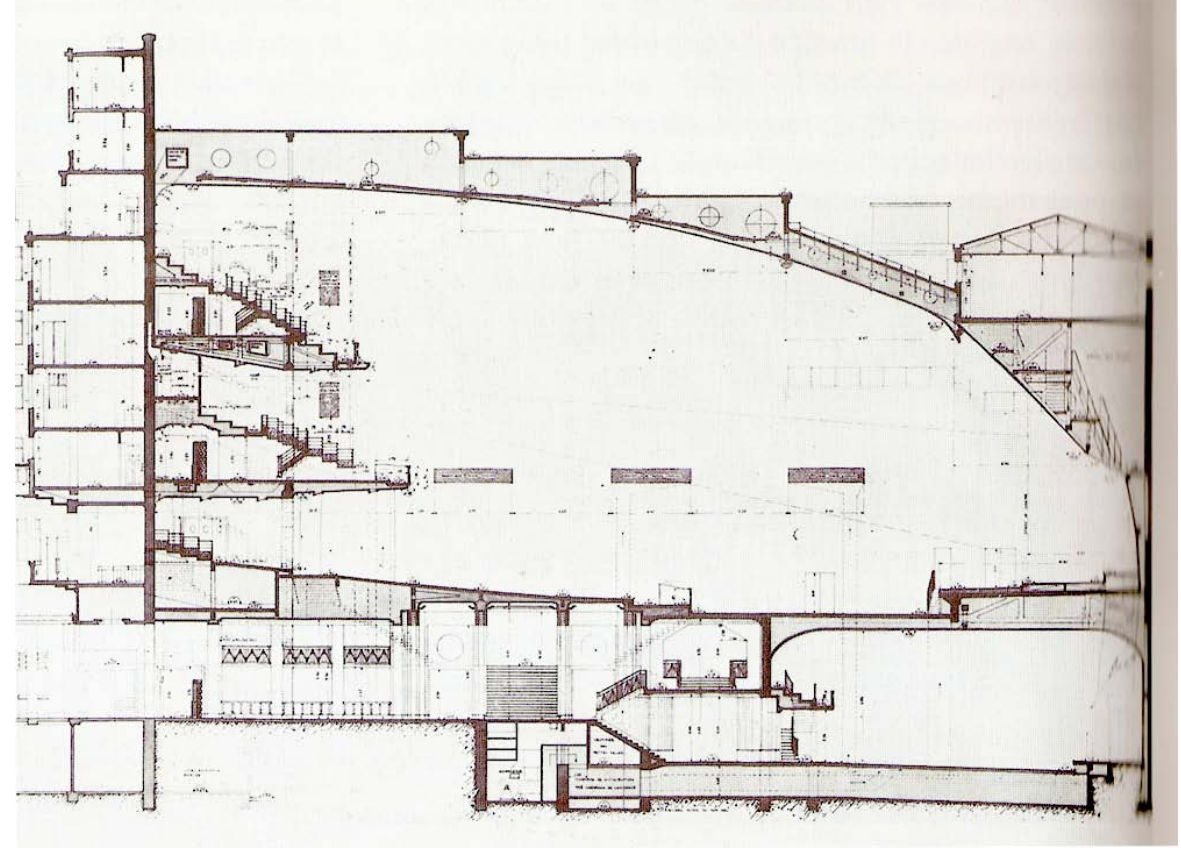

Corte longitudinal. Sala Pleyel-Paris. Fonte: FORSYTH, 1985 


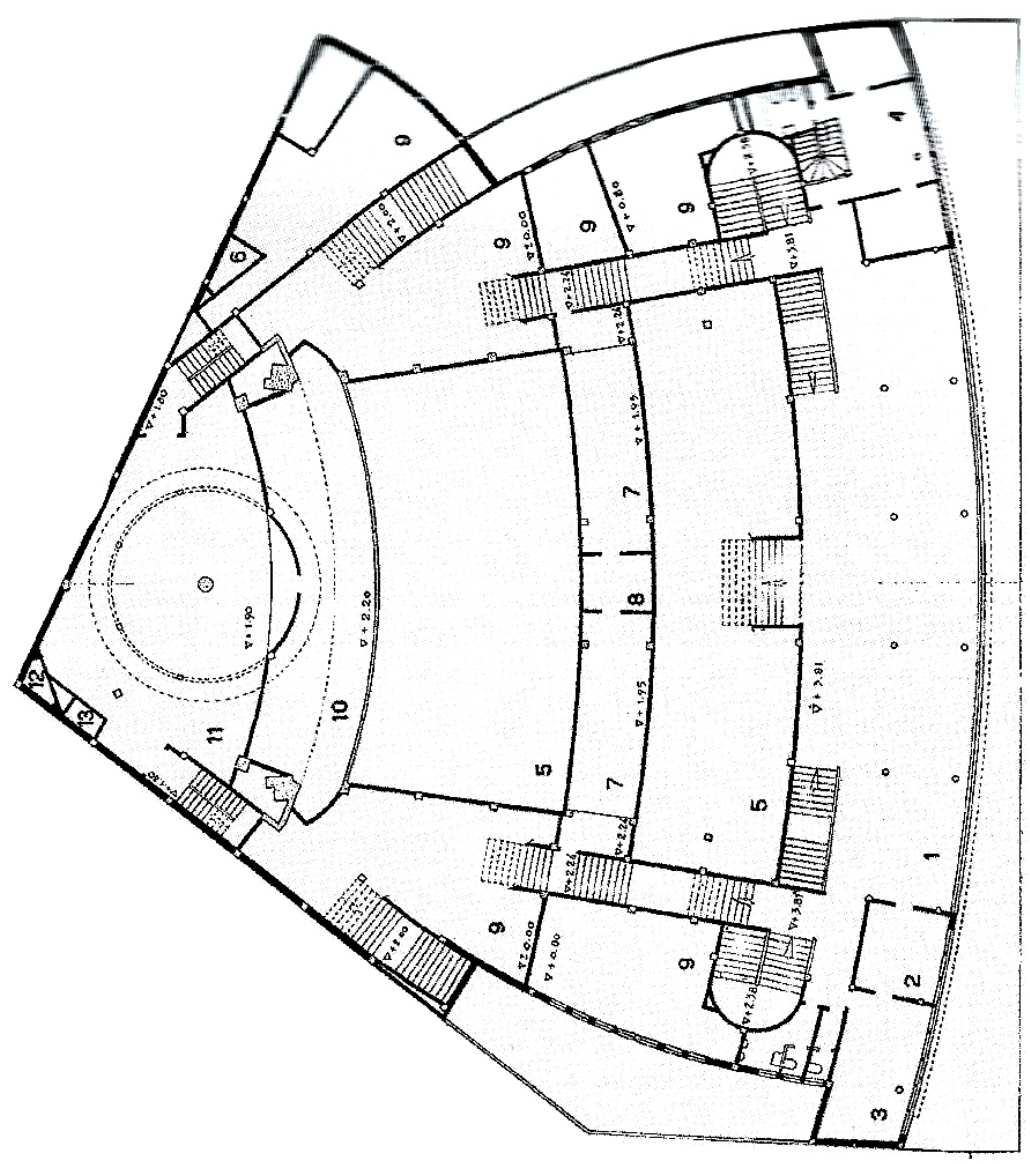

Planta inferior, escala 1:500

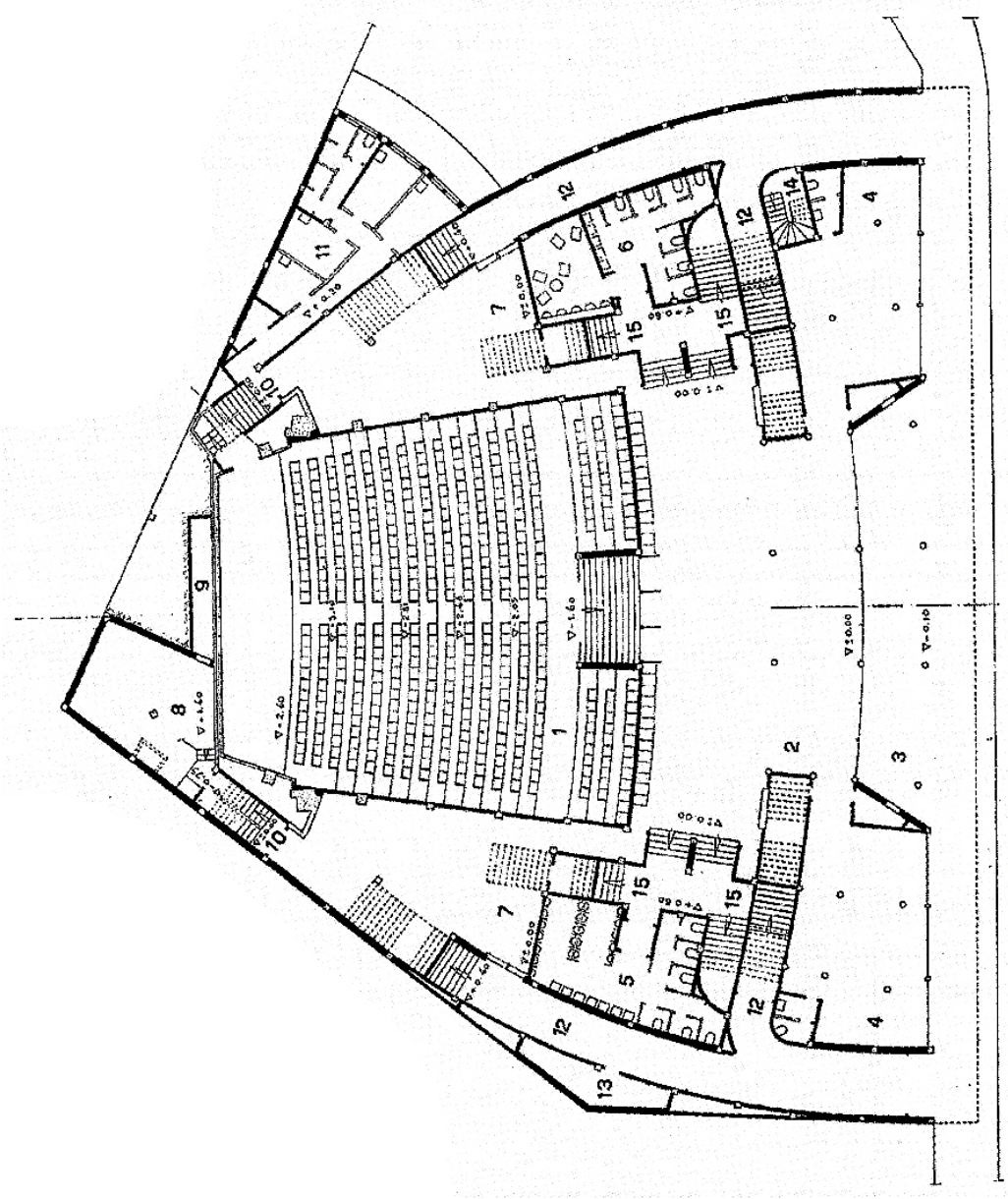

Planta térreo-platéia pequeno auditório, escala 1:500 


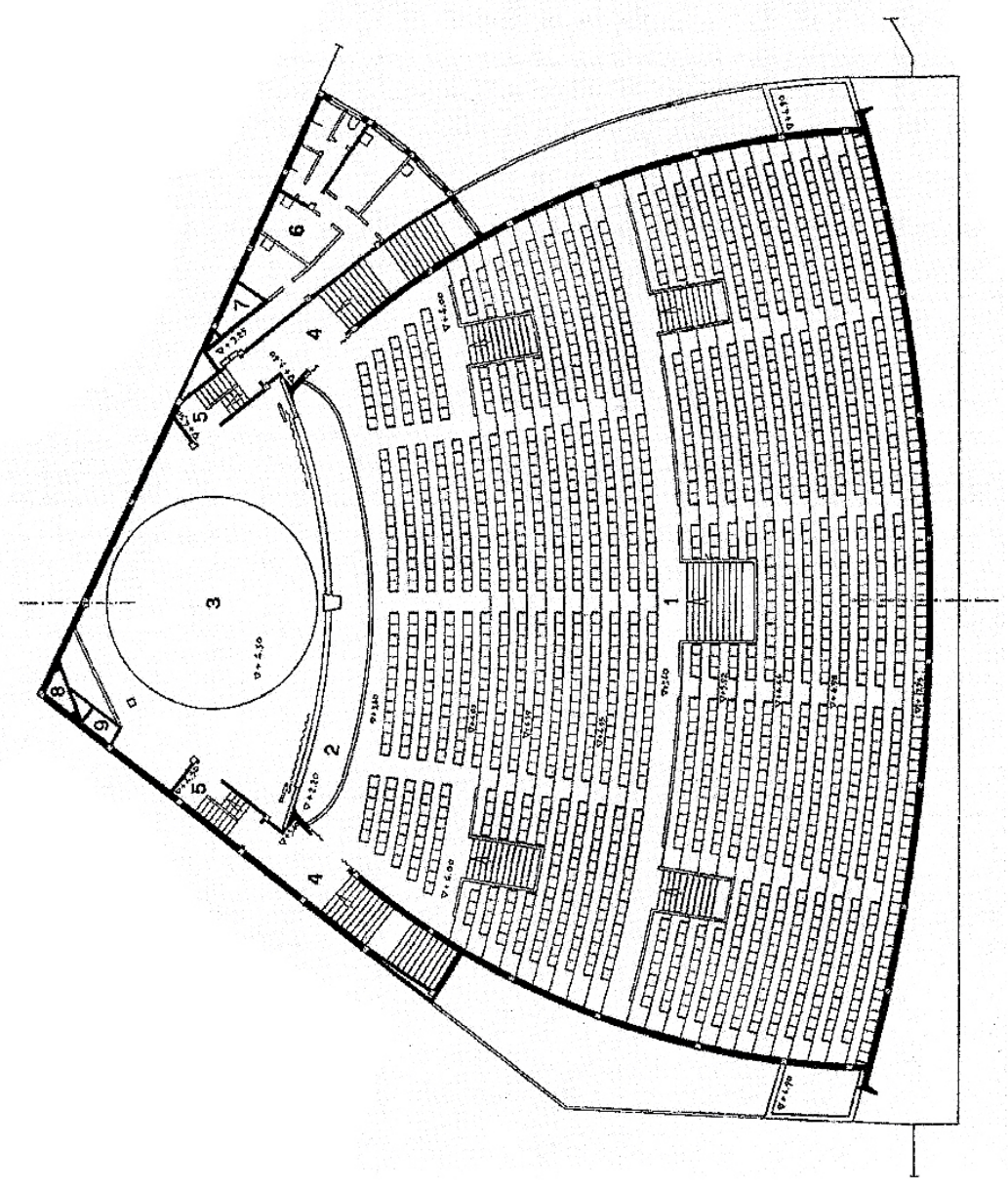

Planta Superior-platéia grande auditório, escala 1:500

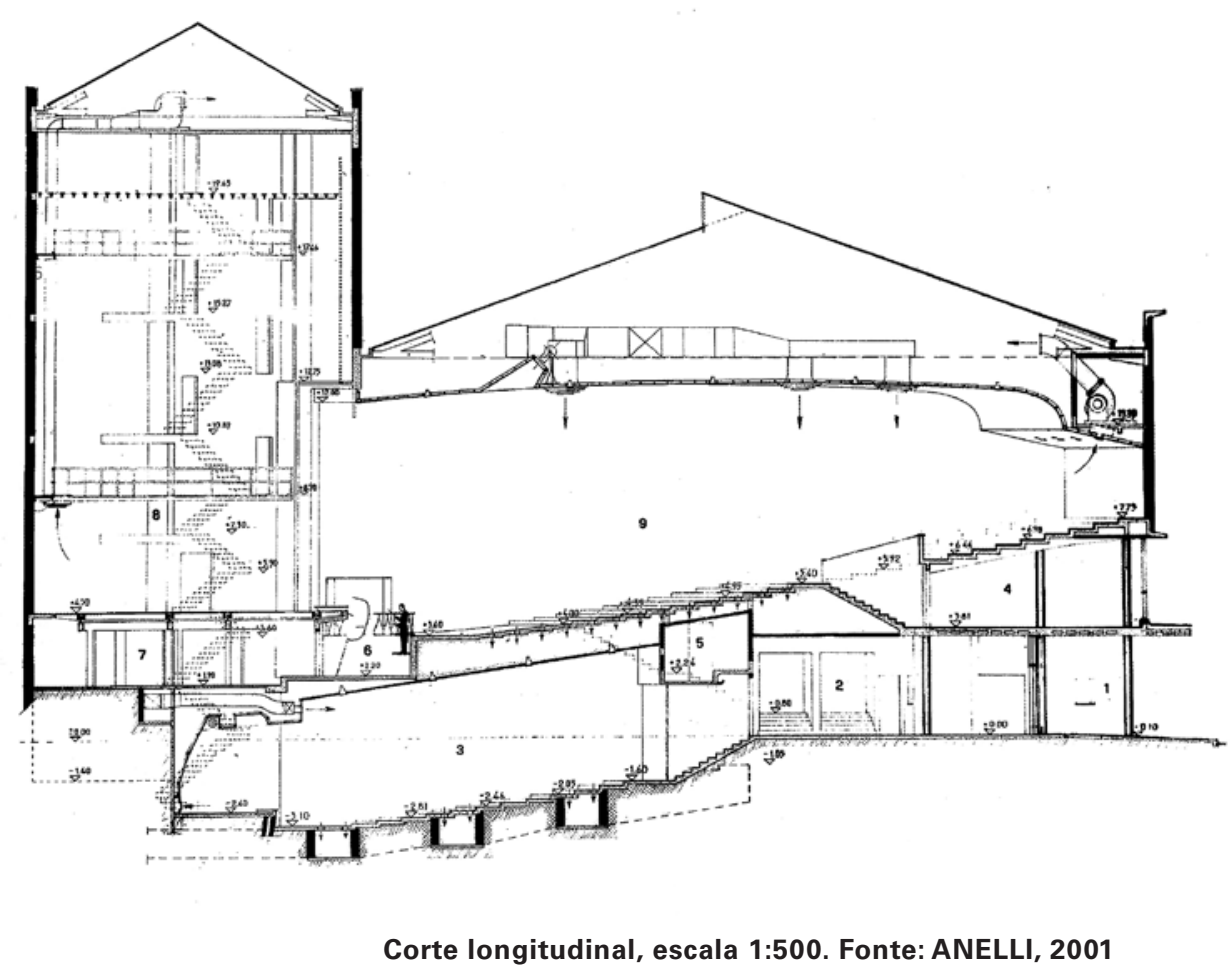


marquise e o superior, que atende à sala principal, são amplamente envidraçados. Diferente do ritual das seções cinematográficas, os concertos e os espetáculos teatrais exigem amplos espaços de convivência, em que o público é recebido, aguarda os intervalos e permanece, mesmo após o seu término. É esse um dos aspectos relevantes do projeto: a integração entre as áreas sociais, que os arquitetos chamaram de "foyer e exposição de artes plásticas", e a cidade, a continuidade entre o espaço público e o teatro, a demonstração visual da movimentação e da dinâmica do lugar do espetáculo como concepção de uma fachada urbana.

A engenhosa articulação encontrada para resolver o programa é responsável então pela qualidade da arquitetura proposta. É a decisão de elevar o grande volume representado pela sala principal que introduz, a partir do Teatro Cultura Artística, uma das características da arquitetura de Rino Levi nas décadas seguintes, que já se manifestara nos projetos anteriores dos cinemas, mas que agora se consolida de maneira definitiva. Para essa arquitetura, o aprofundamento dos aspectos técnicos, fundamentais na Modernidade, são superados pelas noções de consistência visual em respeito à cidade. Rino Levi trata o fundo da plateia voltado para a rua com um grande painel em mosaico vidroso $^{124}$, criado pelo artista plástico Di Cavalcanti, que, valorizado pela transparência dos foyers envidraçados, pode ser identificado e admirado, representando uma proposta de integração entre as artes e a arquitetura vinda dos ensinamentos da Bauhaus, e que o arquiteto utilizara em espaços internos de outros projeto ${ }^{125}$, mas que nesse momento torna-se primordial para a construção da qualidade estética da obra perante a cidade.

Em 2008 um incêndio de grandes proporções marcou a destruição do teatro. Todo o seu interior foi destruído, restando como testemunho a fachada com o painel de Di Cavalcanti, por ter sido solidamente estruturada durante sua construção. A decisão da Sociedade de Cultura Artística em reconstruir o teatro no mesmo local vem ao encontro do desejo de dar continuidade e de consolidar as atividades

124 Antes do Cultura Artística, em 1938, o Ministério da Educação e Saúde no Rio de Janeiro, projeto de Lúcio Costa, Oscar Niemeyer, Affonso Eduardo Reidy, Jorge Moreira, Ernani Vasconcellos e Carlos Leão, utilizou painéis em azulejo de autoria de Cândido Portinari nos volumes sob os pilotis, uma clara intenção de integrar a arte com o espaço público. Mas Rino Levi vai além ao usar a arte como definidora da forma, como a própria fachada do teatro.

$125 \mathrm{Na}$ década anterior Rino Levi contou com a colaboração de artistas com Joun Graz e José Wancole para o projeto de interiores de residências e de apartamentos. 
culturais que o bairro tem retomado desde o início da década de 2000, como vimos.

o projeto de arquitetura é um processo formativo constituído por uma série concatenada de juízos estéticos que - em dialética constante entre intuição e conhecimento, entre sentido da forma e sentido comum - culmina com a construção de uma estrutura formal consistente. (PIÑON, 2006, p. 90)

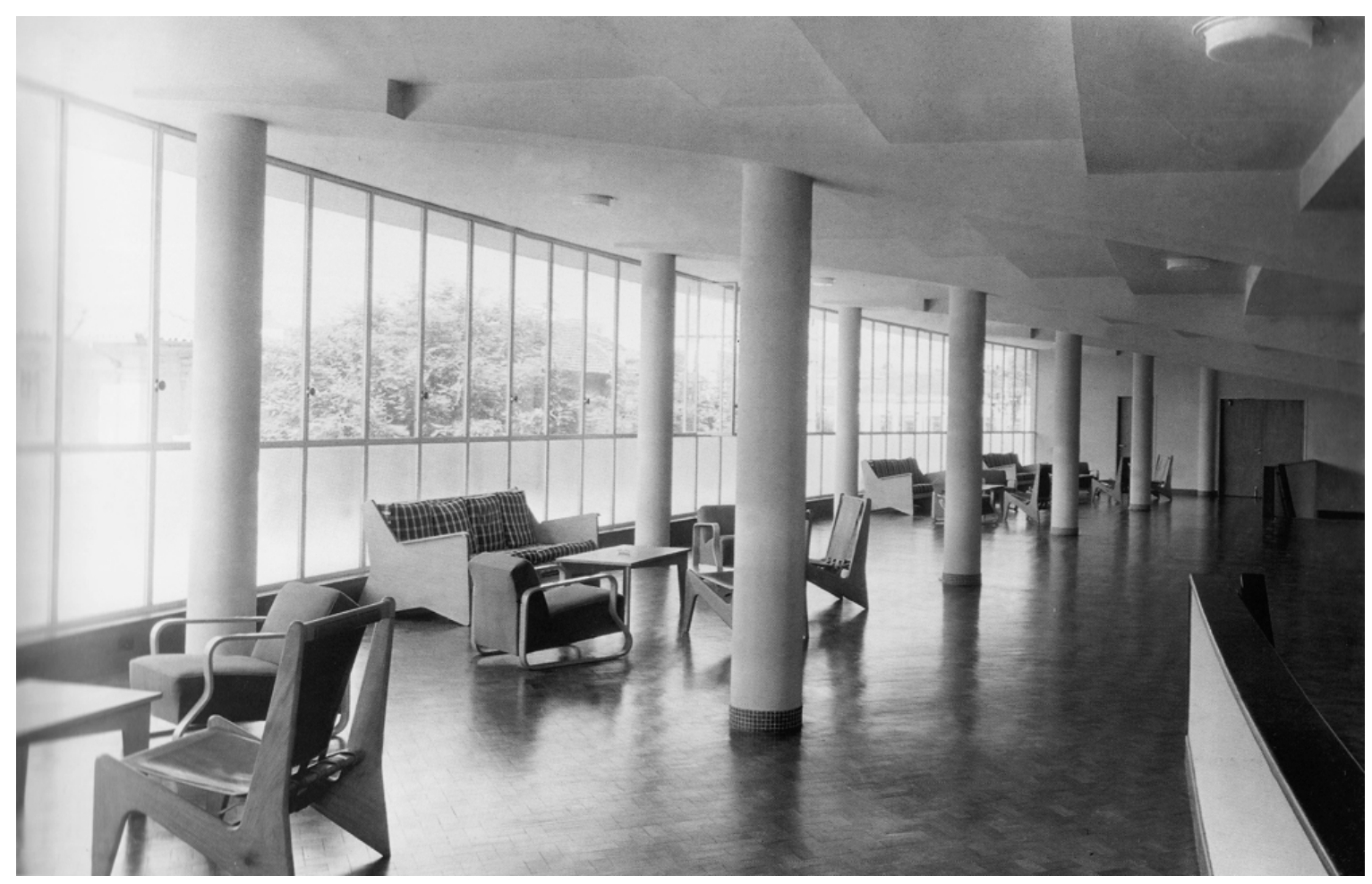

Foyer Superior. Fonte: ANELLI 2001 


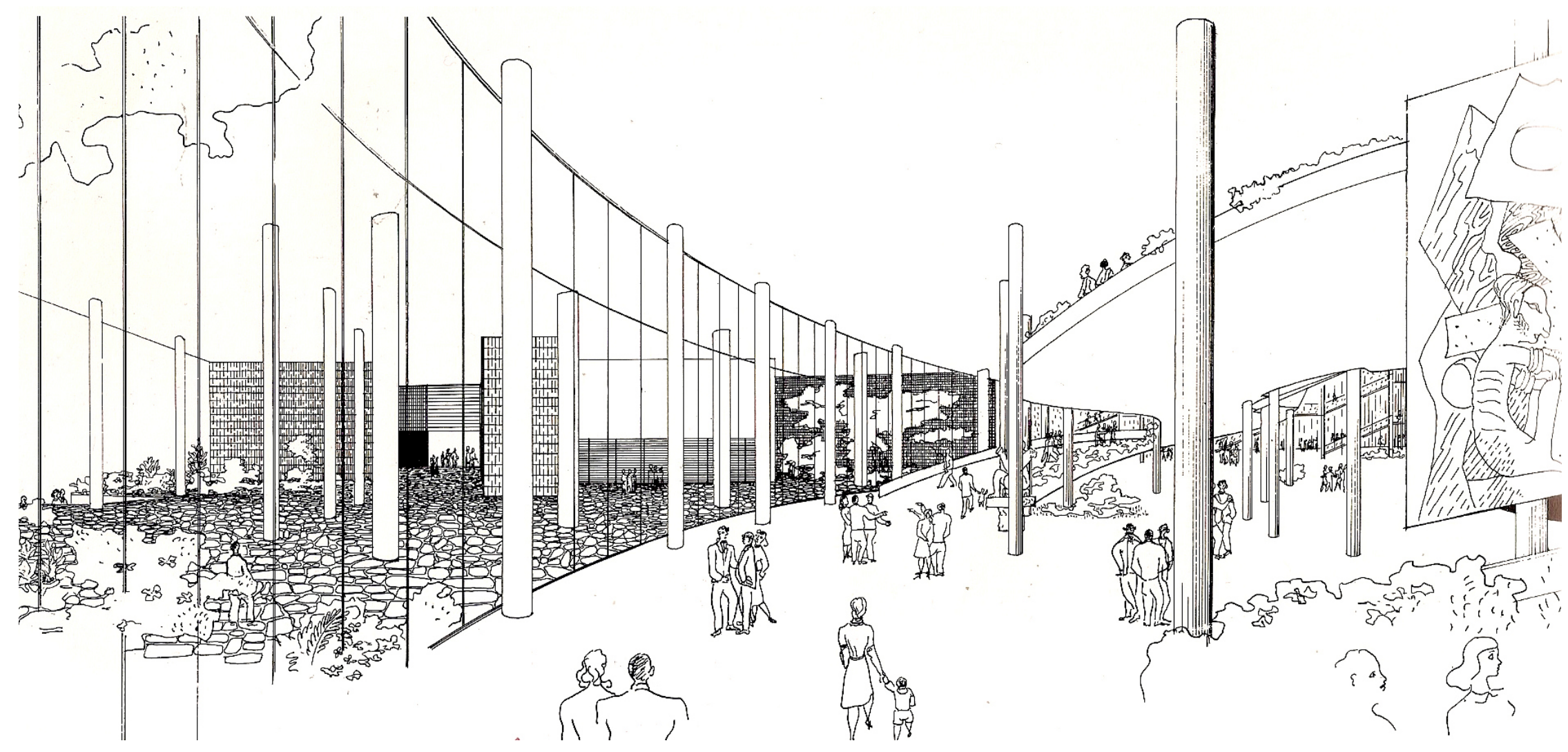

Edifício Diários Associados. Acesso auditório. Fonte: FERRAZ, 1993 
A obra de Lina Bo Bardi tem sido estudada intensamente nos últimos anos. Seus projetos de teatro realizados para o Grupo Oficina e para o Sesc Fábrica Pompéia têm merecido destaque ${ }^{126}$, em particular por sua contribuição para a compreensão da linguagem teatral contemporânea, na busca da essência do teatro enquanto ingrediente de sua arquitetura de acentuada "sensibilidade acerca da vivência humana”, nas palavras de Evelyn F. Werneck Lima. ${ }^{127}$

Há entretanto os projetos desenvolvidos para os Diários Associados em 1947 e 1951, em São Paulo, que ainda

Edifício Diários Associados Edifício Taba Guaianases - São Paulo merecem um olhar mais atento para a compreensão do lugar do espetáculo dentro das propostas da arquiteta.

126 Sobre o assunto ver: BARDI, LINA BO. TEATRO OFICINA SÃO PAULO,1999 BARDI, LINA BO. Lina por Escrito, São Paulo, 2011.

FERRAZ, Marcelo Carvalho - Lina Bo Bardi, 1993.

OLIVEIRA, Olivia - Lina Bo Bardi, Sutis Substâncias da Arquitetura, 2006.

127 LIMA, Evelyn F. Werneck - Por uma revolução da arquitetura teatral: o Oficina e o SESC da Pompéia. http://www.vitruvius.com.br/revistas/read/arquitextos/09.101/100 


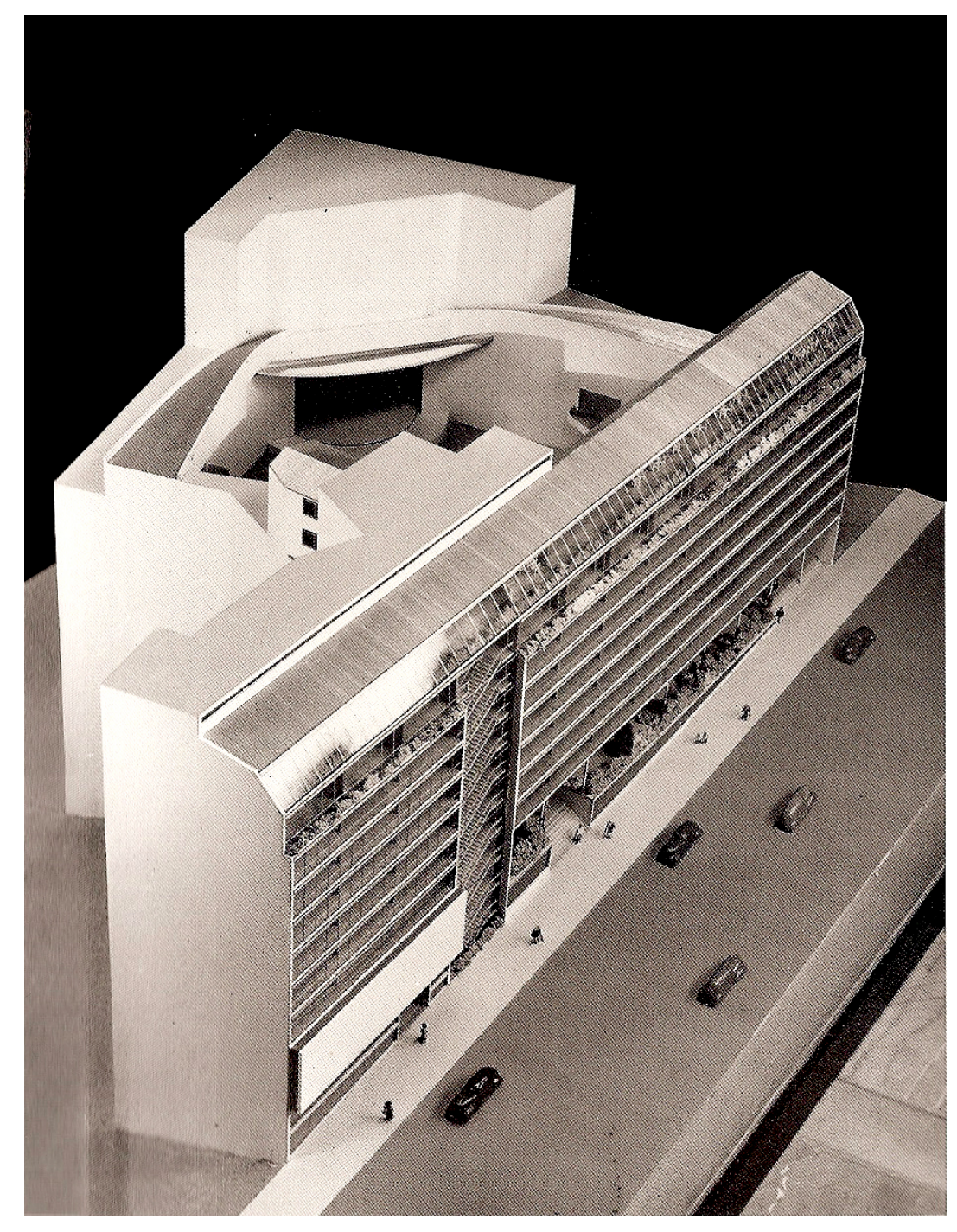

Maquete, vista da rua Álvaro de Carvalho. Fonte: FERRAZ, 1993
Os dois projetos, de 1947 e 1951, foram desenvolvidos para o mesmo terreno situado no bairro da Bela Vista, em São Paulo, delimitado pela rua Álvaro de Carvalho, o Viaduto Major Quedinho e a avenida Nove de Julho. 0 exame das implantações indica entretanto que à versão de 1951 fora acrescentada uma nova área, o que permitiu a ampliação do programa do empreendimento. A versão original possuía frente apenas para a rua Álvaro de Carvalho.

Na primeira proposta foi previsto um teatro-auditório para 2.500 lugares, um auditório para 350 lugares e um edifício de escritórios, além de todas as áreas técnicas e de apoio necessárias.

Ao examinarmos o material disponível, como as plantas e corte apresentados nas páginas seguintes, vemos que o teatro-auditório é o volume mais significativo, ocupando cerca de dois terços do lote. Ele ocupa a parcela posterior, deixando livre a extensa fachada voltada para a rua Álvaro de Carvalho. Lina Bo Bardi resolve a disposição e a geometria da sala com extrema habilidade, apropriando- 
-se da conformação original do lote e propondo a plateia em leque, solução adequada para grandes capacidades de público, onde seriam apresentados espetáculos para rádio e, futuramente, poderiam ser usados para a televisão que estava nascendo.

Ao elevar esse grande volume em relação à rua, como mostra o corte transversal, foi possível criar um foyer de grandes proporções em pilotis, totalmente integrado com o espaço urbano. Além dos sistemas de circulação vertical e de segurança necessários para esse tipo de programa, o elemento mais marcante nesse espaço semi-público criado são duas largas rampas elípticas que reforçam a presença da geometria da sala, e podemos dizer que é o único elemento a ser percebido de quem da rua observa, ou seja, a peça de maior valor plástico.

Assim como no Auditorium Building, o edifício de escritórios é que faz a relação do conjunto com o espaço urbano, como uma proteção, um filtro urbano, contribuindo também aqui para a proteção e o isolamento necessários para resolver as questões acústicas exigidas. É essa extensa

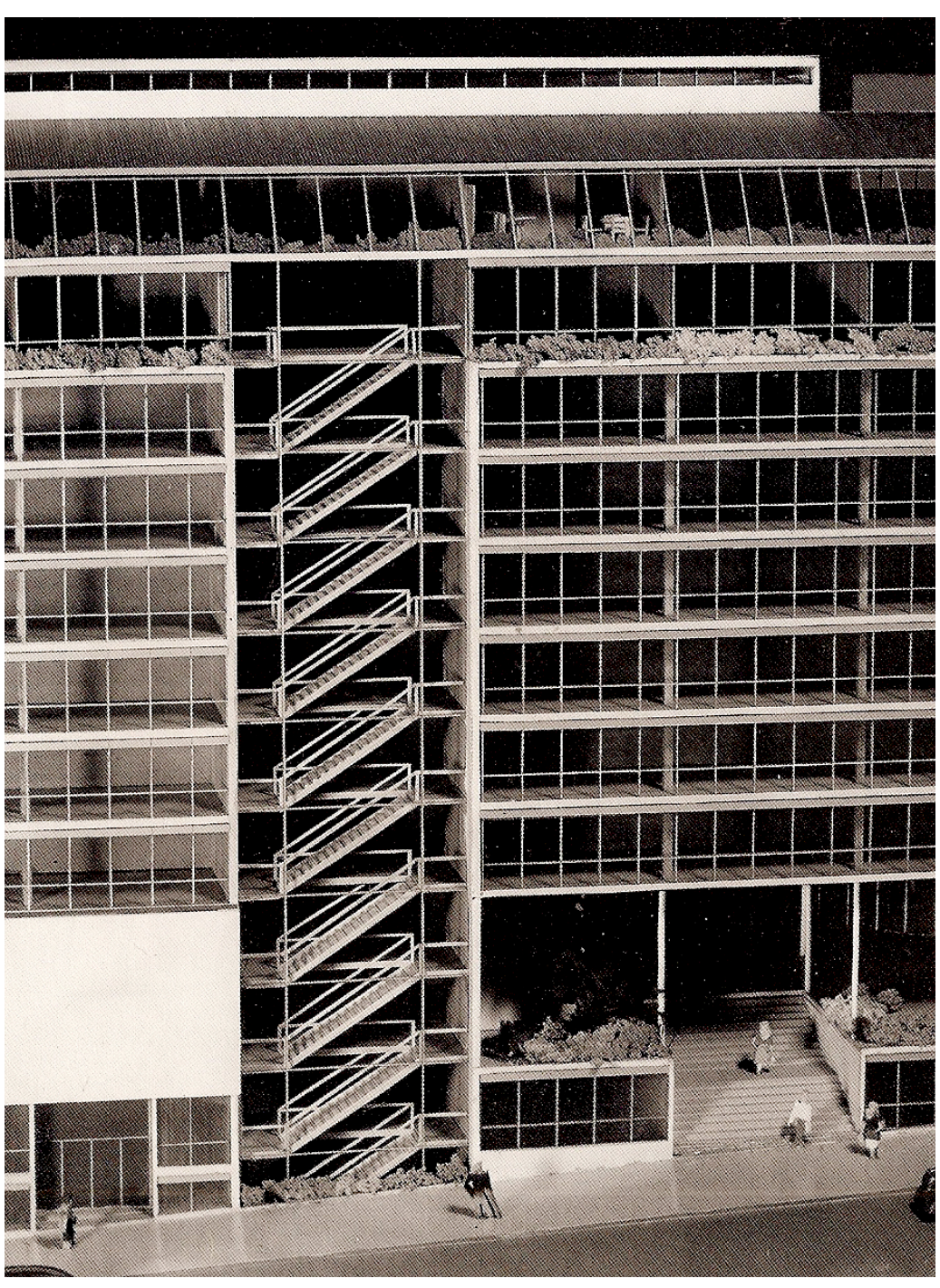

Maquete, detalhe dos acessos. Fonte: FERRAZ, 1993 


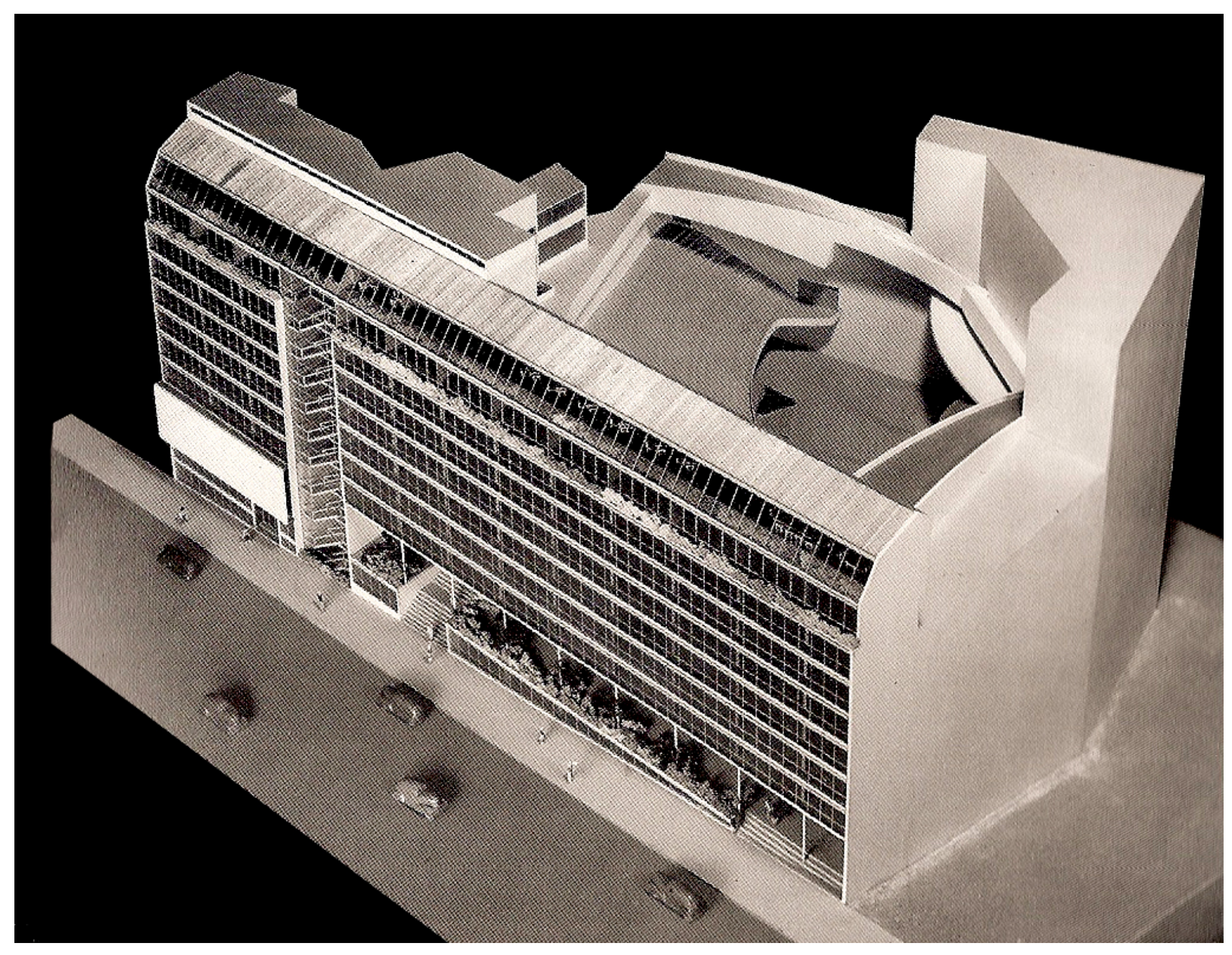

Maquete, vista da rua Álvaro de Carvalho. Fonte: FERRAZ, 1993 
barra que ocupa a totalidade do alinhamento que seria o principal elemento de expressão formal. Sua organização, também em onze pavimentos, é marcada pelo pilotis de dupla altura no térreo, elevado em relação à rua, e pela cobertura em terraço envidraçado, onde estavam previstos um restaurante e o clube dos artistas. A partir dessa observação podemos dizer que, apesar do edifício teatral não se relacionar diretamente com o espaço urbano, sua vitalidade poderia ter presença marcante no ambiente cultural em função da posição estratégica do foyer em pilotis.

$\mathrm{Na}$ barra frontal predominam as linhas horizontais, marcando de forma definitiva essa única fachada. 0 recuo dos pilares coloca em evidência as bordas das lajes dos pavimentos. Os cerca de cem metros de extensão são apenas interrompidos pela escada posicionada junto ao alinhamento, reforçando a intenção da arquiteta em usar as atividades como meio de animação da fachada.
A Sala

Como a vocação da sala foi primordialmente atribuída para a locução e para a música, sua configuração nos parece acertada. Podemos lembrar que o Teatro Cultura Artística tem uma solução semelhante, em leque, apesar de ter menor capacidade e de não possuir balcão, como já apresentado nessa dissertação.

Lina, em seus estudos, sinaliza seu desejo de um desenho limpo, abstrato, sem recursos decorativos, onde o tratamento neutro das laterais e do forro em preto contribuiria para a valorização da cena.

Os recursos cênicos apresentados no projeto mostram que o edifício estaria preparado para receber uma grande variedade de espetáculos. Caixa de palco de dimensões generosas, palco giratório, proscênio, fosso de orquestra, etc, demonstram o nível de flexibilidade que se poderia atingir. 

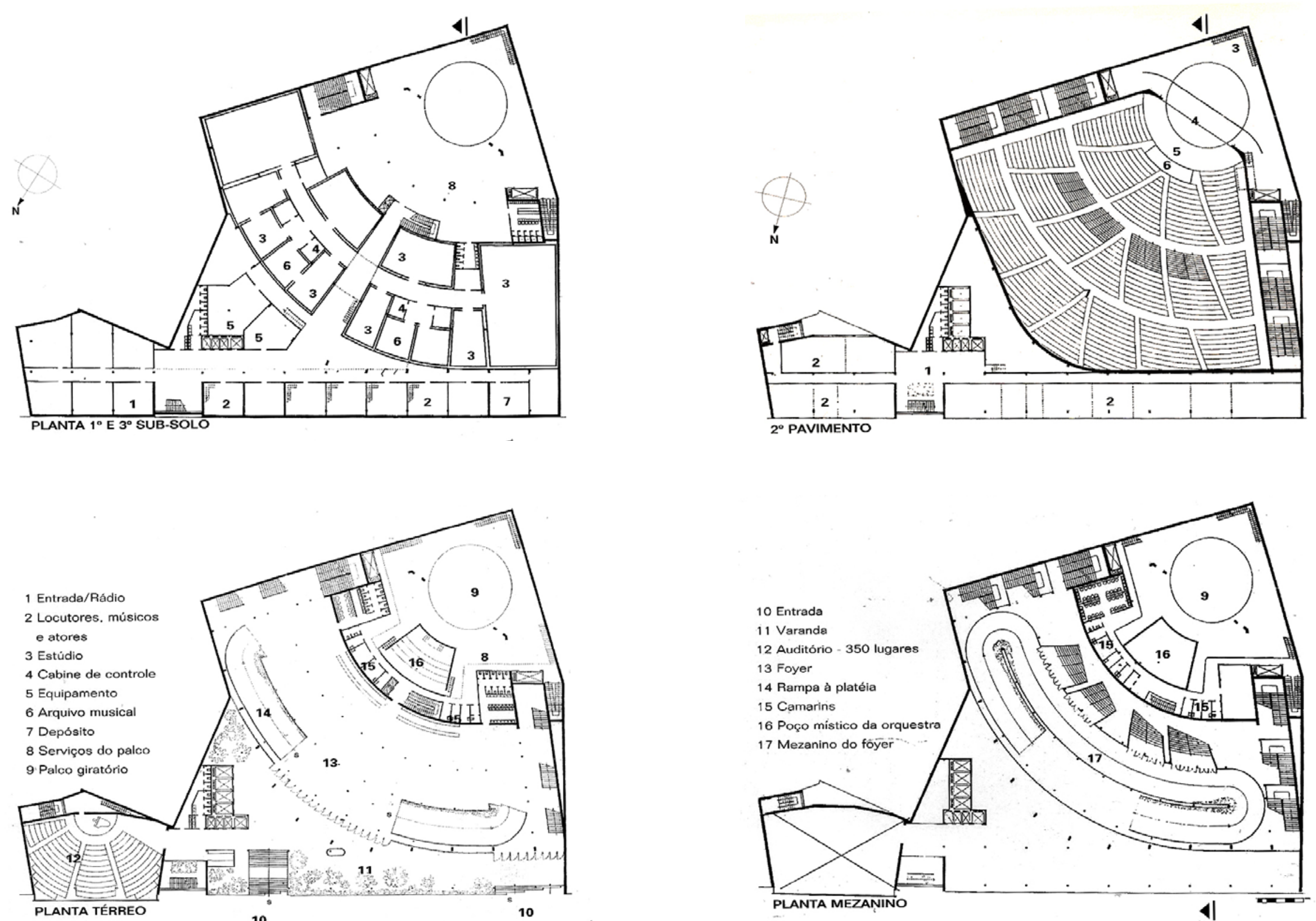

Fonte: FERRAZ, 1993 

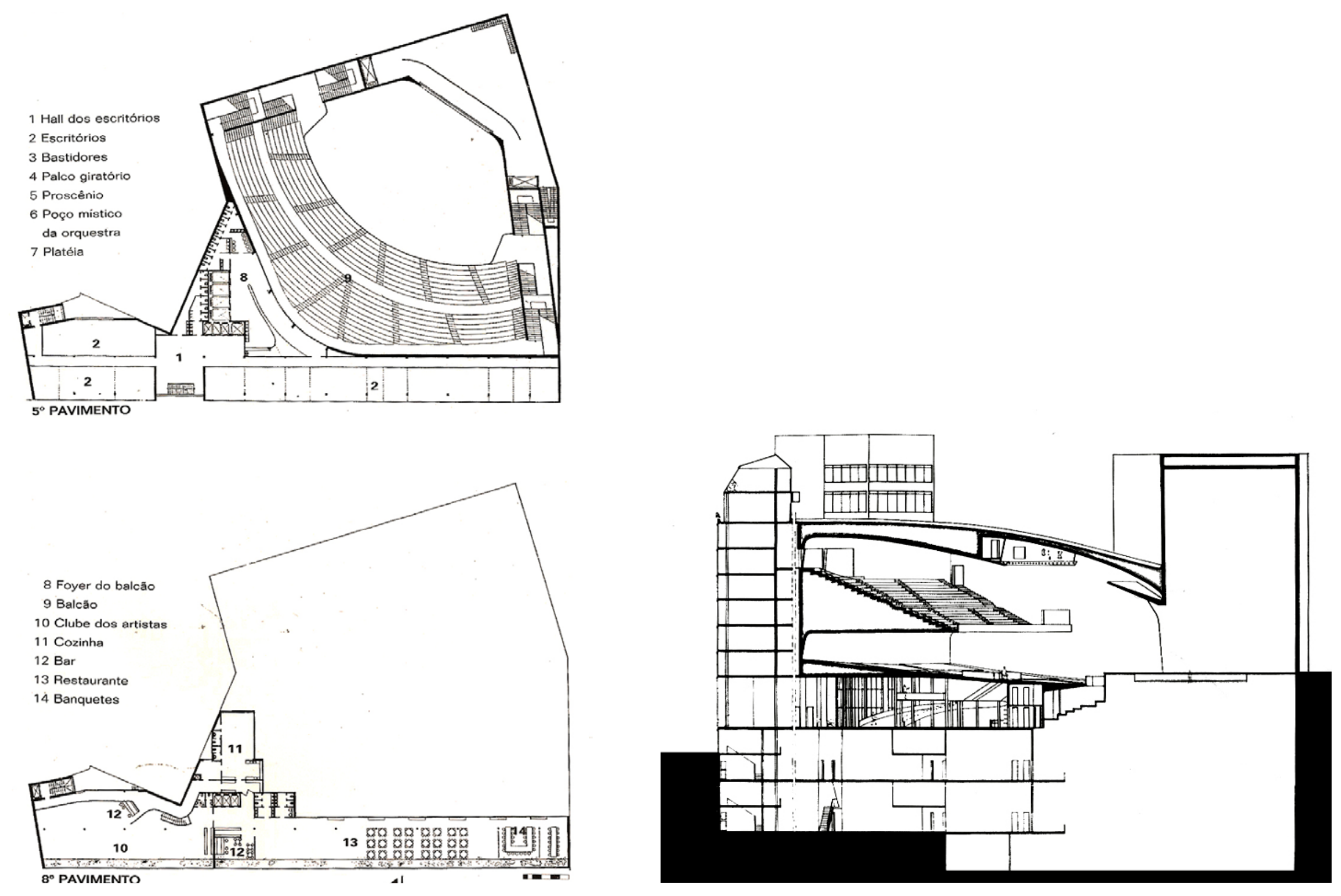

Corte transversal. Fonte: FERRAZ, 1993 

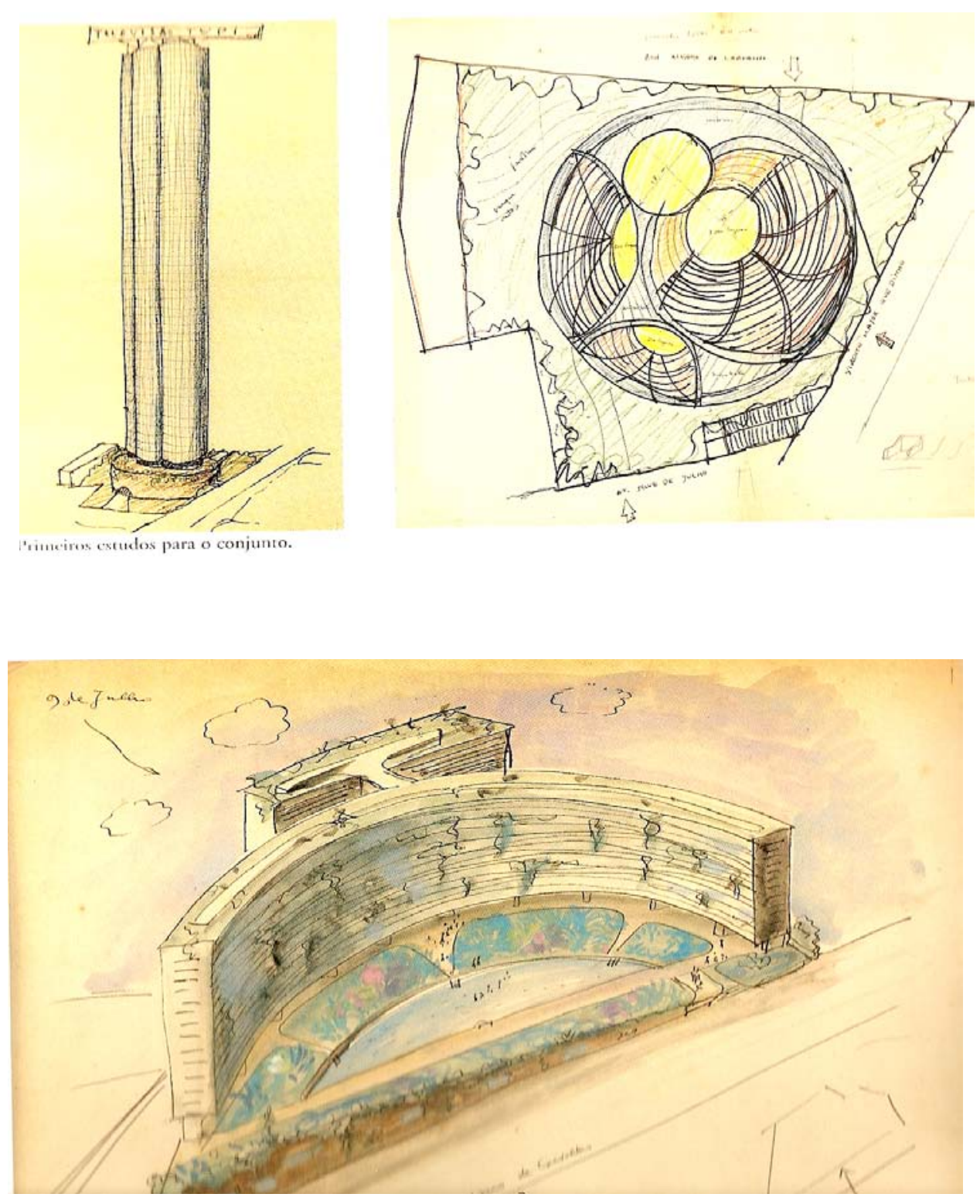

Estudos. Edifício Diários Associados. Fonte: FERRAZ, 1993

Na versão de 1951, o conjunto assume nova escala, ocupando um lote de maiores dimensões e incorporando outros usos que o transformaram em um complexo multiuso de grandes proporções.

Durante a fase de estudos, a arquiteta simulou diversas implantações geradas pela vontade de trabalhar com configurações de salas de espetáculos que fugissem da tradicional cena frontal, sendo essa estratégia responsável por resultados formais que viriam a habitar o seu imaginário nas décadas seguintes.

Observamos o uso de geometrias curvas que fazem surgir o teatro em arena, com palco central ou em anfiteatro, podendo ser divisíveis. Essas soluções geram torres ou barras que seguem esse desenho, mas sempre subordinados ao local do espetáculo. Lina deixa claro que o elemento indutor do conjunto é o grupo de salas, que se apresenta como elemento principal. É verdade que com as fachadas que foram incorporadas para o viaduto Major Quedinho e para a avenida Nove de Julho, a inversão da implantação, posicionando as salas de espetáculo para a rua Álvaro de Carvalho traria melhores possibilidades de proteção e de acesso, já que a avenida Nove de Julho já assumira o papel de um dos grandes eixos de ligação entre o centro e a zona sul da cidade, pólo gerador de muito ruído. 

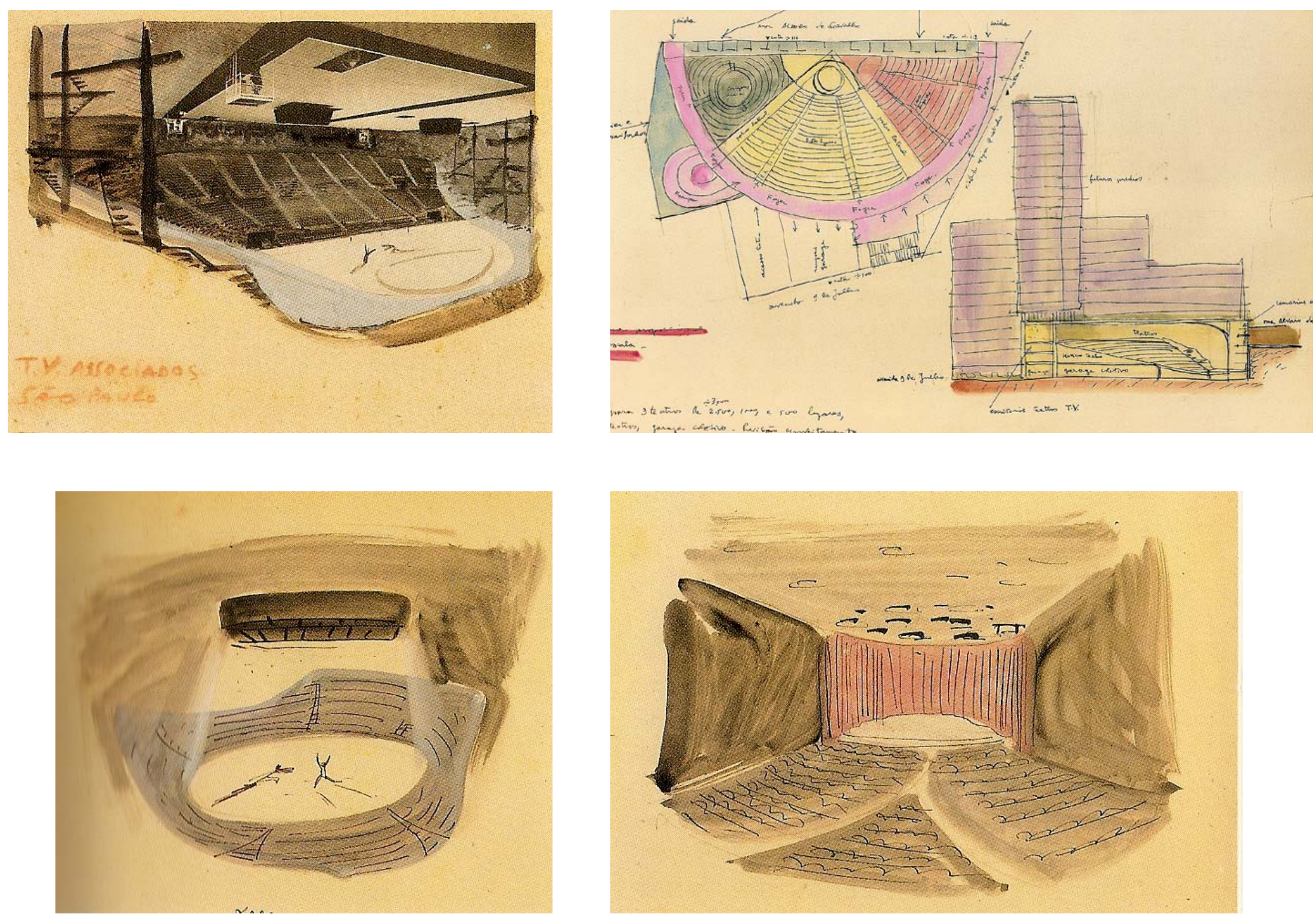

Estudos. Edifício Diários Associados. Fonte: FERRAZ, 1993 


\section{Taba de Guaianases}

Esse título foi dado ao conjunto de edifícios projetado em 1951 para demonstrar as qualidades da solução final. Para Lina se tratava-se de um conjunto autônomo, como uma aldeia.

A participação do engenheiro calculista italiano Pier Luigi Nervi no projeto foi fundamental, como pode ser observado na solução estrutural da base que abriga as salas de espetáculos, que vence o grande desnível entre a rua Álvaro de Carvalho e a avenida Nove de Julho e que cria uma praça elevada em sua cobertura, onde vêm se apoiar as duas torres-lâminas. 0 uso do concreto protendido para vencer o vão de 70 metros representado pela cobertura da plateia do grande auditório pode ser visto como um ensaio para o que a arquiteta faria seis anos depois em seu projeto para o MASP.

Ao programa original foram acrescentados edifícios de habitação com 1.500 apartamentos, o que contribuiu para diversificar o uso e aumentar as dificuldades de implantação. Além disso, foram incluídos estúdios para tele- visão, dois auditórios para 1.500 lugares, e a capacidade do auditório principal passou para 5.000 espectadores.

0 projeto final posiciona as torres-lâminas de apartamentos na periferia do terreno, seguindo o alinhamento das ruas, como na solução de 1947. Porém agora as torres repousam em pilotis sobre a base elevada da grande praça central criada na cobertura do auditório principal. Essa base, ao vencer o grande desnível existente, faz ainda a arti-

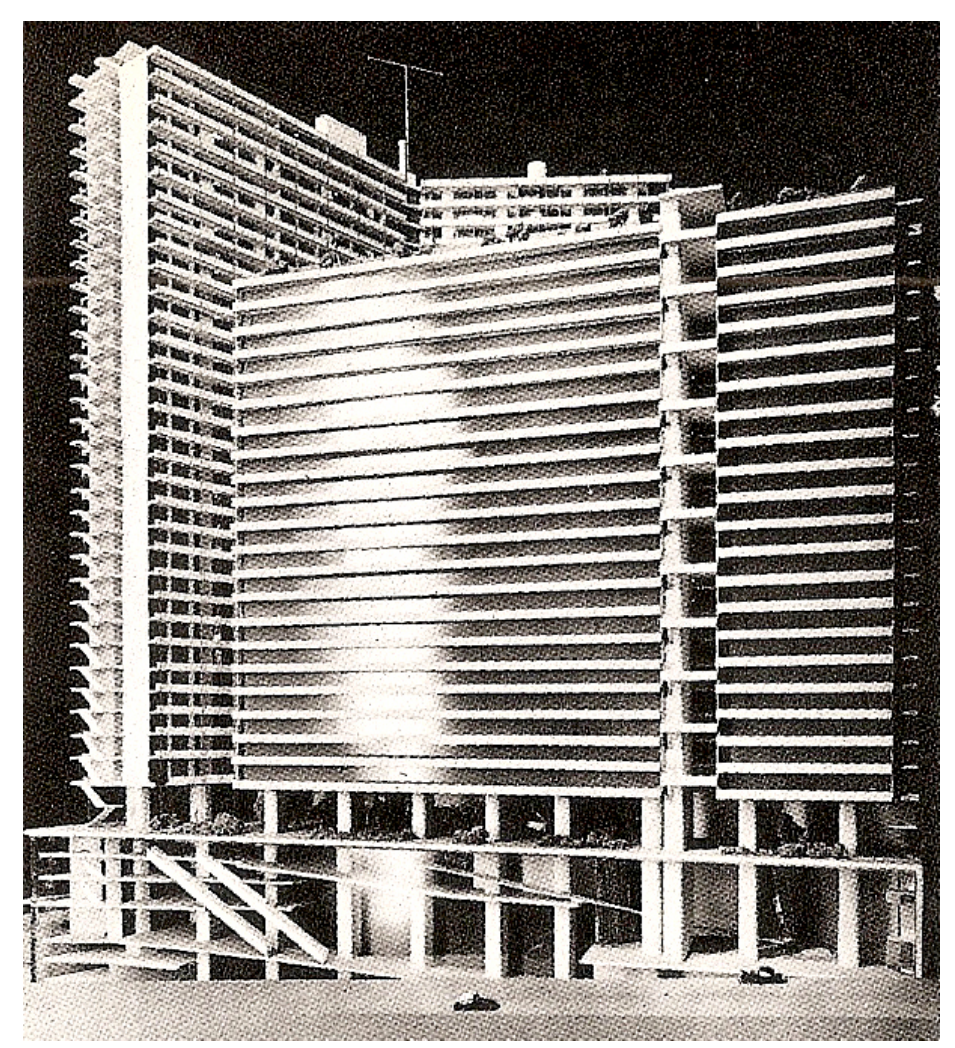

Maquete, vista da rua Álvaro de Carvalho. Fonte: FERRAZ, 1993 
culação dos acessos do público e, dessa forma, cria a entrada principal pela rua Álvaro de Carvalho e uma segunda entrada pela avenida Nove de Julho que serve as duas outras salas.

Essa é sem dúvida a grande expressão do conjunto, uma base de proporções urbanas, articuladora das conexões, que recebe as torres em sua cobertura em torno de uma praça suspensa. Não podemos esquecer que nesse mesmo ano de 1951 Lina projeta sua Casa de Vidro, que segundo Montaner: "Aqui inicia a mudança de adequação dos modelos estritamente modernos ao lugar e à cultura do Brasil”. (2011, p. 17)

A relação franca com as ruas é tratada com uma certa monumentalidade que estabelece escala com a cidade. Essa situação é alcançada não somente pela forte presença da estrutura, marcada por grandes colunas e por vãos generosos, como também pela profusão dos sistemas de circulação verticais - rampas, escadas e elevadores.

Deve ser ainda destacada a bela solução dos apartamentos, intercalados com terraços ajardinados, permitindo permeabilidade funcional e visual das torres lâmina. Como na solução de 1947 os pavimentos se expressam por linhas horizontais, mas agora com muito mais força.

A análise das duas versões dos edifícios Diários Associados nos leva às seguintes observações:

. Se não há nesse caso um edifício isolado como expressão do lugar do espetáculo, há, sem dúvida, uma presença marcante articulada pela base. Sua participação no cenário da cidade se apresenta de maneira evidente, o que fica ainda mais claro na proposta de 1951;

. A contribuição desses projetos para o trabalho que Lina Bo Bardi viria a desenvolver nos anos seguintes é inegável, seja pela elaboração das soluções estruturais de forte caráter expressivo, seja pela procura de configurações de salas de espetáculos não convencionais. Esse fato já justifica um exame mais apurado dessas obras;

. Do ponto de vista da historiografia da Arquitetura Moderna em São Paulo podemos destacar também que se trata de uma obra exemplar em programas multifuncionais de grande porte. Nesse momento em que essa tipologia está em franco desenvolvimento na cidade, julgamos oportuno incluí-la nos estudos que tratam sobre nosso tema. 


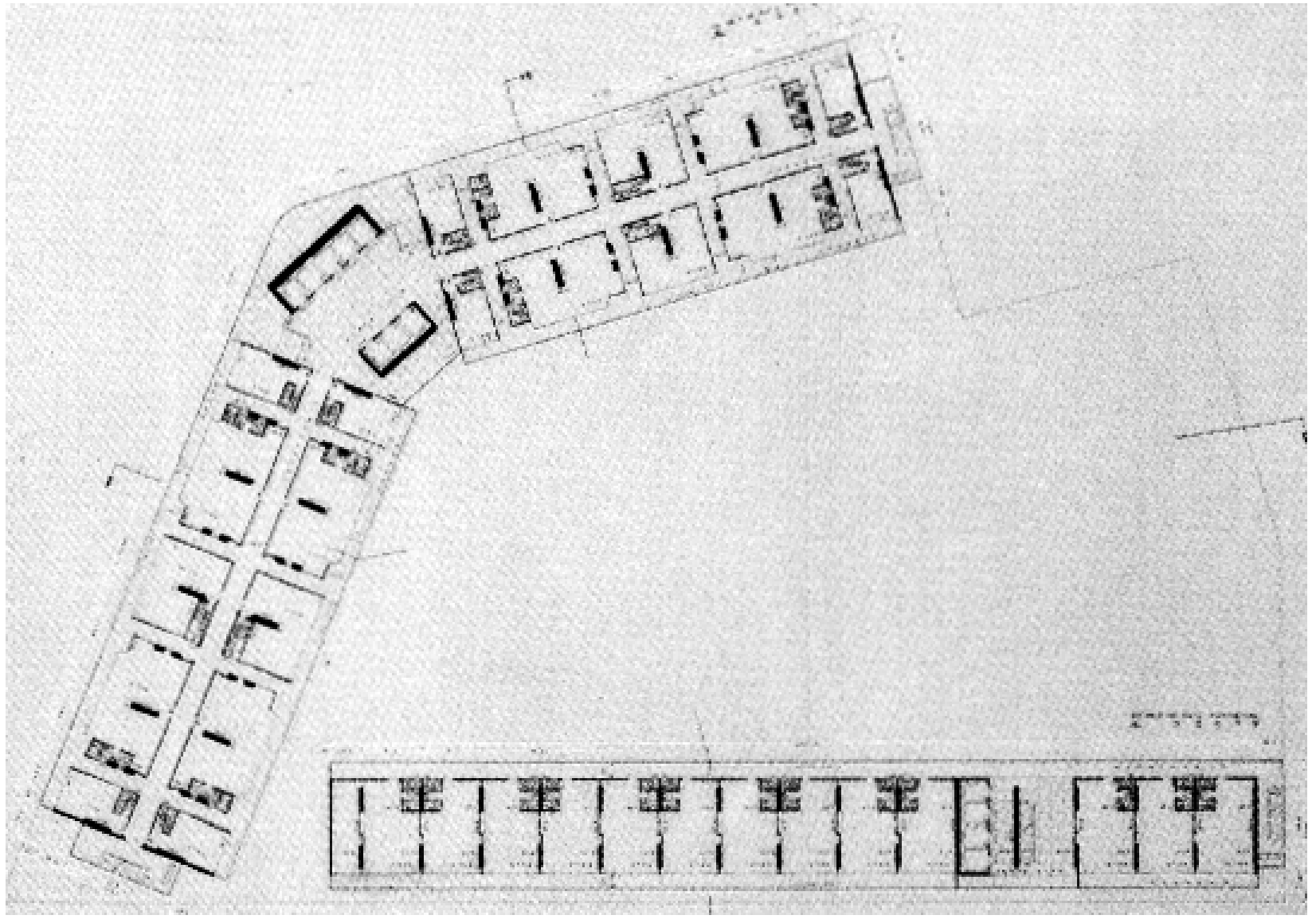

Planta do pavimento tipo. FERRAZ, 1993 


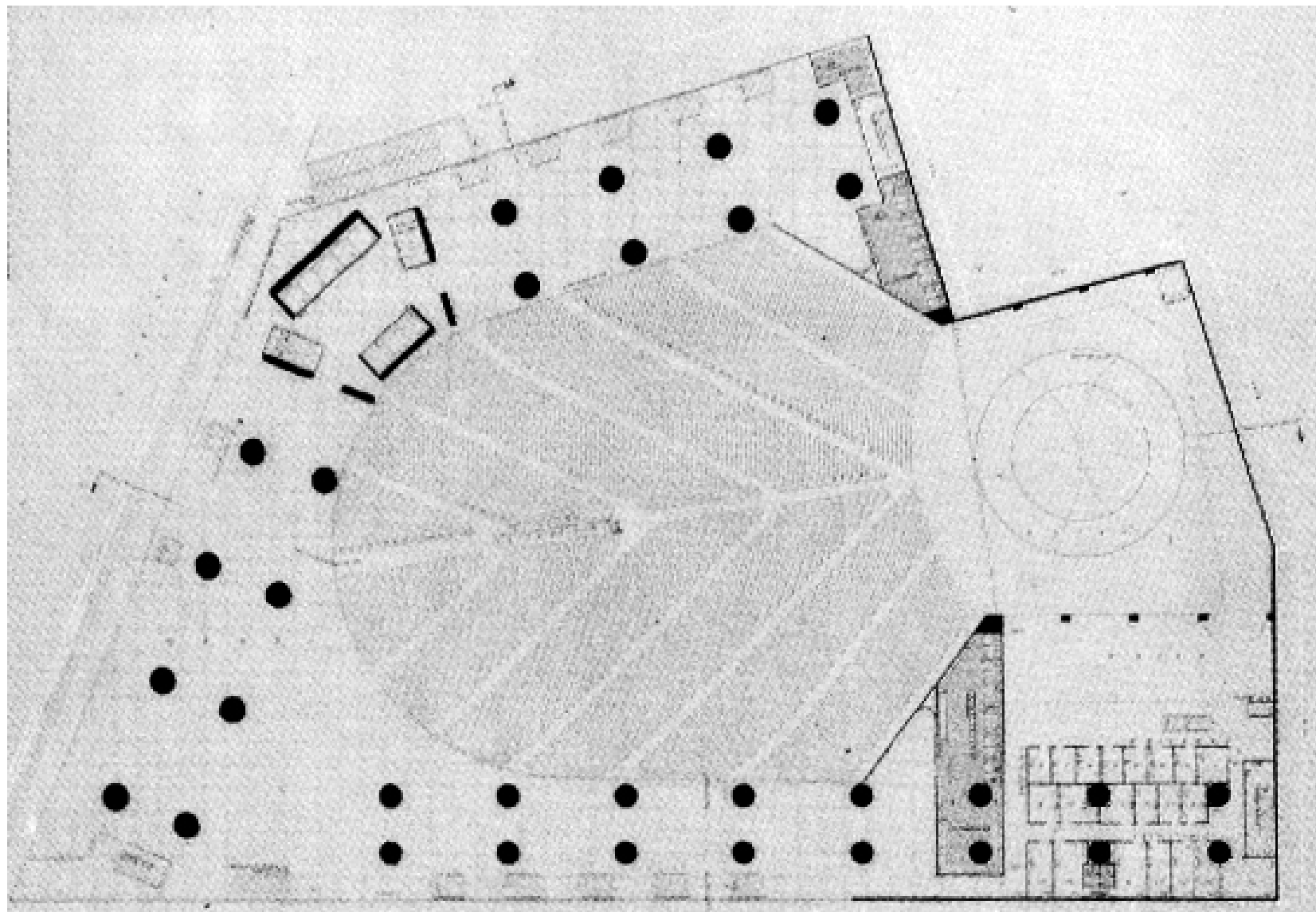




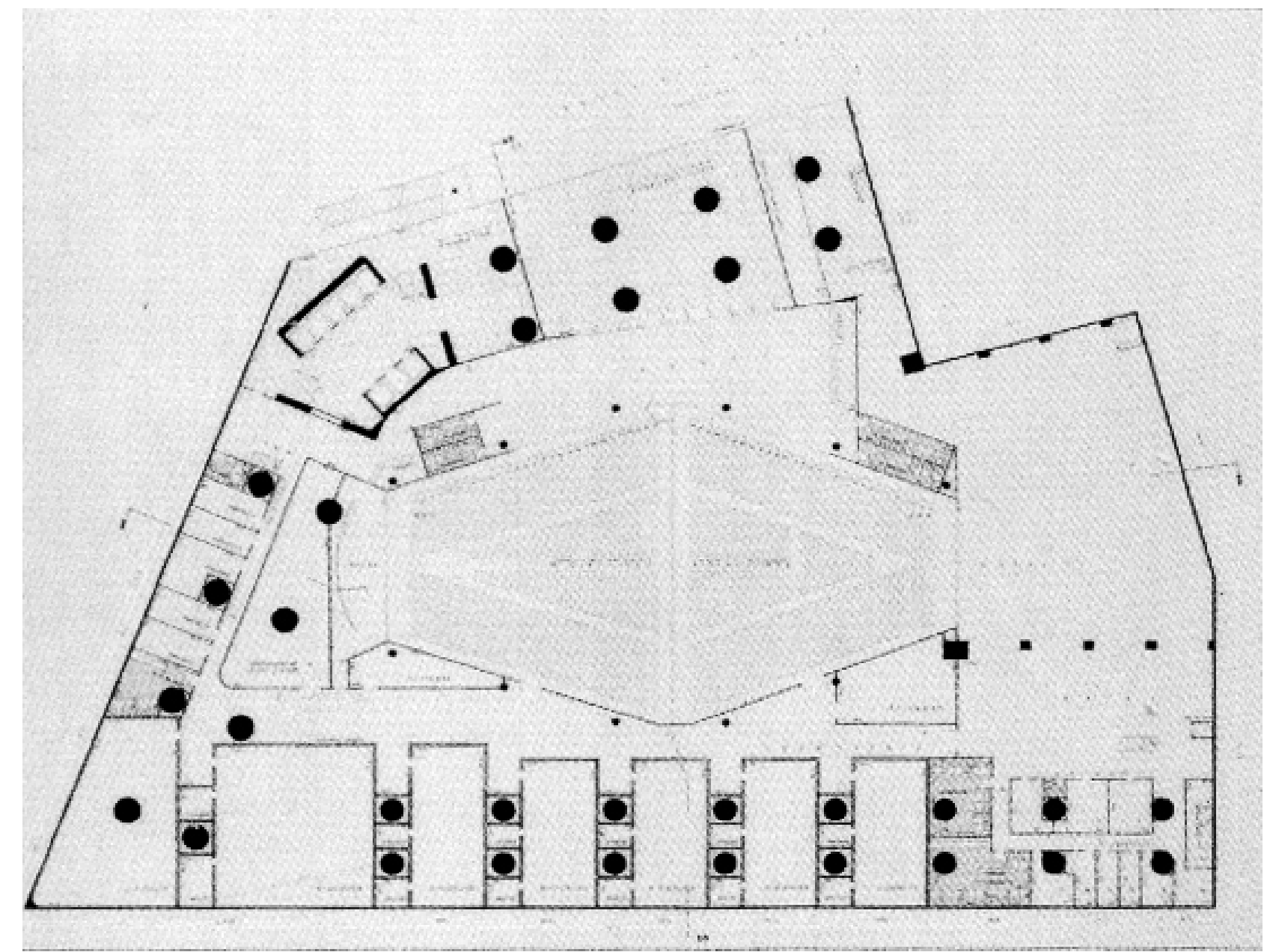

Planta do pavimento inferior. FERRAZ, 1993 


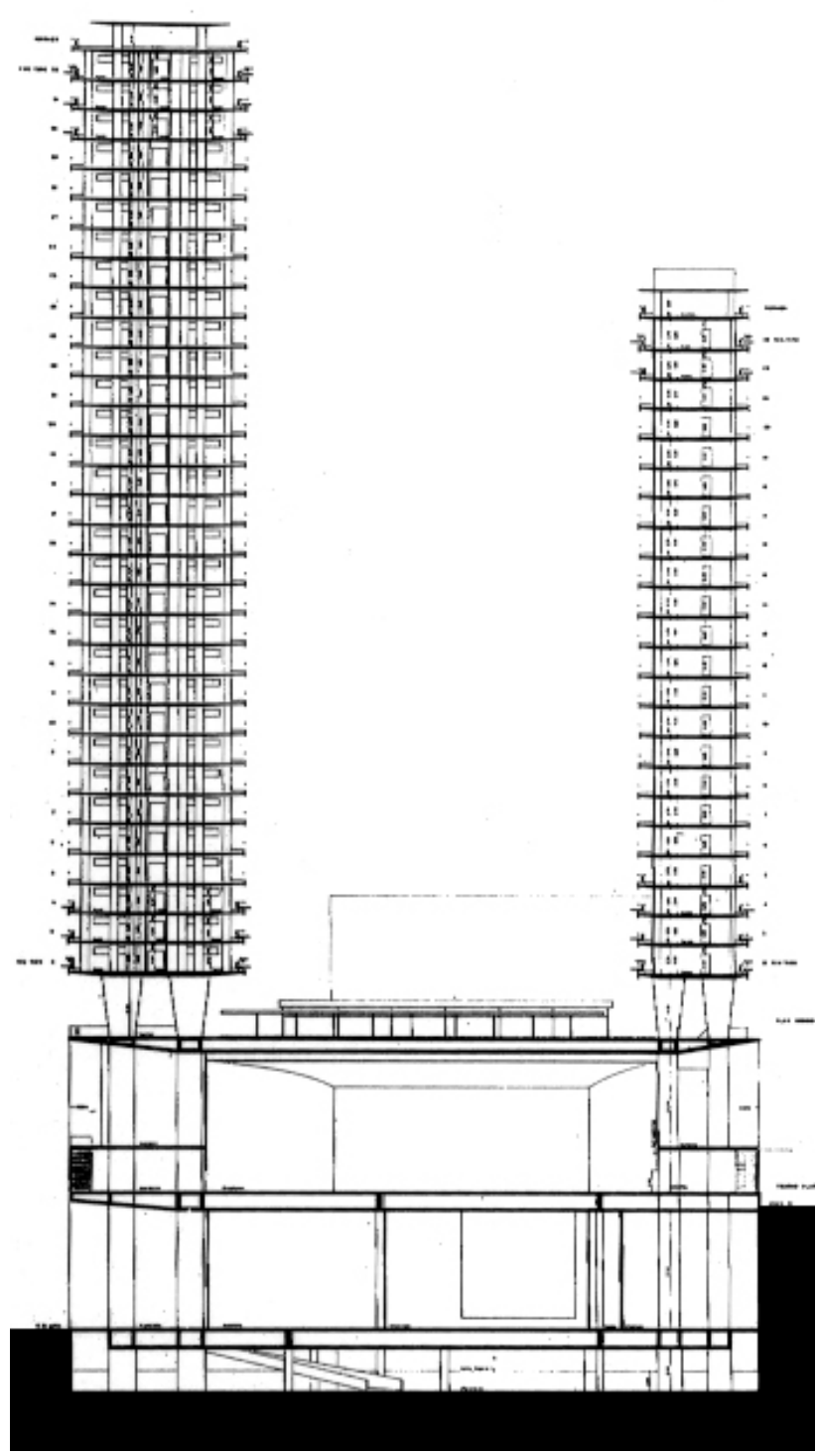

Corte transversal. FERRAZ, 1993

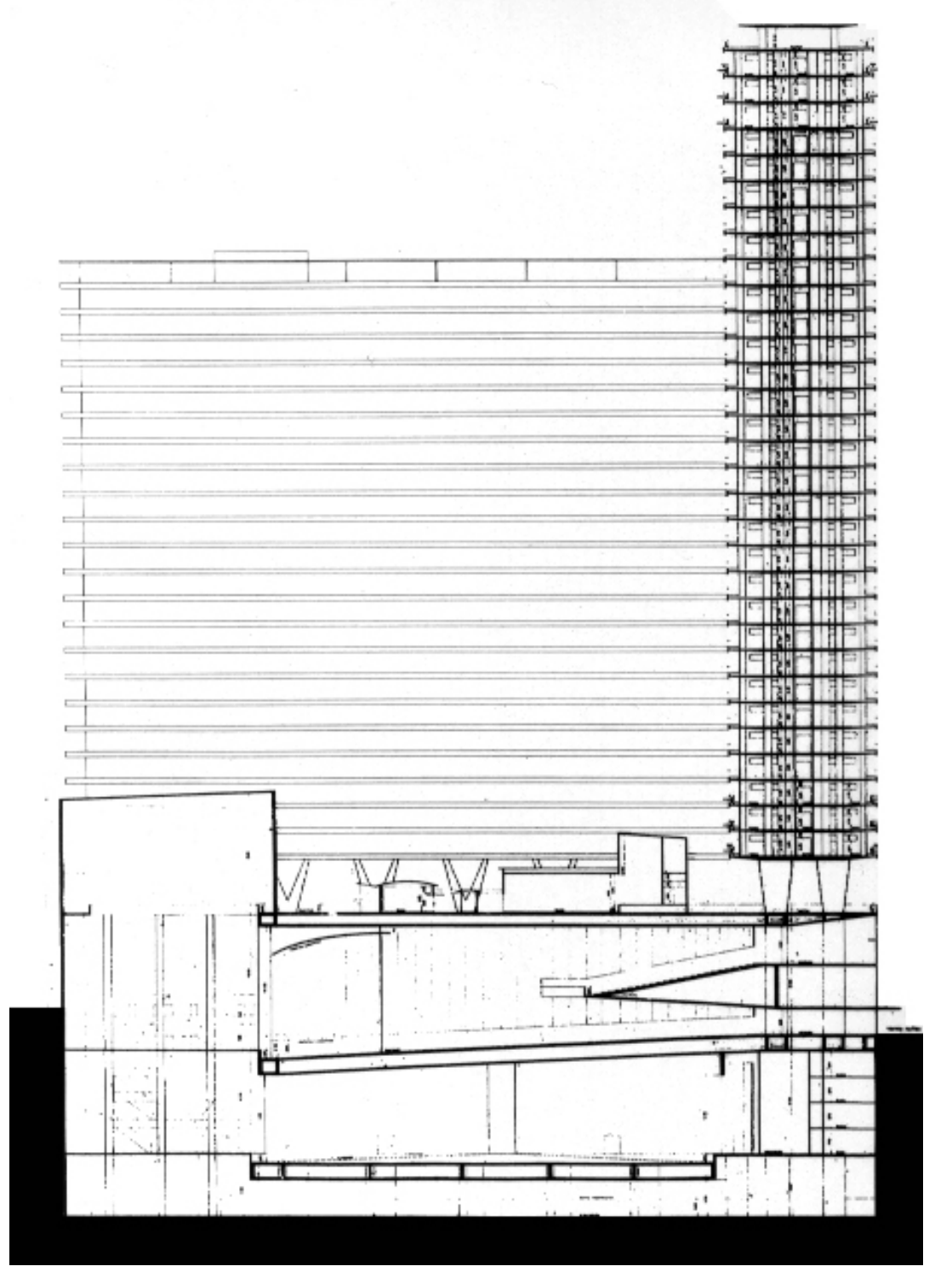

Corte longitudinal. FERRAZ, 1993 
Um exemplo [da necessidade de reconquista do centro] foi a ação, durante a última Virada Cultural em maio, de um coletivo de arquitetos que projetou luzes sobre os prédios vazios do centro, oferecendo um contraponto silencioso à festa ao mostrar que o palco do espetáculo fica vazio a maior parte do tempo e poderia servir de moradia. (Beiguelman, apud Martí, 2013)

As intervenções no centro da cidade de São Paulo realizadas nos últimos anos procuram oferecer condições para que ele retome parte da qualidade urbana que o caracterizou até os anos de 1960. Esse período, o mais expressivo da arquitetura moderna na cidade, coincide com a época áurea do teatro, do cinema e da música nessa região.

O presente capítulo apresenta alguns projetos implantados ou em vias de realização, procurando entendê-los sob o ponto de vista da arquitetura do espetáculo e quais foram as estratégias utilizadas para a solução das questões que se colocaram.

Alguns deles se tornaram referência na área cultural, como foi o caso da Sala São Paulo ${ }^{128}$, sede da OSESP
(Orquestra Sinfônica do Estado de São Paulo), outros, como o Teatro da Dança (também conhecido por Complexo Cultural Luz $)^{129}$, trouxeram visibilidade internacional, mesmo estando este último ainda em fase de projeto.

Curiosamente falar de realizações recentes da arquitetura do espetáculo no centro da cidade de São Paulo é antes de tudo falar do passado, ainda que do passado recente da jovem metrópole. 


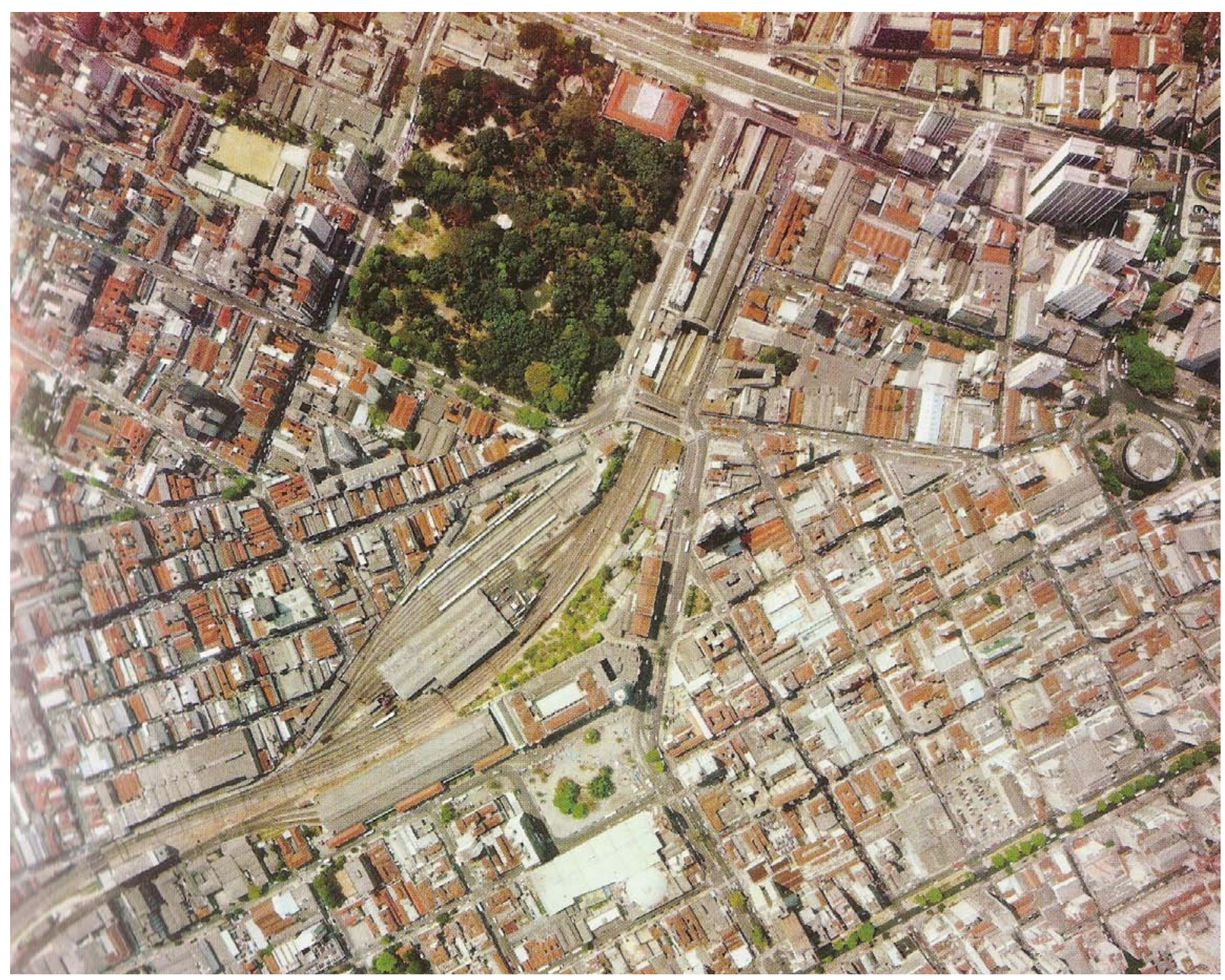

Vista aérea Campos Elíseos e Luz. Fonte: ZEIN, 2011 
Poucas vezes na história do urbanismo terá ocorrido um fenômeno semelhante, uma cidade reconstruída duas vezes sobre o mesmo assentamento. A descoberta de uma cidade inteiramente construída de barro surpreendeu os viajantes no início do século XIX, como surpreendera anteriormente o Morgado de Mateus. Há um século, a cidade contava com trinta mil habitantes e, a partir do momento em que a ferrovia chegou às novas terras produtoras de café, a cidade conheceu um crescimento incontrolável. Crises econômicas, revoluções, guerras, nada conseguiu infletir a curva de crescimento da cidade. Com os imigrantes vieram as novas técnicas de construir e a cidade foi reconstruída integralmente, disso resultando uma nova imagem: a metrópole do café.

Por essa época, houve tanto por parte de cidadãos como dos poderes públicos uma preocupação com a estética urbana e com a qualidade de vida da cidade. Até a Segunda Grande Guerra a cidade conservou sua imagem de metrópole do café. 
mentos arquitetônicos da cidade. Os poderes públicos sempre ficaram para trás da iniciativa privada e um código de obras anacrônico permitiu um uso abusivo do solo.

(TOLEDO, Benedito - São Paulo, três cidades em um século, São Paulo: Liv. Duas Cidades, 1981, p. 141)

Por razões distintas, a arquitetura pode perder o significado urbano para o qual foi concebida. Como já pudemos observar nesta pesquisa, isso não significa a perda de seus valores e de suas qualidades primordiais. Mais do que o próprio artefato construído, a cidade, e em particular os centros assistiram à degradação do seu espaço urbano, o que ocorreu de maneira intensa no centro da cidade de São Paulo nas últimas quatro décadas do século $\mathrm{XX}^{130}$, como nos mostra Benedito Lima de Toledo na passagem acima citada.

Se foram abandonados como equipamentos urbanos dignos, capazes de se adaptar aos novos usos, isso não se deve à qualidade de sua arquitetura ou à dificuldade que esta possa ter tido em evoluir ou em adquirir um outro sentido. Muitos são os fatores , em especial, de ordem econômi- ca, política e social que podem explicar esse processo, o que não nos parece oportuno abordar. Tal processo interessa a esse trabalho por representar o foco principal das intervenções ocorridas recentemente no centro, com o objetivo de implantar equipamentos voltados para o espetáculo, como uma estratégia de reconquista desse importante patrimônio urbano. Essa estratégia visa a recuperar a diversidade de usos perdida pelo centro.

Janes Jacobs (2009, p. 167) aponta a especialização como uma das causas da autodestruição dos centros urbanos. A autora propõe, através da análise da cidade-norte americana, diversas condições, como a indução de usos combinados, para que seja possível a diversidade urbana, necessária para a recuperação da cidade. Admite, entretanto, que não seria através de mecanismos que imponham por decreto a manutenção de usos no centro, mas o estímulo que poderia ser dado ao serem utilizadas o que ela chama de "peças de xadrez", nos lugares certos, como um primeiro passo. (2009, p. 184)

Para prosseguir nossa análise, torna-se necessário

130 Autores como Benedito Lima de Toledo e Ângelo Bucci apresentam análises fundamentais a esse respeito, do ponto de vista histórico e arquitetônico respectivamente: Ver TOLEDO, B. L. 1981 e BUCCI, A. 2010. 
considerar a cidade, e seu centro em especial, constituída pela somatória de sua arquitetura. Esse entendimento primário estabelece uma relação de valor entre o artefato edificado e o espaço urbano, que nos ajuda a melhor compreender sua realidade em função do processo histórico de justaposição e superposição ocorrido na cidade de São Paulo. Em outras palavras, utilizando o raciocínio de Aldo Rossi ao relacionar a forma da cidade e o tempo, existem muitos tempos na forma do centro de São Paulo, alguns foram perdidos, outros persistem graças a seus valores constitutivos. $\mathrm{O}$ autor chama a atenção, quando aborda a Teoria da Permanência e os Monumentos, para o risco de que a permanência possa se tornar um fato isolado e aberrante por estar desvinculado de um sistema, a não ser sob a forma de um passado. (2001, p. 52) 


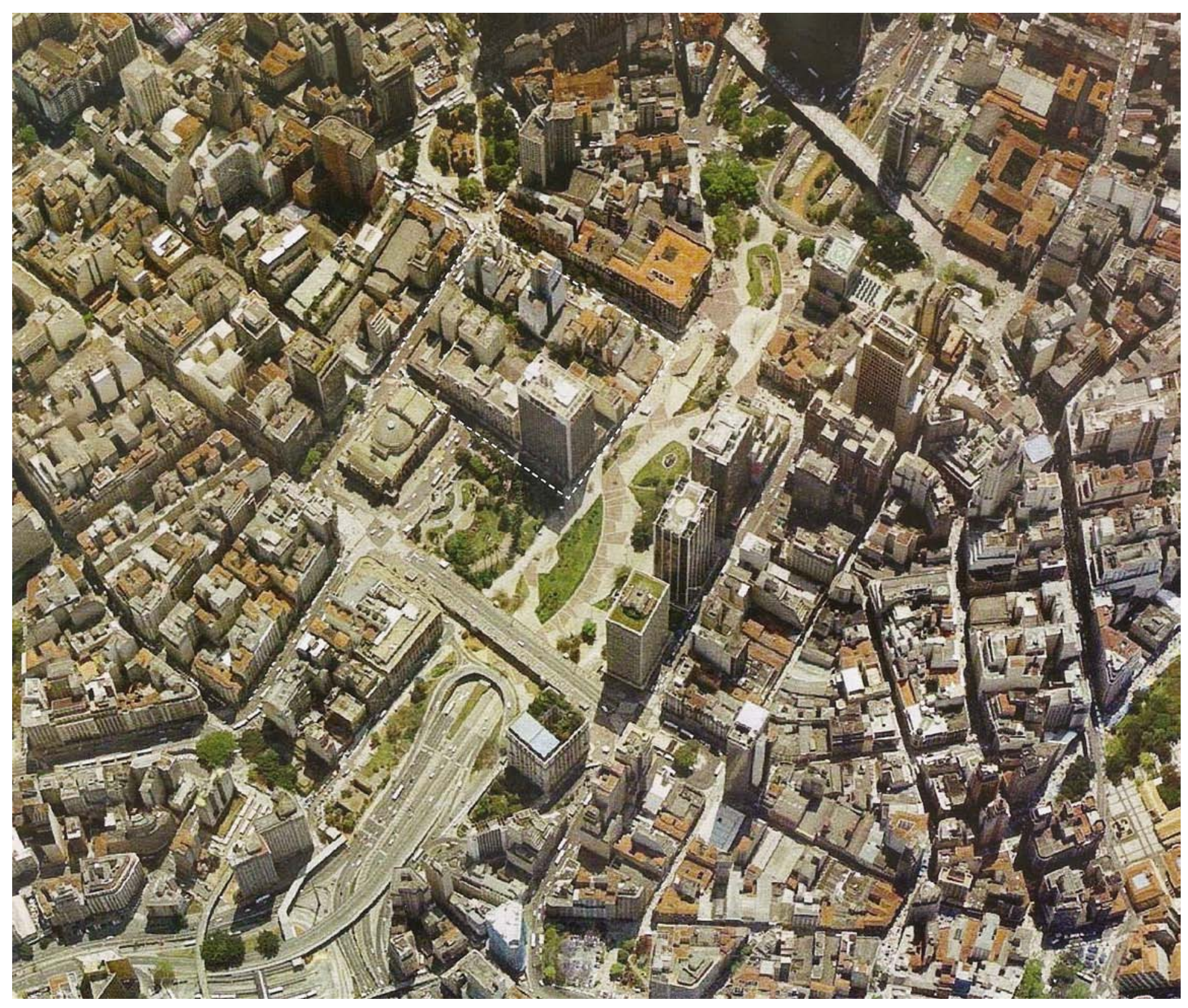

Vista aérea do centro de São Paulo - Vale do Anhangabaú. Fonte: NOZEK, 2013 


\section{O Espetáculo em uma Década}

Além de dar casa a alunos e artistas dos corpos estáveis abrigados no Teatro Municipal, a Prefeitura tem tratado a Praça das Artes como mais uma obra de "revitalização" do Centro. É um perigo colocar esta responsabilidade no ombro dos arquitetos. Os mais talentosos gestores culturais do país fizeram a trinca Pinacoteca - Sala São Paulo - Museu da Língua Portuguesa tornar-se referência nas artes plásticas, na museografia e na música clássica no país. Mas não conseguiram alterar, sequer, a paisagem das praças que os cercam.

(LORES, in NOZEK, 2013, p. 32)

As considerações de Raul Juste Lores, presentes na primeira publicação que trata da obra Praça das Artes, baseiam-se no período de pouco mais de uma década da arquitetura produzida no centro de São Paulo ${ }^{131}$. 0 elo de ligação entre essas obras é sem dúvida os programas culturais aos quais foram destinadas, dentro das chamadas "políticas públicas" de incentivo e de fomento à indústria cultural.

131 O projeto de Paulo Mendes da Rocha para a Pinacoteca do Estado é de 1993, enquanto o projeto da Praça das Artes, de Marcelo Ferraz, Francisco Fanucci e Marcos Cartum, é de 2006. 
Não se pode reduzir as realizações da arquitetura ali produzida nesse período a essas obras, mas são elas, sem dúvida, de grande interesse para presente trabalho. Não se pode também limitar as iniciativas de revitalização do centro às ações culturais. Fazem parte significativa desse processo importantes obras como as de reutilização de prédios vazios para moradia ou como a construção de escolas, a exemplo da recém inaugurada FATEC Santa Efigênia ${ }^{132}$.

Outro aspecto fundamental, além dos programas culturais, do curto período de tempo que as separa e do fato de terem sido implantadas no centro, é a característica do lugar encontrado para sua implantação. É comum a essas obras a preexistência do patrimônio construído sob a forma de bens a serem preservados, protegidos pelos órgãos públicos responsáveis pela preservação do patrimônio. Isso traz mais um ingrediente para a complexidade do tema tratado na presente pesquisa, o que nos permite confrontá-las de maneira a entender a posição tomada por cada um dos arquitetos para situações bastante próximas.

Segundo Matina Watsman, haveria no contexto lati-

132 Faculdade de Tecnologia Centro Paula Souza dos arquitetos Francisco Spadoni e Pedro Taddei, projeto de 2009. noamericano uma dificuldade da nova arquitetura em estabelecer uma relação de continuidade formal, tipológica ou urbanística com o existente, pela rapidez com que as mudanças ocorrem, sem que haja "a consolidação das imagens, que não conseguem força suficiente para se fixar na memória social" (1993, p. 52). Essa mentalidade que ignora o passado e recebe o progresso com entusiasmo estaria, como assinala, sendo modificada. Pode-se considerar que parte dessas experiências recentes no Centro de São Paulo estariam dentro dessa perspectiva, como poderá ser verificado adiante.

Para prosseguir, torna-se necessário destacar dentre os projetos citados aqueles que mais se aproximam do assunto tratado aqui: a Sala São Paulo ${ }^{133}$ e a Praça das Artes. A esses dois deve-se acrescentar o projeto para o Centro Cultural Agência Central dos Correios ${ }^{134}$, por ter uma parcela de seu programa destinado ao espetáculo, além de possuir as mesmas condições descritas acima para os outros projetos.

A autora Françoise Choay dedica uma parte signifi-

133 De autoria de Nélson Dupré, 1997.

134 Concurso vencido em 1997 por UNA Arquitetos (Fábio Valentin, Fernanda Bárbara, Fernando Viégas e Christiane Muniz), e Ana Paula Pontes e Catherine Otondo. 
cativa de seu trabalho ao estudo da relação entre a indústria cultural e o patrimônio histórico. Em especial em seu livro Alegoria do Patrimônio em que traça o percurso do nascimento do conceito de Patrimônio Histórico, a invenção do Patrimônio Urbano, além da própria Industria Cultural. Discute ainda as diversas estratégias para a recuperação desse patrimônio com a finalidade de reintegrá-lo a um sistema urbano mais amplo e conclui:

Finalmente, o grande projeto de democratização do saber, herdado das Luzes e reanimado pela vontade moderna de erradicar as diferenças e os privilégios na fruição dos valores intelectuais e artísticos, aliado ao desenvolvimento da sociedade do lazer e de seu correlato, o turismo cultural dito de massa, está na origem da expansão talvez mais significativa, a do público dos monumentos históricos - aos grupos de iniciados, de especialistas e de eruditos sucedeu um grupo em escala mundial, uma audiência que se con- ta aos milhões. (2006, p. 210)

Choay considera a reutilização uma forma de reintegração paradoxal e uma maneira difícil de valorização de um edifício cujo uso normal foi modificado, e isso pelas dificuldades e pela complexidade de dar-lhe um novo destino, a tal ponto que afirma haver a necessidade de haver uma pedagogia especial para sua prática.

0 que se aplica diretamente ao tema de nosso trabalho refere-se à modernização pela qual passaram as três obras estudadas para assumir o novo papel urbano a que foram destinadas. Como explica ainda Choay:

Modernizar não é, nesse caso, dar a impressão de novo, mas colocar no corpo dos velhos edifícios um implante regenerador. Dessa simbiose imposta, espera-se que o interesse suscitado pela obra do presente se reflita na obra antiga, dando origem, assim, a uma dialética. (2006, p. 217) 


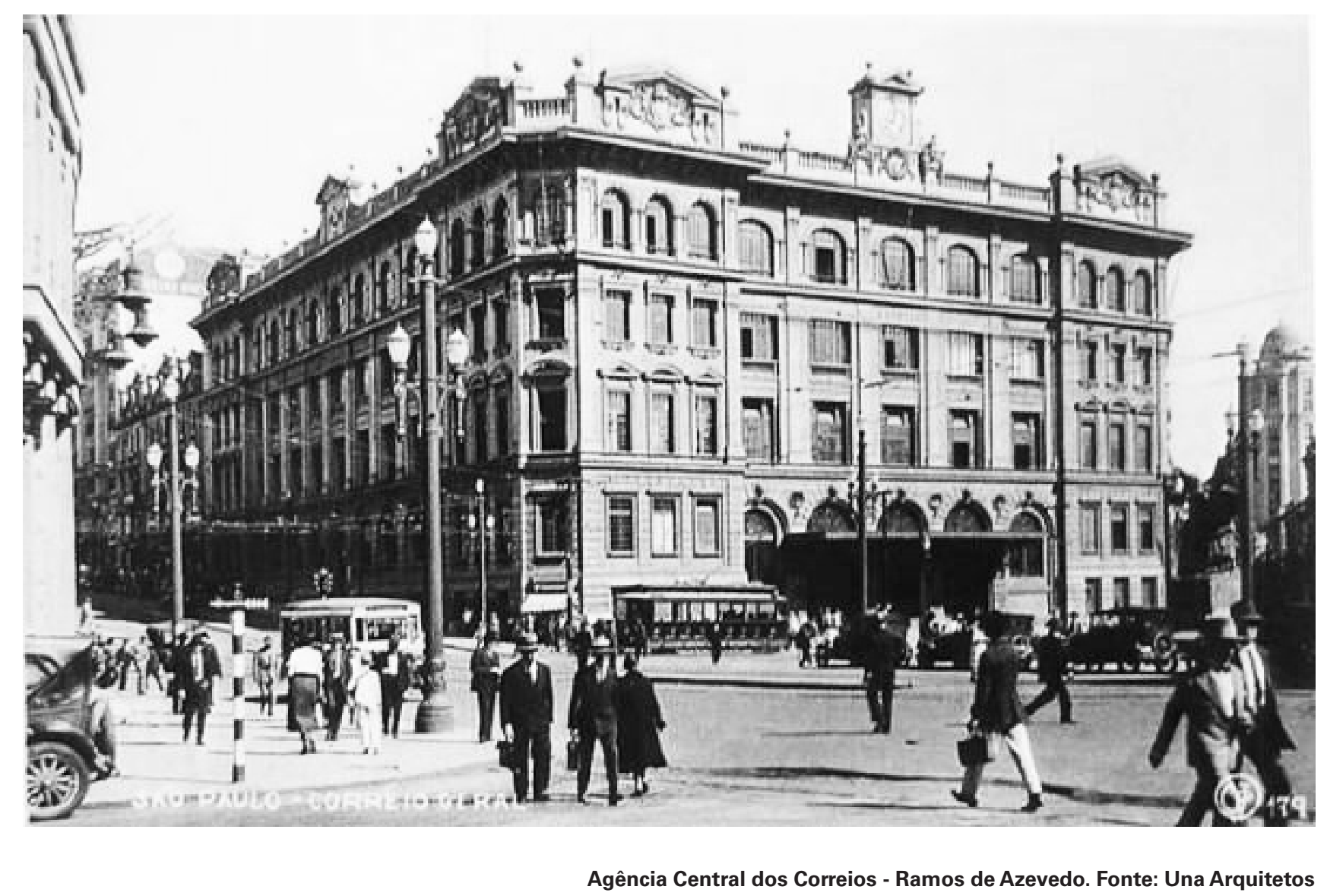


Ramos de Azevedo foi responsável pelo projeto e construção de boa parte do que Benedito Lima de Toledo chamou de a Metrópole do Café. Dentre suas realizações destacam-se sobretudo edifícios públicos, verdadeiros palácios e monumentos da cidadania como o Teatro Municipal, o Palácio da Justiça, a Escola Normal e o Liceu de Artes e Ofícios, inacabado, que abriga a Pinacoteca do Estado, além da Agência Central dos Correios e Telégrafos. Sobre esse último, observa Carlos Lemos:

A cidade se modernizava em continuação às iniciativas deflagradas após a inauguração do Teatro Municipal, quando os planos das "grandes avenidas" privilegiaram o Vale do Anhangabaú. Pois ali ao lado, na esquina da novíssima Avenida São João, o governo federal comprou vasto terreno para erguer o seu palácio das comunicações e essa obra grandiosa não poderia deixar de ter sido dada à experiência de Ramos de Azevedo. dos Correios (LEMOS, 1993, p. 91) 
Como assinala o autor, a prioridade do escritório de Ramos de Azevedo baseou-se sempre na volumetria e sobretudo no partido monumentalista, pois ele acreditava muito mais na importância de guarnecer a cidade de grandiosidade arquitetônica do que no bom cumprimento dos programas

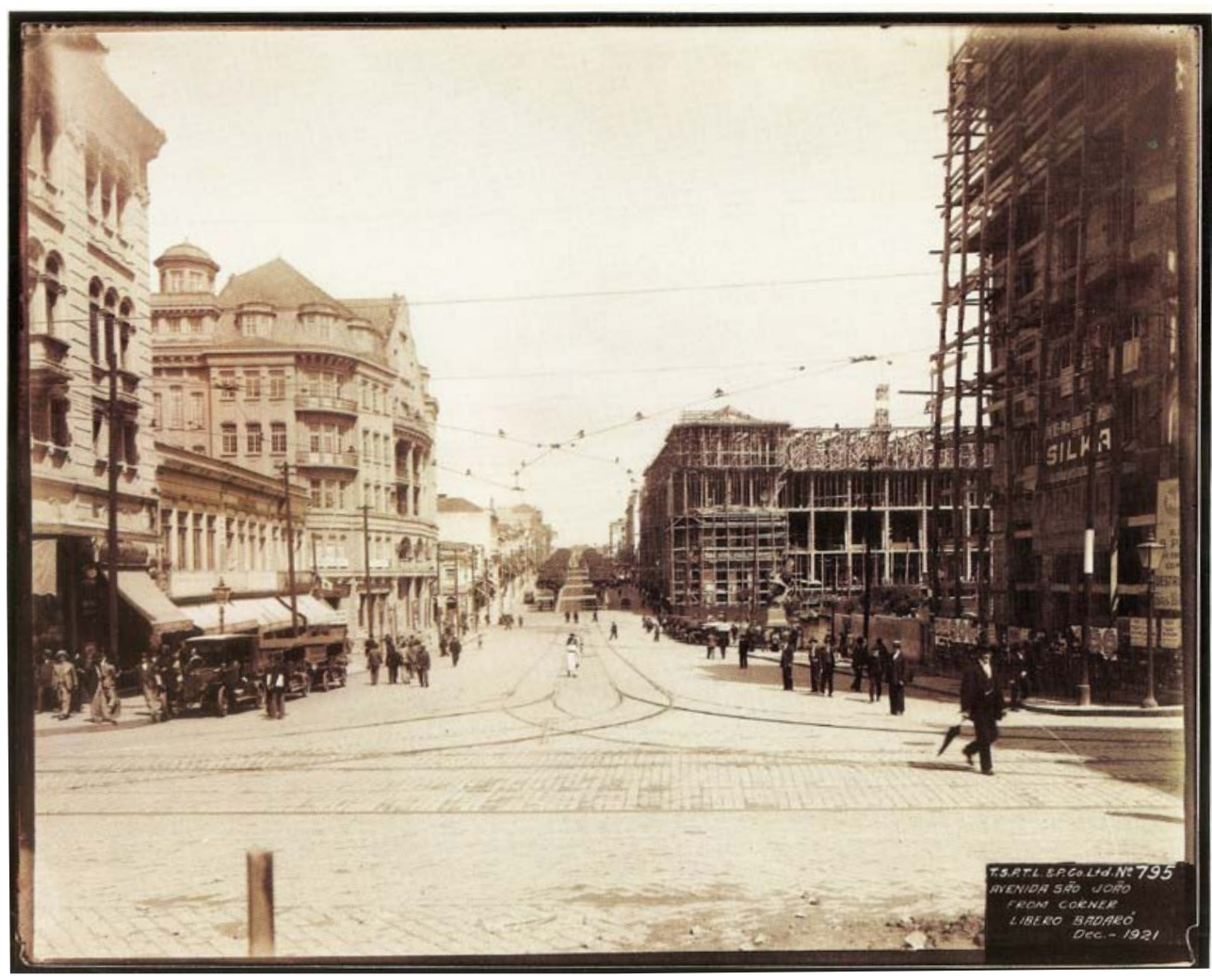

Construção da Agência Cetral dos Correior. Fonte:TOLEDO, 1989 de necessidades. Para os Correios e Telégrafos, em 1920, o processo ocorreu exatamente dessa maneira, resultando em um bom exemplo das preocupações estéticas diretamente ligadas à nova técnica construtiva que sucedeu a cidade de barro a que se referiu Benedito Lima de Toledo.

\section{Centro Cultural: Concurso}

Em 1997 foi realizado um concurso nacional promovido pelo governo federal, através Empresa Brasileira de Correios e Telégrafos, e organizado pelo Instituto de Arquitetos do Brasil-SP, para o projeto arquitetônico do Centro Cultural dos Correios, a ser instalado em sua Agência Central construída por Ramos de Azevedo em 1920. 
Esse é um fato importante que destaca o projeto do Centro Cultural em relação às outras obras estudadas: o projeto do Una Arquitetos ter sido escolhido por concurso público.

A ocupação parte de decisões que ficam claras quando se percorre o edifício:

. a cobertura translúcida implantada no pátio central, em torno do qual se organiza a edificação original, onde são distribuídas as funções administrativas e de exposição, permite ampliar a integração dos espaços, desejável nesse tipo de programa, valorizando suas fachadas internas. Para Ana Luiza Nobre, essa estratégia deriva diretamente dos ensinamentos da Pinacoteca de Paulo Mendes da Rocha, em que a praça central esvaziada permite uma nova ordem espacial do edifício acadêmico secular, uma forma de subverter seu regime de compartimentação. (NOBRE, apud MILHEIRO, 2006, p. 24) [em destaque no texto original]

. a criação de um acesso público posterior, pela rua Abelardo Pinto, pelo qual pode-se ingressar no átrio central ao mesmo tempo em que permite que as atividades de

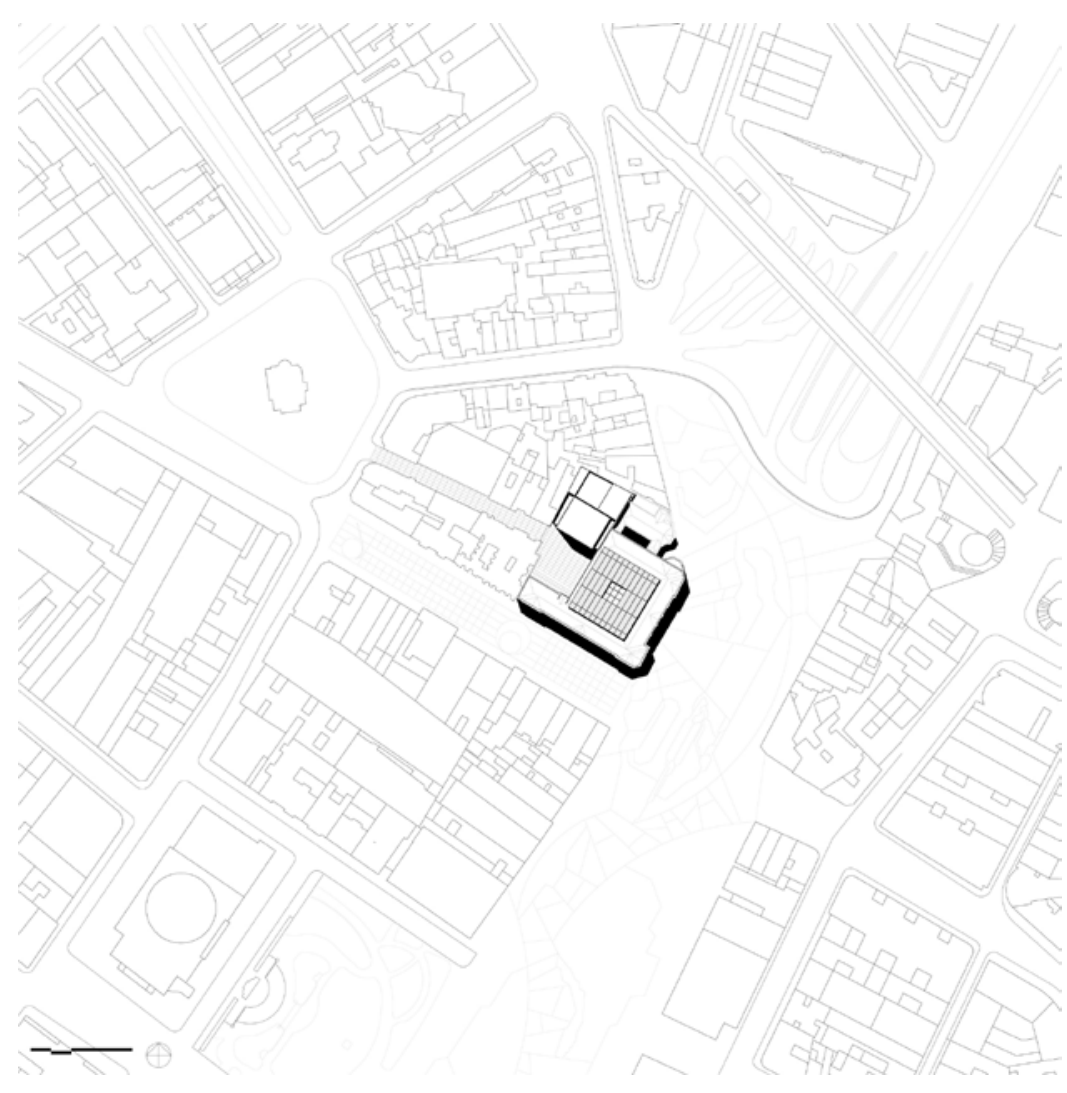

Implantação.

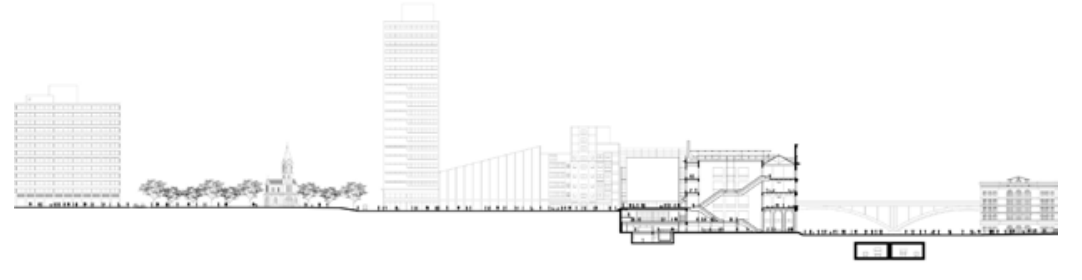

Corte Longitudinal. Fonte: Una Arquitetos 
maior afluência de público, teatro e auditórios, sejam implantadas na continuidade do espaço urbano.

. a concentração dos espaços de espetáculos em uma nova edificação adjacente ao acesso posterior, que completa o gabarito do edifício histórico. Essa nova ala não se apresenta de forma simétrica à ala do edifício original voltada para a avenida São João, mas cria o equilíbrio necessário para a configuração desse foyer urbano posterior, protegido.

Fica claro que essa última decisão permitiu colocar em evidência as qualidades da edificação original ao estabelecer uma relação direta entre os volumes, sem que haja a sobreposição de seu novo uso e de sua consequente modernização em relação às condições estabelecidas historicamente pela obra de Ramos de Azevedo. Mesmo lamentando que essa nova edificação não tenha sido construída e que o projeto tenha sido implantado parcial e consideravelmente descaracterizado, as decisões de projeto indicam um caminho seguro para a intervenção. Nela a arquitetura do espetáculo se manifesta de forma serena, muito próxima do que afirma Choay ao parafrasear os linguistas sobre o valor semiótico do contraste: "O sentido constrói-se na contiguidade, com base na diferença, mas desde que a justaposição dos signos se converta em articulação." (2006, p. 225)

Como pode ser visto no corte longitudinal, foi criada a praça urbana do projeto, a praça foyer que abriga o teatro mas que não concorre com a avenida São João e com o próprio Vale do Anhangabaú como espaço público de fluxos e de trocas. Podemos considerá-la promotora de um percurso específico, especializado, direcionado para a atividade principal a que o Centro Cultural fora destinado.

Do ponto de vista das soluções construtivas necessárias à sua modernização, o projeto mantém a mesma linha da intervenção organizacional, deixando clara sua leitura, com o devido respeito aos valores fundamentais da edificação eclética de Ramos de Azevedo sem, contudo, abrir mão da precisão funcional e construtiva.

0 que se destaca para nosso estudo, além do exposto acima, é a continuidade espacial dada à plateia do teatro em relação à área externa, à praça foyer. A concepção de 


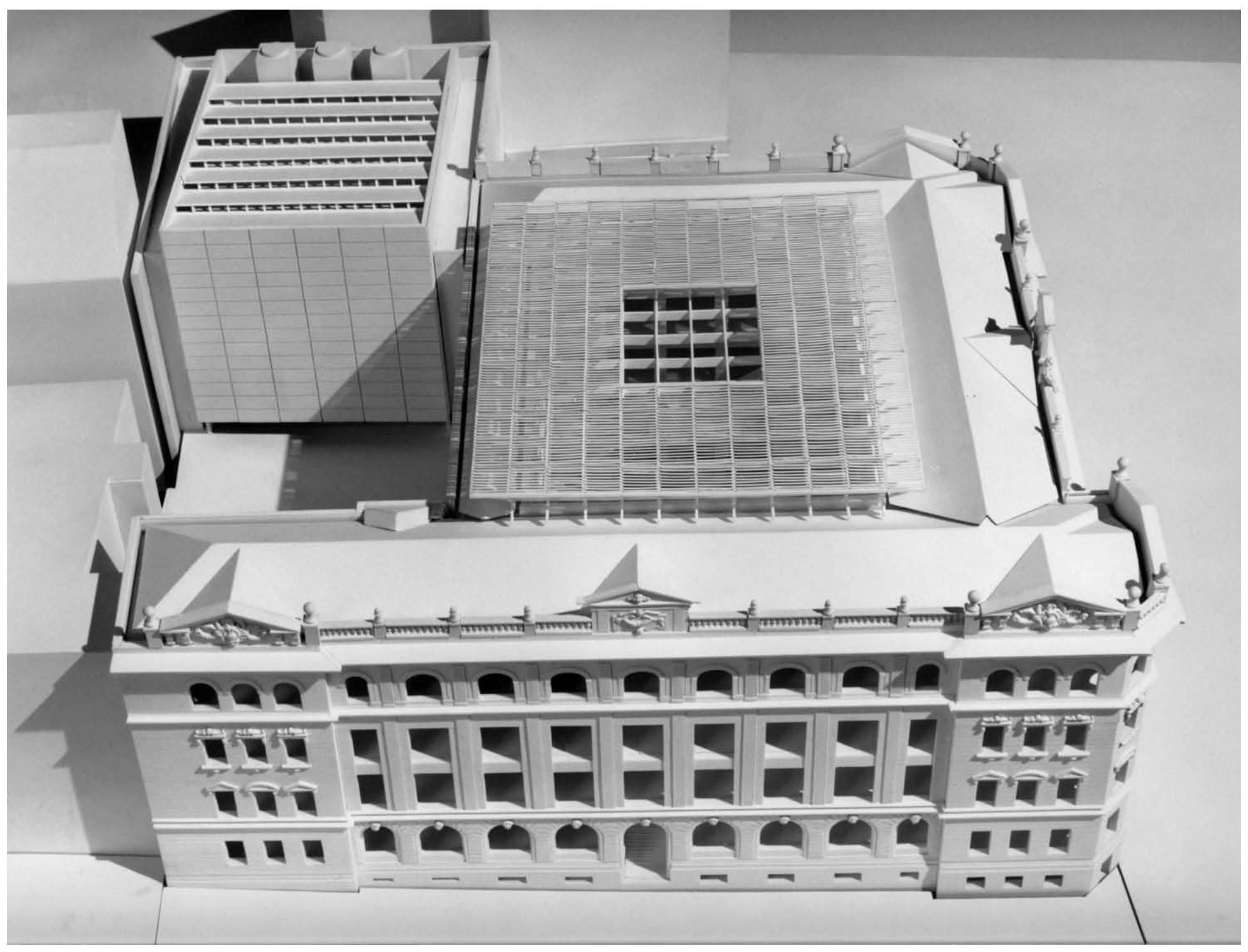

Maquete - acesso lateral para Av. São João e praça foyer posterior. Fonte: Una Arquitetos 


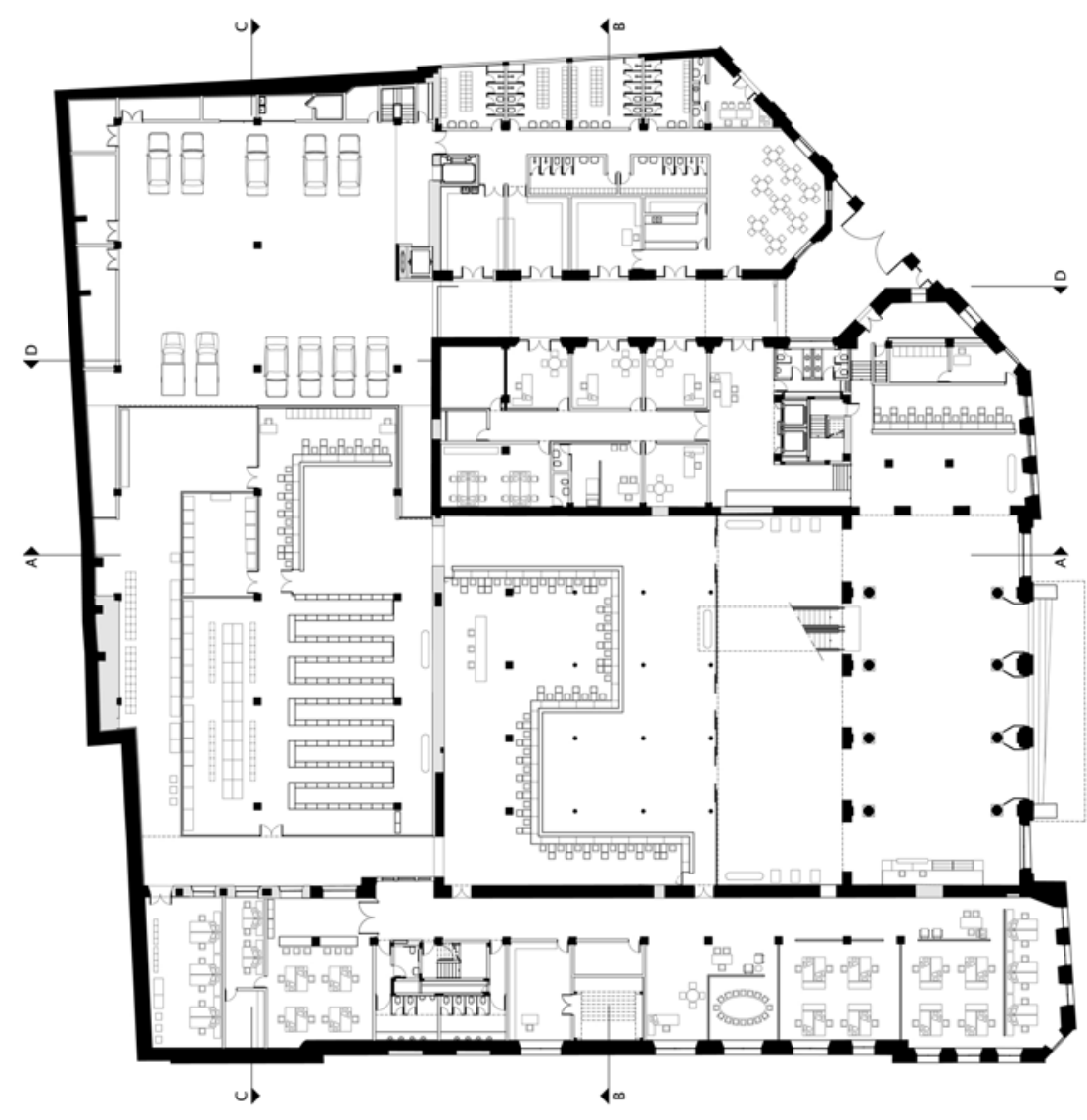

Planta nível Anhangabaú. Escala 1:500. Fonte: Una Arquitetos

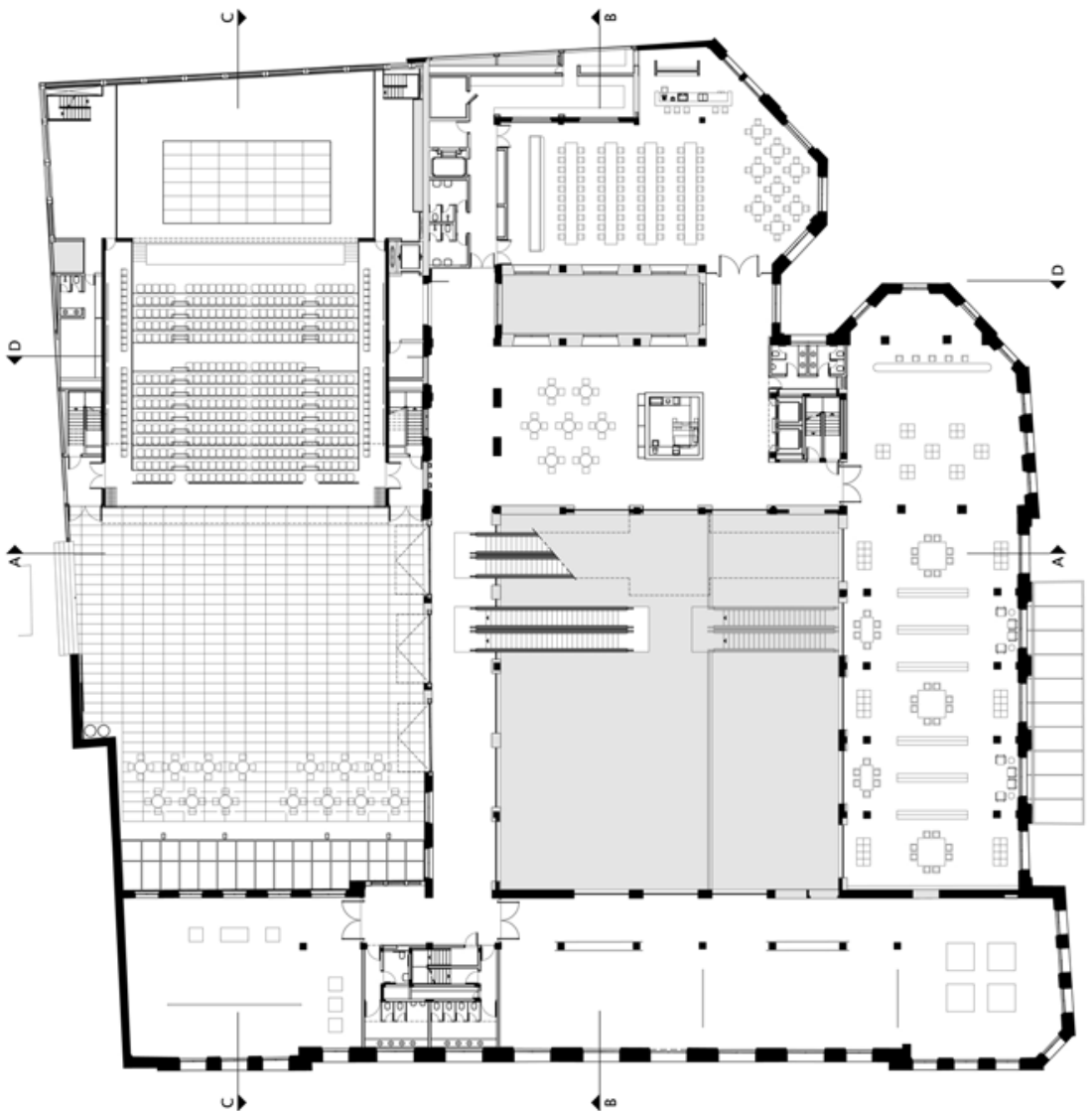

Planta foyer superior - Rua Abelardo Pinto. Escala 1:500. Fonte: Una Arquitetos 


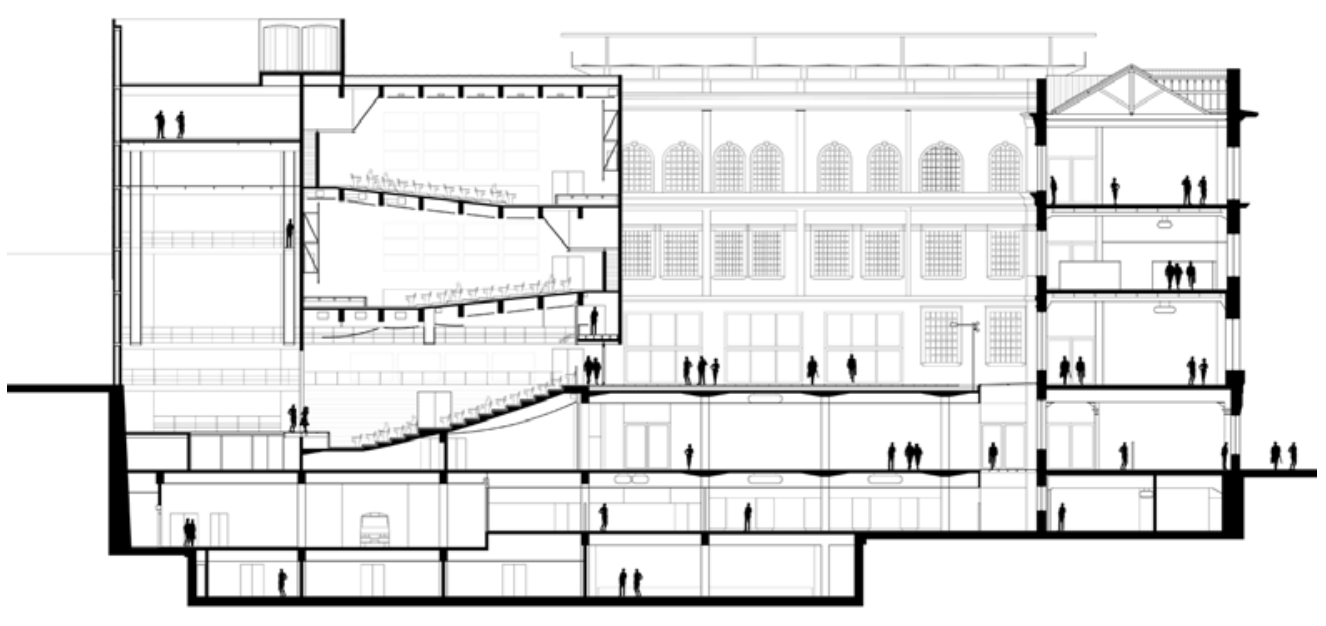

Corte transversal C. Escala 1:500. Fonte: Una Arquitetos

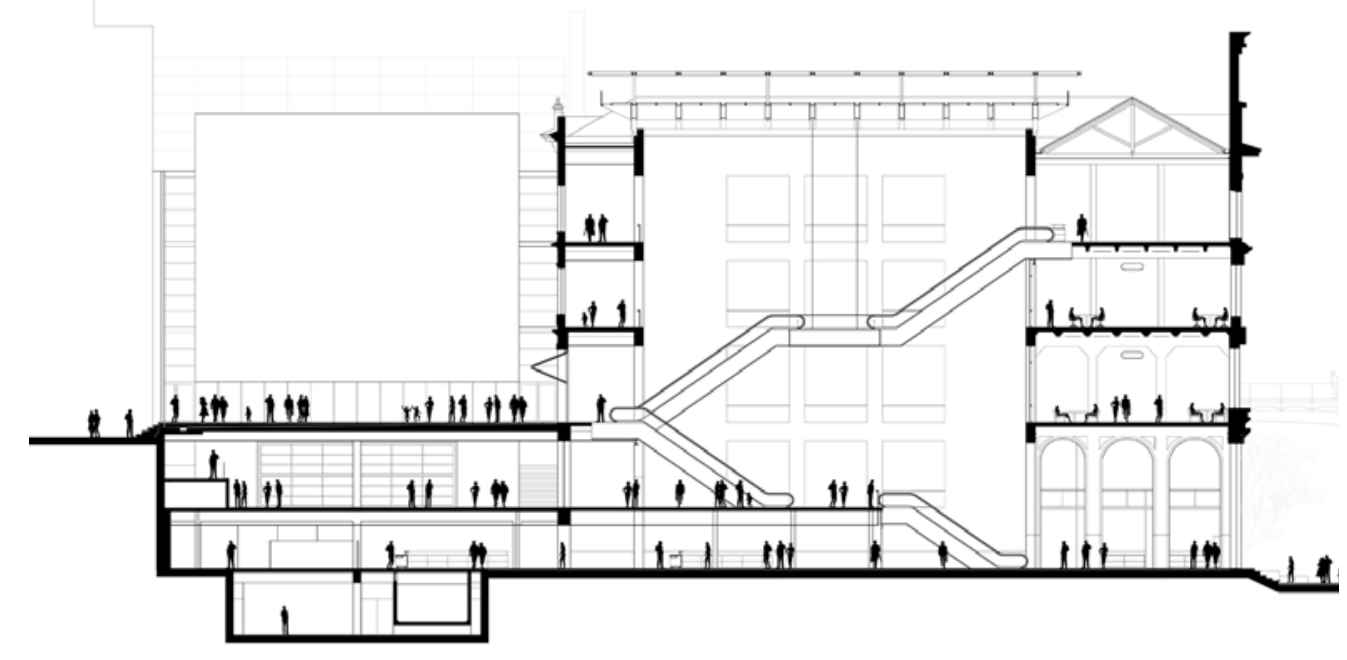

Corte longitudinal A. Escala 1:500. Fonte: Una Arquitetos

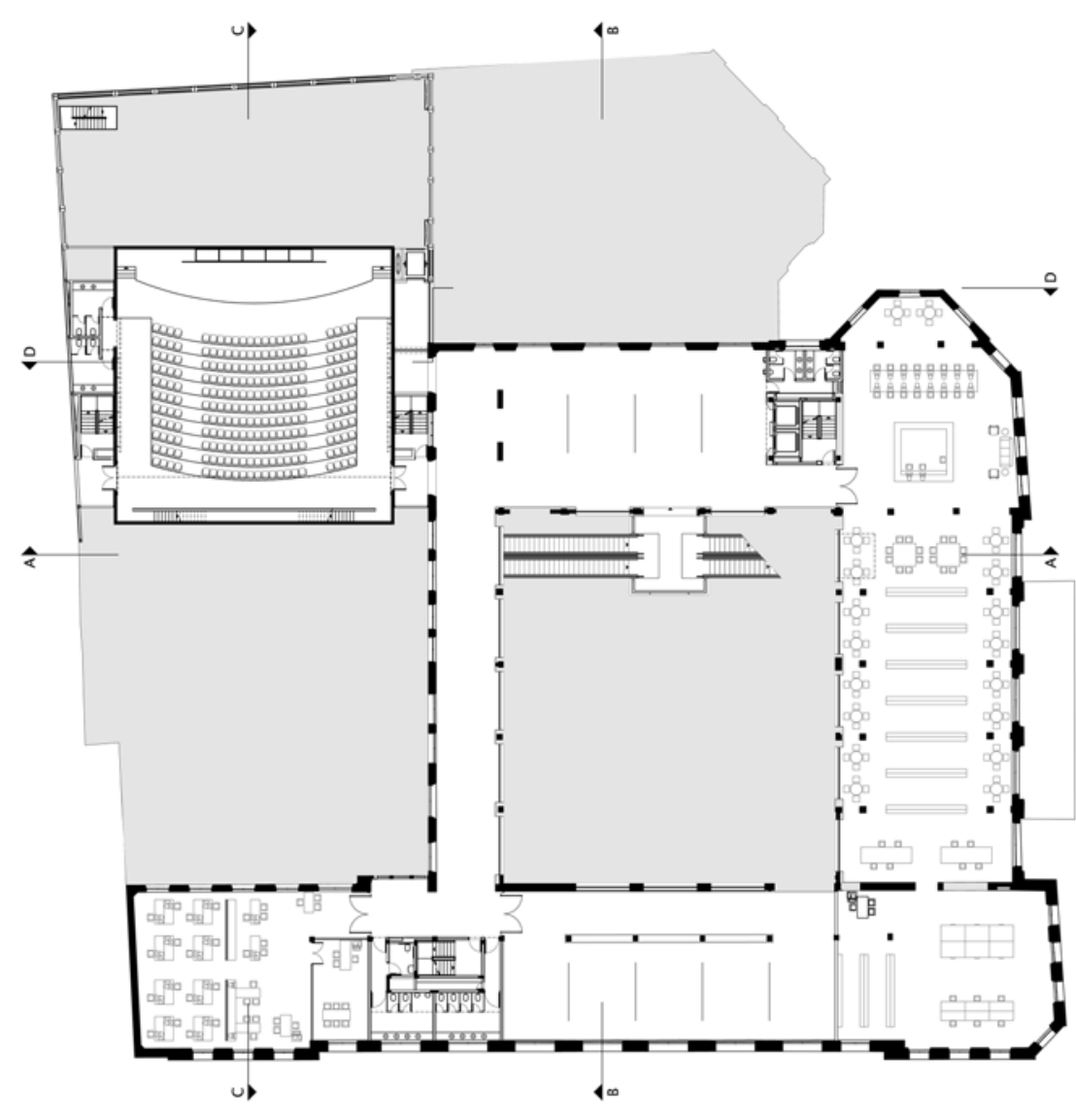

Planta pavimento superior. Escala 1:500. Fonte: Una Arquitetos 
sala frontal, unidirecional, é compensada pelo generoso vão livre que se manifesta não somente no palco e proscênio propriamente ditos, mas também nessa ligação externa da plateia com o foyer urbano. Não se trata, nesse caso, de inverter o sentido da cena, buscando o espaço urbano. Para os arquitetos, trata-se de ampliar o alcance da assistência, ou seja, tornar a cidade plateia.

O trabalho do Una concentra-se na prospecção dos arquétipos e no questionamento da sua capacidade de resposta aos usos atuais. É uma sondagem que invade uma história "mais" antiga. Essa predisposição permite-lhes testar sucessivos esquemas de cidade em espaços dilacerados (Centro Universitário Maria Antônia, 2000) ou ensaiar uma "praça" dentro de um edifício eclético (Agência Central dos Correios, São Paulo, 1997). A cultura local funde-se aqui na sua origem universal, cerzindo uma só identidade "clássica". Nos seus projetos a tensão entre a história e a modernidade é menos fraturante e a linguagem, novamente, uma causa menor.

(MILHEIRO, 2006, p. 96) [destaque da autora]
A afirmação de Ana Vaz Milheiro, descrita acima, baseia se no argumento usado pela autora para seu texto Coletivo: a Invenção do Clássico, em que analisa a produção contemporânea de um grupo de arquitetos paulistanos, dentre eles o Una. Para a autora, as obras citadas são exemplos claros de uma postura de arqueologia dos modelos e imagens reconhecíveis e do respeito pelo patrimônio edificado. 0 raciocínio nos parece importante para prosseguir a análise de outras propostas no ambiente construído do centro de São Paulo.

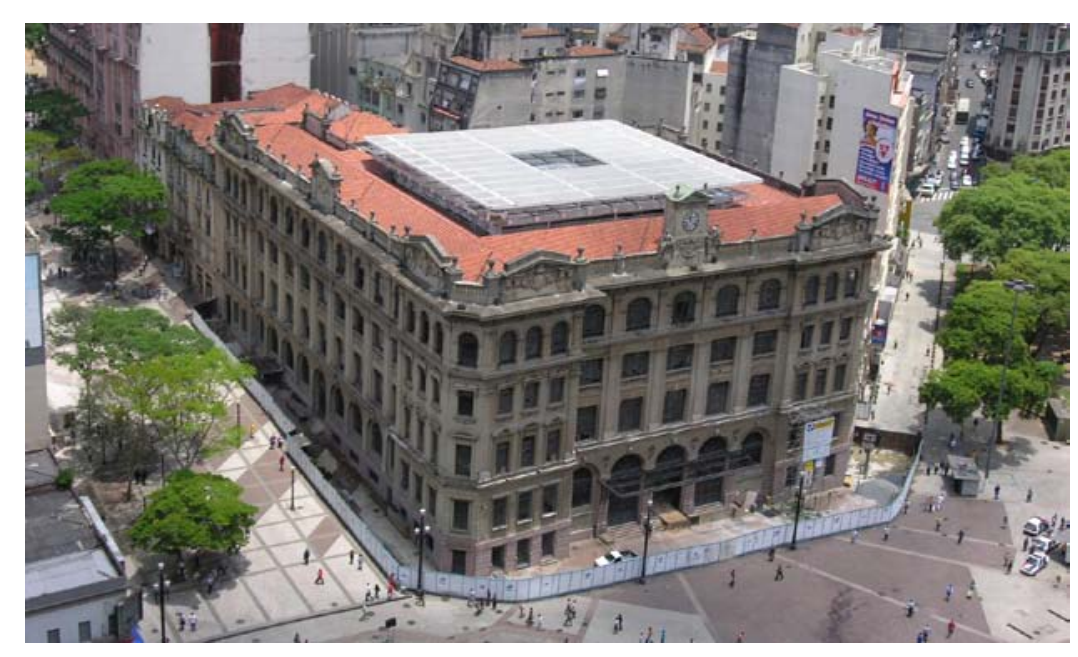

Vista aérea da esquina da Av. São João com o Vale do Anhangabaú Fonte: Una Arquitetos 


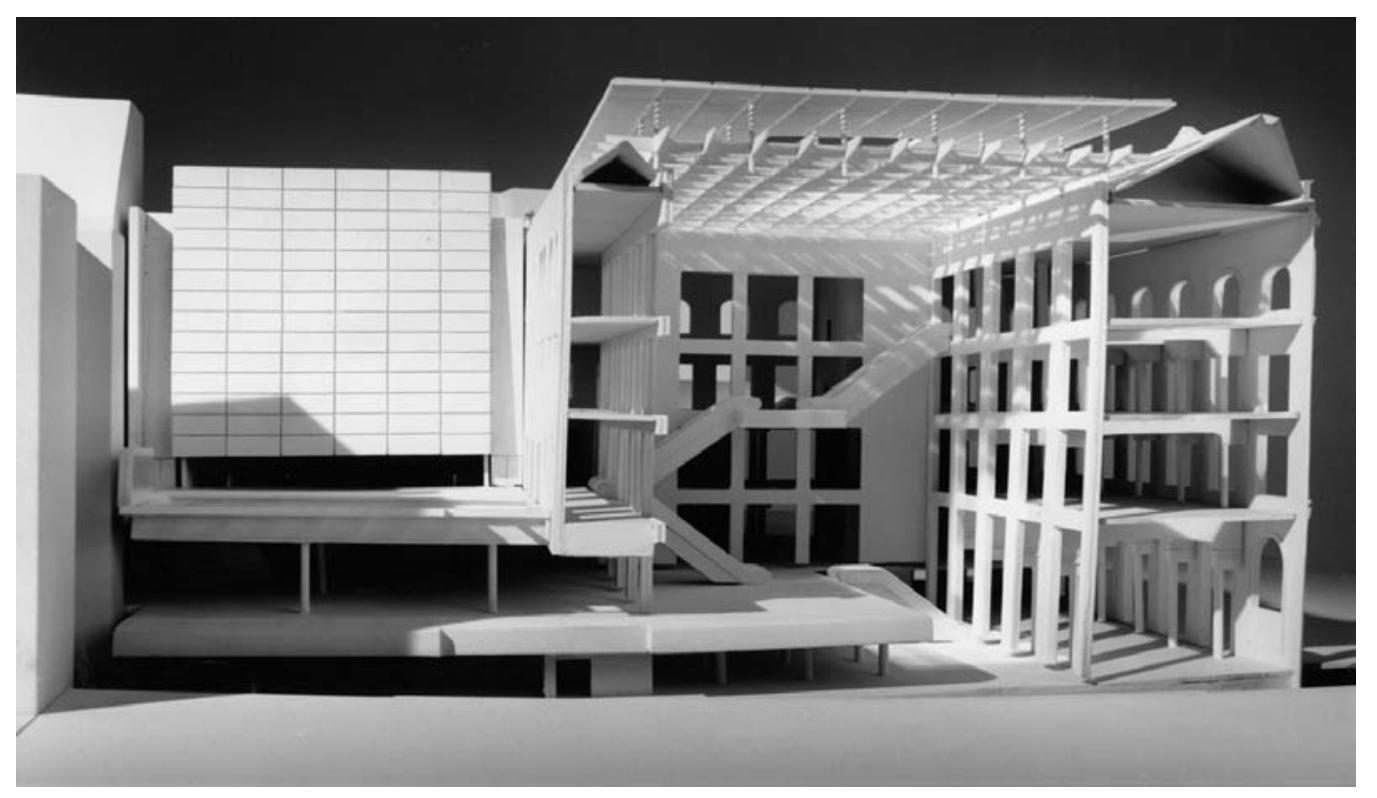

Maquete - articulação entre os acessos Anhangabaú, Av. São João e Rua Abelardo Pinto Fonte: Una Arquitetos

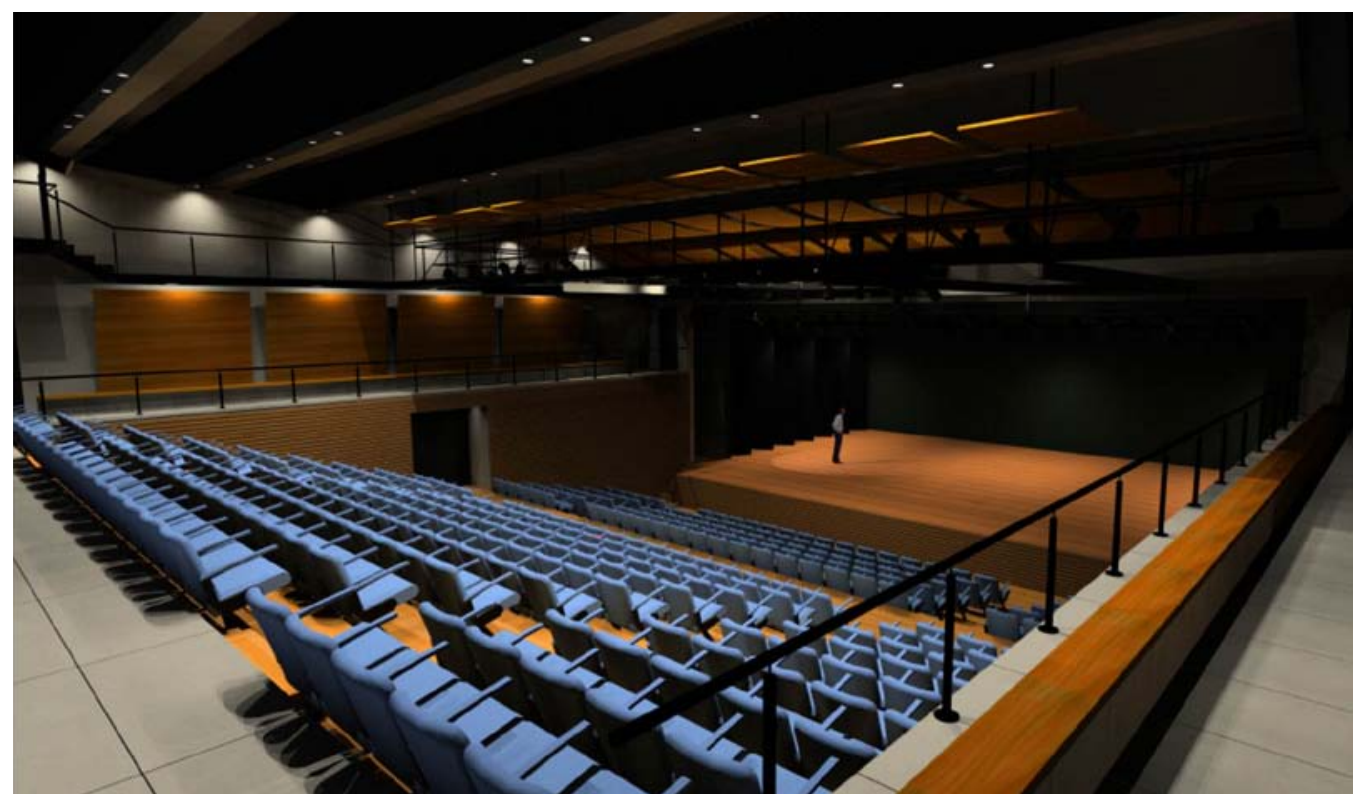

Vista interna do teatro acessível pela praça foyer da Rua Abelardo Pinto Fonte: Una Arquitetos

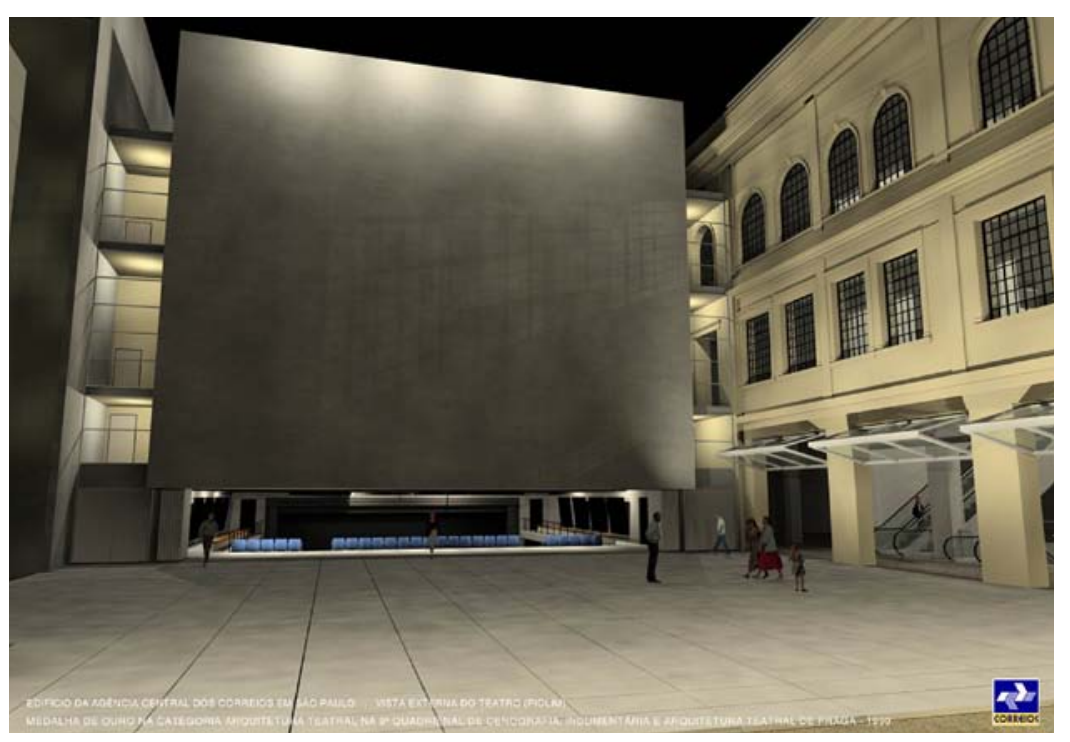

Vista da praça foyer da rua Abelardo Pinto Fonte: Una Arquitetos

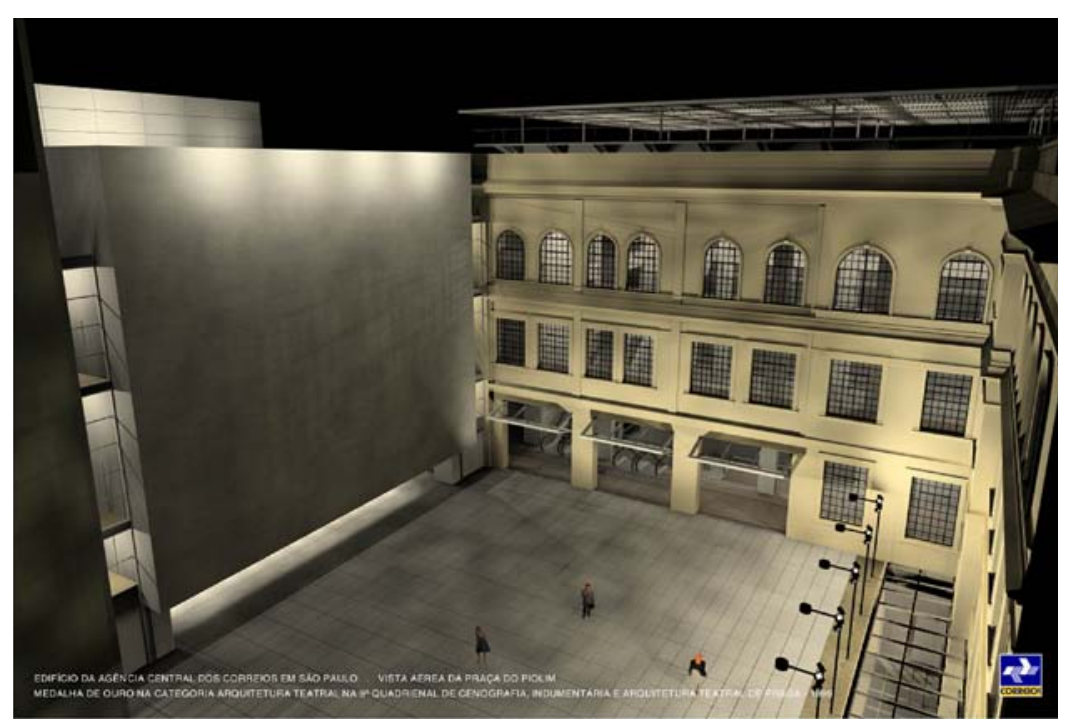

Vista da praça foyer da rua Abelardo Pinto Fonte: Una Arquitetos 


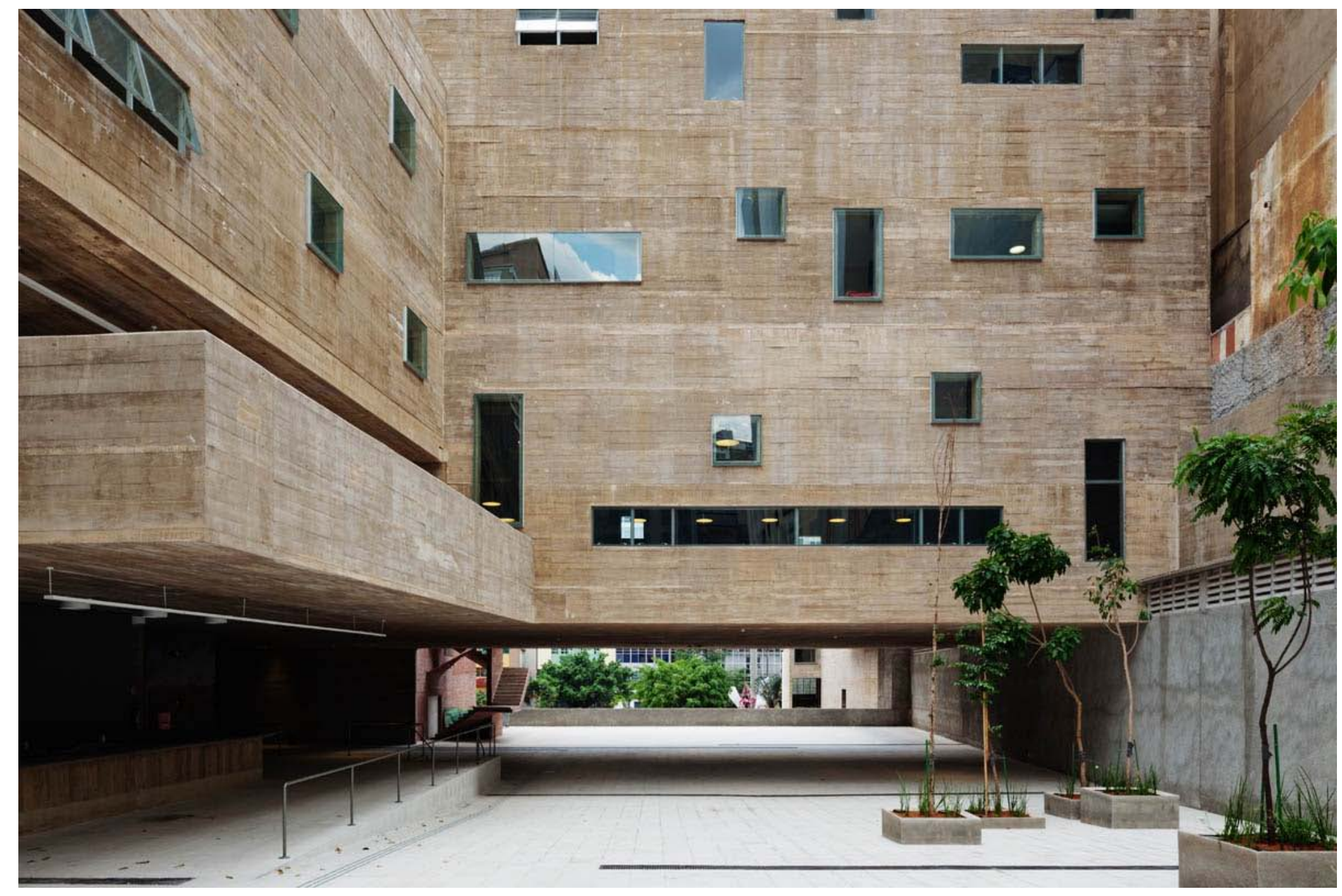

Praça das artes - vista interna - foto: Nelson Kon 
A mais recente das realizações aqui estudadas, inaugurada no verão de 2013, a Praça das Artes, é também a que engloba de forma mais completa a diversidade de ações que são as bases da política municipal de reconquista do Centro de São Paulo. Como será possível notar, a extensão do programa, distribuído na sua primeira etapa em $28.500 \mathrm{~m}^{2}$ de área construída, demonstra que se trata de um equipamento, ou melhor, de um conjunto de equipamentos públicos municipais de alcance metropolitano, edificado na área mais densamente ocupada da capital paulista, o centro da cidade $^{135}$.

Outro aspecto de interesse é que a equipe designa$\mathrm{da}^{136}$ para a concepção do projeto, Brasil Arquitetura, liderado por Marcelo Ferraz e Francisco Fanucci, vem, desde sua formação, atuando diretamente em projetos voltados para a área cultural, muitos deles elaborados com a recuperação ou reconversão de edificações existentes. Vale lembrar que a formação da equipe se deu durante o trabalho com Lina Bo Bardi no projeto de reconversão do Sesc Fábrica Pompéia, obra pioneira de 1983 e que melhor representa

$135 \mathrm{O}$ terreno possui $7.210 \mathrm{~m} 2$; o coeficiente de aproveitamento máximo permitido pode chegar a 4, como ocorreu no projeto da Praça das Artes.

136 Não nos foi possível precisar a forma utilizada pela Prefeitura Municipal para a escolha da equipe, já que não foi realizado concurso público nem licitação pública, como recomenda a legislação vigente. 


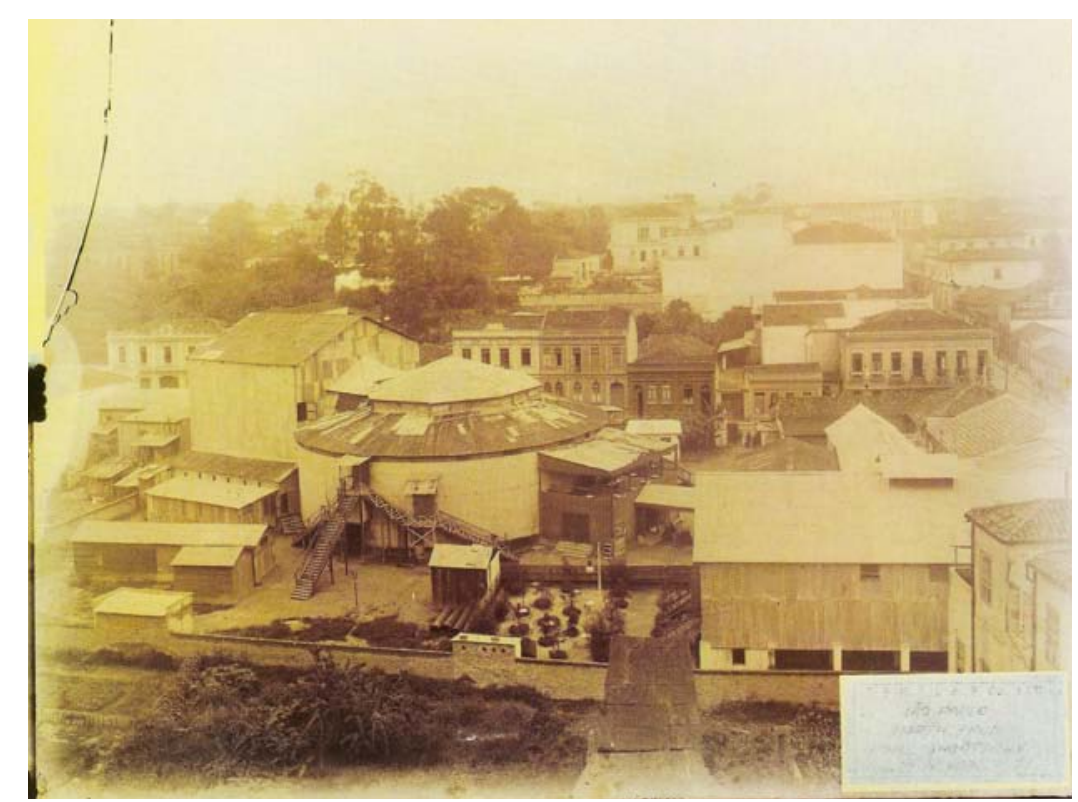

Vale do Anhangabaú - Teatro Politheana. Fonte:TOLEDO, 1982

na cidade as intervenções no patrimônio construído ${ }^{137}$.

Historicamente a quadra, conhecida como Quadra 27, a que pertence o lote da Praça das Artes, assumiu a vocação de lugar de espetáculos, como testemunham algumas edificações que ainda compõem o conjunto e outras que desapareceram durante o processo de crescimento da cidade, assinalado por Benedito Lima de Toledo, e que culmi-

137 A equipe de Lina Bo Bardi contou ainda com os arquitetos André Vainer, GuiIherme Pauliello e Marcelo Suzuki, esse último integrante do Brasil Arquitetura até 1995 . nou com o projeto de reabilitação do Vale do Anhangabaú, de Jorge Wilhein e paisagismo de Rosa Klias, vencedor em 1981 de concurso público ${ }^{138}$ e inaugurado em 1991. Como apresenta Victor Nosek (2013, p. 13-17) em seu trabalho iconográfico, deve-se lembrar que o local abrigou o Teatro Polytheana (entre 1892 e 1914), o Bijou Théâtre (de 1910, que foi o primeiro cinema de São Paulo), o Cine Marrocos, atualmente desocupado, além do Conservatório Dramático e Musical (1909) e o Cine Cairo (1952), que fazem parte da Praça das Artes.

\section{Entrave de Corpos Artísticos}

O projeto nasceu para abrigar os corpos artísticos permanentes do Teatro Municipal de São Paulo (orquestras, corais e quarteto de cordas), em lote pertencente ao município, localizado na quadra 27, limitada pela Praça Ramos de Azevedo, onde se localiza o Teatro, pelo Vale do Anhangabaú, pela avenida São João e pela rua Conselheiro Crispiniano. A esse programa inicial foram acrescentados o Centro de Documentação, a Escola de Dança e Música e a

138 Concurso promovido pela Prefeitura Municipal de São Paulo e pela EMURB-Empresa Municipal de Urbanização. Jpuri composto por Maximiliano Fayet, Fábio Penteado, Regina Meyer e Eduardo Leira. Ver KLIAS, 2007, p. 130. 
Discoteca Oneyda Alvarenga, além de toda a infraestrutura administrativa fundamental para seu funcionamento.

Para atender à extensão desse programa e com a nítida intenção de interligá-lo de maneira mais ampla ao espaço urbano, foram acrescentados ao lote original da rua Conselheiro Crispiniano, o edifício do Conservatório Dramático e Musical (preservado) e mais duas construções vizinhas (que foram demolidas), voltados para a av. São João. $\mathrm{Na}$ face oposta, o antigo Cine Cairo e os edifícios adjacentes também foram incorporados, ampliando essa integração em direção ao Vale do Anhangabaú e a esquina com a avenida São João. Vale lembrar que esse trecho da Avenida é reservado somente aos pedestres, o Boulevard São João, conhecido popularmente por calçadão desde a década de 1970 e que faz frente com o Centro Cultural Agência Central dos Correios.

A descrição acima resume a estratégia escolhida pela equipe de arquitetos: em um primeiro momento penetrar na quadra por três frentes diferentes com o objetivo de torná-la "aberta". Esse passo inicial pode explicar o caráter de "praça" embutido no nome e nos objetivos fundamentais do processo de projeto. Temos então o desafio que se coloca: quais decisões de projeto devem ser tomadas para que o programa de $28.500 \mathrm{~m}^{2}$ cumpra sua função e permita que a quadra se mantenha franca para que a Praça exista? A resposta se deu pela ocupação dos flancos e pela verticalização do programa, distribuído nos blocos que ocuparam cada um dos flancos. Os arquitetos comparam a estratégia aos tentáculos de um polvo e essa comparação fica clara quando observadas as passarelas que interligam os edifícios no primeiro e segundo pavimentos, prismas horizontais que seguem a direção predominante.

Ao lançarmos um olhar mais atento aos documentos de projeto, como a Planta do Pavimento Térreo, o resultado dessa implantação apresenta-se muito mais como uma rua do que como uma praça, pois é dominada pela direção norte-sul. 0 espaço mais amplo e generoso induz o visitante na direção da rua Conselheiro Crispiniano para o Vale do Anhangabaú, vencendo o desnível entre os dois logradouros com escadarias e planos inclinados ao longo dos 
quais os arquitetos posicionaram de maneira estratégica lanchonete, restaurante, café, banca de revistas e os acessos principais do auditório, da discoteca e da sala de ensaio da orquestra. Essa nos parece a característica principal do projeto: a verticalização dos blocos construídos nos flancos e a organização dos seus acessos e das áreas de convivência ao longo de um percurso, de uma rua (no lugar de praça) interna à quadra e paralela à avenida São João.

Não seria nem a continuidade das fachadas no alinhamento que caracterizara o centro da cidade de taipa e da metrópole do café, nem a quadra arrasada e o objeto construído destacado, isolado em seu interior, de maneira a romper com a noção de rua que marcara as utopias do Movimento Moderno. Podemos compará-la à quadra aberta ilustrada por Christian de Portzamparc no que ele denominou a Cidade da Terceira Era: a quadra que mantém relação direta com a rua mas que sofre deslocamentos, abre novas perspectivas, sem romper com a cidade tradicional. 0 arquiteto considera a primeira era a da cidade histórica e a segunda era a da cidade moderna:
A quadra aberta permite reinventar a rua: legível e ao mesmo tempo realçada por aberturas visuais e pela luz do sol. Os objetos continuam sempre autônomos, mas ligados entre eles por regras que impõem vazios e alinhamentos parciais. Formas individuais e formas coletivas coexistem. Uma arquitetura moderna, isto é, uma arquitetura relativamente livre de convenção, de volumetria, de modenatura, pode desabrochar sem ser contida por um exercício de fachada imposto entre duas paredes contínuas. (...) As fachadas externas deslocam-se com alternância, constituindo uma atmosfera densa e íntima. (PORTZAMPARC, 1997, p. 47)
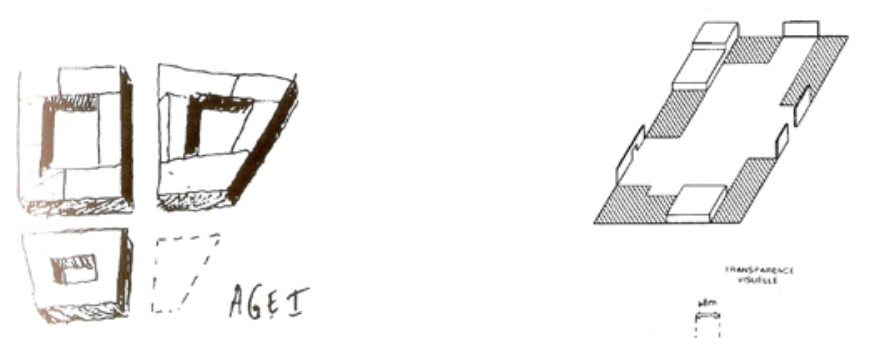

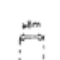

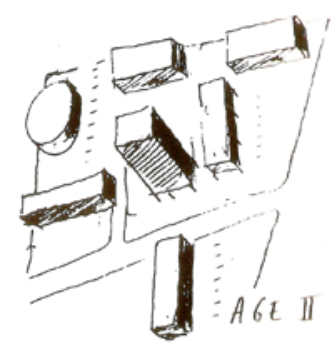

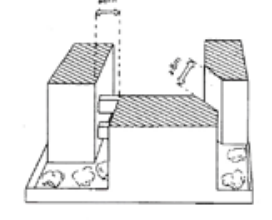

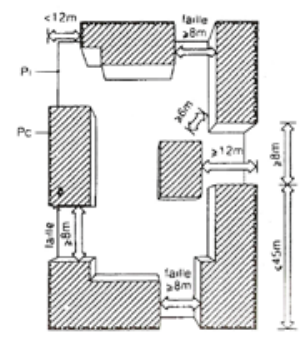




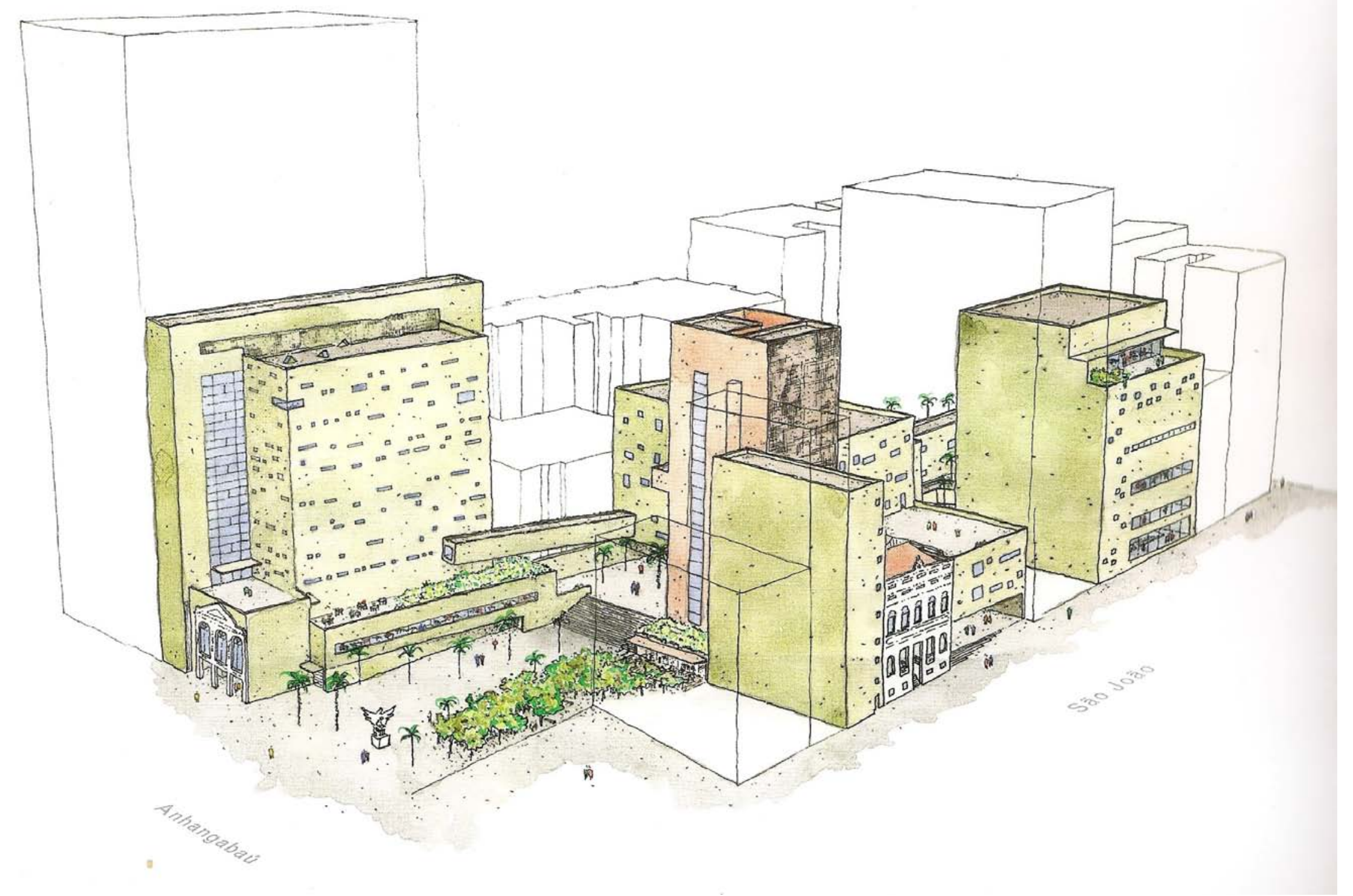

Praça das Artes. Croqui. Fonte: Projeto Design n. 395 01/2013 


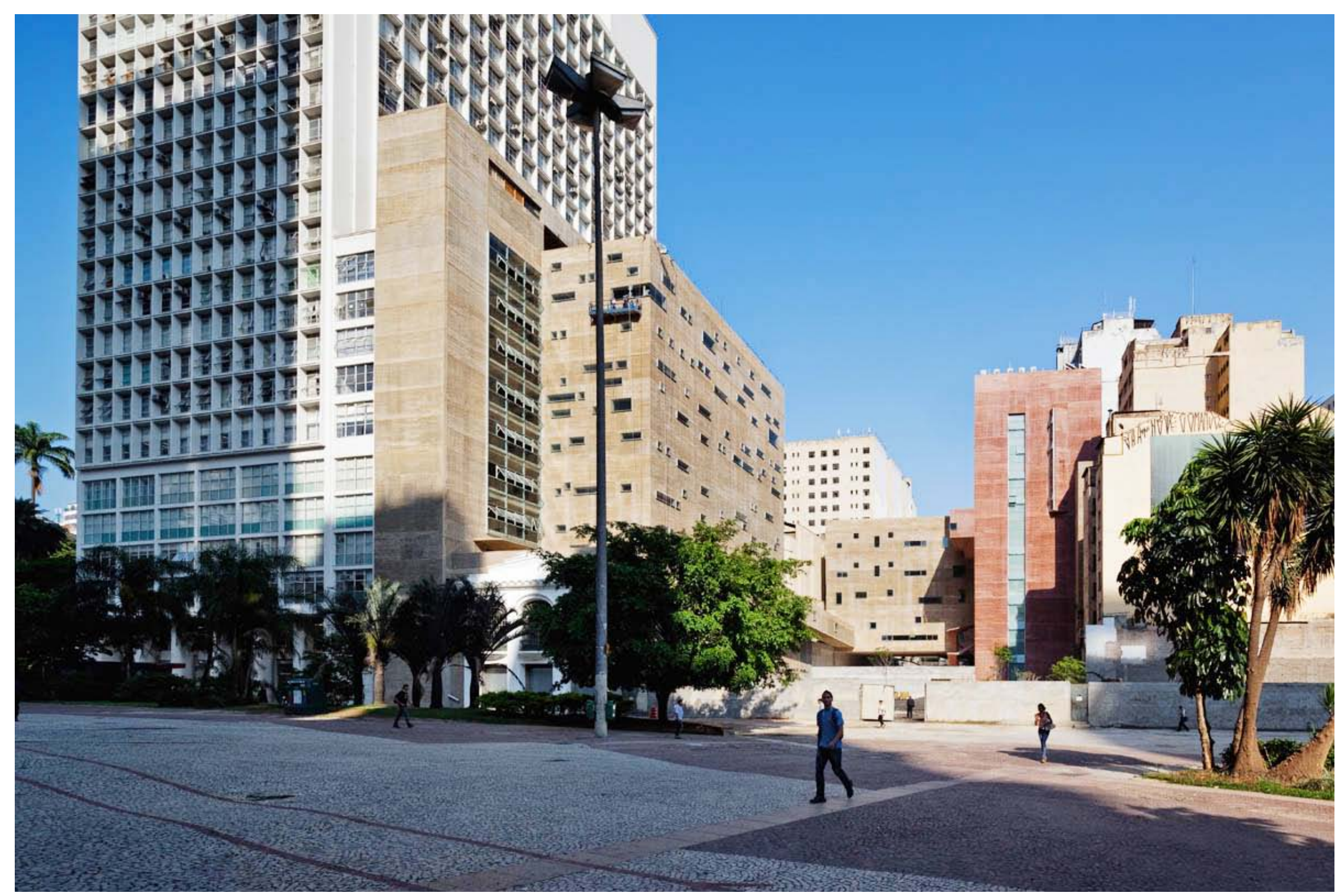

Praça das Artes. Vista do acesso do vale do Anhangabaú. Foto: Nelson Kon 


\section{Onde Está o Espetáculo}

Mesmo trabalhando predominantemente com edifícios verticais articulados, mas isolados, onde foram distribuídas as unidades do programa, como descrito anteriormente, os arquitetos não se preocuparam em identificar a especialização dos usos, isto é, as edificações foram projetadas desde uma mesma visão de cidade em que a arquitetura encerra suas formas em função de regras construtivas, nesse caso, aquelas regidas pela expressão do concreto armado bruto. 0 uso da pigmentação para a execução desse concreto aparente, que vai do cinza ao terracota, e que tem o ocre como predominante, não permite a leitura funcional, nem foi usada com essa finalidade. 0 resultado está muito mais comprometido com as pesquisas formais empreendidas pelo Brasil Arquitetura desde o período em que colaborou intensamente com o trabalho de Lina Bo Bardi, como é o caso da área esportiva do Sesc Fábrica Pompéia: um deck linear, uma rua ladeada por duas torres e passarelas em concreto bruto.

No interior dos edifícios da Praça das Artes foram distribuídos os espaços que são especializados para o espetáculo. Naquele que se encontra frontal ao Vale do Anhangabaú está a sala de ensaio das orquestras que reproduz as condições físicas do fosso a elas reservado no Teatro Municipal, mesmo obedecendo a uma situação acústica distinta. Há ainda outras salas de ensaio, como as dos corais, que ocupam os pavimentos superiores. Já na Escola de Dança, frontal à avenida São João, os pavimentos recebem, além das salas de ensaio, um auditório ao qual o público tem acesso.

Dessa maneira o projeto indica que não há um lugar do espetáculo e sim que o conjunto se propõe a produzir o espetáculo, a formar os atores do espetáculo e que este pode ocorrer na diversidade de espaços criados, que vão dos mais especializados no interior das edificações aos improvisados na rua interna criada. Trata-se de um artefato, um organismo, ou mais precisamente, de um sistema de organismos que estabelecem entre si e com a cidade as trocas inerentes ao desempenho de cada especialidade. 


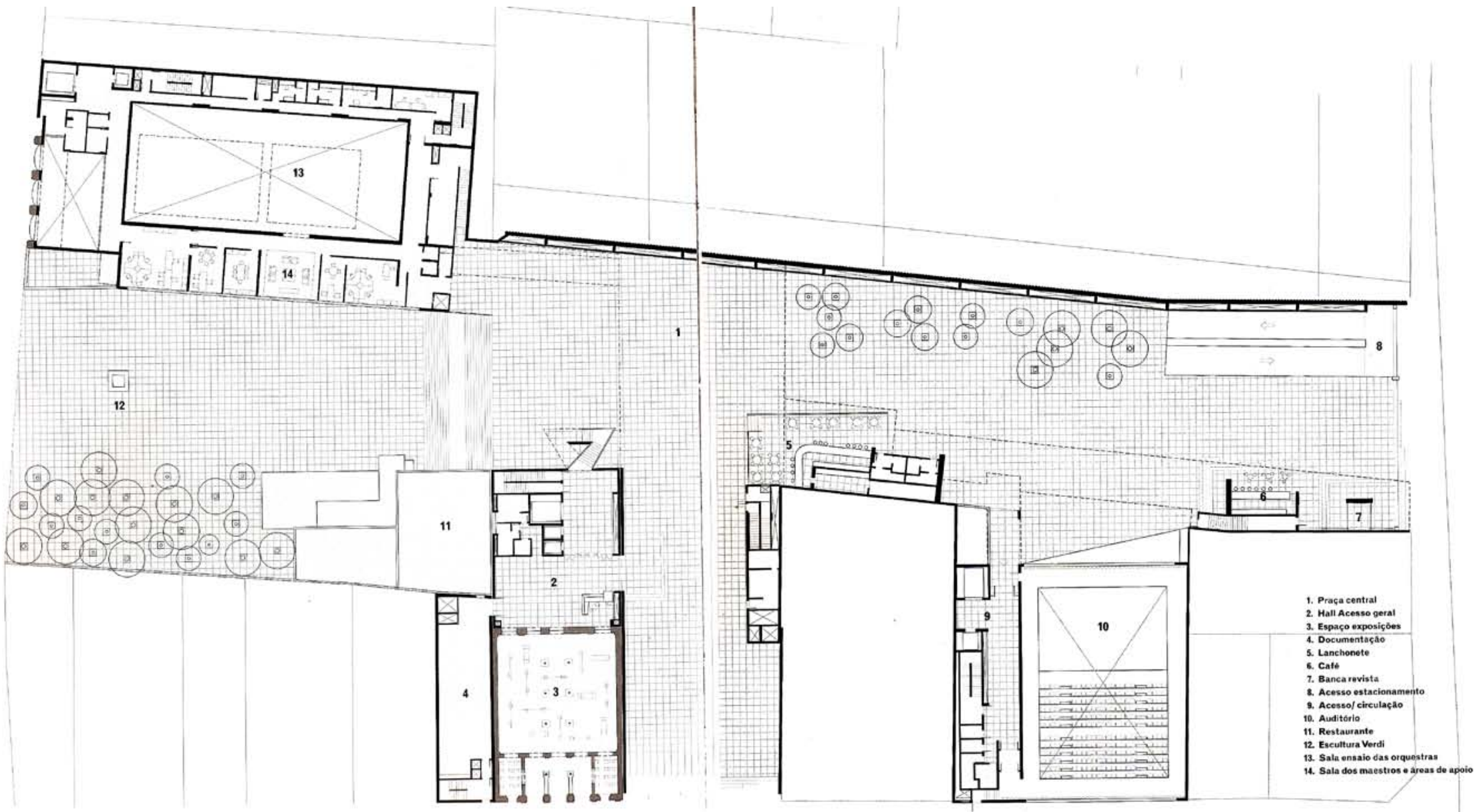

Planta - pavimento térreo. Fonte: Projeto Design 395 01/2013 


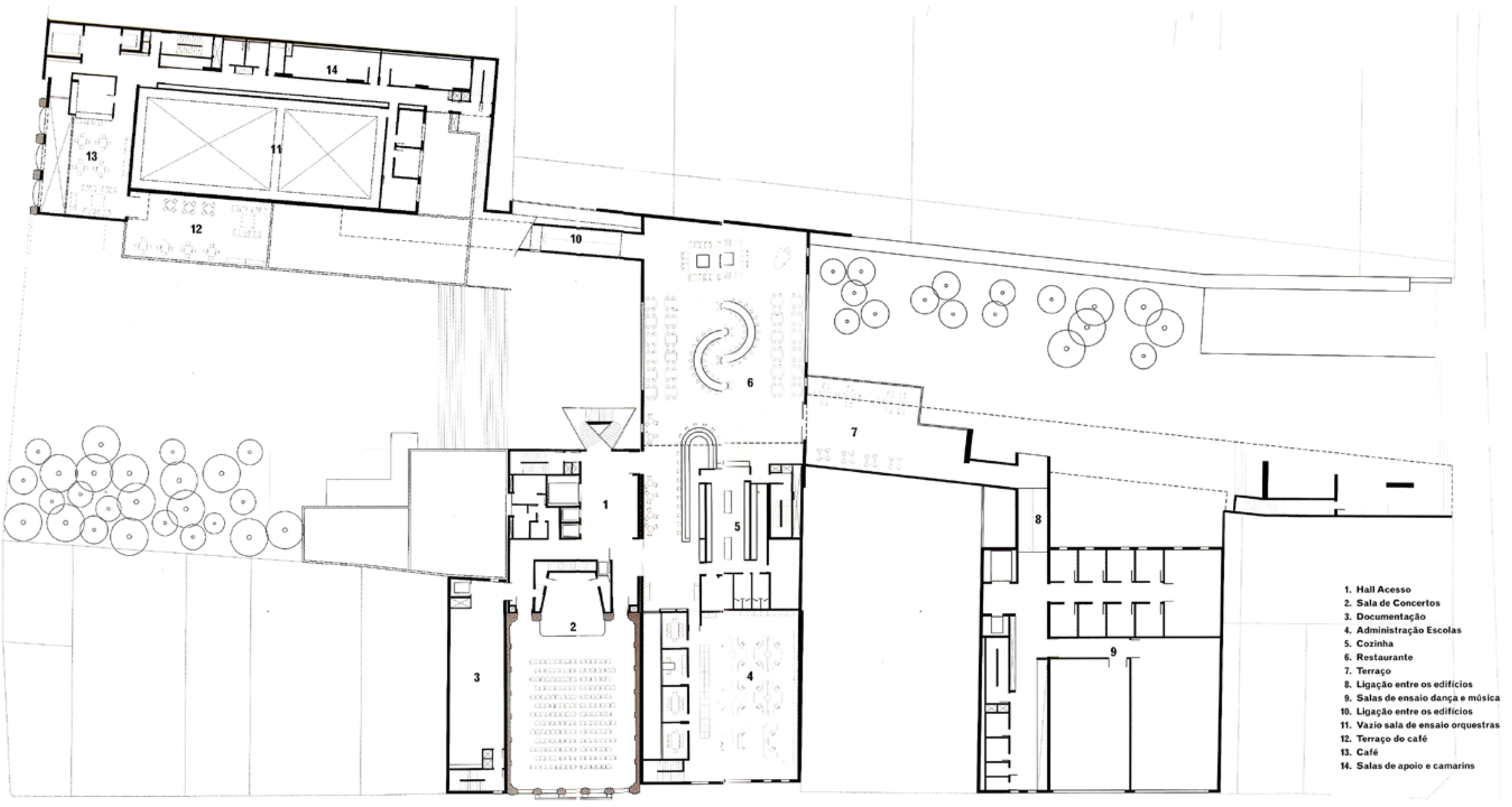

Planta - pavimento superior. Fonte: Projeto Design 395 01/2013 


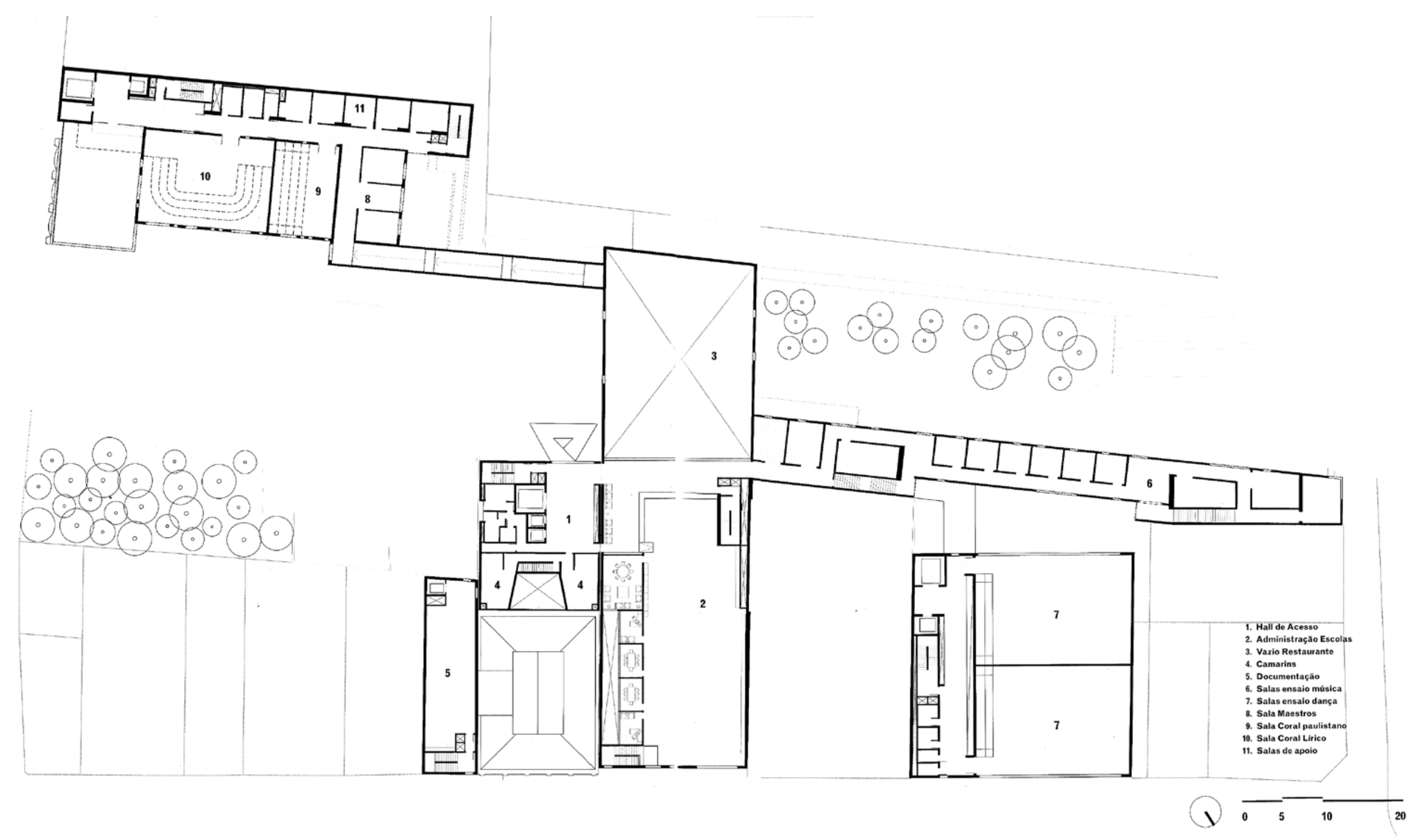

Planta - pavimento superior 2. Fonte: Projeto Design 395 01/2013 


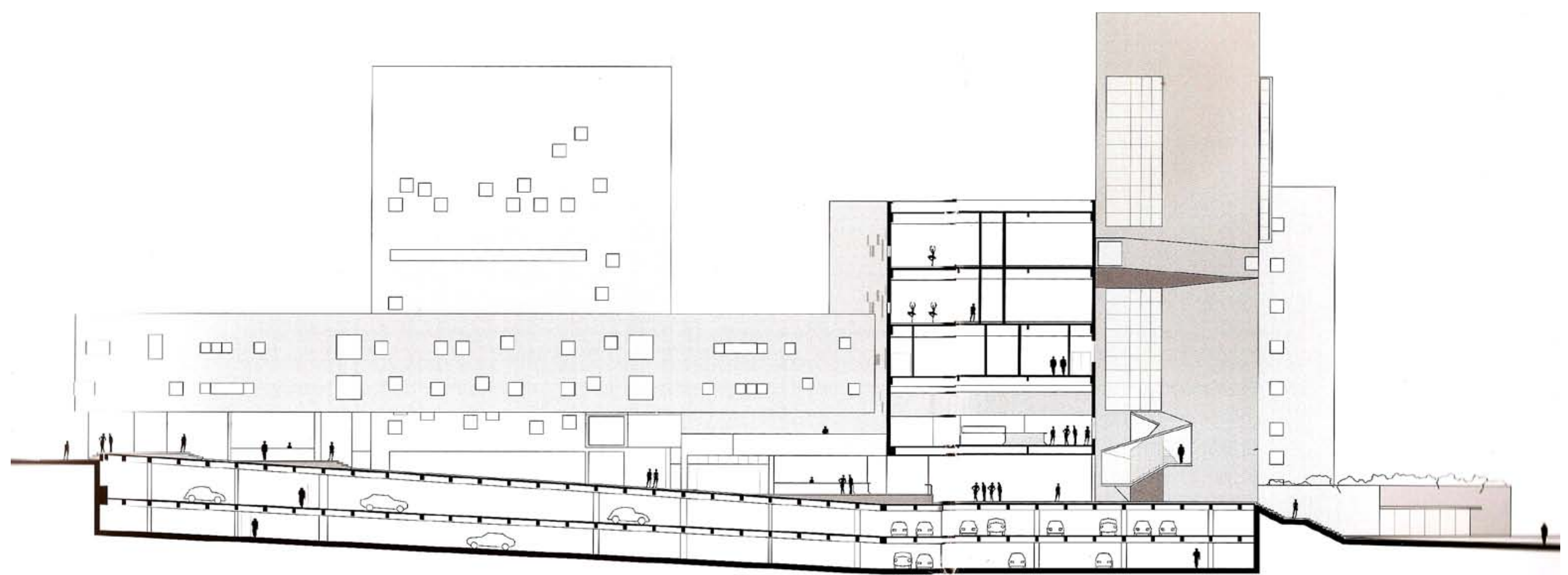

Corte longitudinal. Fonte: Projeto Design 395 01/2013 
Foge a essa regra o Conservatório Dramático Musical. 0 edifício centenário foi brilhantemente recuperado, com o restauro de sua fachada para a avenida São João e de seu auditório, restabelecendo toda a aura da época em que recebeu professores e alunos expoentes da história musical da cidade, como os maestros e compositores Luigi Chiaffareli, Camargo Guarnieri e Francisco Mignone. Ele mantém valorizada sua relação direta com a avenida mas, ao mesmo tempo, ganha estreita ligação com o restante do conjunto pela continuidade posterior de seu acesso que se prolonga em direção ao restaurante do primeiro pavimento, único volume a "tocar" todos os outros e que é também o único a cobrir a parte central da quadra.

O Conservatório, assim como a fachada do antigo Cine Cairo, permanecem como parte integrante do conjunto, em uma intervenção que buscou ser cuidadosa, delicada e inclusiva, nas palavras dos arquitetos. (NOSEK, 2013, p. 125)

Chama a atenção porém a situação desses dois edifícios históricos frente aos maciços verticais em concreto 
aos quais se submetem. Essa situação é claramente percebida quando são analisadas as imagens do ensaio fotográfico elaborado por Nelson Kon, fotógrafo especializado em arquitetura e urbanismo, que captou de maneira precisa as proporções e situações urbanas originais e as reordenadas depois da implantação da obra.

O raciocínio nesse caso se distancia daquele descrito para a reconversão do Centro Cultural Agência dos Correios na esquina oposta. Mesmo considerando que os programas são de escalas extremamente diferentes, não há, como no caso do Una Arquitetos , um caminho traçado desde o artefato construído. A constatação fica mais nítida na fachada do Cine Cairo, incorporada pelo bloco principal, como um anexo aplicado a ele.

As quatro imagens (mirar, transpor, invadir e infiltrar), juntas e simultâneas, permitem o desfrute estético das possibilidades arquitetônicas contidas, em potência, na espessura incomum que tem o chão da cidade de São Paulo. (BUCCI, 2010, p. 125)
Ângelo Bucci utiliza um raciocínio para sua hipótese de como propor projetos em uma cidade que parece ter perdido o sentido. Tal raciocínio pode ser ilustrado aplicando-se as quatro operações para eliminar as espessuras entre o Centro Velho e o Centro Novo de São Paulo. 0 texto demonstra como o crescimento do centro eliminou as qualidades do sítio original levando a perda de sentido de lugares primordiais, como a rua Boa Vista, do alto da qual não se pode mais admirar a várzea do rio Tamanduateí.

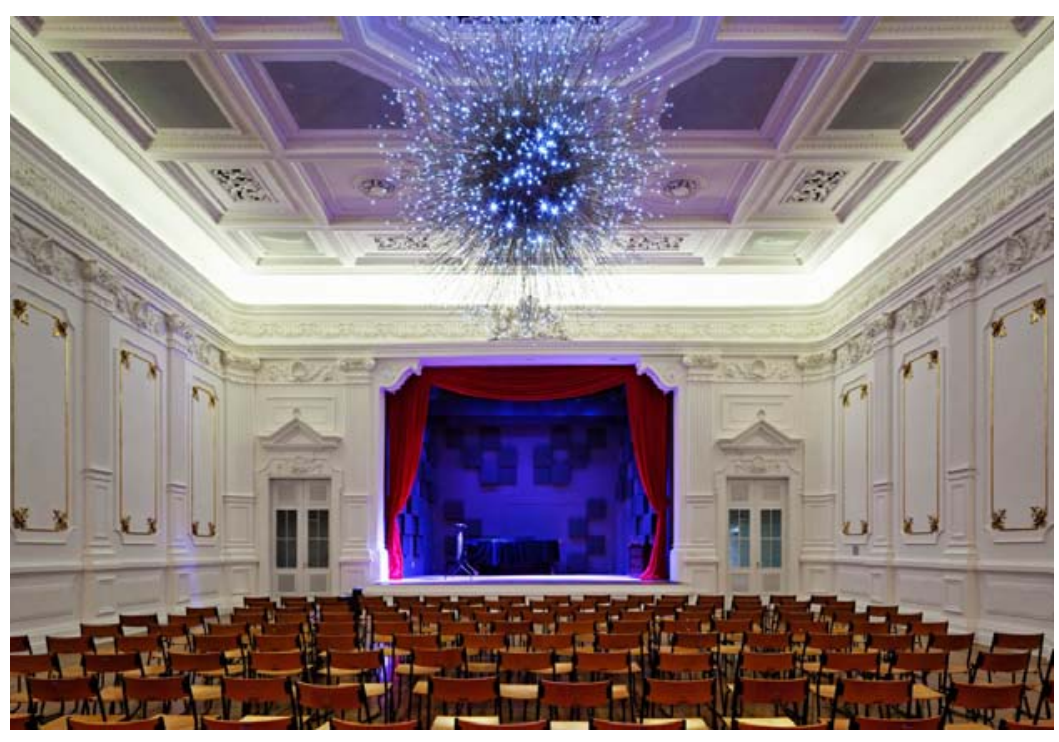

Conservatório Dramático Musical. Foto: Nelson Kon 


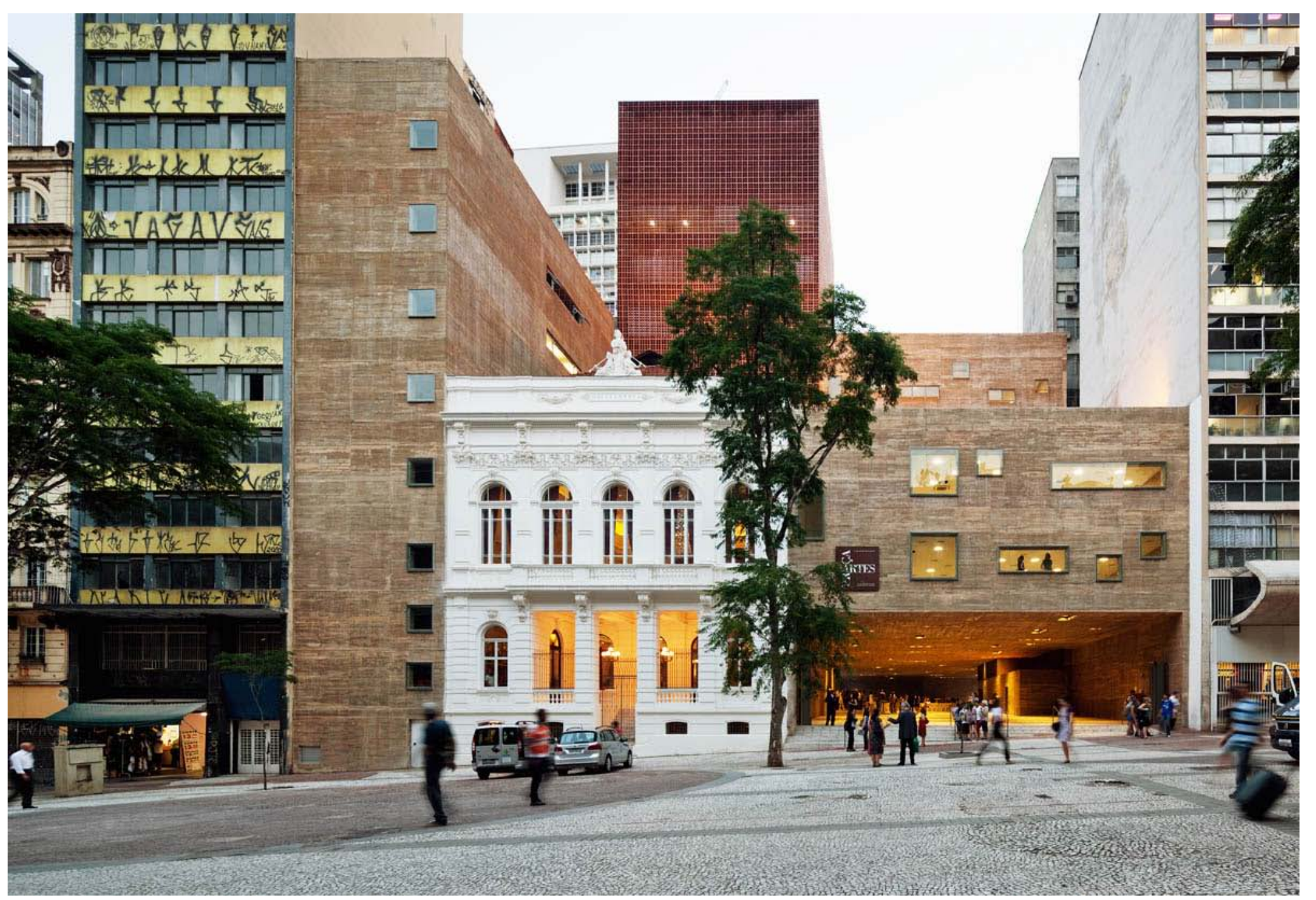

Vista do acesso da Av. São João e do conservatório restaurado à esquerda. Foto: Nelson Kon 
As operações sugeridas por Bucci parecem muito próximas das utilizadas para resolver o projeto da Praça das Artes. Em discordância está o fato de o projeto não devolver ou revelar a situação ou qualidade histórica do lugar. Entretanto, assemelha-se enquanto processo de valorização, enquanto sucessão de ações de valorização, como afirma Argan em relação à capacidade do projeto de atribuir valor:

É por isso que o projeto não pode ser tão simplesmente um exame dos dados objetivos $e$ um cálculo da resistência dos materiais ou do preço dos materiais em relação à disponibilidade financeira, mas um fator de intervenção ativa na realidade para resolver as contradições existentes. (ARGAN, 1993, p. 164)

Não fica claro, entretanto, os motivos que levaram à demolição do grande número de edifícios existentes na quadra e nem a retirada da significativa vegetação originária dos tempos em que o lote da rua Conselheiro Crispiniano era ocupado pelo exército ${ }^{139}$.
Luiz Antônio Jorge (in NOZEK, 2013, p. 69) atribui a essa obra a metáfora da costura em relação à dimensão urbana de sua arquitetura. Talvez referindo-se ao que Janes Jacobs (2009, p. 437) propôs para o processo de revitalização e fortalecimento da trama urbana ao redor. Porém o

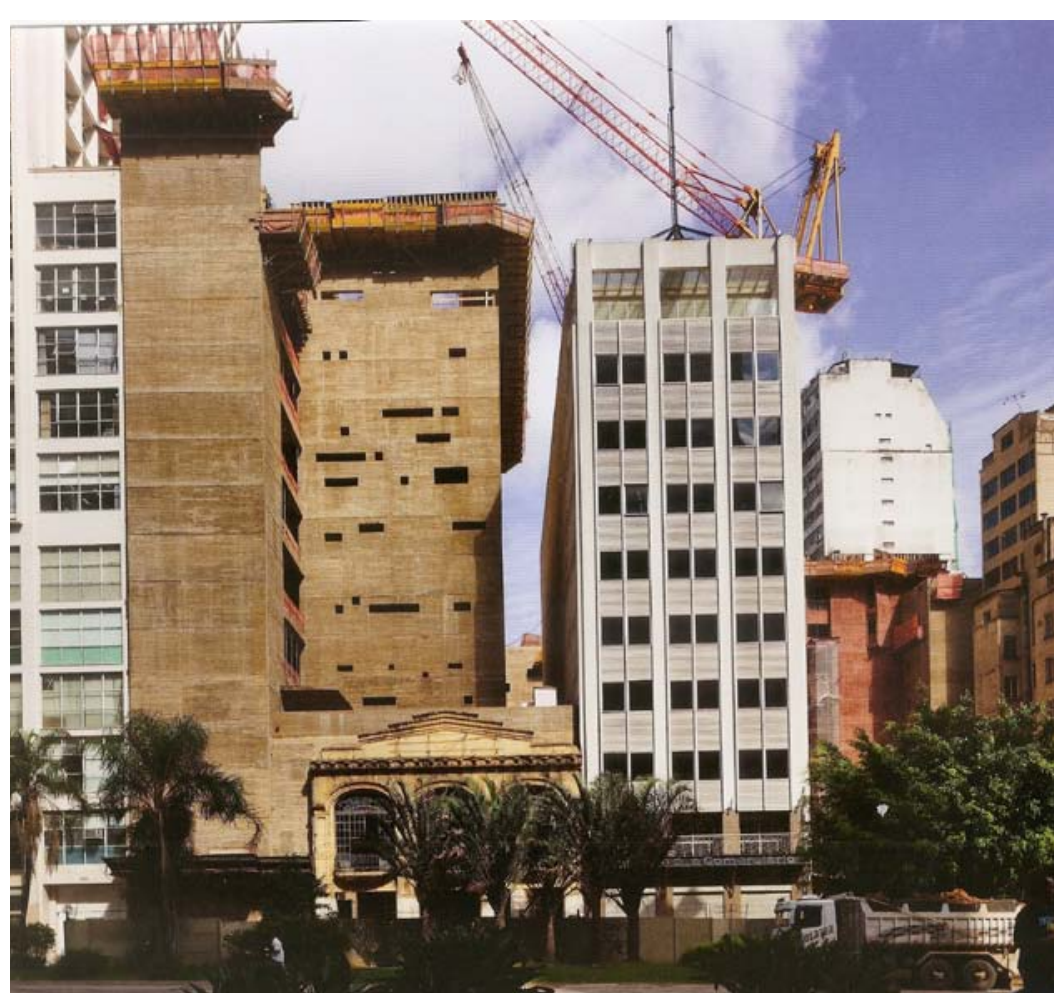

Praça das Artes em Obras. Foto: Nelson Kon 


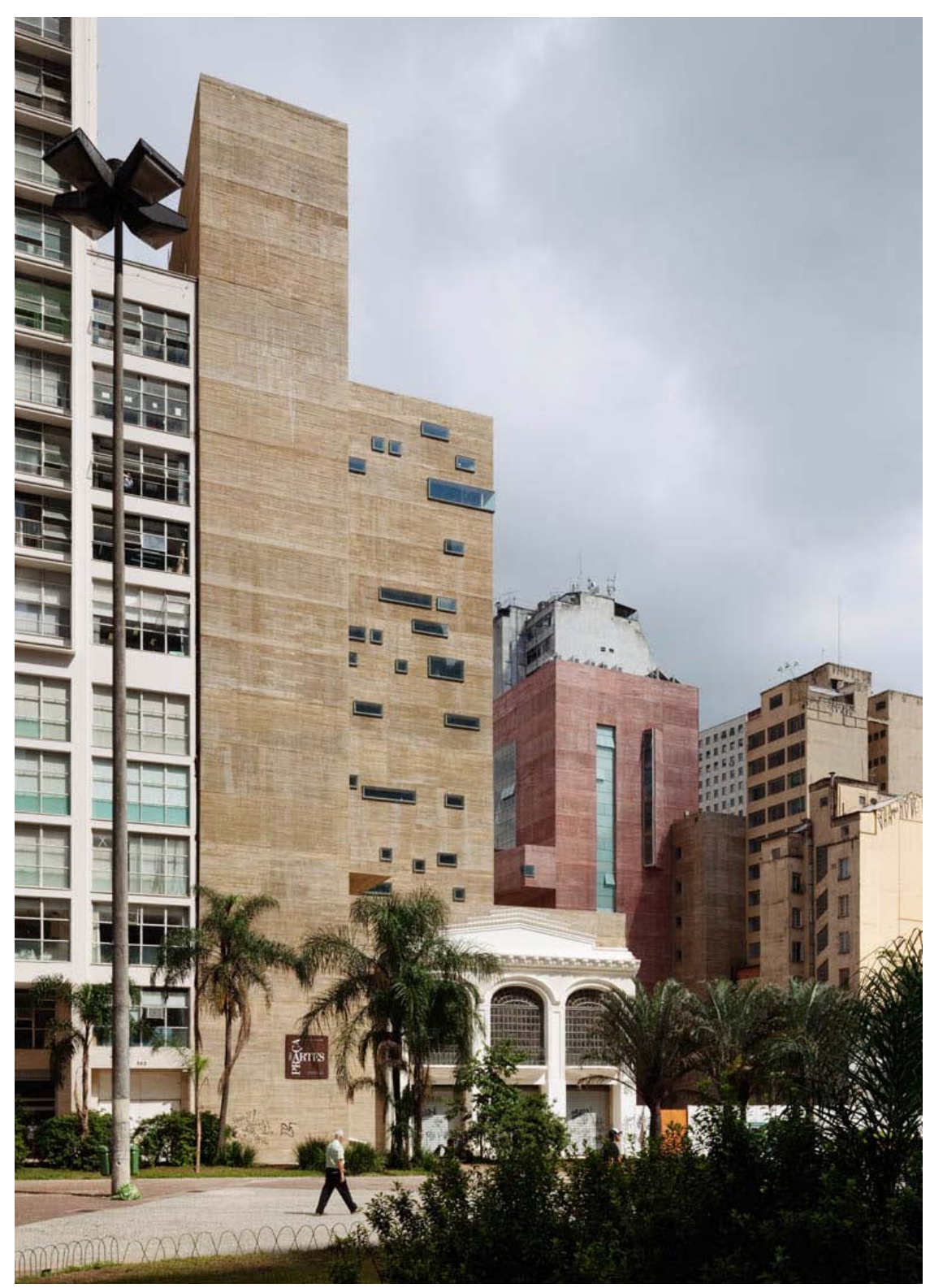

Praça das Artes - Cine Cairo. Foto: Nelson Kon projeto não parece costurar, recompor, ou mesmo alinhavar com a linha oca, como explica. A obra nesse caso se exime de uma missão reconciliadora ou restauradora. Os arquitetos se defrontaram com o desafio de um programa extenso e complexo em uma região densamente ocupada e optaram por penetrar a espessura da quadra. 0 que nos parece ser 0 valor do projeto, nesse caso, é a situação da rua "anfiteatro", interna à quadra, que cria um rico diálogo formal entre as faces posteriores dos edifícios remanescentes e os projetados. Esse aspecto fica claro no acesso da rua Conselheiro Crispiniano.

A imagem aérea sobre o eixo da avenida São João coloca ainda uma questão a ser debatida: a sucessão de espaços públicos onde predomina o fluxo de pedestres justificaria mais uma rua, isto é, se a centenária Praça Ramos de Azevedo do paisagista Bouvard, o Boulevard da Avenida São João da década de 1970 e o Vale do Anhangabaú, transformado em praça em 1991, ainda não cumpriram o papel de catalizadores de manifestações coletivas para as quais foram criados, mesmo após a inauguração parcial do Centro Cultural Agência Central dos Correios, o caminho seria qualificar um novo espaço público em detrimento desses existentes? 


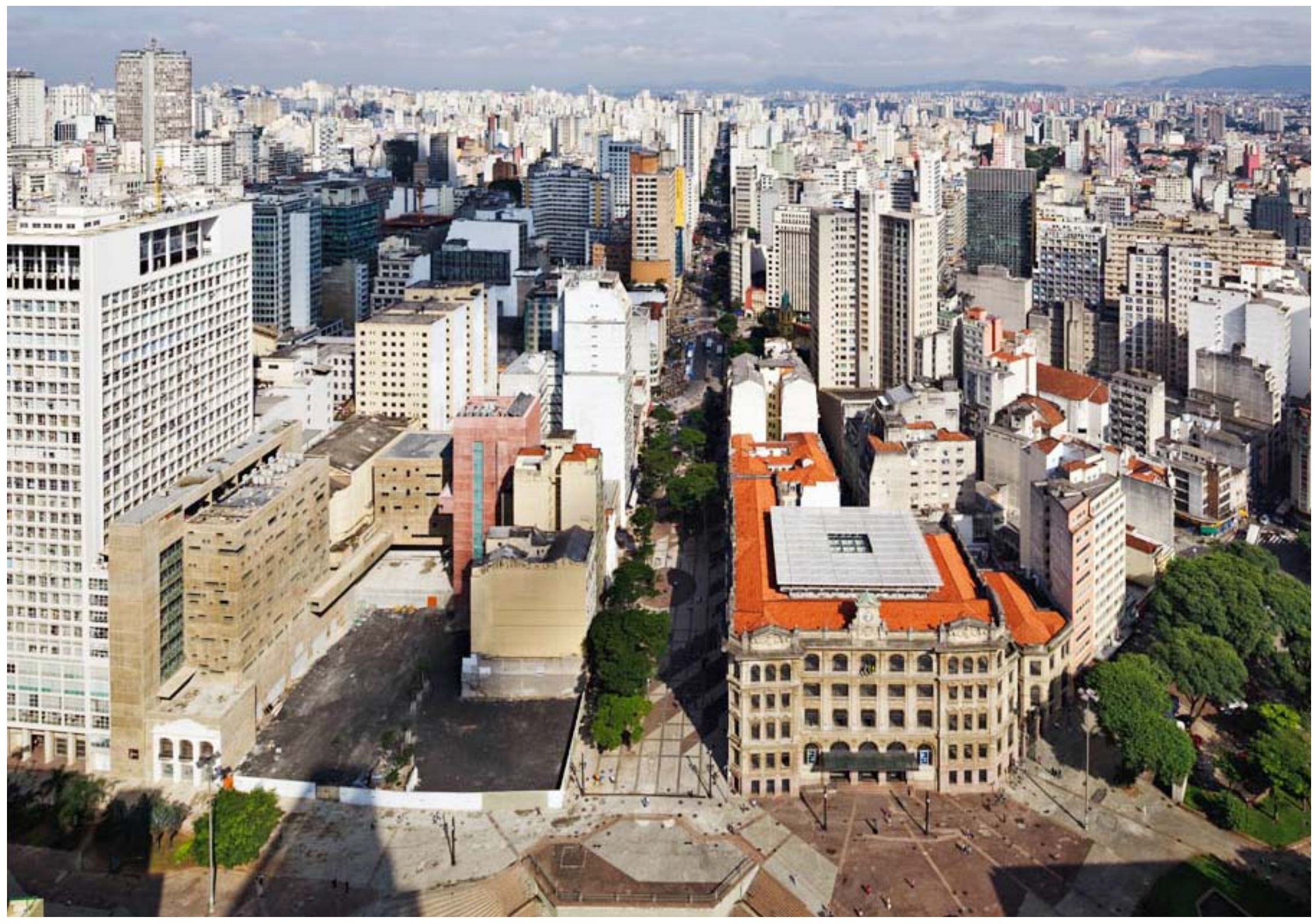

Vale do Anhangabaú e Av. São João. Vista Aérea. Praça das Artes e Centro Cultural Agência Central dos Correios Foto: Nelson Kon 


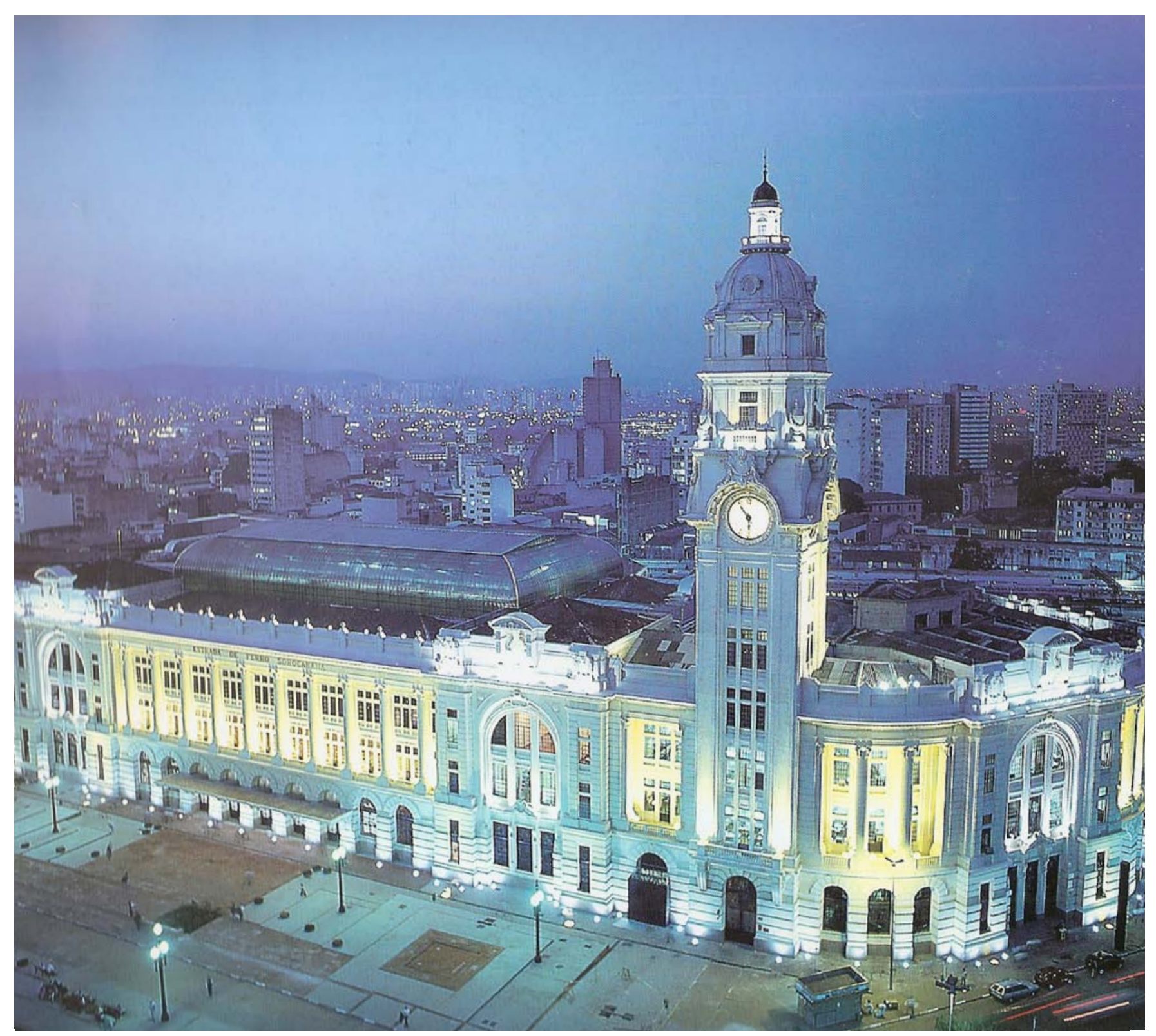

Sala São Paulo. Fonte: ZEIN, 2001 
Assim, o interstício vazio do edifício sede da Sorocabana tornou-se o ponto central de sua transformação em sede da Osesp [Orquestra Sinfônica do Estado de São Paulo]. A perfeita adequação aos fins observada nas proporções daquele espaço, sem dúvida foi um estímulo à qualidade da intervenção, pois uniu o objeto de recuperação do patrimônio arquitetônico à possibilidade de uma sala de concertos de excelência para a Osesp.

A tecnologia está na retaguarda, permitindo a metamorfose do pátio vazio em uma sala sinfônica vizinha à linha do trem $e$, ainda, o adequado funcionamento da sala em harmonia com o edifício eclético.

(BASTOS, 2010. p.345-346)

Dos três projetos aqui apresentados, a Sala São Paulo de Concertos Sinfônicos, inaugurada em 2000, é o único totalmente construído até o momento. É também o que alcançou notoriedade internacional sobretudo pelas qualidades acústicas oferecidas à Orquestra.

Estação Julio Prestes Sala São Paulo de Concertos Sinfônicos

Curiosamente a intervenção se deu no sentido oposto das outras duas obras, o Centro Cultural Agência dos 
Correios e a Praça das Artes. Enquanto, como observado aqui, os dois últimos obedeceram a uma operação de desobstrução, abertura de novos caminhos, criação de vazios e de arqueologia dos espaços, o projeto de Nelson Dupré optou pelo preenchimento, pela ocupação do "vazio". Como explicam acima Maria Alice Junqueira Bastos e Ruth Verdi Zein, trata-se da metamorfose do pátio vazio, a oportunidade de preencher o que a obra deixou inacabado, segundo as autoras.

Nesse caso, a estação ferroviária Júlio Prestes perdera sua função; na realidade a estação continua em operação, mas parte significativa do edifício monumental se tornou ociosa em virtude da decadência do transporte sobre trilhos ocorrida no Brasil nas últimas décadas do século XX. Mas qual seria o valor do pátio vazio em uma estação ferroviária localizada no centro histórico da metrópole? Ou melhor dizendo, qual seria o valor do pátio vazio em um edifício eclético?

\section{A Qualidade do Antigo}

Como afirmara Carlos Lemos (1993, p.91), em São Paulo os expoentes da arquitetura que melhor contribuíram para definir a paisagem urbana desse período, como é o caso de Ramos de Azevedo, e ao lado de quem podemos também incluir o autor da Estação Júlio Prestes, Christiano Stockler das Neves, defendiam uma visão de cidade organizada pela monumentalidade dos edifícios públicos. Para atingir essa qualidade, o projeto não se limitava a resolver as exigências do programa estabelecido, mas também cumpria seu papel de criador de formas e de espaços monumentais capazes de articulá-los em relação à cidade. A obra que abriga a Estação Júlio Prestes, projetada por Christiano Stockler das Neves em 1925 e inaugurada em 1938, é um bom exemplo dessa arquitetura.

A segunda metade do século XIX corresponde a um período de esplendor da arquitetura do espetáculo, em que podemos destacar além dos edifícios especializados, como as grandes óperas [Ópera Garnier, de 1875, em Paris e a Konzerthaus de Shinkel ,1821, em Berlim] obras de caráter 
cívico como as prefeituras, em que uma ou até mesmo várias salas de concertos integravam obrigatoriamente o programa de necessidades desses equipamentos. Como mostra Michel Forsyth (1985, p. 149-153), os espetáculos musicais se tornaram atividade cívica permanente, um serviço oferecido pela municipalidade, o que levou à proliferação desses equipamentos em diversas cidades inglesas. 0 autor apresenta alguns exemplos significativos dos quais destacamos o St. George Hall de Liverpool, construído por Harvey Lonsdale Elmes a partir de 1838 e inaugurado em 1854. Logo após o concurso para a escolha do projeto, que previa duas salas, uma para 1.000 e outra para 3.000 lugares, Liverpool organiza em 1840 um segundo concurso que acrescenta ao programa original as funções de tribunal de justiça. Elmes vence novamente, mas a direção da empreitada é entregue ao arquiteto da prefeitura local.

A observação de sua planta revela a concepção comum nessas obras em que há no volume construído o predomínio do eixo mediano transversal ao acesso, o que amplia a escala monumental da fachada principal. 0 eixo

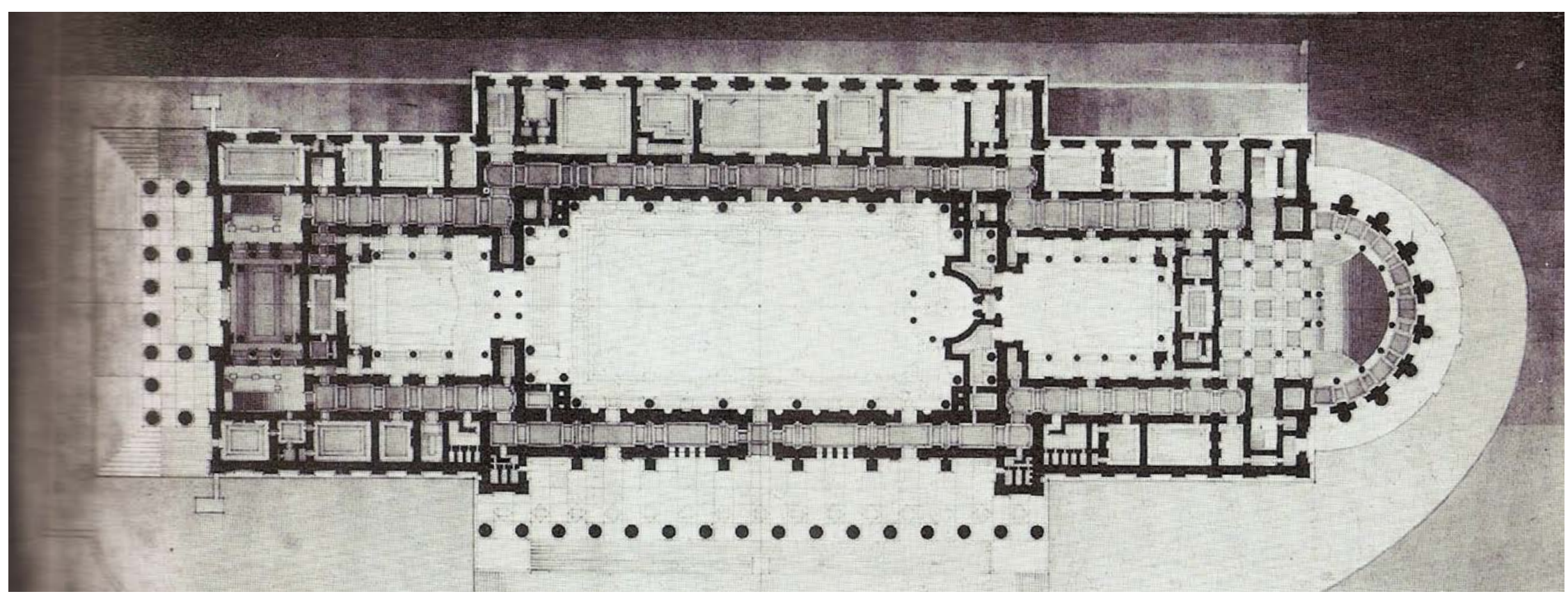

St. George Hall - Liverpool - Planta térreo. Fonte: FORSYTH, 1985 
se presta de forma objetiva para organizar a sequência de espaços internos onde estão localizadas suas funções principais. Essa sequência de salas de proporções diferentes, salas para concertos centralizadas e uma sala do tribunal em cada extremidade, é envolvida por um anel de circulação, espécie de grande galeria de distribuição que antecede as áreas menores localizadas em toda a periferia da edificação.

A organização descrita acima foi uma das soluções bastante utilizadas na arquitetura acadêmica desse período, independentemente de qual tratamento estilístico tenha sido dado à sua volumetria.

Essa regra compositiva foi empregada para garantir proporções predominantes para a forma. Verificado o cumprimento das necessidades de cada destino a que a obra deveria obedecer, cabia ao arquiteto determinar quais seriam os elementos capazes de garantir a integridade do estilo escolhido.

É verdade que as regras expostas acima são menos evidentes da obra de Christiano Stockler das Neves do que em St. George Hall. A obra de Liverpool, quase cem anos antes, é um exemplo de Neoclassicismo, em que essas preocupações são fundamentais. Como apresenta John Summerson (1982, p. 106), trata-se do que ele chamou de "simplicidade antiga", em que as silhuetas de geometria simples, tratadas com a pureza arqueológica dos detalhes, marcaram os monumentos neoclássicos tardios, como St. George Hall e o Altes Museum de Berlim de Karl Friedrich Schinkel. Como observa Forsyth (1985, p. 151), após vencer o segundo concurso, Elmes viaja para Alemanha para estudar a obra de Shinkel.

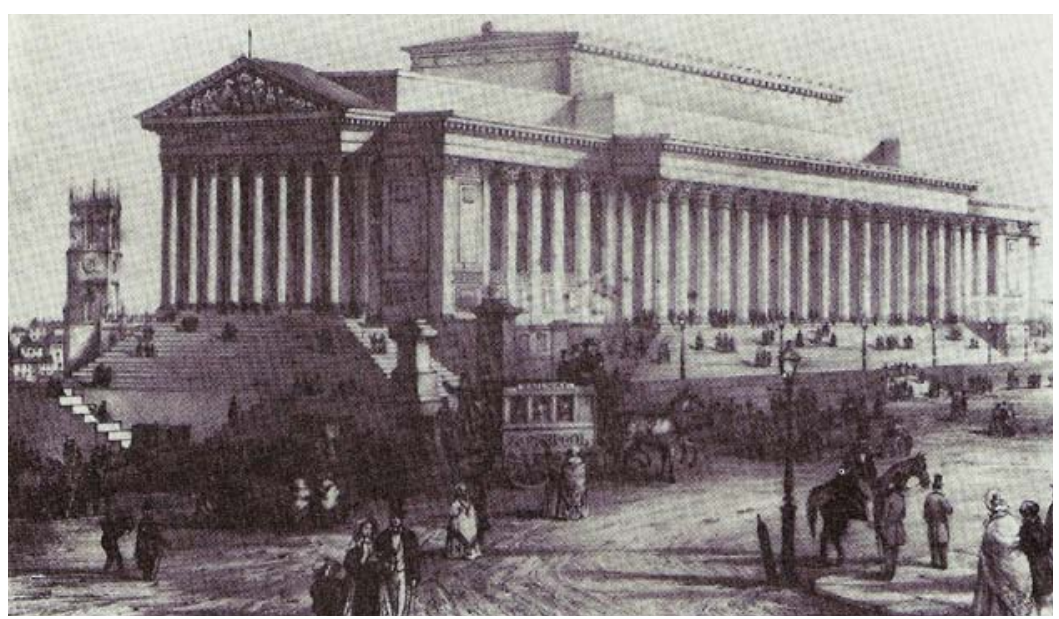

St. George Hall - Liverpool - Vista externa. Fonte: FORSYTH, 1985 


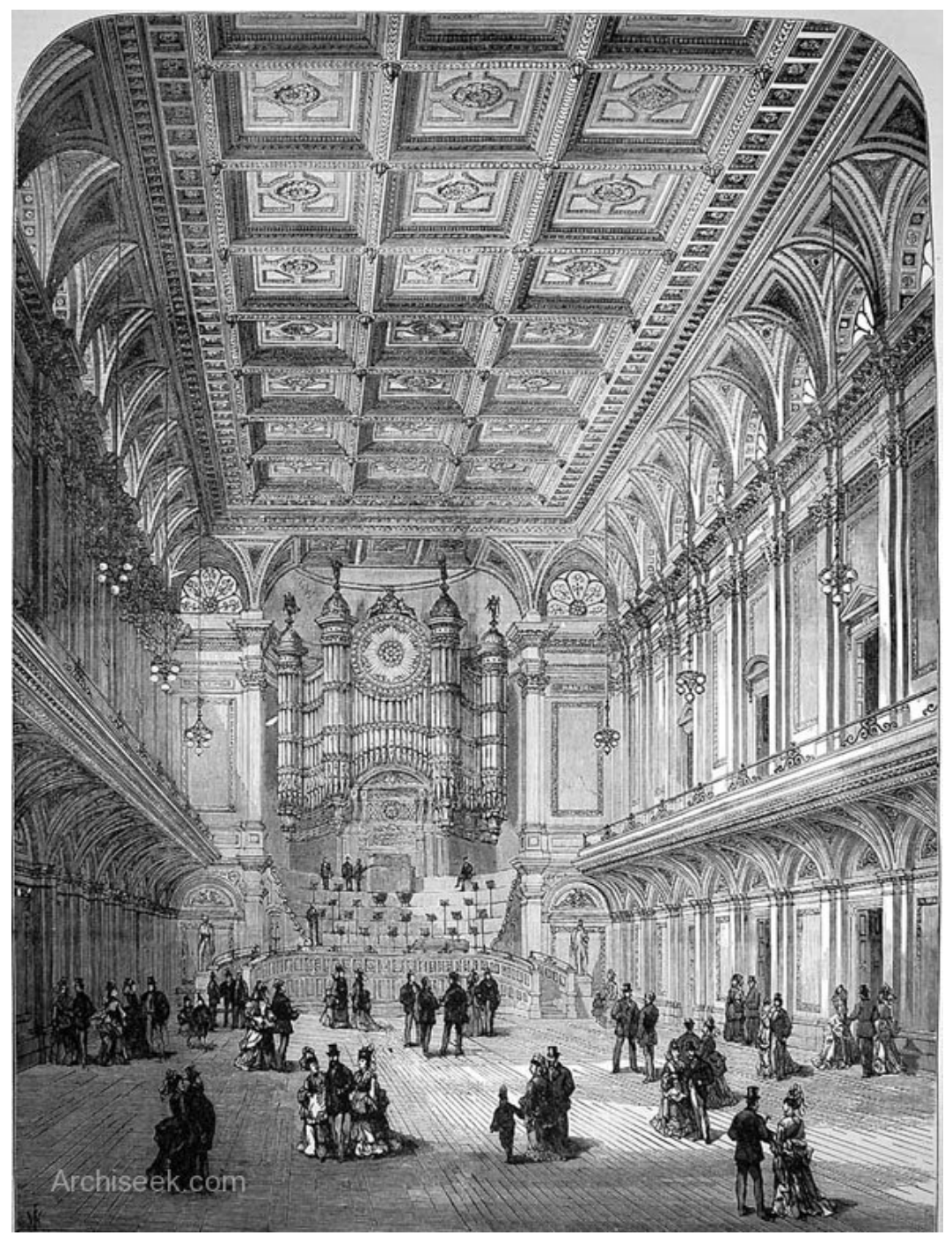

Bolton City Hall - Vista interna. Fonte: www.archiseek.com

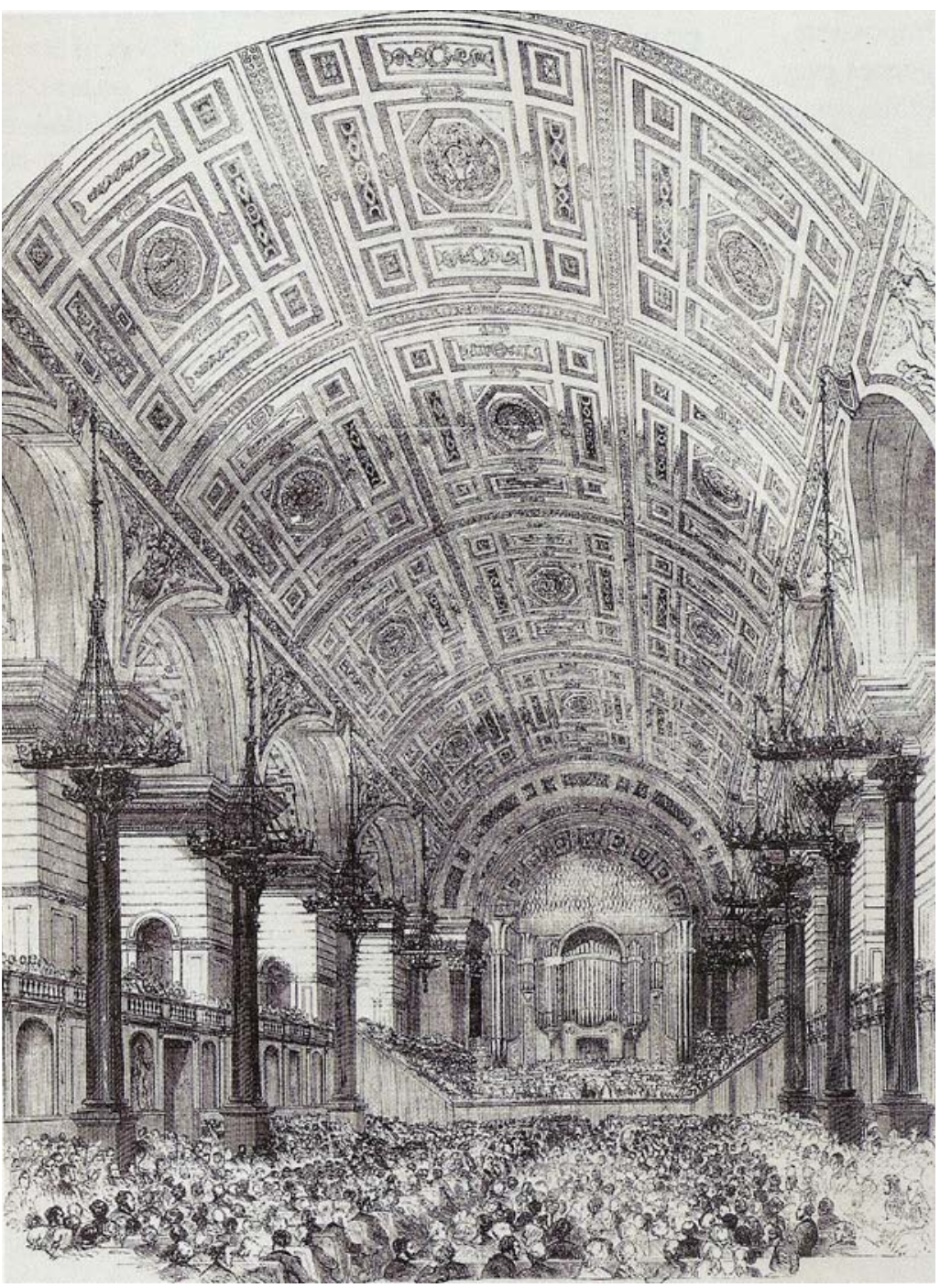

St. George Hall - Liverpool - Vista interna. Fonte: FORSYTH, 1985 


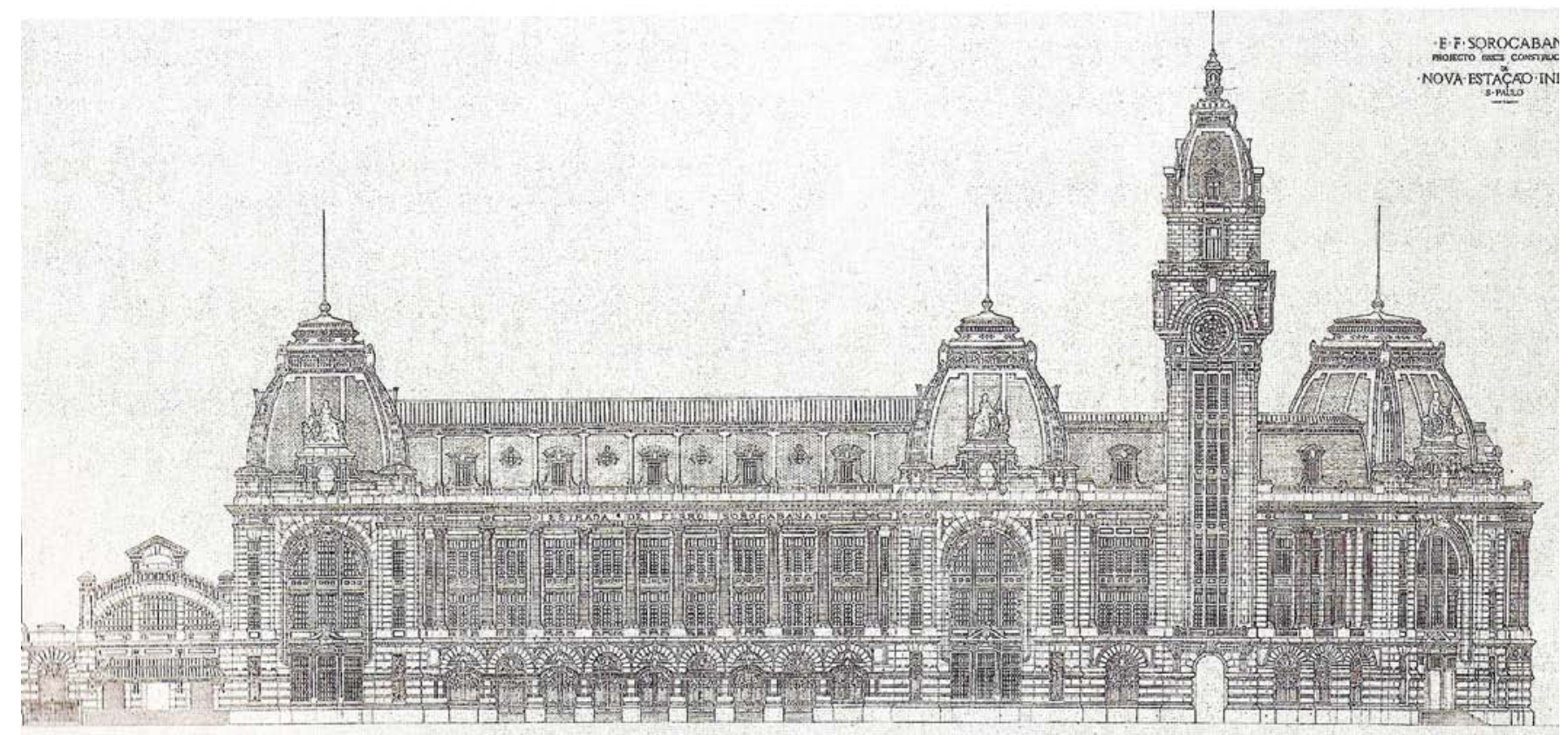

Elevação Projeto Original. Estação Júlio Prestes. Fonte: ZEIN, 2001

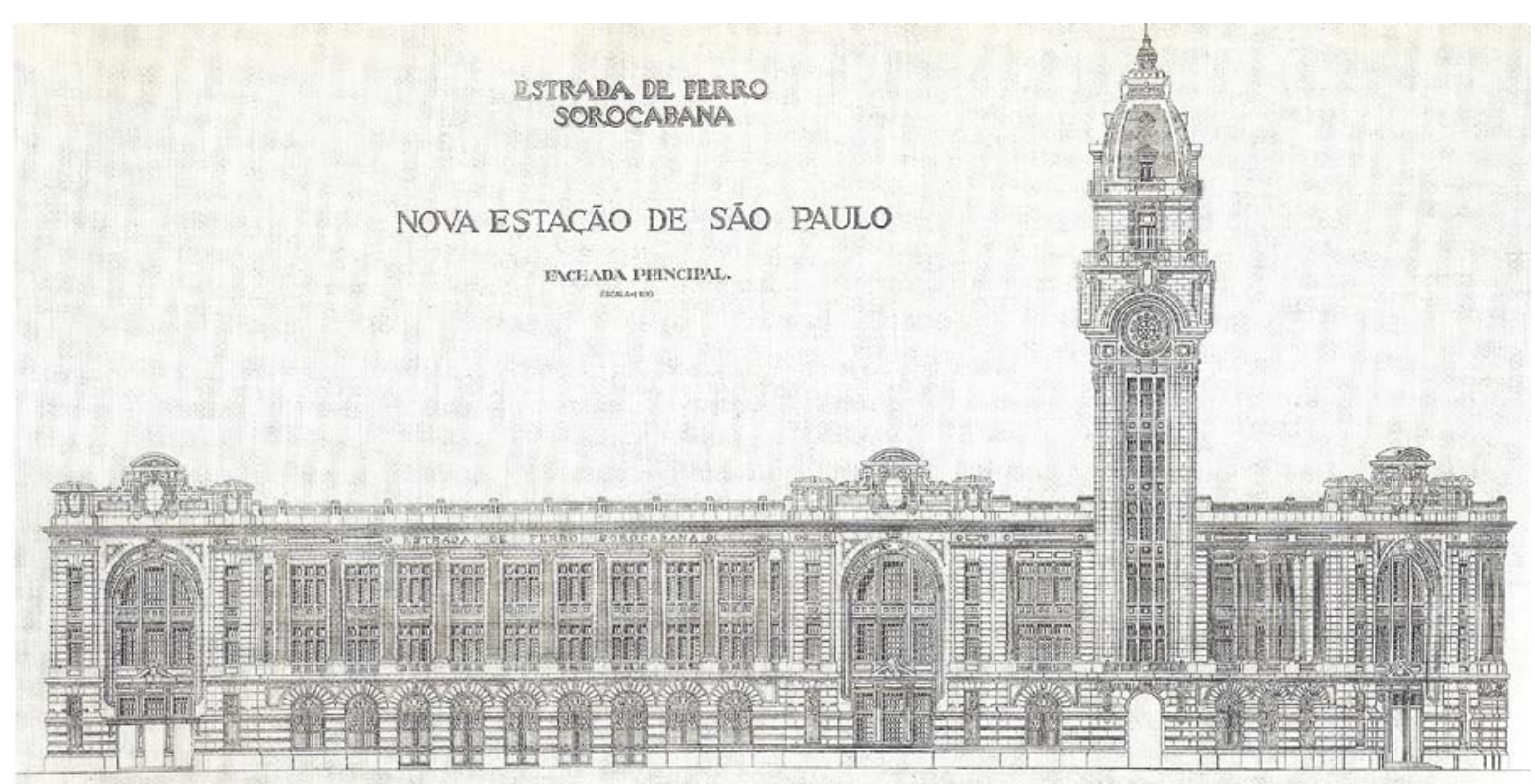

Elevação Projeto Construído. Estação Júlio Prestes. Fonte: ZEIN, 2001 


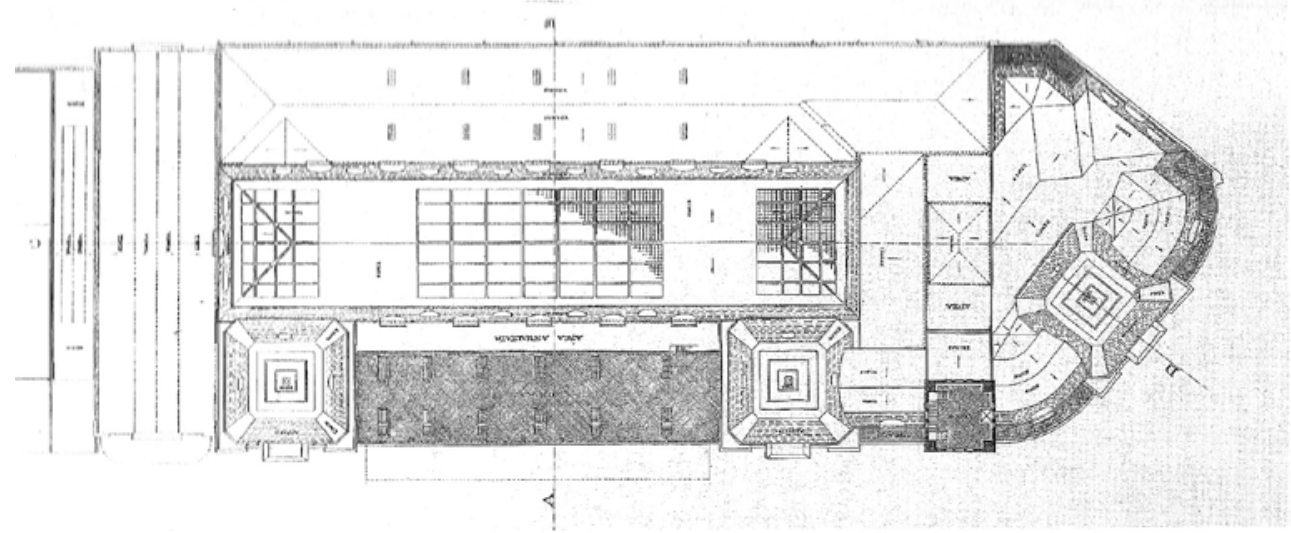

Planta $3^{\circ}$ pavimento

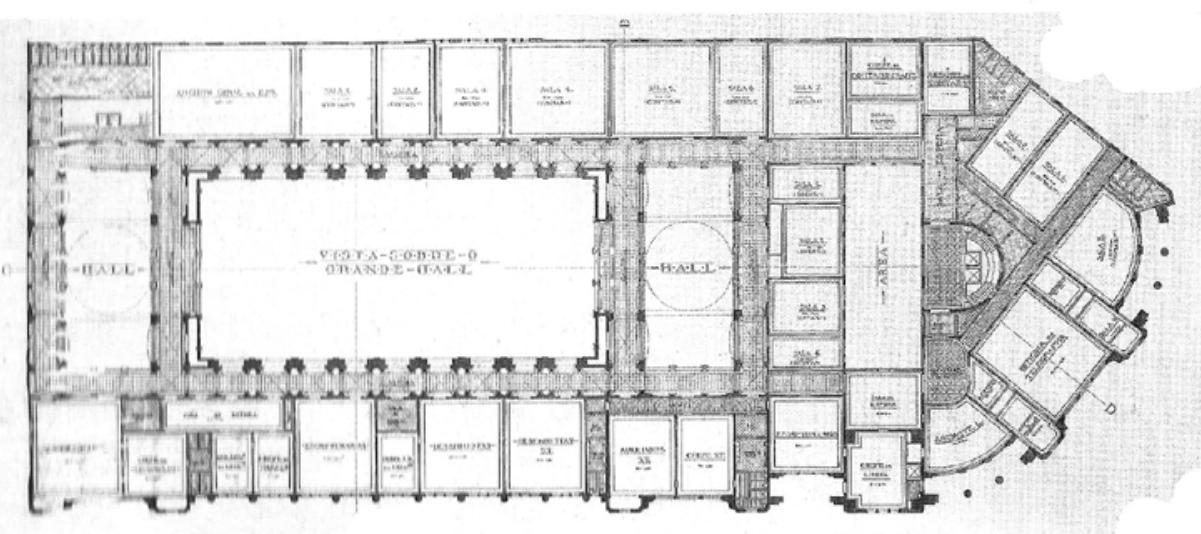

Planta $1^{\circ}$ pavimento. Estação Júlio Prestes. Fonte: ZEIN, 2001

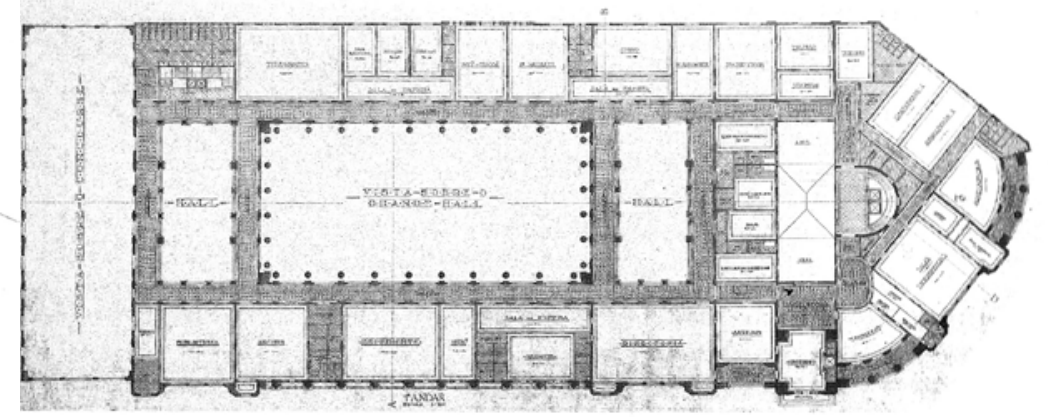

Planta $2^{\circ}$ pavimento

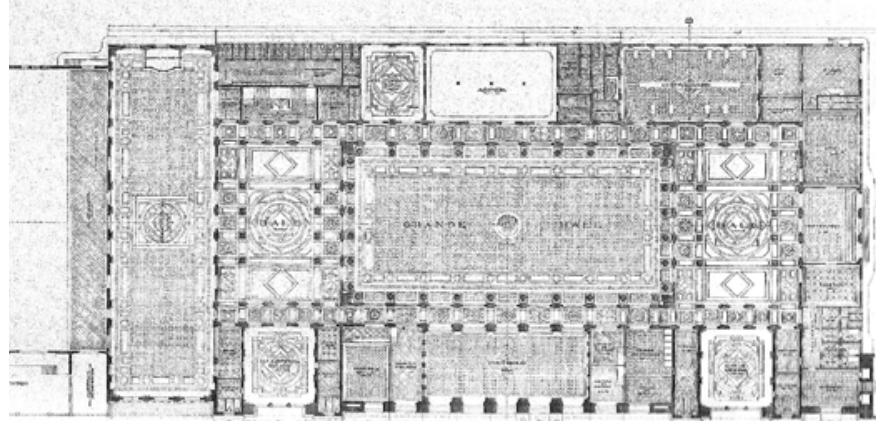

1.romo-metio

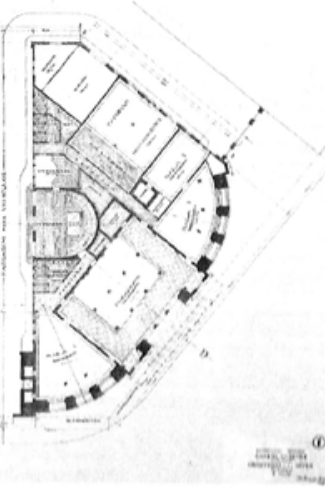

Planta Térreo 
Ao observarmos o projeto das fachadas da Estação Júlio Prestes, em suas duas versões, a original e a construída, não é possível fazer essa leitura com a mesma clareza. É evidente que o estilo usado pelo arquiteto, que Ruth Verdi Zein (2001, p. 43) chamou de "Luiz XVI modernizado", introduziu na edificação um grande número de elementos decorativos de inspiração francesa, o que não facilita essa leitura. Mas tal fato não descarta o emprego da metodologia de projeto semelhante a do projeto inglês.

0 mesmo não ocorre quando examinamos as plantas. A organização linear da grande massa construída em função da sequência de diversos halls de dimensões distintas (os pátios citados por Zein), contribui de maneira determinante para a definição da volumetria monumental da obra. Nesse caso, o eixo paralelo à fachada principal voltada para a Praça Júlio Prestes é o eixo de simetria que se prolonga da área das plataformas da estação a oeste até o limite com a rua Mauá, sendo este o elemento de articulação com o ângulo formado com essa rua.

Outro aspecto singular da obra é que nessas duas ex- tremidades a transição é feita por dois outros espaços vazios transversais ao eixo principal, a oeste em relação à gare propriamente dita, e a leste, onde há uma via interna de veículos, em relação à ala onde está localizada a sede da Companhia Sorocabana, proprietária da Estação e de toda a estrada de ferro.

Também nessa obra um anel de circulação envolve os pátios internos e permite a transição com os ambientes distribuídos na periferia da edificação. Mas seria este um edifício com pátios internos ou na realidade ele seria constituído por dois blocos paralelos, afastados por um vazio longitudinal que, mesmo se coberto, garantiria a iluminação dos espaços internos?

Essas considerações nos mostram claramente valores que constituem a essência da arquitetura praticada no século XIX e que se manifestou tardiamente na obra estudada, já nas primeiras décadas do século XX. Cabe refletir sobre que or- 
dem de valores ou qualidades verificamos.

Ignasi de Solà-Morales Rubió (1985, p. 37-45) nos explica como evoluíu nesse período a sensibilidade para julgar o patrimônio artístico. Para isso, utiliza a descrição de 1903 elaborada por Aloïs Riegel em que este analisa a postura em relação aos valores assumidos pelo Movimento Moderno e sua evolução desde o século anterior. Podemos admitir então que o edifício em questão possui um valor de exemplaridade como modelo prévio da boa arte do passado, conforme suas características essenciais descritas aqui, o que Riegel chama de valor monumental. Podemos ainda dizer que o seu valor histórico artístico, apesar da curta existência da Estação como tal, está diretamente vinculado com a evolução urbana da cidade. Tal conceito baseia-se no valor adquirido por um bem histórico em função do registro de uma situação factual e documentada, isto é, o valor assumido em função de seu papel desempenhado na histó-

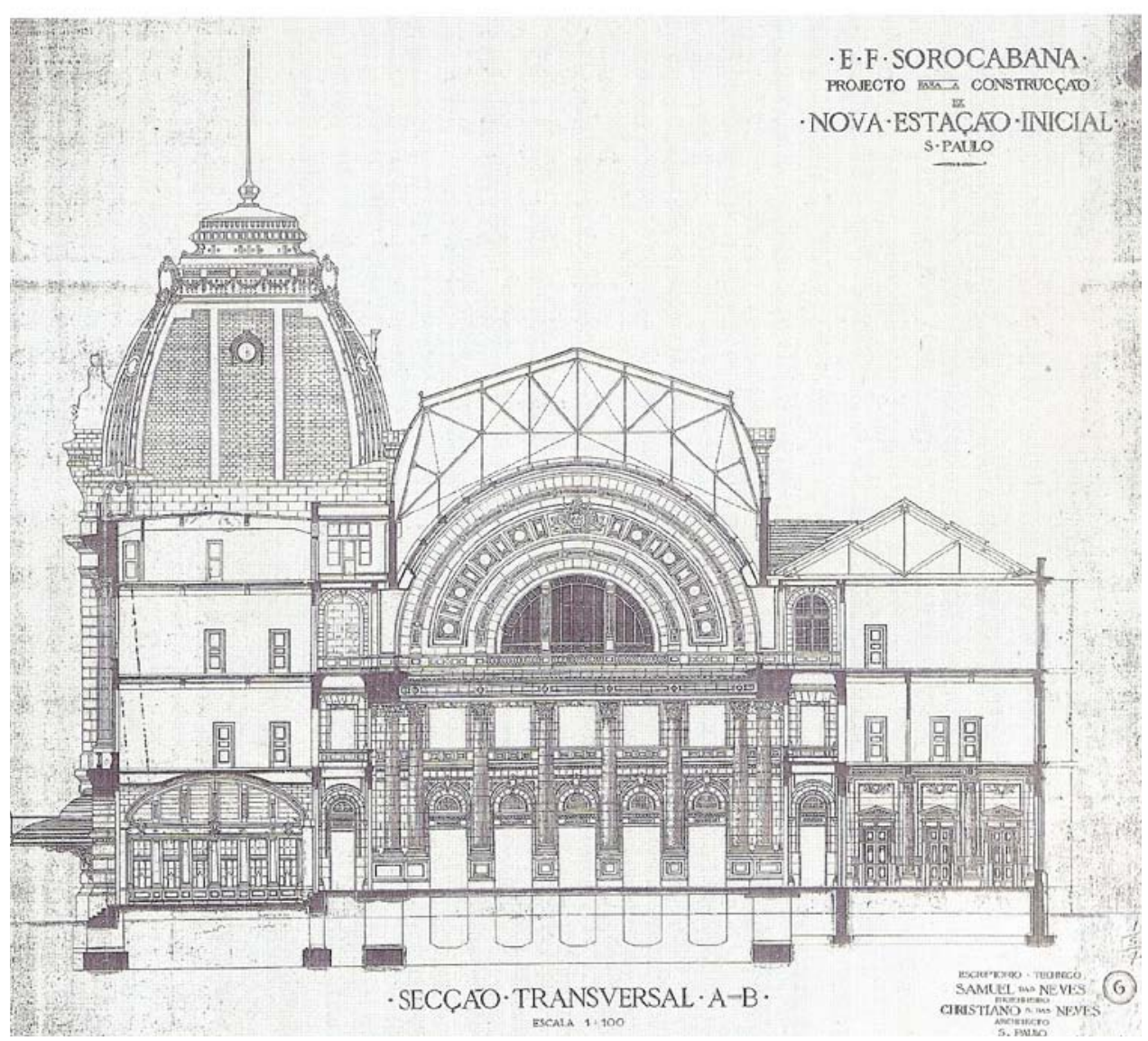

Corte Transversal. Projeto Original. Estação Júlio Prestes. Fonte: ZEIN, 2001 
ria da cidade. Esse último seria, sem dúvida, o que atraiu a atenção do poder público ao empreender sua reconversão. Riegel finaliza mostrando a nova relação estabelecida pelo Movimento Moderno, a qualidade do antigo, que relativiza toda espécie de padrão artístico estabelecido e se preocupa muito mais com o valor cultural atribuído a determinado bem. Em outras palavras, o autor acredita que o homem moderno está muito mais preocupado com o testemunho de uma determinada época do que com as informações eruditas contidas no tratamento estilístico de um monumento. Como explica Solà-Morales:

Considerando precisamente que o valor fundamental de uma cultura urbana estava, e ainda está, na perfeição acabada dos novos edifícios $e$ tendo em vista que os novos edifícios só têm valor à medida que desafiam a passagem do tempo e que constituem uma imagem de imunidade à erosão da história e de permanência em sua forma, cor e acabamento, essa mesma subjetividade das massas, pouco afeitas à cognição racional, vai descobrir na antiguidade o valor universal que lhe serve de base para a interpretação da arquitetura histórica. A satisfação estética fundamental provém da necessária alternância entre a arquitetura nova e antiga. (2008, p. 256)

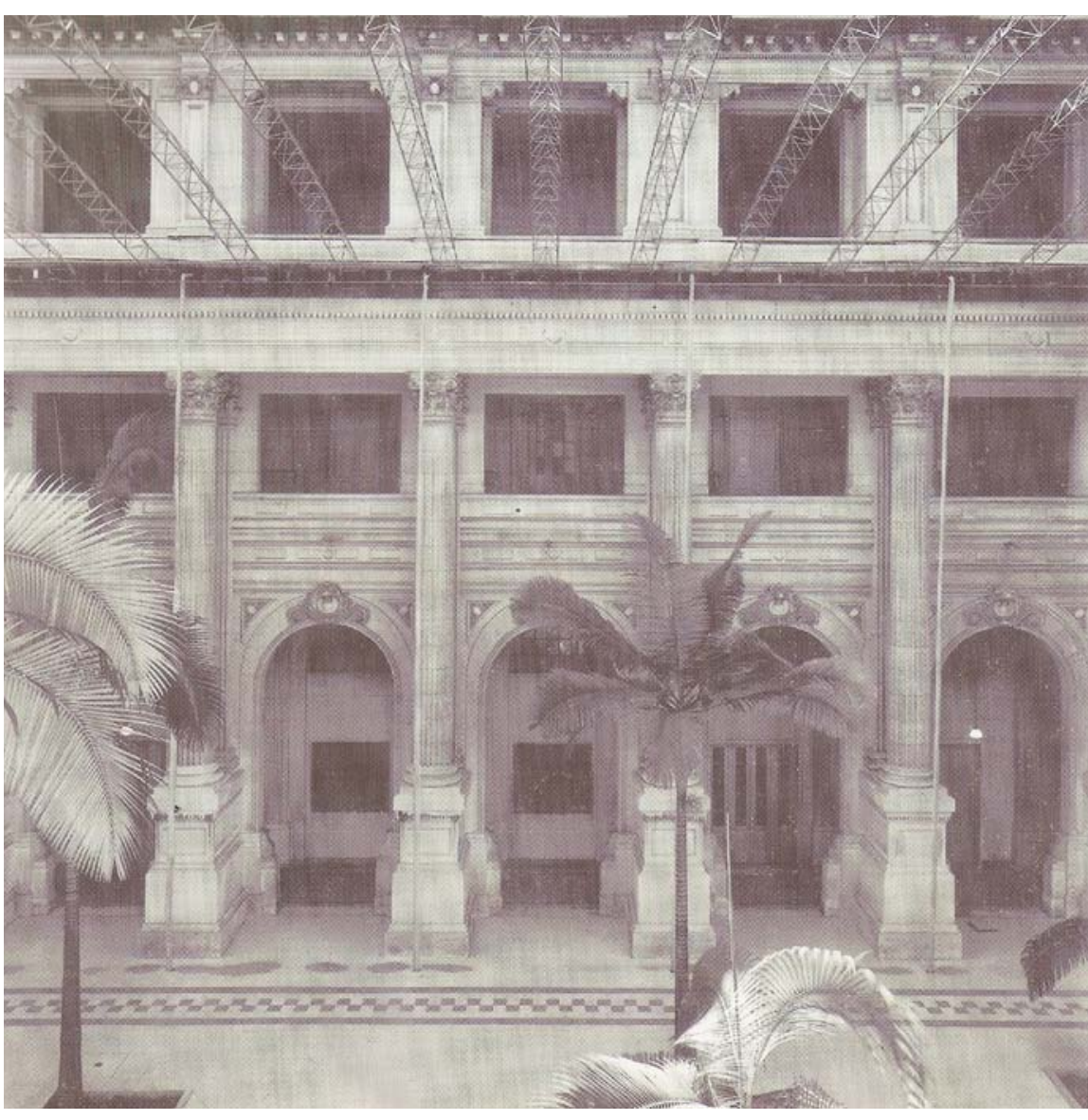

Estação Júlio Prestes. Pátio Interno. Fonte: ZEIN, 2001 


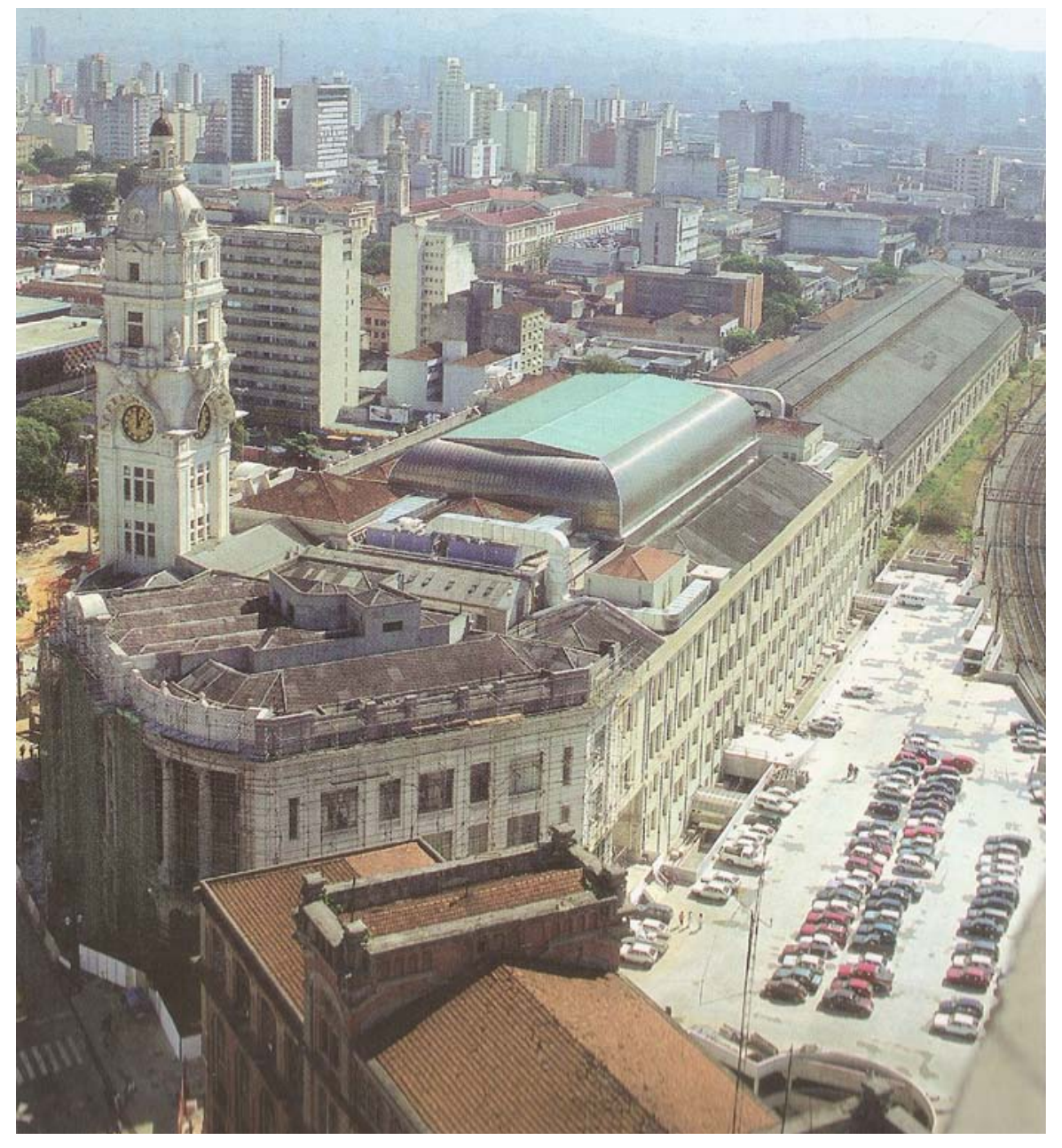

\section{Implantação}

A imagem aérea de 1958, na página 296, mostra o conjunto Estação e Praça Júlio Prestes perfeitamente alinhados, fazendo a transição entre o espaço urbano e os diversos ramais ferroviários que cortam a capital desde a construção das primeiras linhas férreas. A disposição é semelhante à da Estação da Luz em relação ao Jardim da Luz, porém de maneira oposta ou inversa em relação à cidade.

É significativa também a área ocupada pelo pátio de manobras posterior à Estação, que preenche a totalidade do espaço formado pelo ângulo entre a Praça e a rua Mauá. A decadência do transporte sobre trilhos fez dessas grandes áreas adjacentes vazios de grandes proporções para onde a Metrópole direciona hoje suas reflexões. Já na imagem anterior à intervenção, na página 232, pode-se verificar o pátio desativado onde a arborização se faz presente. 


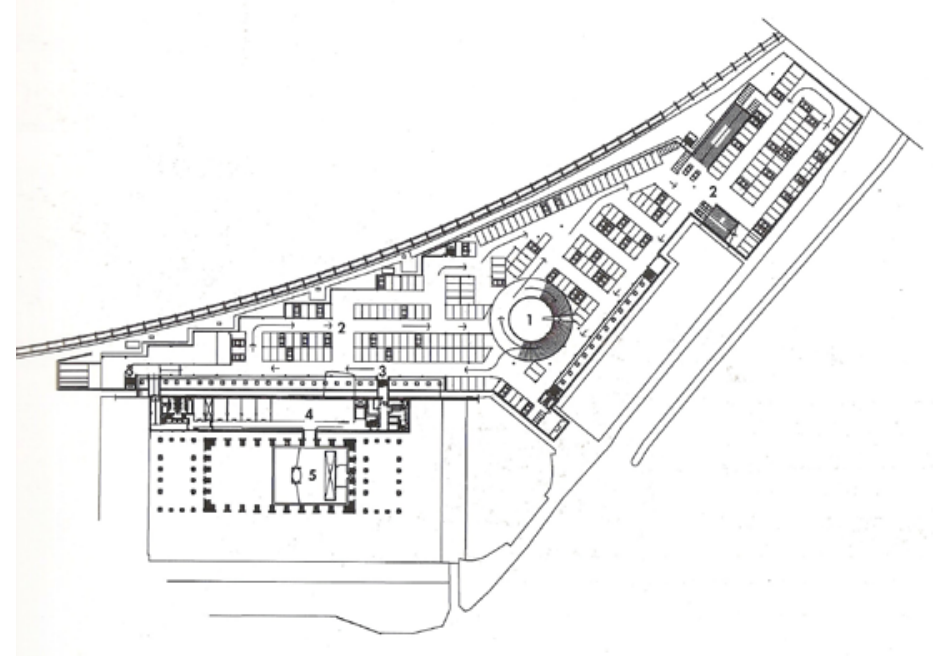

Implantação. Estacionamento 1
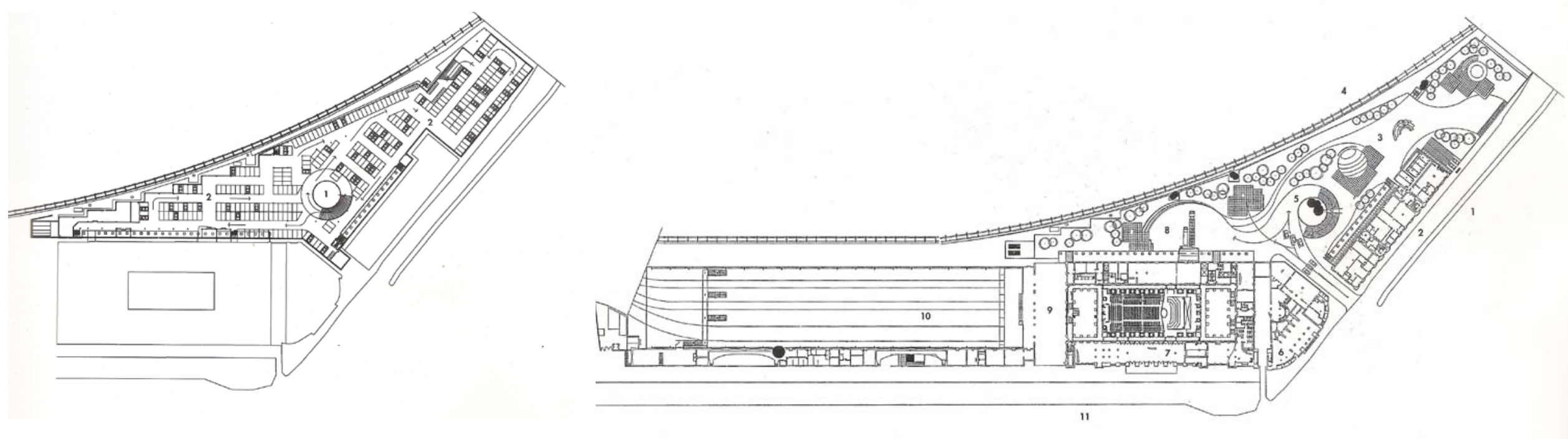

Implantação. Estacionamento 2

Implantação térrea. Sala São Paulo, situação sem escala. Fonte: ZEIN, 2001 


\section{A Ocupação do Vazio}

Uma sala tem "espacialidade" se a música executada parece para o ouvinte como sendo tocada por uma fonte mais larga que a largura visual da fonte em si (no caso a orquestra). Esse atributo é chamado "largura aparente da fonte". A Sala São Paulo, sendo retangular e "estreita, as reflexões primárias do som chegam lateralmente e parecem "alargar" a fonte, dando a sensação de espacialidade e envolvimento.

(NEPOMUCENO, apud ZEIN, 2001, p. 127) [destaque do autor]

Ao descrever todo o procedimento de projeto, em que a disciplina da Acústica não se limitou a corrigir a arquitetura existente, e aquela proposta pelo novo uso, José Augusto Nepomuceno deixa evidente que o grande mérito da nova Sala de Concertos é o resultado de seu desempenho acústico, o que por si só já mereceria destaque. Ao descrever os principais procedimentos que uniram os especialistas conceptores, ele reserva especial atenção às características da arquitetura original da edificação, que mesmo não tendo sido pensada para tal finalidade, foi fundamental para atingir o resultado de excelência.

Por essa leitura podemos melhor entender que a alternativa inicial de ocupação do pátio vazio, devido à suas proporções favoráveis do ponto de vista acústico, não seria tão justificada se as qualidades construtivas encontradas por Nepomuceno na Estação não tivessem sido exploradas. Ou seja, a arquitetura proposta para a Sala São Paulo se baseou no intenso uso da tecnologia para garantir o melhor desempenho da sala. Um exemplo significativo é o sistema de painéis móveis que compõe o forro e que permite, pela combinação dos diversos módulos em alturas diferentes, modificar o volume interno da sala, adaptando-a com maior propriedade às diversas formações musicais.

Mas não é esse o aspecto de maior interesse. Do ponto de vista da arquitetura, foram os valores primordiais internos à obra que, resgatados como elementos de reflexão sonora, qualificaram o pátio para o novo uso. Portanto, pode-se dizer que não foi a arquitetura do espetáculo que se manifestou na construção de seu novo sentido; foram as 


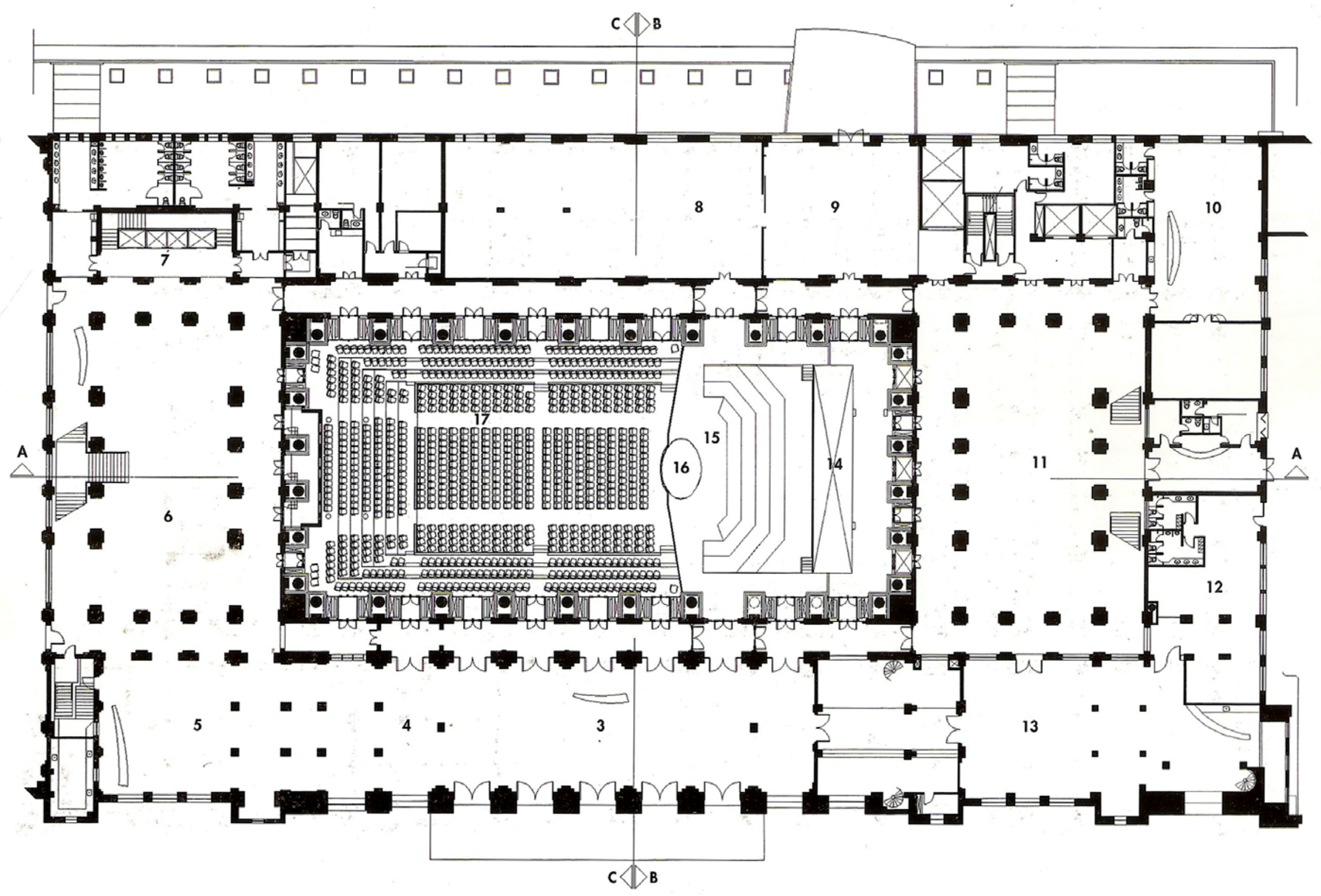

Planta do térreo - platéia, escala 1:500. Sala São Paulo. Fonte: ZEIN, 2001 


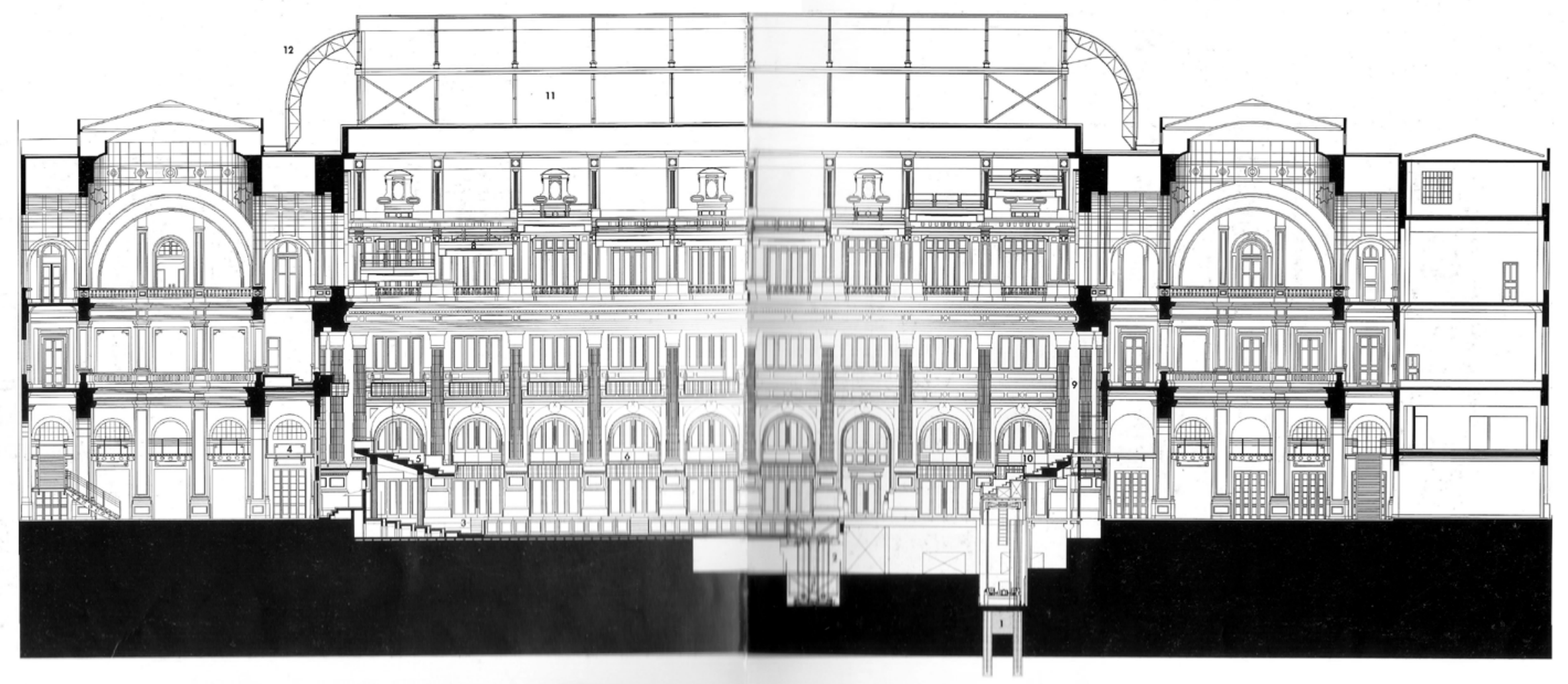

Corte Longitudinal. Sala São Paulo. Fonte: ZEIN, 2001 


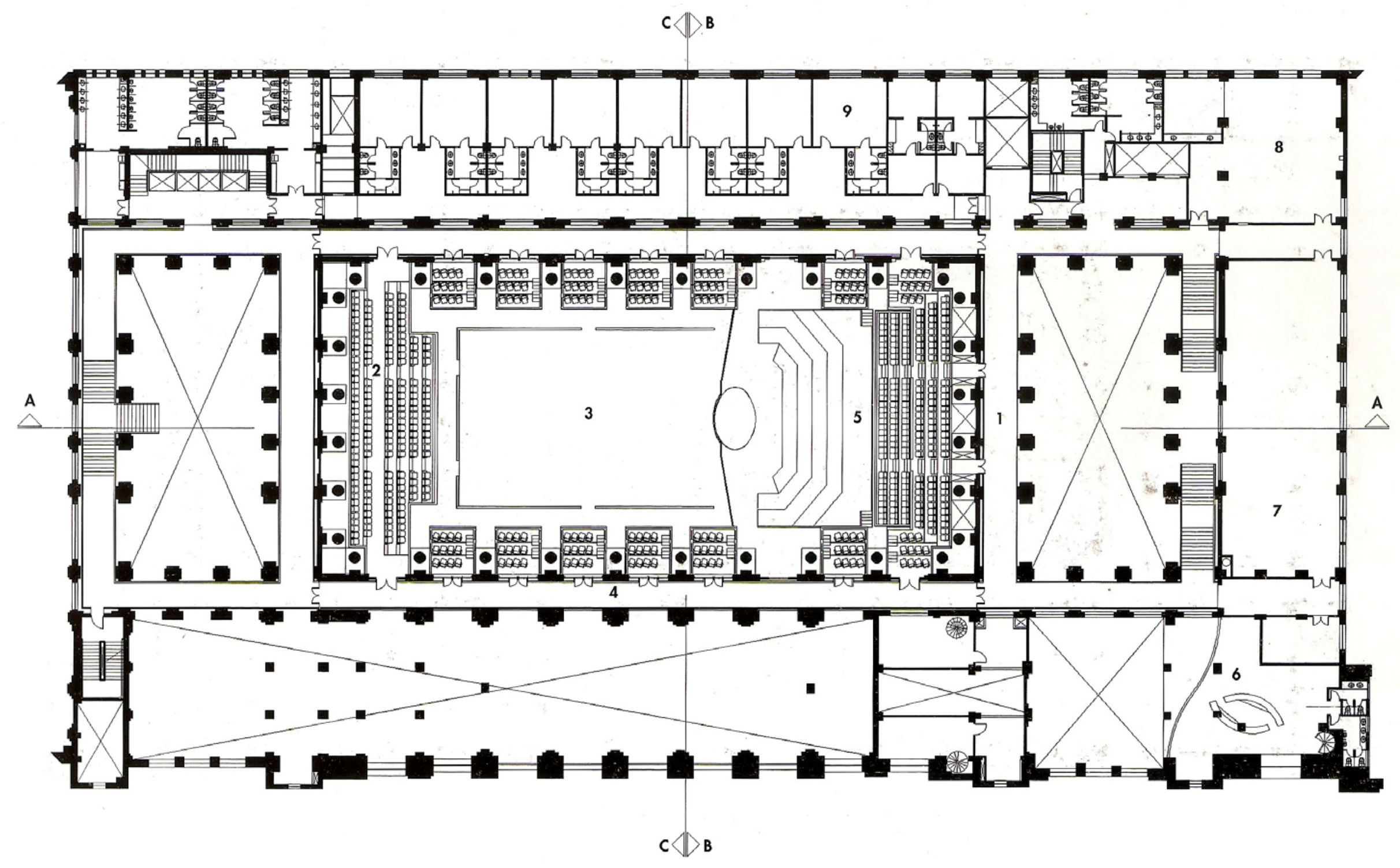

Planta do Mesanino, escala 1:500. Sala São Paulo. Fonte: ZEIN, 2001 


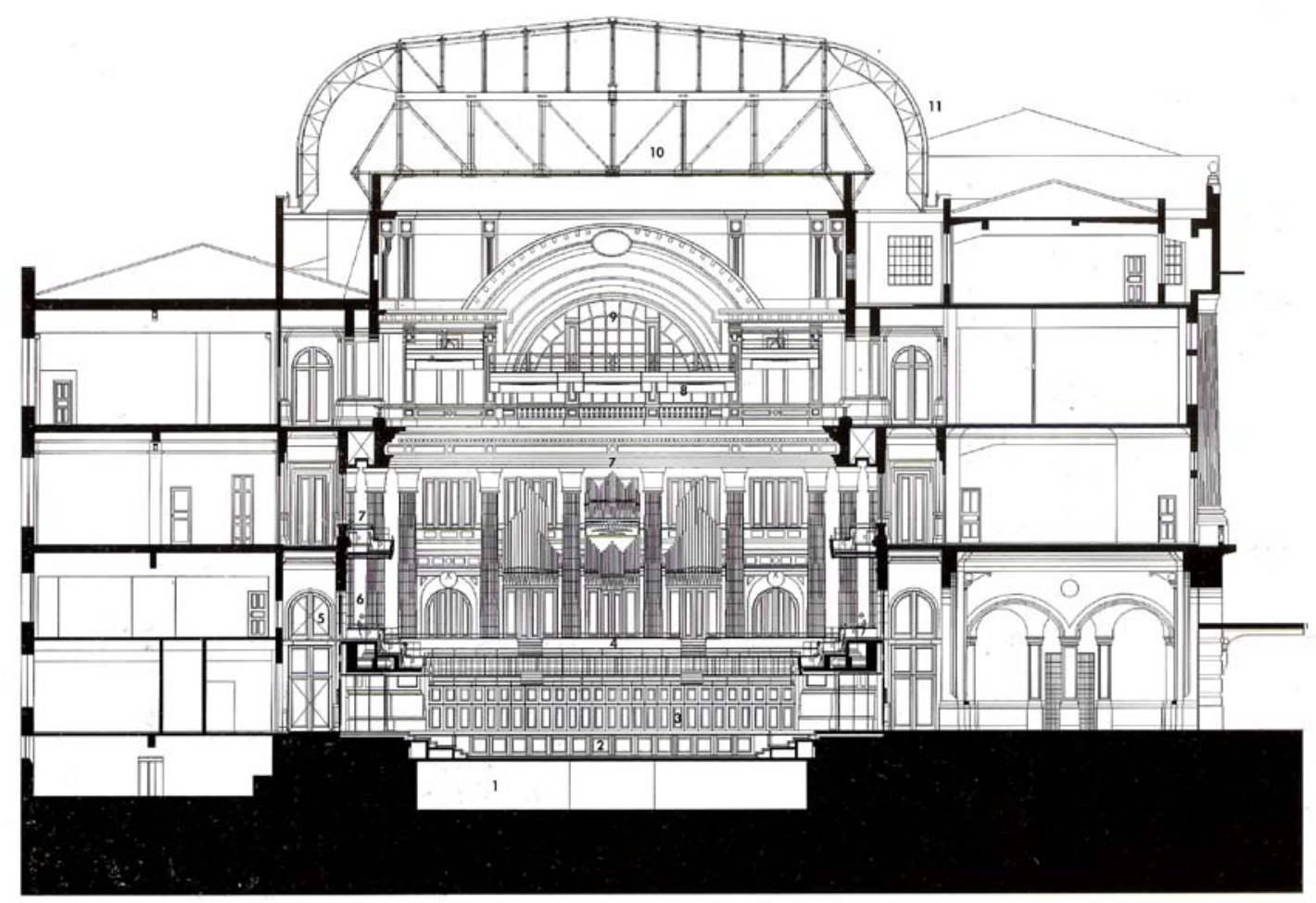

Corte transversal, escala 1:500. Sala São Paulo. Fonte: ZEIN, 2001 
condições existentes que, entendidas de maneira correta, estabeleceram a nova situação.

Essas considerações nos parecem importantes pois trata-se de uma intervenção até certo ponto radical no patrimônio tombado, na medida em que modifica sua estrutura formal, muito menos do ponto de vista da demolição de seus elementos ou alas, ou mesmo de acréscimos desproporcionais, e do que pela eliminação de espaços que fundamentaram sua concepção.

A estratégia de ocupação do vazio central no pavimento térreo transformou a sala de concertos no coração do conjunto. Em torno desse centro se organizam as funções diretamente ligadas ao público, como foyer, restaurante, loja e as áreas de apoio da própria orquestra, que se prolongam pelos dois pavimentos superiores. Essa distribuição segue com clareza a estrutura original do edifício. Dessa forma, a massa construída na periferia da edificação desempenha importante papel de envoltória no isolamento da sala em relação às fontes de ruído externo, em especial à linha férrea ao norte e as ruas ao sul.
Estariam, então, estabelecidas as condições primordiais para o artefato arquitetônico desempenhar de maneira exemplar o seu papel: Sala São Paulo de Concertos Sinfônicos.

Como operação estética, a intervenção é a proposta livre, arbitrária e imaginativa pela qual se procura não só reconhecer as estruturas significativas do material histórico existente, como também usá-las como marcos analógicos para a nova construção.

(SOLÀ-MORALES, 1985, in Nesbitt, 2008, p. 262) [em itálico no original] 


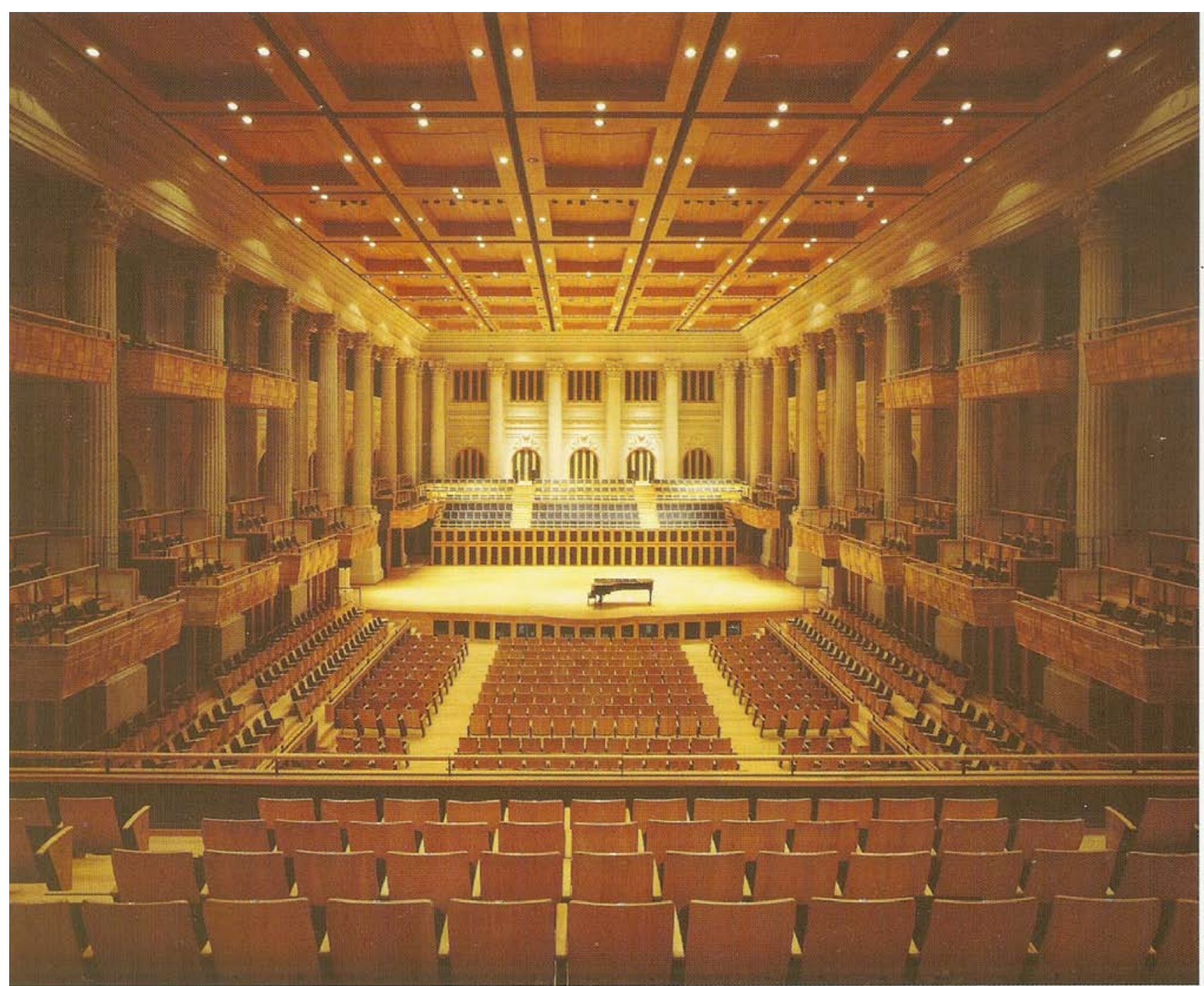

Sala São Paulo. Vista Interna. Fonte: ZEIN 2001 


\section{O Lugar do Concerto}

Diversas foram as manifestações que identificaram determinado distanciamento entre o papel cultural de excelência assumido internacionalmente pela Sala São Paulo desde sua inauguração e o prometido papel transformador de uma região marcada pela decadência urbana. Como vimos aqui, as reflexões de Ana Carla Fonseca Reis, sobre a $\mathrm{Ci}$ dade Criativa , e as de Raul Juste Lores, sobre os Quarteirões Doentes e a Praça das Artes, são testemunhos, em momentos distintos, das qualidades específicas da obra em relação à sua função cultural, mas que não conseguiu ir além de seu limite construído, isto é, há um verdadeiro isolamento entre esse importante equipamento e a cidade.

Nossa contribuição vem também da análise da metodologia de projeto adotada. Se por um lado as opções da equipe liderada por Nelson Dupré alcançaram notoriedade em função da qualidade acústica obtida, elas foram por outro lado responsáveis por determinar o isolamento verificado. Se na origem o edifício público possuía um pavimento térreo aberto, franco, em que sua monumentalidade inte- rior era apreendida pelo viajante que chegava à capital, sua transformação potencializou o aspecto monumental como barreira formal frente à cidade. Isto é, por mais que a erudição cultural praticada em seu interior possa ser um obstáculo em relação à sua interação com o espaço urbano, não há no projeto a expressão do seu franqueamento ao espaço público coletivo da cidade. Nem mesmo naquelas atividades de apoio que fazem parte do dia a dia de uma instituição do porte de uma orquestra sinfônica dessa importância. Seria a falta do que Jane Jacobs (2009, p. 191) chamou de "matriz cotidiana" ou "matriz profana", necessária para garantir a vitalidade em torno dos marcos arquitetônicos?

Quando se observa a implantação geral do conjunto, as opções de acessos e as fronteiras existentes, percebe-se que houve uma inversão, quase um caminho contrário em relação à proposta original de Christiano Stocker das $\mathrm{Ne}$ ves: a maioria dos usuários, espectadores, músicos e funcionários utiliza a fachada posterior, onde foi construído um estacionamento com três pavimentos, o que indica claramente a intenção dos projetistas. Essa fachada posterior 
é desprovida de qualquer tratamento quando comparada às demais. Como não foi possível observá-la no projeto original por falta de documentação, não é possível afirmar que a decisão veio da redução de custos da obra ou do próprio Christiano Stocler das Neves. Não haveria vontade expressa de que a Praça Júlio Prestes participasse do espetáculo?

É verdade que o monumental esteve sempre vinculado ao distanciamento. Como afirma Roberto Segre: "A diferença entre o edifício público e o doméstico será mais marcante quanto maior for essa distância"(2013, p. 284). Mas o que se observa é que, enquanto fez parte integrante da Estação, a arquitetura monumental esteve mais próxima da cidade do que após sua transformação em Sala de Concertos.

A mudança de escala imposta ao meio construído pelo desenvolvimento da técnica ("O urbanista, assim como o arquiteto, deve elaborar uma escala de intervenção adequada à cidade moderna de vários milhões de habitantes") tem por corolário um novo modo de conservação dos conjuntos an- tigos, para a história, para a arte e para vida presente. Esse "patrimônio urbano", assim nomeado pela primeira vez por Giovannoni, adquire seu sentido e valor não tanto como objeto autônomo de uma disciplina própria, mas como elemento e parte de uma doutrina original da urbanização. (CHOAY, 2006, p. 195) [destaques da autora]

A justificativa principal dessa premissa se deu em função das proporções favoráveis do pátio, conforme o comparativo apresentado pela consultoria de acústica, que apresenta outras três salas do século XIX consideradas as mais veneráveis por Forsyth: Grosser Musikvereinssaal de Viena, Concertgebouw de Amsterdan e Neues Gewandhaus de Leipzig. É importante notar que essa última, destruída durante os bombardeios da Segunda Grande Guerra, foi construída no pavimento superior, possuindo um andar térreo aberto onde se localizavam os acessos e foyers.

Outra justificativa utilizada para o partido adotado foi o isolamento que a massa construída proporcionou à sala em relação ao ruído representado pela proximidade da linha férrea. São conhecidos exemplos bem sucedidos de 
salas de concertos em que essa situação foi resolvida com medidas de projeto, como é o caso da Royal Festival Hall de Londres, a primeira grande sala construída no pós guerra, em 1951. Não só a linha férrea na lateral mas também a linha de metrô sob o edifício foram desafios que a equipe dos arquitetos Leslie Martin e Robert Matthew enfrentou ${ }^{140}$. É verdade que Forsyth assinala que a acústica primorosa da sala, com uma clareza musical remarcável, possui uma plenitude tonal reduzida, o que convém muito mais aos concertos de Mozart do que aos compositores do final do Romantismo. (FORSYTH, 1985, p. 265) 

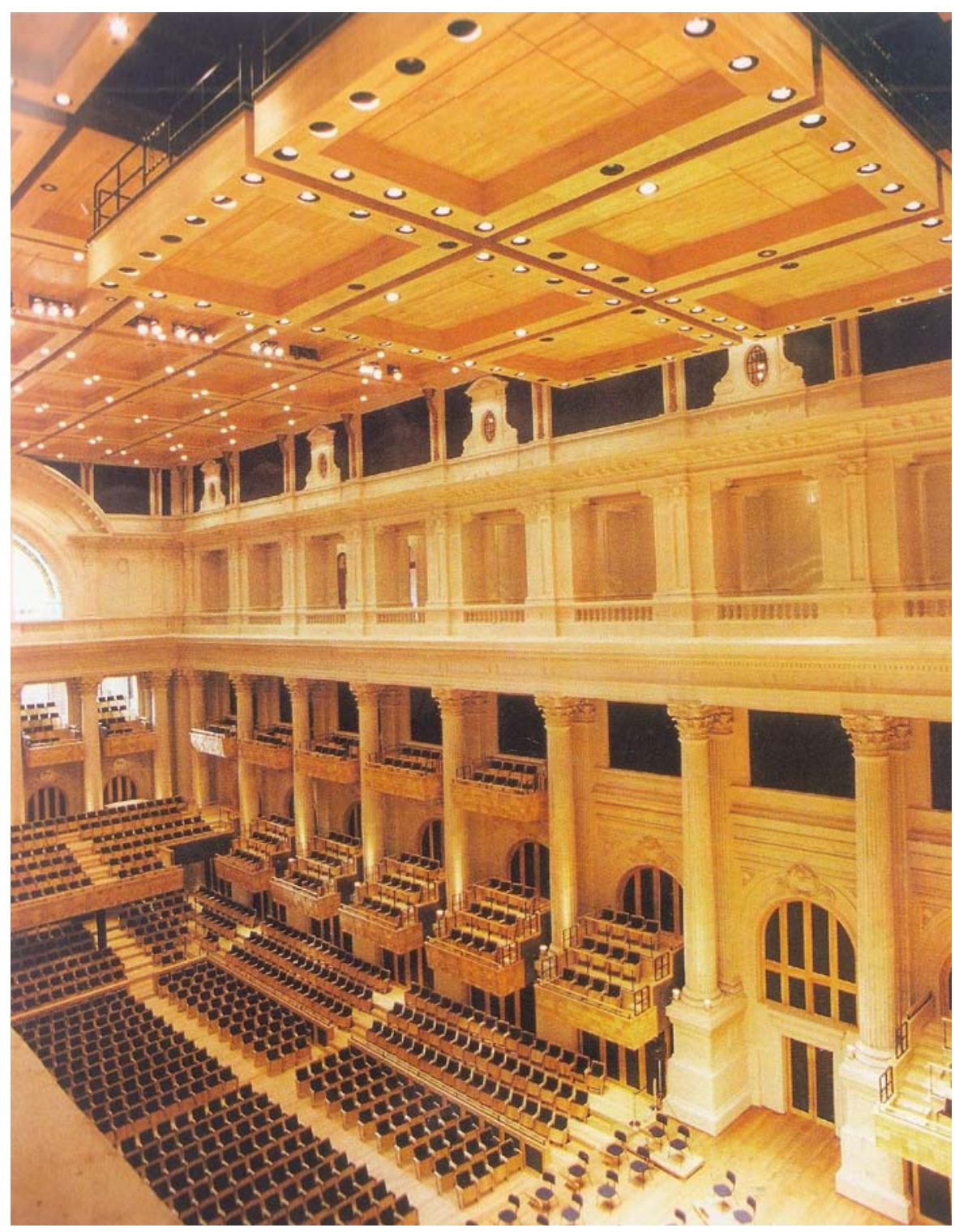

Sala São Paulo. Vista Interna. Fonte: ZEIN, 2001 


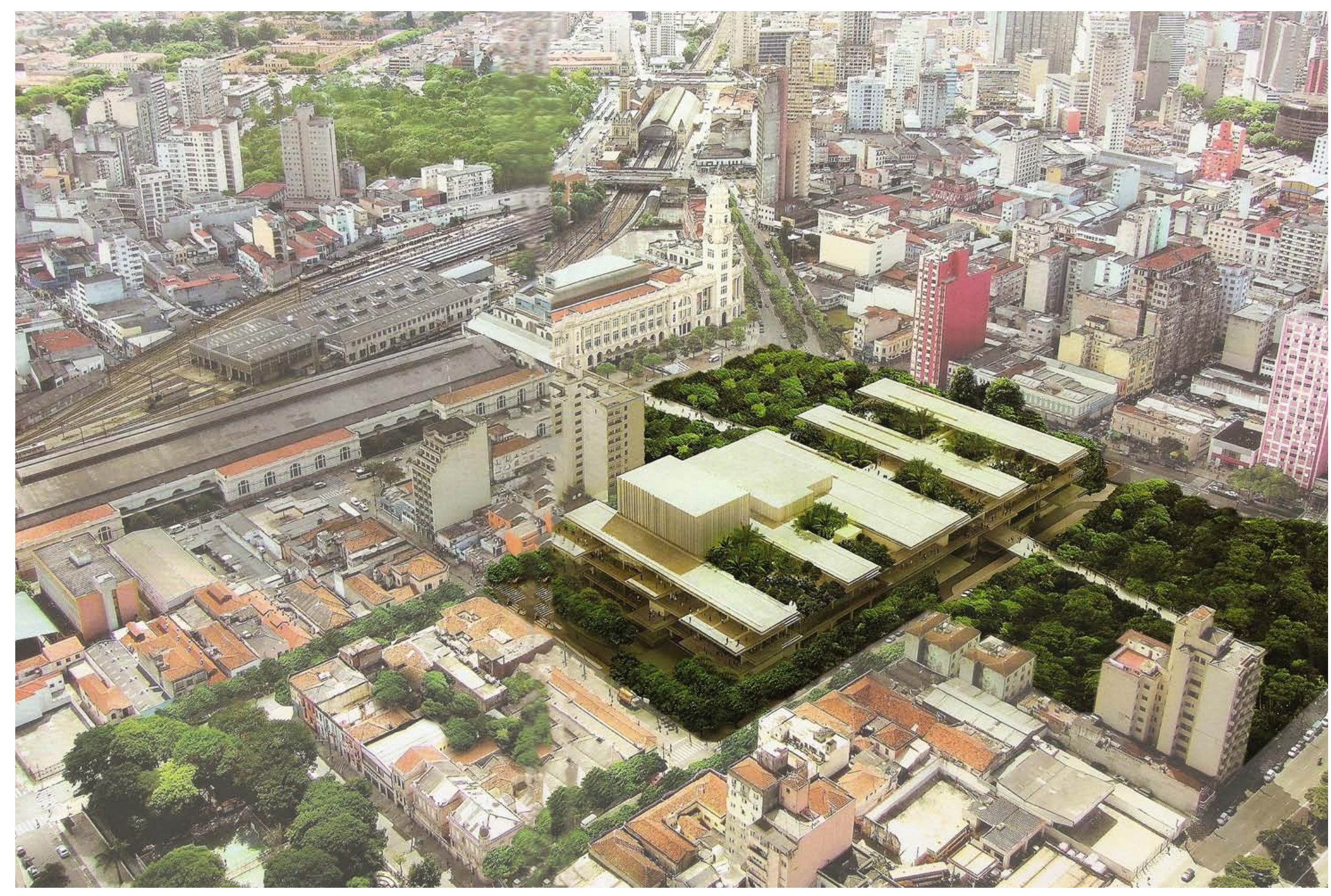

Complexo Cultural Luz - Campos Elíseos. Vista Aérea. Fonte: Projeto Design 386 03/2002 
Mas o que temos para falar sobre as nossas cidades não é motivo de zombaria. A ordem complexa que apresentam - manifestação da liberdade de inúmeras pessoas de fazer e levar adiante seus inúmeros projetos - é sob muitos aspectos um grande milagre. Não devemos relutar em tornar mais compreensível esse acervo vivo de usos independentes, essa liberdade, essa vida por aquilo que eles são, nem ser inconscientes acerca do que representam.

(JACOBS, 2009, p. 435)

Quando Rafael Moneo em 1990 preparou seu curso para os estudantes da Harvard Graduate School of Design, selecionou os arquitetos que no seu entendimento estavam se destacando no cenário contemporâneo da época, mas que ainda não tinham passado ao Olimpo dos manuais: James Stirling, Venturi \& Scott Brown, Aldo Rossi, Peter Eisenman, Álvaro Siza, Frank O. Ghery e Ren Koolhaas, além de Herzog \& de Meuron. A última das oito aulas foi sobre Jacques Herzog e Pierre de Meuron, os mais jovens (nascidos em 1950) entre os selecionados por ele. 0 curso se tornou livro Inquietação e Estratégia Projetual (2008), um 
importante documento para a compreensão da arquitetura produzida naquele momento e de seus desdobramentos até os dias atuais.

Quando em 2009 a Secretaria de Cultura do Estado de São Paulo organizou a seleção do escritório de arquitetura para a concepção do Complexo Cultural da Luz, Herzog \& de Meuron também eram os mais jovens entre os convidados, entretanto o reconhecimento internacional de sua obra os qualificava, conforme as considerações das autoridades responsáveis pela escolha desse escritório ${ }^{141}$.

Para Moneo, no momento em que se encerrava uma década de excessos, a única possibilidade seria a busca da origem, objetivo tão procurado por artistas da segunda metade do século XX. Foi dessa forma que o trabalho da dupla de arquitetos suíços chamou-lhe a atenção, pelo fato da obra se apresentar como "resultado da expressão lógica da construção". (2008, p. 325)

0 autor assinala como a arquitetura produzida por eles conseguiu, através da expressão da técnica construtiva, eliminar qualquer referência iconográfica, ou seja, a ima- gem não existe, e conclui:

Em tempos de massificação democrática, a arquitetura deixa de pertencer ao indivíduo, deixa de ser pessoal, para tornar-se um simples objeto de reflexão, uma base inócua e inerte para a ação. Algo semelhante ao que aconteceu no terreno da estética nas artes plásticas. Sua arquitetura pretende atingir o específico a partir do universal: o conhecimento do universal é o que importa.

(MONEO, 2008, p. 327)

A reflexão de Moneo aponta diretamente para as preocupações das vanguardas artísticas da década de 1920, como as afirmações de Piet Mondrian, que considera a substância como a expressão direta do universal, isto é, usando a definição de Aristóteles para o mais profundo elemento universal:

(...) a substância, como aquilo que subsiste em si mesmo independentemente dos acidentes de tamanho, forma ou qualidade que constituem apenas a exterioridade que a substância se manifesta. (MONDRIAN, 2008, p. 72)

141 Além de Herzog \& de Meuron, foram convidados Norman Foster, Cesar Pelli e Ren Koolhaas; ver Projeto Design n. 354, 2009. 
E nesse caso, admite Moneo, é a construção a substância de sua arquitetura. (2008, p. 336)

Josep Maria Montaner em seu livro de 1997 (p. 174) faria um raciocínio semelhante acrescentando que os arquitetos suíços seriam obcecados pela resolução do envoltório da fachada e pela negação da tradição. Nesse ponto, entretanto, o autor não deve se referir à tradição construtiva suíça, sobre a qual a obra de Herzog \& de Meuron fundamenta sua arquitetura. Seria, portanto, uma referência ao tradicionalismo conservador, como explica Antônio Risério:

Podemos definir tradição como a soma seletiva de atos técnicos e simbólicos nos quais foi gravando a criatividade de um povo.

Enquanto a tradição pode inspirar e mover, o tradicionalismo busca imobilizar.

De qualquer sorte, as vanguardas estéticas internacionais se comportaram, quase sempre, como se tradição fosse sinônimo de poeira, velharia, reumatismo ou artrite cultural.

(RISÉRIO, 2012, p. 266)

\section{O Espetáculo do Vazio}

A comparação entre as imagens aéreas dos Campos Elíseos, onde o projeto será implantado, com um intervalo de meio século (1958 - 2008), ilustram parte das transformações ocorridas na região na segunda metade do século XX e início do século XXI. São testemunhos de como a estrutura do bairro foi transformada até o momento em que foi decidida a construção de um complexo cultural do espetáculo, especializado na dança e na música. ${ }^{142}$

Podem ser observados os grandes espaços e equipamentos públicos de escala metropolitana: a Estação e Praça Júlio Prestes, o Liceu e o Largo Coração de Jesus e a Praça e Terminal Princesa Isabel, articulados pelo traçado generoso das avenidas Rio Branco e Duque de Caxias.

O final da década de 1950 pode ser considerado o momento de maior esplendor da Estação Júlio Prestes. Vinte anos após sua inauguração, o transporte sobre trilhos vivia um grande momento, quando antecedeu a chegada da indústria automobilística e as mudanças de matriz ocorridas no transporte do país. 0 paisagismo da Praça Júlio Prestes

142 O anúncio foi feito em 2007, mas a escolha do escritório de arquitetura se deu somente em 2008. 


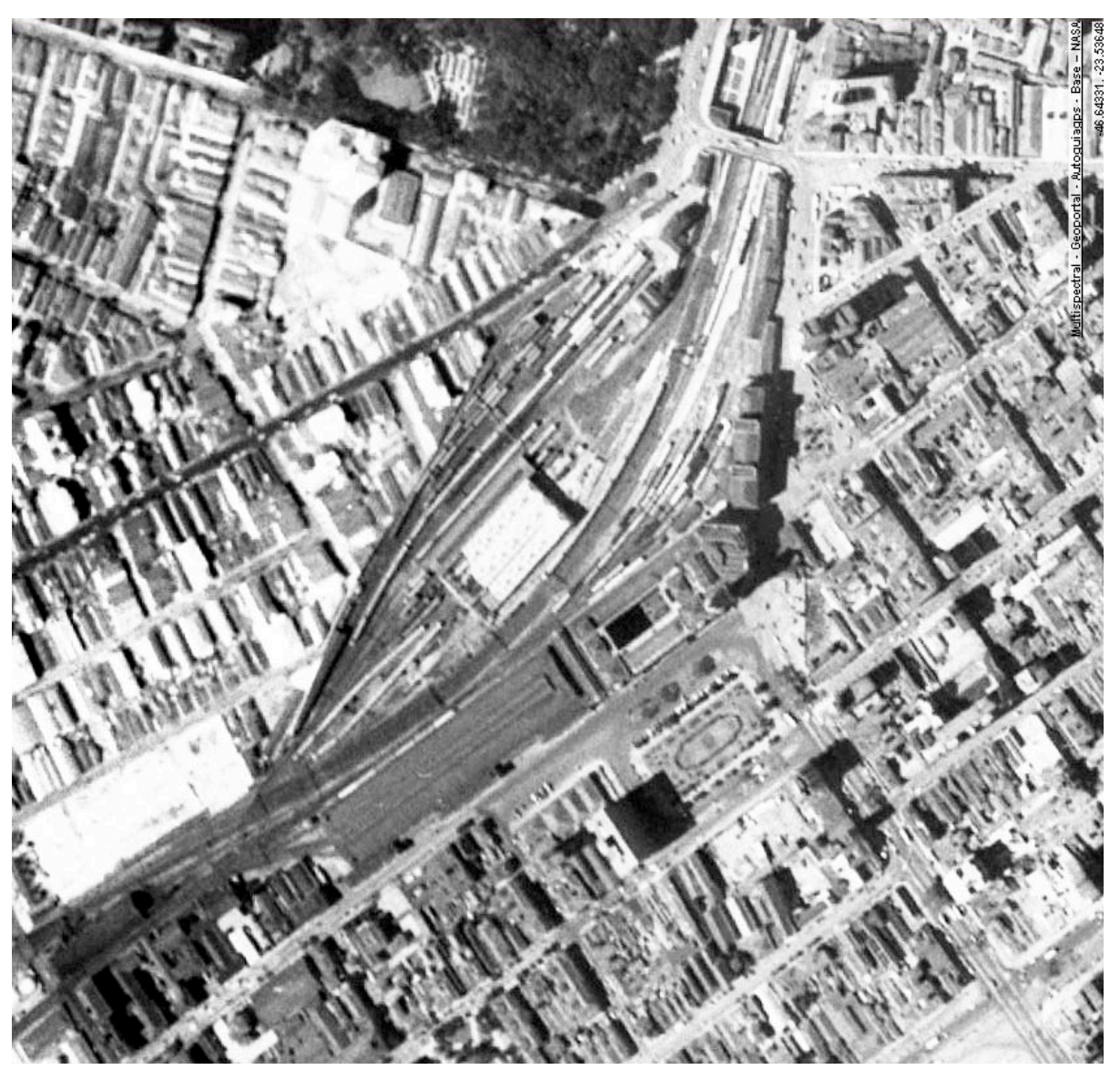

Campos Elíseos, vista aérea 1958. Fonte: www.geoportal.com.br

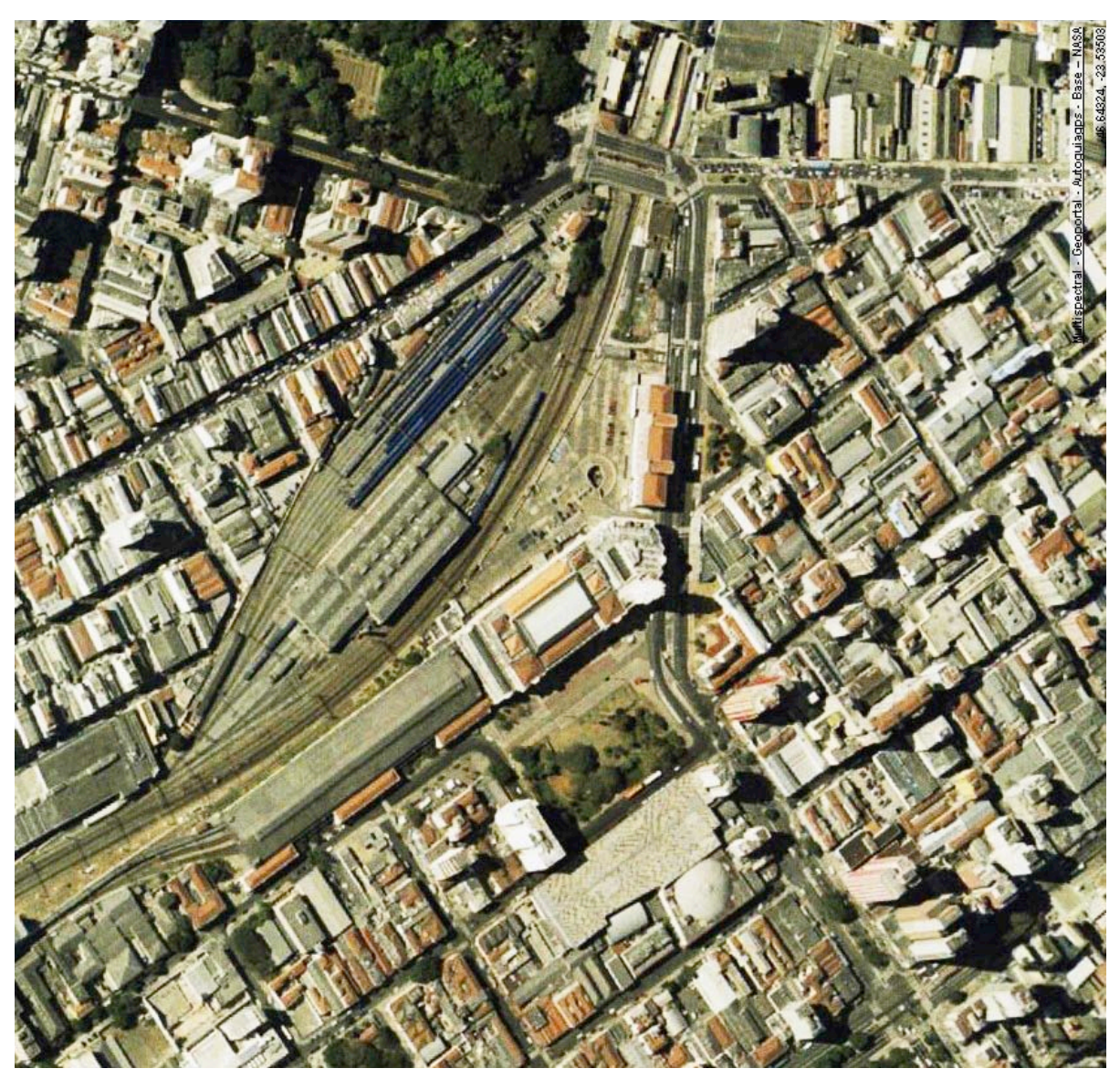

Campos Elíseos, vista aérea 2008. Fonte: www.geoportal.com.br 
obedece às proporções do Grande Hall do vizinho edifício de Christiano Stocker das Neves, alinhado simetricamente a seu eixo. É o momento que antecede também a construção da primeira Estação Rodoviária de São Paulo, que seria inaugurada em $1961^{143}$, e que ocuparia grande parte da quadra oposta à Praça, formando um conjunto simétrico de estações, uma versão primitiva do que conhecemos hoje como terminal intermodal de transporte de passageiros ${ }^{144}$. Esse é o fato que inicia o processo de declínio do bairro. Ao volume crescente de ônibus interurbanos atendido pela Rodoviária acrescenta-se o número significativo de linhas de ônibus urbanos necessários para o acesso dos passageiros, durante o período de maior crescimento econômico da cidade. É possível verificar que a bela marquise construída para esse fim junto à avenida Duque de Caxias se tornou rapidamente subdimensionada.

Em função dessa situação foi criada uma nova estrutura para desempenhar a função de ligação entre passageiros urbanos e interurbanos na década de 1970, o Terminal Princesa Isabel, que ampliou a transformação do bairro.

143 Algumas tentativas foram planejadas para outros locais, como o Jardim da Luz, mas não foram aprovadas pela população; ver Folha de São Paulo, 02/09/1953, p.8.

144 Pode-se também considerar como uma versão primitiva de parceria público privada, pois a construção esteve a cargo da Prefeitura Municipal e dos empresários Carlos Caldeira Filho e Octávio Frias de Oliveira.
Em 1982, a implementação de um plano de descentralização do transporte rodoviário de passageiros, com a construção dos Terminais do Jabaquara, do Tietê e posteriormente da Barra Funda, desativou a Estação Rodoviária da Luz, após vinte anos de funcionamento, deixando ociosa toda a estrutura formada desde a inauguração da Estação Júlio Prestes em 1938

Se o início do declínio do bairro foi marcado pela saturação do espaço urbano, as duas décadas seguintes ao fechamento da Estação Rodoviária foram marcadas pelo fenômeno inverso, o fenômeno do esvaziamento, que coincide também com o declínio do transporte ferroviário de passageiros.

A imagem de 2008 mostra as edificações originais da Estação Rodoviária transformadas em centro comercial e ainda a presença marcante da nova Estação Júlio Prestes transformada na Sala São Paulo de Concertos Sinfônicos. Mostra ainda o Terminal Princesa Isabel, de autoria do arquiteto João Walter Toscano, que substituíra em 1996 as instalações precárias existentes ${ }^{145}$.

145 Sobre a obra e o trabalho do arquiteto ver: TOSCANO, João Walter - João Walter Toscano. São Paulo, Unesp, 2002. 
Foi esse o cenário urbano encontrado pelos arquitetos escolhidos pelo poder público em 2008 para a seleção do projeto do conjunto cultural, batizado posteriormente de Complexo Cultural Luz, considerado o maior equipamento público voltado para a recuperação da região ele completa o sistema cultural iniciado com a inauguração da Pinacoteca do Estado no Liceu de Artes e Ofícios, em 1994, e que inclui a Sala São Paulo na Estação Júlio Prestes, em 1999, e o Museu da Língua Portuguesa na Estação da Luz, em $2006{ }^{146}$.

Se a historiografia considerou que, num primeiro momento, a obra arquitetônica de Herzog \& de Meuron destacou-se no cenário internacional pelos volumes sóbrios e prismáticos, como admitiu Moneo (2008, p. 326), ou ainda pelas formas contidas e minimalistas, observadas por Montaner (2001, p. 151), tais observações devem ser revistas quando se observa a produção desses arquitetos na primeira década do século XX.

A expertise justificada para sua contratação deve-se sem dúvida a obras que se transformaram em ícones urbanos, proporcionando a visibilidade midiática desejada pelo poder público.

É curioso observar de que maneira a simplificação da forma potencializou a expressão dos materiais que formam a pele da edificação, como assinalou Montaner. Uma das principais obras do período, a Arena de Munique para a Copa do Mundo de Futebol de 2006 na Alemanha, inspira-se no brasão do time local para criar uma malha lozangular cujas cores se alternam em função da iluminação, uma versão sofisticada do envoltório da antiga Estação Rodoviária da Luz hoje demolida.

\section{A Leitura e a Compreensão}

Portanto, o edifício moderno, mais que um objeto delimitado e construído, é um episódio urbano, por definição, seja porque o edifício é proposto como um universo peculiar que assume o entorno mediante sua posição - Le Corbusier - seja porque a própria arquitetura é concebida como um modo de habitar o mundo, sem outras barreiras que as que determinam a proteção e o controle climático - Mies van der Rohe.

146 Há ainda a Nova Luz, que é um plano de transformação urbana do bairro adjacente aos Campos Elíseos, baseado na construção de moradia e do incremento das atividades comerciais e de serviços que o bairro possui. Até a presente data não há a confirmação da aprovação de tal plano pela municipalidade. 
O projeto moderno não apenas atende à vizinhança do edifício como não pode prescindir da sua consideração, se quiser usar as possibilidades de síntese por meio da forma. As condições do lugar - na medida em que estimulam e ao mesmo tempo limitam a concepção - são um elemento essencial para a identidade do edifício; a maioria dos projetos exemplares da modernidade não serão entendidos sem uma sutil mas intensa consideração do entorno. (PIÑON, 2006, p. 150-154)

O projeto para o Complexo Cultural Luz apresentado por Herzog \& de Meuron demonstra um cuidado especial à compreensão do lugar. Mais do que a precisão como o extenso e complexo programa de $70.000 \mathrm{~m}^{2}$ foi resolvido, é na leitura feita dos Campos Elíseos atual que reside as características que o qualificam. A proposta, na realidade, é muito mais abrangente, adequando-se à escala metropolitana a que foi destinada. Ou seja, a apreensão que o projeto faz da arquitetura local, com forte domínio dos espaços públicos e espaços vazios, articulando as funções principais do artefato arquitetônico à cidade, desfaz o simbolismo que poderia

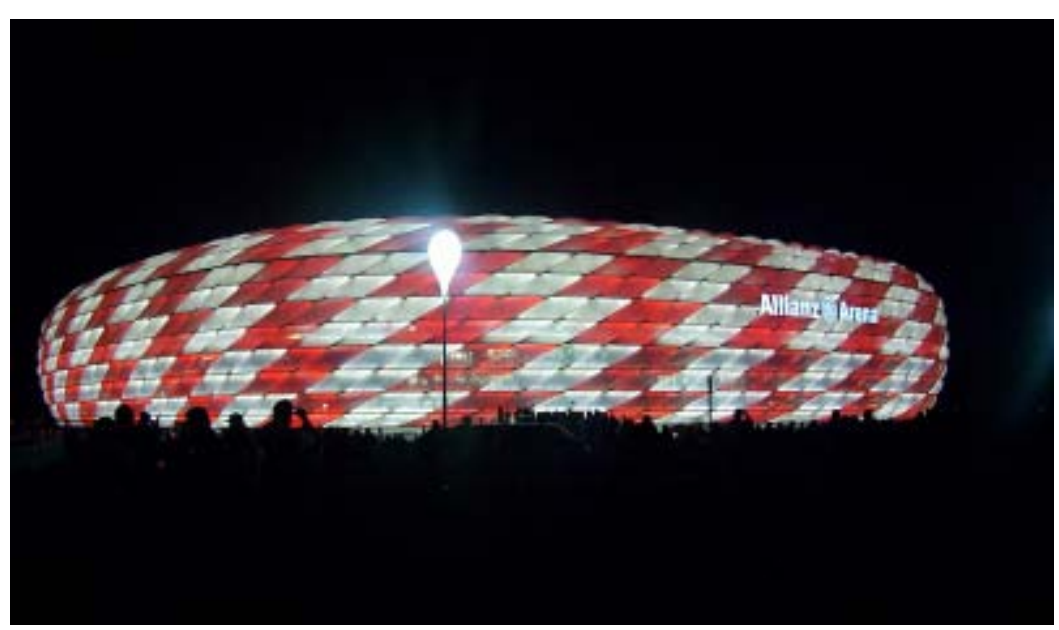

Bayern Arena - Munique. Fonte: www.fcbayern.de

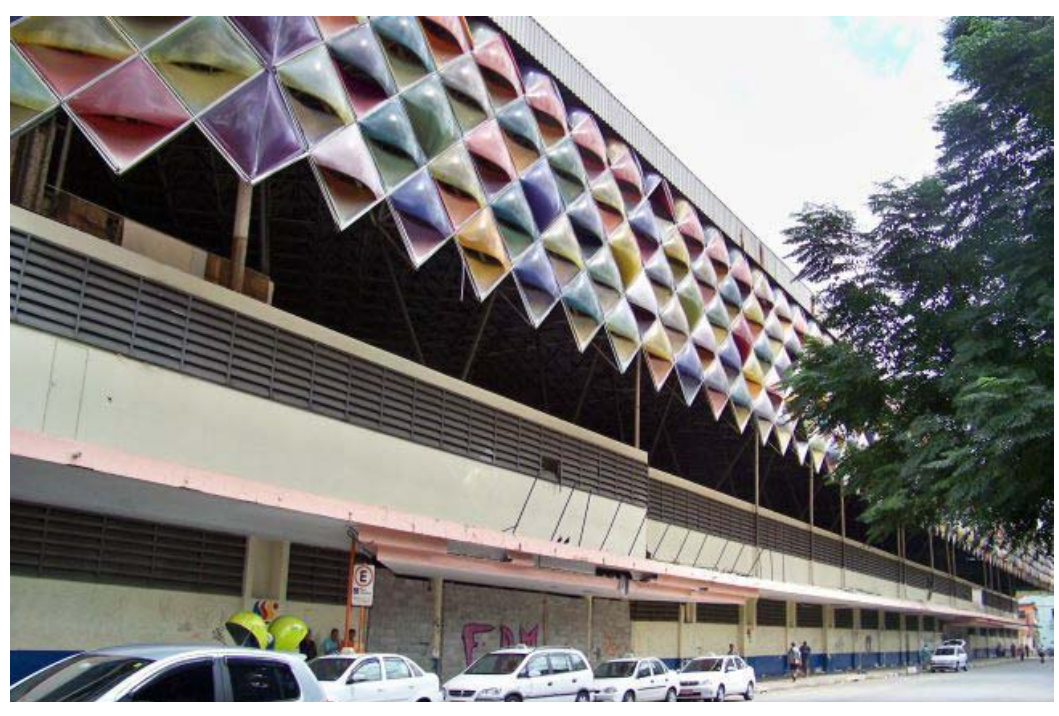

Rodoviária - Luz - São Paulo. Fonte: www.g1.globo.com 
ser esperado em função do alcance da obra, em função da importância e da escala da obra.

Como pode ser observado, a solução encontrada tratou de criar um sistema de espaços abertos, públicos e semi públicos, cobertos e descobertos, sobrepostos em camadas e articulados por diversos mecanismos de ligação vertical. Esse sistema, que ocupa a totalidade do lote, cria o envoltório dos volumes onde serão desempenhadas as atividades principais, ao mesmo tempo em que envolve os vazios de um grande jardim tropical.

Podemos perceber a insistência no emprego dos materiais que definem os volumes fechados, como também o cuidado com o desenho desses volumes dentro desse grande sistema, mas nos parece que nesse projeto, diferentemente das obras anteriores, essas preocupações se tornaram secundárias.

A intervenção pretende estender seu alcance aos espaços urbanos que sofreram com a degradação do bairro, como a Praça Princesa Isabel e o Largo Coração de Jesus, não se restringindo ao lote da antiga Estação Rodoviária que ocupa. Essa estratégia é empreendida por uma rampa transversal ao conjunto, uma rua suspensa que parte da Praça Júlio Prestes, serve o nível principal do Complexo e desce na quadra seguinte, junto à avenida Rio Branco.

Fica claro, assim, que há uma estreita relação do projeto com a tradição da arquitetura local em relação à articulação de equipamentos culturais através de espaços verdes e de grandes planos construídos, como por exemplo na marquise de Oscar Niemeyer para o Parque do Ibirapuera. No caso do Complexo da Luz, a verticalização da solução trouxe uma nova situação de intensa urbanidade ao conjunto, ingrediente fundamental para as trocas culturais em escala metropolitana a que a obra se propõe.

\section{Onde Está o Espetáculo}

As plantas dos pavimentos mais significativos, $2^{\circ} \mathrm{e}$ $3^{\circ}$, resumem as decisões que definiram a solução:

. os organismos principais - a São Paulo Companhia de Dança e a Tom Jobim Escola de Música - foram posicionados respectivamente nas faces oeste e leste do lote, ocu- 


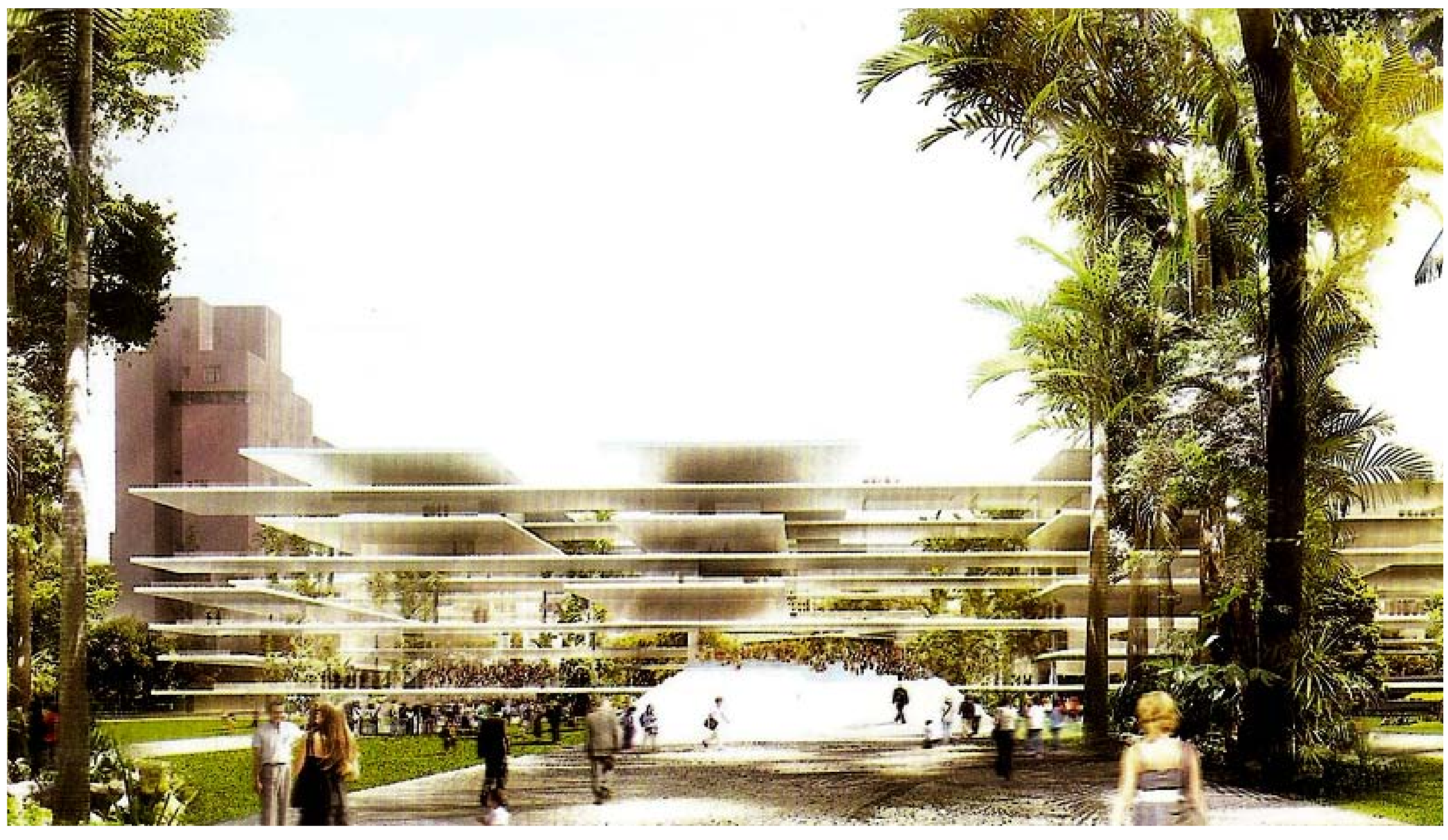

Complexo Cultural Luz, acesso Praça Júlio Prestes. Fonte: Projeto Design 385 03/2012 
pando diversos níveis;

. a Grande Rampa Central ocupou o coração do conjunto, criando o foyer urbano aberto;

. os teatros (teatro de dança com 1.750 lugares, teatro experimental com 400 lugares e teatro de recitais com 500 lugares) foram distribuídos isoladamente no conjunto, em função de sua escala e de sua especialidade. Assim, o grande volume construído do primeiro, que possui caixa cênica, foi posicionado na parcela posterior do lote, diretamente vinculado à Cia de Dança, próximo à rua Helvétia, $o$ que garante seu isolamento em relação ao ruído externo e contribui para manter a escala do sistema. 0 segundo, próximo à alameda Barão de Piracicaba, forma com o primeiro uma praça suspensa, um foyer aberto na extensão da rampa central. 0 terceiro, por seu caráter mais intimista, foi posicionado na porção oposta, inserido na Escola de Música. É também o que terá sua forma ovoide como a mais marcante, ao contrário dos outros;

. a ocupação das diversas alas criadas pelo sistema de planos superpostos parece não seguir uma ordem defi- nida. Na realidade, essas áreas do projeto parecem se inspirar na aleatoriedade das ocupações urbanas espontâneas, o que é intensificado pelas formas livres e ângulos desconexos distribuídos pelo sistema ortogonal dos pisos. Um estudo mais apurado, entretanto, demonstra haver uma lógica por trás dessa aparente liberdade que permite, pelo posicionamento das circulações verticais e dos fechamentos em vidro, criar a hierarquia necessária entre os espaços públicos, próximos aos locais de espetáculos e os semi-públicos, junto à Escola de Música e à Cia. de Dança. No início a obra chegou a ser chamada de Cidade da Dança. A solução de um sistema estruturado pelos fluxos nos remete aos projetos de Candillis, Josic e Woods, como vimos no capítulo $A$ Metrópole Em Cena. Os projetos da década de 1960, a Universidade Toulouse le Mirail, a de Frankfurt-Römerberg e a Universidade Livre de Berlin, apesar de desfigurada pela intervenção recente de Norman Foster, seguem proposta semelhante.

Os locais especializados foram projetados pensando-se muito mais em seu desempenho técnico do que em 

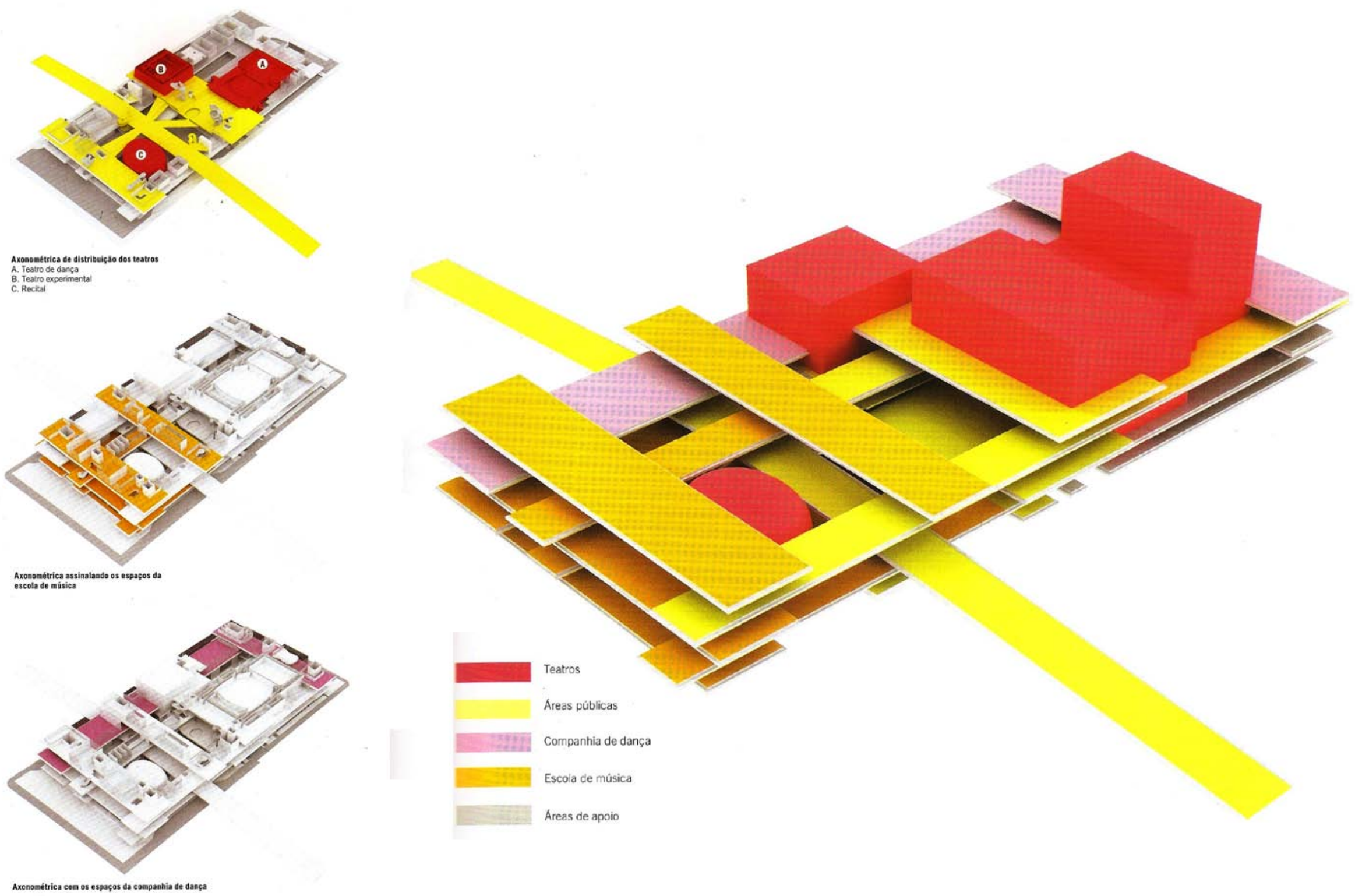

Complexo Cultural Luz, Diagramas do Projeto. Fonte: Projeto Design 385 03/2012 


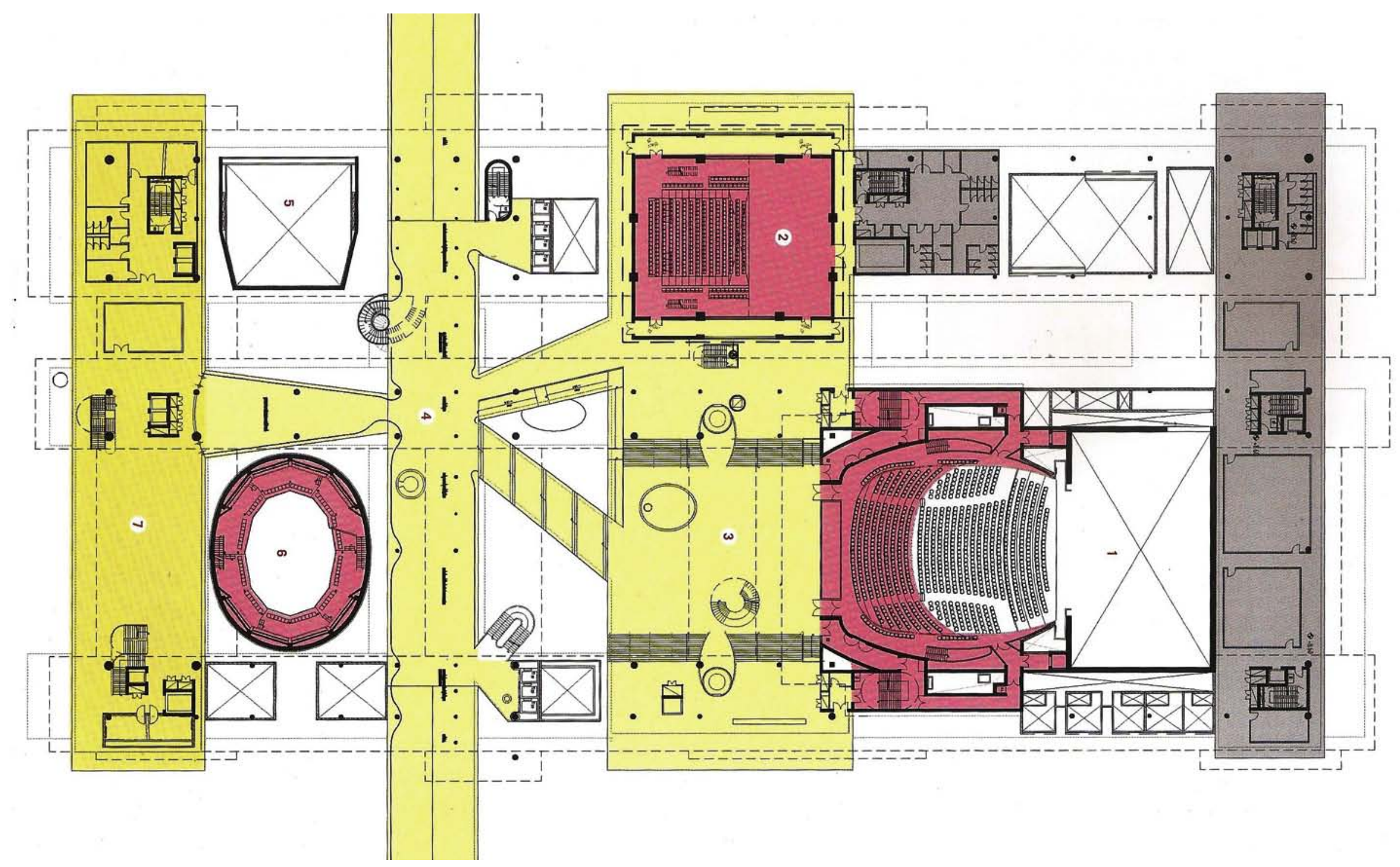

Complexo Cultural Luz, planta $2^{\circ}$ pavimento - nível público superior, escala 1:1000

1. Teatro de Dança; 2. Teatro Experimental; 3. Foyer; 4. Rampa Central; 5. Sala de Ensaios - Orquestra; 6. Sala Recital; 7. Escola de Música Fonte: Projeto Design 385 03/2012 


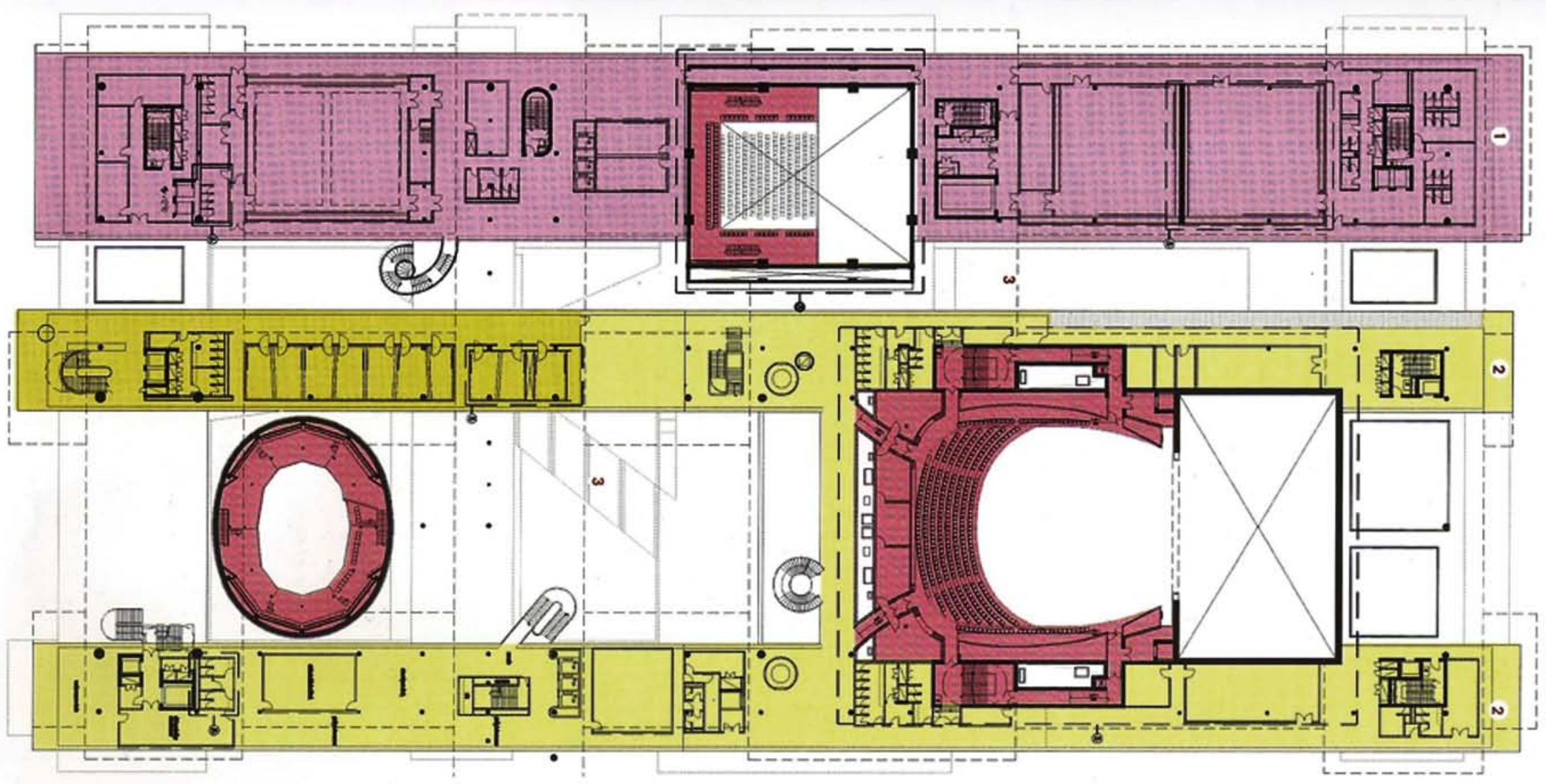

Complexo Cultural Luz, planta $3^{\circ}$ pavimento - escala 1:1000

1. Companhia de Dança; 2. Escola de Música; 3. Vazios: Fonte: Projeto Design 385 03/2012 


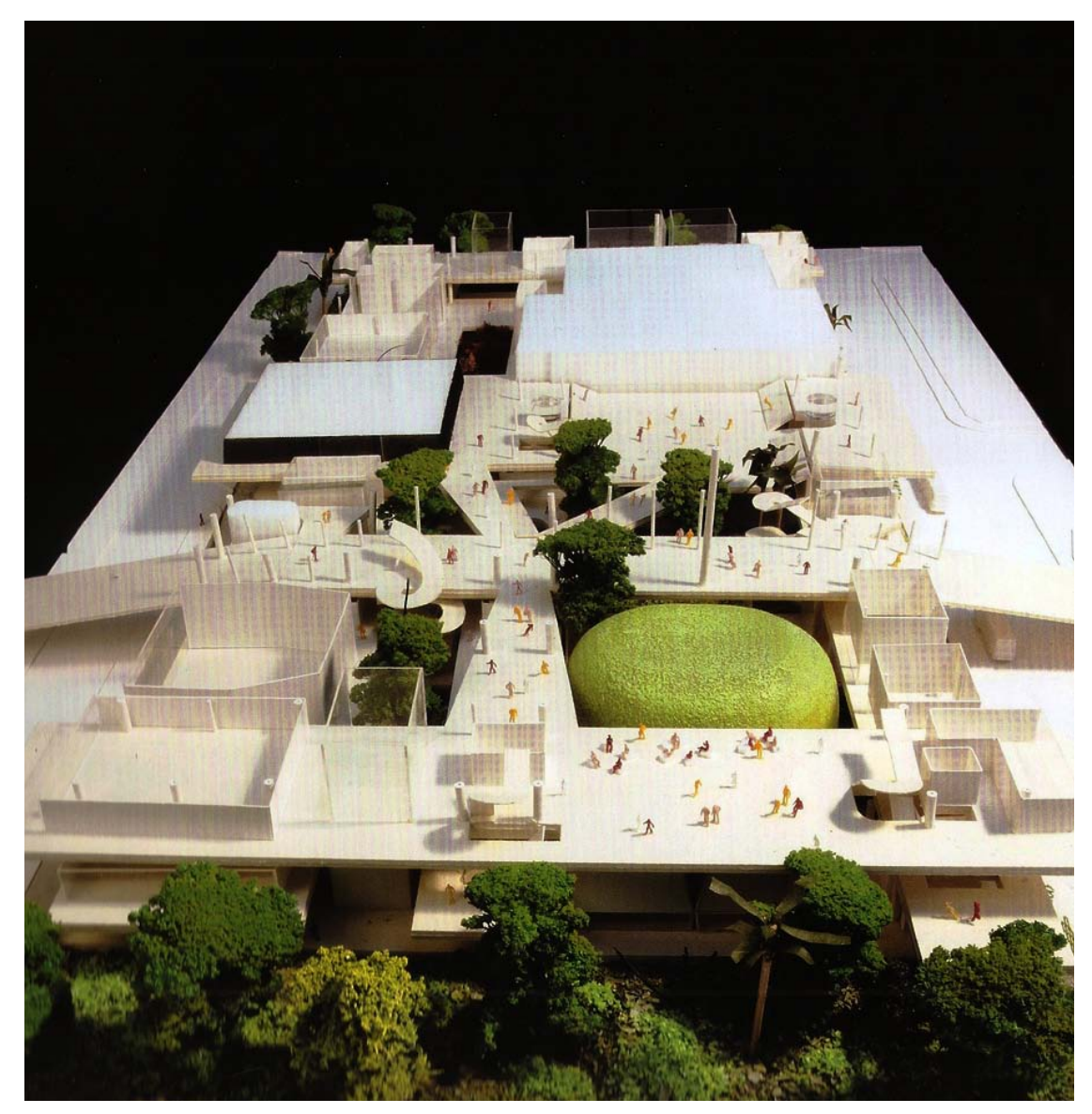

Maquete Nível Público Superior Fonte: Projeto Design 385 03/2012 seu valor simbólico, como pudemos observar. Pelo material disponível até o momento é possível perceber que o teatro de dança segue a solução de frontalidade do palco italiano, justificado pelos especialistas como o mais adequado. Há porém menos opção em relação a cenários, como profundidade e largura, para que possa ser adaptado para o uso em óperas, como foi anunciado.

0 teatro experimental segue a solução da caixa retangular flexível em que a plateia pode ser modificada e até eliminada, o que permite a liberdade necessária para tais espetáculos.

A articulação entre os dois teatros junto ao foyer central cria o ponto alto do projeto, não só pelo seu posicionamento como também pela sua conformação, que tira partido dos desníveis e do fundo do balcão superior para gerar um lugar para espetáculos aberto, visível de diversos pontos do conjunto.

0 teatro de recital forma com a sala de ensaio um grupo de espaços vinculados à Escola de Música, emergindo do jardim tropical. A situação, considerada excepcional 
pelos arquitetos, demonstra a preocupação do projeto com a concentração necessária ao desempenho das atividades de ensino.

As decisões de projeto levaram assim à dissolução do monumental, em oposição à forte rigidez da grande massa construída representada pela Sala São Paulo à sua frente. Em oposição a ela, os arquitetos trataram de construir o vazio, de deixá-lo livre em níveis sucessivos, onde se pretende sabiamente fazer conviver estudantes e profissionais, espectadores e dançarinos, produção e ensaio, ou seja, unir educação, cultura e espetáculo de uma maneira franca, aberta para a cidade.

A arquitetura do espetáculo é aqui parte primordial de um sistema que para exercê-la, pretende torná-la meio e não somente fim.

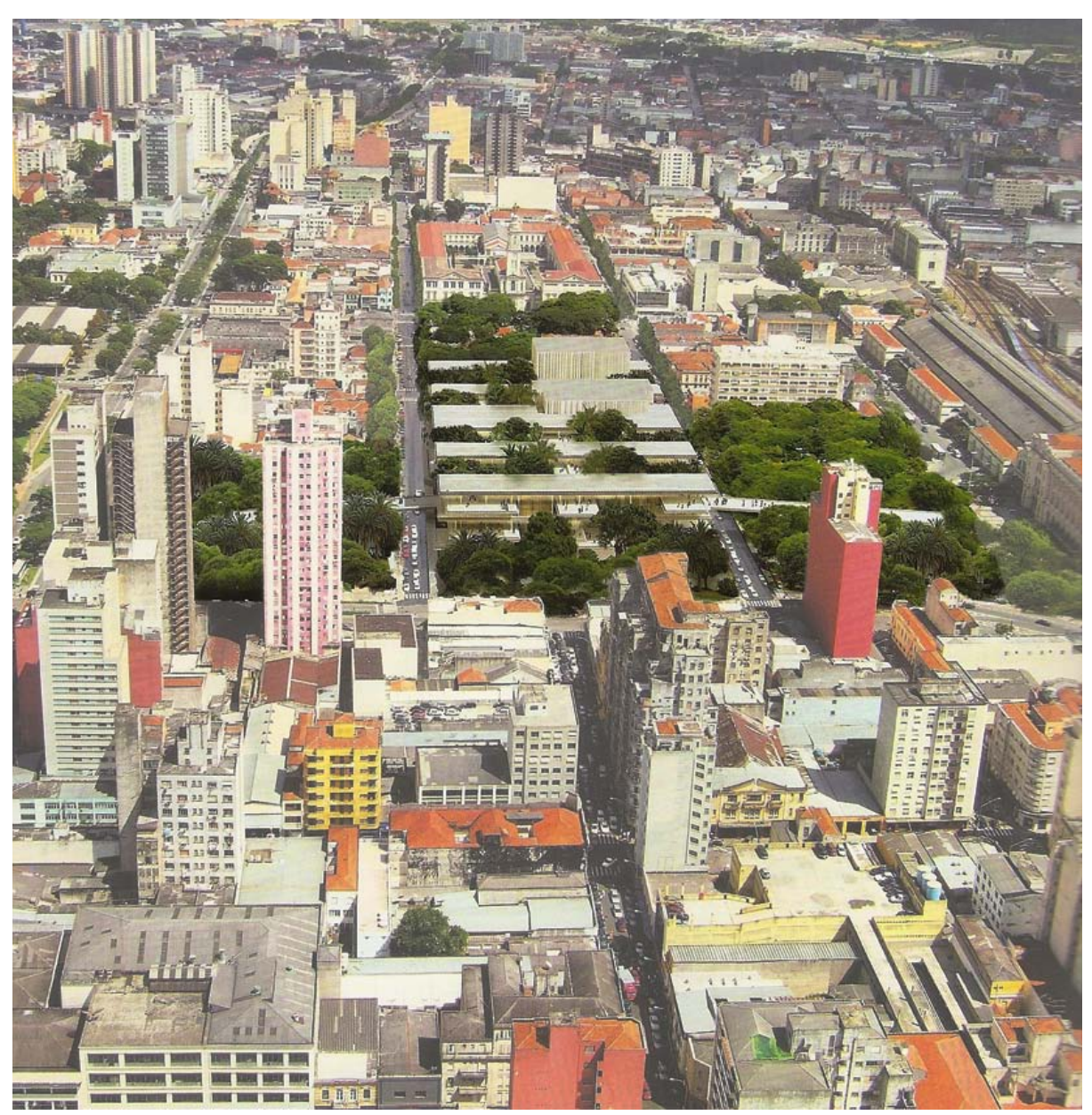

Complexo Cultural Luz - Vista Aérea Fonte: Projeto Design 385 03/2012 


\section{Considerações Finais}


(...) por que continuamos sensíveis à tragédia grega, visto que as condições materiais que as inspiraram desapareceram há muito tempo[?] Seria porque, responde ele [Jean Duvignaud], "entre a trama da representação social e a trama da representação dramática insere-se um sistema de valores, crenças, mitologias que nos remete menos às relações sociais reais que à relação homem e natureza em geral". Mas poderíamos acrescentar que essas obras nos deixariam indiferentes se não existissem certas constantes, certas situações fundamentais que se encontram na sociedade $e$ em obras dramáticas as mais diferentes, na relação homem com o homem.

(JACQUOT, in BABLET, 2002, p. 227) $)^{147}$
Ao final deste trabalho, o raciocínio de Jean Jacquot, inspirado nas reflexões de Jean Duvignaud (1967), parece-nos ainda presente atualmente. Podemos afirmar, baseados no que observamos em nossa pesquisa, que apesar de toda a transformação da percepção e da própria representação, os princípios constitutivos, os valores essenciais do teatro e da arquitetura permanecem reveladores de qualidades dramáticas e de consciência estética fundamentais. Uma das respostas para a permanência da arte sobre o descrédito da imagem seria a revelação de tais valores. Em outras palavras, caberia ao projeto a missão de compreender as condições que estabelecem os fundamentos da obra e de revelá-las.

Os desafios se colocam no momento das escolhas, dos instrumentos dos quais o projeto se valerá para tal empreitada. Não seria somente a arquitetura do espetáculo que estaria sofrendo para responder adequadamente a esses desafios. Ainda que a complexidade do tema demonstrada na presente dissertação seja uma prova, tais desafios

147 Nossa tradução do texto original: (...) pourquoi nous restons sensibles à la tragédie grecque, alors que les conditions matérielles qui l'ont suscitée ont depuis longtemps disparu. Ne serait-ce pas, dit-il, "qu'entre la trame de la vie sociale et la trame de la représentation dramatique s'insèrent les systèmes de valeurs, les croyances, les mythologies qui renvoient moins aux relations sociales réelles qu'aux relations de l'homme et de la "nature" en général." Mais ne pourrait-on ajouter que ces oeuvres nous laisseraient indifférents s'il n'existait certaines constantes, certaines situations fondamentales, dans les rapports de I'homme avec l'homme, qui retrouvent dans les sociétés, et dans les oeuvres 
fazem parte da essência da própria natureza da arquitetura.

Marina Waissmann pondera que, mesmo aceitando a existência de valores universais na arquitetura, há a necessidade de afirmação de valores próprios, historicamente esquecidos pela dependência cultural:

No caso da arquitetura é necessário confrontar permanentemente a problemática real de cada lugar com os conceitos e valores convencionalmente aceitos, o que conduz a estabelecer valores próprios e a rever juízos que tenham sido formulados com base nessas pautas. (1994, p. 37) ${ }^{148}$

Pudemos, então, verificar que a relação com o lugar, assunto significativo das discussões teóricas da arquitetura desde a metade do século XX, ganha importância nas apropriações que os espetáculos empreenderam em período semelhante, seja pela ocupação do galpão genérico abandonado ou do edifício exemplar que perdera sua função original ou até mesmo de bairros inteiros, como observamos no capítulo $O$ Lugar da Arquitetura do Espetáculo. ${ }^{149}$

A arquitetura, enquanto artefato e enquanto cidade, serviria, dessa forma, como lugar, como território das incursões dramáticas, o que pressupõe sua preexistência, ainda que não consolidada ou mesmo em processo de transformação, pela própria dinâmica urbana em que se insere.

Nesse sentido, os diversos subtemas tratados nos capítulos revelaram aspectos que merecem ser novamente destacados:

Primeiramente, não há um lugar do espetáculo e sim uma diversidade de situações que promove o espetáculo e garante a formação de público e de atores, o que pode ocorrer nos inúmeros espaços criados ou apropriados, que vão dos mais especializados no interior das edificações aos lugares improvisados. Trata-se então de um artefato, um organismo, ou mais precisamente, de um sistema de organismos que estabelecem entre si e com a cidade as trocas inerentes ao seu desempenho.

Algumas obras citadas são exemplos claros de uma postura de arqueologia dos modelos e imagens reconhecíveis e do respeito pelo patrimônio edificado. 0 raciocínio é fundamental para entender as propostas no ambiente cons-

148 Nossa tradução do texto original: En el caso de la arquitectura es necesario confrontar permanentemente la problemática real de cada lugar con los conceptos y valores convencionalmente aceptados, lo que conduce a establecer valores propios y a revisar juicios que han sido formulados en base a aquellas pautas.

149 Como o Palais des Papes de Avignon, e toda a Avignon que se transforma anualmente para o Festival de Teatro. 
truído, em especial aquele referente ao Centro de São Paulo, território escolhido no presente trabalho.

As qualidades de natureza essencial são determinantes para a sobrevivência e sobretudo para a evolução da obra, muito mais pela permanência de sua estrutura formal arquitetônica, dentro de um quadro de evolução de usos, do que da conservação integral dos seus aspectos estéticos, como monumento ou como obra de arte. Entretanto, ficou evidente que o resultado alcançado nos casos estudados seria inferior se a mesma tecnologia fosse empregada em um galpão genérico, desprovido dessas qualidades essenciais.

A monumentalidade da técnica estaria a serviço da expressividade criativa da cena, muito mais do que a própria tecnologia. Nesse caso, a técnica é a expressão de uma determinada monumentalidade. A expressão estrutural se manifesta como pura expressão da Modernidade.

No conjunto multifuncional a arquitetura do espetáculo assume função ordenadora do espaço urbano proposto. Mais do que fazer parte, de pertencer ao conjunto edificado, ela desempenha o papel de protagonista. E a partir daí, a forma é determinada pela articulação entre elementos primordiais do projeto, nesse caso, o lugar do espetáculo, o metrô, a praça e a rua, ou seja, a cidade.

Finalmente, há um aspecto referente ao que podemos chamar da cidade como geradora da forma. Nessa situação, a arquitetura do espetáculo e sua relação com a cidade não seria exatamente o resultado das condições encontradas em determinado território. Isso significa que cabe ao projeto promover a identidade da obra coerente com as condições do lugar. 


\section{Bibliografia}


ALBERTI, Leon Battista - Da Pintura, Campinas, Unicamp, 2009.

- L'art d'Edifier, Paris, Seuil, 2004;

1a. edição: 1452 .

ALOI, Roberto - Architettura per lo Spetacolo, Milão, Uricio Holpie, 1958.

AMARAL, Elisabeth Cristina Ecker - O Edifício Teatral Paulistano, São Paulo, FAUUSP, Dissertação de Mestrado, 2005.

AMBONVILLE, Marlène (coord.) - Musée des Confluences, Concours International, Lyon, SERL, 2001.

ANDO, Tadao - Tadao Ando Arquiteto, São Paulo, BEI Comunicação, 2010.

ANELLI, Renato - Centri Unificati di Educazione a São Paulo. In Casabella, n. 727. Milão, 2004.
- Rino Levi Arquitetura e Cidade, São Paulo, Romano Guerra, 2001.

- Arquitetura de Cinemas em São Paulo. O Cinema e a Construão do Moderno, [1992], in Textos Fundamentais sobre História da Arquitetura Moderna Brasileira: v.1/ GUERRA, Abílio (org.). São Paulo, Romano Guerra, 2010.

- O Mediterrâneo nos Trópicos. Interlocuções entre Arquitetura Moderna Brasileira e Italiana, [1999], in Textos Fundamentais sobre História da Arquitetura Moderna Brasileira: v.2/ GUERRA, Abílio (org.). São Paulo, Romano Guerra, 2010.

ARANHA, Maria Beatriz de Camargo - Rino Levi: Arquitetura como Ofício [1993], in Textos Fundamentais sobre História da Arquitetura Moderna Brasileira: v.2/ GUERRA, Abílio (org.). - São Paulo, Romano Guerra, 2010. 
ARANTES, Paulo - Entrevista em 11/08/2007, São Paulo, $O$ Estado de São Paulo.

ARANTES, Otília - O lugar da arquitetura depois dos modernos, São Paulo, Edusp, 1993.

- Urbanismo em Fim de Linha, São Paulo,

Edusp, 1998.

ARAVENA, Alejandro. Conferência na Universidade de Palermo, Itália. 21/10/2010. Disponível em < http://www. youtube.com/watch?v=dbM_jHvm2vU>. Acessado em 14/01/2012.

ARGAN, G. Carlo - História da arte como história da cidade, São Paulo, Martins Fontes, 1998.

- A História na Metodologia do Projeto, in Caramelo 6, São Paulo, FAUUSP, 1993. Palestra proferida na Escola Politécnica Federal de Lausanne em 1983.

- L'Europe des capitales, 1600-1700, Genève,
- Projeto e Destino, São Paulo, Ática, 2000.

- Walter Gropius e a Bauhaus, Rio de Janei-

ro, José Olímpio, 2005, 1a. edição 1951.

ARTIGAS, Rosa (org.) - Paulo Mendes da Rocha, São Paulo, Cosac \& Naify, 2000.

AZEVEDO, Ricardo Marques de - Metrópole: Abstração. São Paulo, Perspectiva, 2006.

- Antigos Modernos: Estudo das Doutrinas Arquitetônicas nos Séculos XVII e XVIII, São Paulo, FAUUSP, 2009.

BABLET, Denis - Le lieu théâtral dans la Société Moderne, Paris,: CNRS Ed., 2002, 1a. edição: 1963.

BARDI, Lina Bo - Teatro Oficina São Paulo, Lisboa - São Paulo - Blau, Instituto Lina Bo e P.M. Bardi. 1999.

- Lina por Escrito, São Paulo, Cosac \& Naify,

Skira, 1964. 
BARONE, Ana Cláudia Castilho - Team X Arquitetura como Crítica, São Paulo, Annablume/ Fapesp, 2004.

BARRERA FAURE , Esteban - Mario Roberto Alvarez Arquitectura Forma y Ciudad, Barcelona, UPC/ETSAB, 2009.

BARRETO, Gabriela Mafra - A cidade como cena para os grupos teatrais:o caso do Grupo Galpão, do Grupo Armatrux e do Teatro da Vertigem, São Paulo, Dissertação de Mestrado, FAUUSP, 2008.

BASTOS, Maria Alice Junqueira - A Escola Parque: ou um Sonho de uma Educação Completa (em Edifícios Modernos), In AU n. 178, São Paulo, Pini, 2009.

- Brasil: Arquiteturas após

1950, São Paulo, Perspectiva, 2010.

BAUDRILLARD, Jean - L'Effet Beaubourg, Paris, Galilée, 1977.

BAXANDALL, Michael - Padrões de Intenção. São Paulo, Cia das Letras, 2006.
BECKER, A. Cândida - A cidade como espetáculo, São Paulo, Dissertação de Mestrado, FAU USP, 2000.

BENEVOLO, Leonardo - A História da Cidade, São Paulo, Ed. Perspectiva, 1983.

- A Arquitetura do Novo Milênio, São Paulo,

Estação Liberdade, 2007.

BENJAMIN, Walter. - Paris, Capitale du XIXeme Siècle, Paris, Allia, 2004.

- A Obra de Arte na época de suas técnicas de reprodução, São Paulo, Ed. Abril, 1961.

BLASER, Werner - Mies Van Der Rohe, São Paulo, Martins Fontes, 1994.

BOGÉA, Marta - Cidade Errante. São Paulo, Senac, 2009.

BRAGA, Milton - O Concurso de Brasília: Sete Projetos para uma Capital. São Paulo, Cosac Naify, 2010. 
BRETON, Gaelle - Théâtres, Paris, Editions du Moniteur, 1989.

BROADBENT, Geoffrey H. - Diseño arquitectonico arquitectura y ciencias humanas, Barcelona : Gili, 1976.

BRUNA, Paulo Júlio Valentino - Os Primeiros Modernos: Habitação Social no Brasil 1930-1950, São Paulo, Edusp, 2010.

BUCCI, Ângelo - São Paulo, Razões de Arquitetura, São Paulo: Romano Guerra, 2010.

BURROWS, John - Guia de Música Clássica, Rio de Janeiro, Zahar, 2008.

CALVINO, Italo - Seis Propostas para o Próximo Milênio, São Paulo, Cia das Letras, 1991.

- Les Villes Invisibles, Paris, Éditions du Seuil,

1996.

CANDILIS, Georges - Toulouse le Mirail : gebrut einer neuen stadt., Stuttgart, Kramer, 1975.
CARDOSO, Ricardo J. Brugger - A cidade como palco: o centro do Rio de Janeiro como locus da experiência teatral contemporânea - 1980/1990, Rio de Janeiro: SMC/CDIC/GI, 2008.

CARON, Jorge O. - O Território do Espetáculo, A Arquitetura e o Espetáculo Teatral, São Paulo, FAUUSP, Tese de Doutorado, 1994

CARPEAUX, Otto Maria - Uma Nova História da Música, Rio de Janeira, Zahar, 1958.

Centre National D'art et de Culture Georges Pompidou Mies Van Der Rohe : Sa Carriere, Son Héritage et Ses Disciples, Paris , Centre National d'art et de Culture Georges Pompidou, 1987.

CESTAU OLIVERI, Patricia - La Obra de Luis García Pardo como material de proyecto. Master en teoría y práctica del proyecto de arquitectura, Barcelona, ETSAB UPC, 2009.

CHOAY, Françoise - Alegoria do Patrimônio, São Paulo: Estação Liberdade, Unesp, 2006. 
COElHo NETTO, J. Teixeira - A Construção do Sentido, São Paulo, Perspectiva, 1979.

COLLINS, George - Camillo sitte y el nacimiento del urbanismo moderno, Barcelona, Gustavo Gili, 1980.

COLLINS, Peter - Los Ideales de la Arquitectura; su Evolución (1750 - 1950), Barcelona, Gustavo Gili, 1998.

COMMUNAUTÉ FRANÇAISE WALLONIE-BRUXELLES - Architectures, Wallonie-Bruxelles. Inventaires 2005-2010. Pauwels Impresor, Bruxelles, 2010.

CULLEN, Gordon - Paisagem Urbana, São Paulo, Liv. Martins Fontes, 1984.

CURCIO, Giovanna, - La Città del Settecento, Roma, Laterza, 2008.

DEBORD, Guy - La société du spectacle, Paris: Gallimard, 1992.

DEL NERO, Cyro - Máquina para os Deuses: anotações de um cenógrafo e o discurso da cenografia, São Paulo, Senac, 2009. DERNTL, Maria Fernanda - Uma reflexão sobre a pesquisa em arquitetura. Resenhas Online, São Paulo, Vitruvius <http://www.vitruvius.com.br/revistas/read/resenhasonline/07.075/3082>

DROSTE, Magdalena - Bauhaus, Berlin, Taschen, 1990.

DUPAVILLON, Christian, Les Lieux du Spectacle, Tous les Lieux, in L'Architecture d'Aujoud'hui, n. 199, Paris, 1978.

DUVIGnaud, Jean, Réalisme et Poésie au Théâtre. Paris, CNRS, 1967.

ECO, Umberto - Como se Faz uma Tese, São Paulo, Perspectiva, 2010.

ESPALLARGAS GIMENEZ, Luis - Eduardo de Almeida. São Paulo, Romano Guerra, 2006.

. Da Geometria e da Arte da Palavra. Resenha . d'AGOSTINO, Mário Henrique Simão. Geometrias simbólicas da arquitetura: espaço e ordem visual do Renascimento às Luzes. São Paulo, Hucitec, 2006. 
- Autenticidade e Rudimento. Paulo Mendes da Rocha e as Intervenções em Edifícios Existentes [1988], in Textos Fundamentais sobre História da Arquitetura Moderna Brasileira: v.1/ GUERRA, Abílio (org.) - São Paulo, Romano Guerra, 2010.

EVERS, Bernd - Teoria da arquitectura do renascimento até aos nossos dias - 117 tratados apresentados em 89 estudos. Koln, Taschen, 2003.

FACHARD, Sabine - Architectures Capitales, Paris 1979-1989, Milão, Electa, 1987.

FANUCCI, Francisco - Brasil Arquitetura, São Paulo, Cosac Naify, 2005.

FERNANDES, Sílvia - Teatralidades Contemporâneas, São Paulo, Perspectiva, 2010.

\section{- Performatividade e Gênese da Cena}

Revista brasileira de estudos da presença, Porto Alegre, v. 3, n. 2, p. 404-419, maio/ago. 2013. Disponível em: <http:// www.seer.ufrgs.br/presenca>
FERRAZ, Marcelo Carvalho - Lina Bo Bardi, São Paulo, Inst. Lina Bo e P. M. Bardi, 1993.

FORSYTH, Michel - Architecture et Musique, Paris, Pierre Mardaga, 1985.

FRAMPTON, Kenneth - História Crítica da Arquitetura Moderna, São Paulo, Martins Fontes, 1997.

FREYDEFONT, MARCEL, in Teatro do Mundo, What's our Life? A Play of passion, Lugares do palco, espaços da Cidade. Porto, Centro de Estudos Teatrais da Universidade do Porto, 2008 .

GOLDBERGER, Paul - The Skyscraper, New York, Alfred A. Knopf, 1985.

GUERRA, Abílio e ANELLI Renato - Rino Levi Arquitetura e Cidade, São Paulo, Romano Guerra, 2001.

Virada Cultural. <http://www.youtube.com/ watch?v=eel13qFVPwg>, acessado em 30/04/2011 
GUERREIRO, Isadora - CEUs: Potencialidades e Contradições. http://urbania4.org/2011/04/17/ceus-potencialidades-e-contradicoes/ acessado em 15/09/2010.

HERTZBERGER, Herman - Lições de Arquitetura, São Paulo, Martins Fontes, 1999.

HOBSBAWN, Eric - História Social do Jazz, São Paulo, Paz e Terra, 2010.

IZENOUR, George C. - Theater Design, New Haven, Yale University Press, 1996, 1a. edição: 1977.

JACOBS, Jane - Morte e Vida das Grandes Cidades, São Paulo, Martins Fontes, 2009.

JENCKS, Charles - Wexner Center for the Visual Arts. Architectural Design. Londres, Andreas Papadakis Editor, 1989.

JEUDY, Henry-Pierre, PAOLA, Jacques - Corpos e cenários urbanos. Territórios urbanos e políticas culturais. Salvador, UFBA, 2006.
JOEDICKE, Jürgen - Candilis-Josic-Woods. Paris, Eurolles, 1968.

JOHnSON, Philip, Mies van Der Rohe, Buenos Aires, Victor Leru, 1960.

JUNQUEIRA, Mônica de Camargo - Joaquim Guedes. São Paulo, Cosac \& Naify, 2000.

KATINSKY, Júlio - Pesquisa Acadêmica na FAUUSP. São Paulo, FAUUSP, 2010.

KAUFMANN, Emil - De Ledoux à Le Corbusier, Origine et Dévellopement de L'Architecture Autonome. Paris, Editions La Villette, 2002; 1a. edição: 1933.

KIEFER, Flávio (org) - Fundação Iberê Camargo. São Paulo, Cosaf Naify, 2008.

KLIAS, Rosa Grena - Rosa Klias: Desenhando Paisagens, Moldando uma Profissão. São Paulo, Senac, 2007. 
KOOLHAAS, Rem - "Life in Metropolis" or "The Culture of Congestion", in Architectural Design, vol. 47 n. 5, Londres, 1977.

KOPP, Anatole - Quand le Moderne n'était pas un Style mais une Cause, Paris, Ecole Nationale Supérieure des Beaux-Arts, 1988.

LAUTENSCHLAEGER, Graziele - Bauhaus Imagem e Espaço: Oskar Schlemmer e Maholy-Nagy. São Carlos, Escola de Engenharia de São Carlos, 2007.

LEGER, Fernand - Funções da Pintura, São Paulo, Nobel, 1989.

LEMOS, Carlos A. C. - Ramos de Azevedo e seu Escritório, São Paulo, PINI, 1993.

LIMA, Evelyn F. Werneck - Arquitetura do Espetáculo, Rio de janeiro, 2006.

- Das vanguardas à tradição; arquitetura, teatro e espaço urbano, Rio de Janeiro, 2006.
- Espaço e teatro: do edifício teatral à cidade como palco, Rio de Janeiro, Sete Letras, 2008.

- Por uma revolução da arquitetura teatral: o Oficina e o SESC da Pompéia. São Paulo: Vitruvius, disponível em:

http://www.vitruvius.com.br/revistas/read/arquitextos/09.101/100

- Arquitetura e Teatro. O Edifício Teatral de Andrea Palladio a Christian de Portzamparc, Rio de Janeiro, Contra Capa, 2010.

LLOSA, Mario Vargas - A Civilização do Espetáculo, São Paulo, Objetiva, 2013.

LYNCH, Kevin - A Imagem da Cidade, São Paulo, Ed. WMF Martins Fontes, 2011.

MAGROU, Raphael - Utopies et réalités des lieux de spectacle, Scènes d'Architecture. Nouvelles architectures françaises pour le spectacle, Paris, Editions du Patrimoine, 2007. 
MAHFUZ, Edson - A Pesquisa e suas Possíveis Relações com o Projeto. In O Lugar do Projeto no Ensino e na Pesquisa em Arquitetura e Urbanismo, DUARTE, Cristiane Rose; RHEINGANTZ, Paulo Afonso; AZEVEDO, Giselle; BRONSTEIN, Lais, (org.), Rio de Janeiro, Contra Capa Livraria, 2007.

- Formalismo como Virtude. Helio Piñón:

Projetos 1999-2003, Arqtexto, ano VII, n. 2, Porto Alegre, PROPAR FAU-UFRGS, 2006.

MCCARTER, Robert - Louis Kahn, New York, Phaidon, 2006.

MCKEAN, John - Royal Festival Hall, London, Phaidon, 1993.

MILHEIROS, Ana Vaz; Nobre, Ana Luiza; Wisnik, Guilherme. Coletivo - arquitetura paulista contemporânea. São Paulo, Cosac Naify, 2006.

MONDRIAN, Piet - Neoplasticismo na Pintura e na Arquietura. São Paulo, Cosac Naify, 2008.

MONEO, Rafael - Inquietação Teórica e Estratégia Projetual. São Paulo, Cosac Naify, 2008.
MONTANER, Josep Maria - A Modernidade Superada. Barcelona, Gustavo Gili, 2001.

- Arquitetura e Crítica. Barcelona, Gus-

tavo Gili, 2007.

- Depois do Movimento Moderno, Bar-

celona, Gustavo Gili, 1993.

MOTTA-ROTH, Desirée e HENDGES, Graciela Rabuske - Produção Textual na Universidade, São Paulo, Parábola Editorial, 2010.

MUNFORD, Lewis - A Cidade na História: suas origens, desenvolvimento e perspectivas. São Paulo, Martins Fontes, 1982.

MULRYNE, Ronnie e SHEWRING, Margareth - Making Space for Theatre: British Architecture and Theatre since 1958. Stratfort-upon-Avan, A.H. Joly, 1995.

NANGRETTE-CHRISTOPHE, Catherine - La fin des promenades: le théâtre dans la ville: les voies de la créaction théâtrale, Paris: CNRS, 1987. 
NESBITT, Kate - Uma nova Agenda para a Arquitetura. São Paulo, Cosac Naify, 2006.

NERDINGER, Winfried - Walter Gropius, Opere Complete, Milano, Electa, 1988.

NOSEK, Victor (org.) - Praça das Artes, Rio de Janeiro, Beco do Azougue, 2013.

OISTAT (International Organisation of Scenografers Theatre Architects and Technicians) Schaubuhne Lehniner Platz Boletim Guia de Visita, Taipei, 2010.

OLIVEIRA, Olivia - Lina Bo Bardi, Sutis Substâncias da Arquitetura, São Paulo, Romano Guerra, 2006.

OZENFANT, Amedée e JEANNERET, Charles Édouard - Depois do Cubismo, São Paulo, Cosac Naify, 2005.

PEREC, Georges - Espèces d'Espaces, Paris, Galilée, 2000.

PESAMENTO, Sandra Jatahy - Cidades Visíveis, Cidades Sensíveis, Cidades Imaginárias, in Revista Brasileira de História, v. 27, n. $57,2007$.

PEVSNER, Nikolaus - Historia de las Tipologia Arquitectonicas, Barcelona : Gili, ,1979.

PFEIFFER, Helen - Helio Piñón. Idéias e Formas, São Paulo, Ed. da Cidade, 1999.

PIÑón, Helio - Teoria do Projeto, Porto Alegre: Livraria do Arquiteto, 2006.

- O Estilinho Internacional, São Paulo, FAUUSP, Revista Pós v.17 n.27, junho 2010 (1) Tradução de Luis Espallargas Gimenez de artigo publicado na coletânea Estudios de Historia del Arte en Honor a Tomás Llorens, Madri, A. Machado, 2007. Livro organizado para homenagear o reconhecido crítico de arte por ocasião do encerramento, em 2005, de sua direção no Museu Thyssen-Bornemisza de Madri.

- "No hay forma sin lugar". Prefácio a GASTON GUIRAO, Cristina, "Mies y el proyecto como revelación del lugar". Barcelona, Fundación Caja de Arquitectos, 2005. Apud FAURE, Esteban Barrera Tesina final de Master . Curso 200809 - UPC . ETSAB Master en Teoría y Práctica del Proyecto 
de Arquitectura Línea: la Forma Moderna Tutor: Helio Piñón. - Paulo Mendes da Rocha, São Paulo, Romano Guerra, 2002.

PREFEITURA MUNICIPAL DE SÃO PAULO - O teatro e a cidade, São Paulo, Secretaria Municipal de Cultura. 2004.

PUNTONI, Álvaro - Ocupação dos vazios da memória, São Paulo, FAUSP, Dissertação de Mestrado, 1998.

PUPPO, Maria Lúcia de Souza Barros - Processos contemporâneos de criação teatral e pedagogia. ECA-USP, 2010. Projeto de pesquisa fornecido pela autora.

REIS, Ana Maria Fonseca, Cidades Criativas, Turismo Cultural e Regeneração Urbana. Disponível em: http://www. gestaocultural.org.br/pdf/Ana-Carla-Fonseca-Cidades-Criativas.pdf

REIS FILHO, Nestor Goulart - Rino Levi. Milano, Ed. Di Continuità, 1974.

RISÉRIO, Antônio - A Cidade no Brasil, São Paulo, Editora 34, 2012.
RISSELADA, Max - Raumplan versus Plan Libre. Delft, Delft University Press, 1988.

ROJAS ALDANA, Roberto - El edificio de la biblioteca y administracion del iit (Mies Van der Rohe, Chicago 1944 - 1945), Procesos de Proyecto, Master en Teoría y Práctica del Proyecto de Arquitectura, Barcelona, ETSAB/UPC, 2009.

ROSSI, Aldo - A Arquitetura da Cidade. São Paulo, Martins Fontes, 2001.

- Buildings and Projects, New York, Rizzoli, 1985.

ROUSSEAU, Jean Jacques - Discurso sobre as Ciências e as Artes, São Paulo, E. Abril, 1980.

ROWE, Colin - Maneirismo y Arquitectura Moderna y otros Ensayos, Barcelona, Gustavo Gili, 1999; 1a. edição: 1976.

RYKWERT, Joseph - A Ideia de Cidade, São Paulo, Perspectiva, 2006. 
SALTER, Chris- Entangled : technology and the transformation of performance, Massachusetts/London, The MIT Press Cambridge, 1967.

SCHULZE, Franz - Mies Van Der Rohe, Una Biografia Crítica, Madrid, Hermann Blume, , 1986.

SCULLY JUNIOR, Vincent Joseph - Arquitetura Moderna: Arquitetura da Democracia, São Paulo, Cosac \& Naify, 2002.

SECCHI, Bernardo e BIANCHETTI, Cristina - Progetto Bicocca Milão, Edizioni Electa, 1986.

SEGAWA, Hugo - Contrastes en el Cono. Uma Nova Visibilidad Chilena. In Arquitectura Viva, n. 85, Madrid, 2002.

- Arquiteturas no Brasil 1900 - 1990, São Pau-

lo, Edusp, 2002.

e MAZZA DOURADO, Guilherme - Oswaldo

Arthur Bratke, São Paulo, PH Editoras, 2012.
SEGRE, Roberto - Ministério da Educação e Saúde, Icone Urbano da Modernidade Brasileira (1935-1945), São Paulo, Romano Guerra, 2013.

SERRONI, José Carlos - Teatros, Uma Memória do Espaço Cênico no Brasil, São Paulo : Editora SENAC São Paulo, [2002].

SHARP, Dennis - The Picture Palace and Other Buildings for the Movies,- Munique, F. A. Praeger, 1969

SIMMEL, Georg - A Estética e a Cidade, São Paulo, Annablume, 2011.

SOLÀ-MORALES, Ignasi de - Do Contraste à Analogia: Novos Desdobramentos do Conceito de Intervenção Arquitetônica, Lotus International n. 46, Milano, 1985.

SOLÀ-MORALES, Manuel de - De cosas urbanas, Barcelona, Gustavo Gili, 2008.

SUMMERSON, Sir John - A Linguagem Clássica da Arquitetura, São Paulo, Martins Fontes, 1982. 
SYKES, A. Krista - O Campo Ampliado da Arquitetura: Antologia Teórica (1993-2009), São Paulo, Cosac Naify, 2012.

SZAMBIEM, Werner - Schinkel, Paris, Hazan, 1989.

TAFURI, M. et alli - Dela Vanguardia a la Metropoli: Crítica Radical a la Arquitetura, Barcelona, Gustavo Gili, 1982.

- Esfera y el Laberinto - Vanguardias y Arquitectura de Piranesi a los anos 70. Barcelona, Gustavo Gili, 1984.

TAKIYA, André - Edif 60 anos de Arquitetura Pública. São Paulo, FAUUSP, Dissertação de Mestrado, 2009.

TEIXEIRA, Carlos M. - Em Obras: História Do Vazio em Belo Horizonte, São Paulo, Cosac \& Naify, 1999

TSCHUMI, Bernard - L'entre-deux : de l'espace à l'événement et de l'événement à l'espace, entrevista a Yves Dessuant, in FREYDEFONT, Marcel (org.) "Le lieu, la scène, la salle, la ville. Dramaturgie, scénographie et architecture à la fin du XXème siècle en Europe", , Louvain-la-Neuve, Université Catholique de Louvain la Neuve, Etudes théâtrales, 1997. Disponível em: www.thea.ucl.ac.be acessado em 31/03/2012.

TOLEDO, Benedito - São Paulo, três cidades em um século, São Paulo, Duas Cidades, 1981.

- Prestes Maia e a Origem do Urbanismo Moderno em São Paulo - São Paulo, Empresa das Artes, 1996.

- São Paulo Registros 1899 - 1940, São

Paulo, Eletropaulo, 1982.

VALÉRY, Paul - Eupalinos ou o Arquiteto, São Paulo, Editora 34, 2006.

VENTURI, Robert - Complexidade e Contradição em Arquitetura. São Paulo, Martins Fontes, 2004.

VIDLER, Anthony - Claude-Nicolas Ledoux 1736-1806, Milano, Electa, 1994.

- Histories of the Immediate Present: Inventing Architectural Modernism, 1930-1975 , Delfet, Technische Universiteit Delft, 2005. 
VILCOT, Estelle - Quel Espace architectural pour quel Projet artistique? Lyon, DESS Université Lyon II, 2003.

WAISMAN, Marina - El Interior de la História. Hitoriografia Arquitectónica para uso de Latinoamericanos. Bogotá, Escala, 1993.

ZEIN, Ruth Verde e DI MARCO, Anita Regina - Sala São Paulo de Concertos, Revitalização da Estação Júlio Prestes: O Projeto Arquitetônico, São Paulo, Alter Market, 2001.

ZEVI, Bruno - Erich Mendelsohn Opere Completa, Milano, Etas Compass, 1970.

ZILIO, Daniela Tunes - A Evolução da Caixa Cênica transformações sociais e tecnológicas no desenvolvimento da dramaturgia e da arquitetura teatral, São Paulo, FAUUSP, Revista Pós 17 n.27 junho 2010.
Jornais:

MARTÍ, Silas, Pesadelo Americano - da Decadência do Subúrbio ao Renascimento da Metrópole. São Paulo, Folha de São Paulo, 28/07/2013.

MENEZES, Maria Eugênia - O Estado de São Paulo, 02/03/2011.

\section{Periódicos:}

$A+U$ n.12/1888, Tóquio, 1988.

L'Archa n. 01, Il Territorio dello Spettacolo, Milano, 1986.

Architectural Record - February 28, 2012; disponível em http://archrecord.construction.com/news/2012/02/Johansen-Theater.asp

Aujourd'hui, Art et Architecture n. 17, Paris, 1958 - Spectacles, 50 ans des recherches, org. Jacques Polieri 
Casabella n. 431, Milano, 1977 - L'Ambiente dello Spettacolo.

Criticat\#3, 03/2009, Paris, 2009.

L'Architecture d'Aujourd'hui n. 199, Paris, 1978.

L'Architecture d'Aujiurd'hui n. 152 Paris, 1970, editor Christian Dupavillon

Projeto Design n. 385, São Paulo, 2012

Projeto Design n. 395, São Paulo, 2013.

Oculum 9, Campinas, PUCCAMP, 1997, editor Abílio Guerra.

Techniques \& Architecture, n. 310, Paris, 1976. Rupture dans L'Architecture du Spectacle.

\section{Documentos e legislação:}

Programa Monumenta: seleção de imóveis privados, Prefeitura Municipal de São Paulo - Empresa Municipal de Urbanização - EMURB, edital de seleção de propostas uep n. 001/2009 processo n.o 005893000

Projeto Nova Luz - Visão e Diretrizes Urbanísticas, Prefeitura Municipal de São Paulo - Empresa Municipal de Urbanização - EMURB, 2011.

Lei Municipal 3598/1995 - Lei dos Teatros.

\section{Sites consultados:}

Biblioteca do Congresso Norte-Americano:

http://www.loc.gov/search/?q=auditorium+building

Global Performing Art Database:

http://www.glopad.org/pi/en/record/digdoc/1010

http://3dvisa.cch.kcl.ac.uk/project107.html

CHAPTER 13 HANS SCHAROUN: NATIONAL THEATRE PROJECT MANNHEIM 1953, DISPONÍVEL EM http://faculty. arch.utah.edu/miller/National\%20Theatre\%20Project.pdf

http://faculty.arch.utah.edu/miller/National\%20Theatre\%20Project.pdf 
